United States Geological Survey

Bulletin 42 ?

MANGANEST DEPOSITS OF THE UNITED

STATES

by

Zdmund 0 . Harder

$19.3: 427$ 
TEXAS TECH UNIVERSITY

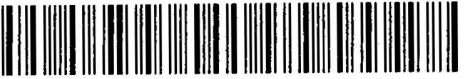

31295013470264 
DEPARTMENT OF THE INTERIOR

UNITED STATES GEOLOGICAL SURVEY

GEORGE OTIS SMITH, DIRECTOR

\section{BULLETIN 427}

\section{MANGANESE DEPOSITS OF THE UNITED STATES}

WITH SECTIONS ON

FOREIGN DEPOSITS, CHEMISTRY, AND USES

BY

EDMUND CECIL HARDER

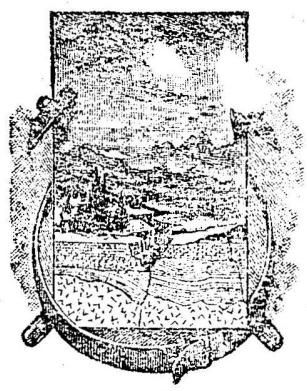

WASHINGTON

GOVERNMENT PRINTING OFEICE

1910 

DEPARTMENT OF THE INTERIOR

UNITED STATES GEOLOGICAL SURVEY

GEORGE OTIS SMITH, DIRECTOR

BULLETIN 427

\title{
MANGANESE DEPOSITS OF THE UNITED STATES
}

\author{
WITH SECTIONS ON
}

FOREIGN DEPOSITS, CHEMISTRY, AND USES

BY

EDMUND CECIL HARDER
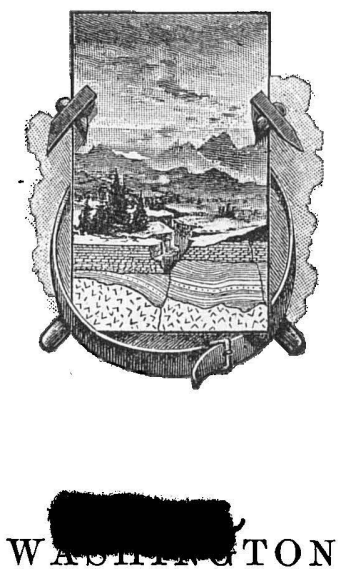

GOVERNMENT PRINTING OFFICE

1910 



\section{CONTENTS.}

INTRODUCTION $\quad$ Page.

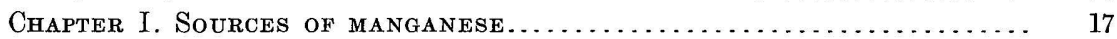

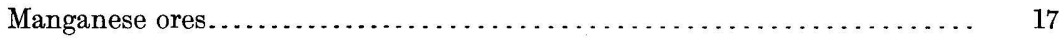

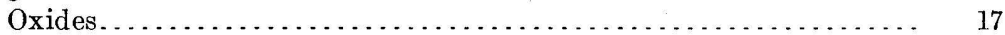

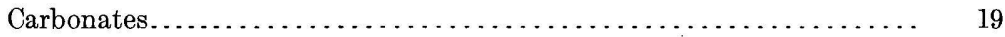

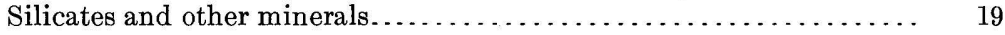

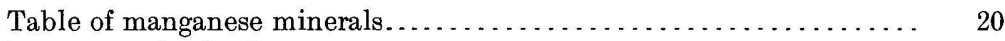

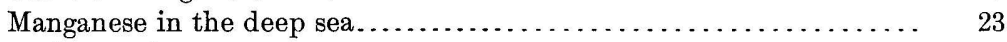

Manganiferous iron ores.................................. 24

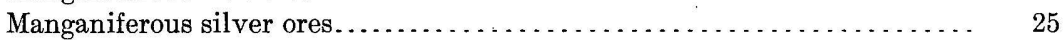

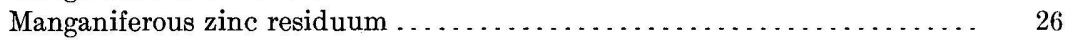

Chapter II. Manganese deposits of the United States............. 27

New England region and New York. . . . . . . . . . . . . . . . . . 27

New England crystalline area . . . . . . . . . . . . . . . . . . . 27

New England sedimentary area. . . . . . . . . . . . . . . . . . . 28

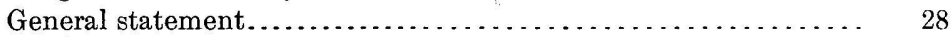

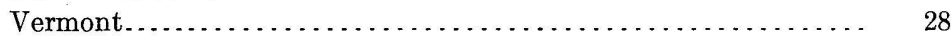

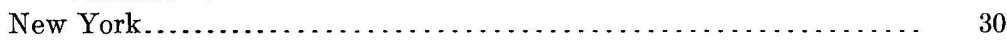

Commercial importance of the ores...................... 30

Piedmont region and Coastal Plain ......................... 31

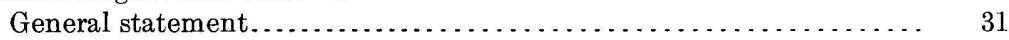

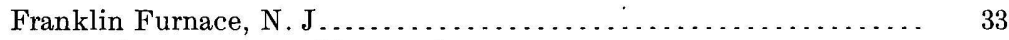

James River-Staunton River region . ....................... . . 37

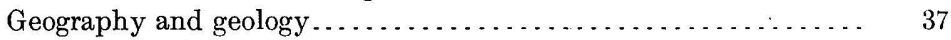

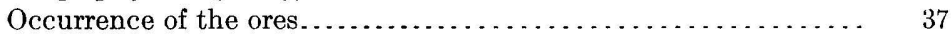

Descriptions of mines and deposits..................... 38

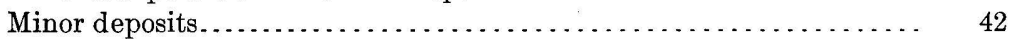

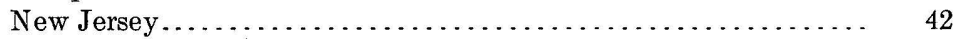

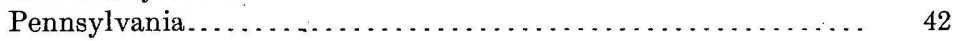

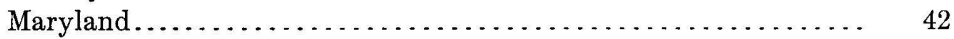

North Carolina and South Carolina................... 43

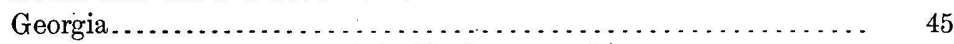

Origin of the manganese ores of the Piedmont region. . . . . . . . . . 46

Commercial importance of the ores .................... 47

Appalachian region................................... 47

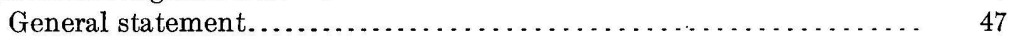

Blue Ridge region. . . . . . . . . . . . . . . . . . . . . . . . . . 49

Geography and topography $\ldots \ldots \ldots \ldots \ldots \ldots \ldots \ldots \ldots \ldots \ldots \ldots$

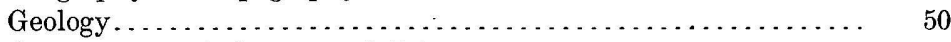

Occurrence and character of the ores.................. 53

General relations. . .

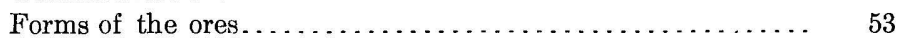

Descriptions of mines and deposits ................. 55 
Chapter II. Manganese deposits of the United States-Continued. Appalachian region-Continued.

Northwestern Virginia.

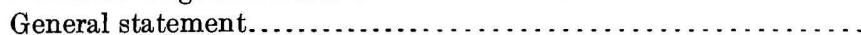

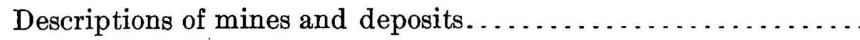

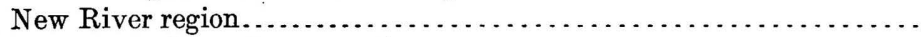

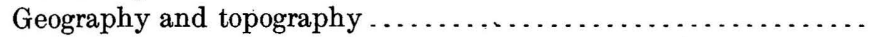

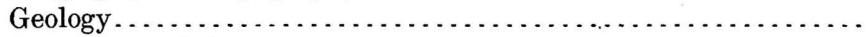

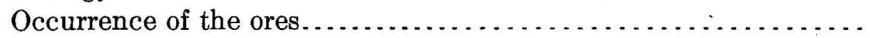

Descriptions of mines and deposits . . . . . . . . . . . . . . . . . . . . .

Northeastern Tennessee ............................

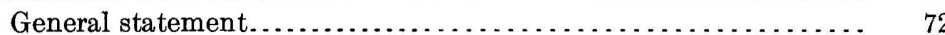

Shady Valley.................................... 73

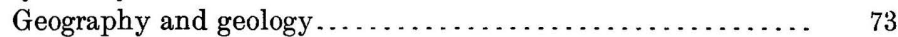

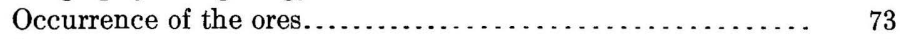

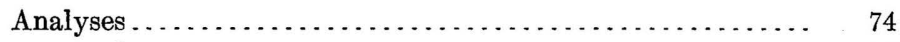

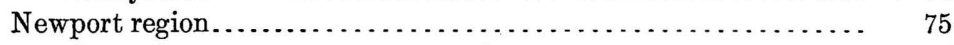

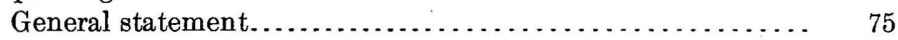

Descriptions of mines and deposits . . . . . . . . . . . . . 75

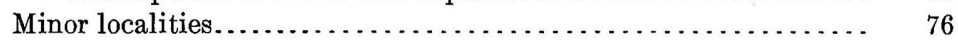

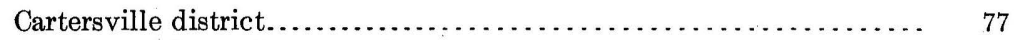

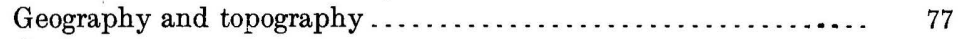

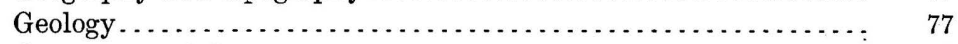

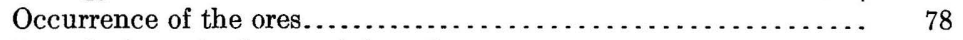

Descriptions of mines and deposits ................. 81

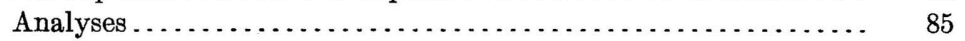

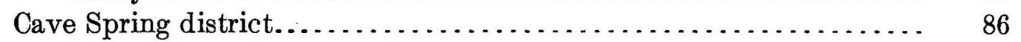

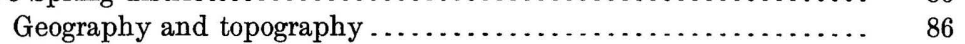

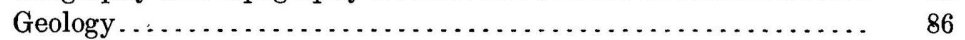

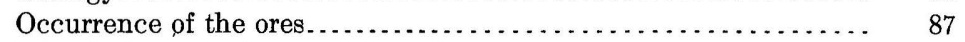

Descriptions of mines and deposits . . . . . . . . . . . . . . . . 89

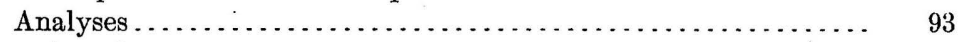

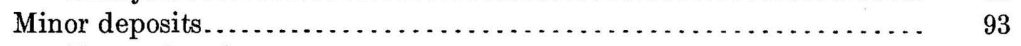

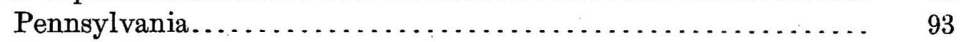

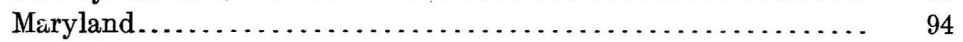

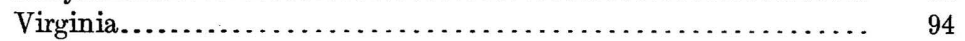

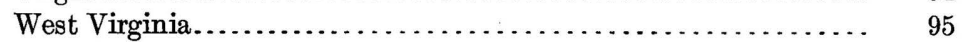

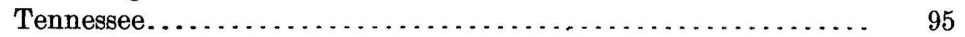

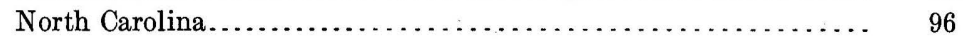

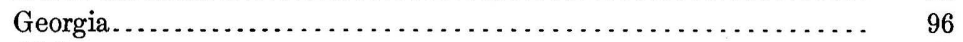

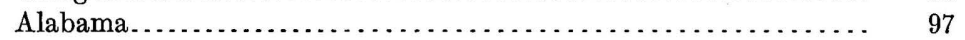

Origin of the ores of the Appalachian region. . . . . . . . . . . . . . . 99

Commercial importance of the ores....................... 101

Lower Mississippi Valley and Gulf region . . . . . . . . . . . . . . . . 102

Batesville district.................................. 102

Geography and topography ......................... 102

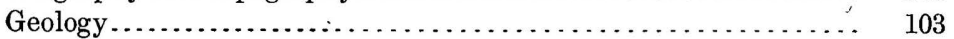

Occurrence of the ores............................ 108

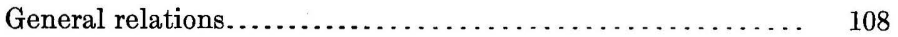

Forms of the ores............................... 109

Descriptions of mines and deposits. . . . . . . . . . . . . . . 110

Analyses. . . . . . . . . . . . . . . . . . . . . . . . . . 115

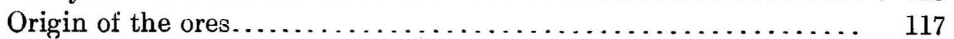


Chapter II. Manganese deposits of the United States-Continued

Lower Mississippi Valley and Gulf region-Continued. Page.

West-central Arkansas .................................... 119

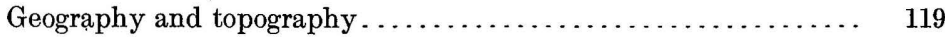

Geology ....................................... 119

Character and occurrence of ores.................... 120

Analyses........................................ 121

Central Texas........................................ 122

Character and occurrence of ores...................... 122

Descriptions of mines and deposits...................... 123

Analyses ........................................ 125

Minor deposits....................................... 125

Tennessee...................................... 125

Missouri.......................................... 125

Oklahoma....................................... 126

Commercial importance of the ores.......................... 127

Lake Superior region...................................... 127

Character and occurrence of ores. . . . . . . . . . . . . . . . . . . $\quad 127$

Cuyuna iron range, Minnesota............................. 130

Rocky Mountain region....................................... 132

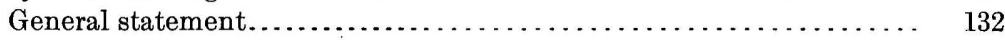

Butte district....................................... 132

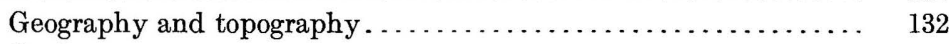

Geology ............................................ 132

Occurrence of the ores............................ 133

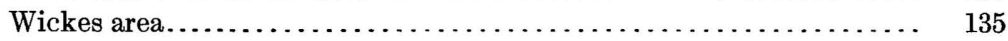

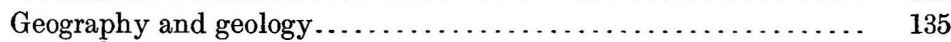

Occurrence of the ores............................... 136

Leadville district. . . . . . . . . . . . . . . . . . . . . . . . . . . 137

Geography and topography ....................... 137

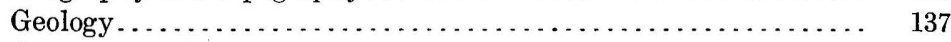

Occurrence of the ores.............................. 140

Nature of the ores.................................. 141

Uses of the ores.................................... 142

Producing mines................................... 143

Analyses....................................... 143

Little Grande district............................. 145

Geography and topography ........................ 145

Geology ........................................ 145

Occurrence of the ores............................. 146

Minor deposits...................................... 147

South Dakota..................................... 147

Montana.......................................... 148

Colorado........................................... 149

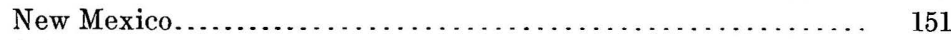

Arizona......................................... 151

Commercial importance of the ores....................... 152

Great Basin region...................................... 152

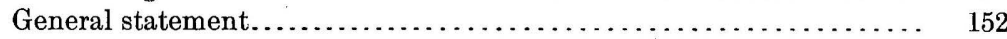

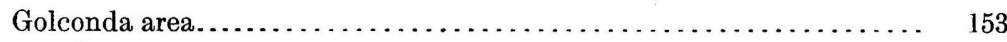

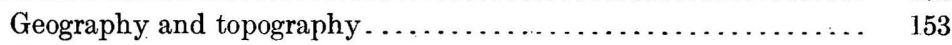

Geology ............................................ 153

Occurrence and character of ores....................... 154 
Chapter II. Manganese deposits of the United States-Continued.

Great Basin region-Continued. Page.

Minor deposits....................................... $\quad 157$

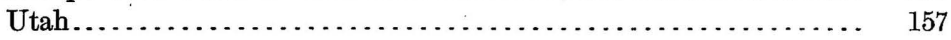

Nevada....................................... $\quad 157$

Commercial importance of the ores........................... 158

Pacific Coast region ........................................... 158

General statement.................................... 158

Livermore-Tesla district................................ $\quad 159$

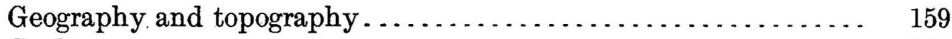

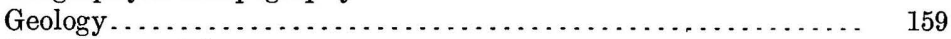

Occurrence of the ores.............................. 160

Descriptions of mines and deposits . . . . . . . . . . . . . . . 160

Minor deposits in California............................... 163

Analyses.......................................... 166

Origin of manganese ores in the Franciscan jaspers............... 166

Commercial importance of the ores:......................... 167

Chapter III. Foreign manganese deposits....................... 168

North America........................................ 168

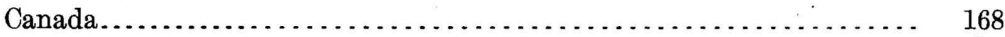

General statement....................................... 168

New Brunswick...................................... 169

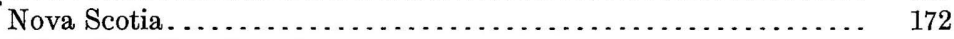

Other Canadian deposits............................... 176

Newfoundland........................................ 177

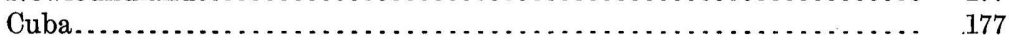

Situation of deposits................................ 177

Ponupo, Boston, and Ysabellita mines..................... 178

Deposits south of Cristo and at Dos Bocas.................. 179

Other deposits.................................... 179

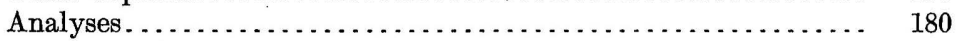

Other West Indies.................................. $\quad 180$

Mexico........................................... 180

Panama.............................................. 181

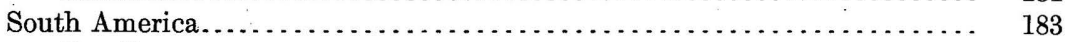

Brazil............................................... 183

Nazareth district..................................... 183

Minas Geraes districts................................. 184

Geography and geology ............................ 184

Miguel Burnier district.............................. 185

Ouro Preto district............................ 187

Lafayette or Queluz district...................... 188

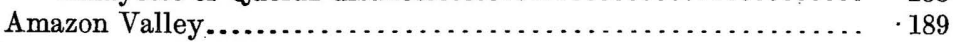

Chile............................................... 189

Distribution of deposits............................. 189

Aculeo district.................................... 190

Corral Quemada district............................. $\quad 190$

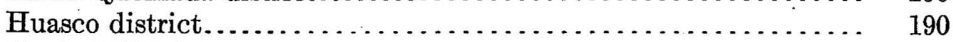

Carrizal district........................................... 191

Minor deposits.................................... 191

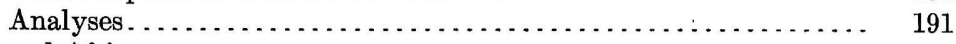

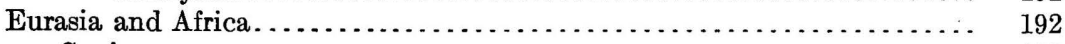

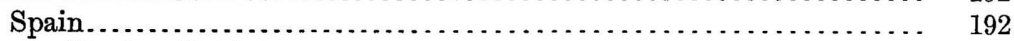

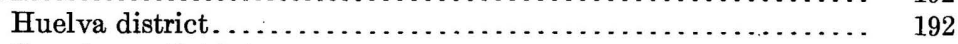

Covadonga district................................... 193

Minor deposits..................................... 195 
Chapter III. Foreign manganese deposits-Continued.

Eurasia and Africa-Continued.

Portugal ..... Page.

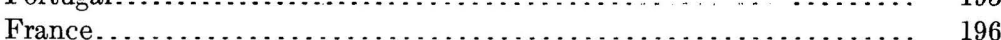

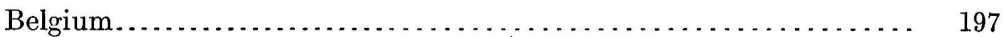

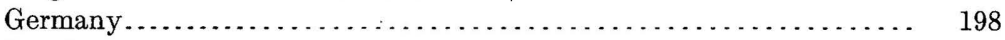

Sweden......................................... 200

Great Britain ....................................... 202

North Wales.................................... 202

Minor deposits...................................... 204

Austria-Hungary ........................................ 204

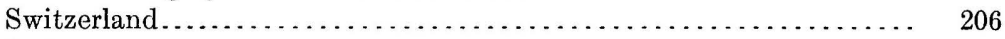

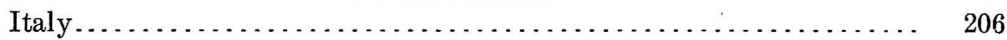

Greece.............................................. 207

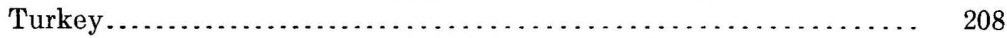

Russia.............................................. 208

Sharopan district.................................. $\quad 209$

Other deposits in Transcaucasia....................... 210

Nikopol district.................................... 211

Ural Mountains..................................... 211

Tunis............................................... 212

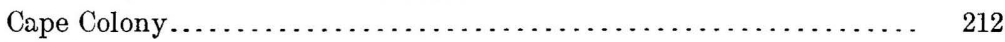

Egypt.............................................. 212

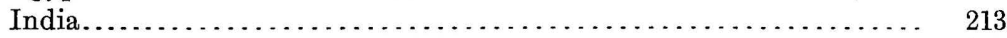

Distribution and character of ores...................... 213

Vizagapatam district............................. 215

Jabalpur district................................ 216

Sausar tahsil...................................... 217

Other districts.................................... 218

Ceylon.............................................. 219

Japan.......................................... $\quad 219$

Oceania...................................................... 219

Philippine Islands................................... 219

Java................................................ 221

Borneo................................................. 221

New Zealand............................................ 221

Australia.............................................. 222

New South Wales............................... 222

South Australiạ.................................... 222

Queensland.................................... 222

Chapter IV. Chemistry of manganese ....................... 224

Metallic manganese and its alloys............................. 224

Manganese compounds.................................. 226

Manganese oxides, hydrates, and acids..................... 226

Manganese and the halogens............................... 229

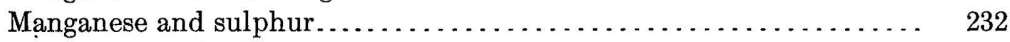

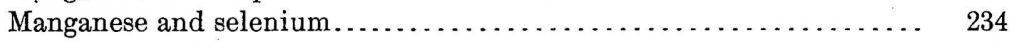

Manganese and nitrogen ............................... 234

Manganese and phosphorus............................... 235

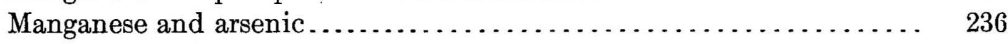

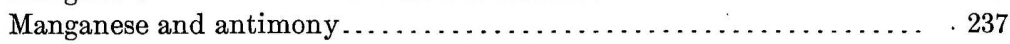

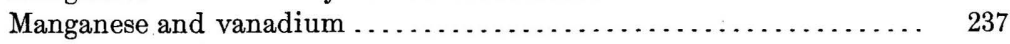

Manganese and boron ..................................... 237

Manganese and carbon................................... 237 
Chapter IV. Chemistry of manganese-Continued.

Manganese compounds-Continued. Page.

Manganese and silicon................................... $\quad 239$

Manganites.......................................... 240

Manganates........................................... $\quad 240$

Permanganates......................................... 241

Chapter V. Uses of manganese................................ 243

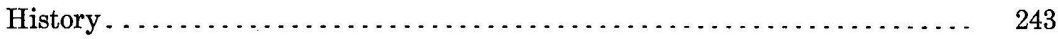

Metallurgical uses....................................... 244

Ferromanganese, spiegeleisen, silicomanganese, and silicospiegel..... 244

General description . . . . . . . . . . . . . . . . . . . . . . . . . . 244

Manufacture.................................... 246

Constitution ..................................... 248

Uses in steel manufacture . . . . . . . . . . . . . . . . . . . . 250

Hadfield's manganese steel.............................. 251

First experiments . . . . . . . . . . . . . . . . . . . . . . . 251

Physical properties................................ $\quad 252$

Uses............................................ 255

Quaternary manganese steels ............................ 255

Alloys with other metals than iron ......................... 256

Cupromanganese................................... 256

Manganese bronze.................................... 257

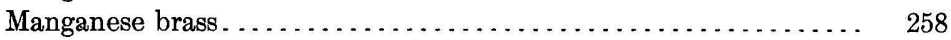

Manganese German silver......................... $\quad 258$

Manganese amalgam................................ 258

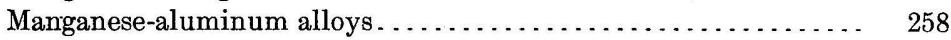

Heusler's alloys................................. $\quad 259$

Other alloys..................................... 260

Copper, lead, and silver reduction...................... $\quad 260$

Chemical uses......................................... 261

Uses as an oxidizer.................................. 261

General statement. . . . . . . . . . . . . . . . . . . . . . 261

Manufacture of chlorine ........................... 261

Manufacture of bromine ............................ 263

Manufacture of oxygen ............................... 264

Disinfectants................................... $\quad 265$

Decolorizer of glass. . . . . . . . . . . . . . . . . . . . . . . $\quad 265$

Dryer in paints and varnishes. . . . . . . . . . . . . . . . . . .

Leclanché cell. . . ............................... 265

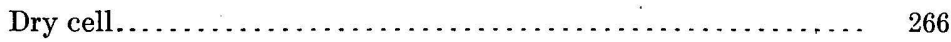

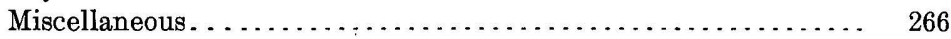

Uses as a coloring material............................. 267

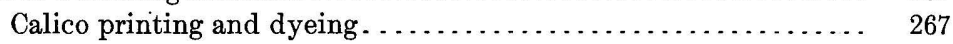

Coloring of glass, pottery, and bricks.................. $\quad 267$

Paints.............................................. 268

Miscellaneous..................................... 268

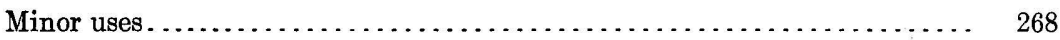

Chapter VI. The manganese industry in the United States.......... 269

Production of ores................................... 269

History of production by States......................... 269

Tennessee........................................ $\quad 269$

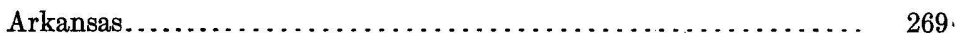

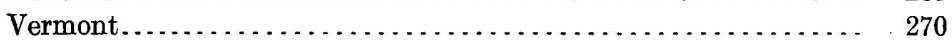

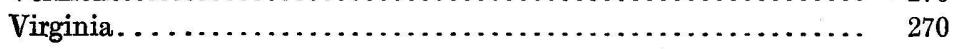


Chapter VI. The manganese industry in the United States-Continued. Production of ores-Continued.

History of production by States-Continued. Page.

Georgia......................................... 271

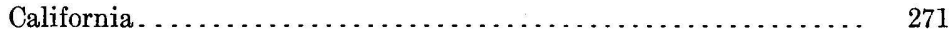

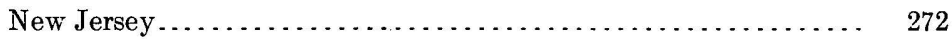

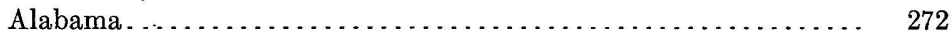

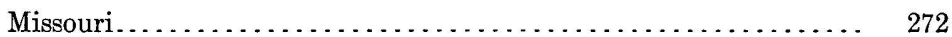

Lake Superior region. . . . . . . . . . . . . . . . . . . . . . . . 272

North Carolina..................................... 272

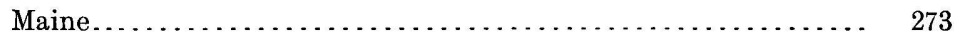

South Carolina.................................... $\quad 273$

Pennsylvania..................................... $\quad 273$

Colorado....................................... 273

Montana........................................... $\quad 273$

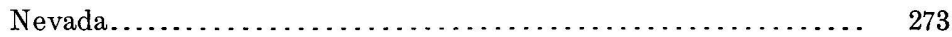

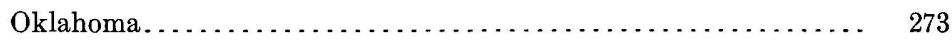

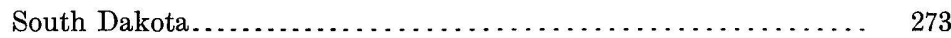

West Virginia...................................... $\quad 273$

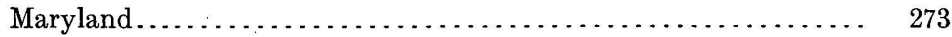

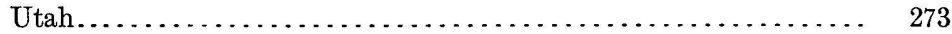

New Mexico....................................... 274

Production tables.................................... 274

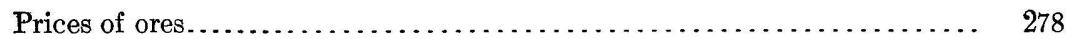

Importation of ores......................................... 279

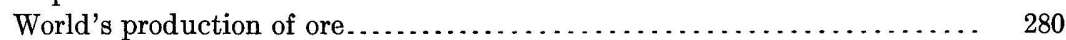

Ferromanganese and spiegeleisen............................ 281

Production . . . . . . . . . . . . . . . . . . . . . . . . . . . . . . . $\quad 281$

Prices................................................ $\quad 282$

Importation ......................................... 282

Chapter VII. Bibliography.................................... 284

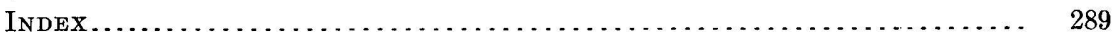




\section{ILLUSTRATIONS.}

Plate I. Map showing the distribution of manganese and manganiferous ore deposits in the United States.......................... In pocket.

II. Map showing the principal manganese mines in Virginia and the probable extent of the ore-bearing areas.......................

Figure 1. Section through the South Wallingford ore deposit, showing the occurrence of the manganese-bearing clay...................

2. Sketch showing the occurrence of manganese ore at the Piedmont Manganese Company's mine............................

3. Sketch showing the occurrence of a pocket of manganese ore at the foot of the Blue Ridge ............................. $\quad 5_{52}$

4. Ground plan of the Crimora manganese deposit............... 58

5. Sections through the Crimora manganese deposit.............. 59

6. Sketch showing distribution of manganese ore lumps in clay at the Crimora mine.................................... 60

7. Sketch showing concentric layers of pyrolusite and psilomelane.... $\quad 60$

8. Map showing the principal manganese mines in the Cartersville district, Georgia, and the probable extent of the ore-bearing areas..

9. Sketch showing distribution of manganese ore in clay at the Chumbler Hill mine......................................

10. Sketch showing distribution of manganese ore in clay at the May-

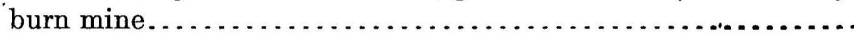

11. Sketches showing occurrence of manganese ore at the Dobbins mine.

12. Sketches showing structure of breccia ore......................

13. Map showing the principal manganese mines in the Cave Spring district, Georgia, and the probable extent of the ore-bearing areas.

14. Sketch showing occurrence of breccia ore at Reynolds Mountain...

15. Sketch showing distribution of pellets and irregular masses of ore in

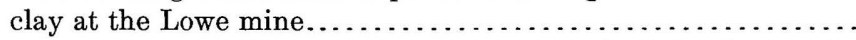

16. Sketch showing the distribution of manganese ore in clay at the

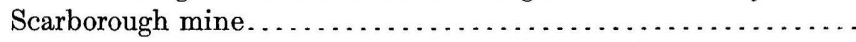

17. Sections showing different phases of the Cason shale..............

18. Generalized section showing the occurrence of the Batesville man-

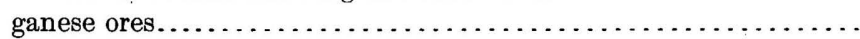

19. Map showing the principal manganese mines in the Batesville district, Arkansas, and the probable extent of the ore-bearing area. .

20. Sketch showing the occurrence of manganese ores at the Montgomery

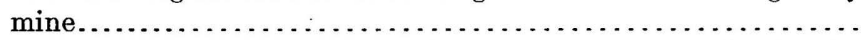

21. Sketch showing the occurrence of manganese ores at the Meeker

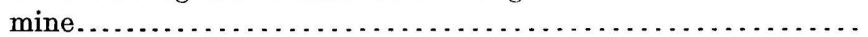

22. Section showing the occurrence of manganese ores in west-central

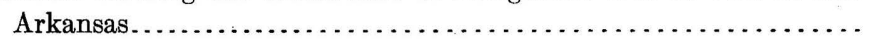

23. Sketch showing the occurrence of manganiferous iron ores in ironore deposits of the Cuyuna range, Minnesota.................. 
Page.

Fic URE 24. Sections through the bog manganese deposit near Wickes, Mont.: $A$, General section through the ore bed; $B$, Detailed sketch of the bog manganese and ocher contact.

25. Typical section showing the occurrence of the ore deposits at Leadville, Colo ........................................

26. Section showing the relation of the Golconda manganese deposit to the rocks of the Edna Mountains, Nevada.....................

27. Section through the Golconda manganese deposit, Nevada........

28. Section through the replacement deposit of manganiferous iron ore near Golconda, Nev...............................

29. Sketch showing the occurrence of manganese ore at the old Ladd mine, California.................................. $\quad 161$

30. Section through the manganese deposit at the Fable mine, Galifornia ........................................... 162

31. Section through the ore body of the Pedras Pretas mine, Brazil... 184

32. Typical section of the manganese-bearing series, Miguel Burnier.. 185

33. Section showing the occurrence of manganese ores in the Sharopan district............................................ 


\title{
MANGANESE DEPOSITS OF THE UNITED STATES.
}

\author{
By Edmund Cecil Harder.
}

\section{INTRODUCTION.}

This report is the result of an attempt to present as briefly as possible all available important information concerning manganese, including accounts of the deposits, the geology and chemistry of the ores, the methods of mining, and the uses of the metal and the nature and extent of the industries to which it gives origin. It is not designed to be an exhaustive study of manganese, but is chiefly a brief account of its principal sources of supply, both domestic and foreign, and of its useful applications. With regard to the foreign sources, most emphasis is laid on those districts that supply the United States with ore.

Manganese is obtained commercially from manganese ores, manganiferous iron and silver ores, and manganiferous residuum from zinc roasting.

Manganese ores are found in many parts of the United States, but at only a few places do they occur in sufficient quantity to be of high commercial value. They have been mined in the New England, Appalachian, and Piedmont regions in the eastern United States, in northern Arkansas, and, to a small extent, in central-western California. The principal producing mines have been those in the Blue Ridge region and the James River-Staunton River region of Virginia, the Cartersville and Cave Spring districts of Georgia, the Batesville district of Arkansas, and the Livermore-Tesla district of California. (See Pl. I, in pocket.)

Manganiferous iron and silver ores are also widely distributed. The former have been mined for their manganese content in the New England, Appalachian, and Piedmont regions in the eastern United States, in northern Arkansas, and in a few localities in the Lake Superior district, and the latter in several western silver districts, principally Leadville. In many manganiferous-ore deposits, however, the manganese content is so low that the ores are used only for the other metals which they contain. Such is the case with most of the manganiferous ores of the Lake Superior district, of the Appalachian region, and of the western silver districts. 
Manganiferous zinc residuum is obtained only from zinc oxide works using New Jersey manganiferous zinc ores.

The manganese ores proper and the manganiferous ores are so closely associated that even in detail it is hard to separate them. In this report, therefore, they are discussed together under the same general headings.

The manganese and manganiferous ore deposits throughout the United States are largely secondary concentration deposits. Such are the ores of eastern United States, except certain rhodonite deposits, and such also are the ores in northern Arkansas, in the Lake Superior region, at Leadville and in other silver districts, and in western California. A few deposits of bog manganese ore occur locally, and these also are secondary concentrations. The rhodonite and rhodochrosite in the unoxidized portions of the silver veins at Butte, however, are primary concentrations, as are also the manganese silicate veins in central Texas and elsewhere.

The secondary manganese deposits of the eastern United States have originated directly or indirectly by the concentration of manganese once contained in manganese-bearing silicates of the crystalline rocks of this region. The deposits of the Piedmont region and some of the New England deposits are direct accumulations of manganese from this source, and the manganese of the Appalachian deposits has been derived from this original source through sedimentation, these ores having accumulated from manganese disseminated through sedimentary rocks, the materials of which were obtained from crystalline areas.

The northern Arkansas ores are largely reconcentrations from lowgrade secondary deposits derived by sedimentation from old crystalline rocks, while the California ores are concentrations within chert lenses of material originally present in a disseminated form. The western manganiferous silver ores are the result of oxidation and concentration of primary deposits derived from igneous intrusion.

Bog manganese deposits have accumulated largely from deposition of manganese by waters issuing from springs. .The bog deposits of New England, New York, Wisconsin, and those near Wickes, Mont., have been obtained directly from manganese-bearing silicates in igneous or metamorphic rocks; others, as those in central Arkansas and at Golconda, Nev., have been derived from waters issuing from sedimentary formations.

Manganese mining has never been a very important industry in the United States, owing to the small extent and the discontinuous and scattered nature of most of the deposits. Nearly all the ore mined must be either washed or sorted or both. Single pockets are of small extent and are soon exhausted, discouraging the erection of expensive concentrating plants. 
In the eastern United States the ore is mined either by open cuts or by underground workings, according as the deposit is near the surface or some distance underground. Cars are used for carrying the ore from the mines when the open cuts or underground workings are of considerable extent; buckets and wheelbarrows when the workings are small. The ore is washed either by hand or in log washers. In the larger workings, as at Crimora, Va., several sets of log washers are employed. After washing, the ore is screened to separate the large fragments from the small ones. Frequently the fragments have to be sorted by hand to separate manganiferous iron ores from pure manganese ores, or to separate high-grade ores from highly siliceous ores containing sand grains and sandstone or chert fragments.

The crude mining methods that naturally result from the conditions stated make the concentration of ores slow and expensive, so that the resulting product can not compete on the market with foreign high-grade ores which do not require concentration.

Most of the manganese ore consumed in this country is imported from Brazil, India, and Cuba, smaller amounts being obtained from Russia, Germany, Great Britain, Belgium, Japan, the East Indies, and other countries. The total quantity of manganese ore imported from the beginning of 1900 to the end of 1908 was $1,777,653$ long tons; the domestic production of manganese ore during the same period was 60,001 tons. Besides the raw ore there are considerable quantities of ferromanganese and spiegeleisen imported annually.

The imported raw ore is used largely in the manufacture of ironmanganese alloys, and these, together with the imported alloys, are consumed in steel manufacture. A considerable quantity of highgrade foreign ore is used in the manufacture of dry cells for electric batteries. Most of the domestic manganese ore, with perhaps a small portion of the imported ore, is used in the manufacture of brick and pottery as a coloring material, or for other chemical purposes. Only a small portion of the domestic ore is used in steel manufacture. Manganiferous ores of iron and silver are used both in the manufacture of iron-manganese alloys and as flux in smelting copper, lead, and silver ores. The manganiferous residuum from zinc-oxide works using New Jersey manganiferous zinc ores has been used in the manufacture of spiegeleisen for the last forty years.

The material of this report is in part the result of personal investigation by the writer and in part a compilation of facts from all available sources. In a trip occupying most of the months of January, February, March, and April, 1908, the writer covered all of the important manganese districts of the United States and many unimportant ones. The part of the report describing the deposits of these districts is therefore based on original observations. The chapters on foreign manganese deposits and on the chemistry and uses of manganese have been compiled from innumerable sources. 
The writer desires to express his obligations to the following persons for acts of courtesy which have helped materially in gathering subject-matter for the preparation of this report: Prof. R. J. Holden, Virginia Polytechnic Institute; Prof. Thos. L. Watson, University of Virginia; Prof. A. H. Purdue, University of Arkansas; Dr. S. W. McCallie, state geologist, Atlanta, Ga.; Mr. D. W. Myers, president of the Piedmont Manganese Company, Lynchburg, Va.; Capt. John J. Calhoun, Cartersville, Ga.; Mr. Victor Rakowsky, mining engineer, Duluth, Minn.; Mr. R. C. Davis, mining engineer, Butte, Mont.; Mr. R. M. Davis, mining engineer, Butte, Mont.; Mr. Carl Zapffe, mining geologist, Brainerd, Minn.; Prof. C. F. Burgess and Prof. Eliot Blackwelder, University of Wisconsin; Mr. Chas. G. Yale, San Francisco, Cal.; Mr. Victor Heikes, Salt. Lake City; Mr. Walker, California State Mining Bureau, San Francisco; Mr. W. H. Bramel, Salt Lake City; Mr. Lucian Ray, Salt Lake City; Mr. Howard A. Broughton, San Francisco; Mr. W. T. Jones, Oakland; and Prof. F. W. Clarke, Dr. C. W. Hayes, Dr. E. O. Ulrich, Dr. R. S. Bassler, Mr. Arthur Keith, Mr. Waldemar Lindgren, Mr. H. D. McCaskey, Mr. S. F. Emmons, Mr. J. A. Taff, Mr. D. B. Sterrett, Mr. F. C. Schrader, Mr. E. F. Burchard, and others of the United States Geological Survey. 


\section{CHAPTER I. \\ SOURCES OF MANGANESE.}

The commercial sources of manganese are four, namely,(1) manganese ores, (2) manganiferous iron ores, (3) manganiferous silver ores, (4) Manganiferous residuum from zinc roasting. The first three of these are ores; the fourth is a residual product obtained after roasting the zinc from an ore consisting of zinc, iron, and manganese minerals.

\section{MANGANESE ORES.}

The only forms of manganese occurring in nature in sufficient quantities to be of commercial value are the oxides, the carbonate, and the silicate. Most manganese ores are oxides, mainly psilomelane and pyrolusite. Other oxides of manganese are mined, but much less abundantly. The carbonate of manganese, rhodochrosite, is not found in sufficient quantities in this country to be commercially valuable, but is mined in several foreign countries, as Spain and Wales. Both the oxides and the carbonate are used in the manufacture of steel and for chemical purposes. The silicate of manganese, rhodonite, contains too much silica to be used for its manganese content, but is sometimes mined for ornamental purposes on account of its beautiful pink color. Other minerals of manganese are too rare to be of commercial-alue.

\section{OXIDES.}

There are many varieties of oxides, but only five of them are important as ores, namely, psilomelane, pyrolusite, braunite, manganite, and wad.

Psilomelane.-Psilomelane $\left(\mathrm{MnO}_{2}\right.$. $(\mathrm{Mn}, \mathrm{K}, \mathrm{Ba}) \mathrm{O} . \mathrm{nH}_{2} \mathrm{O}$; or $\left.\mathrm{H}_{4} \mathrm{MnO}_{5}\right)$ is a bluish or grayish-black mineral occurring in the amorphous form with a tendency to botryoidal surfaces, concentric structure, and conchoidal fracture. It has a hardness of 5 to 6 and a specific gravity of 3.7 to 4.7 . The chemical composition of psilomelane is not definite; the potash, baryta, and water occur in it in varying amounts and are supposed by some mineralogists to be mechanically admixed. The percentage of metallic manganese in psilomelane varies from 45 to 60 ; that of baryta from 0 to 17 , that of potassa from 0 to 5 ; and that of water from 3 to 6 . Psilomelane is abundant in the manganese ores of Vermont, Virginia, Tennessee, Georgia, Arkansas, and California. 
Pyrolusite.-Pyrolusite $\left(\mathrm{MnO}_{2}\right.$, generally containing a little $\left.\mathrm{H}_{2} \mathrm{O}\right)$ is a grayish-black to black mineral with crystalline or granular structure, belonging to the orthorhombic system of crystallization. It has a hardness of 2 to 2.5 , being much softer than psilomelane, and a specific gravity of 4.8 . When pure pyrolusite contains 63.2 per cent of metallic manganese, but it is rarely found in the pure state. It generally occurs in association with psilomelane, either lining or filling cavities in it, or occurring in alternating layers with it in botryoidal masses. In such masses it consists of numerous parallel needles arranged perpendicular to the faces of the layers. Locally crystals of pyrolusite are found scattered through masses of psilomelane, the association being generally such as to lead to the conclusion that pyrolusite is an alteration product of psilomelane. It also occurs pseudomorphous after manganite. Pyrolusite is found with psilomelane in the manganese ores of Virginia, Tennessee, and Georgia.

Braunite.-Braunite $\left(3 \mathrm{Mn}_{2} \mathrm{O}_{3} \cdot \mathrm{MnSiO}_{3}\right)$ is a heavy, shiny, brownish or grayish-black mineral, either massive or crystalline, but generally the latter. It crystallizes in the tetragonal system and has a welldeveloped cleavage. Braunite has a specific gravity of 4.8 and a hardness of 6 to 6.5 , being frequently too hard to scratch with a knife. The silica is, by some mineralogists, thought to be present as a mechanical admixture, but some of it, at least, has been proved to be in chemical combination. It varies in quantity from a mere trace to 10 per cent. When pure, braunite contains 69 per cent metallic manganese, but it never occurs so in nature. Braunite is a characteristic mineral in the manganese deposits of Arkansas, where it occurs with psilomelane.

Manganite.-Manganite $\left(\mathrm{Mn}_{2} \mathrm{O}_{3} \cdot \mathrm{H}_{2} \mathrm{O}\right)$ is a heavy, black mineral, massive or crystallizing in the orthorhombic system. It has a hardness of 4 and a specific gravity of 4.2 to 4.4. Manganite has a theoretical content of 62.4 per cent metallic manganese and 10 per cent of water. It is found in this country mainly in California but it is said to occur also in association with psilomelane in Virginia, Georgia, and Arkansas.

Wad.-Wad, an impure mixture of manganese oxides, is a soft, black, earthy mineral occurring with other oxides of manganese, or with manganese carbonates and silicates as an alteration product of these. In the latter case it frequently occurs in the oxidized portions of veins having these minerals as gangue. Dendrite is a branching form of wad.

Bog manganese.-Bog manganese consists of manganese oxides and water, with an admixture of iron oxide, baryta, alumina, and silica, and sometimes nickel and cobalt.

Other oxides.-The remaining oxides of manganese are of small imponce as ores, and are rare in this country. The principal ones 
are hausmannite $\left(\mathrm{Mn}_{3} \mathrm{O}_{4}\right.$ or $\left.2 \mathrm{MnO} \cdot \mathrm{MnO}_{2}\right)$, a brownish-black mineral occurring as tetragonal octahedrons, or in a granular form; polianite $\left(\mathrm{MnO}_{2}\right)$, a very pure form of pyrolusite; franklinite $((\mathrm{Fe}, \mathrm{Zn}, \mathrm{Mn}) \mathrm{O} .(\mathrm{Fe}$, $\mathrm{Mn})_{2} \mathrm{O}_{3}$ ), a heavy, black mineral occurring in isometric octahedrons; and pelagite $\left(\mathrm{MnO}_{2} \cdot \mathrm{Fe}_{2} \mathrm{O}_{3}\right.$ with $\mathrm{SiO}_{2}, \mathrm{Al}_{2} \mathrm{O}_{3}$, and $\mathrm{H}_{2} \mathrm{O}$ in mechanical admixture), a deep-sea deposit.

\section{CARBONATES.}

Rhodochrosite.-R Rodochrosite $\left(\mathrm{MnCO}_{3}\right)$ is a pink mineral commonly occurring as a gangue in association with rhodonite in veins traversing granitic rocks. It crystallizes in the hexagonal system, and is frequently found in beautiful rhombohedrons. On exposure it becomes black by oxidation. Rhodochrosite has a specific gravity of 3.45 to 3.6 , is soluble in warm hydrochloric acid, and has a hardness of 3.5 to 4.5 , being scratched easily by a knife. Its theoretical percentage of metallic manganese is 47.56. The principal occurrences of this mineral in the United States are in New Jersey, Colorado, and Nevada, and at Butte, Mont., in association with ores of silver, lead, copper, and zinc.

Other carbonates.-Other manganiferous carbonates that occur sparingly, are manganocalcite $\left((\mathrm{Ca}, \mathrm{Mn}) \mathrm{CO}_{3}\right)$, manganosiderite $\left((\mathrm{Fe}, \mathrm{Mn}) \mathrm{CO}_{3}\right)$, and ankerite $\left((\mathrm{Ca}, \mathrm{Mg}, \mathrm{Fe}, \mathrm{Mn}) \mathrm{CO}_{3}\right)$. Manganese occurs also in carbonates of magnesium, zinc, and, rarely, cobalt.

\section{SILICATES AND OTHER MINERAIS.}

Rhodonite.-Rhodonite $\left(\mathrm{MnSiO}_{3}\right)$ is a pink mineral that generally occurs as a gangue in ore or pegmatite veins in association with other minerals as quartz and rhodochrosite. It has a triclinic crystallization, a hardness of 5.5 to 6.5 , and a specific gravity of 3.4 to 3.7. On exposure it becomes black, like rhodochrosite. This is well illustrated in the oxidized portions of the silver veins at Butte. There, in the lower portions, the gangue is rhodonite and rhodochrosite with quartz, but at the surface the manganese silicate and carbonate are altered to manganese oxides.

Rhodonite contains theoretically 41.9 per cent of metallic manganese. It is frequently found in considerable quantities in veins or lenses in granitic and schistose rocks, but is not commercially valuable on account of its high content of silica. Rhodonite occurs at Blue Hill, Me., in western Massachusetts, in New Jersey, in the Piedmont region, and at various localities in the western United States.

Other silicates.-Other manganese silicates are tephroite $\left(\mathrm{Mn}_{2} \mathrm{SiO}_{4}\right)$, a manganese olivine, red to gray in color, and spessartite $(3 \mathrm{MnO}$. $\mathrm{Al}_{2} \mathrm{O}_{3} \cdot 3 \mathrm{SiO}_{2}$ ), a manganese garnet, pink to brownish red in color. 
In a great many of the silicate groups, such as the garnets, amphiboles, pyroxenes, micas, chlorites, olivines, epidotes, zeolites, and others, there are manganese minerals, or admixtures of manganese with other minerals, which are interesting mainly on account of their chemical and mineralogical characters.

Other manganese minerals.-Many other interesting though rare compounds of manganese occur in nature, such as sulphides, sulphates, arsenides, arsenates, antimonates, phosphates, tungstates, borates, titanates, niobates, and tantalates.

TABLE OF MANGANESE MINERALS.

The following manganese minerals have been recognized in nature and described:

Manganese minerals. ${ }^{a}$

Oxides: Mineral. Composition.

Psilomelane ................. $\mathrm{MnO}_{2} \cdot(\mathrm{Mn}, \mathrm{K}, \mathrm{Ba}) \mathrm{O} . \mathrm{nH}_{2} \mathrm{O}$ or $\mathrm{H}_{4} \mathrm{MnO}_{5}$.

Pyrolusite.................. $\mathrm{MnO}_{2}$.

Braunite................ $3 \mathrm{Mn}_{2} \mathrm{O}_{3} \cdot \mathrm{MnSiO}_{3}$.

Manganite................. $\mathrm{Mn}_{2} \mathrm{O}_{3} \cdot \mathrm{H}_{2} \mathrm{O}$.

Wad.................... Impure mixture of manganese oxides. Includes bog manganese, asbolite, and lampadite.

Bog manganese............ Manganese oxides with oxides of iron, barium, aluminum, silicon, and sometimes nickel and cobalt.

Wackenrodite (peloconite)... Bog manganese with a considerable percentage of lead.

Reissacherite.............. A variety of bog manganese with a high percentage of water.

Groroilite................A variety of bog manganese.

Lampadite (Lepidophacite)...Cupriferous wad.

Asbolite................. Wad with a large percentage of cobalt.

Dendrite................. A branching form of wad.

Hausmannite.............. $\mathrm{Mn}_{3} \mathrm{O}_{4}$ or $2 \mathrm{MnO}^{-\mathrm{MnO}_{2}}$.

Polianite................. $\mathrm{MnO}_{2}$. Like pyrolusite chemically, but of different crystallographic form.

Varvicite................ An impure pyrolusite derived from the alteration of manganite.

Pyrochroite.............. $\mathrm{Mn}(\mathrm{OH})_{2}$. White manganese hydrate.

Pelagite................... $\mathrm{MnO}_{2} \cdot \mathrm{Fe}_{2} \mathrm{O}_{3}$ with $\mathrm{SiO}_{2}, \mathrm{Al}_{2} \mathrm{O}_{3}$, and $\mathrm{H}_{2} \mathrm{O}$ in mechanical admixture. Found in the deep sea.

Halobolite................. Similar to pelagite. Found in the deep sea.

Dysluite................. ( $\mathrm{Zn}, \mathrm{Fe}, \mathrm{Mn}) \mathrm{O} .(\mathrm{Al}, \mathrm{Fe})_{2} \mathrm{O}_{3}$. Zinc - manganese - iron gahnite (spinel).

Franklinite.............. $\mathrm{Fe}, \mathrm{Zn}, \mathrm{Mn}) \mathrm{O} .(\mathrm{Fe}, \mathrm{Mn})_{2} \mathrm{O}_{3}$.

Chalcophanite.............. (Mn, $\mathrm{Zn}) \mathrm{O} .2 \mathrm{MnO}_{2} \cdot 2 \mathrm{H}_{2} \mathrm{O} . \mathrm{A}$ decomposition product of franklinite.

Manganbrucite............ Brucite $\left(\mathrm{MgO} . \mathrm{H}_{2} \mathrm{O}\right)$ with considerable manganese.

Manganomagnetite........... Magnetite $\left(\mathrm{Fe}_{3} \mathrm{O}_{4}\right)$ with 4 to 6 per cent manganese.

$a$ Compiled from Dana, E. S., System of mineralogy; Palache, Charles, Franklin Furnace folio (No. 161), Geol. Atlas U. S., U. S. Geol. Survey, 1909, pp. 89-110; and other sources. 
Mineral.

Oxides-Continued.

Composition.

Bixbyite. $\mathrm{FeO} \cdot \mathrm{MnO}_{2}$.

Crednerite. $3 \mathrm{CuO} .2 \mathrm{Mn}_{2} \mathrm{O}_{3}$.

Jacobsite................. (Mn, $\mathrm{Mg}) \mathrm{O} .(\mathrm{Fe}, \mathrm{Mn})_{2} \mathrm{O}_{3}$.

Hetærolite............... $\mathrm{ZnO} \cdot \mathrm{Mn}_{2} \mathrm{O}_{3} \cdot \mathrm{H}_{2} \mathrm{O}(?)$. A zinc-bearing hausmannite.

Manganosite.................

Zincite (manganiferous)..... (Zn,Mn)O.

Carbonates:

Rhodochrosite.................

Manganocalcite (calcimangite, spartaite $) \ldots \ldots \ldots \ldots \ldots \ldots(\mathrm{Ca}, \mathrm{Mn}) \mathrm{CO}_{3}$. Calcite $\left(\mathrm{CaCO}_{3}\right)$ with varying amounts of manganese.

Manganosiderite............ $(\mathrm{Fe}, \mathrm{Mn}) \mathrm{CO}_{3}$.

Ankerite............... (Ca, $\mathrm{Mg}, \mathrm{Fe}, \mathrm{Mn}) \mathrm{CO}_{3}$.

Silicates:

Rhodonite.................. $\mathrm{MnSiO}_{3}$. Manganese metasilicate.

Bustamite................ (Mn, $\mathrm{Ca}) \mathrm{SiO}_{3} \cdot \mathrm{nCaCO}_{3}$. Manganese-calcium metasilicate.

Ferrorhodonite.............. (Mn, $\mathrm{Fe}) \mathrm{SiO}_{3}$. Manganese-iron metasilicate. .

Fowlerite................ (Mn, $\mathrm{Zn}, \mathrm{Fe}, \mathrm{Ca}) \mathrm{SiO}_{3}$. Manganese-zinc metasilicate. Hydrorhodonite............ Alteration product from rhodonite to serpentine.

Leucophoenicite........... $\mathrm{H}_{2}(\mathrm{Mn}, \mathrm{Zn}, \mathrm{Ca})_{7} \mathrm{Si}_{3} \mathrm{O}_{14}$.

Glaucochroite............... $\mathrm{CaMnSiO}_{4}$.

Tephroite................ $\mathrm{Mn}_{2} \mathrm{SiO}_{4}$. Manganese olivine.

Knebelite.................. $(\mathrm{Fe}, \mathrm{Mn})_{2} \mathrm{SiO}_{4}$

Hortonolite.............. $(\mathrm{Fe}, \mathrm{Mg}, \mathrm{Mn})_{2} \mathrm{SiO}_{4}$. Manganiferous olivines.

Rœpperite..............Zinc-bearing tephroite.)

Helvite.................

Danalite................ (Gl, Fe, $\mathrm{Zn}, \mathrm{Mn})_{7} \mathrm{Si}_{3} \mathrm{O}_{12} \mathrm{~S}$.

Friedelite............... $\mathrm{H}_{7}(\mathrm{Mn}, \mathrm{Cl}) \mathrm{Mn}_{4} \mathrm{Si}_{4} \mathrm{O}_{16}(\mathrm{Groth}) . \quad \mathrm{H}_{7}(\mathrm{Mn}, \mathrm{Cl}) \mathrm{Mn}_{4}\left(\mathrm{SiO}_{4}\right)$ (Palache).

Pyrosmalite............... $\mathrm{H}_{7}((\mathrm{Fe}, \mathrm{Mn}) \mathrm{Cl})(\mathrm{Fe}, \mathrm{Mn})_{4} \mathrm{Si}_{4} \mathrm{O}_{16}$.

Trimerite.................

Spessartite.............. $\mathrm{Mn}_{3} \mathrm{Al}_{2}\left(\mathrm{SiO}_{4}\right)_{2}$. Manganese-aluminum garnet.

Rothoffite (polyadelphite)...Manganese-calcium-iron garnet. Manganiferous andradite $\left(\mathrm{Ca}_{3} \mathrm{Fe}_{2}\left(\mathrm{SiO}_{4}\right)_{3}\right)$. (Polyadelphite $(\mathrm{Ca}, \mathrm{Mn})_{3}$ $\left.(\mathrm{Fe}, \mathrm{Al})_{2} \mathrm{Si}_{3} \mathrm{O}_{2}\right)$.

Manganpectolite............. Pectolite $\left(\mathrm{HNaCa}_{2}\left(\mathrm{SiO}_{3}\right)_{3}\right)$, with 4 per cent of $\mathrm{MnO}$. Willemite (manganiferous) ...( $\mathrm{Zn}, \mathrm{Mn})_{2} \mathrm{SiO}_{4}$. Troostite and tephrowillemite are varieties of willemite rich in manganese.

Manganchlorite............. Clinochlore $\left(\mathrm{H}_{8} \mathrm{Mg}_{5} \mathrm{Al}_{2} \mathrm{Si}_{3} \mathrm{O}_{18}\right)$ with 2.3 per cent $\mathrm{MnO}$.

Piedmontite............... Epidote $\left(\mathrm{HCa}_{2}(\mathrm{Al}, \mathrm{Fe})_{3} \mathrm{Si}_{3} \mathrm{O}_{13}\right)$ with 5 to 15 per cent $\mathrm{Mn}_{2} \mathrm{O}_{3}$.

Manganophyllite........... Biotite with considerable manganese.

Dannemorite.............. Iron-manganese amphibole.

Hornblende (manganiferous).

Richterite................. $\left(\mathrm{K}_{2}, \mathrm{Na}_{2}, \mathrm{Mg}, \mathrm{Ca}, \mathrm{Mn}\right)_{4}\left(\mathrm{SiO}_{3}\right)_{4}$. Sodium - magnesiummanganese amphibole.

Edenite (manganiferous)....Aluminous calcium-magnesium amphibole with manganese.

Arfvedsonite (manganifer-

ous) ................ Sodium-calcium, ferrous iron metasilicate with manganese. 
Silicates-Continued.

Mineral.

Manganhedenbergite

Schefferite.

Jeffersonite.

Hancockite.

Babingtonite

Staurolite (manganiferous).... $\mathrm{H}_{2} \mathrm{O} .2 \mathrm{FeO} .5 \mathrm{Al}_{2} \mathrm{O}_{3} .4 \mathrm{SiO}_{2}$ with manganese.

Manganandalusite............Manganiferous andalusite $\left(\mathrm{AlSiO}_{5}\right)$.

Ilvaite (manganiferous)...... Calcium-iron silicate with manganese.

Ardennite. . . . . . . . . . . Aluminum-manganese vanadio silicate.

Carpholite............... $\mathrm{H}_{4} \mathrm{MnAl}_{2} \mathrm{Si}_{2} \mathrm{O}_{10}$.

Inesite. . . . . . . . . . . . . . $2(\mathrm{Mn}, \mathrm{Ca}) \cdot \mathrm{SiO}_{3} \cdot \mathrm{H}_{2} \mathrm{O}$. Manganiferous zeolite.

Ganophyllite............6 $\mathrm{H}_{2} \mathrm{O} .7 \mathrm{MnO} . \mathrm{Al}_{2} \mathrm{O}_{3} \cdot 8 \mathrm{SiO}_{2}$. Manganiferous zeolite.

Axinite.

( $\mathrm{Ca}, \mathrm{Mn}, \mathrm{Fe})_{7} \mathrm{Al}_{4} \mathrm{~B}_{2}\left(\mathrm{SiO}_{4}\right)_{8}$.

Bementite.

$2 \mathrm{MnSiO}_{3} \cdot \mathrm{H}_{2} \mathrm{O}$.

Caryopilite.

$-4 \mathrm{MnO} .3 \mathrm{SiO}_{2} \cdot 3 \mathrm{H}_{2} \mathrm{O}$.

Neotocite

Miscellaneous:

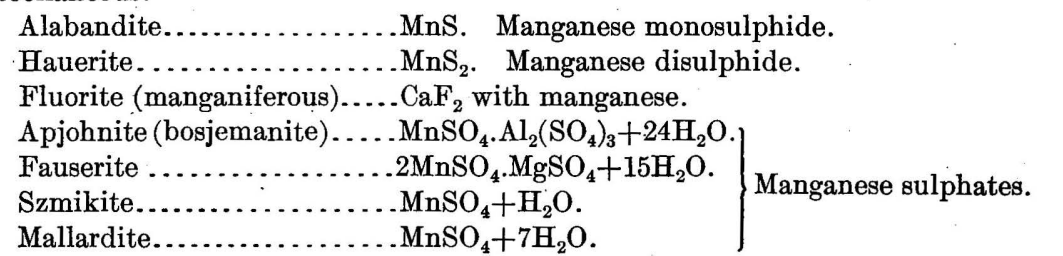

Kaneite................. $\mathrm{Mn}_{5} \mathrm{As}_{4}$. Manganese arsenide.

Chondrarsenite. . . . . . . . . . Mn $\mathrm{Mn}_{3} \mathrm{As}_{2} \mathrm{O}_{8} \cdot 3 \mathrm{Mn}(\mathrm{OH})_{2}$. Manganese arsenate.

Xantharsenite............. Near chondrarsenite, but contains more water.

Sarkinite................. $\mathrm{Mn}(\mathrm{OH})_{2} \cdot \mathrm{Mn}_{3} \mathrm{As}_{2} \mathrm{O}_{8}$.

Allactite................... $\mathrm{Mn}_{3} \mathrm{As}_{2} \mathrm{O}_{8} .4 \mathrm{Mn}(\mathrm{OH})_{2}$.

Synadelphite. . . . . . . . . . $2(\mathrm{Al}, \mathrm{Mn}) \mathrm{AsO}_{4} .5 \mathrm{Mn}(\mathrm{OH})_{2}$.

Flinkite................... $\mathrm{MnAsO}_{4} .2 \mathrm{Mn}(\mathrm{OH})_{2}$.

Hematolite. . . . . . . . . . (Al, Mn $) \mathrm{AsO}_{4} .4 \mathrm{Mn}(\mathrm{OH})_{2}$.

Arseniopleite.............. Calcium-manganese arsenate.

Manganostibiite............ Basic manganese antimonate.

Retzian................... Basic arsenate of yttrium earths, manganese and calcium.

Triphylite............... Li $(\mathrm{Fe}, \mathrm{Mn}) \mathrm{PO}_{4}$. Lithium - iron-manganese phosphate.

Lithiophilite............ Li(Mn,Fe) $\mathrm{PO}_{4}$. Lithium - manganese - iron phosphate.

Natrophilite............. Na, $\mathrm{MnPO}_{4}$. Sodium-manganese phosphate.

Hureaulite................ Manganese phosphate.

Dickinsonite.............. Chiefly Mn,Fe,Na hydrated phosphate.

Reddingite............... $(\mathrm{Mn}, \mathrm{Fe})_{8}\left(\mathrm{PO}_{4}\right)_{2} \cdot 3 \mathrm{H}_{2} \mathrm{O}$.

Manganapatite........... $[(\mathrm{Ca}, \mathrm{Mn}) \mathrm{F}] \mathrm{Ca}_{4}\left(\mathrm{PO}_{4}\right)_{3}$. Apatite with manganese replacing calcium to 10.5 per cent $\mathrm{MnO}$.

Fairfieldite (leucomanganite $) \ldots \ldots \ldots \ldots \ldots \ldots(\mathrm{MnCa})_{3}\left(\mathrm{PO}_{4}\right)_{2} \cdot 2 \mathrm{H}_{2} \mathrm{O}$.

Triplite. . . . . . . . . . . . Iron-manganese-calcium-magnesium phosphate.

Wolframite................. $(\mathrm{Fe}, \mathrm{Mn}) \mathrm{WO}_{4}$. Iron-manganese tungstate. 


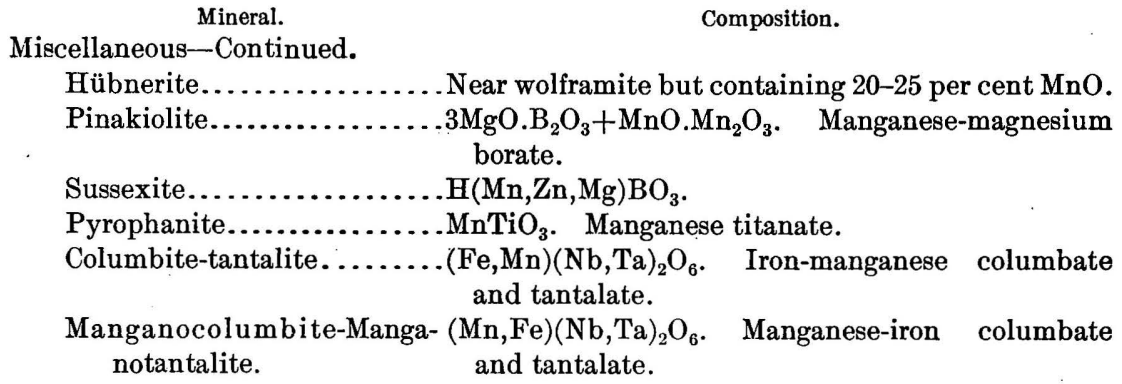

MANGANESE IN THE DẸP SEA.

Manganese oxides occur locally in the deep sea in the form of concretions and nodules, ${ }^{a}$ to which the names pelagite and halobolite have been given. During the Challenger expedition ${ }^{a}$ these were found in many parts of the Pacific Ocean in deep-sea red clay at depths of about 2,220 fathoms. They were especially abundant between Hawaii and Japan, where locally the floor of the sea was covered with these potato-like concretions associated with pumice and red clay. The concretions are made up of concentric layers, thin on the outside but coarser in the interior, and many of them contain fragments of pumice, shark's teeth, mollusk shells, coral, and other materials.

The nodules vary considerably in composition, the percentage of ferric oxide ranging up to 40 and that of manganese dioxide up to 55 , the one being low when the other is high. Silica, alumina, and lime are present in considerable quantities.

The following are analyses of deep-sea manganese concretions, No. 1 by Schwager, Nos. 2 and 3 from the Challenger report.

Analyses of deep-sea manganese concretions.

\begin{tabular}{|c|c|c|c|c|}
\hline & 1. & . & 2. & 3. \\
\hline 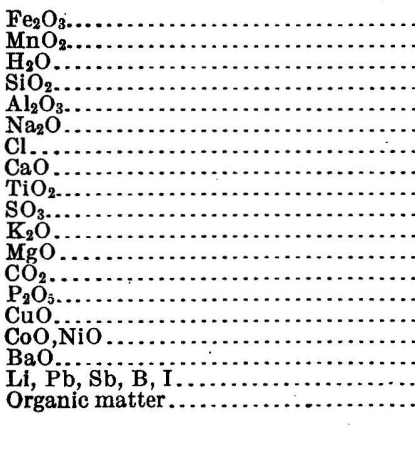 & \begin{tabular}{|c}
27.46 \\
23.60 \\
17.82 \\
16.03 \\
10.21 \\
2.36 \\
.94 \\
.92 \\
.66 \\
.48 \\
.40 \\
.18 \\
.05 \\
.02 \\
.02 \\
.01 \\
.009 \\
Trace. \\
Trace. \\
101.17
\end{tabular} & 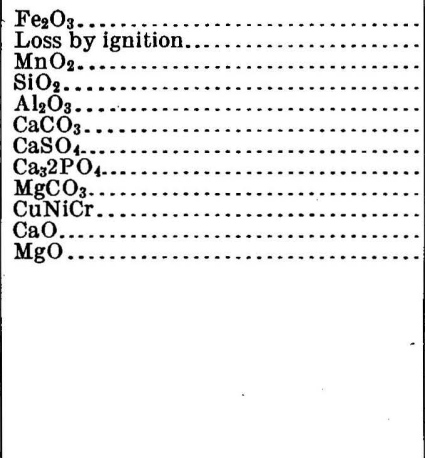 & $\begin{array}{r}6.78 \\
55.67 \\
11.80 \\
14.10 \\
3.00 \\
5.57 \\
.58 \\
\text { Trace. } \\
1.90 \\
\text { Trace. } \\
.49 \\
.11\end{array}$ & $\begin{array}{r}41.39 \\
22.80 \\
18.30 \\
6.66 \\
2.25 \\
5.15 \\
1.17 \\
.34 \\
1.51 \\
\text { Trace. } \\
.25 \\
.18\end{array}$ \\
\hline
\end{tabular}

$a$ Deep-sea deposits: Rept. Scientific Results Voy. H. M. S. Challenger, 1873-1876, p. 341; also, Stelzner, A. W., and Bergeat, A., Die Erzlagerstätten, 1. Hälfte, p. 261. 
The Gazelle, ${ }^{a}$ during its expedition, found manganese concretions in many places in the Pacific Ocean, but in greatest abundance near Cook Island. Chun ${ }^{b}$ speaks of the occurrence of manganiferous iron concretions, some of which are as large as 8 centimeters in diameter, in the southern Atlantic Ocean, at a depth of 6,700 meters. Andrussow ${ }^{c}$ mentions the occurrence of similar concretions in the Black Sea.

Gümbel believes that deep-sea manganese concretions find their origin in subterranean volcanic eruptions, and that they originate by the accumulation of manganese and iron oxides on the sea bottom without any additions from organisms.

\section{MANGANIFEROUS IRON ORES.}

Manganiferous iron ores consist of a mixture of iron and manganese oxides in varying proportions. The iron is generally in the form of limonite, as in the manganiferous iron ores of the Appalachian region, though frequently it occurs as hematite, as in the Lake Superior ores. The manganese is mostly in the form of psilomelane, though pyrolusite is often abundant. Rarely iron oxides and manganese carbonate are associated, as at Chevron, Belgium, and in Wales. The manganese and iron oxides may occur together as a coarse mixture easily separated, or they may be so closely associated as to be indistinguishable to the eye. In most deposits where the individual oxides may be recognized the manganese seems to have penetrated into the mass, while the iron is nearer the surface. Small masses of psilomelane are frequently found in the interior of limonite nodules, and limonite is found lining cavities in manganese ores. The two oxides may be so intermixed, however, that there seems to be no definite relation between them. In some iron-ore deposits there are portions in which pockets of manganese ore occur, while the rest of the body may be pure iron ore. In many manganese deposits the upper portion is ferruginous, containing limonite as surface coatings or intimately mixed with the manganese ore.

The amount of metallic manganese in manganiferous iron ore varies from less than 1 per cent to 40 per cent or more. The high and medium grades of ore are used in the manufacture of spiegeleisen and ferromanganese, but the ore that contains only a small percentage of manganese is not used for this metal, but for its iron only. Highgrade manganiferous iron ore is found in the Appalachian and New England regions; low-grade ore occurs in the same regions and also in the Lake Superior district and in Arkansas.

- $a$ Gümbel, K. W. von, Forschungsreise S. M. S. Gazelle, II. Teil, pp. 33-36.

$b$ Chun, Carl, Aus den Tiefen des Weltmeeres: Schilderungen von der deutschen Tiefsee Expedition, 1903, pp. 162-63.

c Andrussow, N., Guide des excursions du VII Congrès géol. Internat., 1897, XXIX, p. 13. 


\section{MANGANIFEROUS SILVER ORES.}

Manganiferous silver ores occur abundantly in the oxidized portions of many of the silver deposits of western United States. They consist of manganese and iron oxides, carrying silver chloride and lead carbonate. The iron and manganese are intimately associated, forming a black amorphous ore. The iron is probably in the form of limonite and the manganese in the form of wad. As a rule, iron oxide predominates over manganese oxide, though locally, as at Butte, it is almost entirely absent. The lead sometimes occurs partly as the unaltered sulphide.

The unoxidized ores from which these ores are derived consist of silver, lead, zinc, and iron sulphides in a gangue of quartz, which in some places, as at Butte, is mixed with manganese carbonate and silicate. In other places, as at Leadville, manganese minerals are altogether lacking in the unoxidized ore, though they are abundant in the oxidized product. Zinc is rarely present in the oxidized zone, being readily dissolved and carried downward. Gold occurs in small quantities locally.

With regard to use, manganiferous silver ores may be classed under three heads:

(1) Ores with a high percentage of silver and lead and used for these metals only. The manganese and iron oxides present are a valuable aid in fluxing, and such ores as contain considerable quantities of them draw higher prices than other silver ores with the same silver content.

(2) Ores that are low in silver and lead but contain a large quantity of iron and manganese are utilized in the manufacture of spiegeleisen and ferromanganese. Under this head there may be included as a subclass ores that are too low in manganese to be used as a source for iron-manganese alloys and that are used for their iron content only.

(3) Ores that are too low in silver and lead to be used directly as a source of these metals and too low in iron and manganese to be used for the manufacture of spiegeleisen and ferromanganese are sent to the smelters to be used for fluxing purposes on account of their content of iron and manganese oxides. The silver and lead present, however, are recovered during the smelting, while the iron and manganese pass into the slag and are lost.

Ores of the first and third classes are mined in many silver districts of the West; those of the second class have been shipped only from the Leadville district. 


\section{MANGANIFEROUS ZINC RESIDUUM.}

Manganiferous zinc residuum consists essentially of a mixture of iron and manganese oxides in various proportions. The ore from which it is obtained is a mixture of franklinite, willemite, and zincite, the first predominating. Tephroite and rhodonite are present in some ores and calcite forms the gangue. During the roasting the zinc is removed as zinc oxide, while the oxides of the other metalsthat is, iron and manganese-remain as a waste product. This material has been used for the manufacture of spiegeleisen since 1870 . It is obtained only from zinc works treating New Jersey zinc ores. 


\section{CHAPTER II.}

\section{MANGANESE DEPOSITS OF THE UNITED STATES.}

\section{NEW ENGLAND REGION AND NEW YORK.}

\section{NEW ENGLAND CRYSTALIINE AREA.}

Manganese deposits occur in New England in both crystalline and sedimentary areas. Those in the crystalline area consist principally of rhodonite, but include some deposits of wad, probably derived from it. The deposits of this nature are scattered and are too small to be of any importance. Among the best known are the rhodonite at Blue Hill, Me., said to have been mined for fluxing purposes, and that at Cummington, Mass., mined for ornaments and for jewelry on account of its beautiful pink color. At Blue Hill ${ }^{a}$ the rhodonite occurs in a vein 15 feet wide running east-northeast by west-southwest through a hill of contorted gneiss; at Cummington it occurs in Emerson's ${ }^{b}$ Conway schist, of Silurian age, about 1 mile west of the town. Impure mixtures of rhodonite and wad occur near Winchester and Hinsdale, N. H., ${ }^{c}$ at Plainfield, Conway, ${ }^{c}$ Chesterfield, ${ }^{d}$ Sheffield, ${ }^{e}$ and other localities in Massachusetts, and at Sneech Pond $f$ and Pawtucket in Rhode Island. Deposits of bog manganese occur in Knox and Oxford counties, Me.

Analyses of manganese ore from the New England crystalline area are given below:

Analyses of manganese ore from Blue Hill, Me.a

\begin{tabular}{|c|c|c|c|}
\hline . & 1. & 2. & 3. \\
\hline 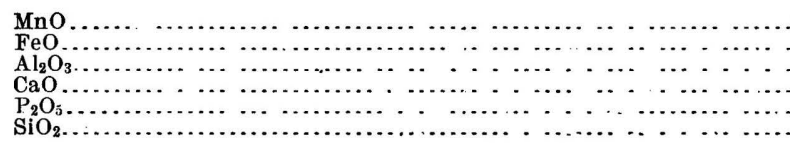 & $\begin{array}{r}35.13 \\
14.01 \\
7.45 \\
3.49 \\
1.02 \\
35.84\end{array}$ & $\begin{array}{r}29.72 \\
24.31 \\
3.04 \\
5.02 \\
35.70\end{array}$ & $\begin{array}{l}15.00 \\
12.00 \\
\cdots \cdots \\
39.00\end{array}$ \\
\hline $\begin{array}{l}\text { Mn } \\
\text { Fe } \\
\text { P } \ldots \ldots \ldots\end{array}$ & $\begin{array}{r}27.20 \\
10.90 \\
.45\end{array}$ & $\begin{array}{l}23.02 \\
19.37\end{array}$ & $\begin{array}{r}11.62 \\
9.33 \\
\cdots\end{array}$ \\
\hline
\end{tabular}

$a$ Weeks, J. D., Sixteenth Ann. Rept. U. S. Geol. Survey, pt. 3, 1895, p. 416.

$b$ Emerson, B. K., Holyoke folio (No. 50), Geol. Atlas U. S., U. S. Geol. Survey, 1898, p. 2.

$c$ Hitchcock, Edward, Report on the geology of Massachusetts: Am. Jour. Sci., 1st ser., vol. 22, 1832, p. 61 .

d Mead, William, Localities of minerals: Am. Jour. Sci., 1st ser., vol. 7, 1834, p. 54.

e Am. Jour. Sci., 1st ser., vol. 4, 1822, p. 189.

f Jackson, C. T., Am. Jour Sci., 1st ser., vol. 40, p. 185. 
$\mathrm{FeO}$

$\mathrm{SiO}_{2}$

$\mathrm{CO}_{2}$

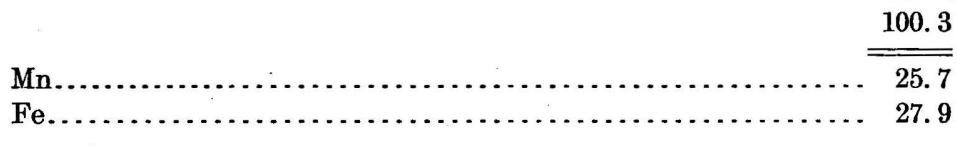

NEW ENGLAND SEDIMENTARY AREA.

GENERAL STATEMENT.

Manganese ores associated with sedimentary rocks occur in western New England together with the iron-ore deposits. Small quantities of manganese ore are present in most of the brown iron ore deposits in this region and in a few of them it is present in sufficient amount to form a manganiferous iron ore, as in Vermont. Even in Vermont, however, the larger part of the deposits is brown iron ore.

The manganese ore occurs as kidneys and irregular pockets in clay. The kidneys are scattered through clay beds in association with fragments of brown iron ore, or occur separately. They are composed mainly of black psilomelane with nests of pyrolusite. The ore in the pockets consists of a mixture of psilomelane and pyrolusite. In some pockets pure manganese ore occurs; in others manganese and iron ores are mixed in all proportions. Such mixed iron and manganese deposits occur at Redding, Salisbury, and elsewhere in western Connecticut; in the Berkshire Hills and southward in western Massachusetts; and at Brandon, South Wallingford, Chittenden, and many other localities in Vermont.

\section{VERMONT.}

The deposits at Brandon and South Wallingford ${ }^{b}$ occur in Otter Creek valley near the base of the west slope of the Green Mountains. Otter Creek flows northward through this valley, emptying into Lake Champlain. To the east of it are the Green Mountains and to the west are various minor ranges.

The rock forming the lower ridges on the west slope of the Green Mountains is a vitreous Cambrian quartzite; that underlying the valley is a massive or semicrystalline Cambrian limestone of later age. Both have a general north-south strike and a nearly vertical dip. East of the quartzite and forming the main part of the Green Mountains are earlier metamorphic rocks, while west of the valley are fossiliferous rocks of Ordovician and Silurian age.

a Jackson, C. T., loc. cit.

b Penrose, R. A. F., jr., Manganese: Its uses, ores, and deposits: Ann. Rept. Arkansas Geol. Survey for 1890, vol. 1, p. 391 . 
At South Wallingford the ores are found in a clay layer at the contact of the Cambrian quartzite and limestone. (See fig. 1.) This layer has a general north-south direction and a nearly vertical dip. The deposit consists of associated iron and manganese ores, occurring in pockets and nests, in yellow, red, gray, or white clay. The ores of iron and manganese may be in separate pockets or may occur together in the same pocket, mixed in all proportions. The clay bed has a probable average thickness of several hundred feet, and ore is scattered through this at intervals. The deposit is overlain by 10 to 60 feet of glacial drift. The iron ore is limonite; the manganese ore consists of massive psilomelane, crystalline pyrolusite, and probably some manganite. The massive ore occurs mainly in the form of geodes; the crystalline ore, in general, lines cavities in the massive ore.

The deposit near Brandon is in a small tributary valley at a point several miles east of the main Otter Creek valley. It consists of iron

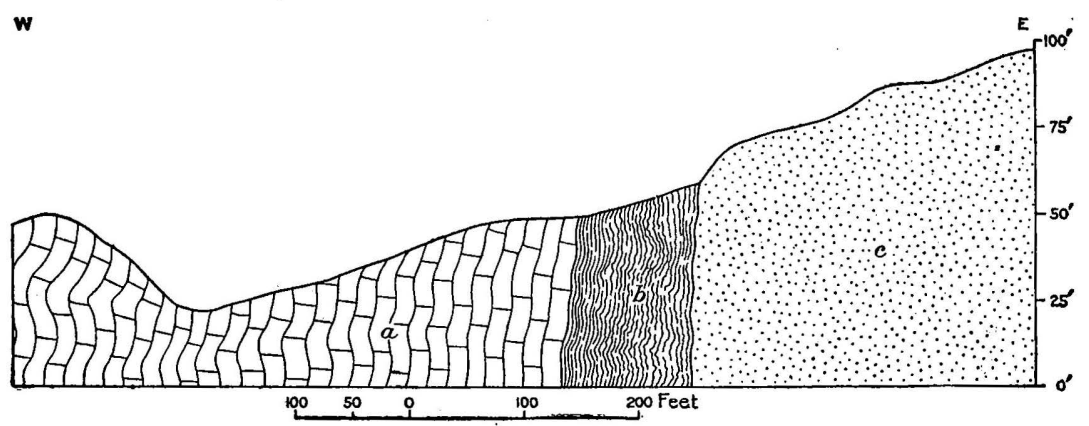

FIGURE 1.-Section through the South Wallingford (Vt.) ore deposit, showing the occurrence of the manganese-bearing clay. (After Penrose.) $a$, Limestone; $b$ manganese-bearing clay; $c$, quartzite.

ore containing manganese ore in subordinate quantities. The ores occur in a brown and white clay that occupies the bottom of the tributary valley. To the east are ridges of quartzite; to the west is white dolomitic limestone. The clay bed overlies their contact, and is in turn overlain by glacial deposits. Fossil plants and fruits of Tertiary (probably Miocene) age have been discovered in lignite in a similar clay bed in the same locality. This makes it probable that the iron and manganese bearing clay is a Tertiary deposit derived from an underlying clay layer similar in position to that containing the South Wallingford ores.

The manganese ore occurs in nodules and in irregular masses, ranging in size from a fraction of an inch to 12 inches or more in diameter. Its characteristic form, however, is that of small kidneyshaped nodules a few inches in diameter, of massive texture, and of steel-blue or black color-probably psilomelane. Many of the larger masses contain cavities lined with crystalline pyrolusite. Some of 
the ore shows concretionary structure. The iron ore is limonite, and the manganese and associated iron ore are concentrated in pockets or scattered irregularly through the clay.

Manganese and manganiferous iron ores have been reported from many other localities in Vermont, ${ }^{a}$ among which are Bennington and Stamford, Bennington County; Pittsford and Chittenden, Rutland County; Plymouth, Windsor County; Topsham, Orange County; Bristol and Monkton, Addison County; Colchester, Chittenden County; and Irasburg and Coventry, Orleans County.

The following are analyses of manganese ore and manganiferous iron ore from Vermont. ${ }^{b}$

Analyses of manganese ores and manganiferous iron ores from Vermont.

\begin{tabular}{|c|c|c|c|c|c|c|}
\hline & 1. & 2. & 3. & 4. & 5. & 6. \\
\hline 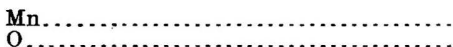 & 44. 107 & 35.00 & 48. 778 & \multirow{2}{*}{$\begin{array}{l}58.62 \\
27.72\end{array}$} & 20.369 & 19. 706 \\
\hline 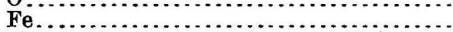 & 7.18 & 25.00 & 4. 97 & & 31.648 & \multirow{3}{*}{$\begin{array}{r}29.268 \\
14.000 \\
.145 \\
8.000\end{array}$} \\
\hline $\mathrm{SiO}_{2 .}$ & 9.23 & 3.10 & 7. 90 & \multirow{2}{*}{$\begin{array}{r}3.60 \\
9.75\end{array}$} & 12. 770 & \\
\hline Moisture.......... & $\cdots$ & & .111 & & $\begin{array}{r}.125 \\
5.000\end{array}$ & \\
\hline
\end{tabular}

1, 2, 3. Manganese ore from South Wallingford.

4. Manganese ore from Brandon.

5, 6. Manganiferous iron ore from Vermont.

NEW YORK.

Small deposits of manganese ore, mainly in the form of wad and bog manganese, are distributed through various parts of New York, being most numerous in the southeastern part. No ores, however, have been shipped from this State.

Manganese ores ${ }^{c}$ occur in the eastern part of the State at Austerlitz, Hillsdale, and Canaan Center, Columbia County; At Unionvale, Dutchess County; near Sing Sing, Westchester County; near Warwick, Orange County; near Keeseville, Essex County, and in New York, Albany, Warren, and Rensselaer counties. In the north-central part they are found at Tug Hill, near Houseville, Lewis County; in the western part small deposits are found in Conewango and Little valleys, and near Randolph, Cattaraugus County, and in Allegany County.

The deposits of Columbia County consist of beds of wad on low ground below a slate ridge. In the slates are veins of quartz containing brown spar composed of lime and magnesia and oxides of iron and manganese, the solution and redeposition of which forms the deposits.

At Unionvale a crystalline gray oxide of manganese is found in geodes in brown iron ore. It has the following composition:

Mn oxides.......................................... 83.33

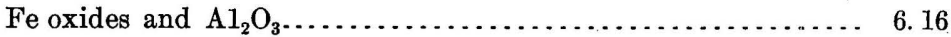

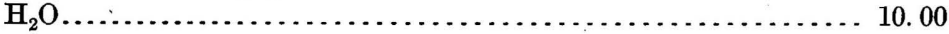

$a$ Geology of Vermont, 1861, p. 811.

b Penrose, R. A. F., jr., op. cit., pp. 395, 398.

c Beck, L. C., Nat. Hist. New York, Div. III, Mineralogy, 1842, pp. 53-54 and 406-407. 
Near Sing Sing the manganese occurs in dolomite as nodules of black oxide with a trace of copper; near Warwick as a black oxide mixed with iron ores. In Warren and Essex counties it occurs as a mixture of rhodonite and wad. At Tug Hill in Lewis County manganese occurs as a bed of earthy oxide in a marsh. In Cattaraugus and Allegany counties the black oxide is found scattered through the surface soil in grains and fragments ranging in size from that of shot to that of a walnut.

The following analyses show the composition of manganese and manganiferous iron ores from New York:

Analyses of manganese ore and manganiferous iron ore from New York. ${ }^{a}$

\begin{tabular}{|c|c|c|c|c|c|c|c|}
\hline & 1. & 2. & 3. & 4. & 5. & 6. & 7. \\
\hline 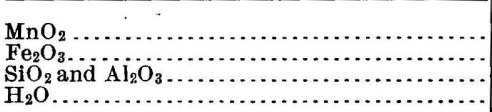 & $\begin{array}{r}68.50 \\
16.75 \\
3.25 \\
11.50\end{array}$ & $\begin{array}{r}58.50 \\
22.00 \\
2.50 \\
17.00\end{array}$ & $\begin{array}{r}50.50 \\
24.50 \\
4.50 \\
20.50\end{array}$ & $\begin{array}{r}53.00 \\
32.15 \\
6.90 \\
6.85\end{array}$ & $\begin{array}{r}33.40 \\
34.10 \\
8.75 \\
24.00\end{array}$ & $\begin{array}{l}11.45 \\
28.20 \\
44.75 \\
15.60\end{array}$ & $\begin{array}{r}26.66 \\
6.00 \\
57.50 \\
9.83\end{array}$ \\
\hline
\end{tabular}

$a$ Beck, L. S., op. cit., p. 55 .

$\begin{array}{ll}\text { 1. From Hillsdale, Columbia County. } & \text { 5. From Keeseville, Essex County. } \\ \text { 2. From Austerlitz, Columbia County. } & \text { 6. From Tug Hill, Lewis County. }\end{array}$

$\begin{array}{ll}\text { 2. From Austerlitz, Columbia County. } & \text { 6. From Tug Hill, Lewis County. } \\ \text { 3. From Canaan Center, Columbia County. } & \text { 7. From Warwick, Orange County. }\end{array}$

4. From Sing Sing, Westchester County.

\section{COMMERCIAL IMPORTANCE OF THE ORES.}

The manganese deposits of New England and New York are of very little commercial importance, and no manganese ore is being produced here at present. A small amount of rhodonite has been mined in western Massachusetts and used for ornamental purposes, and manganiferous iron ore has been shipped from the South Wallingford, Brandon, and Chittenden districts in Vermont, and from Salisbury, Conn. The Vermont ores were used for their manganese content, but the Salisbury ores were used largely for their iron content. A mixture of rhodonite and wad is said to have been mined at Blue Hill, Me., and used for fluxing in the Katahdin furnaces. New York has never produced manganese ores.

The Vermont deposits are the only ones to which any importance can be attached. They are of considerable extent and may be expected to yield a fair supply of ore for use in the manufacture of spiegeleisen.

\section{PIEDMONT REGION AND COASTAL PLAIN。}

\section{GENERAL STATEMENT.}

The Piedmont region, as here treated, comprises a belt of territory underlain by crystalline rocks, extending from New Jersey to Alabama. In the northern half it contains considerable areas of Triassic trap and sandstone that conceal the underlying crystalline 
rocks and also a few areas of Paleozoic sediments. It is bounded on the east by the fall line, which marks the contact between the crystalline rocks and the Mesozoic sediments of the Coastal Plain, and on the west by the Appalachian Mountains. In Virginia the Blue Ridge marks the contact between the crystalline rocks of the Piedmont region and the Paleozoic sediments of the Appalachian Valley belt. Farther north the boundary is somewhat indefinite, for the Paleozoic rocks extend southoastward beyond the front ranges of the Appalachians. Southward from Virginia the crystalline rocks extend west of the Blue Ridge into the Appalachian Mountains. All the manganese deposits in the crystalline and metamorphic rocks will be described as in the Piedmont region.

East of the Piedmont region is the Coastal Plain, which occupies a belt of territory lying parallel to the Piedmont region and extending eastward from it to the Atlantic Ocean. It is underlain by sediments, largely unconsolidated, of Mesozoic and Cenozoic age.

Manganese ores occur in the Piedmont region from New Jersey to Georgia, the principal deposits being in the James River-Staunton River region, in Virginia; between Kings Mountain and Blacksburg on the boundary of North Carolina and South Carolina; and near McCormick, S. C. Minor deposits occur at Mount Airy, Bowersville, and Draketown, Ga., ${ }^{a}$ and in other parts of South Carolina, North Carolina, and Virginia.

As far as known only one small deposit of manganese ore has been found on the Coastal Plain -in Tertiary rocks near City Point, Prince George County, Va., in association with iron ores. Several hundred tons of ore are said to have been mined. ${ }^{b}$

Manganiferous zinc ores occur at Franklin Furnace and Ogdensburg, Sussex County, N. J., and manganiferous iron ores are found in small quantities at various localities in the Piedmont region.

The rocks of the Piedmont Plateau are ancient crystallines and metamorphics, in many places so altered that their original character is indistinguishable. The main types are schists, granites, and gneisses, with which are associated smaller amounts of slates, quartzites, and crystalline limestones. These are intricately folded, faulted, and metamorphosed and form a basement into which dikes and masses of gabbro, diabase, and diorite have been intruded.

All of these rocks have suffered considerable disintegration and decomposition, the weathered zone in some places reaching to a depth of 150 feet or more. It is in this zone that the manganese deposits occur. Generally the surface material consists of unconsolidated sands and clays that retain to a marked degree the structure of the

$a$ Watson, Thomas L., Preliminary report on the manganese deposits of Georgia: Bull. Georgia Geol. Survey No. 14, pp. 158 et seq.

$b$ Weeks, J. D., Mineral Resources U. S. for 1885, p. 309 . 
original rocks and contain the original rock materials, such as flakes of mica and fragments of quartz and feldspar. The weathering is rarely so complete as to obliterate structures and textures entirely. Hard masses of less easily disintegrated rock are imbedded in the clay and sand, and at many places relatively solid layers of granite are found between soft, decomposed layers of mica schist.

\section{FRANKLIN FURNACE, N. J.}

Deposits of manganiferous zinc ores occur at Mine Hill (Franklin Furnace) and Sterling Hill (Ogdensburg), Sussex County, N. J. ${ }^{a}$ These two deposits, which are about 3 miles apart, occur as bands in white crystalline limestone, associated with bands of gneiss. Both limestone and gneiss are intruded by masses of later granitoid gneiss and by pegmatite lenses and trap dikes.

The ore band at Mine Hill is closely associated with the gneiss both in position and structure, being only 30 feet from the boundary of a gneiss band on the west and outcropping parallel to it in a northeast-southwest direction for 2,600 feet. At its northeast end it disappears under Paleozoic sediments. At its southwest end it turns sharply to the northeast and continues in this direction nearly parallel to the main band for 600 feet, when it disappears from the surface, but continues underground for a distance of 1,000 feet or more. The deposit is in the form of a northward-pitching trough with limbs of unequal height, the elbow at the south end being formed where the bottom of the trough comes to the surface. The west limb has an average dip of $55^{\circ}$ to the east and a maximum depth along this dip of 1,350 feet at a point near its northernmost outcrop. The east limb has a nearly vertical dip, though locally it dips steeply to the east. It has a maximum height of 300 feet at a point just north of the place where it disappears from the surface. North of this point it gradually shortens and at length disappears and only the west limb remains. The ore body varies in width from 12 to 100 feet, the average width of the west limb being 70 feet and that of the east limb 35 feet.

The deposit at Sterling Hill is also in the form of a northeastwardpitching trough, causing the ore band to outcrop in a hook, both ends of which strike northeast. The west limb outcrops for a distance of 600 feet and the east limb for 1,500 feet from the turn of the hook. Both limbs dip to the southeast at angles ranging from $45^{\circ}$ to $60^{\circ}$. They vary in thickness from 10 to 30 feet.

The ores consist principally of zincite (red oxide of zinc $(\mathrm{ZnO})$ ), willemite (silicate of zinc $\left.\left(\mathrm{Zn}_{2} \mathrm{SiO}_{4}\right)\right)$, and franklinite $((\mathrm{Fe}, \mathrm{Zn}, \mathrm{Mn}) \mathrm{O}$. $\left.(\mathrm{Fe}, \mathrm{Mn})_{2} \mathrm{O}_{3}\right)$, associated locally with tephroite $\left(\mathrm{Mn}_{2} \mathrm{SiO}_{4}\right)$ and rhodonite

$a$ Spencer, A. C., Franklin Furnace folio (No. 161), Geol. Atlas U. S., U. S. Geol. Survey, 1908, p. 24. Wolff, J. E., Zinc and manganese deposits of Franklin Furnace, N. J.: Bull. U. S. Geol. Survey No. 213, 1903, p. 214.

$37336^{\circ}-$ Bull. $427-10-3$ 
$\left(\mathrm{MnSiO}_{3}\right)$ in small quantities. Zincite, franklinite, and willemite have the following metalliferous content, from which it will be seen that all contain some manganese:

Metalliferous content of ores from Franklin Furnace, $N . J$.

\begin{tabular}{|c|c|c|c|}
\hline & Zincite.' & Willemite. & Franklinite. \\
\hline $\begin{array}{l}\mathrm{Mn} \\
\mathrm{Zn} \\
\mathrm{Fe}\end{array}$ & $\begin{array}{r}a 5 \\
77\end{array}$ & $\begin{array}{r}1 \frac{1}{2}-3 \\
58 \\
1 \frac{1}{2}-3\end{array}$ & $\begin{array}{r}10-19 \\
6-18 \\
39-47\end{array}$ \\
\hline
\end{tabular}

$a$ Includes some iron.

Zincite, willemite, and franklinite occur in varying proportions, sometimes one, sometimes another, being predominant. Calcite is associated with them in considerable quantities as gangue. Garnet is frequently present.

Locally the veins consist entirely of franklinite, while elsewhere this is associated with willemite or zincite, or both. In still other places zincite only is present, occurring in rounded grains or bunches in coarsely crystalline calcite.

The following are estimates of the average mineral composition of zinc ore from Mine Hill:

Mineral composition of zinc ore from Mine Hill.

[1, Ulke; 2, 3, Ricketts.]

\begin{tabular}{|c|c|c|c|}
\hline & 1. & 2. & 3. \\
\hline \multirow[t]{2}{*}{ 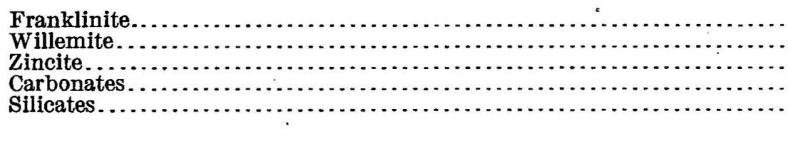 } & $\begin{array}{r}51.92 \\
31.58 \\
1.52 \\
12.67 \\
3.31\end{array}$ & $\begin{array}{r}48.20 \\
28.10 \\
2.70 \\
11.32 \\
9.50\end{array}$ & $\begin{array}{r}51.50 \\
20.23 \\
6.40 \\
10.00 \\
11.13\end{array}$ \\
\hline & 100.00 & 99.82 & 99.26 \\
\hline
\end{tabular}

The minerals occur in different forms and sizes-in small flattened lenses, in which the ore shows fine banding or foliation, or in shotlike aggregates. In some places large crystals, 1 to 2 inches in diameter, of zincite or franklinite, are scattered through coarse calcite like a pudding stone. None of the minerals have very distinct crystal faces, although franklinite has a tendency to assume an octahedral form. The minerals appear to be of contemporaneous origin, for each is found inclosed in the other.

From their structure it appears that the ore deposits assumed their present form at the same time as the associated limestone, in which they were probably originally segregated in some other form. They are also closely related to the gneisses. 
The following are analyses of New Jersey zinc ore:

Analyses of New Jersey zinc ore. ${ }^{a}$

\begin{tabular}{|c|c|c|c|c|c|c|c|c|c|c|}
\hline & 1. & 2. & 3. & 4. & 5. & 6. & 7. & 8. & 9. & 10. \\
\hline $\begin{array}{l}\mathrm{SiO}_{2} . \\
\mathrm{Fe}_{2} \mathrm{O}_{3} \\
\mathrm{ZnO} \mathrm{ZnO} \\
\mathrm{Al}_{2} \mathrm{O}_{3} \\
\mathrm{CaO} . \\
\mathrm{MgO} .\end{array}$ & $\begin{array}{r}10.21 \\
.31 .41 \\
15.84 \\
32.83 \\
.21 \\
5.09\end{array}$ & $\begin{array}{r}9.91 \\
31.63 \\
16.46 \\
34.07 \\
.80 \\
4.08 \\
.21\end{array}$ & $\begin{array}{r}11.08 \\
27.54 \\
17.63 \\
35.88 \\
.24 \\
2.01 \\
.77\end{array}$ & $\begin{array}{r}10.28 \\
30.46 \\
15.66 \\
27.15 \\
.09 \\
8.45 \\
.91\end{array}$ & $\begin{array}{r}10.33 \\
30.36 \\
15.95 \\
26.34 \\
1.16 \\
7.15 \\
1.09\end{array}$ & $\begin{array}{r}4.86 \\
30.33 \\
12.30 \\
29.42 \\
.67 \\
12.65\end{array}$ & \begin{tabular}{r}
4.43 \\
30.13 \\
12.21 \\
27.12 \\
\hdashline 12.63 \\
1.69
\end{tabular} & $\begin{array}{r}5.15 \\
27.62 \\
13.09 \\
23.38 \\
.64 \\
14.37 \\
1.98\end{array}$ & $\begin{array}{r}11.77 \\
30.91 \\
10.27 \\
25.71 \\
2.01 \\
10.43 \\
.99\end{array}$ & $\begin{array}{r}9.78 \\
27.20 \\
17.81 \\
22.94 \\
.67 \\
11.46 \\
.74\end{array}$ \\
\hline $\begin{array}{l}\mathrm{Fe} . . . \\
\text { Mn... } \\
\text { Zn... }\end{array}$ & $\begin{array}{l}21.98 \\
12.27 \\
26.34\end{array}$ & $\begin{array}{l}22.14 \\
12.75 \\
27.34\end{array}$ & $\begin{array}{l}19.28 \\
13.60 \\
28.78\end{array}$ & $\begin{array}{l}21.32 \\
12.12 \\
21.79\end{array}$ & $\begin{array}{l}21.25 \\
12.35 \\
21.14\end{array}$ & $\begin{array}{r}21.23 \\
9.53 \\
23.61\end{array}$ & $\begin{array}{r}21.09 \\
9.46 \\
21.76\end{array}$ & $\begin{array}{l}19.33 \\
11.13 \\
18.76\end{array}$ & & $\begin{array}{l}19.04 \\
13.79 \\
18.41\end{array}$ \\
\hline
\end{tabular}

$a$ Weeks, J. D., Manganese: Eleventh Census U. S., Mineral industries, p. 324; also Mineral Resources U. S. for 1885, p. 337

$1,2,3,4,5,9$, and 10 . Ore from Mine Hill.

6, 7, 8. Ore from Sterling Hill.

The ore taken from the mines is crushed and treated with magnetic separators, which yield three products, known as (1) franklinite (2) half-and-half, and (3) willemite. The first product is largely franklinite and is used in the preparation of zinc white (zinc oxide). The residuum left after the zinc is volatilized is used in blast furnaces for the manufacture of spiegeleisen. The second product consists of franklinite, rhodonite, garnet, and other silicates with attached particles of richer zinc minerals. This product also is used in preparing zinc white, but the residuum contains too much silica to be used in the manufacture of spiegeleisen. The third product consists of willemite and zincite with calcite and silicates as impurities. The calcite is removed by means of jigs and concentrating tables and the resulting product is used in making high-grade spelter.

The ores used in the manufacture of zinc white are mixed with anthracite and spread over a thin layer of finely powdered anthracite in the volatilizing and oxidizing furnace. Rarely a flux, dolomite, is used with the half-and-half ore, but never with the franklinite ore. After the furnace is charged an underblast is applied which ignites the lower layer of anthracite and heats the mixture above it. The anthracite mixed with the ore reduces it to metallic zinc, which is volatilized by the heat. The zinc vapor is immediately oxidized and, together with the gasses of combustion, is drawn from the furnace by flues and collected in bags as zinc oxide $(\mathrm{ZnO})$.

The residuum or clinker from the franklinite product, consisting largely of manganese and iron oxides, is sent to the blast furnace to be used in the manufacture of spiegeleisen. It is, of course, richer in manganese and iron than the ores, but still contains considerable impurities derived from both ore and anthracite. The clinker is partly in the form of flat cakes about 2 inches thick and 4 to 10 inches in diameter, and partly in small fragments ranging in size from that of dust to pieces 2 inches in diameter. Only the coarse fragments are util- 
ized in the manufacture of spiegeleisen, the fine material being sifted out. When a low-grade spiegeleisen is desired, the clinker is mixed with iron ore in the blast furnaces, but usually the clinker alone is used.

The following are average analyses of the manganiferous zinc residuum now produced by the New Jersey Zinc Company:

Analyses of manganiferous zinc residuum.

[By the New Jersey Zinc Company.]

\begin{tabular}{|c|c|c|c|c|c|}
\hline $\begin{array}{l}\text { Mn } \\
\mathbf{F e} \\
\mathrm{SiO}_{2}\end{array}$ & $\begin{array}{l}13.80 \\
40.68 \\
12.08\end{array}$ & $\begin{array}{l}12.71 \\
37.66 \\
12.73\end{array}$ & $\begin{array}{l}12.96 \\
38.81 \\
13.01\end{array}$ & $\begin{array}{l}12.52 \\
39.33 \\
14.17\end{array}$ & $\begin{array}{l}\text { 12. } 42 \\
\text { 37. } 70 \\
\text { 14. } 75\end{array}$ \\
\hline
\end{tabular}

Before the installation of the magnetic separators a rough mixture of the ore was used in the zinc oxide furnaces together with anthracite and limestone. The resulting clinker was much more impure and contained almost twice as much silica as the present product.

The following are analyses of various types of clinkers produced by the old methods:

Analyses of clinker from zinc oxide furnaces. ${ }^{a}$

\begin{tabular}{|c|c|c|c|c|c|}
\hline 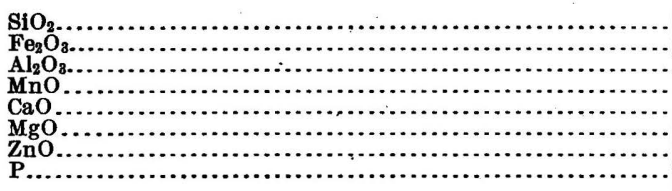 & \begin{tabular}{r|}
19.97 \\
33.21 \\
2.25 \\
17.83 \\
11.96 \\
2.30 \\
10.74 \\
0.37
\end{tabular} & $\begin{array}{r}25.02 \\
31.06 \\
6.36 \\
16.22 \\
10.73 \\
2.67 \\
6.98 \\
\hdashline\end{array}$ & $\begin{array}{r}23.47 \\
33.84 \\
8.24 \\
15.66 \\
11.04 \\
1.84 \\
4.98\end{array}$ & $\begin{array}{r}18.14 \\
36.16 \\
6.94 \\
18.90 \\
11.81 \\
1.98 \\
4.06\end{array}$ & $\begin{array}{r}21.29 \\
31.06 \\
5.98 \\
21.03 \\
7.60 \\
4.01 \\
7.84 \\
\ldots . .\end{array}$ \\
\hline Fen & $\begin{array}{l}23.25 \\
13.82\end{array}$ & $\begin{array}{l}21.74 \\
12.56\end{array}$ & $\begin{array}{l}23.69 \\
12.13\end{array}$ & $\begin{array}{l}25.30 \\
14.64\end{array}$ & $\begin{array}{l}21.74 \\
16.29\end{array}$ \\
\hline
\end{tabular}

a Weeks, J. D., Mineral Resources U. S. for 1885, p. 338.

The following are average analyses of the old clinker from different furnaces:

Average analyses of clinker from the zinc oxide furnaces. ${ }^{-}$

\begin{tabular}{|c|c|c|c|c|c|c|}
\hline \multirow[b]{2}{*}{ 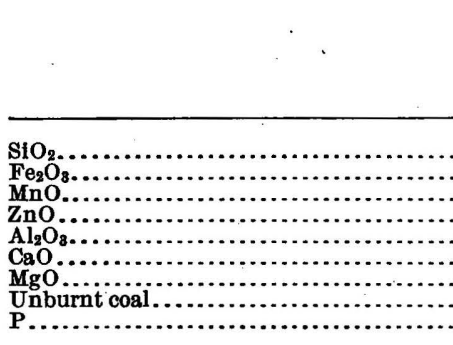 } & \multirow{2}{*}{$\begin{array}{c}\begin{array}{c}\text { Passaic } \\
\text { Zinc } \\
\text { Com- } \\
\text { pany. }\end{array} \\
18.56 \\
36.21 \\
15.69 \\
4.70 \\
4.07 \\
16.70 \\
1.92 \\
1.85\end{array}$} & \multicolumn{2}{|c|}{$\begin{array}{l}\text { New Jersey and } \\
\text { Passaic Zinc } \\
\text { companies. }\end{array}$} & \multicolumn{3}{|c|}{$\begin{array}{l}\text { Lehigh Zinc and Iron Com- } \\
\text { pany. }\end{array}$} \\
\hline & & $\begin{array}{r}20.14 \\
31.37 \\
15.96 \\
3.76 \\
4.44 \\
15.61 \\
2.59\end{array}$ & $\begin{array}{r}18.43 \\
30.13 \\
13.18 \\
4.43 \\
8.65 \\
14.67 \\
3.20\end{array}$ & $\begin{array}{r}25.16 \\
28.99 \\
9.45 \\
4.55 \\
6.57 \\
12.80 \\
4.55 \\
.036\end{array}$ & 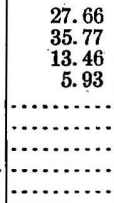 & 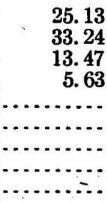 \\
\hline Fen. & $\begin{array}{l}25.35 \\
12.37\end{array}$ & & & $\begin{array}{r}20.29 \\
7.32\end{array}$ & & \\
\hline
\end{tabular}

$a$ Weeks, J. D., Mineral Resources U. S. for 1885, pp. 339-340; also Eleventh Census U. S., Mineral inuustries, p. 328 . 


The following analyses show the composition of spiegeleisen produced by the New Jersey Zinc Company from the old clinker:

Analyses of spiegeleisen produced by New Jersey Zinc Company.

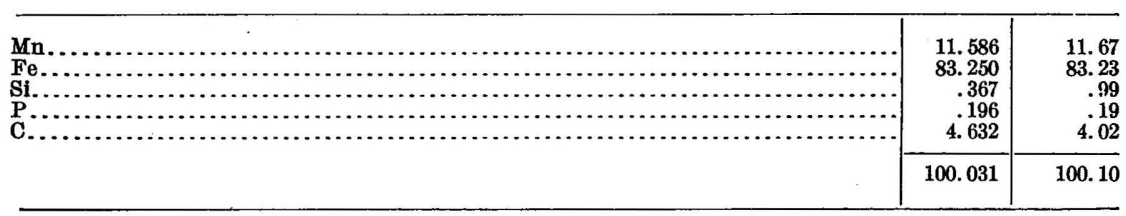

JAMES RIVER-STAUNTON RIVER REGION.

GEOGRAPHY AND GEOLOGY.

The manganese-bearing area of the Piedmont region of Virginia lies northeast and southwest of Lynchburg. It extends from the southern end of Albemarle County southwestward along James River and passes through Mount Athos, Evington, and Lynch to Pittsville, its total length being about 75 miles. (See Pl. II.)

The country rock is decomposed mica schist interlayered with partially decomposed granite. Although this material is largely sand and clay, it retains the original textures to a remarkable degree. It is generally reddish in appearance, though frequently gray and brown colors prevail.

\section{OCCURRENCE OF THE ORES.}

The ore commonly occurs as nodules in layers of micaceous brown and yellowish-brown clay, at or near the contact of decomposed mica schist with granite. Such clay layers vary in width from a few inches to 20 feet or more, grading on both sides into the rocks bounding it.

Most of the ore is in the form of kidneys or large nodular masses embedded in the clay, some masses weighing as much as 600 pounds having been taken from the mines. These often contain cavities, lenses of white quartz, or partly replaced fragments of rock. The ore is mainly dark-blue or steel-gray granular pyrolusite, but crystalline pyrolusite and amorphous psilomelane occur with the granular ore.

The ore-bearing clay is very similar to the mica schist residuum forming the wall, though generally of different color, and grades into it imperceptibly, the ore masses becoming less abundant with increase of distance from the contact and finally disappearing. The granite near the ore-bearing layer is partly replaced by granular pyrolusite. At some places considerable masses are entirely replaced; at others, irregular specks of ore are scattered through the granite; the nearer the ore body the more thorough is the replacement. This partly 
replaced zone is generally several feet in thickness. Crystalline limestone has been found associated with the ore deposits, but its relation to the ores is not known.

The quantity of ore in the ore-bearing clay layer varies greatly. In some places 80 to 90 per cent may be ore, and 50 feet distant along the strike more than half the material may be clay. The same conditions prevail across the layer and with depth.

Besides the large masses of manganese ore, there occur in some of the mines, in association with these, small buttons of ore and small seams and irregular replacements in residual clay. In some of the mines a black manganiferous earth, locally known as "umber," is associated with the ore-bearing clays. This occurs in compact masses, but is soft and brittle and contains an abundance of mica flakes. The original nature of the umber is not known, but it is thought by some ${ }^{a}$ that it may be residual from crystalline limestone layers.

There are a large number of old mines and workings in the James River and Staunton River valleys, but only one mine is now operating, namely, that of the Piedmont Manganese Company, southeast of Lynchburg. Among the better known of the mines are the Cabell, Bugley, and Piedmont mines, near Warminster, Nelson County; the Belmont or Simpson mine, in Nelson County, near Midway Mills; the Davis mine, in Nelson County; the Leets mine, near Mount Athos, Campbell County; the Saunders property, near Evington, Campbell County; the Theresa mine, near Otter River, Campbell County, and the Bishop mine, near Lynch, Campbell County. Besides these, small manganese prospects occur at other localities in Campbell, Nelson, and Appomattox counties.

Manganiferous iron ores occur at Pittsville, Pittsylvania County, and in Amherst County.

DESCRIPTIONS OF MINES AND DEPOSITS.

Piedmont Manganese Company's mine.-The Piedmont Manganese Company's mine is east of Little Beaver Creek, in Campbell County, about 2 miles southeast of Mount Athos. The workings are on the east and west slopes of a small ridge and consist of several old tunnels near the eastern base and a recent shaft near the summit. The shaft has drifts at the 80-foot and 105-foot levels, the latter just begun. The ores occur in a brown micaceous clay bed which has a general northeast-southwest strike and dips steeply to the southeast. This layer is between a decomposed granite on the hanging wall and a residual micaceous clay on the foot wall. It runs diagonally through the hill on which the mine is situated, and may be traced for a quarter 
of a mile to the northeast. Masses of "umber" are found here and there along it. The main ore-bearing layer as exposed on the 80-foot level is about 50 feet southeast of the shaft. It varies in thickness from a few feet to 10 feet or more, but it grades into the formations on either side, and small quantities of ore occur in both hanging and foot walls. (See fig. 2.) Later development not seen by the writer has shown the ore to extend for a distance of 20 or 25 feet on either side of the main layer at the widest part and to continue along the strike for 100 to 150 feet.

The ore occurs in kidneys or large masses and is mainly in the form of granular pyrolusite, either massive or with concentric structure. Crystalline pyrolusite and amorphous steel-blue psilomelane are associated with it, but are much less abundant. Lenses of quartz, fragments of unaltered rock, and cavities lined with botryoidal surfaces likewise occur in the ore masses. The ore locally may compose 85 or 90 per cent of the ore-bearing layer, forming a nearly solid body with interstices filled with clay, while elsewhere more than half the layer

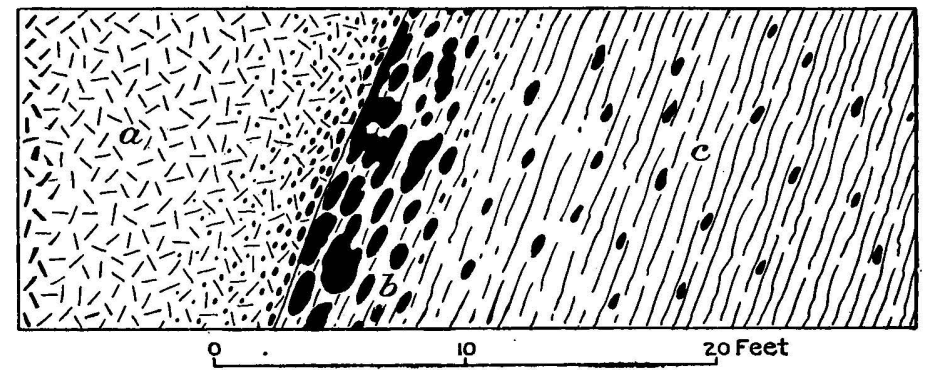

Figure 2.-Sketch showing the occurrence of manganese ore at the Piedmont Manganese Company's mine. $a$, Granite (containing ore); $b$, manganese ore; $c$, decomposed mica schist (containing ore).

may be clay in which the ore is embedded in lumps. The micaceous clay foot wall is light brown, dark brown, or gray, by layers, and is residual from mica schist. The layers and schistosity have the same strike and dip as the ore-bearing layer. The foot-wall clay is similar to the clay associated with the ore and grades imperceptibly into it.

There is a well-defined contact between the ore-bearing clay and the decomposed hanging-wall granite, although the ore itself is not confined by this contact. For some distance from the contact the granite contains specks and irregular patches of pyrolusite, which stain and partly replace it. The specks nearest the contact are larger and more numerous and in some places compose more than half of the mass of the rock.

The relation of the "umber" to the ore is not definitely known, but where it occurs in this mine it forms part of the hanging wall.

The ore is washed and dried and ground in a mill near the mine, and the powder is shipped away in barrels. It is used mostly for chemical work and coloring fancy brick. 
The following is an analysis of ore from the Piedmont Manganese Company's mine:

Analysis of manganese ore from the Piedmont Manganese Company's mine. ${ }^{a}$

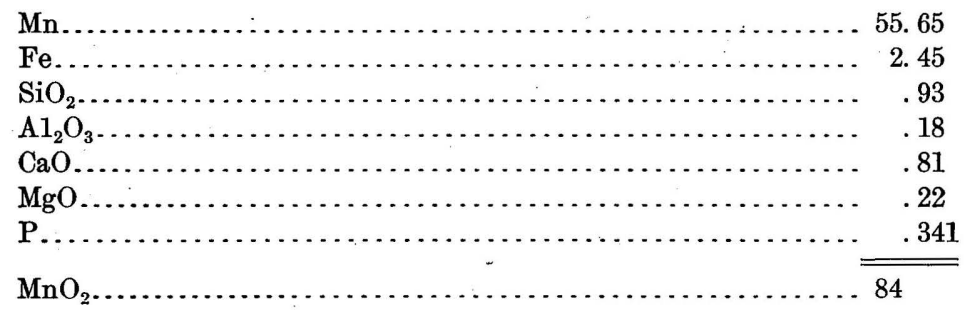

Leets mine.-The Leets mine is in Campbell County, about 1 mile east of Mount Athos. The workings are underground and are now inaccessible, but in a surface cut the probable occurrence of the ores is shown. In this cut there is a vertical layer of brown micaceous clay between decomposed granite, with a few layers of micaceous clay, and alternating layers of various-colored micaceous clays. The ore occurs in seams at the contact of the granite and the brown micaceous clay layer, and in specks in the granite adjacent. Judging from analogy with other mines, the ore underground is probably distributed through the brown micaceous clay layer. The ore mined consisted of kidneys and large masses, mainly of granular pyrolusite, associated with smaller amounts of crystalline pyrolusite and of psilomelane. The following are analyses of ore from the Leets mine:

Analyses of manganese ore from the Leets mine. ${ }^{a}$

\begin{tabular}{|c|c|c|c|}
\hline 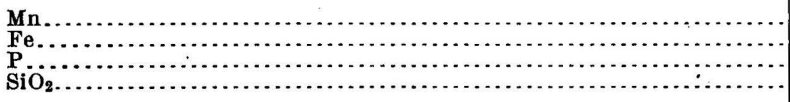 & $\begin{array}{l}43.58 \\
5.24 \\
.316 \\
7.15\end{array}$ & $\begin{array}{l}45.87 \\
5.34 \\
.257 \\
7.77\end{array}$ & $\begin{array}{l}44.18 \\
6.64 \\
.274 \\
7.73\end{array}$ \\
\hline
\end{tabular}

$a$ Weeks, J. D., Mineral Resources U. S. for 1885, p. 311.

Saunders property.-The Saunders property is in Campbell County, about 2 miles east of Evington. The country rock consists of alternating layers of red, yellow, and gray sand and clay, residual from schist and granite, having a general northeast-southwest strike and a dip of $50^{\circ}$ to $75^{\circ}$ southeast. Manganese ore occurs locally in several of these layers for a distance of about a quarter of a mile along the strike. In places the ore is in the form of soft, black seams, or of small, irregular nodules of psilomelane, an inch or two in diameter, while elsewhere large kidneys of granular pyrolusite, 5 or 6 inches in diameter, are found. The ore is scattered and the deposits are small. The Saunders property has been a recent producer, but not long ago operations were suspended.

a Pennsylvania Steel Company, analysts. Kindly furnished by Mr. D. W. Myers̈, president Piedmont Manganese Company, Lynchburg, Va. 
Piedmont mine.-The Piedmont mine is in Nelson County, about 2 miles north by west of Warminster. It has not been worked for many years and the former shaft is completely fallen in. The relation of ore to country rock, however, may be seen near the surface. The deposit here also, as in the mines described above, has a northeast-southwest strike and dips to the southeast. Decomposed granite forms the hanging wall. Near the contact with the ore it contains specks, patches, and bands of manganese oxide as fillings and replacements. Below the granite is the main deposit of ore, consisting of pyrolusite and psilomelane in brown micaceous clay. The ore and clay are intimately intermixed, but the former is predominant. Below the main deposit psilomelane occurs as small buttons scattered through hard, micaceous clay of the same nature as that above.

Cabell mine.-The Cabell mine is in Nelson County, about a quarter of a mile southwest of the Piedmont mine. The workings are very old and consist of a large, irregular pit and several shafts. Manganese ore, red residual clay, and grayish-white quartz-mica sand are exposed at several places on the walls of the pit, but their relations could not be determined. The main deposit of ore is a fairly solid mass of lumps and bands, associated with reddish residual clay.

The following are analyses of ore from the Cabell mine:

Analyses of manganese ore from the Cabell mine.

\begin{tabular}{|c|c|c|c|}
\hline & 1. & 2. & 3. \\
\hline 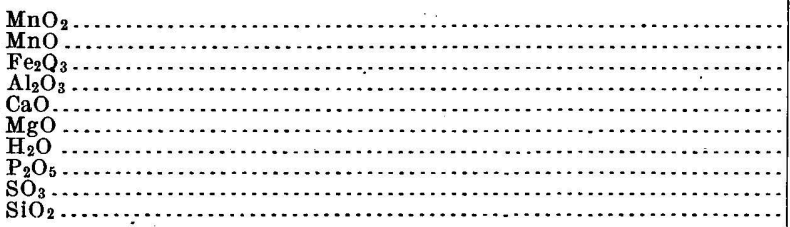 & \begin{tabular}{r|}
65.20 \\
4.75 \\
6.20 \\
3.93 \\
1.43 \\
.41 \\
3.02 \\
.42 \\
.30 \\
14.20
\end{tabular} & 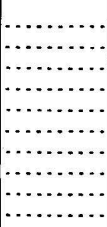 & ( \\
\hline & 99.86 & & $\ldots \ldots \ldots \ldots$ \\
\hline 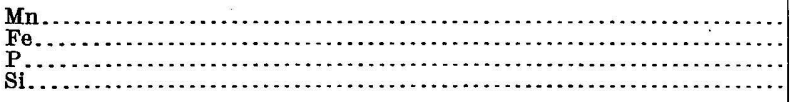 & $\begin{array}{r}44.87 \\
4.34 \\
.18\end{array}$ & $\begin{array}{l}44.30 \\
3.67 \\
.243 \\
17.45\end{array}$ & $\begin{array}{c}43.02 \\
4.24 \\
.182 \\
18.51\end{array}$ \\
\hline
\end{tabular}

1. Am. Chemist, August, 1871 , p. 50.

2, 3. Weeks, J. D., Mineral Resources U. S. for 1885, p. 312.

Other mines.-The Davis mine in Nelson County was operated during the eighties. The following is an analysis of a picked sample of the manganese ore mined:

Analysis of manganese ore from the Davis mine. a

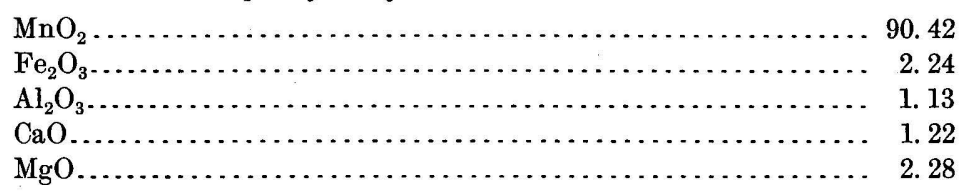

a Weeks, J. D., Mineral Resources U. S. for 1885, p. 312. 


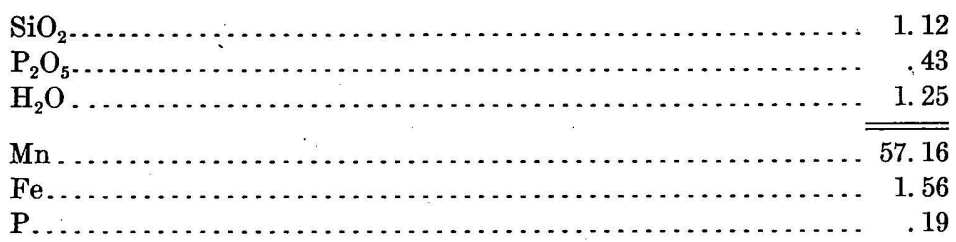

A deposit of manganiferous iron ore occurs at Pittsville, ${ }^{a}$ Pittsylvania County. The ore has the following composition:

Analyses of manganiferous iron ore from Pittsville.

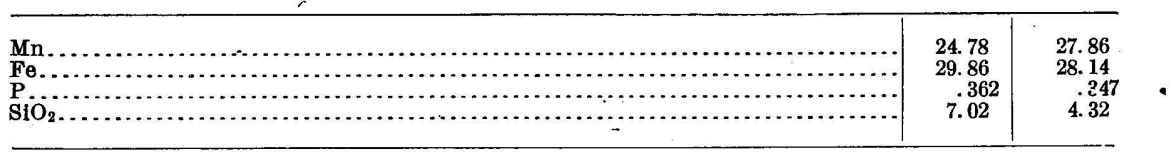

At Stapleton Mills and Walkers Ford station, in Amherst County, ${ }^{a}$ manganiferous iron ore has also been found. The ore from the former locality has the following composition:

Analysis of manganiferous iron ore from Stapleton Mills.

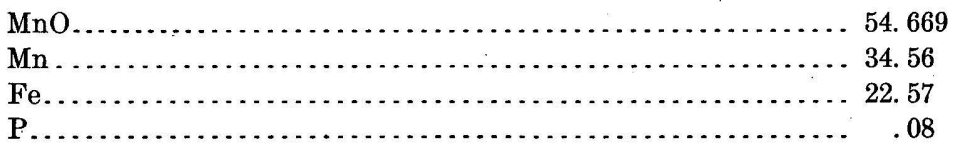

MINOR DEPOSITS.

NEW JERSEY.

A small deposit of manganese ore was found in Triassic rocks near Clinton, ${ }^{b}$ Hunterdon County, N. J. The ores consist partly of pyrolusite and partly of braunite and have the following composition:

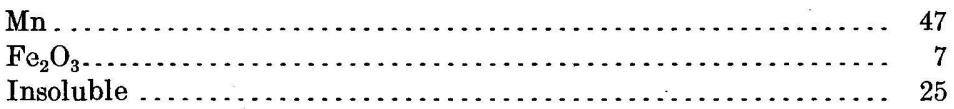

\section{PENNSYLVANIA.}

Oxides and carbonate of manganese, as well as silicates, such as manganiferous garnets, occur in the crystalline area of Pennsylvania. They have been found in the gneissic rocks on Pennypack Creek near Bustleton, ${ }^{c}$ Philadelphia County, and near West Chester, ${ }^{c}$ Chester County.

\section{MARYLAND.}

In the Maryland crystalline area manganese ores have been found in small quantities at Brookeville ${ }^{d}$ and Mechanicsville, ${ }^{e}$ Montgomery County, and at New Market, Frederick County.

$a$ Weeks, J. D., Mineral Resources U. S. for 1885, p. 311.

$b$ Idem, p. 336.

$c$ Carpenter, G. W., Am. Jour. Sci., 1st ser., vol. 14, 1828, pp. 4, 12.

d Penrose, R. A. F., jr., Manganese: Its uses, ores, and deposits: Ann. Rept. Arkansas Geol. Survey for 1890 , vol. 1, p. 401.

e Ducatel, J. T., and Alexander, J. H., Am. Jour. Sci., 1st ser., vol. 27, 1835, pp. 20, 25. 


\section{NORTH CAROLINA AND SOUTH CAROLINA.}

Ores of manganese, in the form of silicates and of oxides, are found in the crystalline and metamorphic rocks of the Piedmont region of North Carolina and South Carolina. The best-known deposits are associated with a narrow belt of schists that crosses the boundary between North Carolina and South Carolina in a northeast-southwest direction, passing a short distance east of the towns of Blacksburg, S. C., and Kings Mountain, N. C. This belt extends northeastward into Lincoln and Catawba counties, N. C., and southwestward beyond Glenn Springs, Spartanburg County, S. C. ${ }^{a}$

From North Carolina manganese ore has been reported, $b$ also from localities west of Lenoir, Caldwell County, and north of Dobson, Surry County, and from Cabarras and Stokes counties. The deposits in Surry County consist of manganiferous garnet. ${ }^{c}$ Manganiferous iron ore occurs at the Buckhorn iron mine, Chatham County.

In South Carolina other manganese deposits occur in a belt extending from New Market, Greenwood County, southward to McCormick, Abbeville County. Wad or bog manganese occurs in the northeastern part of Chester County, 4 miles southeast of Catawba Junction, ${ }^{b}$ and ores are also reported from Greeneville, ${ }^{d}$ Greeneville County.

The manganese deposits of the Blacksburg-Kings Mountain area consist of silicates superficially altered to black oxide. The manganese-bearing formation ${ }^{c}$ consists largely of dark schists with some conglomerate beds. It occupies a belt which varies in width from a half mile to less than a mile, but may be traced for long distances in a northeast and southwest direction along the strike. In general the conglomerate beds form the outer boundaries of the belt, but locally they are interstratified with schists. All the beds have a nearly vertical dip and a general northeast-southwest strike. The schist-conglomerate series' is bounded on the southeast by a belt of metamorphosed volcanic tuffs and on the northwest by a belt of chloritic and hornblende schists and biotite granite.

The manganese ores occur in the form of psilomelane and pyrolusite along the outcrop of the dark schist belt, appearing as black stains and in small particles along cracks. The area stained by manganese oxide is in some places 200 or 300 yards wide, but ore occurs only in a small portion of this area, appearing as small veins and probably as replacements along fractures. Near Blacksburg the manganese stains occur along two leads ${ }^{e}$ running northeastward for about 5

$a$ Sloan, Earle, Mineral localities of South Carolina: Bull. South Carolina Geol. Survey, ser. 4, No. 2, p. 95.

$b$ Penrose, R. A. F., jr., op. cit., p. 413.

$c$ Sterrett, D. B., personal communication.

$d$ Sloan, Earle, op. cit., p. 98 .

e Weeks, J. D., Seventeenth Ann. Rept. U. S. Geol. Survey, pt. 3, 1896, p. 200 (H. B. C. Nitze quoted). 
miles to a point where they join and continue as one. At points along this extent one lead measured 7 or 8 feet and the other 25 feet in width. At the surface the manganese is largely present as a stain, but with depth the rocks become richer in manganese oxide and small streaks of ore occur, until at a depth of about 25 feet solid crystalline ore, with a matrix of shale and quartzite and a foot wall of hard yellow shale, is said to have been reached.

In North Carolina the principal locality where manganese occurs in this belt is in the southern part of Gaston County, about 1 mile southeast of Kings Creek. The following are analyses of manganese ore from the black schist belt:

Analyses of manganese ores from the black-schist belt.

\begin{tabular}{|c|c|c|c|c|c|c|c|c|}
\hline & 1. & 2. & 3. & 4. & 5. & 6. & 7. & 8. \\
\hline \multirow{7}{*}{ 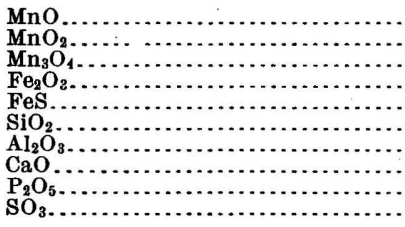 } & \multirow{5}{*}{$\begin{array}{r}29.78 \\
12.146 \\
.218 \\
40.395 \\
9.025\end{array}$} & & & & & & \multirow{2}{*}{$\begin{array}{r}14.11 \\
6.71\end{array}$} & \multirow{2}{*}{$\begin{array}{r}23.13 \\
1.85\end{array}$} \\
\hline & & & & & & & & \\
\hline & & & & & & & 13.88 & 11.06 \\
\hline & & 2.92 & 7.37 & 4.66 & 1.00 & 2.45 & & \multirow{2}{*}{$\begin{array}{l}\text { 45. } 70 \\
\text { 13. } 42\end{array}$} \\
\hline & & & & 3.50 & & & \multirow{2}{*}{$\begin{array}{r}14.72 \\
\cdots\end{array}$} & \\
\hline & \multirow{2}{*}{$\begin{array}{l}.030 \\
.024\end{array}$} & & & & & & & . \\
\hline & & & & & & & & \\
\hline \multirow{4}{*}{$\begin{array}{l}\text { Mn } \\
\text { Fe } \\
\text { P } \\
\text { S } \\
\text { Ti } \\
\text { ( }\end{array}$} & & 57.353 & & & & & \multirow{4}{*}{$\begin{array}{r}15.17 \\
9.71 \\
.06 \\
.06 \\
\text { Trace. }\end{array}$} & \multirow{4}{*}{$\begin{array}{r}19.09 \\
7.74 \\
.04 \\
\text { Trace. } \\
.43\end{array}$} \\
\hline & 8. 602 & 1. 435 & 1. 98 & 2. 00 & .67 & .78 & & \\
\hline & $\begin{array}{l}.013 \\
.011\end{array}$ & & & & & & & \\
\hline & & & & & & & & \\
\hline
\end{tabular}

1. Kings Mountain, N. C. Weeks, J. D., Eleventh Census U. S., Mineral industries, p. 305.

$2,3,4,5,6$. Blacksburg, S. C. Weeks, J. D., Seventeenth Ann. Rept. U. S. Geol. Survey, pt. 3, 1896, p. 201 .

7. Smith Mountain, near Cherokee Ford, Cherokee Creek, S. C. Sloan, Earle, loc. cit.

8. Wofford property, 8 miles south of Glenn Springs, Spartanburg County, S. C. Sloan, Earle, loc. cit.

In Chatham County, ${ }^{a}$ N. C., sheets of laminated black oxide of manganese 1 to 2 inches thick occur with iron ore at the Buckhorn iron mine. The iron ore in the lower part of the deposit is manganiferous, the manganese occurring as silicate. The following is an analysis of the lower ore:

Analysis of manganiferous iron ore from the Buckhorn mine:

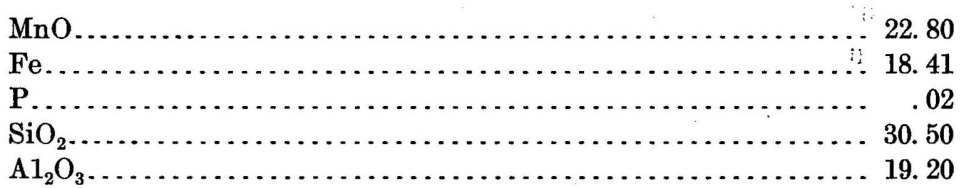

The manganese belt between New Market, Greenwood County, and McCormick, Abbeville County, S. C., contains several deposits of ore of rich quality, ${ }^{b}$ asssociated with mica and sericite schists. The best known of these are about 1 mile southwest and one-half mile north of 
McCormick, Abbeville County, 2 miles west of Breezewood and 5 miles south of Greenwood, Greenwood County.

The deposit north of McCormick consists of nodular concretions of psilomelane and pyrolusite embedded in soft brown earth consisting of hydromica and manganese oxide particles, in a zone about 7 feet wide at the base of a soft gray mica schist formation, striking $\mathrm{N} .72^{\circ}$ E. and dipping $70^{\circ} \mathrm{NW}$. The foot wall of this zone consists of hard red mica schist. Manganese may be traced for a distance of a thousand feet along the strike in a belt of varying width. Locally hard siliceous ore occurs in a solid body with numerous veins of white quartz.

West of Breezewood, Greenwood County, the manganese ore occurs in a vein 5 to 6 feet wide in mica slates.

The following are analyses of manganese ore from the New MarketMcCormick area:

Analyses of manganese ore from the New Market-McCormick area.

\begin{tabular}{|c|c|c|c|c|c|}
\hline & 1. & 2. & 3. & 4. & 5. \\
\hline $\begin{array}{l}\mathrm{MnO} \\
\mathrm{MnO} \\
\mathrm{MnO}_{2} \ldots \ldots \ldots\end{array}$ & $\begin{array}{r}3.73 \\
75.28 \\
14.56 \\
3.54 \\
2.63 \\
.24 \\
\end{array}$ & $\begin{array}{l}3.10 \\
9.00\end{array}$ & $\begin{array}{r}10.66 \\
71.56 \\
2.07 \\
2.59\end{array}$ & $\begin{array}{r}15.68 \\
31.78 \\
6.22 \\
15.70\end{array}$ & $\begin{array}{r}18.54 \\
39.77 \\
4.63 \\
12.63\end{array}$ \\
\hline $\begin{array}{l}\text { Mn }{ }_{\mathrm{F}} \\
\mathrm{Fe} \\
\mathrm{P} \\
\mathrm{S} \\
\mathrm{T}\end{array}$ & r. & $\begin{array}{r}45.018 \\
2.75 \\
.085 \\
\cdots \cdots \\
\cdots\end{array}$ & $\begin{array}{r}53.50 \\
1.45 \\
.24 \\
.04 \\
\text { Trace. }\end{array}$ & $\begin{array}{r}32.24 \\
4.35 \\
.03 \\
\text { Trace. } \\
\text { Trace. }\end{array}$ & $\begin{array}{r}39.50 \\
3.24 \\
.07 \\
\text { Trace. } \\
\text { Trace. }\end{array}$ \\
\hline
\end{tabular}

1, 2. Dorn lands, McCormick, Abbeville County, S. C. Weeks, J. D., Eleventh Census U. S., Mineral industries, p. 307.

3. Hard nodular ore, one-half mile north of McCormick, Abbeville County, S. C. Sloan, Earle, Mineral. localities of South Carolina: Bull. South Carolina Geol. Survey, ser. 4, No. 2, p. 97.

4. Soft ore forming the matrix for the preceding. Same locality as above. Sloan, Earle, loc. cit.

5. Burnet property, 2 miles west of Breezewood, Greenwood Creek, S. C. Sloan, Earle, loc. cit.

\section{GEORGIA. ${ }^{a}$}

In the crystalline area of Georgia there are a number of small deposits of manganese ore, but none of commercial importance have been found. In Lumpkin County manganese oxide occurs in small seams along planes of schistosity or fracture in residual clays of hornblende, chlorite, mica, and quartz schists. Botryoidal masses of very pure oxide have been found locally.

Near Mount Airy, Habersham County, there are several localities where manganese oxides occur in small quantities. The prevailing rock in this area is mica schist, in places very quartzose, cut by dikes of basic eruptives and by quartz veins. About 2 miles northeast of Mount Airy manganese oxide occurs as cement in a brecciated quartz vein 3 feet wide, cutting mica schist. It is also found as seams along

$a$ Watson, T. I., Preliminary report on the manganese deposits of Georgia: Bull. Georgia Geol. Survey . No. 14, pp. 168-177, 182-199. 
schistose planes and as cement between quartz grains in residual clay and sand from the mica schist.

The following is an analysis of the ore:

Analysis of manganese ore from Mount Airy. ${ }^{a}$

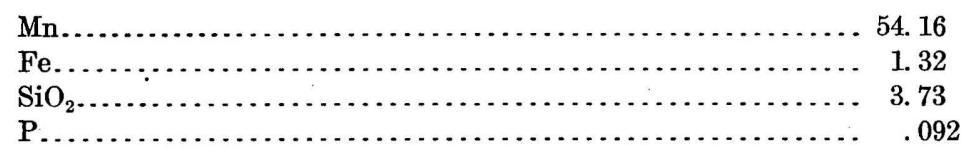

Near Currahee Mountain, 6 miles southwest of Toccoa, Habersham County, small fragments of manganese and iron oxides and seams and stains of manganese occur in residual clays of mica schist.

Manganese ores occur in Hart and Franklin counties, near Bowersville, as stains and fragments in residual clays from mica schist. On the Brown property, $1 \frac{1}{2}$ miles east of Bowersville, massive blue or steel-gray manganese oxide occurs in red residual clay as large masses, the largest several yards in diameter. These masses are generally porous or cellular and contain a large amount of silica in the form of quartz grains. Small pellets of soft ore also occur. The ores appear to have been derived from the mica and to have become concentrated between the quartz grains on the decay of the latter.

Manganese ore is found in Haralson and Paulding counties, several miles north of Draketown. It occurs in masses along the contact of a banded quartzite and a decomposed mica schist, and not in the nodular form so common elsewhere. The quartzite carries numerous grains and crystals of magnetite. The manganese ore is either amorphous or crystalline and generally contains considerable magnetite and some hematite and limonite, forming a manganiferous iron ore. Many of the ore masses occur through the banded quartzite layer rather than at its contact with the residual clays. At a number of places the mica schist is garnetiferous, the garnets being altered in the residual clay to iron and manganese oxides.

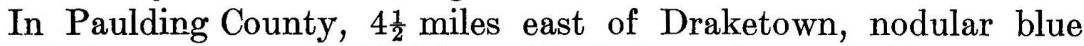
pyrolusite occurs, embedded in residual clays of a garnetiferous mica schist.

\section{ORIGIN OF THE MANGANESE ORES OF THE PIEDMONT REGION.}

The crystalline rocks of the Piedmont region contain an abundance of manganese-bearing minerals, such as amphiboles, pyroxenes, garnets, and micas. The manganese is present in these largely in the form of protoxide, which on the decomposition of the minerals becomes converted into peroxide, forming pyrolusite when pure and psilomelane or wad when it contains an admixture of other oxides and foreign constituents. Frequently the minerals are altered in place 
and the manganese and iron oxides and other residual products resulting from the decomposition remain as specks in the residual sand and clay. In some places they are concentrated in nodular masses or in seams along joints or planes of schistosity. Silica seems to have considerable affinity for manganese oxides, which in many places form cementing material between sand grains. Workable deposits are formed where the seams, nodules, or irregular masses of manganese oxide are gathered into pockets or along layers. This concentration takes place through the medium of circulating meteoric waters, the manganese being taken into solution on the decomposition of the manganese-bearing minerals and deposited where conditions are favorable. Layers of crystalline limestone or of quartzite, brecciated quartz veins, fault or joint planes, masses of sandy material, or previous deposits of manganese minerals may constitute favorable places or conditions for the deposition of manganese.

\section{COMMERCIAL IMPORTANCE OF THE ORES.}

The ore associated with the granites and schists of the Piedmont region is very pure and of high grade. It is largely granular and crystalline pyrolusite, valuable as an oxidizer and as a coloring material. The principal deposits are those in the James River and Staunton River valleys in Virginia and those near McCormick, in southern South Carolina, at both of which localities a small quantity of ore has been recently mined. The deposits of the Kings Mountain belt, in northern South Carolina, while occupying a considerable area, are mostly in the form of small veins and replacements, few of which are of sufficient extent to be mined. No ore has been shipped from this region. All the other deposits mentioned are unimportant.

Manganese ore has been produced in the James River valley for many years, and a large number of pockets there have been mined and abandoned. They were found to be of small extent, and after a number of years of steady mining became exhausted. Most of the deposits consisted of a group of pockets, each of which was mined in turn. Only one deposit, that of the Piedmont Manganese Company, is being mined at present, and this promises to be more continuous than the deposits previously mined. Ore of high grade is produced and is ground at the mine for use as coloring material.

In South Carolina the McCormick deposit has been mined recently, the ore being used in the manufacture of spiegeleisen and ferromanganese. South Carolina has not been an important producer.

\section{APPALACHIAN REGION.}

\section{GENERAL STATEMENT.}

The Appalachian region is the southern continuation of the western New England sedimentary area and extends from Pennsylvania through Virginia and Tennessee into Georgia and Alabama, including 
a small part of western North Carolina. This belt is bounded on the east and southeast by the Piedmont region and on the west by the Cumberland and Allegheny plateaus. In Pennsylvania and Maryland the Appalachian belt includes a number of parallel mountain ranges and valleys. In Virginia and in the area farther south its eastern portion is occupied by a broad valley with minor ridges, while the western part consists of a number of parallel ridges and valleys. In Virginia the Appalachian Valley is bounded on the east by the Blue Ridge; in Tennessee and North Carolina its eastern boundary is formed by the broad mountain belt between the Unaka Mountains on the west and the Blue Ridge on the east. The rocks of the Appalachian region are of Paleozoic age. They extend eastward to the Blue Ridge, forming its western slope in Virginia, while farther south, where the mountain belt broadens, they form the Unakas and several interior ranges east of them.

Manganese ores occur at intervals throughout the Paleozoic rocks from Pennsylvania to Alabama. The principal deposits lie in a narrow belt along the extreme eastern edge of the Appalachian Valley. It includes the chief Pennsylvania deposits, and in Virginia is represented by the deposits at the western foot of the Blue Ridge and by those of the New River district south of Pulaski, Wytheville, and Marion. In Tennessee the deposits in Shady Valley, near Unicoi, in the vicinity of Newport and Del Rio, and in the Chilhowee Mountains belong in this belt; and farther south Cherokee County, N. C., Blue Ridge, Cohutta Springs, and the Cartersville region in Georgia, and Cleburne County, Ala., are included in it. Other deposits occur inside the Appalachian Valley, in a second belt a little west of and parallel with the main belt. This is represented in Virginia and West Virginia by the deposits near Cedar Creek, Woodstock, Gale, Glenmore, and Goshen and by others farther southwest, which are undeveloped. In Tennessee a deposit is found near Sweetwater and others are reported from Morristown and points farther northwest. In Georgia the deposits of Tunnel Hill, Lindale, Barnsley, and the Cave Springs district are in this belt, and continuations of it are found in Alabama, ores being reported from Cherokee County, Ala., and other localities.

Closely associated with the manganese deposits and coextensive with them there are numerous deposits of limonite.

The manganese deposits of the Appalachian region occur in residual clay and sand derived from Cambrian, Ordovician, and, to a slight extent, from Silurian sediments. With the residual clays there are associated in many localities later fluviatile clays of Tertiary or Cretaceous age. The Appalachian Mountains, represented by the Blue Ridge in the north and by the broad mountain belt between the Unaka Mountains and the Blue Ridge in the south, are on the 
contact between the crystallines of the Piedmont region and the Paleozoic sediments to the west. Near the contact the sediments dip in general to the west and northwest and have a general northeast-southwest strike, but in the valley there has been much folding and faulting, making the dips irregular, though the general strike of the beds remains the same. On going westward from the mountains one therefore crosses successively higher geologic horizons. The principal ore deposits - that is, those of the eastern belt-are in the area underlain by Cambrian shale, quartzite, and limestone; those in the western belt are underlain in Tennessee and Georgia by the Cambro-Ordovician Knox dolomite and in Virginia by Silurian rocks.

In the Appalachian region, besides the deposits of manganese ore, there are numerous manganiferous iron ore deposits-in fact all gradations may be seen from pure manganese to pure iron ore deposits. Most of the manganese-ore deposits contain some iron ore, and, on the other hand, many of the iron-ore deposits contain small quantities of manganese ore. The term manganiferous iron ore is applied to those ores that contain a notable amount of both constituents, and such deposits occur at many places, especially in the eastern belt.

\section{BLUE RIDGE REGION.}

\section{GEOGRAPHY AND TOPOGRAPHY.}

The principal deposits of the valley of Virginia are situated at the western foot of the Blue Ridge at intervals between Front Royal on the north and Roanoke on the south. (See Pl. II.) The following is a list of the locations of the principal mines and prospects, from north ta south. Of these only the Happy Creek, Dry Run, Crimora, Lyndhurst, and Vesuvius mines have recently produced ore.

Manganese deposits of Blue Ridge region.

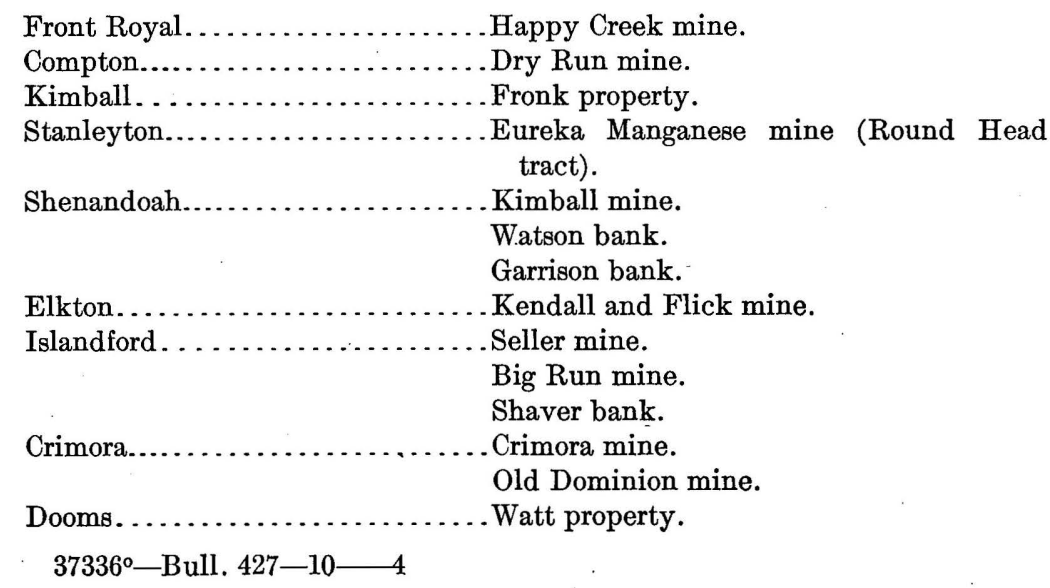




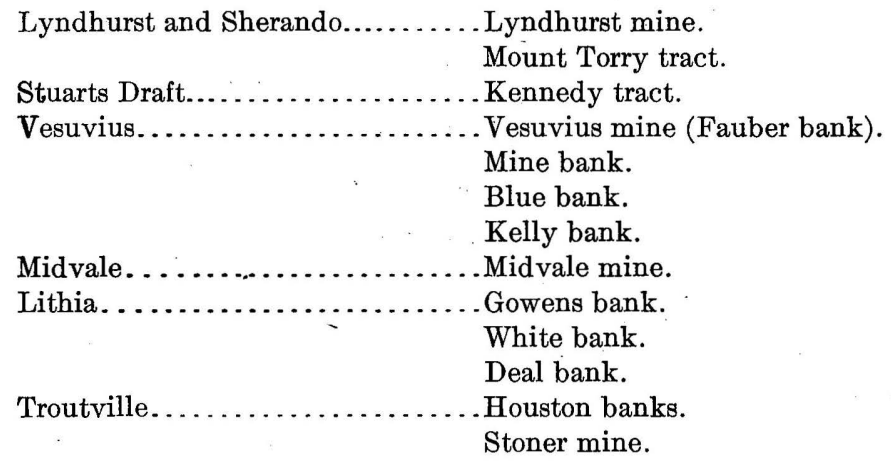

The mines are all east of the Norfolk and Western Railway, either at or very near the foot of the Blue Ridge. The same area contains the Blue Ridge iron-ore mines, but these are not confined so closely to the foot of the ridge, some of them being several miles up in the mountains and some a half mile out from the foot.

The Blue Ridge runs in a northeast-southwest direction and varies in width from 5 to about 15 miles. To the east of it is the Piedmont Plateau; to the west the valley of Virginia. The crest line has a general elevation from 2,500 to 4,000 feet, its highest point being Mount Pleasant, opposite Midvale, which reaches an elevation of 4,098 feet. The Blue Ridge consists of a central backbone with short transverse ridges extending out from it on either side between stream valleys. At the foot of these ridges on the west there is a gently sloping shelf which merges westward into the broad valley of Virginia. Most of the manganese deposits are on this shelf near the foot of the ridges. The valley of Virginia contains a large number of minor northeast-southwest ridges which divide it into smaller valleys. The valley immediately west of the Blue Ridge is drained southward by South River, a branch of the James, and northward by the South Fork of Shenandoah River. The headwaters of these streams rise at Lofton, a few miles north of Vesuvius.

\section{GEOLOGY.}

The Blue Ridge is on the contact between the ancient crystalline and metamorphic rocks of the Piedmont region and the Paleozoic rocks of the valley of Virginia and the region farther west. The following tables give the general succession of rocks for the northern and middle portions of the valley of Virginia: ${ }^{a}$

$a$ Bassler, R. S., Cement materials of western Virginia: Econ. Geology, vol. 3, No. 6, p. 510.

Campbell, H. D., The Cambro-Ordovician limestones of the middle portion of the valley of Virginia: Am. Jour. Sci., 4th ser., vol. 20, p. 445.

Keith, Arthur, Harper's Ferry folio (No. 10), Geol. Atlas U. S., U. S. Geol. Survey, 1894.

Darton, N. H., Staunton folio (No. 14), Franklin folio (No. 32), and Monterey folio (No. 61), Geol. Atlas U. S., U. S. Geol. Survey. 
Devonian:

General succession of rocks for the northern valley of Virginia.

Jennings formation.

Romney shale. (Black shale.)

Silurian:

"Monterey" (Oriskany) sandstone.

Lewistown limestone. (Carries Oriskany brown ore and manganese ore.)

Clinton (Rockwood) formation.

Cacapon sandstone.

Tuscarora quartzite.

Ordovician:

Juniata sandstone.

Martinsburg shale.

Shenandoah group-

Chambersburg limestone.

Stones River limestone.

Cambro-Ordovician:

Undifferentiated Shenandoah.

Sequence broken. (Brown ore and manganese ore.)

Cambrian:

Antietam sandstone.

Harpers shale.

Weverton sandstone.

Loudoun formation.

Algonkian:

Catoctin schist and granite.

Devonian:

General succession of rocks for the middle valley of Virginia.

Jennings formation.

Romney shale. (Black shale.)

Silurian:

"Monterey" (Oriskany) sandstone.

Lewistown limestone-

Pure heavy-bedded limestone. (Carries Oriskany brown ore and manganese ore.)

Cherty limstone.

Limestone and sandstone.

Clinton (Rockwood) formation-

White quartzite.

Purple and gray shale. (Carries fossil hematite.)

Red sandstone.

Ordovician-Silurian:

Massanutten sandstone.

Ordovician:

Martinsburg shale.

Liberty Hall limestone.

Murat limestone.

Cambro-Ordovician:

Natural Bridge limestone. (Carries "valley" brown ore.) Shenandoah group.

Cambrian:

"Buena Vista" shale.

Sherwood limestone.

Lower Cambrian quartzite. (Carries "mountain" brown ore and manganese ore.)

Lower Cambrian shales and quartzites. (Carries specular hematite.)

Pre-Cambrian:

Crystalline and metamorphic rocks. 
The crystalline rocks are mostly granite, gneiss, and schist, very much metamorphosed and containing numerous intrusives. They compose the eastern portion of the Blue Ridge and form the basement

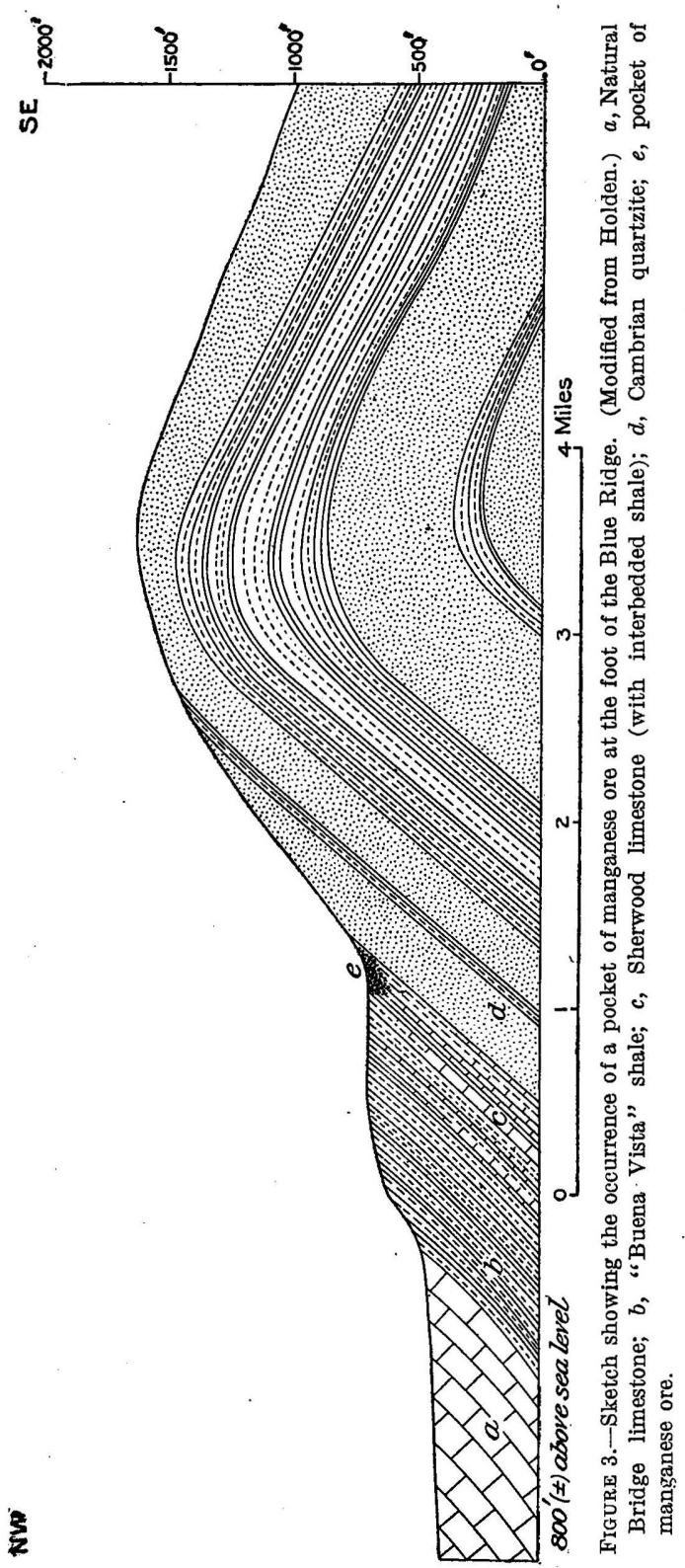
upon which the later sediments have been deposited. They contain no manganese ores in this district.

The Cambrian formations consist in general of lower quartzites and shales. Above these is a heavy quartzite bed, which is the surface rock in the western portion of the Blue Ridge, and above this is the Sherwood limestone with the overlying "Buena Vista" shale, which forms the gently sloping bench at its western foot. On this bench occur the manganese deposits and most of the Blue Ridge limonite deposits. (See fig. 3.) The "Buena Vista"shale and Sherwood limestone have been removed from the top and slopes of the Blue Ridge, leaving the quartzite as the surface rock. On the western slope, the dip of the rocks is in general steeply to the northwest, but becomes very irregular through the valley on account of folding and faulting. For a considerable extent along the west front of the Blue Ridge either or both the Sherwood limestone and "Buena Vista" shale are absent on account of faulting. 
The Natural Bridge limestone forms most of the eastern portion of the valley, but overlying Ordovician, Silurian, and Devonian rocks occur locally in the valley ridges. The Natural Bridge limestone in general is bluish gray and crystalline, and locally contains an abundance of chert.

OCCURRENCE AND CHARACTER OF THE ORES.

GENERAL RELATIONS.

Manganese ores occur as scattered fragments in small quantities throughout the Blue Ridge belt, but only locally are they sufficiently concentrated to be of commercial value. As a rule these local concentrations consist of fragments gathered in irregular pockets in clay several hundred yards in area and generally not more than a few hundred feet deep, but in some places, as at Crimora, the ores have collected in clay in basins in the underlying bed rock and the deposits are of greater extent.

The clay in which the ores occur is derived largely from the decomposition of the lower Cambrian quartzite and the Sherwood limestone, though undoubtedly some of it was derived from the overlying shale. It is probable that small quantities of manganese ore also occur in the later fluviatile clays associated with the residual material. Usually the clay is stiff, though locally it is sandy. In color it varies from white through yellow, brown, and red to black, the differentcolored varieties being generally intermixed. The black clays are colored by manganese and are often associated with manganese pockets. Frequently fragments of undecomposed rock, mostly sandstone or chert, are contained in the residual clay.

The deposits occur at or near the contact of the lower Cambrian quartzite with the overlying formations, both where faulting has taken place and where the rocks are in their normal succession.

\section{FORMS OF THE ORES.}

The ores occur in several different forms and associations, the principal forms being the following:

1. Blue or black psilomelane in kidney-shaped masses scattered through clay. Generally these are massive and structureless in the interior, but some of them show a concentric arrangement of layers.

2. Irregular bodies of psilomelane and pyrolusite, occurring in black manganiferous clay and to a smaller extent in other clays.

3. Breccia ore, composed of sandstone or chert fragments cemented by psilomelane or pyrolusite. This ore generally occurs in large masses rather than as small fragments scattered irregularly through clay.

4. Crystalline and granular pyrolusite with some psilomelane, occurring as cavity fillings, seams, and replacements in sandstone horses or in compact sandy clay. 
(1) The ores of the first class are scattered through horizontal or slightly inclined layers or lenses of clay which are separated by areas of barren clay. (See fig. 6.) A number of such ore-bearing lenses grouped together constitute a deposit or pocket. The clay in which the ore occurs is orange, yellow, brown, or variegated, and generally contains fragments of sandstone which may have ores of classes 3 and 4 associated with them. The ore kidneys range in diameter from half an inch to 6 or 8 inches, but the larger ones are irregular and not of the typical nodular form. In general the kidney ore is massive, compact, and structureless, but some of the nodules show concentric layering, and in some of them cavities lined with black, sooty wad occur between the layers. Rarely the nodules include small crystals of pyrolusite. When taken from the mine the ore masses are covered with a thin coating of clay, generälly yellow or brown, but in some deposits bright red, as at the Crimora mine. This coating is removed during the washing and the kidneys become black. Where the clay is markedly sandy the nodules contain grains of sand and small fragments of sandstone, thus grading toward breccia ore.

In some places the nodules are a foot or more apart; in others they are closely packed together and may even be connected into branching masses.

(2) Irregular areas of black manganiferous clay are associated with the variegated clays in most of the deposits. Scattered through this clay and probably representing local spots of greater concentration there are irregular bodies and seams of manganese ore. Less numerous bodies of a similar nature are embedded in variegated clay, in the manner of kidney ore, with which they frequently occur in the same bed. They vary in diameter from a few inches to a foot or more and in shape from thin seams to masses consisting of irregular, crooked, intersecting cylinders with numerous cavities between, after the nature of coral. The term stalactitic ore has been applied to such porous cellular masses.

Most of the ore of this class is psilomelane, though some of the cavities in it are lined with pyrolusite. Pyrolusite appears to be more abundant in the bodies that are embedded in manganiferous clay.

(3) The breccia ore is found in large masses, many of them 2 or 3 feet in diameter. It consists of smal' fragments of sandstone or chert cemented together by psilomelane or pyrolusite, the former being predominant. A breccia ore mass may contain either of these minerals, exclusive of the other, but more commonly the two occur together in successive layers. Breccia masses are generally embedded in clay, but one deposit was found in solid quartzite. The percentage of the volume of the ore made up of the fragments as compared to that formed by the cementing material is variable, though as a rule the fragments make up less than one-half of the total mass. The 
size of the fragments also varies; they range from mere grains of sand to masses 6 inches or more in diameter. Many breccia masses are covered with a thick coating of botryoidal ore in which few or no rock fragments occur.

(4) In many of the deposits, as at Crimora, there are residual masses of sandy clay, grading at some places into fairly compact sandstone; in others there are horses of sandstone below the clay, as in the Houston Banks. In these masses manganese ore, principally crystalline and granular pyrolusite, subordinately psilomelane, occurs as a replacement, as cavity fillings, and in veins. The replacement ore is generally psilomelane or granular and finely crystalline pyrolusite. In some places it occurs along vertical fissures; in others it replaces horizontal layers. Most commonly, however, it occurs irregularly on the border of the sandstone masses. The ores lining cavities and occurring in veins are associated with the replacement ores. Most of the veins are in the sandstone near the border of the replaced areas. The cavity fillings occur both in the replaced portions and in the sandstone. They consist of pyrolusite, often beautifully crystallized in coarse and fine needles. Wad frequently occurs as a coating of crystals in cavities.

\section{DESCRIPTIONS OF MINES AND DEPOSITS.}

Happy Creek mine.-The Happy Creek mine is in Warren County, about 2 miles east of Front Royal, at the base of one of the foothills of the Blue Ridge. It is primarily an iron-ore mine, but pockets of soft, granular pyrolusite occur locally in the limonite deposits, and occasionally a few carloads are shipped. The deposit is associated with a heavy quartzite bed in Cambrian shale.

Dry Run mine.-The Dry Run mine has been recently opened on an old manganese tract in Page County, about 1 mile south of Compton, by the Dry Run Mining and Development Company. The ore is largely psilomelane in botryoidal form, occurring as cement in a brecciated pocket in solid Cambrian quartzite. Quartzite fragments form the principal part of the deposit, the manganese ore seams between them varying in width, reaching in places a maximum of 4 inches. The ore contains numerous cavities lined with botryoidal forms.

Fronk property.-The Fronk property is in Page County, about 1 mile north of Kimball. Soft, dark-blue granular pyrolusite is found here in association with masses of brown iron ore. A shaft and several test pits have been sunk, but no ore has been shipped.

Eureka mine.-The Eureka manganese mine is on the northwest slope of Round Head Mountain, about $1 \frac{1}{2}$ miles southwest of Stanleyton, in Page County. A large amount of open pit work has been done and considerable manganese ore shipped. The ore is mainly 
psilomelane in porous masses up to a foot in diameter, scattered through red and yellow clay. Pyrolusite in needle-like crystals lines cavities in the psilomelane masses. Fragments of brown and purple quartzite are abundantly scattered through the clay.

The following analyses show the composition of this ore:

Analyses of manganese ore from Stanleyton, Va.a

\begin{tabular}{|c|c|c|}
\hline . & 1. & 2. \\
\hline $\begin{array}{l}\mathrm{Mn} \\
\mathrm{Fe} \\
\mathrm{P} \\
\mathrm{S} \\
\mathrm{H}_{2} \mathrm{O}_{2}\end{array}$ & $\begin{array}{r}51.46 \\
2.94 \\
.23 \\
4.17 \\
4.97\end{array}$ & $\begin{array}{r}49.61 \\
1.05 \\
.31 \\
.\end{array}$ \\
\hline
\end{tabular}

$a$ Watson, T. L., Manganese oxides: Mineral Resources of Virginia, p. 245.

Kimball mine.-The Kimball mine is an old manganiferous iron ore mine in Page County, on the west slope of Grindstone Mountain, about $3 \frac{1}{2}$ miles east of Shenandoah. The manganese ore is soft blue granular pyrolusite, embedded as pockets in variegated clay. Ore has been mined at two openings, known as the Atwood and the Bolan. The following are analyses of ore from this locality: ${ }^{a}$

Analyses of manganiferous iron ore from the Kimball mine.

\begin{tabular}{|c|c|c|}
\hline . & 1. & 2. \\
\hline 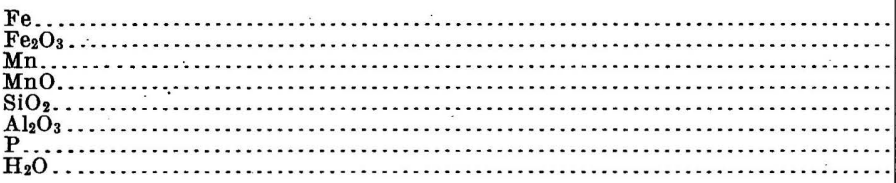 & $\begin{array}{r}40.875 \\
7.349 \\
15.44 \\
.084 \\
. .7 .\end{array}$ & $\begin{array}{r}70 \\
13.31 \\
4.73 \\
.86 \\
\text { Trace. } \\
11.02\end{array}$ \\
\hline
\end{tabular}

Analysis 1 represents mixed ore (two-thirds Atwood and one-third Bolan).

Watson bank.-The Watson bank is on the west slope of Grindstone Mountain, about 1 mile south of the Kimball mine. It was being prospected during 1908.

Garrison bank.-The Garrison bank is an old manganiferous ironore mine on the lower west slope of Grindstone Mountain, about 1 mile northwest of the Watson bank. The manganese occurs as blue granular pyrolusite in pockets and seams in residual shaly and sandy clay. Ore of the following composition was reported in the early eighties from this mine: ${ }^{a}$

Analyses of manganese ore from the Garrison tract.

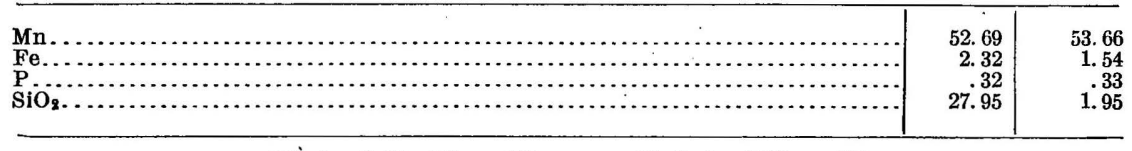

$a$ Weeks, J. D., Mineral Resources U. S. for 1885, p. 314. 
Kendall \& Flick mine.-The Kendall \& Flick mine is about 1 mile southeast of Elkton, Rockingham County. Several cuts, tunnels, and shafts have been opened at three localities, about onefourth mile apart, on the west slope of a foothill of the Blue Ridge. The deposits consist of a mixture of manganese and iron ores embedded in variegated clay, either in separate pockets or mixed in the same mass. The manganese ore is largely psilomelane in cellular and nodular masses, with locally small scattered kidneys. Layers or lenses of dark-colored clay with wad are interbedded with the lighter-colored clays. The following are analyses of ore from the Kendall \& Flick mine ${ }^{a}$ and from other mines ${ }^{b}$ near Elkton:

Analysis of manganese ore from the Kendall \& Flick mine.

$\mathrm{Mn}$

$\mathrm{Fe}$.

$\mathrm{SiO}_{2}$

$\mathrm{H}_{2} \mathrm{O}$
48.25

2.70

10.50

4. 00

Analyses of manganese ore from Elkton, Va.

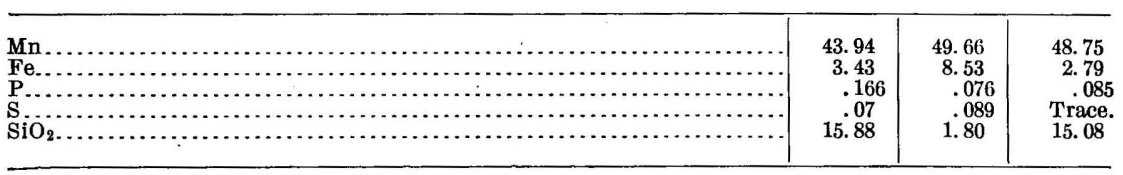

Analysis of manganese ore from the Church Mountain mine, Elkton, Va.

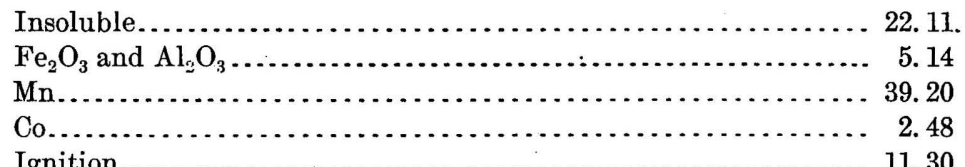

Seller and Big Run mines and Shaver bank.-South of the Kendall $\&$ Flick mine, along the base of the Blue Ridge east of Islandford, between Elkton and Grottoes, there are several manganese and manganiferous iron-ore banks, among which the Seller mine, the Big Run mine, and the Shaver bank are the most important.

The ore at the Seller mine is blue psilomelane in kidneys and in porous, cellular masses embedded in sandy variegated clay. The kidneys vary in size from tiny particles to masses 8 or 10 inches in diameter, while the cellular ore occurs in large masses including areas of clay.

At the Big Run mine cellular psilomelane is found in large masses, some of them 4 or 5 feet in extent, embedded in dark brown and black clay. The black clay occurs in specks and irregular masses through the brown clay. Several deposits of brown iron ore are found near the manganese-ore deposits. 
The Shaver bank is about half a mile south of the Big Run mine. Both iron and manganese ores are found here, the latter in the form of cellular psilomelane.

Crimora mine.-The Crimora mine is situated in Augusta County, 2 miles east of Crimora station, at the foot of the Blue Ridge. It is at present operated by Frank W. Wood, for Henry W. Poor \& Co., of New York City. The deposit consists of manganese-ore masses of various sizes scattered through variegated clays in an elliptical basin in a canoe-shaped syncline of the Cambrian quartzite. The basin has a general north-south trend, and is about half a mile long, several hundred yards wide, and 200 feet deep. (See figs. 4 and 5.) It occupies a flat area bounded on the east and north by spurs of the Blue Ridge.

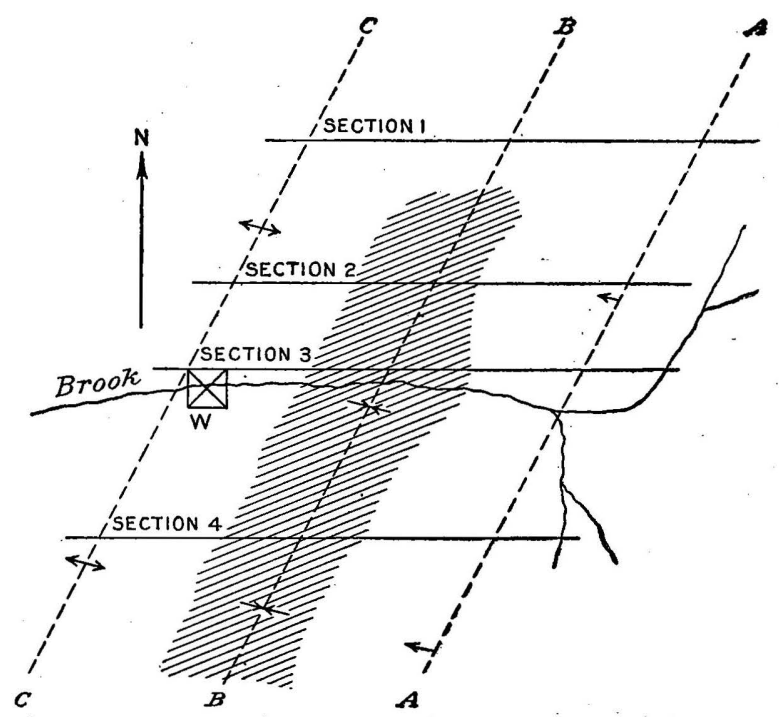

Figure 4.-Ground plan of the Crimora manganese deposit. (After Hall.) A-A, Eastern extent of syndine; B-B, axis of syncline; C-C, axis of anticline; W, location of washer. Shaded part shows manganese area. Scale, 1 inch $=$ several hundred yards.

In the eighties and early nineties the Crimora mine consisted largely of underground workings. About 1895 these were abandoned and operations were begun for a system of hydraulic mining. A tunnel, over a mile long, was driven through the western rim of the quartzite basin into the lower portion of the deposit, thus draining the entire basin above it. A shaft connects the eastern end of the tunnel with the surface. Water is brought to the mine by flumes from several points in the neighboring hills.

This system, however, was never put fully into operation, and mining since its installation has consisted in taking out ore left between the old levels and has been done only on a small scale. The mine at present consists of a large open pit, several hundred 
yards in extent and about 50 feet deep, near the north end of the basin. From the bottom of this pit a shaft 137 feet deep connects with the drainage tunnel; thus 137 feet of workable ground is left between the bottom of the pit and the level of the tunnel, and about half of this is untouched by former workings. Mining operations are also being conducted in small surface cuts north of the main pit.

The clays are for the most part residual from the upper Cambrian shale and are white, yellow, orange, brown, and black in color. In general they are stiff, but here and there are masses of yellow sandy clay or white sand or fragments of undecomposed sandstone. The black manganiferous clay generally occurs in separate beds, lenses, or irregular pockets, or interlaminated with the other clays, while the light-colored clays as a rule are intimately intermixed. Stiff
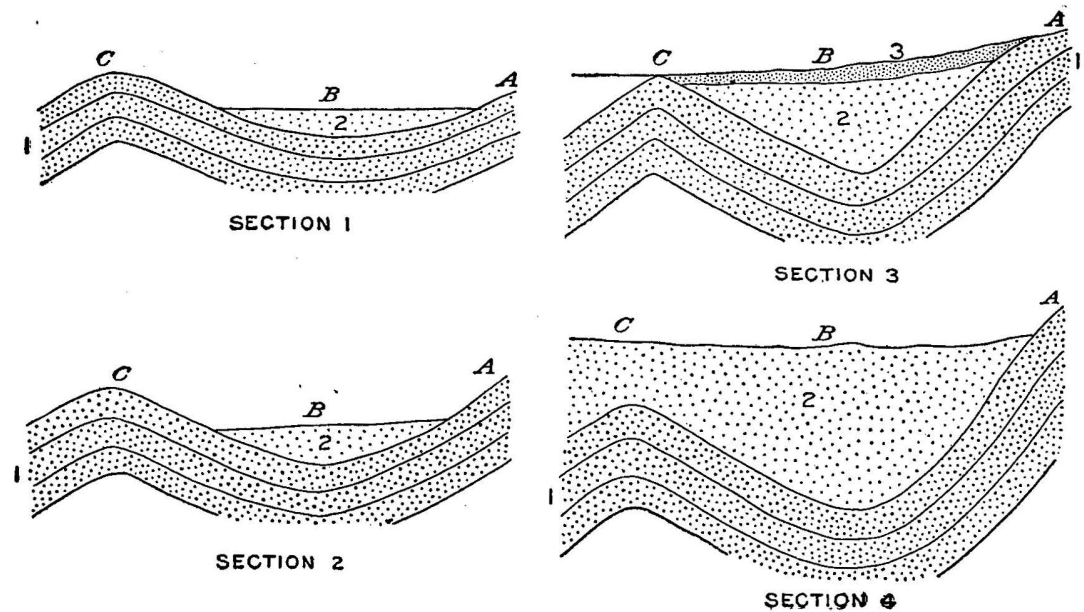

FIGURE 5.-Sections through the Crimora manganese deposit. (See fig. 4.) 1, Quartzite; 2, manganesebearing clay; 3, surface drift. (After Hall.) Vertical scale, 1 inch $=600$ feet; horizontal scale, 1 inch $=$ several hundred yards.

orange and yellow clays are the most abundant and contain most of the ore. The residual clays are covered by a layer of drift averaging about 15 feet in thickness.

The ore is hard and is of three varieties: (1) Kidney ore of bluishblack psilomelane in stiff orange and yellow clay; (2) irregular pockets of pyrolusite and psilomelane in manganiferous clay; and (3) replacements and cavity fillings of psilomelane and pyrolusite in sandy clay.

1. The kidney ore is most abundant and occurs in lumps ranging in diameter from a few inches to 10 inches. The lumps are of rounded, irregular shapes and bear nodular projections on the surface. At many places a number of kidneys are connected, making branching forms. The ore is coated with a thin layer of bright red clay, which is removed during the washing. The lumps are segregated in local 
layers, lenses, and irregular bodies of clay separated by barren areas. (See fig. 6.) This ore is generally homogeneous in texture, showing little or no tendency toward concentric layering. Some of the bodies contain cavities lined with brown, sooty wad. but most of them are solid and hard.

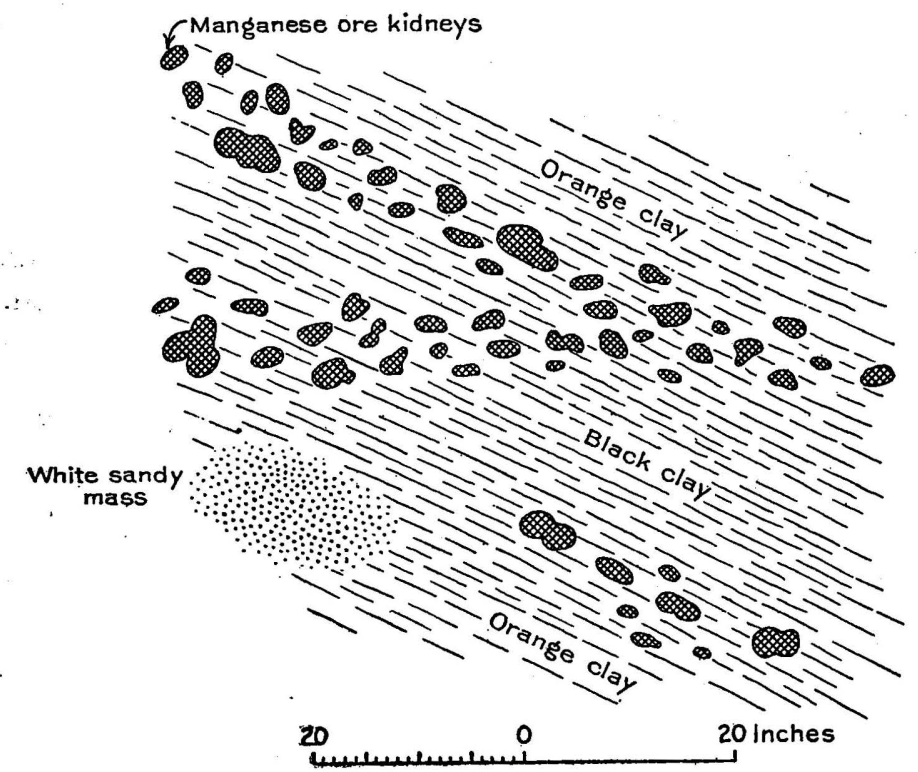

FIGURE 6.-Sketch showing distribution of manganese ore lumps in clay at the Crimora mine.

2. The bodies of ore in manganiferous clay are composed of both psilomelane and pyrolusite. They are very irregular in size and shape and grade into the clay, probably representing local areas of greater concentration.

3. The ore of the third type commonly occurs in yellow or brown
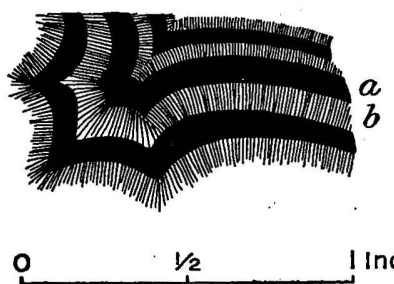

$1 / 2$

I Inch

FIGURE 7.- Sketch showing concentric layers of pyrolusite and psilomelane. $a$, Psilomelane; $b$, pyrolusite. sandy clay masses as fillings of seams and cavities and as irregular replacements. Psilomelane and crystalline pyrolusite are found in equal abundance, and as a rule occur in successive layers, the pyrolusite, being in the form of fine needles, transverse to the surface of the layer. (See fig. 7.) Here and there beautiful crystals of pyrolusite line small, irregular cavities. The ore masses are very irregular in shape and the largest are 6 inches or more in thickness. Small areas of sandy clay grading indefinitely into the ore are included locally in the ore masses. Replacement has taken place along cracks in the clay for half an inch on each side, plainly showing recent deposition. 
Manganese oxide also occurs in beautiful dendritric forms and crystalline coatings in the underlying quartzite, as is shown in the material taken out of the drainage tunnel.

In the upper portion of the basin the ores are generally very ferruginous, but with depth the iron becomes less abundant.

The following are analyses of ore from the Crimora mine:

Analyses of manganese ore from the Crimora mine. ${ }^{a}$

\begin{tabular}{|c|c|c|c|c|c|c|}
\hline . & 1. & 2. & 3. & 4. & 5. & 6. \\
\hline $\begin{array}{l}\mathrm{Mn} \\
\mathrm{Fe} \\
\mathrm{SiO}_{2} \\
\mathrm{P} \\
\mathrm{M} \\
\mathrm{M} \text { oisture }\end{array}$ & $\begin{array}{r}57.291 \\
.373 \\
.075\end{array}$ & $\begin{array}{r}49.16 \\
1.75 \\
9.80 \\
6.00\end{array}$ & $\begin{array}{c}48.53 \\
1.99 \\
10.20 \\
.103 \\
3.00\end{array}$ & $\begin{array}{r}50.54 \\
1.96 \\
10.12 \\
3.00\end{array}$ & $\begin{array}{c}48.16 \\
4.57 \\
10.30 \\
.095 \\
3.00\end{array}$ & $\begin{array}{r}44.54 \\
3.26 \\
14.00 \\
.087 \\
. .2\end{array}$ \\
\hline
\end{tabular}

$a$ Penrose, R. A. F., jr., Manganese: Its uses, ores, and deposits: Ann. Rept. Arkansas Geol. Survey for 1890, vol. 1, 1893, p.405; also Weeks, J. D., Sixteenth Ann. Rept. U. S. Geol. Survey, pt. 3, 1895, p. 430.

Analysis 1 shows the composition of best quality of ore; the other analyses give averages of monthly shipments during 1887 and 1888 .

The following table gives a complete analysis of Crimora ore:

Complete analysis of Crimora manganese ore.

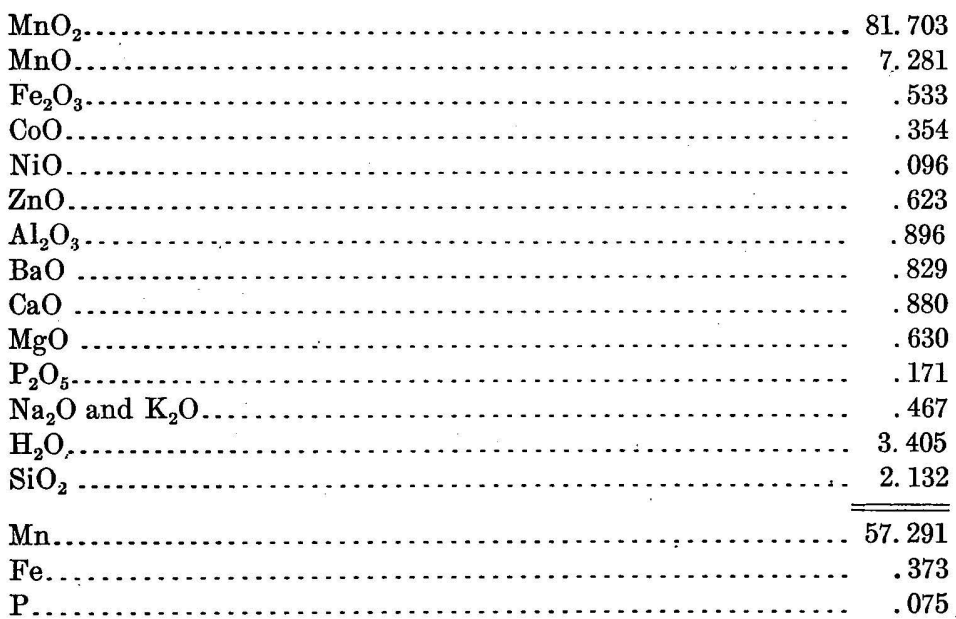

Old Dominion mine.-The Old Dominion mine adjoins the Crimora mine on the southwest, occupying the southern part of the Crimora basin.

The workings have been mainly near the surface and the ore mined has been ferruginous. It occurs in clay in seams and irregular fragments that show a tendency to assume nodular forms. Ore like that in the Crimora pit will probably be encountered at greaterdepth. 
Watt property.-The Watt property is located in Augusta County, about $1 \frac{1}{2}$ miles east of Doom Crossing, a short distance from the foot of the Blue Ridge. The workings, consisting of several shafts, have been abandoned and the ore was not seen in place. From the dumps it appears that the ore is embedded in yellow sandy clay and that it is of the same variety as the Crimora ore of the third class, described above. It consists of psilomelane and crystalline pyrolusite in concentric layers, the psilomelane being the more abundant. The pyrolusite is in needles that lie transverse to the faces of the layers. Areas of sandy clay are included in the ore, and at the contact with it show partial replacement.

Lyndhurst mine.--The Lyndhurst mine, operated by the Metallic Alloys Company, of Elkton, Va., is in Augusta County, about $2 \frac{1}{2}$ miles south of Lyndhurst, 1 mile north of Sherando, and about 1 mile west of the foot of the Blue Ridge. The workings consist of several shafts, with drifts at four or five levels. The ore occurs at intervals in a pocket that has been tested to a depth of about 60 feet and a horizontal extent of about 300 feet. The ore consists of (1) small nodules of psilomelane scattered through yellow and variegated clay, and (2) irregular bodies of psilomelane in black manganiferous clay, which occurs as lenses and layers interbedded with the variegated clay.

The nodules in the variegated clay range from one-fourth inch to several inches in diameter, but are characteristically small and of irregular shape. In some spots they are packed close together, while elsewhere they may be scattered at intervals of 6 inches. The ore in the manganiferous clay is hard or soft and occurs in seams or corallike masses, the largest a foot in diameter, though most of them are smaller. The interstices are filled with clay. Fragments of sandstone are common in the clay, and the ore is in places deposited around them and cements together the small fragments.

The ore is scattered, and much dirt has to be washed to obtain a small quantity of it. The extent of the deposit, however, seems to warrant the expense of mining and concentrating.

The following are analyses of ore from the Lyndhurst deposit:

Analyses of manganese ore from the Lyndhurst mine. $a$

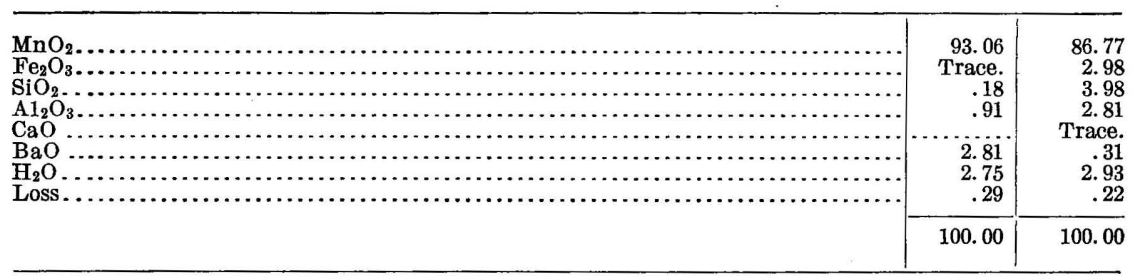

a Weeks, J. D., Mineral Resources U. S. for 1885, p. 317. 
Mount Torry property.-The Mount Torry property is in Augusta County, on the west slope of Torry Mountain, a spur of the Blue Ridge, about 6 miles south-southwest of Lyndhurst and 3 miles southwest of Sherando. The workings consist of a large number of old pits and a recent shaft and are scattered over an area a little over a quarter of a mile square. The deposits consist of manganiferous iron ore, the iron and manganese oxides being intimately intergrown. At many points the limonite occurs in fragments surrounded by psilomelane, which also penetrates it in veins. The psilomelane is mainly of the coral-like variety and is very hard. The ore occurs in irregular masses in yellow clay.

Kennedy tract.- The Kennedy tract is in Augusta County near the foot of the northern slope of Kennedy Mountain, a spur of the Blue Ridge, 4 miles east-southeast of Stuarts Draft. The workings consist of a large open pit, in which water at present conceals the main ore strata.

The ore is largely psilomelane, and occurs as kidneys in reddish and variegated light-colored clays. Nodular masses of limonite, with cores and intergrowths of psilomelane, are found near the surface. Here also occur hard, coral-like masses of ferruginous psilomelane with interstices filled with clay, seams of psilomelane in manganiferous clay, and crystals of pyrolusite lining small cavities in red clay.

The following is an analysis of ore from the Kennedy tract:

Analysis of manganese ore from the Kennedy tract.a

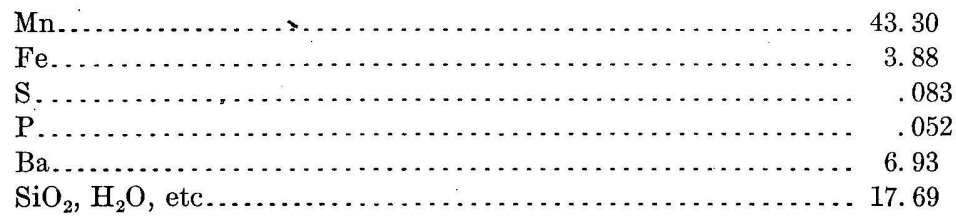

Vesuvius mine.-The Vesuvius mine, operated by the Manganese Corporation of Virginia, is in Augusta County, about $1 \frac{1}{2}$ miles northeast of Vesuvius. The workings consist of several old pits, an abandoned shaft with drifts, and two recent shafts which are still being sunk (1908). The ore could be examined only in the old surface pits formerly worked under the name of the Fauber mine. Here it occurs most abundantly as a cement in chert and sandstone breccias, but is also found as kidneys embedded in clay. The breccia ore occurs in large masses several feet in diameter in brown or yellow clay. The manganese may be in the form of either black psilomelane or gray crystalline pyrolusite, but is generally the former. The fragments consist for the most part of white chert, which frequently have been partly replaced near the surface by manganese oxide. Where 
psilomelane is the cement, the breccia masses often have a thick botryoidal coating of this ore containing few or no rock fragments.

The kidneys vary considerably in size, though generally they average over 2 or 3 inches in diameter. As a rule they are composed of massive black psilomelane and are solid and textureless, but some of them include small particles of rock, thus grading toward breccia ore.

Soft ore occurs in irregular streaks and patches through the clay. Some of the clay retains the original shaly structure, and in such clay manganese oxides have penetrated along bedding planes and in veins across them.

Several bodies of manganiferous iron ore in which psilomelane occurs in small irregular masses through the brown iron ore are also found in the pits.

Mine bank and Red Mountain.-At Mine bank and Red Mountain, 6 miles northeast of Vesuvius, large deposits of manganiferous iron ore are found. Both localities are south of St. Mary River, several miles up in the Blue Ridge. During the eighties considerable iron ore was mined at Mine bank for use in the old Cotopaxi furnace, but operations were finally suspended on account of the high manganese and silica content of the ores.

Both deposits consist of large lens-shaped bodies of ore, some of them 50 or 60 feet in extent. Manganese oxide, largely psilomelane, occurs in the iron ore in small irregular pockets and lenses, ranging up to 4 or 5 inches in the longer diameter. The deposit was evidently formed by successive deposition of iron and manganese oxides, the iron in layers and the manganese in discontinuous lenses. Stalactites of psilomelane are frequently found in cavities. The following is an analysis of the ore:

Analysis of manganiferous iron ore from Mine bank.

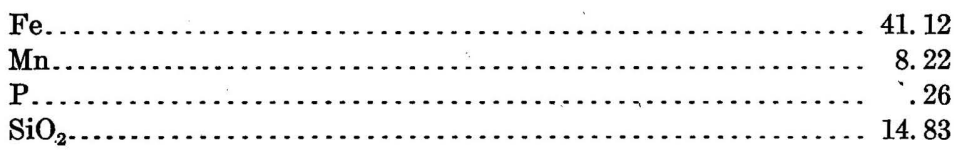

Blue bank.-Blue bank is about 3 miles northeast of Vesuvius, near the west end of Cellar Mountain. The workings consist of a series of open cuts and tunnels some distance apart. The ore mined was a dark brown to blue, highly manganiferous iron ore. In the principal type of ore manganese and iron oxides occur thoroughly intermixed, and psilomelane and pyrolusite are found separately lining cavities in it. The ore apparently occurs in large masses.

Kelly bank.-Kelly bank is about 1 mile northeast of Vesuvius. The ore mined here has been largely iron ore, but manganese ores are associated with it. 
Midvale mine.-The Midvale mine is located on top of a ridge about 1 mile northeast of Midvale, Rockbridge County. The workings consist of an incline, a shaft, and a few test pits. Considerable ore is said to have been mined here, but the poor condition of the incline prevented an investigation of the deposit. It is said to have been largely wash ore disseminated through clay.

Gowens, White, and Deal banks.--Several mixed manganese and iron ore deposits are found at the foot of the Blue Ridge, between Lithia and Nace in Botetourt County. Ores have been mined at Gowens bank, White bank, and Deal bank. The manganese ore is largely blue granular pyrolusite occurring in small masses in brown sandy clay. The iron ore occurs separately in large masses.

Stoner mine.-The Stoner mine is in Botetourt County about 1 mile northeast of Troutville. The workings consist of several old pits and a recent shaft. Very little ore has been taken out and this consists of black psilomelane in small irregular masses embedded in yellow clay. The following is an analysis of ore from this vicinity:

Analysis of manganese ore from the Chapman property. ${ }^{a}$

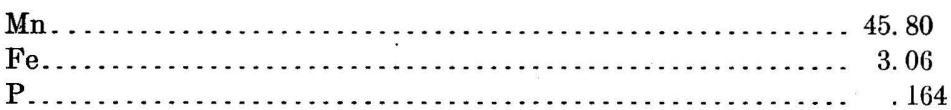

Houston mines.-The Houston mines are in Botetourt County about 3 miles northeast of Troutville. The workings consist of two large banks about one-half mile apart near the foot of the western slope of the Blue Ridge. This property was first worked as a source of manganiferous iron ore, but pure manganese ores were encountered in the lower part and attention was turned to them.

The upper part of the banks consists of pink, orange, yellow, and brown clays with local masses of partly decomposed sandstone. Toward the lower part the brown clays prevail and at the bottom there are horses of brown sandstone. Masses of dark manganiferous clays occur with the brown clays in the lower portion. The upper clays contain mainly fragments of brown iron ore, but locally there are small irregular masses of psilomelane, or of psilomelane and pyrolusite.

The principal portion of the manganese ore, however, occurs in the lower brown and manganiferous clays around the sandstone horses and as seams and replacements in the sandstone itself. This ore is in the form of rather soft and friable blue granular pyrolusite. With it are associated small amounts of crystalline pyrolusite in the form of coarse needles. The granular ore appears to be largely a replacement, and the needles to be a cavity filling. Some of the ore

$a$ Weeks, J. D., Mineral Resources U. S. for 1885, p. 321 ,

$37336^{\circ}-$ Bull. $427-10-5$ 
is in irregular masses and some in definite layers. A good deal of partly replaced material is generally associated with it and grades into it.

The following are analyses of ore from the Houston mines: ${ }^{a}$

Analyses of manganese and manganiferous iron ore from the Houston mines.

\begin{tabular}{|c|c|c|c|c|}
\hline . & 1. & 2. & 3. & 4. \\
\hline 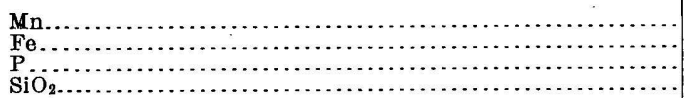 & $\begin{array}{r}44.312 \\
12.325 \\
.101 \\
5.470\end{array}$ & $\begin{array}{c}7.277 \\
47.15 \\
.061 \\
8.03\end{array}$ & $\begin{array}{l}59.870 \\
.50 \\
.049 \\
2.30\end{array}$ & \begin{tabular}{r}
39.00 \\
12.00 \\
\hdashline... \\
\end{tabular} \\
\hline
\end{tabular}

1. Manganese ore. 3 . Selected sample.

2. Manganiferous iron ore. $\quad$ 4. Average of monthly shipment, 1884-85.

\section{NORTHWESTERN VIRGINIA.}

GENERAL STATEMENT.

Local deposits ${ }^{b}$ of manganese and manganiferous iron ore occur in the region of parallel ridges west of the Blue Ridge district, where they are found in association with the Oriskany iron ores. The ores occur largely in the Oriskany horizon, but are said $^{c}$ to occur also in the "Hudson River" (Martinsburg) shale and the Clinton formation. They are nearly always associated with brown iron ore. (See p. 51.) The most important of these deposits occur in the Great North and Massanutten mountains, in northwestern Virginia, but minor deposits are present to the southwest.

\section{DESCRIPTIONS OF MINES AND DEPOSITS.}

Paddy Mills mine.-The Paddy Mills manganese mine is in the southwest corner of Frederick County. It occupies a conical hill about a square mile in extent and 150 feet above the surrounding country. The ore is chiefly soft pyrolusite embedded in limestone strata, but hard ore also occurs. The following is an average analysis of hard ore associated with the soft ore:

Analysis of manganese ore from the Paddy Mills mine.d

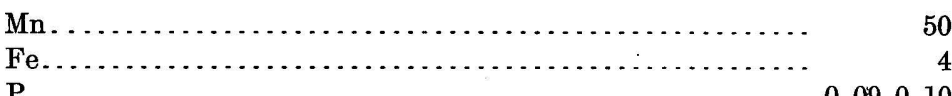

Cedar Creek.-Recently manganese deposits have been reported. from Cedar Creek in the southeastern part of Frederick County, but the extent of these is not known.

$a$ Weeks, J. D., Mineral Resources U. S. for 1885, p. 320

$b$ Idem, pp. 324-327.

$c$ Weeks, J. D., Sixteenth Ann. Rept. U. S. Geol. Survey, pt. 3, 1895, p. 434.

$d$ Weeks, J. D., Mineral Resourçes U. S. for 1885, p. 324 . 
Van Buren furnace.-At Van Buren furnace, ${ }^{a}$ in the northwestern part of Shenandoah County, an extensive deposit of manganese is found with the iron ores. The ore was reported as accompanying the Oriskany horizon in more or less continuous pockets over an area 3 miles long. The main deposits are at the western end of Cupola Mountain, but outcrops occur in the broken hills that prolong it to the southwest. . The ore was reported to contain 70 per cent manganese oxide.

Powells Fort.-The Powells Fort manganese deposits ${ }^{b}$ are located on Northeast Massanutten Mountain at Powells Fort, in the eastern part of Shenandoah County, and extend slightly into the western part of Warren County. The ore was reported as very pure crystalline pyrolusite, and as occurring in two parallel beds over a mile in length, only one of which has been developed. This bed was said to be 4 to 7 feet thick and to have a conglomerate for a hanging wall and a sandstone for a foot wall. The following are analyses of manganese ore from Powells Fort:

Analyses of manganese ore from Powells Fort. ${ }^{a}$

\begin{tabular}{|c|c|c|c|c|}
\hline & 1. & 2. & 3. & 4. \\
\hline \multirow{10}{*}{ 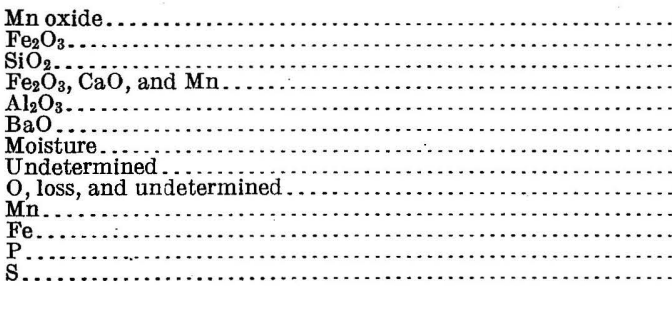 } & $\begin{array}{c}94.30 \\
\ldots \ldots \ldots\end{array}$ & 0.43 & & \\
\hline & 1.78 & 3.78 & 9.20 & 1.50 \\
\hline & $\begin{array}{r}.50 \\
1.10\end{array}$ & 25 & & \\
\hline & 1.30 & $\begin{array}{l}.42 \\
\end{array}$ & & \\
\hline & .28 & .37 & & \\
\hline & & 34.09 & & \\
\hline & & 60.66 & 48.59 & 59.302 \\
\hline & & & 3. 07 & .844 \\
\hline & & & $\begin{array}{l}.349 \\
.12\end{array}$ & \\
\hline & 00 & 100.00 & & \\
\hline & & & & \\
\hline
\end{tabular}

$a$ Weeks, J. D., Mineral Resources U. S. for 1885, p. 326 .

The following description of the manganese mines of Powells Fort in the Massanutten Mountain was furnished the writer by Mr. R. J. Holden. ${ }^{c}$

Powells Fort, or Little Fort Valley, lies in the eastern corner of Shenandoah County, Va., southeast of Strasburg and Woodstock. Structurally this valley is a syncline of Silurian and Devonian sediments and constitutes the most northerly syncline of the Massanutten synclinorium. This valley carries ores both of manganese and of iron, which have been mined at several points within an area 5 miles long, the iron for use in the local Mine Run furnace and the manganese for shipment. The principal manganese mines are the Baltimore mine and the Philadelphia mine.

The Baltimore mine is about 6 miles east of Woodstock and one-third mile west of the Mine Run furnace, near the southwest end of the Little Fort Valley. It is reported to have been opened in 1880 and equipped with concentrating machinery. Apparently the mine was not worked for any considerable time. The machınery is said

$a$ Weeks, J. D., Mineral Resources U. S. for 1885, p. 324,

$b$ Idem, p. 325.

$c$ Holden, R. J., unpublished notes, 1909. 
to have been removed about 1901, but the mine is reported to have been worked for eighteen months in 1907 and 1908, the ore being sorted by hand. The ore occurs on the outcrop of the southeast limb of the syncline in a northeasterly dipping sandstone and in an overlying conglomerate. A. C. Spencer $a$ refers to "a valuable deposit of manganese" in the "Monterey" (Oriskany) sandstone in Little Fort Valley under the name of the Powells Fort mine. This is evidently the same as the Baltimore mine. He describes the mine as follows:

"The manganese ore, which is a well-crystallized oxide, appears to occur in a veinlike body along the bedding of the sandstone, which here dips about 45 degrees to the northwest. No clay is present with the ore, as is the case in the deposits along the Blue Ridge, but it is found coating the walls of the crevice in which it occurs, and often as a cement binding fragments of conglomerate and penetrating the contiguous sandstone. The width of the vein varies from 2 to 9 feet, with occasional pinches where it is cut out entirely."

The lower sandstone is a white or gray loose-textured rock with various sizes of grain and is more or less impregnated with blue manganese. This produced the low-grade siliceous ore, mined from a shaft said to be 20 feet deep, with drifts in the bottom. The overlying conglomerate carries pebbles one-half inch and less in diameter and has a decidedly vitreous appearance. This carries the high-grade ore and has been worked in a V-shaped open cut for about 400 feet on the strike and 10 to 20 feet deep, and to some extent in underground workings which are said to have a maximum depth in a shaft of 120 feet. At the surface the conglomerate is seen to be fractured and to have crevices up to 4 inches in width containing brown wad and some crystalline dark-colored hard manganese, but no clay. Lining the cavities in the ore there are distinct crystals of manganese oxide 1 to 2 millimeters in diameter, of undetermined crystal form but apparently orthorhombic. In mining it is reported that the method was to follow the crevices which carried wad, and in this way cavities were found which carried as high as half a ton of high-grade ore.

The Philadelphia mine is about a mile and a half northeast of the Baltimore mine and a half mile west from Mud Hole Gap. It is in the same syncline with the Baltimore mine, but apparently on the northern limb of the syncline, although the stratigraphic relations were not studied. The mine is near the base of Three Top Mountain and in a talus of clay and sandstone bowlders. The main visible opening is a small circular pit 15 feet deep. This shows a soft blue manganese which crumbles to a powder on touching. There are some other workings, including tunnels. It is reported that several hundred tons of manganese were shipped, but apparently the powdery condition has prevented satisfactory saving of the ore.

In the Oregon iron mine, which is in the same valley with these manganese mines and some 4 miles northeast of the Baltimore mine, there is abundant blue hard manganese and some manganiferous iron ore. This mine consists of a number of shallow cuts, but much of the ore was taken from the surface without much mining. The stratigraphic relations are not evident, but apparently this mine is on the strike of the formation of the Baltimore mine, and the relations appear to be the same.

In the Oriskany iron-ore mines of Virginia the iron ores are not uncommonly locally high in manganese, and at places in the ore horizons where iron is absent, or present in small quantities only, it is not infrequently the case that the rocks are more or less impregnated with manganese. There is strong evidence that these materials were leached from the overlying black Devonian shale. It is not improbable that the iron and manganese of the ores of Little Fort had the same origin. The explanation of the peculiar character of the deposit in the Baltimore mine is to be found in the exceptional character of the Oriskany sandstone at this point. The clean fractures furnished cavities where the manganese could be precipitated without being contaminated by the phosphorus of the associated material. 


\section{NEW RIVER REGION.}

GEOGRAPHY AND TOPOGRAPHY.

The ores of the New River region occur in several belts south of Pulaski, Wytheville, and Marion in Smyth, Wythe, and Pulaski counties in southwestern Virginia. (See Pl. II.) The region consists of short parallel east and west ridges with intervening valleys. It is drained on the east by Cripple Creek, the waters of which flow eastward into New River and thence northward into the Ohio by way of the Kanawha. On the west the district is drained by South Fork of Holston River, which flows southwestward into the Tennessee. The principal manganese area is southeast of Marion, between that place and the Iron Mountains. In this area there are several parallel ridges and valleys. First southeastward from Marion is Pond Mountain, beyond which is a small valley known as Currin Valley. On the south side of Currin Valley is Brushy Mountain, and south of this a level region 2 or 3 miles wide and 6 or 8 miles long known as Rye Valley. Beyond Rye Valley are the Iron Mountains.

\section{GEOLOGY.}

The district is best known for its limonite deposits, with many of which there is associated a small amount of manganese ore. In some localities the manganese ore is abundant enough to form a manganiferous iron ore, or even a ferruginous manganese ore. The orebearing rocks are of Cambrian and Ordovician age, with a succession similar to that farther northeast, in the valley of Virginia. ${ }^{a}$

General succession of rocks in southwestern Virginia.

Mississippian:

Pennington shale.

Newman or Greenbrier limestone.

Pulaski shale.

Price sandstone.

Devonian:

Grainger shale.

Chattanooga shale.

Silurian:

Giles formation.

Clinton (Rockwood) formation. (Carries fossil hematite.)

Clinch sandstone.

Ordovician:

Bays sandstone.

Sevier shale.

Moccasin limestone-Tellico sandstone.

Chickamauga limestone-Athens shale.

Holston marble lentil.

$a$ Keith, A., Cranberry folio (No. 90); Campbell, M. R., Pocahontas folio (No. 2(i); 'Tazewell folio (No. 44), and Bristol folio (No. 59), Geol. Atlas U. S., U. S. Geol. Survey. 
Cambro-Ordovician.

Knox dolomite.

Cambrian:

Nolichucky shale.

Honaker limestone.

Watauga shale.

Shady limestone. (Carries valley brown ore.)

Erwin quartzite. (Carries mountain brown ore and manganese ore.)

Hampton shale.

Unicoi sandstone.

Pre-Cambrian:

Crystalline and metamorphic rocks.

The Shady limestone is the principal surface rock in the northern part of the manganese areas, the underlying sediments being more prominent to the southeast. The contact between the Paleozoic rocks and the crystalline rocks of the Piedmont region is on the south slope of the Iron Mountains, which are just south of the district. There has been a great deal of thrust faulting, bringing about complexity of areal distribution of the rocks. The fault planes ${ }^{a}$ dip southeast, and the general dip of the sediments is in the same direction. There has been considerable folding, causing the formation of a number of east and west anticlinal ridges. The ores are associated mainly with clays derived from the Erwin quartzite, though locally small deposits occur.in clays of the Shady limestone.

\section{OCCURRENCE OF THE ORES.}

The manganese ores of the New River region are somewhat different in their associations from the ores of the Blue Ridge region, although areally and stratigraphically they occupy a similar position with regard to the crystalline rocks. In the principal deposits the ores are found in large masses in variegated clay. Though in general irregular, these masses tend roughly to take the form of vertical lenses several feet thick. They consist of a mixture of psilomelane and limonite in varying proportions with a large amount of decomposed sandstone and clay in the form of small fragments and irregular masses. The ore is deposited around the fragments, and in veins through them, and in part replaces them. There are many small irregular cavities, into which protrude numerous nodular points of psilomelane. Where the clay is sandy, as in the Currin Valley mine, the ore contains an abundance of sand grains. The relation between the iron and manganese is complex, though in general the manganese penetrates deeper into the mass. Generally they interpenetrate coarsely and can be easily distinguished in a specimen, but in some places they are intimately mixed. Limonite commonly

$a$ Holden, R. J., The brown ores of the New River-Cripple Creek district, Virginia: Bull. U.S. Geol. Survey No. 285, 1906, p. 190. 
lines cavities in the manganese ore, and in such places it is clearly a later deposition.

Besides these large masses, manganese is found in a few places as small, irregular, nodular bodies disseminated through yellow and brown clay. These have not been found to form workable deposits.

\section{DESCRIPTIONS OF MINES AND DEPOSITS.}

Umbarger mine.-The Umbarger mine is situated in Smyth County about $1 \frac{1}{2}$ miles east of Sugar Grove, near the headwaters of South Fork of Holston River. It is south of Brushy Mountain, in the eastern portion of Rye Valley. The main workings consist of several small pits in red, brown, yellow, and manganiferous clays, but considerable trenching and drilling has been done as exploration work. The principal occurrence of ore is in the form of large masses 4 or 5 feet thick, consisting of a porous mixture of psilomelane and brown iron ore, deposited around decomposed sandstone fragments so as to form a breccia. Many of the fragments have been largely replaced by ore. The masses are generally somewhat elongated and stand vertically in red and brown clay: Ore also occurs in the form of gray and black psilomelane in small irregular masses scattered sparingly through red and yellow clay. They are generally less than 3 or 4 inches in diameter, and have irregular surfaces with numerous small nodular projections. Deposits are scattered over an area of perhaps 20 or 30 acres.

Currin Valley mine.--The Currin Valley mine is in Smyth County, about $1 \frac{1}{2}$ miles south of Attoway. It consists of several large cuts or banks on the north side of Currin Valley. The banks are in lightcolored clay, which here and there contains masses of partly decomposed sandstone. The ore mined has been mainly brown iron ore, but manganese ore is associated with it. The manganese is largely in the form of psilomelane and occurs as an infiltration in sandstone and clay in irregular streaks and seams. It cements grains of sand and small fragments of sandstone, and contains also masses of clay. It is generally coarsely intermixed with limonite, the association in many places being such as to suggest that limonite is a later deposition. The limonite commonly lines cavities and coats masses of psilomelane; the psilomelane penetrates the ore masses irregularly. Rarely, however, finely crystalline pyrolusite is found filling cavities in the limonite, so as to suggest that this mineral is of later origin than the iron ore.

Other deposits.-Besides the Umbarger and Currin Valley mines, numerous other small deposits of manganese and manganiferous iron ore have been discovered in the New River district. Many of these were encountered in the iron-ore deposits and have been mined; 
others are mere prospects. Among them are deposits at the Atkins mine, southeast of Attoway, Smyth County; at the Walker and Tate properties, north of Sugar Grove, Smyth County; at Razor bank, Rye Valley, Smyth County; on Chestnut Ridge, 6 miles from Seven Mile Ford station, Smyth County; at the Eagle Cliff mine, near Ivanhoe, Wythe County; at several localities in Lick Mountain south of Wytheville, Wythe County; at the Glade bank, 4 miles southwest of Max Meadows, Wythe County; at Noble Furnace, Wythe County; near Allisonia, Pulaski County; and on Macks Mountain, 4 miles east of Radford Furnace, Pulaski County.

Analyses.-The following are analyses of ore from the New River district:

Analyses of manganese ore and manganiferous iron ore from the New River district.a

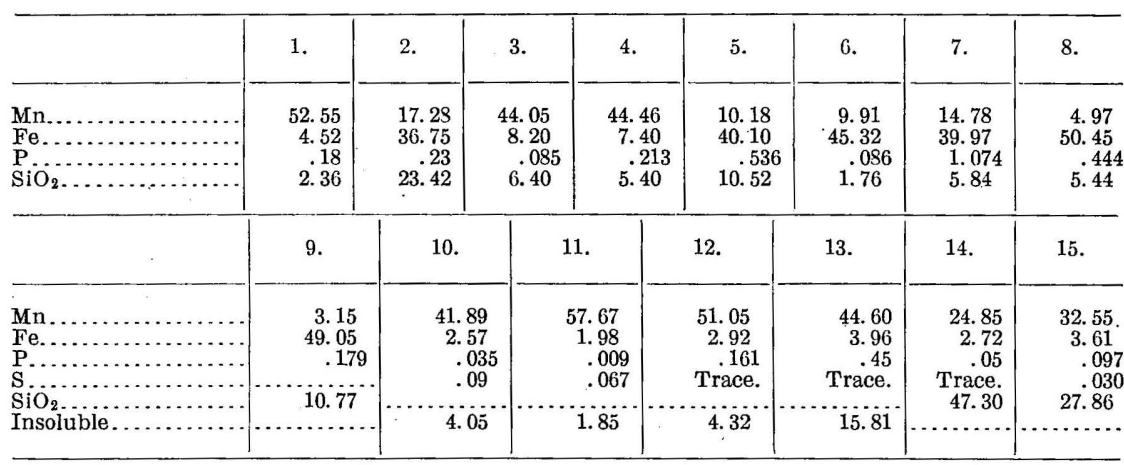

$a$ Weeks, J. D., Sixteenth Ann. Rept. U. S. Geol. Survey, pt. 3, 1895,pp. 432-433; also Mineral Resources U. S. for 1885, pp. 322-323; and Watson, T. L., Manganese oxides: Mineral resources of Virginia, p. 255.

1. From Deans Branch, south of Pond Mountain, Smyth County.

2. From Currin Valley on the west prong of Staleys Creek, Smyth County.

3. From the A tkins property, Smyth County.

4. From the Umbarger mine, Smyth County.

5. From Razor bank, Rye Valley, Smyth County.
6. From Glade Mountain, near Marion, Smyth County.

7. From Macks Mountain, 4 miles east of Radford Furnace, Pulaski County.

8. From Glade manganiferous iron-ore bank, 4 miles southwest of Max Meadows, Wythe County.

10-13. From Lick Mountain, near Wytheville, Wythe County.

14,15. From Cripple Creek, 8 miles from Wy theville, Wythe County.

\section{NORTHEASTERN TENNESSEE.}

GENERAL STATEMENT.

Manganese and manganiferous iron ores occur in the western part of the Appalachian Mountains, in eastern Tennessee and western North Carolina, in a belt extending from Virginia to Georgia. The principal deposits, however, are in northeastern Tennessee.

Two principal groups of deposits are known in the northeastern Tennessee region-those of Shady Valley, Johnson County, and those of Newport and Del Rio, Cocke County. Small deposits have been reported from Carter, Unicoi, Greene, and Sevier counties, Tenn., and the adjoining counties of Madison and Mitchell in North Carolina. 
The following is a general section of the Cambrian rocks of northeastern Tennessee, after Keith: ${ }^{a}$

Cambro-Ordovician: Knox dolomite.

Cambrian:

Nolichucky shale.

Maryville limestone

$\left.\begin{array}{l}\text { Rogersville shale } \\ \text { Rutledge limestone }\end{array}\right\}$ Honaker limestone.

Watauga shale.

Shady limestone.

Hesse quartzite-Erwin quartzite.

Murray slate

Nebo quartzite Hampton shale.

Nichols slate

Cochran conglomerate

Hiwassee slate

Unicoi formation.

Archean:

Snowbird formation

Granite and gneiss.

The iron ores of eastern Tennessee and western North Carolina are very largely associated with the Shady limestone. A large proportion of the manganese ores also occur in connection with these, for instance the ores of Shady Valley. Other deposits, however, which are more purely manganese, such as those around Newport, occur in residual clays of shales and quartzites below the Shady limestore.

\section{SHADY VALLEY. ${ }^{b}$ \\ GEOGRAPHY AND GEOLOGY.}

Shady Valley is in the extreme northeastern corner of Tennessee. It runs in a general northeast and southwest direction and constitutes the northeastern portion of the valley between Holston Mountain on the northwest and Iron Mountain on the southeast. It varies in width from 3 miles to less than half a mile.

Shady Valley is drained by Beaver Dam Creek, which flows northeastward into South Fork of Holston River. The part of the main valley southwest of Shady Valley is drained southwestward by Stony Creek.

The Holston Mountains consist largely of quartzite or sandstone (Erwin quartzite), but on their lower slopes associated shales and limestones (Shady limestone) appear. These, as well as the upper part of the quartzite, are locally very much decomposed and exist at the surface as clay with local fragments of undecomposed rock. The formations are all of Cambrian age.

OCCURRENCE OF THE ORES.

The ores of Shady Valley, mainly brown iron ores, subordinately manganese, occur in residual clays of the quartzite, shale, and lime-

$a$ Keith, A., Roan Mountain folio (No. 151), Geol. Atlas U. S., U. S. Geol. Survey, 1907.

$b$ Penrose, R. A. F., jr., Manganese: Its uses, ores, and deposits: Ann. Rept. Arkansas Geol. Survey for 1890 , vol. 1, 1893, pp. 414-416. 
stone. The iron ores have been worked for a long time, but the manganese ores have been merely prospected. The manganese occurs as steel-gray or black amorphous psilomelane in porous masses of stalactitic branches, and in kidneys. Crystals of pyrolusite line some of the cavities in the massive ore.

The iron and manganese ores are found interbedded in lenticular layers or pockets. In some places they occur together in the same pocket, and elsewhere they are separate. The iron-ore beds are a few inches to 10 feet thick; the manganese ore beds are a few inches to 3 feet thick.

The most important showings of manganese in Shady Valley ${ }^{a}$ are at the Heberlin mine and its vicinity. About 800 tons of ore, which is mainly psilomelane, has been taken out, but none has been shipped. At the Wright opening near the head of the valley ore occurs in the massive form in a bed 6 feet thick. About 150 tons have been mined. Another deposit occurs in a small stream about a mile from the Wright opening, where a ledge of manganese ore 4 feet wide and 6 feet deep is exposed. Manganese ore has also been found in several places on the Sheafer property in the lower end of the valley, and at numerous localities in association with iron ore. Among the latter it occurs principally at the King, Blevins, and Silver banks. ${ }^{b}$

\section{ANALYSES.}

The following are analyses of ores from Shady Valley ${ }^{a}$ and vicinity: Analyses of manganese ores from Shady Valley.

\begin{tabular}{|c|c|c|c|c|}
\hline$\cdot$ & $\mathrm{SiO}_{2}$ & Fe. & Mn. & P. \\
\hline 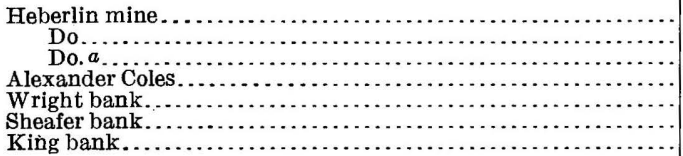 & $\begin{array}{l}1.62 \\
1.1 \\
1.30 \\
1.4 \\
7.6 \\
4.12 \\
1.7\end{array}$ & $\begin{array}{l}\text { 4. } 6 \\
\text { 3. } 0 \\
2.085 \\
2.3 \\
7.1 \\
5.2 \\
16.1\end{array}$ & $\begin{array}{l}51.05 \\
55.00 \\
53.735 \\
53.09 \\
41.44 \\
50.25 \\
40.87\end{array}$ & $\begin{array}{l}0.075 \\
.099 \\
.008 \\
.177 \\
.066 \\
.16 \\
.052\end{array}$ \\
\hline
\end{tabular}

$a$ Birkinbine, John, Mineral Resources U. S. for 1900, p. 124.

Manganese ores also occur in the iron-ore banks of Stony Creek valley, Johnson County, southeast of Shady Valley. The following is an analysis of ore from the Hodge mine near the head of the valley:

$a$ Weeks, J. D., Seventeenth Ann. Rept. U. S. Geol. Survey, pt. 3, 1896, pp. 202-203. $b$ Willis, Bailey, Tenth Census U. S. (1880), vol. 15, Mining industries, pp. 344, 345. 
Analyses of manganiferous iron ore from the Hodge bank. $a$

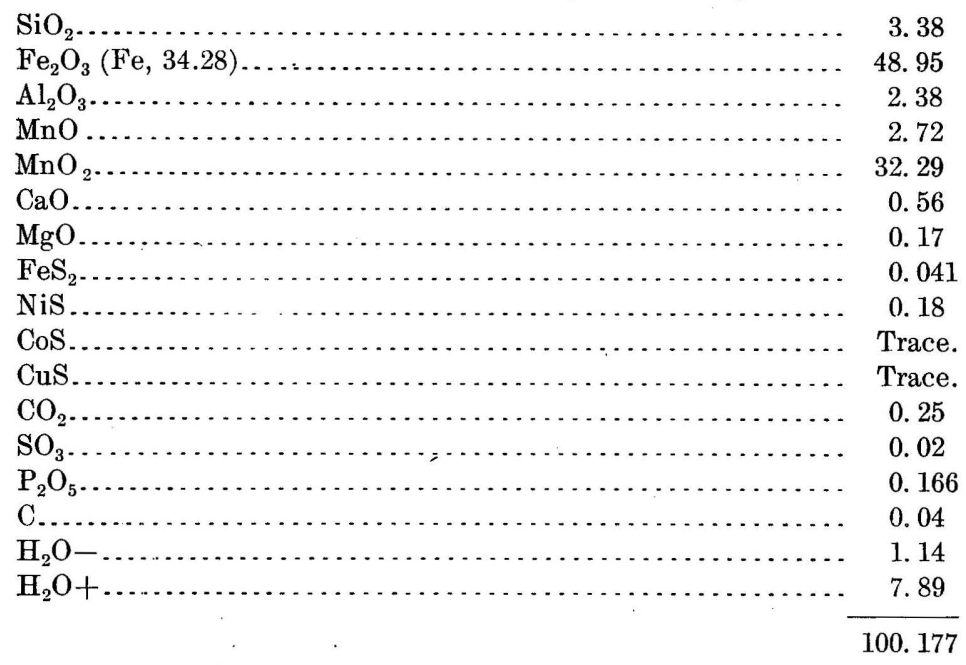

NEWPORT REGION.

GENERAL STATEMENT.

The region around Newport and Del Rio, Tenn., occupies the southwestern portion of the manganese belt, extending northeastward to Shady Valley. Newport is on the southeastern border of the Appalachian Valley near the first outliers of the Unaka Range. The manganese area extends from there to Del Rio, which is farther up in the mountains. The region is drained by French Broad and Big Pigeon rivers.

The rocks in the vicinity of Newport and Del Rio are of Cambrian and Ordovician age. The ore deposits occur in residual clays derived from shale, limestone, and quartzite in the Cambrian.

The manganese ores are either soft or hard. The soft ores are in the form of irregular pockets and seams and are generally associated with manganiferous clay, but also occur with other clays. The hard ore is largely psilomelane and occurs in kidneys and irregular masses. The kidneys as a rule are small and are scattered through the clay. The irregular masses are of various sizes and occur together in pockets or lenses in the clay. Much of the clay is sandy, and in such places the associated ores contain numerous grains of sand and small sandstone fragments.

\section{DESCRIPTIONS OF MINES AND DEPOSITS.}

Yellow Springs mine.-The Yellow Springs mine is on English Mountain, about 5 miles southwest of Newport. It consists of an open pit in brown clay, derived from Cambrian shale and quartzite. This contains streaks and irregular masses of red, yellow, and dark 
manganiferous clay and pockets of sand. Surface fragments of quartzite are abundant. Both soft and hard ores occur and are associated with the more argillaceous material. The soft ore occurs in both the brown and the manganiferous clays in streaks and irregular pockets containing seams of clay. In places it is found in small specks grouped together into pockets. The hard ore consists of psilomelane in two forms-kidneys and irregular masses. The kidneys are very irregular in shape, varying up to 4 inches in diameter, though generally small, and are found scattered through the different clays and also through the soft-ore pockets. The irregular masses generally have botryoidal surfaces and contain cavities filled with clay. They vary in size up to a foot or more in diameter, and occur together in pockets or lenses in the clay.

Jones and McMahon properties.-The Jones and McMahon properties are about one-half mile northeast of the Yellow Springs mine. A very sandy ore occurs here in the form of irregular and stalactitic masses, as float.

Raines property.-About one-half mile northeast of these is the Raines property. Manganese oxide occurs locally in specks and wormlike stringers, replacing brown sandstone fragments embedded in orange clays. In places the replacement has gone so far that the fragments have become black. Irregular masses of psilomelane also are found scattered through the clay.

Other deposits.-Other deposits in this district are reported from Neddy Mountain and Long Creek, 3 miles and $5 \frac{1}{2}$ miles, respectively, east of Bridgeport; from Del Rio, Wolf Creek, and Cosby, all in Cocke County.

\section{MINOR LOCALITIES.}

Ore has been found at several localities in Unicoi County, ${ }^{a}$ but the pockets are too far apart to make mining profitable. It is reported as having an average percentage of 46.73 of manganese and 0.212 of phosphorus. The deposits ${ }^{b}$ occur at the contact of the Shady limestone with the underlying Erwin quartzite at two localities, one $2 \frac{1}{2}$ miles $\mathrm{N} .70^{\circ} \mathrm{E}$. of Unicoi City, and the other the same distance and direction from Erwin.

In Greene County manganiferous iron ore containing 48.87 per cent iron, 6.52 per cent manganese, and 1.031 per cent phosphorus occurs at the Stephens mines ${ }^{c}$ near Hayesville furnace. Ore has also been found 11 miles from Greeneville in the Unaka Range. ${ }^{d}$

From North Carolina manganese ores are reported from Mitchell County, and near Hot Springs in Madison County, where they occur

$a$ Weeks, J. D., Sixteenth Annual Rept. U. S. Geol. Survey, pt. 8, 1895, p. 424.

$b$ Keith, Arthur, personal communication.

cWillis, Bailey, op. cit., p. 337.

$d$ Penrose, R. A. F., jr., op. cit., p. 41 ì. 
in association with iron ores in Cambrian rocks. The following are analyses of ores from Hot Springs:

Analyses of ores from vicinity of Hot springs, N.C.a

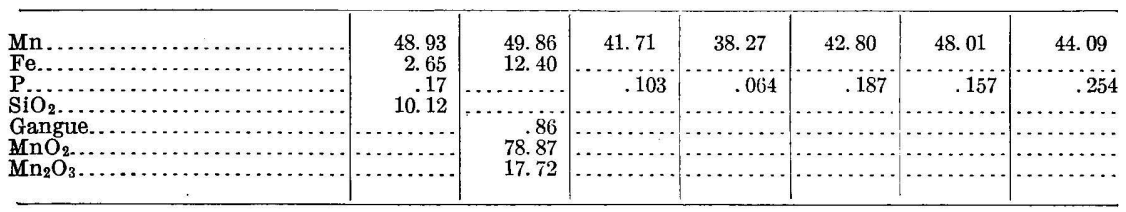

a Weeks, J. D., Eleventh Census U. S. (1890), Mineral industries, pp. 304-305.

\section{CARTERSVILLE DISTRICT.}

\section{GEOGRAPHY AND TOPOGRAPHY.}

The Cartersville district is in northwestern Georgia, northeast, east, and southeast of Cartersville, Bartow County. The manganesebearing area is about 15 miles long in a north and south direction and 5 miles wide. It is drained by Etowah River, which flows westward into Coosa River and thence by way of the Alabama into Mobile Bay.

The region contains a number of detached hills and ridges with smooth and rounded slopes and broad intervening valleys. The ridges are generally wooded, while the valleys are cultivated, cotton raising being the chief industry. The district ranges from 700 to 2,200 feet above sea level, but the difference in elevation between the hill tops and valley bottoms is generally less than 1,000 feet. Northward, however, the difference in elevation becomes more pronounced as the Unakas and other high Appalachian ranges are approached. The manganese ores occur mainly on the slopes of the ridges.

\section{GEOLOGY.}

The rocks of the Cartersville district range in age from preCambrian to Ordovician, with the following succession:

Cambro-Ordovician: Knox dolomite.

Cambrian:

Conasuuga shale.

Rome formation.

Beaver limestone.

Weisner quartzite.

Metamorphic: Conglomerate, slate, and schist. (Ocoee group.)

Crystallines:

Granite and gneiss.

Amphibolite schist.

The contact between the metamorphic and Cambrian rocks is marked by the Cartersville fault, just east and south of the manganesebearing area. (See fig. 8.) East and south of the Cartersville fault 
are the metamorphic and crystalline rocks, while to the north and west are the Paleozoic rocks.

The Weisner quartzite ${ }^{a}$ is exposed in an irregular belt just west of the fault and forms a more hilly area than the formations to the west. It is a brown vitreous quartzite with some beds of fine conglomerate and siliceous shale. The thickness is said to be probably 2,000 to 3,000 feet, but may be considerably more, as the quartzite is very complexly folded and faulted, and the base is nowhere exposed. The residual material derived from the Weisner quartzite is sandy brown, yellow, and variegated clay.

The Beaver limestone forms a belt west of the quartzite exposures. It is seen at few points at the surface, but drilling has shown it to be a gray crystalline dolomitic limestone, shaly in places and containing masses of chert. Near the surface the limestone is decomposed into dark-red residual clay, with chert fragments. In many places the clay contains also quartzite fragments derived from the Weisner quartzite. The thickness is probably between 800 and 1,200 feet.

The Conasauga and Rome formations constitute a great thickness above the Beaver limestone and form the bed rock in the district west of the Beaver limestone area.

\section{OCCURRENCE OF THE ORES.}

The manganese ores of the Cartersville district are found in the residual clays of both the Weisner quartzite and the Beaver limestone, but mainly of the former. They occur scattered throughout the area covered by these clays, but workable deposits are only locally developed. Manganiferous iron ores occur at various places, but they are comparatively unimportant.

The ore is of four varieties: (1) Kidney ore, consisting largely of pyrolusite, rarely of psilomelane, and showing concentric structure; (2) irregular masses, either psilomelane or pyrolusite, or a mixture of the two; (3) breccia and replacement ore with chert or sandstone fragments; and (4) seams and irregular pockets of soft ore with local hard masses. All of these different types occur scattered through clay, grouped into local deposits, the second and fourth being more commonly associated with black manganiferous clay. Generally several types of ore occur together in the same deposit.

1. The kidney ore is largely pyrolusite and occurs in three different forms: (a) The most common type is that consisting of granular and finely crystalline pyrolusite in successive concentric layers. The crystalline pyrolusite may be in the form of fine needles, but is generally in irregular aggregates. Commonly the layering is obscure

$a$ Hayes, C. W., and Eçkel, E. C., Iron ores of the Carterșille district, Georgia: Bull, U, S, Geol, Survey No. 213, p. 233. 


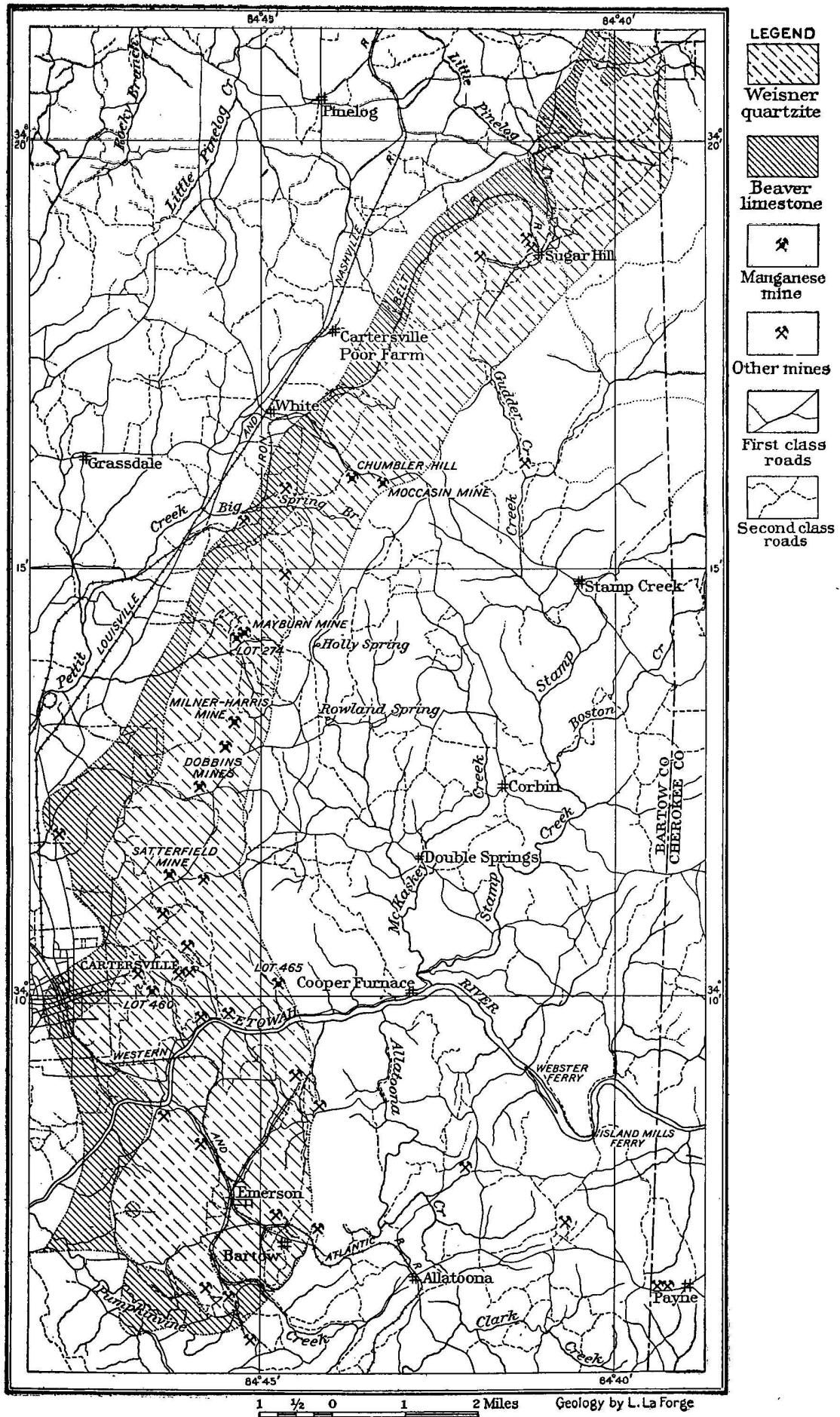

FIGURE 8.-Map showing the principal manganese mines in the Cartersville district, Georgia, and the probable extent of the ore-bearing areas. 
and is interrupted by cavities lined with fine crystals of pyrolusite. (b) Another type of kidney ore consists altogether of thin concentric layers of blue, finely granular pyrolusite. (c) The third type is composed largely of coarsely crystalline pyrolusite in concentric layers. The layers range up to one-third inch in thickness and are composed of short, coarse, parallel needles arranged transversely. Commonly several kidneys become cemented together into a single mass, and thus grade into the second variety of ore-that is, the irregularmass ore.

The kidneys are embedded in clay, in some places being very closely grouped and in other places scattered at considerable intervals. They are generally associated with other types of ore. Separate lumps range up to 4 or 5 inches in diameter, but kidneys that are cemented together may be in masses a foot or more in diameter.

2 . The irregular masses of ore vary up to a foot or more in diameter, and are scattered through the clay or segregated into pockets. They consist either of pyrolusite, of psilomelane, or of a mixture of the two, are porous or solid, and may or may not have a concentric structure. The most common type consists of granular and finely crystalline pyrolusite in varying proportions, either irregularly mixed or in concentric layers. Those of the latter form are probably derived from kidney ore. They generally contain cavities lined with fine pyrolusite crystals. The ore masses composed of psilomelane may be either solid or porous. The solid masses generally exhibit a concentric structure and have botryoidal surfaces; many of the porous masses have botryoidal forms in cavities. Masses containing both psilomelane and pyrolusite are rare and consist simply of a mixture of the types described above.

3. The breccia ore occurs in residual rock masses, many several feet in extent, embedded in clay. The ore is crystalline or granular pyrolusite and the fragments are mostly sandstone. The pyrolusite is found partly filling cavities between fragments and partly replacing the fragments themselves. Cavities are generally abundant in breccia ore and are lined with fine pyrolusite crystals; many have nodular projections in them.

4. Soft ore is abundant in the Cartersville district, the principal occurrence being at the Dobbins mine. The ore is finely crystalline pyrolusite. It is found in various forms ranging from small seams in sandy clay to large pockets several feet in extent containing small scattered masses of clay. (See fig. 11.) Most of the ore has the consistency of sand, but through this there are scattered fragments of hard ore of the same nature. This ore is plainly a replacement in sandy clay. Many of the pockets are surrounded by a zone of clay, stained and partly replaced by manganese oxides. 
DESCRIPTIONS OF MINES AND DEPOSITS.

Location of deposits.-The larger deposits of the Cartersville district (see fig. 8) are in the Chumbler Hill and Moccasin mines east of White; lot 274, the Mayburn mine (lot 303), the Dobbins mine, the Milner-Harris mine, and lots 305 and 306, northeast of Cartersville; lots 460 and 465, east of Cartersville; and the Stegall property near Emerson. Numerous minor deposits occur throughout the district, but very few of them have produced ore. The Cartersville mines have not been operated to any extent for four or five years, so the workings are old and their walls have fallen in.

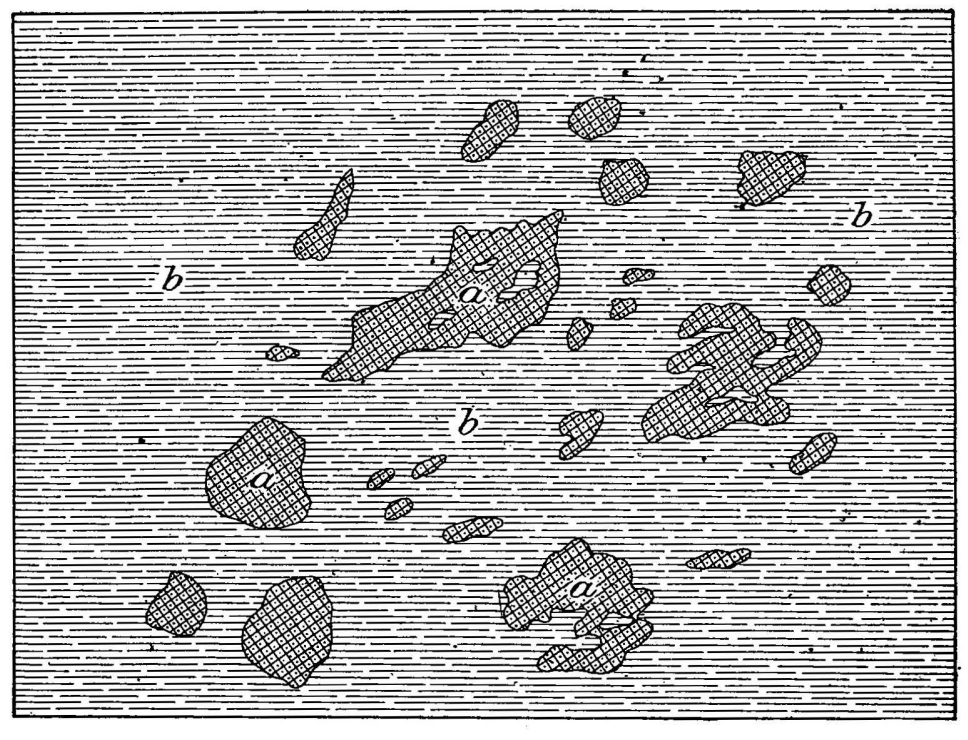

은

5

10

15 Inches

FIGURE 9.-Sketch showing distribution of manganese ore in clay at the Chumbler Hill mine. $a$, Ore; $b$, brown and yellow clay.

Chumbler Hill mine.-The Chumbler Hill mine is about $1 \frac{1}{2}$ miles southeast of White, on the northeast slope of a quartzite ridge. The workings consist of a shaft and a large circular open pit about 500 or 600 feet in diameter and over 50 feet deep. The walls of the pit are composed of yellow and brown clays with streaks and masses of white and chocolate clays and a surface layer of dark-red clay. Masses of undecomposed sandstone are still visible in a few places. Here and there stains of manganese appear on the walls as irregular streaks.

The ore occurs embedded locally in the yellow and brown sandy clays as kidneys and larger masses ranging up to a foot in diameter. (See fig. 9.) The lumps have rounded surfaces and many are composed of concentric layers of alternating crystalline and granular $37336^{\circ}-$ Bull. $427-10-6$ 
pyrolusite and psilomelane. Many are composed entirely of blue granular pyrolusite showing but slight concentric structure. In the clay the ore is soft, but on exposure it hardens.

Moccasin mine.-The Moccasin mine is about one-half mile east of the Chumbler Hill mine, near the foot of the same ridge. The workings consist of a shaft and several small pits in brown clay, in which masses of manganiferous clay and ore occur in a few places. The ore appears to be of the same type as that at Chumbler Hill, but psilomelane is more abundant.

Mayburn mine.-The Mayburn mine, situated about 6 miles northeast of Cartersville, consists of several shafts and small, open

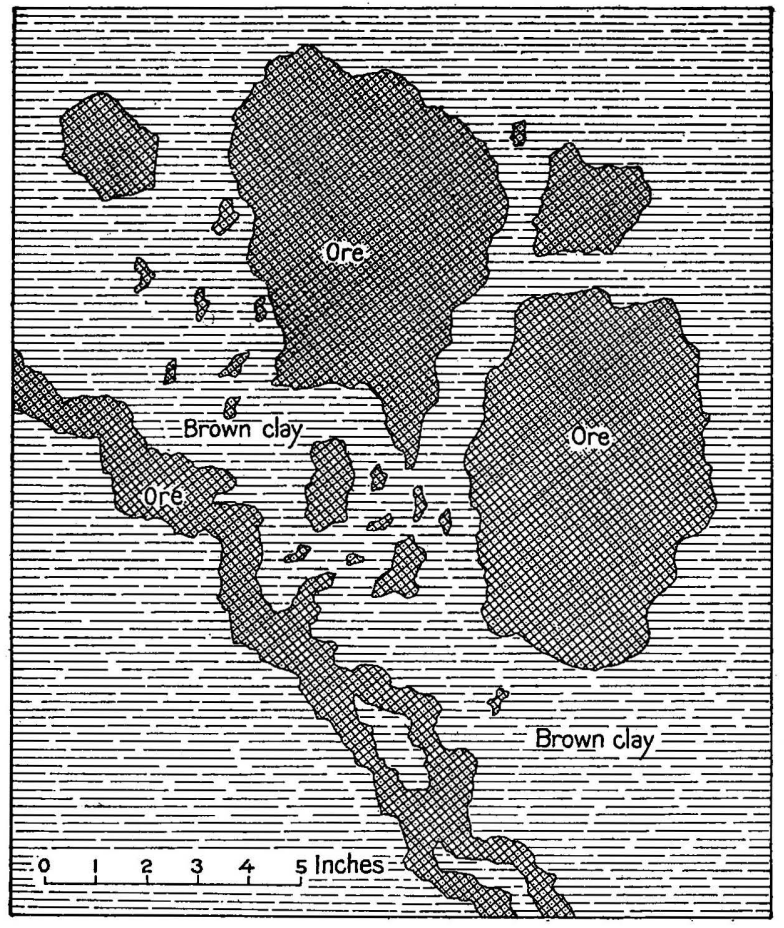

FIGURE 10.-Sketch showing distribution of manganese ore in clay at the Mayburn mine.

pits. The ore is granular and crystalline pyrolusite and it occurs in brown clay as kidneys, seams, and irregular masses. (See fig. 10.) In the clay there are also small fragments of sandstone and pockets of sand. Some of the ore is fairly hard, but much of it is soft and friable. The kidney ore is of two varieties. One variety consists of thin, concentric layers of blue granular and finely crystalline pyrolusite; the other is made up of successive layers of coarse steel-gray needle ore, also pyrolusite. The irregular masses and seams consist of soft ore with fragments of hard ore and many fragments of decomposed yellow sandstone embedded in it. The lumps and 
pockets vary up to 8 or 10 inches in diameter and are embedded at intervals in the clay. In places they are closely spaced with but a small amount of clay intervening, while elsewhere clay is predominant. Stains of manganese are abundant through the clay, especially around ore bodies.

Lot 274.-Lot 274 is a short distance west of the Mayburn mine. The workings consist of several trenches and small open pits in yellow, brown, and dark manganiferous clay. Little ore is shown in the pits, but on the dumps ores of two varieties were found. The most common type consists of an intricate mixture of crystalline and granular pyrolusite, and occurs in irregular bodies containing cavities lined with small steel-gray pyrolusite crystals. The other type is dense, hard, blue psilomelane with concentric structure. The successive layers in this type are very thin, being rarely over one-tenth inch in diameter, and are separated from each other by much thinner, often scarcely visible laminæ of soft black oxide, probably pyrolusite. Near the surface the ore is very ferruginous and fragments of manganiferous iron ore occur.

Dobbins mine.-Probably the most important mine in the district and the one that was first operated is the Dobbins mine. It is located about $4 \frac{1}{2}$ miles northeast of Cartersville and consists of an open pit, a shaft, and numerous trenches, on the south side of a ridge. The deposit has not been worked for many years. The pit is in yellow and brown clays with residual sandstone masses and a surface layer of dark-red clay. Ore is exposed along the walls, and consists chiefly of blue crystalline pyrolusite in a soft, friable form. It occurs in seams and large pockets (fig. 11) through the clay and has somewhat the consistency of sand, though harder lumps are scattered through the soft material. The ore is plainly a replacement in the clay, small masses of clay being still included in the soft-ore pockets. All gradations may be seen from small intersecting seams in clay to large pockets several feet in extent. Manganese ore also occurs in the form of finely crystalline and granular pyrolusite as a cement and replacement in sandstone breccia. The breccia ore contains abundant cavities with botryoidal surfaces, many of which are lined with small pyrolusite crystals.

About half a mile southwest of the principal workings, but still on the Dobbins tract, there are a number of small pits in brown and manganiferous clays. Soft ore with local hard lumps occurs in the manganiferous clay masses.

Milner Harris mine.-The Milner Harris mine is about 1 mile northeast of the Dobbins mine on the same ridge. It consists of old underground workings. No ore was seen in place; that ore on the dumps is similar to the Dobbins ore. 
Lot 460.- - Lot 460 is about 1 mile east of Cartersville. The workings consist of a number of scattered pits and trenches. Ferruginous manganese and manganiferous iron ores occur as irregular porous masses arranged in bands in brown and yellow clay. These bands in general vary from 1 to 4 or 5 inches in thickness, but masses a foot or more in diameter have been found in them. The manganese ore is ferruginous hard blue psilomelane, or granular pyrolusite.

Lot 465.-Lot 465 is located about $2 \frac{1}{2}$ miles east of Cartersville. The workings consist of several open pits in brown, yellow, and red

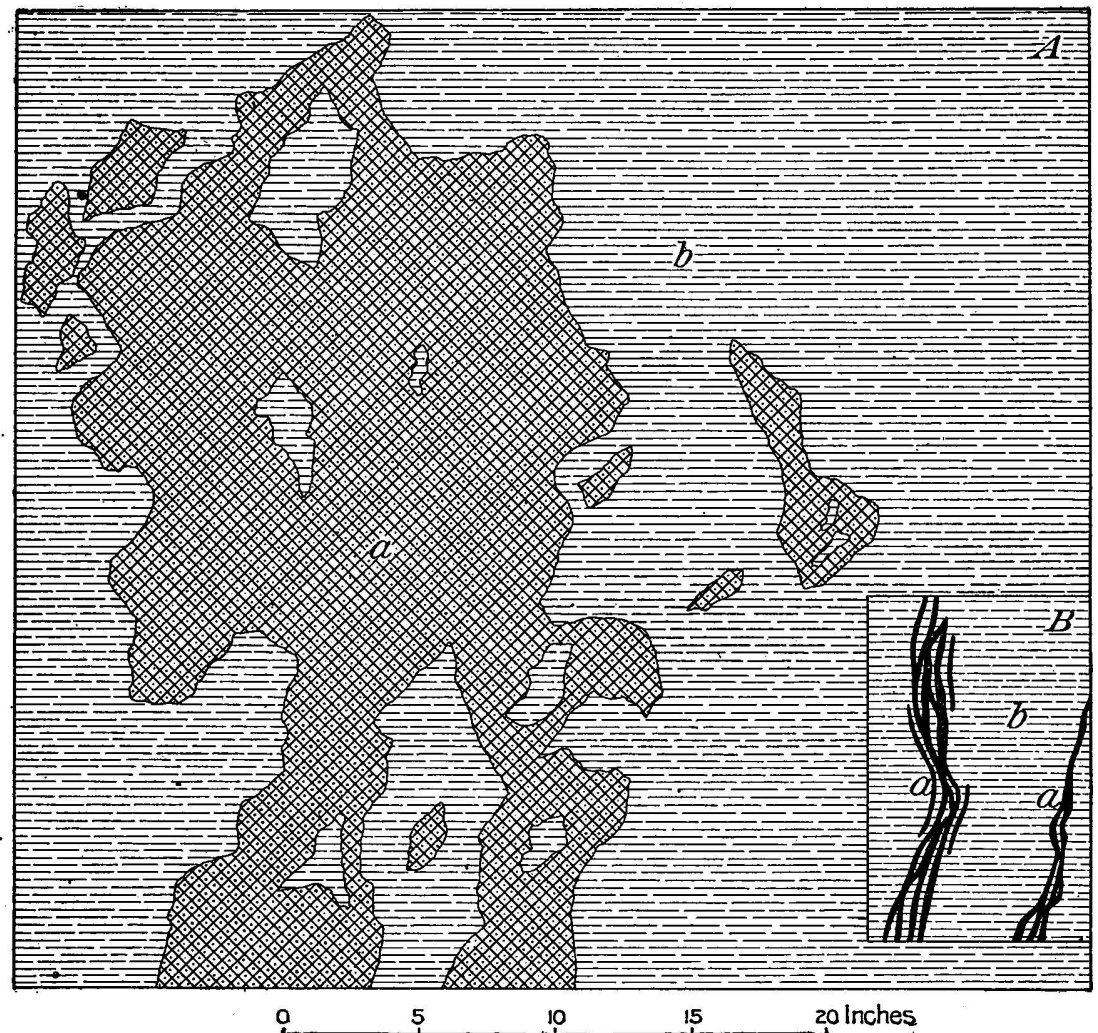

FIGURE 11.-Sketches showing occurrence of manganese ore at the Dobbins mine. $a$, Soft ore; $b$, brown and yellow clay.

clays. The ore is black or blue granular and finely crystalline pyrolusite and occurs in three different associations: (1) As cement in sandstone breccia; (2) as seams and specks in clay; and (3) as kidneys. The breccia ore is black and consists of a mixture of crystalline and granular pyrolusite cementing and partly replacing brown sandstone fragments. The seams and specks in clay are irregular replacements and consist of black pyrolusite, much of it ferruginous. The kidneys average several inches in diameter and consist of dense blue pyrolusite finely granular and arranged in thin concentric layers, 
ANALYSES.

The following are analyses of manganese ores from the Cartersville district, given by lots or mines:

Analyses of manganese ores from the Cartersville district.a

\begin{tabular}{|c|c|c|c|c|c|}
\hline Mine or lot. & Mn. & $\mathrm{Fe}$. & $\mathrm{SiO}_{2}$ & P. & Moisture. \\
\hline 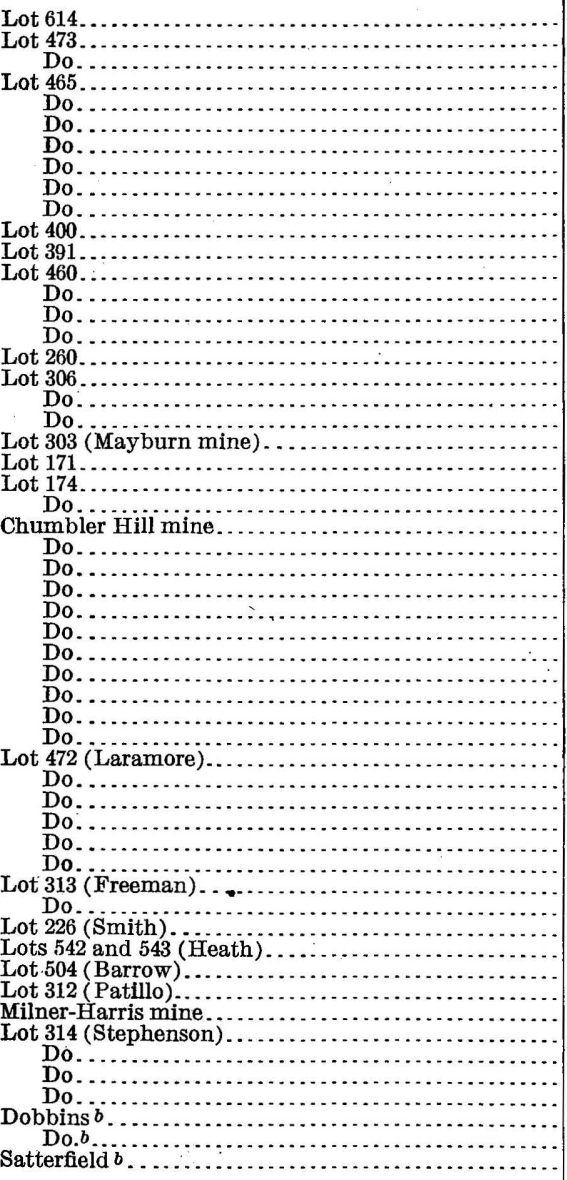 & $\begin{array}{l}47.19 \\
37.75 \\
35.19 \\
47.08 \\
43.71 \\
46.40 \\
44.59 \\
48.35 \\
39.95 \\
47.25 \\
39.02 \\
46.51 \\
40.31 \\
41.41 \\
15.26 \\
48.28 \\
25.09 \\
49.32 \\
39.24 \\
35.32 \\
54.94 \\
24.43 \\
47.24 \\
41.98 \\
30.32 \\
36.489 \\
40.354 \\
41.430 \\
36.95 \\
27.711 \\
42.933 \\
42.612 \\
41.655 \\
39.226 \\
43.457 \\
50.83 \\
53.14 \\
47.60 \\
41.28 \\
56.40 \\
53.61 \\
38.00 \\
42.40 \\
53.20 \\
33.00 \\
47.23 \\
60.61 \\
52.73 \\
38.80 \\
40.52 \\
34.69 \\
37.85 \\
52.726 \\
48.832 \\
44.72\end{array}$ & 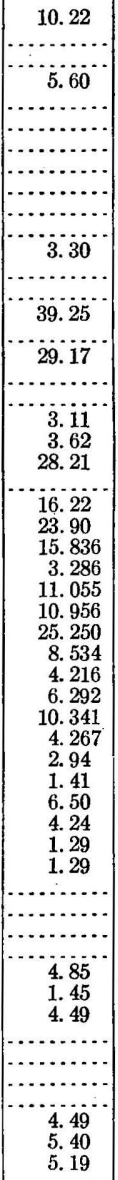 & \begin{tabular}{|c|}
6.37 \\
7.56 \\
17.49 \\
7.520 \\
11.37 \\
9.45 \\
12.30 \\
17.37 \\
20.151 \\
14.10 \\
16.45 \\
7.36 \\
1.35 \\
2.15 \\
10.88 \\
.65 \\
1.13 \\
20.00 \\
8.00 \\
3.32 \\
32.00 \\
$\cdots 2.80$ \\
4.30 \\
11.45 \\
8.42 \\
25.90 \\
21.37 \\
4.30 \\
5.05 \\
17.03
\end{tabular} & $\begin{array}{c}0.28 \\
.222 \\
.206 \\
.194 \\
.236 \\
.277 \\
.144 \\
.122 \\
.198 \\
.198 \\
.245 \\
.055 \\
.127 \\
.134 \\
.193 \\
.127 \\
.155 \\
.208 \\
.154 \\
.063 \\
.034 \\
.322 \\
.155 \\
.227 \\
.100 \\
.089 \\
.119 \\
.215 \\
.167 \\
.123 \\
.109 \\
.106 \\
.134 \\
.179 \\
.103 \\
.16 \\
.074 \\
.182 \\
.159 \\
.158 \\
.154 \\
.10 \\
.10 \\
.146 \\
.329 \\
. .052 \\
.052 \\
.188 \\
.160 \\
.169 \\
.108 \\
.134 \\
.188 \\
.131 \\
. .151\end{array}$ & 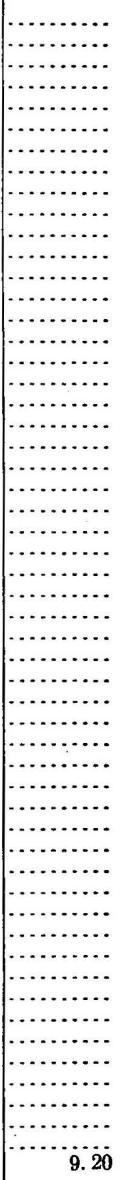 \\
\hline & & & & Lot 391. & Lot 303 . \\
\hline \multicolumn{4}{|c|}{ 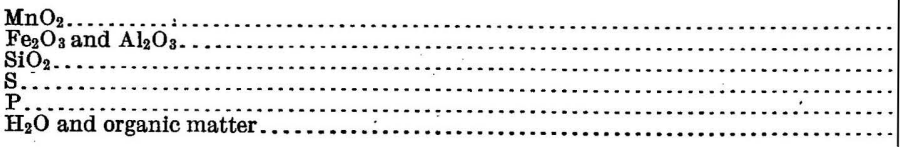 } & $\begin{array}{r}87.60 \\
9.135 \\
2.175 \\
.010 \\
.065 \\
1.015\end{array}$ & $\begin{array}{r}87.96 \\
2.520 \\
8.350 \\
.008 \\
.120 \\
1.042\end{array}$ \\
\hline 1.0 & & & & $\begin{array}{c}100.000 \\
54.75\end{array}$ & $\begin{array}{r}100.000 \\
54.975\end{array}$ \\
\hline
\end{tabular}

a Watson, Thomas L., Preliminary report on the manganese deposits of Georgia: Bull. Georgia Geol. Survey No. 14,1908 , pp. $57-65,67,68,71,76,77,83-85,88,92,94$.

b Weeks, J. D., Mineral Resources U. S. for 1885 , pp. $330-331$. 
CAVE SPRING DISTRICT.

\section{GEOGRAPHY AND TOPOGRAPHY.}

The Cave Spring district is situated in northwestern Georgia, near Cave Spring and Cedartown in Floyd and Polk counties. It has a northeast-southwest extent of about 12 miles and a width of about 5 miles. Big Cedar Creek drains most of the area, its waters flowing northward into Etowah River and thence by way of Coosa and Alabama rivers into Mobile Bay.

The topography of the district is one of broad valleys and low ridges, with differences of elevation generally less than 400 feet, though the elevation above sea level ranges from 700 feet in the lower valleys to 2,000 feet on the ridges. The ridge slopes are smooth and rounded. Large areas of comparatively flat country are interspersed with more hilly districts.

\section{GEOLOGY.}

The rocks of the district are mainly limestone and shale of Cambrian and Ordovician age. They have the following succession:

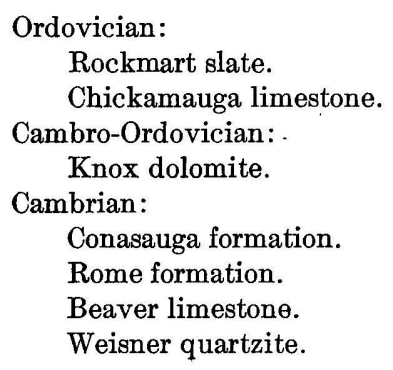

The Chickamauga limestone constitutes the bed rock,in and around Cedartown. It consists of heavy layers of blue limestone and is overlain by the Rockmart slate, consisting principally of black slate with beds of ferruginous sandstone, cherty limestone, and conglomerate in the upper portion. The Chickamauga limestone and Rockmart slate have been removed by erosion between Cedartown and Cave Spring, and northward from Cave Spring, where they appear again, the slate changes gradually to an earthy limestone, and finally to blue limestone with some earthy layers and is included in the Chickamauga limestone.

The Knox dolomite is found underlying a large tract east and south of Cave Spring, and smaller areas to the southwest. It is a massively bedded gray magnesian limestone containing a large amount of silica in the form of chert beds and nodules. The chert beds are in places mixed with or replaced by coarse sandstone: The lower third of the Knox dolomite is supposed to be of Cambrian age and the rest of Ordovician age. The residual material derived from it is of two kinds. 
The first consists of dark-red earthy clay derived from the decay of the limestone, and is generally found at the surface. In most places this contains much undecomposed chert in large masses or small fragments, but locally the chert masses are absent. The second variety of residual material consists of stiff light-colored variegated red, brown, and yellow clays such as would result from the decomposition of sandstone or shale. This contains masses of chert and sandstone breccia, and is locally found underneath the first variety. Both varieties of clay contain manganese ore.

Immediately west and north of Cave Spring there is a northeastsouthwest belt where the rocks are very much faulted, and hence their surface distribution is irregular. There are several alternating bands of rocks of the Conasauga and Rome formations and some Kंnox dolomite in this faulted belt, and west of it is a large area of the Conasauga. In its typical phase, as around Dalton, north of this region, the Conasauga consists of a great thickness of clay shales with occasional beds of limestone. In the vicinity of Cave Spring, however, it contains a variety of rocks. At the base are olive clay shales overlain by oolitic limestones, which in turn are overlain by beds of gray crystalline and earthy limestone containing cellular chert. The limestones make up the larger part of the formation.

The Rome formation consists of thin-bedded, fine-grained sandstones and sandy shales of bright variegated colors. The base of the formation is formed by a bed of red sandstone and the top by white sandstones.

The Beaver limestone and Weisner quartzite are exposed in small areas southwest of the manganese area and are lithologically similar to the corresponding formations in the Cartersville district. (See pp. 77-78.)

OCCURRENCE OF THE ORES.

The ores of the Cave Spring district occur (1) as cement in breccia in both dark-red and light-colored, variegated residual clays; (2) as irregular porous masses in dark-red clays; (3) as small pellets in dark-red clays; (4) as kidneys in light-colored variegated clays; and (5) as soft ore in seams and irregular pockets in light-colored, variegated clays. The residual clays are derived largely from the Knox dolomite, but possibly also to a slight extent from the Conasauga formation.

1. The breccia ore cements residual undisintegrated rock fragments. These consist of chert where they occur in the dark-red clay, and of both chert and sandstone in the light-colored variegated clay. The ore is psilomelane and pyrolusite, the former being predominant and having crystals of the latter disseminated through it. It forms varying proportions of the breccia mass, in some places occurring simply as minute seams in solid rock, in 'others forming the main 
bulk with angular fragments of rock embedded in it. (See fig. 12.) It was deposited partly in spaces between the fragments, and partly as a replacement of the fragments themselves. Frequently the original form - of the replaced fragments may be distinguished in the ore. As a rule the replacement has gone on only a short distance from the surface, although at times entire fragments have been replaced.

The masses of breccia ore vary greatly in size, many being 5 or 6 feet in extent and even more. A single mass may contain large fragments of solid rock, with only seams and stains of ore, surrounded by material which has been greatly broken up and of which the manganese oxide cement constitutes the larger part.

The breccia ore masses in the variegated clay are largely blue psilomelane, but contain considerable portions of gray crystalline pyrolusite free from fragments. Many of them have botryoidal surfaces and contain cavities lined with smooth nodular forms.

2. Irregular, porous masses are scattered through the dark-red clay
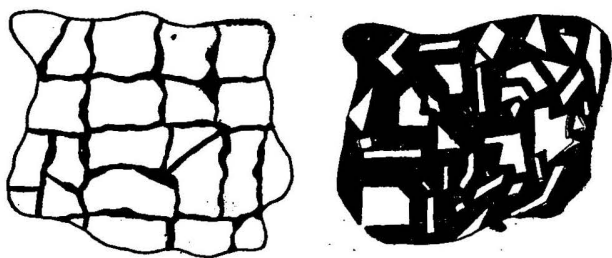

FIG.12.-Sketches showing structure of breccia ore. (After Watson.) White areas, chert or sandstone; black areas, manganese ore. About one-fifth natural size. in association with breccia ore and pellet ore. Where associated with the former, many of them contain fragments of chert and thus grade into breccia ore. The bodies are generally small, though they vary from a few inches to a foot in diameter. Some are composed of finely crystalline blue or gray pyrolusite, and others of an intimate mixture of the pyrolusite with amorphous dark-blue psilomelane. In this type the psilomelane is commonly on the outside and lines the pores and cavities. The cavities generally have smooth surfaces and are filled with red clay.

3. The pellet ore is characteristic of only one mine-the Lowe. Here it is found disseminated through dark-red clay (see fig. 15) associated here and there with irregular masses of porous ore, in such a way as to suggest that it might have been derived from the partial disintegration of such masses. However, each individual pellet has a concentric structure, which would lead to the conclusion that each was formed separately, as the nodules of kidney ore were. The pellets are irregularly spherical in shape and have smooth rounded surfaces. They consist of concentric layers which are thinner and more conspicuous near the surface. The pellets are composed largely of black, amorphous psilomelane with gray and blue luster. Through this there appear to be disseminated tiny crystals of pyrolusite.

4. Kidneys of massive blue psilomelane occur in a few localities in the light-colored, variegated clays, associated with sandstone and 
chert breccia ore. Some of these show concentric structure; others are altogether structureless. They vary from about 3 to 6 inches in diameter. (See fig. 16.)

5. Pockets and streaks of soft ore occur in the variegated clays on the Sanders property. The pockets. are extremely irregular and streaks of ore branch from them into the surrounding clay, while on the other hand bands of clay penetrate the ore in all directions. Dark manganiferous clay generally accompanies and surrounds soft ore pockets, and the contact between the two is very indefinite.

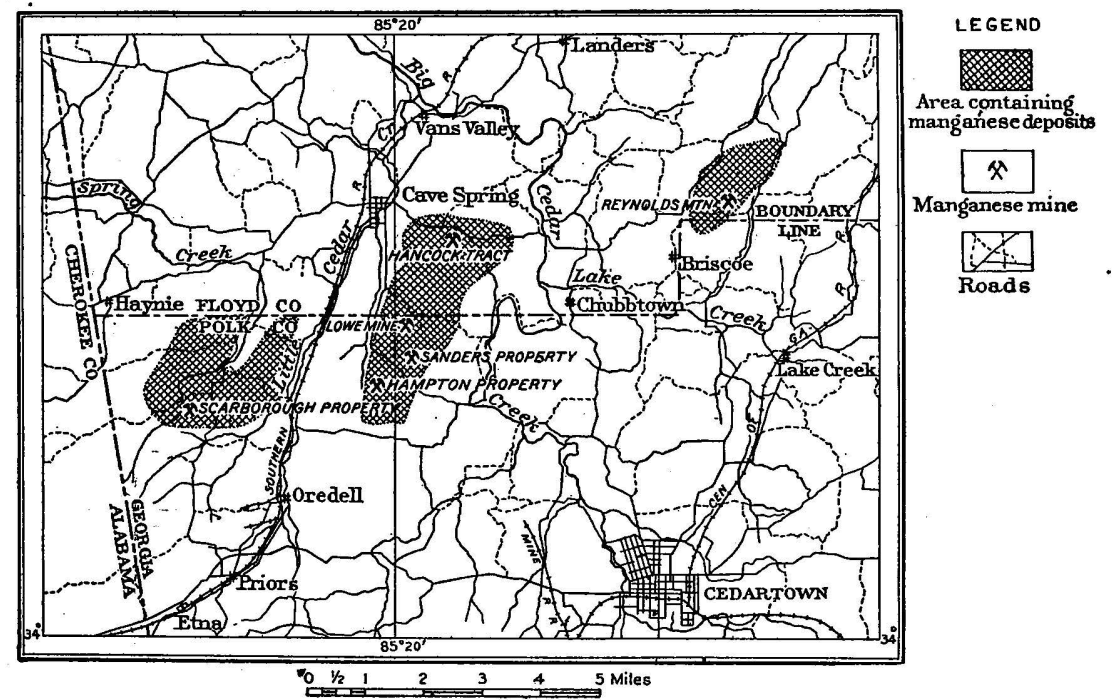

FigURE 13. Map showing the principal manganese mines in the Cave Spring district, Georgia, and the probable extent of the ore-bearing areas. (Modified from Watson.)

The ore is soft, powdery, crystalline pyrolusite. The soft-ore pockets commonly contain masses of harder and more thoroughly cemented ore.

DESCRIPTIONS OF MINES AND DEPOSITS.

Location of deposits.-The principal occurrences of manganese ore in the Cave Spring district are at Reynolds Mountain, at the Lowe mine, on the Hampton property, on the Sanders property, and on the Scarborough tract. (See fig. 13.) Deposits of minor importance are found in areas adjoining these. The Cave Spring district has not produced ore for a number of years.

Reynolds Mountain.-The Reynolds Mountain deposit is in Floyd County about 7 miles north of Cedartown and 6 miles east of Cave Spring. Ores are exposed in several open pits in dark-red clay. The ore is of two kinds: (1) Dark-blue psilomelane with a small amount 
of granular pyrolusite, cementing fragments in chert breccia (fig. 14), and (2) dark-blue finely crystalline and granular pyrolusite in porous masses in clay.

1. The breccia masses vary in size up to 3 or 4 feet in diameter, are of irregular shape, and they are embedded in dark-red clay. They may be composed largely of chert with a few veins of ore filling cracks, or they may consist largely of ore with here and there chert fragments. Between these extremes there are all variations. The ore may be hard or soft, but is most commonly hard. It has botryoidal surfaces in many cavities and contains quartz seams.

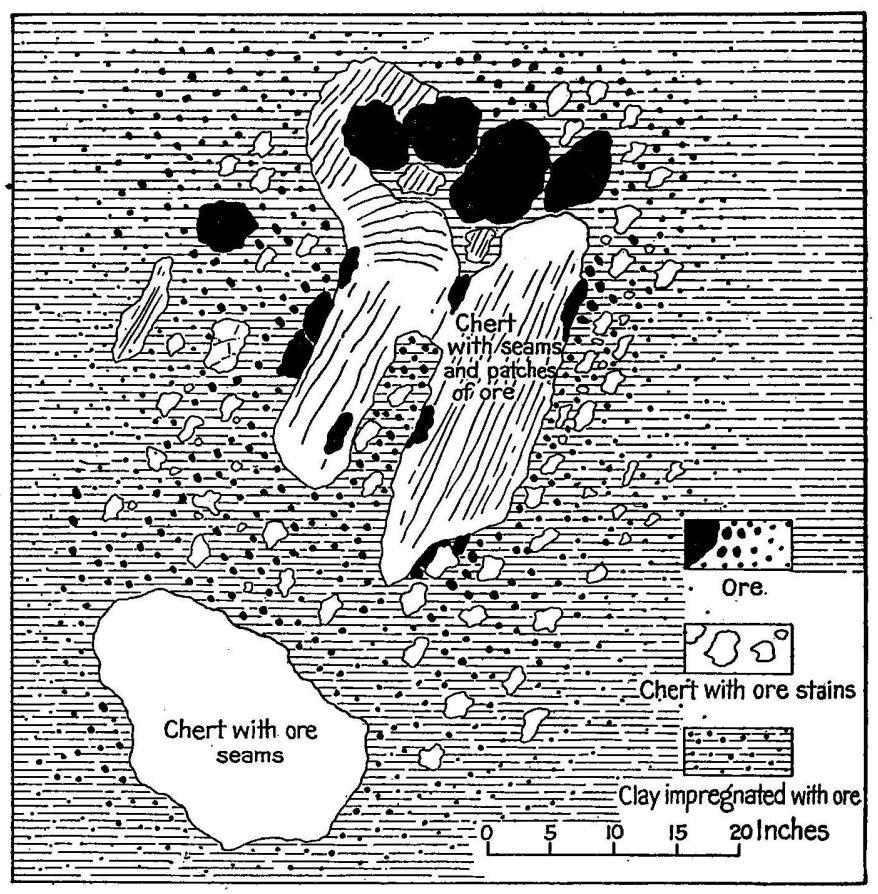

FIGURE 14.-Sketch showing occurrence of breccia ore at Reynolds Mountain.

Ore also replaces the chert fragments, the alteration generally extending but a short distance from the surface, though many small fragments show considerable replacement. The ore is most abundant around the surface of brecciated chert masses between the clay and the more solid interior of the mass.

2. The porous masses of ore are embedded in clay in association with the breccia ore. This porous ore is much softer than the breccia ore and commonly breaks up into little pellets coated with red clay. Scattered masses, however, range up to 8 or 10 inches in diameter and contain numerous pores and cavities filled with red clay. The ore is largely dark-blue or gray crystalline pyrolusite. 
Small irregular bodies of yellow ocher occur with the manganese ores.

Lowe mine.--The Lowe mine consists of a large shallow open pit about 2 miles south of Cave Spring. The upper part of the pit is in dark-red clay, 10 to 20 feet thick, and free from chert, while the lower part is in light-colored, variegated clay with chert masses.

The dark-red clay contains ore in two forms, (1) porous masses of mixed blue psilomelane and pyrolusite ranging up to 8 or 10 inches in diameter, and (2) small pellets, largely of psilomelane, averaging less than one-fourth inch in diameter. The latter is by far the most abundant. (See fig. 15.)

The ore in the light-colored clay is largely soft ore and occurs in masses of manganiferous clay. It grades into these masses so that they can hardly be separated. Generally, the ore is in small

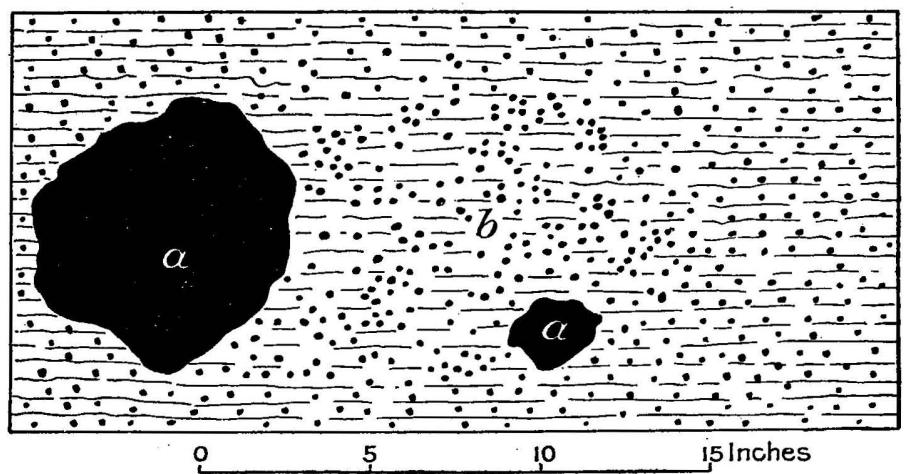

FIGURE 15.-Sketch showing distribution of pellets and irregular masses of ore in clay at the Lowe mine. $a$, Irregular masses of ore; $b$, dark-red clay with pellet ore.

seams and pockets surrounded. by and impregnated with clay, but in some places it is in larger pockets with small seams and masses of clay. A little breccia ore may be associated with it, but as a rule the chert masses contain no ore.

Hampton property.-The Hampton property is in Polk County, a little over 3 miles south of Cave Spring. The workings consist of several open pits in dark-red and brown clay. The ore is largely in chert breccia, though some soft ore occurs in the associated clays.

Sanders property.-The Sanders property is located in Polk County about $2 \frac{1}{2}$ miles south of Cave Spring. The workings consist of several open pits and trenches in variegated stiff clay. Both manganese and manganiferous iron ore are found, the latter more abundantly near the surface. The variegated clay contains considerable masses of black manganiferous clay, and here and there irrelar masses of chert are embedded in it.

The manganese ores are soft or hard. The soft ores occur in streaks and pockets in both the light-colored and the manganiferous 
clays. The bodies are extremely irregular; seams of ore run out into the clay, and stringers of clay run crisscross through the ore. Porous masses of hard ore occur in soft-ore pockets, and these frequently have cavities lined with limonite. Both hard and soft ores are crystalline or granular in texture and consist largely of pyrolusite. The hard ore contains a small amount of psilomelane.

Small nodules or kidneys of hard ore averaging an inch or two in diameter are scattered through the manganiferous clay and softore pockets. Some of them are hard and massive; but others consist of concentric layers of psilomelane and granular pyrolusite, and many of these contain cavities between successive layers, lined with dark-brown amorphous powder. There is little or no breccia ore present, although masses of chert, stained and partly replaced by manganese, occur at intervals.

Scarborough tract.-The Scarborough tract is in Polk County, about

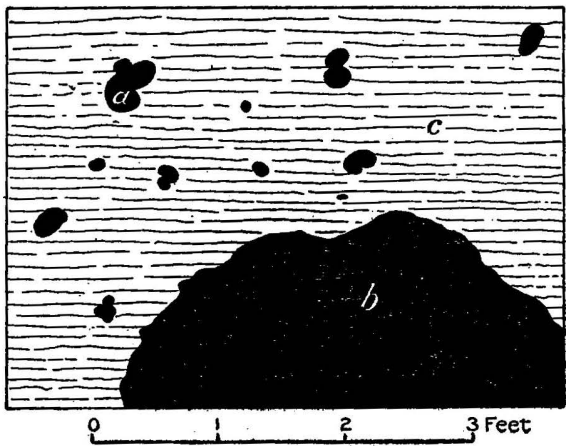

FIGURE 16.-Sketch showing the distribution of manganese ore in clay at the Scarborough mine. $a, \mathrm{Kid}-$ ney ore; $b$, breccia ore; $c$, variegated clay. $4 \frac{1}{2}$ miles southwest of Cave Spring. The workings consist of a pit and shaft.

The ore is embedded in lightcolored red, yellow, and brown stiff clays. It is hard and occurs in two forms, (1) as cement in chert and quartzite breccia masses, and (2) as kidneys in clay. (See fig. 16.)

1. Many of the breccia masses are 3 or 4 feet in diameter, and they consist mainly of hard, massive psilomelane containing chert and quartzite fragments. Granular and crystalline pyrolusite is associated with it locally in irregular masses, which are usually free from rock fragments. Many bodies of breccia ore are arranged in bands in the clay, together with masses of crystalline ore and kidneys. Often a layer of botryoidal psilomelane is found partly coating breccia masses, and where cavities occur in such masses they usually exhibit nodular surfaces.

2. The kidney ore is massive bluish-gray psilomelane, with or without concentric structure. The kidneys are hard and are generally fractured, clay penetrating along the cracks.

Other deposits.-Besides the above, there are a large number of smaller deposits in the Cave Spring district, as the Hancock tract, the Youngblood tract, the Lopez property, and others. The ores in them, however, are similar in all respects to those in the mines described. 
ANALYSES.

The following are analyses of manganese ores from the Cave Spring district: $a$.

Analyses of manganese ores from the Cave Spring district.

\begin{tabular}{|c|c|c|c|c|c|c|}
\hline : & 1. & 2. & 3. & 4. & 5. & 6. \\
\hline 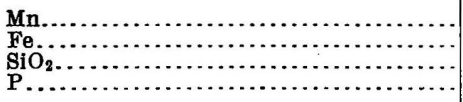 & $\begin{array}{c}46.749 \\
1.746 \\
13.05 \\
.059\end{array}$ & $\begin{array}{c}42.685 \\
1.729 \\
10.00\end{array}$ & $\begin{array}{c}42.938 \\
5.24 \\
8.009\end{array}$ & $\begin{array}{l}42.578 \\
1.50 \\
11.95 \\
.089\end{array}$ & $\begin{array}{c}42.307 \\
2.40 \\
10.39 \\
.072\end{array}$ & $\begin{array}{l}45.189 \\
7.84 \\
7.602 \\
9.035\end{array}$ \\
\hline
\end{tabular}

Analysis of high-grade manganese ore from the Cave Spring district.

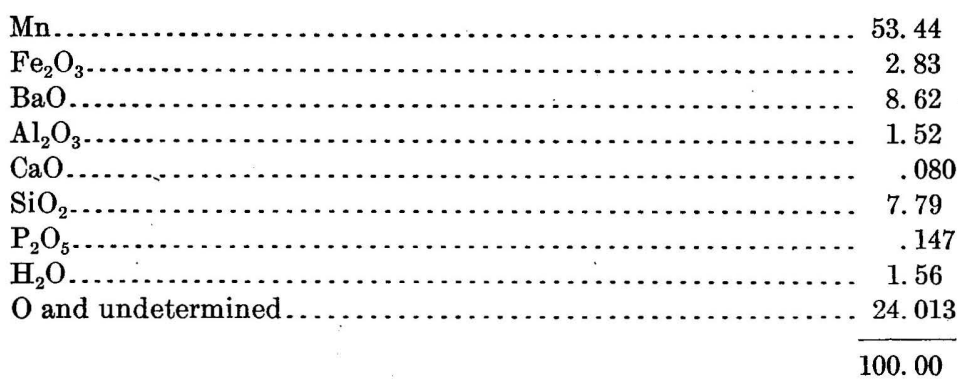

MINOR DEPOSITS.

PENNSYLVANIA.

Manganese ores are found in the Paleozoic rocks of Pennsylvania. As a rule they occur in small quantities in iron-ore deposits and have been mined to a slight extent in that connection. They occur ${ }^{b}$ with the brown ores in the eastern part of the State, at Ironton, Lehigh County; at several places on Broad Mountain, and in Northampton and Berks counties. At the Ironton mines considerable beds of manganese have been encountered. At one place a bed overlies brown iron ore, and at another it is just above limestone and is overlain by brown iron ore but separated from it by a layer of red clay. A bed of manganese ore 2 to 3 feet thick and carrying 50 per cent manganese and 0.4 per cent phosphorus occurs in a red shale in Ground Hog Valley in Broad Top. In the southern part of the State ores occur at Mount Holly Springs, Cumberland County, and at Myers Mills, York County; and in the central part, in Blair, Huntington, and Center counties.

In the Carboniferous region in western Pennsylvania manganese ores $^{c}$ are often found with carbonate of iron in small proportions. 
The following is an analysis of manganese ore from Pennsylvania: Analysis of manganese ore from Ironton, Lehigh County, Pa.a

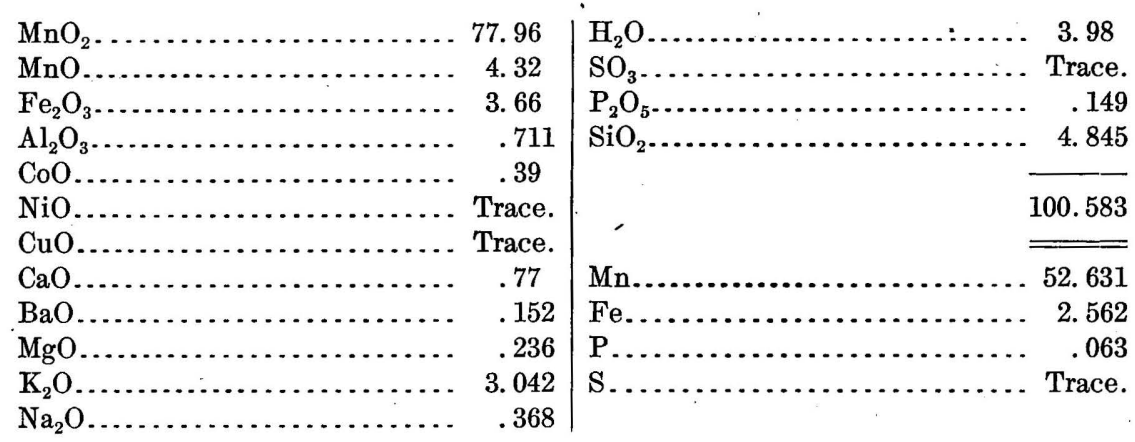

Another analysis ${ }^{b}$ of manganese ore from Lehigh County shows 56.58 per cent manganese and a trace of phosphorus. The following are analyses ${ }^{b}$ of manganiferous iron ores:

Analyses of manganiferous iron ores from Pennsylvania.

\begin{tabular}{|c|c|c|}
\hline & 1. & 2. \\
\hline $\begin{array}{l}\text { Mn } \\
\text { Fe } \\
\text { P } \\
\text { S } \\
\text { Insoluble }\end{array}$ & $\begin{array}{l}17.648 \\
26.40 \\
.095 \\
.010 \\
21.86\end{array}$ & $\begin{array}{r}15.934 \\
32.400 \\
.651 \\
.027\end{array}$ \\
\hline
\end{tabular}

1. From Ironton, Lehigh County. 2. From Myers Mill, York County.

MARYLAND.

In Maryland manganese ores have been found in small quantities in the Cambro-Ordovician rocks on Keysers Ridge and Bear Creek, Youghiogheny Valley, Alleghany County $;^{c}$ and on the north shore of the Potomac opposite Harpers Ferry. ${ }^{d}$

\section{VIRGINIA.}

Besides those in the regions already mentioned (see p. 66) manganese deposits occur elsewhere in western Virginia in association with the Oriskany iron ores.

On Guy Run, about 6 miles south of Goshen, Rockbridge County, is an extensive deposit of manganese ore. The ores are embedded in clays in the form of pockets and occur in close proximity to iron ores of the Oriskany horizon. The following analysis shows the composition of the ore: 
Analysis of manganese ore from Guy Run.a

Mn.

$\mathrm{Fe}$

P.

Ores have also been reported ${ }^{a}$ from Panther Gap and Harts Bottom, Rockbridge County, northwest of Goshen; from Gala and Dagger Springs, Botetourt County; from Gap Mountain, Craig County; from Flat Top, Buckeye, and Spruce River mountains and Sinking Creek furnace in Giles County; from Walker Mountain in Wythe and Pulaski counties; and from Bland, Smyth, and Tazewell counties. All these deposits occur at or near the Oriskany horizon. The ore from Dagger Springs is unique in that it contains numerous fossil bryozoans. The ore at Flat Top Mountain is disseminated through sandstone and is said to contain 59.215 per cent manganese. Manganese ore probably occurring in residual material of the Shenandoah limestone is reported from Middlebrook, Augusta County. The following analyses show the composition of Craig County ores: ${ }^{a}$

Analyses of Craig County manganese ores.

\begin{tabular}{|c|c|c|c|c|c|}
\hline . & 1. & 2. & 3. & 4. & 5. \\
\hline $\begin{array}{l}\mathbf{M n} \\
\mathbf{F}\left({ }_{1}\right. \\
\mathbf{P} \\
\mathbf{S} \\
\mathbf{S} \\
\mathbf{S}\left(\mathrm{O}_{2}\right.\end{array}$ & $\begin{array}{r}45.00 \\
\cdots .085 \\
4.70\end{array}$ & $\begin{array}{c}52.42 \\
.303 \\
.46\end{array}$ & $\begin{array}{l}49.48 \\
6.83 \\
.063 \\
.010 \\
2.53\end{array}$ & $\begin{array}{r}53.06 \\
1.82 \\
.058 \\
1.67\end{array}$ & $\begin{array}{r}50.50 \\
4.81 \\
.026 \\
.58\end{array}$ \\
\hline
\end{tabular}

WEST VIRGINIA.

Manganese ore is found at Glenmore, ${ }^{b}$ Greenbrier County, 7 miles north of White Sulphur Springs, in the same belt as the Oriskany ores of Virginia. It is said to occur as lumps of different sizes embedded in clay and gathered into fairly persistent pockets. It has the following composition:

Analysis of manganese ore from Glenmore.

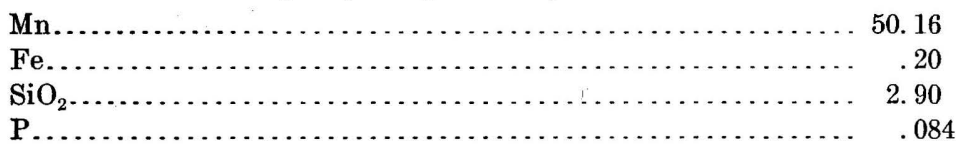

TENNESSEE.

Manganese ore is reported to exist in pockets along the Chilhowee Mountain range, associated with Cambrian rocks. ${ }^{c}$

Ores occur also in dark-red clay residual from the Knox dolomite at several localities about 2 miles southeast of Morristown, ${ }^{c}$ Hamblen

$a$ Weeks, J. D., Mineral Resources U. S. for 1885 , pp. 326-327.

$b$ Weeks, J. D., Sixteenth Ann. Rept. U. S. Geol. Survey, pt. 3, 1895, p. 434.

c Penrose, R. A. F., jr., op. cit., p. 416. 
County, and with the same associations about $1 \frac{1}{2}$ miles northeast of Sweetwater, ${ }^{a}$ Monroe County. In the latter locality the ore is mainly in the form of nodules of blue psilomelane, and occurs in connection with iron ores. The following analysis shows the average composition of the ore:

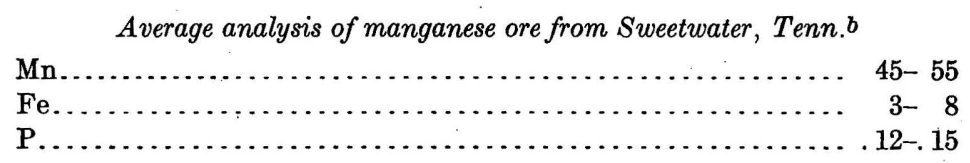

NORTH OAROLINA.

Manganese ores are reported as occurring in Cherokee County, ${ }^{c}$ in the souchwest corner of the State. They are associated with the ironore deposits developed in various Cambrian slates and schists in the vicinity of fault lines. In some places the manganese oxides are so abundant in the iron ore as to make it a manganiferous iron ore.

\section{GEORGIA. ${ }^{d}$}

Manganese deposits are associated with residual clays of the Knox dolomite north of Tunnel Hill in Whitfield and Catoosa counties. At this locality a narrow north and south band of Knox dolomite is faulted down into the Rome formation and the ores occur in the dolomite along the east fault. The dolomite is decayed into dark-red and gray cherty clays, the ores being usually found with the dark-red clays. The ore is in the form of kidneys 1 to 12 inches or more in diameter and generally composed of a crystalline interior. The lumps are either scattered or concentrated into pockets. Deposits of limonite and manganiferous iron ore are associated with the manganese ores as pockets and lenticular layers.

The Barnsley tract is in Bartow County 17 miles northwest of Cartersville. Ore occurs here in dark-red residual clays of the Knox dolomite, as honeycombed, porous masses, or as cement in a chert breccia. The cavities in the ore are generally filled with red clay, but many of them are lined with small pyrolusite crystals.

The following analysis shows the composition of the ore:

Analysis of manganese ore from the Barnsley tract. $e$

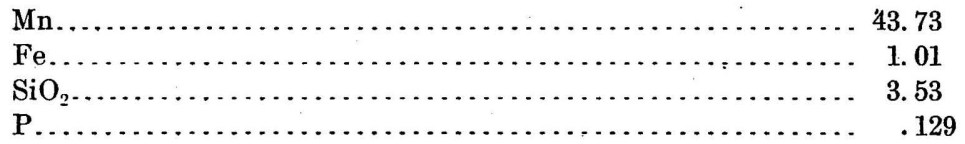

$a$ Burchard, E. F., personal communication.

$b$ Weeks, J. D., Sixteenth Ann. Rept. U. S. Geol. Survey, pt. 3, 1895, p. 424.

c Keith, Arthur, Nantahala folio (No. 143), Geol. Atlas U. S., U. S. Geol. Survey, 1907, p. 10.

$d$ Watson, Thomas L., op. cit., pp. 128-144, 177-182.

e Idem, p. 138. 
Ores similar to the above occur near Nannie post-office, Floyd County, 9 miles to the northwest.

In Big Texas Valley, 12 miles northwest of Rome, small quantities of manganese ore occur with iron ores in residual clays derived from Carboniferous rocks. The valley is in a syncline of Carboniferous rocks bounded on the northwest and southeast by ridges of the underlying sandstone of the Clinton (Rockwood) formation.

Indications of manganese are abundant in the area underlain by Knox dolomite in the vicinity of Rome and Lindale, Floyd County. The manganese ores, however, are mainly confined to the surface, passing downward into manganiferous iron and limonite ores. Manganese ore of two types occurs in residual clays of the dolomite, namely, chert breccia ore and kidney ore. In the breccia masses the ore may be present only in small seams and veins, or it may compose the main part of the mass, and contain only small chert fragments. The kidney ore is largely massive and is dark-blue in color. It shows concentric layering.

Surface indications of manganese consisting of small pellets, fragments, and nodules are found near Ligon post-office, Bartow County, 12 miles west of Cartersville. The manganese ores are associated with deposits of iron ore.

Manganese ores have been found in association with iron-ore deposits 4 to 6 miles north of Cohutta Springs, Murray County, in darkcolored, interbedded quartzites and slates of Cambrian age, classed with the Ocoee group. At one locality black crystalline oxide occurs as a cement in quartzite breccia, but constitutes only a small part of it. Elsewhere it is found as nodules in residual clays, or as small pockets in limonite deposits, the latter being the principal occurrence.

In Fannin County, 10 miles northeast of Blue Ridge, nodular or earthy black oxide of manganese occurs in close association with limonite ores. The nodular ore is usually crystalline and occurs as pellets or kidneys in residual clays derived from mica schist, probably of Cambrian age. The ore-bearing clay appears to be in a zone 18 to 20 feet thick and dipping steeply. On one side of it are other residual clays and on the other side a narrow zone of jaspery quartz impregnated with iron and manganese oxides.

Considerable exploitation for manganese ore has been done in the northeastern part of Fannin County, $1 \frac{1}{2}$ miles south of Culbertson, N. C., but only a small quantity has been found.

\section{ALABAMA.}

Small quantities of manganese ore have been produced intermittently in Alabama, being derived largely from limonite deposits, in which they occurred as pockets, seams, or nodules, commonly forming manganiferous iron ore. The ore is found at the same geologic $37336^{\circ}-$ Bull. $427-10-7$ 
horizon as the limonites; in fact, the same stratum may contain limonite at one locality and manganese ore at another. Manganese ore also occurs in veins and as cement in breccias in sandstone, quartzite, and chert. It is said to be largely in the form of manganite and pyrolusite.

The manganese ores of Alabama occur in three different associations. $^{a}$ In Cleburne County they occur in residual clay near the top of the Wiesner quartzite (Cambrian); in Cherokee County they are found in residual clays of the Knox dolomite (Cambro-Ordovician); while in Blount and Etowah counties they occur near the top and bottom of the Fort Payne chert (Carboniferous).

The ores of Cleburne County are in stratified layers of bowlders and gravels with intermixed sandy loam or in streaks in quartzite bowlders. The principal localities are near Borden Springs.

The deposits of Cherokee County are north and northwest of Piedmont. The ore is in the form of pellets or soft ore in the surface soil or in large masses associated with limonite and bauxite deposits.

The deposits of Blount and Etowah counties are in Murphrees Valley. They are found for a distance of 5 miles along the top and northwest slope of West Red Mountain, but are not continuous, occurring only at intervals along the strike of the rocks. The ore in the lower strata of the Fort Payne chert is in irregular seams and pockets; that in the upper strata is soft powdery ore mixed with surface soil. Bedded layers in the lower strata in a few places reach a thickness of 1 to 3 feet, and bowlders and nodules of very fine ore are associated with them. The deposits in the upper strata also show ore in seams and as hard gravels and small nodules.

The following are analyses of ores from Cleburne County:

Analysis of manganese ore shipped from Stocks Mills, 1886.b

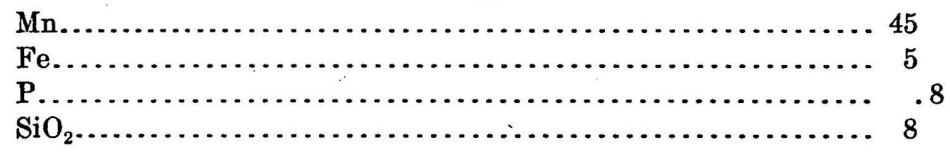

Analysis of manganese ore from Cleburne County.c

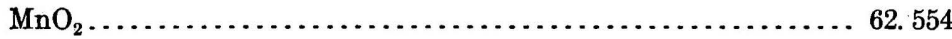

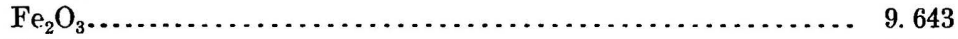

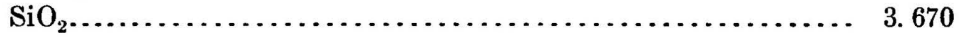

Manganiferous iron ores have been mined at Woodstock, ${ }^{d}$ Bibb County. They occurred in the form of crusts 1 to 3 feet thick overlying the iron ore or in chimneys or pockets in the main deposit. The following are analyses of ores from this locality:

a McCalley, Henry, Alabama Geol. Survey, cited by Birkinbine, John, Eighteenth Ann. Rept. U. S. Geol. Survey, pt. 5, 1897, p. 299; also Smith, E. A., Alabama Geol. Survey, cited by Weeks, J. D., Sixteenth Ann. Rept. U. S. Geol. Survey, pt. 3, 1895, p. 401.

$b$ Weeks, J. D., Sixteenth Ann. Rept. U. S. Geol. Survey, pt. 3, 1895, p. 401.

c Birkin bine, John, Eighteenth Ann. Rept. U. S. Geol. Survey, pt, 5, 1897, p. 299.

dWeeks, J. D., Mineral Resources U. S. for $1885 ;$ p. 345 , 


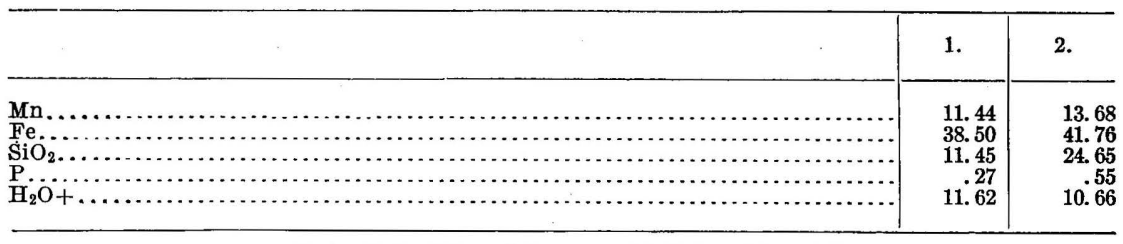

$a$ Weeks, J. D., Mineral Resources U. S. for 1885, p. 345.

\section{ORIGIN OF THE ORES OF THE APPALACHIAN REGION.}

Several theories have been advanced regarding the origin of the Appalachian manganese ores, but all agree that the source of the ores is in the manganese-bearing silicates originally disseminated through the crystalline and metamorphic rocks of the Piedmont region.

J. D. Dana, followed by Penrose, ${ }^{a}$ maintained that the manganese ores were deposited in local basins during the deposition of the rocks in whose residual clays the deposits are now found. The present deposits in the residual clay are supposed to be largely in the same form as the original deposits and to bear the same relation to the clays that the original deposits bore to the inclosing rocks. Penrose points out as evidence of this, in detailed descriptions of numerous deposits, $^{b}$ that the ores extend downward from the residual clays into the underlying bed rock, or into residual rock masses in the clay, and are found there in place in the same form in which they occur in the clay. A number of the localities cited by Penrose have been visited by the writer, and so far as he observed the manganese ores in the rock might well be accounted for as depositions from metearic waters that have percolated downward through the ore deposit in the clay and during their progress have taken manganese into solution. Such ores are generally in the form of veins along joint or bedding planes or irregular replacements in the rock mass.

As corroborative evidence for the theory upheld by Penrose, he points out that the larger number of deposits, especially those of the valley of Virginia, of Tennessee, and of the Cartersville district of Georgia, occur in a fairly definite zone in the Cambrian system, which he has termed the manganese-bearing zone. The rocks of this zone are supposed to have been deposited during a period marked by shallow water and inclosed basins in which manganese and iron were deposited.

As a matter of fact, a large number of deposits are associated with the top of a persistent quartzite bed and the base of the overlying formation, generally a limestone. In Vermont and in the valley of Virginia this quartzite bed is in the lower part of the Cambrian and is as yet unclassified. In the New River region of Virginia and in 
eastern Tennessee it is the Erwin quartzite; near Cartersville, Ga., it is the Weisner quartzite. The overlying formation is unclassified Cambrian limestone in Vermont, Sherwood limestone in the valley of Virginia, Shady limestone in northeastern Tennessee and southwestern Virginia, and Beaver limestone in Georgia. Overlying the limestone in Georgia, Tennessee, and Virginia there is a thick shale formation, the Conasauga and Rome in Georgia, the Watauga in Tennessee and southwestern Virginia, and the "Buena Vista" in westcentral Virginia.

It appears to the writer, however, that the localization is due rather to the impervious nature of the underlying quartzite bed than to original deposition. It seems reasonable that the ores should be deposited by the percolating waters in which they are in solution at the point where the downward course is interrupted by a relatively impervious layer. The same argument has been advanced in a more restricted way for the Cartersville district by Hayes. ${ }^{a}$

The Appalachian manganese ores have not the forms to be expected in residual deposits. It is true that a considerable portion of the ore is in the form of nodular kidneys which might have been present in the original rock in that form, though none have ever been found there. Closely associated with them, however, and far more abundant, are replacement deposits in the form of irregular masses and seams, many occurring along sheared or porous zones in the clay so as to show clearly their secondary origin. Also there are breccia deposits where the ore has been deposited along fault planes or around partly decomposed residual rock fragments in the clay. In these deposits the manganese oxides have largely replaced many of the chert fragments, showing a still later deposition.

The following theory is offered for the origin of the Appalachian manganese deposits: The Cambrian and Ordovician sediments were obtained from the disintegration and decomposition of the crystalline and metamorphic rocks of the Piedmont region. These rocks contained manganese-bearing silicates, such as micas, pyroxenes, amphiboles, and garnets, which were either deposited undecomposed in the shales and to a small extent in the quartzites, or were decomposed and had their manganese content carried in solution and deposited as oxide or carbonate in the shales or limestones. After the sediments emerged from the sea and were consolidated, erosion took place, and during this process the manganese was dissolved, carried downward by percolating waters, and deposited in favorable localities, such as were formed locally by underlying impervious layers or by fault planes. As erosion continued the ores were continually carried downward, being often redissolved and deposited elsewhere,

$a$ Hayes, C. W., Manganese ores of the Cartersville district, Georgia: Bull. U. S. Geol. Survey No. 213, 1903, p. 232; also Hayes, C. W., and Eckel, E. C., Iron ores of the Cartersville district, Georgia: Idem, pp. 233 et sẹ. 
giving rise to veins and replacement deposits of pyrolusite in sandstone and sandy clay masses and also to breccia ores and other forms.

The manganese in the ores, therefore, may have come from any of the originally overlying formations, but it seems reasonable to assume that a very large proportion of it came from shale formations, for these probably contained a considerable quantity of unaltered manganese-bearing minerals, and, on the whole, a larger percentage of manganese than either limestone or quartzite.

\section{COMMEERCIAL IMPORTANCE OF THE ORES.}

The manganese deposits of the Appalachian region are the most important in the United States. The two largest producing districts, the Blue Ridge district in Virginia and the Cartersville district in Georgia, are in this region. More than 80. per cent of all the manganese ore mined in the United States was obtained along this belt, but recently work has been carried on only in Virginia and in northeastern Tennessee, the Cartersville and Cave Springs districts of northern Georgia being idle.

The deposits, though not of great size, are numerous; pockets are frequently worked out and abandoned and new ones discovered. In the Crimora basin this is not the case, for here mining has been done for the past twenty years and-there is still a large quantity of ore in sight. Structural conditions favored the concentration of the Crimora ore body, and others of this belt are not comparable with it. Single pockets rarely contain more than 25,000 tons, and the majority contain much less. Such discontinuous ore bodies can not be worked on a large scale, and hence the manganese mining industry of the Appalachian region has not made great strides in improvement. Indications of manganese occur abundantly throughout the eastern portion of the Appalachian belt, but workable deposits are found only at intervals. Though considerable prospecting and exploration has been done, it is not at all unlikely that many deposits and perhaps large ones still remain to be discovered.

The ores occur in clay and must have considerable treatment before they are fit for the market. The percentage of clay to ore varies considerably. Locally there may be 1 car of ore to 5 of clay, while elsewhere there may be 1 of ore to 15 or 20 of clay. The ore is crushed, screened, and washed, and then the remaining rock fragments and clay balls are picked out by hand. Frequently the ores are sorted into low-grade and high-grade materials and these are sold separately. In view of these various processes that the ore must go through before it can be marketed, it is not difficult to see why the domestic manganese can not compete with the imported product. The lack of activity does not signify that the deposits are becoming exhausted, for in a 
number of localities operations have been suspended or are conducted on a small scale where considerable ore is in sight.

The ore of the Appalachian region is a mixture of psilomelane and pyrolusite. As a rule it is of good grade and may be used for chemical purposes as well as in the steel industry. Locally, however, it contains considerable iron, and such ore can only be used in the steel industry. Large deposits of manganiferous iron ore, such as occur at Mine Bank and Blue Bank, near Vesuvius, Va., are lying idle because the manganese content is not high enough to render the ore attractive to producers of spiegeleisen, and too high to render it fit for ordinary pig-iron manufacture. The manganese ores, as well as the manganiferous iron ores, generally contain a large percentage of silica, and many of them are high in phosphorus; hence much of the ore is not desirable for steel manufaçture nor for chemical uses.

\section{LOWER MISSISSIPPI VALLEY AND GULF REGION.}

Except in the Batesville district, there are only a few manganese deposits in the Mississippi Valley. Of these probably the best known are those of the central Texas crystalline area, of the porphyry area of Pilot Knob, Mo., and of the Silurian or Devonian rocks of westcentral Arkansas. Small deposits occur at Whitfield, Tenn., and in eastern Oklahoma.

The deposits are associated with rocks of pre-Cambrian or early Paleozoic age, like all the manganese deposits of the eastern part of the United States. The ores of Missouri and Arkansas are closely associated with iron ores.

\section{BATESVILLE DISTRICT.}

\section{GEOGRAPHY AND TOPOGRAPHY.}

The Batesville district is situated north of Batesville, in Independence, Izard, and Sharp counties in north-central Arkansas. It extends east and west about 15 miles and north and south about 10 miles. The manganese-bearing area is drained by Polk Bayou on the south and Lafferty Creek on the west, both tributaries of White River, which rises in northwestern Arkansas and flows northward into Missouri and thence southeastward across northern Arkansas. It passes just west and south of the Batesville district and empties into Arkansas River a short distance above the junction of that river with the Mississippi. The area is on the southeast border of the Ozark region, a short distance west of the line dividing that region from the Mississippi flood plain. The topographic contrast between the flood plain and the region around Batesville is very marked. The former is a flat plain with sluggish streams meandering back and forth over it. These are but very slightly below the general level of the country, and in time of 
floods immense tracts are completely under water. On the other hand, the region around Batesville is hilly and has numerous branching streams, of which the smaller have considerable fall. The difference in elevation is not very great, varying from 250 feet above sea level on the banks of White River to about 800 feet on some of the higher ridges. The larger tributaries are at nearly the same elevation as White River, and the small tributaries drop abruptly from the hills into them. The valleys are narrow and steep sided, many of them being inclosed by bluffs; the uplands are undulating and somewhat more extensive, but are considerably cut up by small streams.

GEOLOGY.

Succession of rocks.-Geologically also there is a great contrast between the Mississippi flood plain and the Batesville district. In the former the bed rock is hidden beneath a great thickness of Pleistocene and Recent fluviatile deposits, while in the latter the bed rock is at or very near the surface and is covered only by a thin mantle of residual material.

The rocks of the Batesville district are Pale zoic, ranging from Ordovician to Carboniferous, as shown in the following table:

General succession of rocks in the Batesville district, Arkansas.

Pennsylvanian:

Winslow formation.

Morrow formation.

Mississippian:

Pitkin limestone.

WWedington sandstone member of Fayetteville shale.

Fayetteville shale.

Batesville sandstone.

Moorefield shale.

Boone chert with St. Joe limestone member.

Unconformity.

Devonian (?):

Chattanooga shale (?).

Silurian:

Sylamore sandstone member (?).

St. Clair limestone

Ordovician:

Cason shale.

Polk Bayou limestone.

Izard limestone.

St. Peter sandstone.

Yellville limestone.

There is a general slight southward dip to the beds, so that northward the formations are successively older.

St. Peter sandstone.--The St. Peter sandstone is exposed in the northern part of the manganese-bearing area and along the floors 
of the larger valleys extending through it. Except the underlying Yellville limestone, which contains the lead and zinc deposits to the northwest, it is the oldest formation exposed in northern Arkansas. It consists of sandstone layers from a few inches to several feet thick. The surface exposures have a peculiar rounded form, and frequently protrude above the soil as knobs and mushroom-shaped masses. The rock is composed of well-rounded white quartz grains, with here and there grains of pyrite, which on the surface are oxidized and give a brown color to the exposures. Cross bedding is characteristic of many parts of the formation. The thickness varies from a few feet to 100 feet or more, the variations being due to different conditions of deposition as well as of erosion.

Izard limestone.-The Izard limestone is found throughout the manganese area, outcropping along the streams above the St. Peter sandstone. It is a grayish-blue, compact, even-bedded limestone, 100 to 150 feet thick in the Batesville area, but reaching, it is said, a thickness of 280 feet at the base of Penters Bluff on White River to the northwest.

Locally in the Batesville district there is 1 to 4 feet of lithographic limestone of a buff color and with conchoidal fracture near the top of the Izard limestone. This generally occurs in two or three layers separated by layers of the ordinary compact limestone. Where this material has been tested it has been found to contain thin seams of calcite that prevent its use for fine grades of work, but there may be localities where large pieces can be obtained in which these veins do not occur.

Along Cave Creek and elsewhere there are numerous caves in the Izard limestone due to solution along fissures. They are not of great size, but extend far back into the hills, being composed of a large number of connected chambers.

Polk Bayou limestone.-The Polk Bayou and St. Clair limestones and the Cason shale were classed by Penrose as one formation and designated the St. Clair limestone. Later Williams separated the St. Clair into the Polk Bayou limestone, Cason shale, and St. Clair limestone. Still more recently Ulrich ${ }^{a}$ found an unconformity within the Polk Bayou.

The lower part of the Polk Bayou limestone is of early Trenton age and lies directly on the Izard limestone. It is heavy bedded and coarsely crystalline and has a prevailing white or gray color. Its thickness varies, but probably nowhere exceeds 50 feet. The unconformity above it is marked by a layer of clay from a fraction of an inch to several inches in thickness.

The upper part of the formation, above the unconformity, is thin but very persistent. - Like the lower part it is crystalline, but the 
color is usually a darker gray, and red tints are common and characteristic. Over most of the Batesville district all the formations between the Polk Bayou limestone and the Boone chert are practically absent, being represented only by a few feet of sandstone, shale, and phosphate or manganese bearing formations (Cason shale or Chattanooga shale and Sylamore sandstone member). At such places the surface of the Polk Bayou limestone is generally uneven, with numerous knobs and basins, the former frequently in contact with the overlying Boone chert, and the latter filled with sand, clay, and manganiferous material. The upper part of the Polk Bayou limestone has a persistent thickness of about 15 or 20 feet, so the erosion interval between it and the Cason shale must have been of short duration. The rock is coarsely crystalline and in many parts dark purple, especially near the surface where it is in contact with the manganese deposits.

Cason shale.-The Cason shale where present rests on the Polk Bayou limestone or the Izard limestone, and is overlain by the St. Clair limestone, or, where this is absent, by the Boone chert. It is the manganese-bearing as well as the phosphate-bearing layer in northern Arkansas. It is varied in character, changing in some parts from point to point so as to be hardly recognizable. The material composing it appears to be largely a residual product derived from a land area not far distant. At several localities where the St. Clair limestone is present, as at the Cason mine, the Cason shale consists of a dark-red sandy shale formation about 10 feet thick with a few thin layers of dark quartzite. The entire formation is heavily impregnated with manganese and iron oxides and the shaly layers contain an abundance of small, flattened, button-like pebbles of manganiferous iron ore, some of which have the appearance of fossil brachiopods. Where the St. Clair limestone is absent and the Cason shale is overlain directly by the Boone chert, as at the Meeker, Southern, Adler, Bales, and other mines, the formation is of an altogether different nature. At the Meeker mine it has a thin layer of green shale at the top. Underneath this is a layer of brown sandstone several feet thick, and underneath that a low-grade manganese formation lying on the uneven surface of the Polk Bayou limestone. (See figs. 17 and 21.) The manganese formation consists of a mixture of manganese and iron oxides with sand and clay. In places one or the other of these beds may be absent, or the entire formation may be disintegrated into a manganese-bearing clay bed, as it is at most of the other mines. Other phases of the Cason shale have been described, ${ }^{a}$ but have not been seen by the writer. The following description of the Cason shale is given by Purdue ${ }^{b}$ with 
reference to its occurrence in the phosphate area west of Cushman, where from 8 to 18 feet of St. Clair limestone overlie it:

The rocks at the horizon of the Cason shale are of variable nature. It is at this horizon that the phosphate rocks occur. Usually somewhat more than 4 feet at the top consists of shale, or, in the outer part of clay derived from the disintegration of the shale. The upper part of the shale is yellow to brown in color; the lower portion, which ranges in thickness from 2 to 14 inches, is green. In some places the shale contains a thin bed of low-grade iron ore. In other places it is manganiferous. Such samples as were tested were found to be phosphatic, and the rock is probably so everywhere.

The phosphate rocks of the region are associated with this bed of shale. All of the developed phosphates here are below it, but in other places there are phosphatic beds above shale which is presumably the same as this. The phosphate beds vary in character, ranging from those which are brown and sandy and of low grade to those that on fresh surfaces are bluish gray, apparently without sand, and of uniform texture and color.

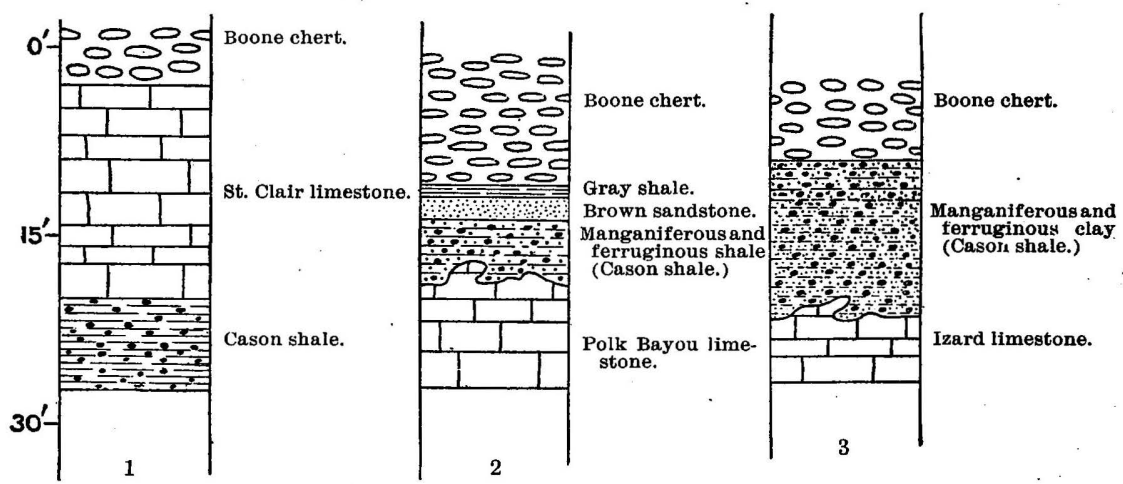

FIGURE 17.--Section showing different phases of the Cason shale. 1, Cason mine; 2, Meeker mine; 3, Southern mine.

Manganese ore is at many places closely associated with the phosphate bed. So common indeed is the association of the two that débris of manganese, which is plainly perceptible where present, is a good guide in prospecting for phosphate rock.

The different phases of the Cason shale will be described more in detail in connection with the ore deposits.

St. Clair limestone.-The St. Clair limestone is present only in the southern part of the manganese area. The only locality where it was observed was the Cason mine, at which locality it immediately overlies the Cason shale, here composed of abundant ferruginous manganese ore pebbles embedded in a red sandy shale formation. The thickness of the St. Clair limestone in this vicinity is given by Penrose ${ }^{a}$ as 100 feet. It rapidly thins out and disappears to the north.

In the phosphate area on East Lafferty Creek, west of Cushman, 8 to 18 feet of St. Clair limestone is said ${ }^{b}$ to be exposed over the Cason shale. Throughout the main manganese area, however, the Boone chert lies directly on the Cason shale, or the manganese-bearing clay equivalent to it, and the St. Clair limestone is absent. 
The St. Clair is a pink or gray crystalline limestone with an abundance of fossils consisting mainly of crinoid stems and brachiopods. It was deposited in narrow embayments, and its irregular distribution and thickness are due to this rather than to subsequent erosion, as is shown by the fact that its upper beds are more widely distributed than its lower ones.

Chattanooga shale.-The Chattanooga shale was not positively recognized in the Batesville district. There is a possibility, however, that where the St. Clair limestone is absent the green shale and brown sandstone layers at the top of the Cason shale, as seen at the Meeker mine, may be equivalent to it. The Chattanooga shale with its basal Sylamore sandstone member is, however, well developed in the lead and zinc district to the northwest. There it lies on the eroded surface of any of the preceding Silurian or Ordovician formations down to the Yellville limestone. As a rule it is followed directly by the St. Joe limestone member of the Boone chert. The greatest thickness of the Chattanooga in Arkansas probably does not exceed 50 feet, the Sylamore sandstone member making up considerably more than half of this thickness. In most exposures the thickness of the Chattanooga is under rather than over 10 feet. The sandstone member is composed of coarse rounded quartz grains. The rock reminds one strongly of the St. Peter sandstone, but is readily distinguished by the presence of small phosphatized pebbles. At many points it thins out and disappears, or is present only in lenses in the shale. Where best developed the shale is black and fissile. A bed of greenish clay shale, 2 to 12 inches thick, is commonly found at the top.

Boone chert.- The Boone chert in Arkansas usually begins with the St. Joe limestone member, which is easily distinguished from the overlying beds of the formation by the even-bedded, coarsely crystalline, noncherty character of its ledges, and also by the reddish color of some of its beds. The St. Joe member does not occur generally in the manganese district, but locally a few feet of pure limestone at the base of the Boone are believed to represent it. ${ }^{a}$ In the lead and zinc district the formation reaches a thickness of 30 feet.

The Boone chert above the St. Joe limestone member is characteristically developed in the Batesville district, where it occupies the tops of the ridges and all high areas. It is supposed to be over 300 feet thick, but the top is not exposed in this district. The formation consists of a very cherty limestone, some of the beds being almost entirely chert: It is generally light-gray in color and even-bedded. It overlies the manganese-bearing formation and is present above most of the deposits. At some places it is horizontal and at others folded and crenulated, apparently on account of the slumping of the underlying clays. 
OCCURRENCE OF THE ORES.

GENERAL RELATIONS.

Ores of the Batesville district occur in three different associations, but all of them are at very nearly the same stratigraphic horizon. (1) The principal deposits (see fig. 18) occur in the manganiferous portions of the Cason shale between the Polk Bayou or the Izard limestone and the Boone chert. In places the lower part of this formation consists of a solid bed of low-grade ore, while elsewhere masses of manganese ore are scattered through an ocherous and manganiferous clay shale formation, probably derived from the disintegration of the ore bed. The Cason shale is manganiferous over a

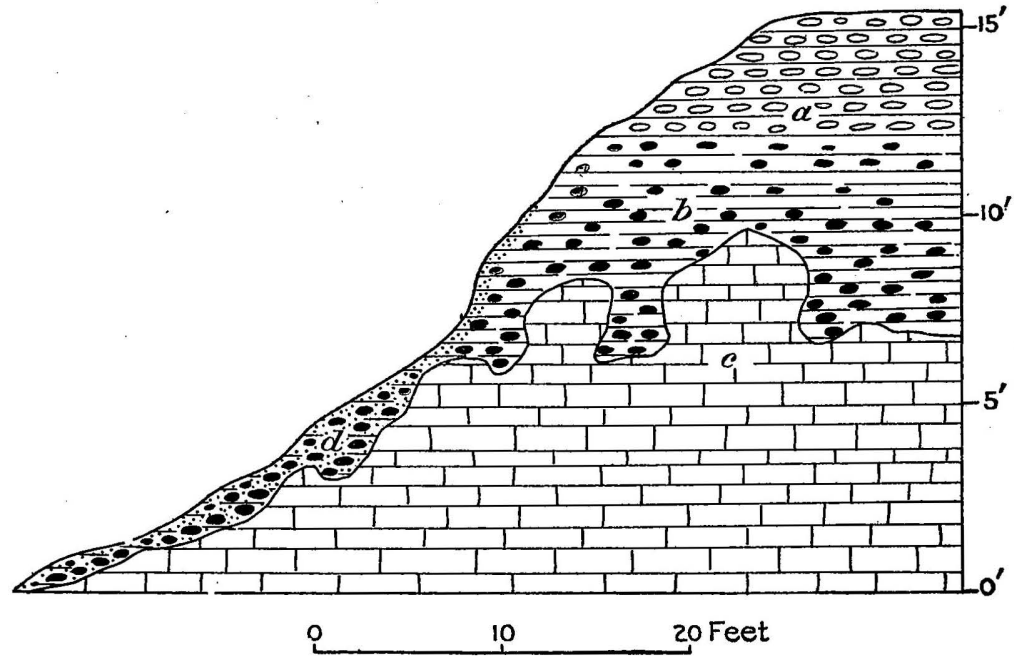

FIGURE 18.-Generalized section showing the occurrence of the Batesville manganese ores. $a$, Boone chert; $b$, Cason shale with manganese deposits; $c$. Polk Bayou limestone; $d$, surface clay with manganese deposits.

large area north and northwest of Batesville. In some parts only stains and thin layers of manganese oxide occur, while elsewhere there are large deposits of ore. As the Boone chert in general caps the ridges, these deposits, occurring under it, outcrop on the hillsides. For the most part the formation where extensive consists of manganiferous and ferruginous clays containing scattered masses of ore, but in a few places it is still consolidated and consists of layers of shale, sandstone, and sandy ferruginous manganese ore. The last contains local masses of pure ore. (2) Numerous deposits of ore occur in clay on the hill slopes below the main manganese-bearing layer, or in places where that layer has been entirely eroded away. The ore occurs in irregular masses in dark-colored clays which lie on the eroded surface of the lower rock formations, where they have accumulated to a thickness varying from a few feet to 20 feet or more. The ore is derived by 
concentration, partly mechanical, partly chemical, from the manganese-bearing bed above where that bed is rich in ore. (3) In the southern part of the district there is a bed of low-grade manganiferous iron ore beneath the St. Clair limestone which is present here under the Boone chert. This class of deposit consists of small, flattened, buttonlike pebbles of manganiferous iron ore arranged along planes of stratification in a dark-red sandy shale. The shale is overlain by the St. Clair limestone and is presumably equivalent to the Cason shale, although its associations and structure are very different from those of the Cason shale over the rest of the area. It is more fully described in connection with the Cason mine.

FORMS OF THE ORES.

The ore masses in the first two classes of deposits are irregular and of various sizes. Similar types of minerals are found in both, but there is a difference in their relative abundance. Each fragment generally consists of but one mineral, although sometimes several different minerals are found in the same mass. The following are the principal forms in which the ore occurs:

(a) Fragments of hard massive blue psilomelane form the most abundant ore in both original and concentration deposits. They generally contain small irregular cavities filled with calcite or clay, or lined with small crystals or black powder of manganese oxide.

(b) Next in importance are fragments of coarsely crystalline brownish or steel-gray braunite. These are very heavy and have a solid interior, but many of them are somewhat porous near the surface. They are much more abundant in the concentration deposits than in the original bed. Veins of braunite occur in many masses of psilomelane, showing that in these masses it is formed later than the psilomelane, and suggesting that a part of it may have been deposited during the reconcentration.

(c) Another type of ore which is more abundant in the concentration deposits is a blue, finely crystalline, pumaceous ore. Some fragments composed of this ore are very hard, while others are soft and friable; but all contain numerous small pores and cavities.

(d) Chert breccia ore in large masses occurs in the concentration deposit at the Roach mine. It is composed of fragments of white chert cemented by amorphous soft oxide of manganese.

(e) Kidney ore of massive blue psilomelane is found in the same locality as the breccia ore.

Besides these types, there occur masses of soft ore replacing limestone or clay and powdery manganese oxide in cavities in other ore masses.

The manganese ore buttons occurring in the third class of depositthat is, in the manganiferous iron ore bed-consist largely of psilomelane. 


\section{DESCRIPTIONS OF MINES AND DEPOSITS.}

Cason mine.-The Cason mine is about $3 \frac{1}{2}$ miles north-northeast of Batesville. (See fig. 19.) The workings consist of two quarries in solid rock on a hillside. In these are exposed 10 to 15 feet of horizontally bedded dark reddish-chocolate sandy shale (the Cason shale) overlain by gray fossiliferous crystalline limestone (the St. Clair limestone), which is exposed on the slope above the pits. Immediately above the shale the limestone is thin-bedded and contains particles of manganese oxide, which are especially abundant around fossils. The shale is interbedded with several thin layers of darkly stained quartzite. The base of the formation is not to be seen, so it is impossible to say what the underlying rock is.

The ore is manganiferous iron ore. It occurs as small buttons or lenses, one-half to 2 inches in the longer diameter, and one-fourth to one-half inch thick, lying along planes of stratification in the shale layers. They are closely grouped and generally make up more than half the mass of the rock. Many of them have forms very similar to fossil brachiopods but none could be definitely determined. Where very closely spaced, they form thin horizontal layers.

The lower portion of the bed contains fewer buttons and more barren layers. These may be hard and quartzitic, or soft and friable, and are darkly stained and partly replaced by manganese and iron oxides. Both barren and ore-bearing layers are soft and decomposed at the surface.

O' Flinn mine.-The O'Flinn mine is about $5 \frac{1}{2}$ miles north-northeast of Batesville. The workings consist of an old shaft. Surface exposures of the Cason shale at this locality show buttons of manganiferous iron ore in dark and sandy shale, similar in occurrence to the ore at the Cason mine.

Trent mine.-The Trent mine is about 1 mile west of the O'Flinn mine. The workings consist of old trenches in dark-brown and black clays, in which occur a few horses of darkly stained Polk Bayou limestone. The ore is scattered through the clay in irregular flattened fragments, varying in size up to 8 or 10 inches in the longer diameter. They are concentrations from the manganese-bearing layer on the hill slope above. As a rule the fragments are dull-black and porous near the surface and have a solid shiny interior, but the reverse may be true, and in that case they have irregular elongated cavities in the interior containing dark clay. Some of the fragments consist of steel-gray or brownish coarsely crystalline braunite, while others are amorphous and consist of dark-blue and gray psilomelane. Still other fragments are composed of a mixture of crystalline and amorphous ore.

Reeves mine.-The Reeves mine is about one-half mile north of the O'Flinn mine and consists of a cut on a hillside. The bank is com- 
posed of horizontally banded yellow, red, and brown clays above and umberous manganiferous clay below. The latter is seamed with red' and brown clay. The ore occurs in the manganiferous clay in irregular fragments of two kinds-(1) solid masses with a shiny interior, such as those of the Trent mine, and (2) blue, friable, pumaceous masses. The first are generally amorphous and hard; the second are finely crystalline.

Adler mine.-The Adler mine is about three-fourths mile north of Reeves mine. The workings consist of a number of old pits scattered

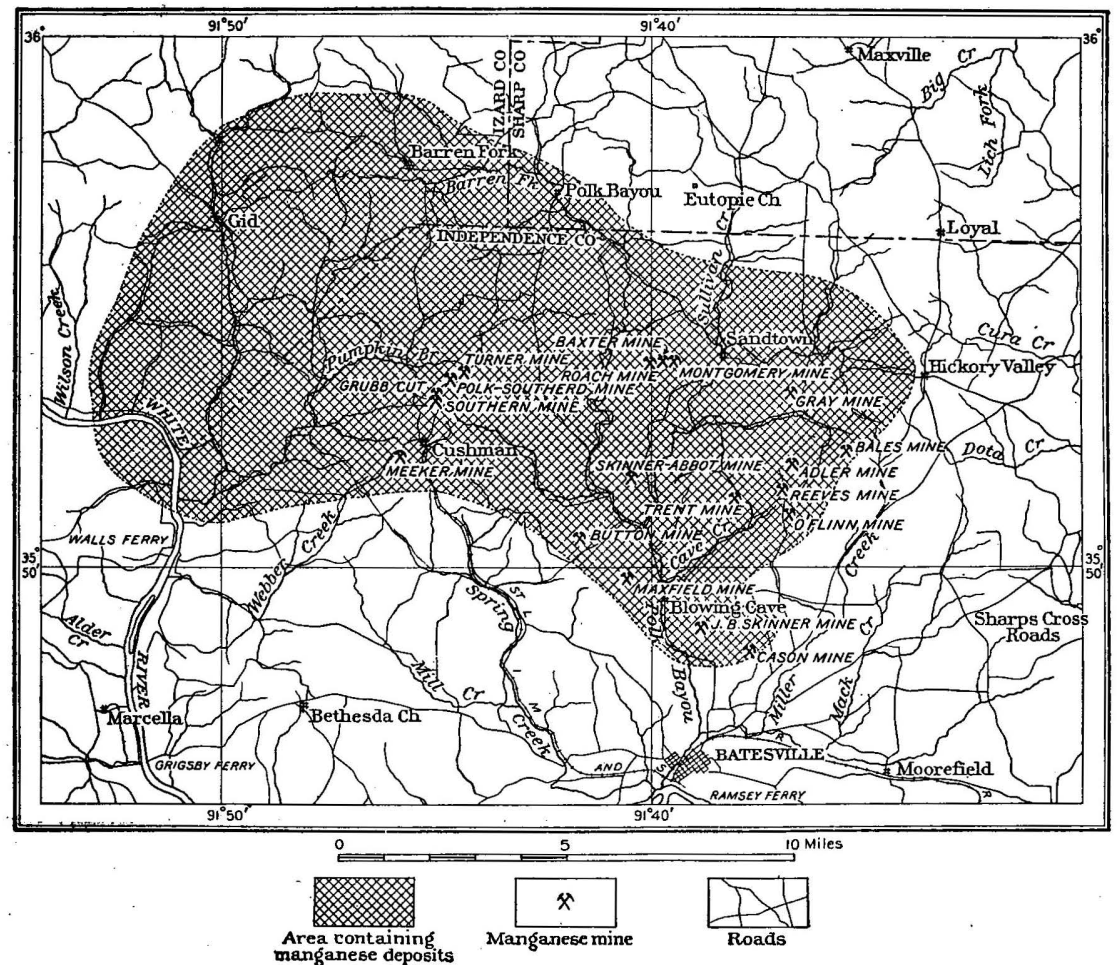

Figure 19.-Map showing the principal manganese mines in the Batesville district, Arkansas, and the probable extent of the ore-bearing area. (Modified from Penrose.)

over a hillside. In some of these the manganese-bearing layer was mined and in others the concentration deposits on the slopes below were mined. Ore is visible only on the dumps and appears to be of the pumaceous crystalline variety found at the Reeves mine. In the pits that enter the ore layer the Boone chert is exposed in the upper part, and underneath it is a thin shale layer, which overlies several feet of manganese-bearing clay. In the lower part of the pits the Polk Bayou limestone is exposed as horses extending upward into the clay. The limestone horses are stained with specks and veins of manganese. 
Bales mine.-The Bales mine is 2 miles northeast of the Reeves mine. It consists of two sets of workings about one-fourth mile apart. One consists of a number of trenches, the other of a tunnel with shaft connection and several pits. Both workings are on the main ore-bearing layer above the Polk Bayou limestone. The ore is dark-blue, friable, and largely amorphous, and occurs in masses in umberous manganiferous clays, and as local replacements in the underlying limestone.

Skinner-Abbot mine.-The Skinner-Abbot mine is about 7 miles north-northwest of Batesville. The Izard limestone is here exposed abundantly at the surface. It has gone into solution along joint planes and formed openings with rounded vertical walls, from a few feet to 10 or 15 feet wide and ranging in length up to 100 feet. These openings contain black soil and brown and manganiferous clays that carry fragments of manganese ore. The ore is of three varieties: (1) Coarsely crystalline gray ore; (2) hard blue massive ore; and (3) hard blue porous finely crystalline ore.

Roach mine.-The Roach mine is 9 miles north of Batesville. The workings consist of several trenches in clay, on a hill lying in a syncline of the St. Peter sandstone. No limestone is visible, but an abundance of chert fragments are scattered over the surface. The clay is darkbrown or chocolate colored and darkly stained by manganese. In some places it is so impregnated with manganese oxide as to form solid bodies of low-grade ore. Manganiferous clays alternate with masses of chocolate clays, and large bodies of chert breccia are found with both. The chocolate clays contain kidney ore of hard blue massive psilomelane in irregular lumps 3 to 6 inches in length. Some of these are very closely packed together, and others are scattered at considerable intervals through the clay.

The chert breccia consists of fragments of white chert cemented by a black amorphous manganese oxide that predominates over the chert. It occurs in large masses, some of them 4 or 5 feet in extent. The fragments of chert are generally small and considerable ore is found in the breccia masses in which there is little or no chert. Where cavities occur in the breccia ore they are lined with nodular projections. Much of the kidney ore contains chert fragments and thus grades into breccia ore.

Baxter mine.-The Baxter mine, about one-half mile east of the Roach mine, consists of a large open cut. The walls are composed of reddish-chocolate clays below and lighter-colored clays with chert fragments near the surface. In the chocolate-colored clays are masses of dark-red decomposed shale and limestone. The ore is of a similar type to that in the Montgomery mine described below. Both the Baxter and the Montgomery cuts contain near their mouths 
large masses of a limestone-marble breccia. These are composed of a mixture of massive limestone like the Izard, and crystalline limestone like the lower part of the Polk Bayou.

Montgomery mine.-The Montgomery mine adjoins the Baxter on the east and likewise consists of a large open cut. On the walls are exposed reddish-chocolate clays with large masses of dark-red decomposed limestone and shale, still showing original textures.

The ore is of two kinds-pumaceous, finely crystalline ore and button-like, pebbly ore. The former occurs in thin parallel layers through the clay, as though it were a replacement of certain layers of rock. (See fig. 20.) Successive layers are varying distances apart and between them are residual clays. The button ore occurs

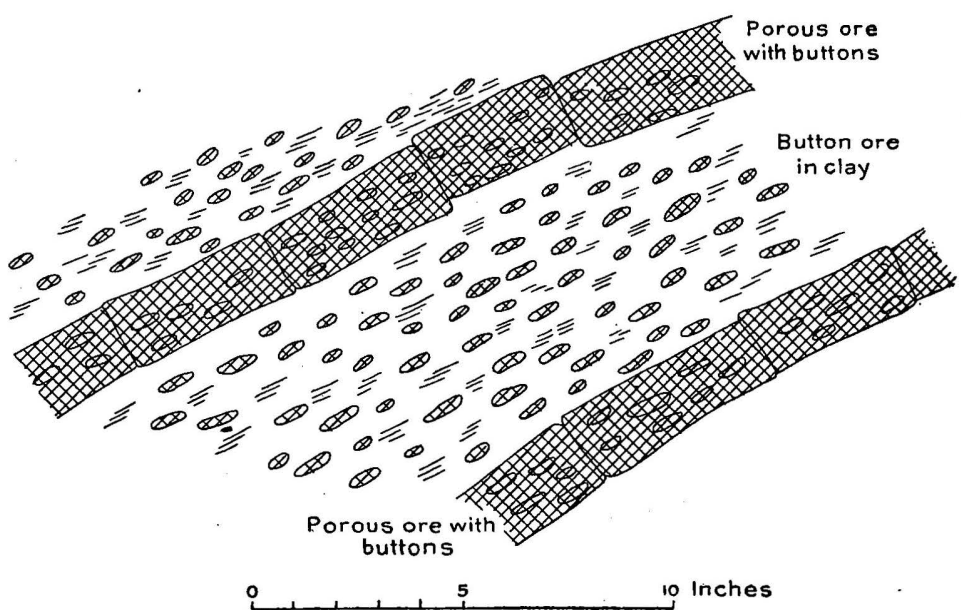

FIGURE 20.-Sketch showing the occurrence of manganese ores at the Montgomery mine.

in the clays as well as in the ore layers. It consists of small flattened and spherical pebbles, the former very much like those in the Cason mine. The flattened pebbles are seldom more than $1 \frac{1}{2}$ inches in the longer diameter, and one-third inch thick, and the spherical pebbles are still smaller. The former lie with their longer diameters in the same plane, this probably being the plane of stratification of the original rock. Both types are dark blue. The button-like concretions are dense and hard; the ore layers, though hard, are porous.

Meeker mine.-The Meeker mine is about one-half mile west of Cushman. The workings consist of several open cuts and tunnels, mostly recent, on the manganese-bearing layer between the Polk Bayou limestone and the Boone chert. The surface of the former is very uneven, as in other places mentioned, and horses of it extend upward into the manganese-bearing layer. This varies from a few $37336^{\circ}-$ Bull. $427-10-8$ 
inches to 10 feet thick, depending on the size of the limestone horses. It is composed of the following succession of layers (fig. 21):

Boone chert.

Manganiferous clay 2 to 3 inches thick.

Green shale varying in thickness up to a foot or more. Absent in places.

Brown sandstone 2 to 3 feet thick.

Sandy manganese and iron oxide formation varying in thickness up to 6 feet or more. Locally the lower foot or two is hard and siliceous, while elsewhere there are 6 inches or a foot of manganiferous clay at the base.

Polk Bayou limestone.
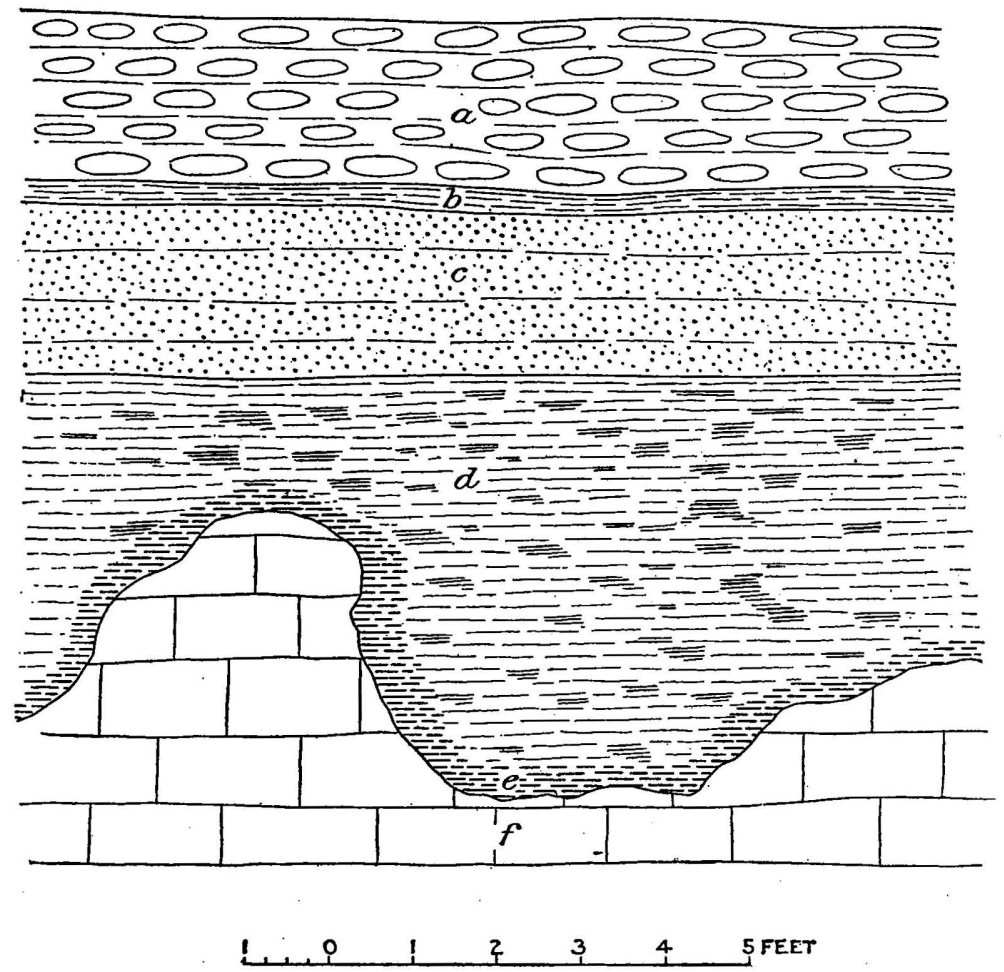

FigURE 21.-Sketch showing the occurrence of manganese ores at the Meeker mine. a, Boone chert; $b$, green shale or manganiferous clay; $c$, brown sandstone; $d$, manganese-hearing ferruginous shale; $e$, manganiferous clay or dark indurated siliceous layer; $f$, Polk Bayou limestone.

The manganese-bearing layer consists of thin horizontal layers of manganese and iron oxides, mainly the former, interlaminated with yellow and red sandy material. The layers are generally crenulated and are one-sixteenth to one-half inch thick. The variations are generally abrupt and sharp, causing great irregularity. Locally large porous masses of manganese ore 4 or 5 inches thick are embedded in the low-grade laminated ore. They consist of dark-blue massive psilomelane, with a small amount of finely crystalline material in cavities. Many of the cavities are entirely or partly filled with calcite.

Southern mine.-The Southern mine is about 1 mile north-northeast of Cushman. It consists of two large open cuts and many shafts. 
The Boone chert is exposed in the upper part of the cuts and beneath it are 10 to 15 feet of ocherous, manganiferous, red and brown clays, in which occur the ores. Many of the shafts go through 20 to 40 feet of chert into the underlying ore-bearing layer. The ore was not seen in place at the Southern mine.

Grubb cut.-The Grubb cut is several hundred yards northeast of the Southern mine. The workings consist of an old open cut with a recent shaft in the floor. The walls of the cut consist of Boone chert in the upper part with 10 to 15 feet of manganese-bearing clay below it. In the bottom there are horses of coarsely crystalline Polk Bayou limestone. The beds of chert are considerably folded as a result of slumping in the underlying clays. The ore recently taken from the shaft is of a hard blue porous variety of psilomelane, with some red ore which is presumably stained by iron.

Polk-Southerd mine.--The Polk-Southerd mine is about 2 miles northeast of Cushman and consists of an old cut and several old shafts. The chert forms the upper part of the walls of the cut, but the orebearing layer below it is covered with débris. Pieces of ore on the dump are of a porous blue variety of psilomelane.

Turner mine.-The Turner mine consists of an old open cut and several shafts about half a mile northeast of the Polk-Southerd mine. In the bottom of the cut there are horses of massive blue Izard limestone with associated green shale. The manganese-bearing clay, which is reddish brown, lies directly on the Izard limestone, and is overlain by the Boone chert locally. The ore, consisting of massive blue psilomelane and gray crystalline braunite, is found in fragments in the clay.

Many other old mines are present in different parts of the district, but those described show fully the different forms and associations in which the ores occur. .

ANALYSES.

The following are analyses of psilomelane and braunite from the Batesville region:

Analyses of psilomelane from the Batesville region. ${ }^{a}$

\begin{tabular}{|c|c|c|c|}
\hline - & 1. & 2. & 3. \\
\hline 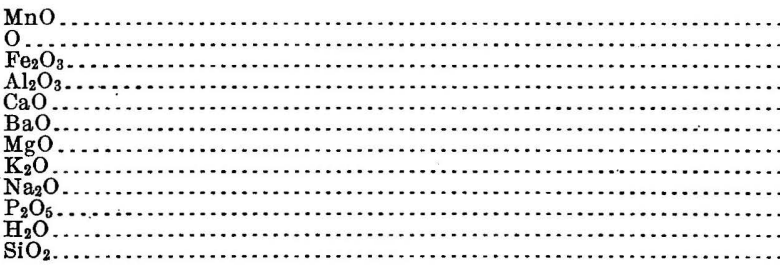 & $\begin{array}{r}77.85 \\
14.56 \\
.90 \\
.80 \\
1.81 \\
.21 \\
\text { Trace. } \\
1.99 \\
.97 \\
.67 \\
.83\end{array}$ & 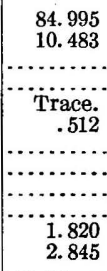 & 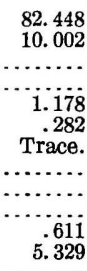 \\
\hline & 100.59 & 100.655 & 99.850 \\
\hline
\end{tabular}

a Penrose, R. A. F., jr., Manganese: Its use, ores, and deposits: Ann. Rept. Arkansas Geol. Survey for 1890 , vol. 1, 1893, pp. 145, 147 . 
Analyses of braunite from the Batesville region. a

\begin{tabular}{|c|c|c|}
\hline & 1. & 2. \\
\hline 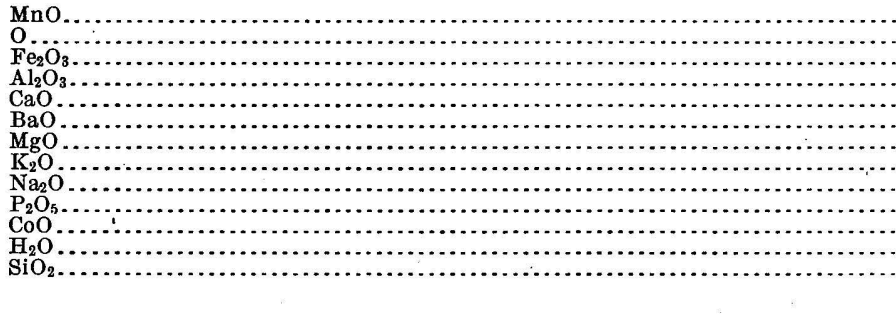 & $\begin{array}{r}87.47 \\
9.62 \\
.44 \\
.11 \\
.34 \\
.48 \\
\text { Trace. } \\
.10 \\
.05 \\
.25 \\
.18 \\
99.04\end{array}$ & 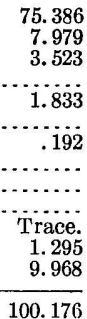 \\
\hline
\end{tabular}

a Penrose, R. A. F., jr., op. eit., pp. 148-149.

The following are analyses of manganese ores of the Batesville district, given by mines:

Analyses of manganese ores of the Batesville district.a

\begin{tabular}{|c|c|c|c|c|c|}
\hline Name of mine. & Mn. & $\mathrm{Fe}$. & $\mathrm{SiO}_{2}$. & P. & Moisture. \\
\hline 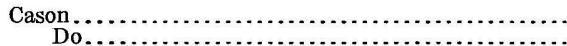 & $\begin{array}{l}34.64 \\
50.41\end{array}$ & 4. 88 & 25.65 & 0.58 & \\
\hline J. B. Skinner & $\begin{array}{l}50.41 \\
38.30\end{array}$ & $\begin{array}{l}7.56 \\
8.45\end{array}$ & 1 & $\begin{array}{l}.06 \\
.38\end{array}$ & \\
\hline Do & 39.35 & 5.30 & $\cdots$ & .217 & $\cdots \ldots \ldots$ \\
\hline 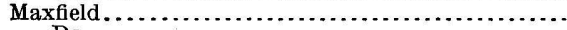 & 44.69 & 9.18 & 3.23 & .319 & \\
\hline 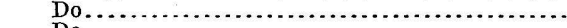 & 41.08 & 10.75 & & .467 & - \\
\hline 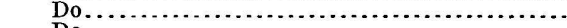 & 43.12 & 12.50 & 1.54 & .339 & ........... \\
\hline 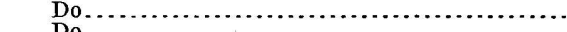 & 42.74 & 4.95 & 10.41 & .385 & \\
\hline Do & 31.90 & 11.20 & 20.50 & .347 & \\
\hline Do ${ }_{\text {Do }}$ & 24.31 & $\begin{array}{l}21.63 \\
78\end{array}$ & 14. 82 & .252 & $\cdot$ \\
\hline $\begin{array}{l}\text { Do } \\
\text { Do }\end{array}$ & $\begin{array}{l}24.50 \\
27.49\end{array}$ & $\begin{array}{l}28.72 \\
23.40\end{array}$ & $\begin{array}{l}5.22 \\
7.08\end{array}$ & .226 & \\
\hline Do $\ldots \ldots \ldots$ & 29.57 & 23.40 & 5.10 & .452 & 19.00 \\
\hline Do.. & 31.56 & 21.47 & 6.75 & .385 & 16.40 \\
\hline$\ldots \ldots \ldots . . .6$ & 26.82 & 24.42 & 7.33 & .273 & 16.20 \\
\hline 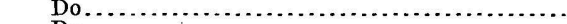 & 27.55 & 24.00 & 7.46 & .268 & 15.50 \\
\hline${ }^{\prime}{ }_{1}$ & 30.55 & 21.70 & 6.48 & .328 & 15.00 \\
\hline 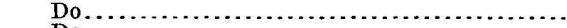 & 33.21 & 18.80 & 6.05 & .194 & 15.10 \\
\hline Do. & 31.35 & 20.70 & 4. 49 & .581 & 14.50 \\
\hline .... & 37.59 & 12.70 & 5.56 & .357 & 18.20 \\
\hline Do & 34.38 & 17.70 & 4.03 & .476 & 21.50 \\
\hline Do.................... & 36.05 & 15.50 & 4.87 & .279 & 18.30 \\
\hline ................. & 37.27 & 15.30 & 4.55 & .481 & 21.10 \\
\hline Do.............. & 28. 69 & 23.00 & 5.42 & .788 & 20.00 \\
\hline$\ldots$. & 33.80 & 16.85 & 5. 70 & .569 & 19.10 \\
\hline Do. & 34.03 & 11.20 & 3.65 & .732 & 16. 30 \\
\hline Do. & 36.88 & 14.70 & 3.97 & .608 & 18.50 \\
\hline ...... & 35.40 & 15.70 & 4.35 & .735 & 16. 30 \\
\hline$\ldots$. & 36.86 & 15.20 & 3.68 & .585 & 12.00 \\
\hline$\ldots \ldots \ldots \ldots$ & 55.45 & 2.95 & 5.60 & .117 & 1.30 \\
\hline 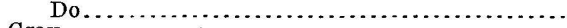 & 57.13 & 1.89 & 5.39 & .078 & 1.30 \\
\hline ray .. & 50.81 & 2.90 & 2.50 & .126 & \\
\hline Do. & 46.36 & 8.53 & 4.25 & .128 & $2: 50$ \\
\hline Do. & 49.36 & 5.97 & 3.90 & .156 & 5.50 \\
\hline kinner Abbot. . . . . . . & 55.68 & 2.00 & .... & .172 & $\cdots$ \\
\hline Do. & 53.60 & 2.50 & & .209 & \\
\hline$\ldots:-$ & 51.86 & 7.80 & & .141 & $\cdots$ \\
\hline Do. & 42.77 & 5.50 & - & .523 & $\cdots$ \\
\hline$\ldots \ldots \ldots \ldots \ldots$ & 56.10 & 2. 61 & 5.44 & .075 & .60 \\
\hline I & 57.01 & 2.05 & 5. 33 & .072 & .80 \\
\hline Do & 57.41 & 1.62 & . 6.00 & .100 & 1.00 \\
\hline 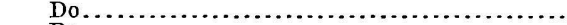 & 55.70 & 1.85 & 6.71 & .078 & .80 \\
\hline$\ldots \ldots \ldots$ & 56.75 & 2.19 & 5.49 & .068 & \\
\hline ........ & 57.39 & 1.55 & 5.46 & .074 & .10 \\
\hline$\cdots$. & 38.49 & 8.80 & 19.96 & .115 & 7.00 \\
\hline$\cdots$ & 56.65 & 1.68 & $\begin{array}{l}5.55 \\
5.78\end{array}$ & .066 & .80 \\
\hline $\begin{array}{r}\text { Do } \\
\text { Baxter }\end{array}$ & $\begin{array}{l}58.31 \\
55.60\end{array}$ & $\begin{array}{l}1.33 \\
8.78\end{array}$ & $\begin{array}{r}5.78 \\
24.58\end{array}$ & $\begin{array}{l}.064 \\
.149\end{array}$ & 9.80 \\
\hline D & 47.70 & 4.77 & 10.98 & .284 & 9.20 \\
\hline Do.... & 45.77 & 4. 67 & 14.06 & .342 & 8.20 \\
\hline Southern. & 53.12 & 2.30 & 2.75 & .165 & 4.40 \\
\hline ......... & 51.82 & 3.40 & 2.50 & .193 & 5.10 \\
\hline & 50.75 & 4.27 & 3.52 & .184 & 5.40 \\
\hline & 49. 73 & 2.15 & 3.10 & .166 & 7.28 \\
\hline - & 51.77 & 2.38 & 3.18 & $.128^{\circ}$ & 1.68 \\
\hline 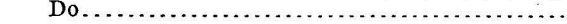 & 49.60 & 3.84 & 4.79 & .184 & 3.88 \\
\hline
\end{tabular}

a Penrose, R. A. F., jr., op. cit., pp. 219, 221, 224, 227, 238, 242, 245, 262. 


\section{ORIGIN OF THE ORES.}

Penrose, in his study of the Batesville manganese deposits, developed the theory that the ores were deposited from solution in local basins at the same time that the rocks associated with them were deposited. ${ }^{a}$ The materials he supposed to have been derived from the crystalline land mass in southeastern Missouri, or from a similar one farther south, the ancient porphyries of this region being known to carry manganese. The St. Clair limestone is given as the formation with which the ores were originally laid down. Penrose did not distinguish the Polk Bayou limestone and Cason shale as separate formations from the St. Clair limestone, as they have been shown to be by the work of Ulrich and others, and supposed the manganese to be interlayered with the St. Clair at different horizons ${ }^{b}$ instead of being at a definite horizon in the Cason shale. The varying thicknesses of the several limestone formations he accounted for by nondeposition rather than by intervening erosion periods, apparently supposing the limestones and the Boone chert to have been laid down during a continuous period of deposition. Shallow water and lagoons developed locally at times, and there manganese was deposited as carbonate or oxide, either in local deposits or in a disseminated state through the rocks. The disseminated material was later concentrated into nodules and masses, such as are seen in the Cason mine.

The present ore deposits Penrose supposed to have been derived from the Polk Bayou limestone (designated by him the lower part of the St. Clair), by its decay, the ores accumulating in siliceous and ocherous material on its surface, while the calcium carbonate was carried off in solution. This decay he supposed to take place underneath the Boone chert, the waters coming downward through fractures in that formation and attacking the underlying limestone; as evidence for that process he points to the local slumping of the chert. This decay produced the uneven surface of the limestone underlying the ore-bearing material.

In the light of later developments it will be necessary to alter this hypothesis considerably. As far as the original source of the manganese and the accompanying sediments is concerned, the hypothesis still holds good. The Izard and Polk Bayou limestones were laid down over wide areas, and between the two periods of deposition there was an intervening period of erosion. While these limestones were being deposited the St. Francis Mountains in southeastern Missouri were being disintegrated and a heavy mantle of residual material formed. When the Polk Bayou had been deposited there was another slight period of erosion, after which the area was again submerged and the residual material which had been gathered on the St. Francis Moun- 
tains land mass to the north was deposited over it, on the uneven surface of the Polk Bayou limestone or lower formations where this had been removed. This material formed the Cason shale. Manganese and iron oxides, mainly the former, became concentrated locally in this layer and phosphatic ${ }^{a}$ material became widely distributed through it. The manganese and iron oxides were brought in from the granite and porphyry areas in the land mass to the north, probably in solution, and were deposited with the residual material where conditions were favorable.

After the formation of the Cason shale local warping took place, resulting in the formation of deep embayments separated by shallow areas or even by land masses. ${ }^{b}$ The St. Clair limestone was deposited on the Cason shale in the embayments, while elsewhere no deposition took place. However, in the areas between these embayments a reconcentration of the manganese and iron oxides took place, as is shown by the fact that only where the St. Clair limestone is absent are there workable deposits. Where it is present the Cason shale contains only low-grade deposits and stains of manganese, as at the Cason mine and at localities mentioned by Purdue ${ }^{c}$ with reference to the phosphate rocks of this bed.

After the restricted deposition of the St. Clair limestone came the deposition of the Boone chert over a wide area, probably preceded locally by the deposition of the Chattanooga-shale. Subsequent erosion has resulted in a concentration, partly mechanical and partly chemical, of the ores in the ore-bearing layer and in the residual clays on the hill slopes below it. The ores are therefore original depositions reconcentrated during two subsequent land stages-first, during late Silurian and Devonian partial emergence, and second, during the post-Paleozoic erosion of the Boone chert.

It is questionable on which concentration most stress should be laid, but from the universal presence of manganese above the Polk Bayou and Izard limestones, it seems likely that most of the materials were gathered during the original deposition. Local concentration into ore bodies, however, did not take place until long after the deposition of the St. Clair limestone.

That the ores were not derived to any extent from the underlying Polk Bayou limestone, as Penrose suggested, is shown by the fact that only a very slight erosion of that formation took place. Neither did the erosion of the St. Clair limestone enrich the deposits, as is shown by the fact that the richest deposits are found where the St. Clair never was present.

$a$ Purdue, A. H., op. cit., p. 471.

$b$ Ulrich, E. O., personal communication.

c Purdue, A. H., op. cit., p. 466. 
WEST-CENTRAL ARKANSAS. $a$

GEOGRAPHY AND TOPOGRAPHY.

The west-central Arkansas manganese-bearing region consists of a belt extending from Pulaski County on the east, west-southwestward through Saline, Garland, Hot Spring, Pike, and Montgomery counties to Polk County on the west. It varies in width from 4 to 12 miles.

The region consists of a series of nearly parallel mountain ridges grouped together under the name of Ouachita Mountains. The ridges have a general east and west trend, but vary in direction on either side. South of the Ouachita Mountains is the low pine-clad region of southern Arkansas, and north of them are other mountain ranges.

\section{GEOLOGY.}

The Ouachita Mountains are formed chiefly of rocks of Ordovician, Silurian, and Devonian age, consisting of novaculite, chert, shale, sandstone, and quartzite. To the north and south are rocks of Carboniferous age, representing the flanks of the anticlinorium of which the Ouachita Mountains form the center. Horizontal beds of Cretaceous, Tertiary, and Quaternary rocks border the disturbed region on the south and east.

Manganese and iron ore deposits are associated with a hard gray novaculite of late Silurian and Devonian age. They occur in veins or in a layer at the top of this bed, in various forms, from mere stains to a network of thin pockets and seams. The ore-bearing layer varies from 4 or 5 to 50 feet in thickness. The novaculite bed has a thickness varying between 300 and 500 feet, is composed of almost pure silica, and varies from a hard translucent white, gray, or buff rock with conchoidal fracture to a soft porous or granular rock with irregular fracture.

The novaculite bed and the ore-bearing layer constitute the Silurian and Devonian formations of this region. ${ }^{b}$ They are overlain by a thick series of Pennsylvanian shales and sandstones and underlain by various Ordovician formations consisting of sandstones, shales, and chert.

The rocks of the Ouachita area are very much disturbed, being thrown into a series of close, parallel, approximately east and west folds. The valleys are occupied by the shale formations, and the more resistant sandstone, chert, and novaculite formations form the ridges and mountains. All the rocks are tilted at steep angles. (See fig. 22.) 


\section{CHARACTER AND OCCURRENCE OF ORES.}

The ores are oxides of manganese, largely black or steel-blue psilomelane in botryoidal masses, and fibrous or granular black pyrolusite. They frequently occur in intimate association, the pyrolusite incrusting masses of psilomelane and lining cavities in them. Other oxides may be present, but have not been identified.

Iron ores of various types occur in the novaculite ore-bearing layer in pockets with or without manganese ores, and also in lenticular layers in the lower part of the overlying Pennsylvanian shales.

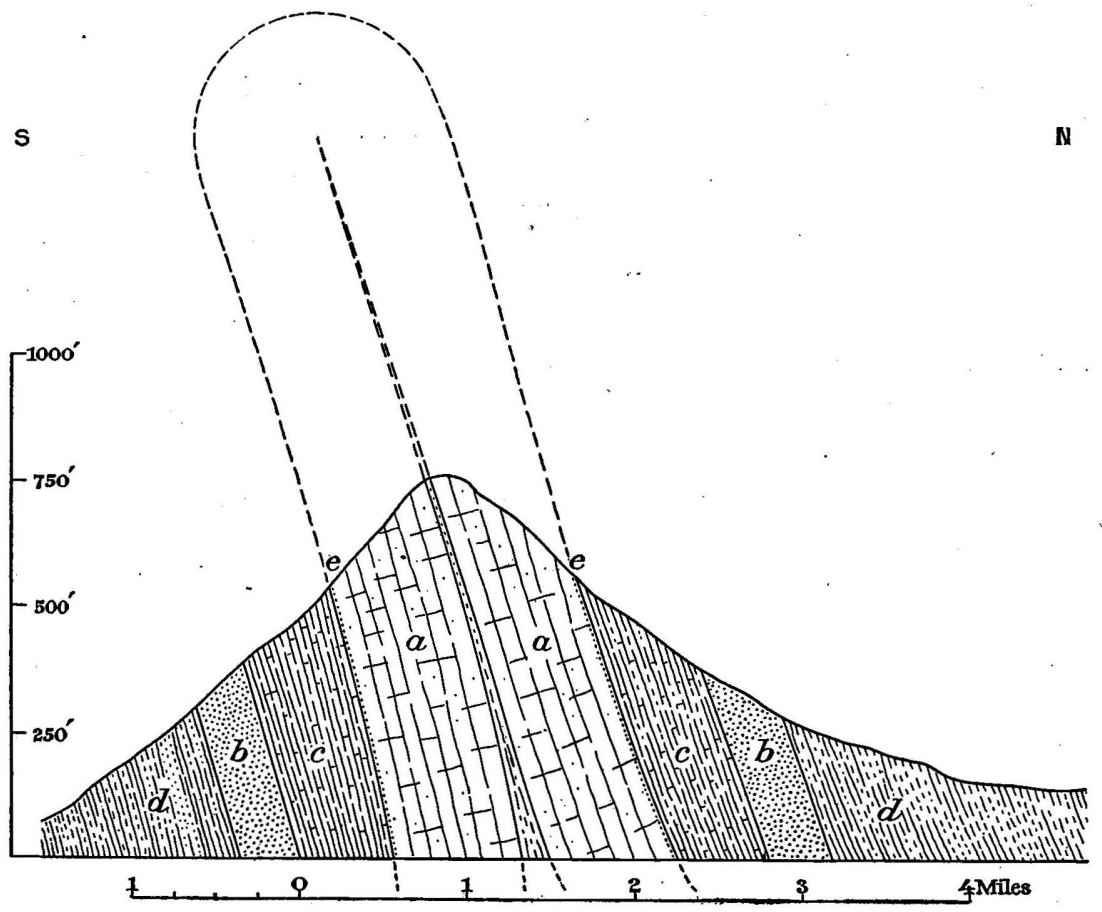

Figure 22-Section showing the occurrence of manganese ores in west-central Arkansas. (After Penrose.) $a$, gray novaculite; $b$, sandstone; $c$, siliceous shale; $d$, shale and sandstone; $e$, manganese-bearing layer.

The types found in the ore-bearing layer are generally glossy darkbrown or black ores in botryoidal masses, while those in the shale are ordinary siliceous brown ores. All the iron ores are hydrated sesquioxides.

The manganese ores occur in nests, pockets, and short discontinuous seams from a fraction of an inch to a foot thick.. Thicknesses of a foot, however, are rare; few single masses are more than 3 or 4 inches in greatest thickness. Such bodies are scattered in varying quantities through the ore-bearing layer. They occupy bedding planes or joint cracks, occur as local segregations in the rock, or form a cement in a novaculite breccia. The iron and manganese ores may occur 
intimately mixed or in separate masses in the same pocket, and thus form manganiferous iron ores, or they may occur in separate pockets.

Manganese and iron stains and small ore pockets extend over the same area as the upper portion of the novaculite bed, though they are only locally concentrated to any degree. They generally occur on both sides of the anticlinal ridges, of which the novaculite bed forms the summit. (See fig. 22.) The principal deposits occur in Pulaski, Montgomery, and Polk counties, and even these are of little or no commercial importance.

A deposit of bog manganese, with clay and rock fragments, is found on the banks of McHenry Creek, Pulaski County. It varies in thickness from a few inches to 10 feet and is mixed with considerable bogiron ore. The ore is black, massive, and earthy, and in some places composes most of the bed, while elsewhere the rock fragments and clay form the larger portion. The deposit is underlain by gray clay.

ANALYSES.

The following are analyses of psilomelane and pyrolusite from westcentral Arkansas:

Analyses of psilomelane and pyrolusite from west-central Arkansas. ${ }^{a}$

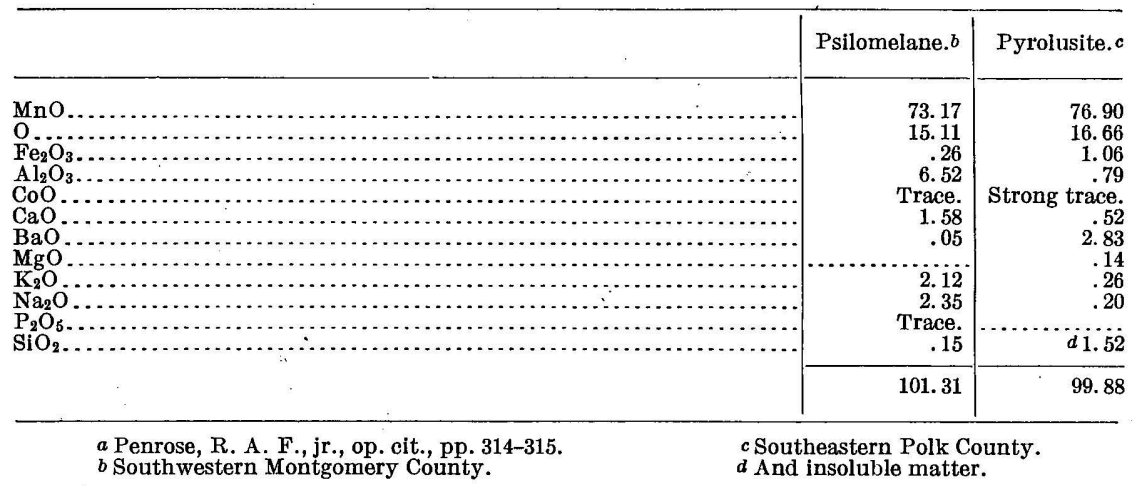

The following are analyses of manganese ores and manganiferous iron ores from west-central Arkansas:

Analyses of manganese and manganiferous iron ores from west-central Arkansas.a

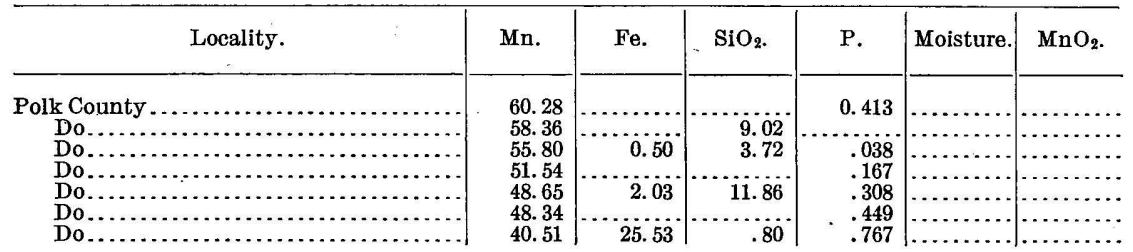

$a$ Penrose, R. A. F., jr., op. cit., pp. 318-319. 
Analyses of manganese and manganiferous iron ores from west-central Arkansas-Cont'd.

\begin{tabular}{|c|c|c|c|c|c|c|}
\hline Locality. & Mn. & Fe. & $\mathrm{SiO}_{2}$. & P. & Moisture. & $\mathrm{MnO}_{2}$ \\
\hline 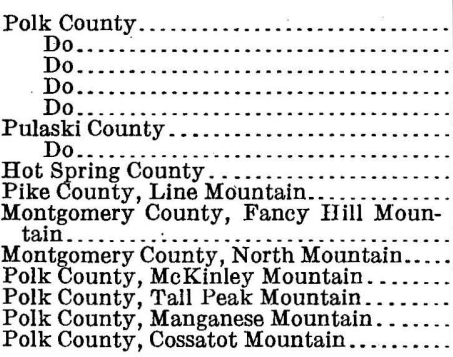 & \begin{tabular}{r|}
27.68 \\
26.20 \\
22.84 \\
11.93 \\
2.06 \\
40.39 \\
13.31 \\
41.54 \\
30.93 \\
48.02 \\
56.66 \\
49.24 \\
52.16 \\
42.75 \\
59.55
\end{tabular} & $\begin{array}{r}35.39 \\
16.83 \\
22.26 \\
50.38 \\
2.17 \\
.87 \\
14.15 \\
9.21 \\
5.55 \\
.18 \\
2.04 \\
4.00 \\
2.72 \\
.74\end{array}$ & $\begin{array}{r}1.88 \\
29.00 \\
.42 \\
44.40 \\
29.30 \\
74.79 \\
1.29 \\
5.86 \\
.52 \\
.15 \\
2.98 \\
.24 \\
10.46 \\
.52\end{array}$ & $\begin{array}{r}0.230 \\
.343 \\
.047 \\
.576 \\
1.450 \\
.003 \\
.015 \\
.560 \\
.320 \\
\\
.310 \\
\text { Trace. } \\
.380 \\
.390 \\
.450 \\
\text { None. }\end{array}$ & $\begin{array}{l}\cdots \\
\cdots \\
\cdots \\
\cdots\end{array}$ & $\begin{array}{l}\cdots \cdots . \\
\cdots \cdots \\
\cdots \cdots . . \\
\cdots \cdots . . \\
\cdots \cdots . \\
60.58 \\
42.09 \\
71.73 \\
82.10 \\
71.41 \\
77.60 \\
62.75 \\
90.52\end{array}$ \\
\hline
\end{tabular}

The following are analyses of bog manganese and iron ores from McHenry Creek, Pulaski County:

Analyses of bog manganese and iron ores from McHenry Creek, Pulaski County, Ark. ${ }^{a}$

\begin{tabular}{|c|c|c|c|c|c|}
\hline & 1. & 2. & 3. & 4. & 5. \\
\hline $\begin{array}{l}\mathrm{Mn} \\
\mathrm{Fe} \\
\mathrm{FiO} \\
\mathrm{Si} \\
\mathrm{P} \\
\text { Moisture }\end{array}$ & $\begin{array}{c}59.68 \\
3.09 \\
4.83 \\
.001 \\
. . . .\end{array}$ & $\begin{array}{c}27.34 \\
2.88 \\
42.83 \\
.116 \\
1.42\end{array}$ & $\begin{array}{c}8.08 \\
11.82 \\
63.19 \\
.270 \\
3.67\end{array}$ & \begin{tabular}{l|}
1.62 \\
27.07 \\
46.37 \\
.470 \\
3.26
\end{tabular} & $\begin{array}{l}0.39 \\
33.80 \\
44.91 \\
.160 \\
3.02\end{array}$ \\
\hline
\end{tabular}

$a$ Penrose,. R. A. F. jr., op. cit., p. 330.

\section{CENTRAI TEXAS. $a$}

The manganese deposits of central Texas occur in the area of crystalline and metamorphic rocks of probable pre-Cambrian age, in Mason, Llano, and San Saba counties. The ores are directly associated with quartzites and gneisses, though micaceous and garnetiferous schists are frequently found in their neighborhood. Paleozoic and Cretaceous rocks border the crystalline area on all sides and form the capping of many hills within the area.

\section{CHARACTER AND OCCURRENCE OF ORES.}

The ores consist of a mixture of oxides and silicates. The former are largely psilomelane and pyrolusite; the latter consist of the manganese garnets spessartite and andradite, the manganese epidote piedmontite, and the manganese olivine tephroite. The oxides have been derived from the oxidation of the silicates.

The ores occur in lenticular layers in both quartzites and gneisses. The layers follow the strike of the inclosing rocks, varying in thickness from a few. inches to several feet, and contain many lenses of the inclosing rock. Deposits have been traced for half a mile or more, 
but within this distance they probably thin out and reappear again several times.

The oxide ores are composed of a mixture of hard, massive black psilomelane with conchoidal fracture and soft granular pyrolusite. Considerable silica is associated with them, sometimes in amounts of 15 to 25 per cent.

The silicates are mostly manganese garnets and piedmontite, tephroite occurring but rarely. Spessartite is the manganese-alumina garnet, and andradite a calcium-iron garnet, which here contains a considerable admixture of manganese. The andradite is of two varieties, one chocolate-brown, the other deep yellow. The spessartite is lemon-yellow and the tephroite varies from gray to greenish gray. The piedmontite has a bright-red color. The silicates occur both in crystalline and in massive form.

The following are analyses of the different silicates:

Analyses of manganese silicates from central Texas.

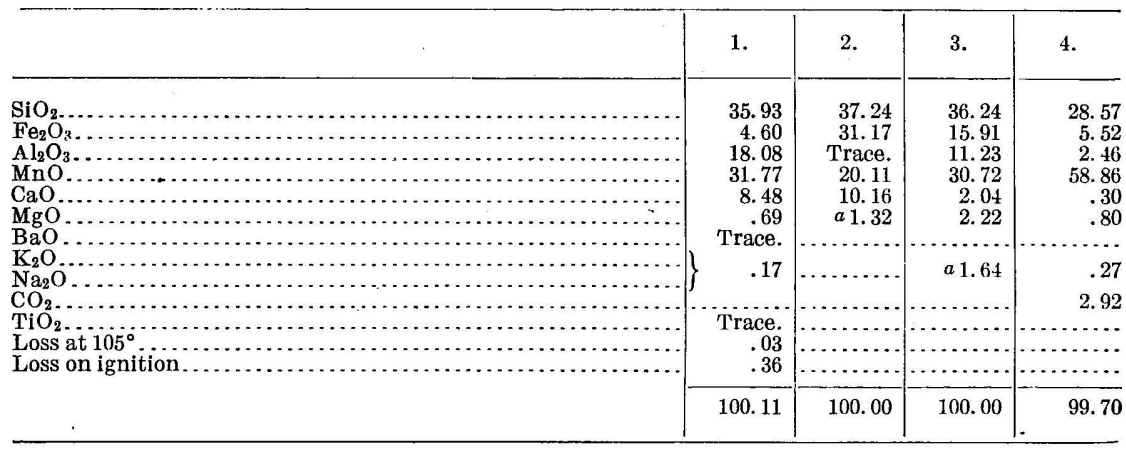

$a$ Difference.

1. Spessartite from Horse Mountain.

2. Brown andradite from Kothmann tract.

3. Yellow andradite from Kothmann tract.

The oxide ores have been derived from the silicates by oxidation, and are intimately mixed with them, but are more abundant near the surface. The alteration varies in different parts of the deposit, being far advanced where the deposit is considerably fractured and slight in places where it is solid. At many points silicates may be found outcropping at the surface. The oxidation follows joints and cracks and proceeds from these inward.

DESCRIPTIONS OF MINES AND DEPOSITS.

The best known of the manganese deposits of central Texas are those of the Spiller mine, of the Kothmann tract, and of Horse Mountain.

Spiller mine.-The Spiller mine is in Mason County, 15 miles northeast of Mason. The deposits are found in lenticular layers interbedded with quartzite, with which are associated beds of mica schist 
and feldspathic rocks. The rocks dip west or southwest at angles varying up to $45^{\circ}$. They form a north and south hill with a gentle western dip slope, and a steep rugged eastern slope where many layers form almost vertical ledges.

The ores are on the west slope, the lenses running parallel to the direction of the hill. They consist largely of hard steel-gray oxide blending into softer finely crystalline pyrolusite. The oxides are associated with yellow manganese silicates, in great part much decomposed and oxidized. The greatest thickness of solid ore reported is 3 feet on the outcrop, and beneath this is a mixture of lenses of yellow silicates interlayered with quartzite. Scattered deposits. are found at intervals along the slope of the hill.

Kothmann tract.- The Kothmann tract is 3 miles southeast of the Spiller mine. Manganese deposits occur here as lenticular beds interbanded with gneiss on the west slope of a north and south ridge. The hill consists largely of gneiss, but garnetiferous and micaceous schist are associated with it. The rocks strike north and south and have a nearly vertical dip. The lenses, three of which are known, consist of manganese silicates stained black at the surface. They have the same strike and dip as the inclosing gneiss, and occur at different levels on the slope. The lowest of them has been followed for one-half mile along the hillside; it consists of chocolate-brown andradite and quartz, the former decomposed to black oxide near the surface and along cracks. It is 2 to 10 feet thick and contains many subordinate lenses of schist or gneiss. The second bed consists largely of impure yellow andradite with associated biotite, hornblende, and feldspar, but at its southern end it contains considerable tephroite. This deposit is discontinuous, varying, where present, up to 3 feet in thickness. Like the lower layer, it is somewhat oxidized at the surface, the tephroite more so than the andradite. The third lens, which is on the summit, has a composition similar to the lowest.

Horse Mountain.- Horse Mountain is in Llano County, 5 miles north of Llano. It consists of fine-grained gneisses cut by quartz veins. The rocks have a north and south strike and dip westward at angles varying from $20^{\circ}$ to $40^{\circ}$. The principal manganese deposit occurs on the eastern slope, interbedded with the gneiss; its greatest thickness is 2 feet. It consists of yellow spessartite and red piedmontite, ${ }^{a}$ with veins, of quartz, lenses of gneiss, and disseminated particles of magnetite. On the surface the deposit is considerably altered to black oxide. It is traceable for 400 yards along the slope, but is very irregular, at many places thinning out or becoming disseminated in the country rock. Several other occurrences of manganese silicates are known on Horse Mountain in association with iron ores.

a Paige, Sidney, Economic resources of the central Texas mineral region, with a report on the pre-Cambrian geology and iron ores: Bull. U. S. Geol. Survey (in preparation). 
ANALYSES.

The following are analyses of central Texas manganese ores:

Analyses of manganese ores from central Texas. ${ }^{a}$

\begin{tabular}{|c|c|c|c|c|c|}
\hline Locality. & Mn. & Fe. & $\mathrm{SiO}_{2}$ & P. & $\mathrm{CaO}$. \\
\hline 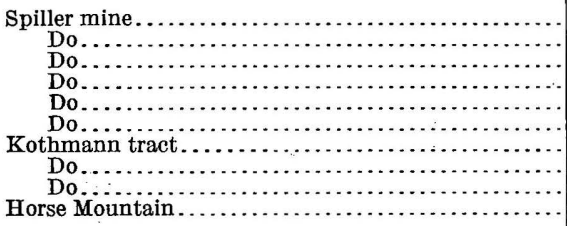 & $\begin{array}{l}57.87 \\
64.60 \\
48.54 \\
56.57 \\
61.59 \\
42.75 \\
15.57 \\
23.79 \\
45.58 \\
24.60\end{array}$ & \begin{tabular}{r|r|}
1.28 \\
2.22 \\
3.30 \\
1.10 \\
\hdashline-1. \\
21.82 \\
11.14 \\
3.86 \\
3.22
\end{tabular} & $\begin{array}{r}5.28 \\
10.22 \\
21.12 \\
5.85 \\
9.70 \\
37.24 \\
36.24 \\
28.57 \\
35.93\end{array}$ & 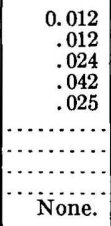 & $\begin{array}{r}\cdots \ldots \\
\cdots \cdots \\
\cdots \cdots \\
\cdots \\
10.16 \\
2.04 \\
.30 \\
8.48\end{array}$ \\
\hline
\end{tabular}

$a$ Penrose, R. A. F., jr., op. cit., p. 440.

Analyses of manganese ores from the Spiller mine, Texas. ${ }^{a}$

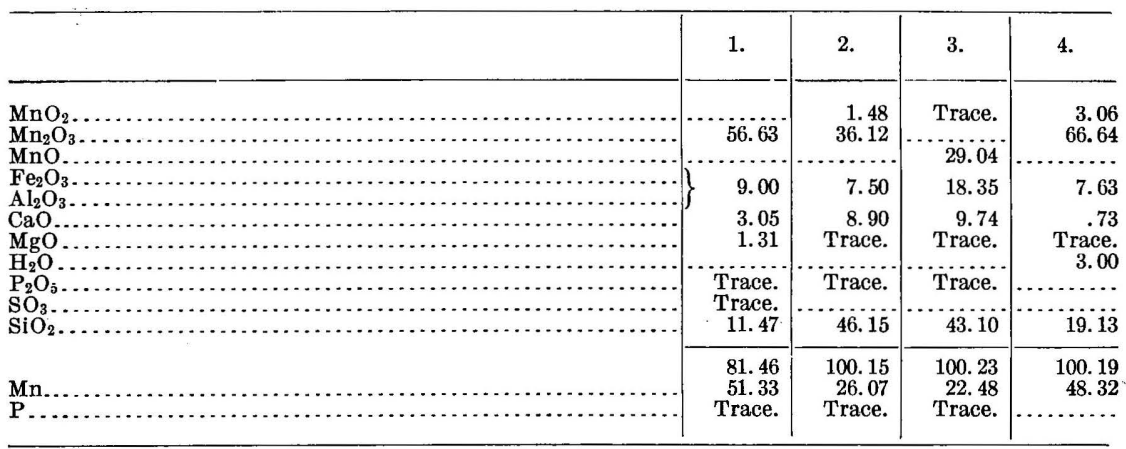

$a$ Penrose, R. A. F., jr., op. cit., p. 441.

\section{MINOR DEPOSITS.}

\section{TENNESSEE.}

A small deposit of manganese ore outcrops on the banks of a small stream near Whitfield, Hickman County, Tenn. This was mined as early as 1837, being the first manganese deposit worked in the United States. The ore was used in coloring pottery, a small quantity, measurable in pounds, being mined yearly.

\section{MISSOURI.}

Manganese and manganiferous iron ores are reported by Pumpelly to occur in the porphyritic region around Pilot Knob in Iron, Reynolds, and Madison counties in association with the iron-ore deposits.

On the Cuthbertson-Buford Hill ${ }^{a}$ in this region several deposits occur. The deposit on the Cuthbertson tract consists of manganese 
ore in irregular tabular masses as float or imbedded in red ocherous clay. The ore is red sesquioxide with a probable admixture of peroxide. The deposit at the Buford bank on the same hill consists of manganiferous iron ore, which occurs imbedded in clay, similarly to the Cuthbertson ore. In Reynolds County ${ }^{a}$ a black oxide of manganese is reported as occurring in stringers in one of the members of a series of bedded porphyry rocks. Considerable manganese ore has been mined at Arcadia, Iron County. ${ }^{a}$

In the porphyry of Shannon and Carter counties, ${ }^{b}$ southwest of the Pilot Knob area, manganese of remarkable purity is said to occur locally in veins varying from mere seams to 3 inches in thickness.

The following analyses show the composition of the Pilot Knob ore: ${ }^{a}$

Analyses of manganese ore from the Pilot Knob region.

\begin{tabular}{|c|c|c|c|c|c|}
\hline . & $\begin{array}{l}\text { Cuth- } \\
\text { bertson } \\
\text { tract. }\end{array}$ & $\begin{array}{l}\text { Buford } \\
\text { bank. }\end{array}$ & $\begin{array}{c}\text { Reynolds } \\
\text { County. }\end{array}$ & $\begin{array}{l}\text { Arcadia, } \\
\text { Iron } \\
\text { County. }\end{array}$ & $\begin{array}{l}\text { Arcadia, } \\
\text { Iron } \\
\text { County. }\end{array}$ \\
\hline 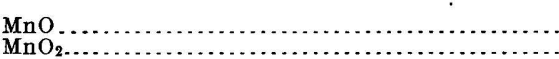 & 68.20 & 15.84 & $\begin{array}{r}37.04 \\
5.48\end{array}$ & & (n.......... \\
\hline $\begin{array}{l}\mathrm{Fe}_{2} \mathrm{O}_{3} \ldots \ldots \ldots \ldots \ldots \ldots \ldots \ldots \\
\text { Insoluble siliceous material. }\end{array}$ & $\begin{array}{r}3.30 \\
.44\end{array}$ & \multirow{2}{*}{$\begin{array}{c}68.30 \\
8.54 \\
.017 \\
.102\end{array}$} & 45.55 & & \multirow{2}{*}{ …… } \\
\hline $\mathrm{S}_{\mathrm{P}_{2} \mathrm{O}_{5}, \ldots \ldots \ldots}$ & .......... & & & & \\
\hline Mn. & - $\quad 52.47$ & \multirow{3}{*}{$\begin{array}{l}12.32 \\
47.81 \\
.044\end{array}$} & & \multirow{3}{*}{$\begin{array}{r}64.98 \\
2.82 \\
.04\end{array}$} & \multirow{3}{*}{$\begin{array}{r}58.02 \\
3.35 \\
.03\end{array}$} \\
\hline $\mathrm{Fe} .$. & . & & …...... & & \\
\hline & ….... & & $\ldots \ldots \ldots$ & & \\
\hline
\end{tabular}

Manganese also occurs in the Ozark region ${ }^{c}$ in association with Paleozoic sediments. In Howell County it forms a cement in sandstone at a number of localities. In Carter County it occurs as cement in chert breccia, and locally also as kidneys in associated clay. Masses of chert breccia are sometimes 10 feet thick.

\section{OKLAHOMA.}

Deposits of manganese ore are reported from a locality 15 miles west of Lehigh, ${ }^{d}$ Okla., and small quantities have been mined.

The ores consist of black oxide and red, gray, or brown carbonates occurring together in beds or pockets in Ordovician and Silurian limestones, the carbonates being the most abundant. The beds are said to lie on limestone of Ordovician age and to be overlain by other limestones. Many pockets occur along faults, and surface bowlders are found in many places over Ordovician and Silurian rocks. ${ }^{e}$

\footnotetext{
$a$ Weeks, J. D., Mineral Resources U. S. for 1885, pp. 347, 348.

$b$ Nason, Frank, Iron ores of Missouri: Missouri Geol. Survey, vol. 2, pp. 20, 95.

$c$ Nason, Frank, op. cit., pp. $94,95$.

$d$ Weeks, J. D., Sixteenth Ann. Rept. U. S. Geol. Survey, pt. 3, 1895, p. 413.

e Taff, J. A., personal communication.
} 
The following analyses show the nature of the ores:

Analyses of manganese ores from Lehigh, Okla.

\begin{tabular}{|c|c|c|c|c|}
\hline Mn. & Fe. & Si: & P. & $\begin{array}{l}\text { Mois- } \\
\text { ture. }\end{array}$ \\
\hline $\begin{array}{l}39.66 \\
39.67 \\
43.18 \\
38.54 \\
40.50 \\
35.78 \\
51.78 \\
59.55 \\
40.28 \\
43.18 \\
49.34 \\
53.35 \\
42.71\end{array}$ & $\begin{array}{l}6 \\
6.15 \\
5.72 \\
6.76 \\
8 \\
8.09 \\
2.46 \\
3.07 \\
4.92 \\
1.23 \\
1.84 \\
5.53 \\
\ldots .\end{array}$ & $\begin{array}{r}1.40 \\
1.45 \\
1.70 \\
1.20 \\
1.50 \\
\ldots . . \\
.30 \\
.75 \\
.85 \\
1.30 \\
2.00 \\
.60 \\
\ldots .\end{array}$ & $\begin{array}{r}0.055 \\
.066 \\
.060 \\
.053 \\
.050 \\
.053 \\
.026 \\
.046 \\
.036 \\
.053 \\
.056 \\
.050\end{array}$ & $\begin{array}{l}4.05 \\
4.57 \\
3.25 \\
4.05 \\
3.70 \\
\ldots . \\
\ldots . \\
\cdots \\
\cdots \\
\ldots . \\
\ldots \\
\ldots . \\
\ldots\end{array}$ \\
\hline
\end{tabular}

COMMERCIAL IMPORTANCE OF THE ORES.

The only ores of commercial value in the Mississippi Valley and Gulf region are those of the Batesville district, which has been one of the most important producers. Though the other deposits are - of much interest geologically, their small size and the character of their ore make it unlikely that they will ever be mined to a great extent.

No ore is being mined at present in the Batesville district, but a large amount has been produced during the last twenty-five years, more than 10 per cent of all the manganese ore mined in the United States having come from this district. There is still considerable ore in sight, and it is probable that a much larger quantity remains to be discovered, though it would be unwise to make any estimate of the amount available.

The principal reason for the cessation of operations is the fact that the ores require too much treatment to prepare them for the market, and that even when prepared they are of low grade. They are generally high in phosphorus and therefore not as desirable in the steel industry as the eastern or the foreign ores. The presence of a large amount of hard braunite and psilomelane, and the absence of high-grade pyrolusite, also make them less desirable for oxidizing and other chemical purposes than the pyrolusite and psilomelane of the Appalachian and Piedmont regions. Nevertheless it is beyond doubt that when foreign ores, which are now playing so important a part in our steel industry, become scarce, the Batesville district will again join the ranks of important producers.

\section{LAKE SUPERIOR REGION.}

CHARACTER AND OCCURRENCE OF ORES.

In the Lake Superior region manganese is found in two forms, (1) as oxide in many of the iron-ore deposits, forming a manganiferous iron ore, and (2) as bog manganese. 
The iron ores of many of the deposits of the Lake Superior district contain a percentage of manganese ranging up to 6 and even 10 per cent. This ore, while not directly utilized in the manufacture of ferromanganese and spiegeleisen, yet furnishes a manganiferous pig iron which is distinguishable from ordinary pig iron and is used for special purposes.

Manganese or manganiferous iron ores occur in the Huronian rocks as pockets in the hematite deposits. Occasionally streaks of high-grade manganese ore, mainly pyrolusite, are found, but they are too small and too much scattered to be separated from the ordinary iron ores. Such ores have been mined and are being mined on the Mesabi, Gogebic, Marquette, and Menominee iron ranges, and are being exploited on the Cuyuna and Baraboo ranges.

Deposits of bog manganese occur near Wilson, St. Croix County, and in other localities in northern Wisconsin.

The following are analyses of Lake Superior manganiferous iron ores:

Analyses of Lake Superior manganiferous iron ores. ${ }^{a}$

\begin{tabular}{|c|c|c|c|}
\hline & 1. & 2. & 3. \\
\hline 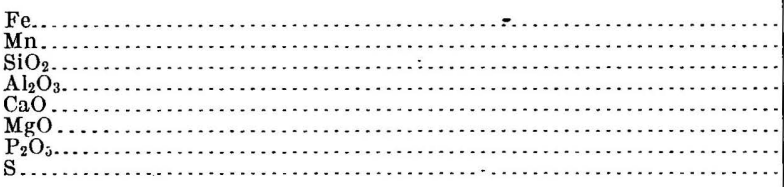 & $\begin{array}{r}58.21 \\
4.50 \\
3.22 \\
.80 \\
.27 \\
.14 \\
.059 \\
\text { None. }\end{array}$ & $\begin{array}{r}55.70 \\
7.40 \\
3.30 \\
.98 \\
.30 \\
.07 \\
.040 \\
.016\end{array}$ & $\begin{array}{r}56.80 \\
5.75 \\
3.20 \\
.98 \\
.24 \\
.18 \\
.071 \\
.10\end{array}$ \\
\hline
\end{tabular}

a Birkinbine, John, Twentieth Ann. Rept. U. S. Geol. Survey, pt. (i, 1899, p. 133.

Analysis of manganiferous iron ore from the McComber mine, Negaunee, Mich.a

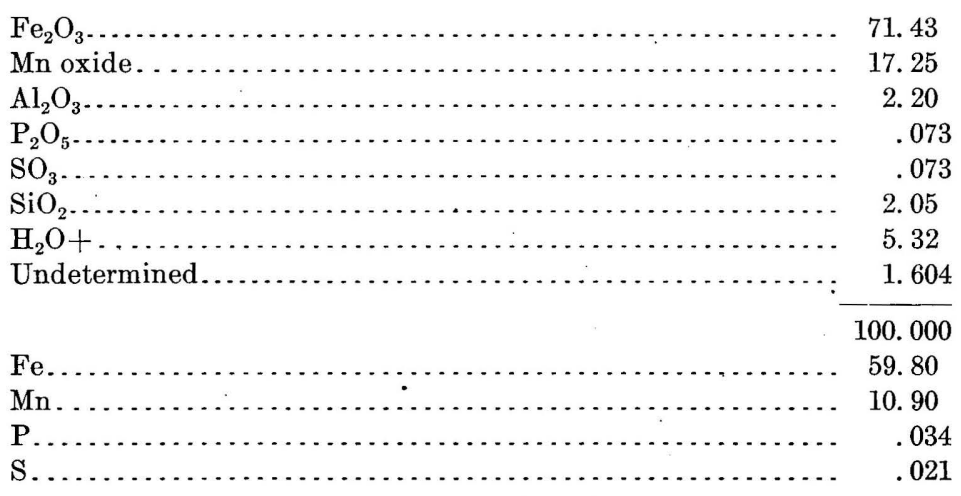

$a$ Weeks, J. D., Sixteenth Ann. Rept. U. S. Geol. Survey, pt. 3, 1895, p. 415. 
Average analyses of manganiferous iron ores shipped from the Lake Superior region in 1892. $a$

\begin{tabular}{|c|c|c|c|c|c|c|}
\hline & 1. & 2. & 3. & 4. & 5. & 6. \\
\hline 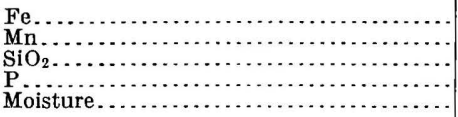 & $\begin{array}{l}44.47 \\
8.00 \\
9.42 \\
.100 \\
5.60\end{array}$ & $\begin{array}{l}50.00 \\
5.00 \\
7.50 \\
.115 \\
7.00\end{array}$ & $\begin{array}{r}47.94 \\
12.03 \\
.046 \\
-.0 .\end{array}$ & $\begin{array}{l}52.62 \\
9.99 \\
. .058 \\
9.96\end{array}$ & $\begin{array}{r}57.00 \\
5.00 \\
.063 \\
.6 .\end{array}$ & $\begin{array}{r}56.36 \\
4.89 \\
.055 \\
.\end{array}$ \\
\hline
\end{tabular}

$a$ Weeks, J. D., Sixteenth Ann. Rept. U. S. Geol. Survey, pt. 3, 1895, p. 414.

Average cargo analyses of Lake Superior manganiferous iron ores of the seasons 1906 and 190\%.a

\begin{tabular}{|c|c|c|c|c|c|c|c|c|c|}
\hline Mine and season. & Fe. & Mn. & P. & $\mathrm{SiO}_{2}$ & $\mathrm{Al}_{2} \mathrm{O}_{3}$ & $\mathrm{CaO}$. & $\mathrm{MgO}$. & S. & $\begin{array}{l}\text { Mois- } \\
\text { ture. }\end{array}$ \\
\hline \multicolumn{10}{|l|}{ Gogebic range. } \\
\hline \multicolumn{10}{|l|}{ Bonnie: } \\
\hline & 45. 30 & 5.01 & 0.029 & 10.46 & 1.04 & 0.27 & 0.08 & 0.012 & 11.09 \\
\hline $1907 \ldots$ & 45. 56 & 5. 41 & .048 & 11.79 & 1. 29 & .27 & .42 & .010 & 9.34 \\
\hline Castile: 1907. & 50.86 & 1.40 & .221 & 7.329 & .28 & .80 & .24 & .014 & $\begin{array}{r}5.04 \\
14.97\end{array}$ \\
\hline \multicolumn{10}{|l|}{ Cary Bessemer: } \\
\hline $1906 \ldots \ldots$ & 50.87 & 2.02 & .051 & 9.41 & .90 & .20 & .29 & .006 & 9.00 \\
\hline $1907 \ldots \ldots$ & 49.11 & 2.19 & .048 & 10.30 & 1.06 & .24 & .32 & .009 & 10.00 \\
\hline \multicolumn{10}{|l|}{ Cary Empire: } \\
\hline $1906 \ldots$ & 50.97 & 2.28 & .055 & 8.88 & .91 & 9.19 & .17 & .011 & 9.00 \\
\hline $1907 \ldots \ldots \ldots$ & 49.00 & 3.21 & .052 & 10.49 & 1.04 & .19 & .20 & .013 & 9.00 \\
\hline \multicolumn{10}{|l|}{ Cary Manganese: } \\
\hline $\begin{array}{l}1906 \ldots \ldots \ldots \\
1907 \ldots \ldots \ldots\end{array}$ & 47.98 & 3.76 & $\begin{array}{l}.005 \\
.048\end{array}$ & $\begin{array}{r}8.05 \\
10.16\end{array}$ & .90 & .20 & .29 & .006 & 9.00 \\
\hline \multicolumn{10}{|l|}{ Newport: } \\
\hline 1906. & 47.63 & 6.56 & .037 & 6.00 & .52 & .28 & .12 & .012 & 10.97 \\
\hline $1907 \ldots \ldots$ & 47.35 & 7.83 & .046 & 6.52 & 1.09 & .027 & .15 & .017 & 9.95 \\
\hline \multicolumn{10}{|l|}{ Ottawa: } \\
\hline 1906. & 51.16 & 3.13 & .049 & 6.867 & .90 & .135 & .43 & .005 & 9.64 \\
\hline $1907 \ldots \ldots \ldots \ldots$ & 50.00 & 2.88 & .046 & 8.084 & .997 & .22 & .41 & .0126 & 10.18 \\
\hline \multicolumn{10}{|l|}{ Ottawa Manganese: } \\
\hline $1906 \ldots$ & 48.097 & 5. 625 & .057 & 6.039 & 1. 34 & .135 & .18 & .005 & 10.00 \\
\hline 1907. & 48.499 & 5.937 & .045 & 6.02 & 1.37 & .18 & .31 & .009 & 9.50 \\
\hline \multicolumn{10}{|l|}{ Rand: } \\
\hline $1906 \ldots$ & 53.36 & 2.81 & .036 & 2.94 & & & & & 11.79 \\
\hline $1907 \ldots \ldots \ldots \ldots \ldots$ & 54.17 & 2.39 & .037 & 3.22 & & & & .... & 11.64 \\
\hline \multicolumn{10}{|l|}{ Marquette range. } \\
\hline \multicolumn{10}{|l|}{ South Jackson: } \\
\hline$\ldots \ldots \ldots \ldots \ldots$ & 40.21 & 2. 49 & .073 & 25.10 & 1. 42 & .27 & .10 & .016 & 8.40 \\
\hline $1907 \ldots \ldots \ldots \ldots \ldots \ldots \ldots$ & 40.21 & 2.49 & .073 & 25.10 & 1.42 & .27 & .10 & .016 & 8.40 \\
\hline \multicolumn{10}{|l|}{ Menominee range. } \\
\hline Groveland: $1907 \ldots \ldots$. & 50.37 & 1.05 & .038 & 10.76 & 2.39 & 3.37 & 4. 43 & .007 & 4.05 \\
\hline Manganate: & 0 & & & & & & & & \\
\hline $\begin{array}{l}1906 \ldots \\
1907 \ldots\end{array}$ & 47.20 & 2.64 & .559 & 5.02 & 2.31 & 1.89 & 2.23 & .035 & 2. 66 \\
\hline \multicolumn{10}{|l|}{ Manganate No. 2 : } \\
\hline $1906 \ldots \ldots$ & 45. 66 & 5.56 & .565 & 4. 33 & 2.22 & 2.01 & 2.22 & .038 & 6.46 \\
\hline $1907 \ldots$ & 45. 60 & 4. 64 & .560 & 5.92 & 2.44 & 1.95 & 2.20 & .038 & 7.22 \\
\hline \multicolumn{10}{|l|}{ Mesabi range. } \\
\hline Alberta $b$. & 52.90 & 1.08 & .040 & 8.42 & 1.22 & .09 & .14 & .025 & 10.00 \\
\hline lba: & & & & & & & & & \\
\hline 1996. & 55.46 & 1.05 & .035 & 4. 23 & .88 & .18 & .29 & .007 & 9.00 \\
\hline 1907. & 54.74 & .75 & .036 & 6.90 & .79 & .25 & .21 & .009 & 8.00 \\
\hline Hobart $b \ldots$ & 53. 10 & .95 & .074 & 7. 29 & 1.35 & .20 & .13 & .009 & 10.00 \\
\hline Kinney: 1907. & 50.30 & 1.08 & .068 & 4.93 & 2.17 & .26 & .28 & .042 & 13.27 \\
\hline Larkin: $1906 .$. & 49.42 & 1.43 & .023 & 13.41 & 1.16 & .19 & .25 & .022 & 10.00 \\
\hline Larkin Manganiferous: $1907 .$. & 43.21 & 2.26 & .024 & 20.77 & 1.68 & .24 & .28 & .057 & 9. 61 \\
\hline $\begin{array}{r}\text { Mayas Man } \\
1906 . . .\end{array}$ & 49.72 & 4.50 & .036 & 7.20 & 1.50 & .207 & .207 & 009 & 10.00 \\
\hline 1907. & 46.12 & $\begin{array}{l}4.30 \\
4.37\end{array}$ & $\begin{array}{l}.000 \\
.042\end{array}$ & & & .20 & .201 & & 10.00 \\
\hline Midway $b$. & 52.66 & 2.17 & .059 & 9.38 & .77 & $.09^{\circ}$ & .12 & .010 & 7.00 \\
\hline Smith: 1906. & 53.89 & 1.44 & .030 & 10.27 & .61 & $\ldots$ & - & & 7.77 \\
\hline Wacotah: 1907. & 48.89 & .91 & .056 & 5.43 & & ... & & $\ldots$ & 13.50 \\
\hline Wilpen: $1906 . \ldots \ldots \ldots \ldots \ldots$ & 47.83 & 1.58 & .063 & 5.41 & 2.94 & .21 & .11 & .013 & 14.77 \\
\hline Wilpen $b \ldots$. & 52.80 & 1. 20 & .062 & 5.59 & 2.99 & .20 & .12 & .013 & 12.00 \\
\hline
\end{tabular}

$a$ Complete average cargo analyses of Lake Superior iron ores, 1906 and 1907, Lake Superior Iron Ore Association.

$b$ Expected analysis for the season 1908.

$$
37336^{\circ}-\text { Bull. } 427-10-9
$$




\section{CUYUNA IRON RANGE, MINNESOTA.}

Recently considerable manganiferous iron ore has been found during exploration work on the Cuyuna iron range of central Minnesota. $^{a}$ The iron ores proper of this district rarely contain more than 0.1 to 0.3 per cent metallic manganese. However, many layers and pockets of manganiferous iron ore are found in them, which may contain as much as 28 per cent metallic manganese.

In general the iron ores of the Cuyuna range occur in steeply dipping beds between a hanging wall of green slate and a foot wall of amphibole-magnetite rock. (See fig. 23.) The ore-bearing bed

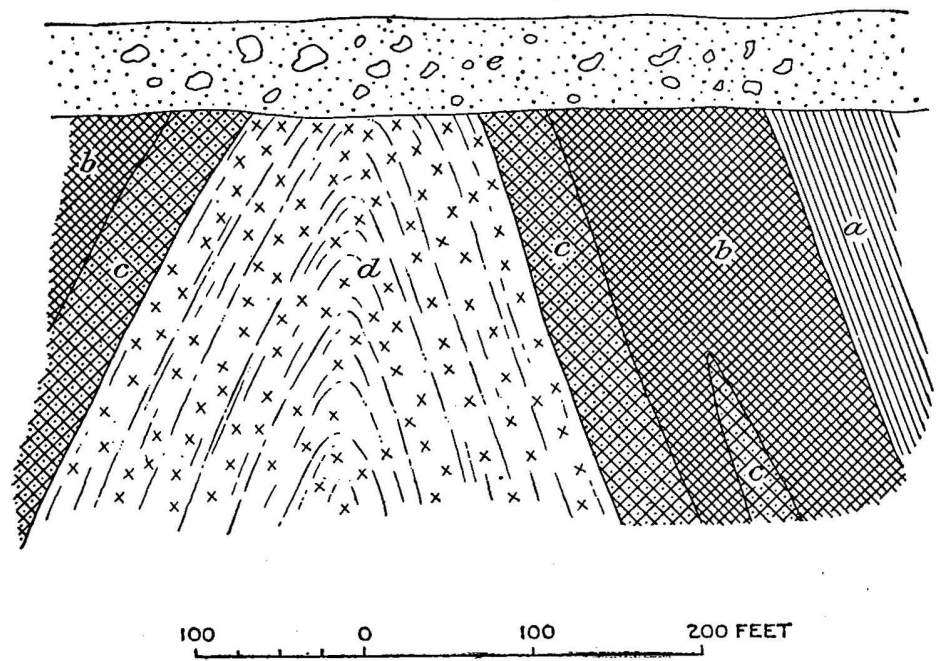

FIGURE 23.-Sketch showing the occurrence of manganiferous iron ores in iron-ore deposits of the Cuyuna range, Minnesota. $a$, Green slate; $b$, iron ore; $c$, manganiferous iron ore; $d$, amphibole-magnetite rock; $e$, glacial drift.

varies in composition from rich iron ore to lean ore. The rocks are of Huronian age and have been folded into a series of close anticlines and synclines. At many places where erosion has cut away the upper portion of the anticlines several parallel bands of iron formation are found.

The iron-ore beds locally contain lenses and layers of manganiferous iron ore of various sizes. Different layers of this material, as well as different parts of the same layer, differ greatly in composition; some contain from 1 to 10 per cent manganese; others contain up to 25 or 30 per cent.

Below are given the analyses ${ }^{a}$ from two drill holes in characteristic manganiferous iron ore. The first shows the high-grade and the second the ordinary type of this ore. 
Analyses of high-grade Cuyuna manganiferous iron ore from specified depths in drill hole.

\begin{tabular}{|c|c|c|c|}
\hline Depth in feet. $a$ & Mn. & $\mathrm{Fe}$. & $\mathrm{SiO}_{2}$ \\
\hline 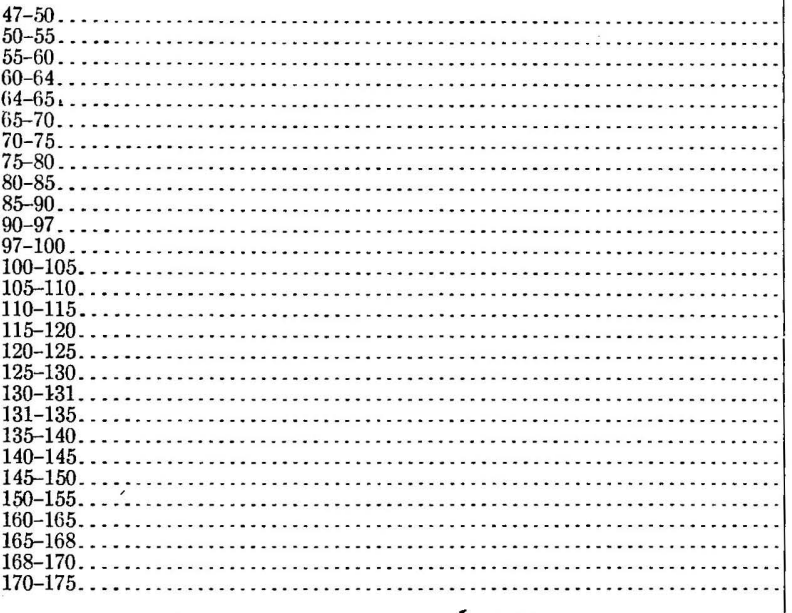 & $\begin{array}{r}27.88 \\
13.52 \\
13.51 \\
14.87 \\
13.65 \\
15.37 \\
4.46 \\
4.86 \\
6.76 \\
7.32 \\
6.79 \\
11.25 \\
7.98 \\
7.21 \\
9.61 \\
12.40 \\
10.72 \\
10.96 \\
15.77 \\
19.84 \\
15.02 \\
19.00 \\
24.33 \\
23.06 \\
6.96 \\
5.44 \\
10.28 \\
7.77\end{array}$ & $\begin{array}{l}23.20 \\
29.57 \\
37.84 \\
32.18 \\
34.16 \\
29.89 \\
49.49 \\
49.19 \\
47.58 \\
46.25 \\
47.24 \\
39.70 \\
47.36 \\
38.82 \\
33.90 \\
34.12 \\
44.07 \\
45.48 \\
40.16 \\
33.96 \\
28.03 \\
18.69 \\
27.91 \\
28.56 \\
25.66 \\
28.92 \\
28.54 \\
28.33\end{array}$ & 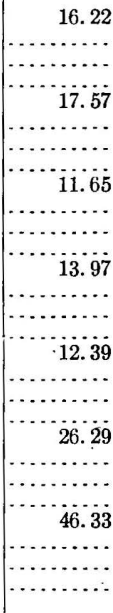 \\
\hline
\end{tabular}

$a$ Surface drift occupied the top 45 feet. To a depth of 260 feet the hole was in ore and ore-bearing rock, and from 260 to 275 feet in chloritic schist, or amphibole-magnetite rock.

Analyses of Cuyuna manganiferous iron ore of the ordinary grade from specified depths. in drill hole.

\begin{tabular}{|c|c|c|c|}
\hline Depth in feet. $a$ & Mn. & $\mathrm{Fe}$. & $\mathrm{SiO}_{2}$ \\
\hline 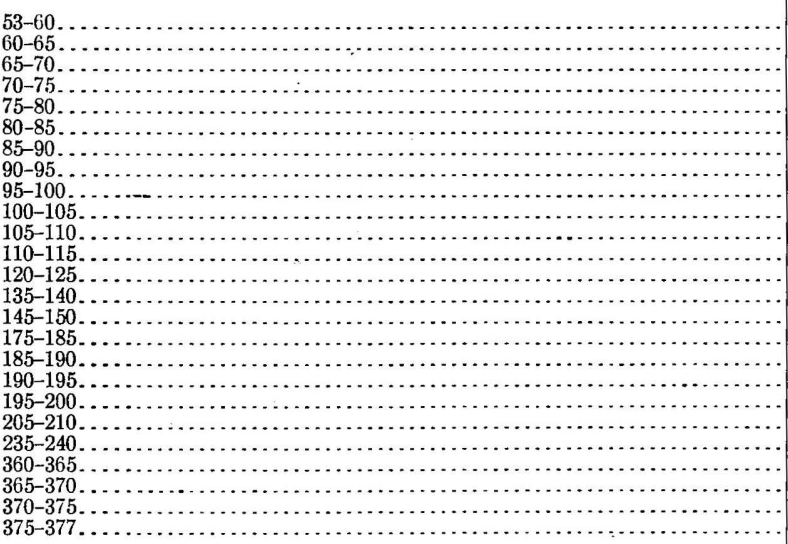 & $\begin{array}{r}3.01 \\
2.75 \\
3.90 \\
3.02 \\
1.28 \\
2.79 \\
2.34 \\
3.41 \\
4.58 \\
4.27 \\
5.28 \\
5.67 \\
1.42 \\
2.34 \\
2.61 \\
1.42 \\
1.70 \\
1.18 \\
1.17 \\
.96 \\
4.79 \\
6.36 \\
12.24 \\
9.91 \\
10.63\end{array}$ & $\begin{array}{l}31.15 \\
24.95 \\
29.63 \\
27.69 \\
30.64 \\
29.00 \\
35.06 \\
29.69 \\
27.75 \\
23.35 \\
22.04 \\
19.28 \\
34.35 \\
31.00 \\
29.77 \\
36.18 \\
36.73 \\
37.26 \\
31.43 \\
37.85 \\
40.46 \\
41.98 \\
38.47 \\
34.79 \\
40.76\end{array}$ & 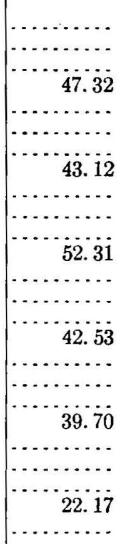 \\
\hline
\end{tabular}

$a$ Surface drift occupied the top 53 feet. 


\section{ROCKY MOUNTAIN REGION.}

\section{GENERAL STATEMENT.}

The manganese ores of the Rocky Mountain region, with a few exceptions, belong to the class of manganiferous silver ores. Most of them contain a considerable percentage of iron. Such deposits occur at Leadville and a few smaller localities in Colorado, at Silver City, Kingston, and Lake Valley, N. Mex., at Tombstone, Ariz., and at Neihart and Castle, Mont. Manganiferous silver ores with little or no iron occur at Butte, Mont. Manganiferous iron ores are found on Taylor Peak and in the Cebolla Valley, Colorado, and near Wickes, Mont.; and manganese ores proper are found in Custer County, S. Dak., in the Little Grande district, Utah, and in negligible quantities in Steuben Valley and Sapinero, Colo. So far only the manganiferous silver ores have been utilized.

\section{BUTTE DISTRICT.}

\section{GEOGRAPHY AND TOPOGRAPHY.}

The Butte district is situated around the city of Butte, Silver Bow County, southwestern Montana, a short distance west and north of the Continental Divide. It is roughly 10 miles square, but the principal mines are confined to a much narrower limit. The city of Butte is on the north slope of a broad valley, in which is the head of Silver Bow Creek, and on the opposite side of which is the Continental Divide. The mines are located on the slopes within and around Butte, on the ridge to the north, and in the valley to the southeast. The elevation of the district ranges from 5,400 feet above sea level in the valley to 6,500 feet on the ridge north of Butte.

\section{GEOLOGY.}

The rocks of the Butte district are all of igneous origin, being Cretaceous and Tertiary intrusives and eruptives. The following list gives the rocks arranged according to their age: ${ }^{a}$

Pleistocene:

Alluvium.

Tertiary:

Lake beds.

Rhyolite.

Post-Carboniferous:

Quartz porphyry.

Bluebird aplite.

Butte granite.

The Butte granite is the characteristic rock of the district. It covers by far the larger part of the ore-bearing area and contains

$a$ Emmons, S. F., Weed, W. H., and Tower, G. W., jr., Butte special folio (No. 38), Geoi. Atlas U. S., 1897; also Weed, W. H., Ore deposits of Butte, Mont.: Bull. U. S. Geol. Survey No. 213, 1903, p. 170; and Jour. Geology, vol. 7, 1899, pp. 744-747. 
most of the mineral veins. It is a coarse, dark-colored rock containing, as principal constituents, orthoclase, plagioclase, quartz, hornblende, and biotite.

The granite around Butte is part of a large granite batholith extending from the Highland Mountains, 20 miles southwest of Butte, to Helena. This mass is surrounded by altered limestones and other sediments and partly covered by dark-colored andesite, both of which are older than the granite. Neither sediments nor andesite, however, are found in the vicinity of Butte. The other rocks of the Butte district are of later age and occur as intrusives in the granite or as flows over it.

The Bluebird aplite is found most abundantly in the western part of the district. It consists of phenocrysts of alkali feldspar, quartz, and small quantities of biotite and plagioclase in a white or brownish sugary matrix. It is intrusive into the Butte granite in dikes or irregular sheets and masses of varying size, but is supposed to have originated from the same magma as the granite, and at but a slightly later period, as the dikes show no chilling effects along the contact.

The quartz porphyry consists of phenocrysts of white feldspar, mainly orthoclase, altered to sericite, and glassy quartz in a fine-. grained dense groundmass. It is intruded into both granite and aplite in lenticular dikes. After its intrusion there was considerable fracturing and formation of veins, which traverse granite, aplite, and porphyry. The formation of veins was followed by renewed volcanic activity, resulting in the intrusion and eruption of rhyolite.

The intruded rhyolite is massive and forms dikes and masses in the older formations, many of the dikes cutting veins of ore. The eruptive rhyolite is fragmental and forms large sheets, consisting of tuffs and breccias. Locally there are areas of rhyolite which consist of a mixture of both phases. The mineral composition of the rhyolite differs in different localities. The principal constituents, however, are sanidine, plagioclase, quartz, and biotite, occurring as phenocrysts in a glassy to fine-grained groundmass. The rock is light in color, varying from gray to reddish. After its eruption there was more fracturing and vein formation.

West of the district there are Miocene lake beds, consisting of sands, gravels, and tuffs, the last being of the same age as the rhyolitic tuffs mentioned above. Alluvium conceals the underlying formations in the valley of Silver Bow Creek.

\section{OCCURRENCE OF THE ORES.}

The ores of the district are found in veins traversing both the granite and the aplite, and in some parts the porphyry. The ores are of two kinds, copper and silver. The former occur in an east and west oblong area, the western part of which is in the city of Butte. 
The silver-bearing veins occur in a much-larger area surrounding the copper area on the north, west, and southwest sides. At their boundary there are veins of mixed copper and silver ores.

The veins, both copper and silver, occur in three distinct systems. The oldest veins have an east and west trend, those of the second set are northwest-southeast in direction and displace the east and west veins, while those of the third set, northeast-southwest in direction, displace the veins of both of the earlier sets. The veins of the first two systems are heavily mineralized, while those of the last consist mainly of fault débris with ore fragments from the earlier veins.

The copper veins contain chalcocite, enargite, bornite, and cupriferous pyrite in a gangue of quartz and included granite. Covellite occurs in a few mines, while tetrahedrite and chalcopyrite are very rare. Chalcocite, enargite, and cupriferous pyrite are abundant throughout the area. Bornite is practically restricted to the western portion; there, however, it is abundant. Manganese minerals are notably absent from the copper area, except where it borders the silver-bearing area. The tungstate of manganese, hübnerite, however, has been found at the Gagnon mine.

The upper portions of the copper veins consist of quartz stained by iron. This passes at a depth of several hundred feet into copper ore bodies, which consist mainly of sulphides, but which are somewhat oxidized and decomposed in their upper portions. Carbonates and oxides are rare. Several copper veins were worked for silver in the upper oxidized part, and it is believed by many mining men that silver veins in the surrounding district pass downward into copper.

The silver veins in the lower unoxidized portion consist of silver sulphide, zinc blende, galena, and pyrite. Chalcopyrite and tetrahedrite occur rarely, adjacent to the copper-bearing area. These minerals are found in a gangue of quartz, rhodonite, and rhodochrosite, quartz being the most abundant. Rhodonite and rhodochrosite occur in streaks and masses scattered irregularly through the quartz. They are intimately mixed, but rhodonite is said to be more abundant near the center, and rhodochrosite on the outskirts of the veins. The silver veins show marked banding and crustification and generally include numerous large and small lenses of granite.

Near the surface the veins are oxidized and consist mainly of quartz and manganese oxide, probably wad, carrying silver. The quartz occurs in small veins or lenses varying in thickness from one-eighth inch up, which run either with or across the direction of the main lode. The spaces between the ramifying quartz veins are filled with manganese oxide, which as a rule predominates over the quartz. Included lenses of granite are abundant.

The veins vary from a few feet to 100 feet in thickness. Their contact with the granite is not very sharply defined, owing to nu- 
merous small anastomosing veins in the granite adjacent to the lodes. Commonly a vein divides into two, which may run along parallel for some distance and then join again, or may branch off from each other at considerable angles.

The unoxidized portions of the veins are light-colored, varying from white where quartz predominates to pink where rhodonite and rhodochrosite are most abundant. Here and there the metallic minerals form darker areas. The included masses of granite in the veins are yellow and are generally more decomposed than the main body of granite. They form a large portion of the lode.

The oxidized portions have a black appearance, due to the presence of manganese oxide, which results from the oxidation of the rhodonite and rhodochrosite. The change from oxidized to unoxidized ores takes place at depths between 150 and 300 feet in the Black Rock mine, where both phases are typically developed.

The Butte manganiferous silver veins are at present being worked only on a small scale by lessees of the old properties. The ores are used for their precious-metal content only, the manganese minerals in them being valuable, however, for fluxing purposes. Ores with a considerable percentage of these frequently draw a higher price than the same grade of ore with little or no manganese.

In the early days of the district, when silver was the main output, small quantities of oxidized manganiferous ore were mined in the aplite area west of Butte and sold simply for flux. At present, however, the manganese is only indirectly utilized.

The following are analyses of oxidized ores from Butte:

Analyses of Butte oxidized manganiferous silver ores. ${ }^{a}$

\begin{tabular}{|c|c|c|c|}
\hline - & 1. & 2. & 3. \\
\hline 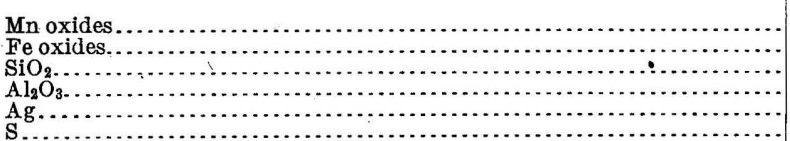 & $\begin{array}{r}88.40 \\
3.20 \\
6.60 \\
6.03 \\
6.1\end{array}$ & $\begin{array}{r}47.60 \\
12.40 \\
34.20 \\
3.70 \\
\text { c. } 11 \\
\text { Trace. }\end{array}$ & $\begin{array}{r}21.00 \\
7.70 \\
66.40 \\
2.40 \\
d .275\end{array}$ \\
\hline \multirow[t]{2}{*}{ 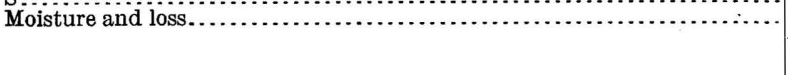 } & 1.77 & 1.99 & 2.22 \\
\hline & 100.00 & 100.00 & 99.995 \\
\hline
\end{tabular}

$a$ Penrose, R. A. F., ir., Manganese: Its uses, ores, and deposits: Ann. Rept. Arkansas Geol. Survey for 1890 , vol. 1,1893, p. 454 .

$b 9$ ounces.

$c 32$ ounces.

$d 80$ ounces.

WICKES AREA.

GEOGRAPHY AND GEOLOGY.

The Wickes manganese deposit is in Jefferson County, Mont., about 6 miles north of Wickes station. It is near the head of a small gulch in a low range of mountains a short distance east of the Continental 
Divide, at an elevation of about 6,000 feet above sea level. The deposit lies in a little flat area several hundred yards long in the bottom of the gulch, which is perhaps a few hundred feet wide at this point. Above and below the level area the bottom of the gulch has a steep grade. The slopes are wooded with pine and fir.

The slopes of the gulch on either side of the manganese deposit consist of granite, which is part of the granite batholith extending northeastward from Butte. ${ }^{a}$ Immediately south of the deposit and extending beyond Wickes is an area of late igneous rocks consisting of light-reddish dacitic rhyolite and andesite porphyry.
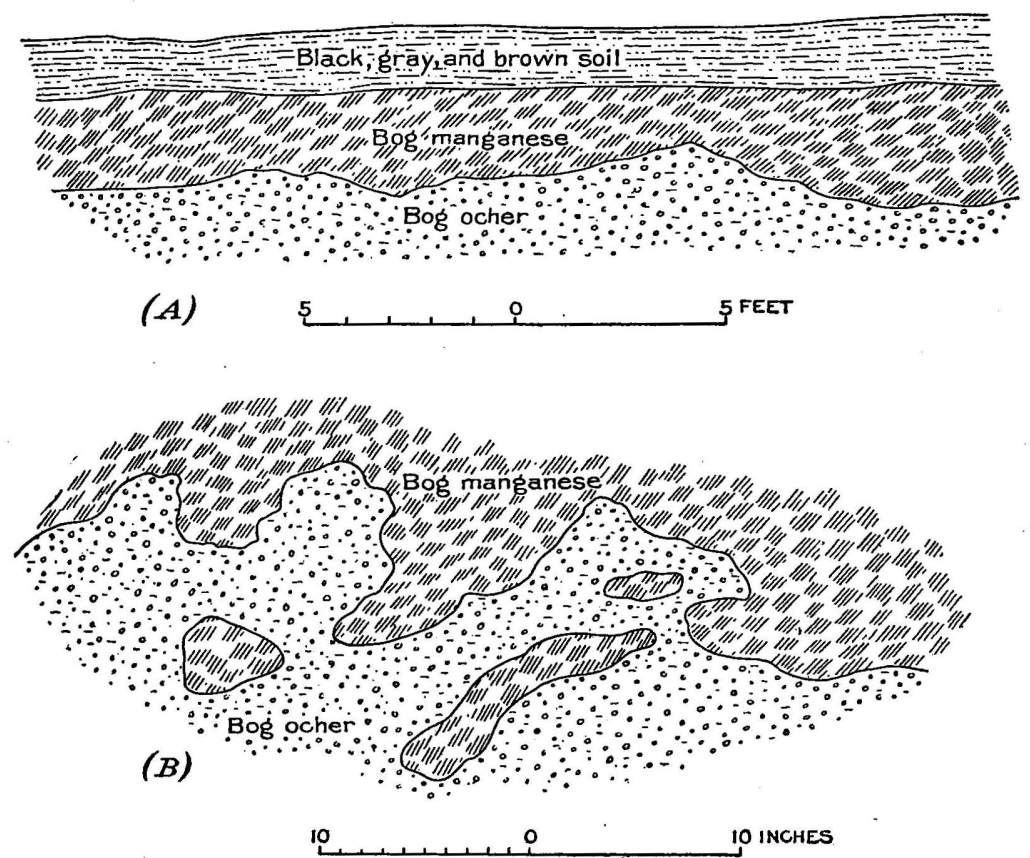

FIGURE 24.-Sections through the bog manganese deposit near Wickes, Mont. $A$, General section through the ore bed; $B$, detailed sketch of the bog manganese and ocher contact.

\section{OCCURRENCE OF THE ORES.}

The deposit is in a horizontal bed and consists of a mixture of bog manganese and bog limonite, the latter being largely ocher. It occupies part of the level area at the bottom of the gulch. Trenches have been made testing the deposit to a depth of about 5 feet and a horizontal extent of about 50 feet. How far it extends beyond these limits is not known.

Above the deposit there are $1 \frac{1}{2}$ feet of brown and black earth, with an admixture of decayed leaves and wood. The upper part 
of the deposit itself consists of bog manganese; the lower part is largely brown and yellow ocher. The bog manganese ore is porous and consists of a skeleton or network of glossy black hard ore with intervening cavities filled with black powder. The bog-iron ore has a globular texture, the globules being about half as large as peas and consisting of yellow ocher, and the intervening spaces are filled with hard glossy brownish-black limonite. In some places the limonite takes the place of considerable masses of ocher, forming a hard, solid ore.

The contact of the two types of ore is very irregular (see fig. 24), small irregular and rounded masses of manganese ore being included in the ocher and small masses of ocher in the bog manganese.

The ore is in all probability derived from the leaching of manganese minerals, such as rhodonite and rhodochrosite, in the granite. These minerals may be disseminated through the rock, or they may be in veins, as at Butte. They were dissolved by meteoric waters, and the manganese and iron were carried down the slopes, partly on the surface, but probably largely below the surface. At or near the bottom of the gulch the waters issued as springs, and were allowed to settle in the little level area and deposit their load in the form of surface bog ore.

\section{LEADVILLE DISTRICT.}

GEOGRAPHY AND TOPOGRAPHY.

The Leadville district is situated around the city of Leadville, in Lake County, Colo. Leadville is on a bench or terrace 10,000 to 10,400 feet above sea level on the west slope of the Mosquito Range, the higher summits of which rise above it to an elevation of 13,000 and 14,000 feet above sea level. West of Leadville is the Arkansas Valley, about 700 feet lower. The Mosquito Range forms the eastern slope and the Sawatch Range the western slope of the upper Arkansas Valley. The deposits from which most of the ore of the district has been taken are within 2 and 3 miles east of Leadville, but more recently considerable mining has also been done west of the city.

\section{GEOLOGY.}

The rocks of the Leadville district are of both igneous and sedimentary origin, ranging in age from Archean to Quaternary. The following table gives the general succession for the region: ${ }^{a}$

$a$ Emmons, S. F., The geology and mining industry of Leadville, Colo.: Mon. U. S. Geol. Survey, vol. 12, 1886, pp. 45 et seq.; Emmons, S. F., and Irving, J. D., The Downtown district of Leadville, Colo.: Bull. U. S. Geol. Survey No. 320, 1907, p. 21. 
Succession of rocks in Leadville district, Colorado.

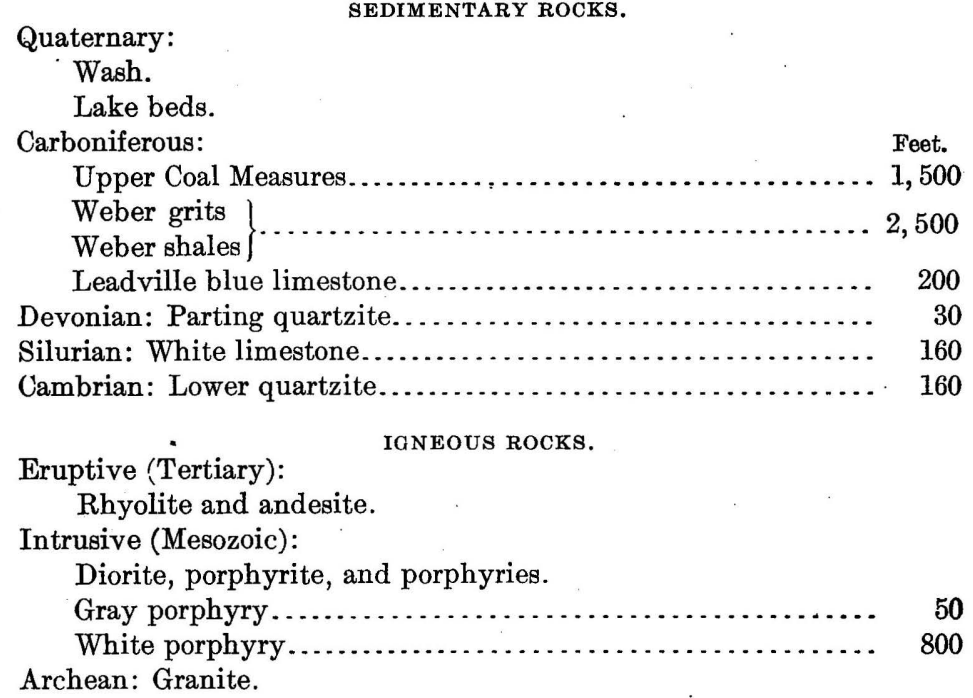

The surface distribution of these formations is very complicated on account of an abundance of faulting and folding. In general there are two lines of displacement along the Mosquito Range, one on the west side of the crest and the other on the east side. They join northeast of Leadville and only one fault continues northward. The eastern fault has a northwest-southeast direction throughout its extent; the western fault has the same direction in the southern part of the district, but in the northern part its course is a little east of north, and the single fault north of the junction continues in that direction. Both faults have the downthrow side to the west. In the ore-bearing district proper, immediately around Leadville, there is considerable minor faulting.

Northeast of Leadville the granite forms the summit and the upper slopes, both east and west, of the Mosquito Range. The Weber formation, with areas of porphyry and rhyolite, forms the lower western slope, being separated from the granite by the fault, and older Paleozoic rocks form the lower eastern slope. South of the junction of the two faults, Paleozoic sediments, ranging from Cambrian to Carboniferous, with large areas of gray and white porphyry, occupy the crest and east slope of the range as far down as the east fault. The Weber formation forms the lower and larger portion of this area. The granite occupies the upper part of the west slope as far down as the west fault, beyond which the Weber again appears, giving place westward to successively lower Paleozoic rocks, down to the granite that occupies the lower slopes. The area east of the eastern fault is formed by Paleozoic rocks, the oldest being 
on the west. The Arkansas Valley and the lower slopes on either side are occupied by Quaternary material. Across the Arkansas Valley is the Sawatch Range, composed largely of granite. Immediately east of Leadville the rocks consist of granite, porphyry, and Paleozoic sediments, with complicated areal distribution due to faulting.

The Archean rocks are of three types, ${ }^{a}$ granite, gneiss, and amphibolite. The granite is the most abundant of these. In places it is coarse grained and porphyritic, elsewhere fine grained, and varies in color from red to gray. Its essential minerals are quartz, orthoclase, microcline, plagioclase, muscovite, and biotite. It contains veins of pegmatite consisting of quartz, feldspar, and muscovite.

The gneiss contains quartz, orthoclase, plagioclase, hornblende, and mica. The mica is largely biotite, but muscovite is present locally in small quantities. It has a typical gneissoid structure, in many places consisting of alternating bands of light and dark material due to variation in amount of mica and hornblende. In some places it is porphyritic, and in others it has a tendency to granitic texture.

Amphibolites are interstratified with the gneisses in beds or lenses. They consist mainly of quartz, orthoclase, plagioclase, and hornblende, and in many places biotite is prominent. The gneiss and amphibolite form the main mass of a series which contains, besides, mica schist, phyllite, and other schistose rocks.

The Cambrian lower quartzite consists mainly of white saccharoidal quartzite with an upper shaly portion which grades into the overlying siliceous Silurian limestone. At the base there is a thin persistent bed of fine-grained conglomerate, composed of pebbles of blue quartz about the size of peas. Above this is the white quartzite, and above that calcareous quartzites and shales of various nature.

The Silurian white limestone is a drab-colored compact dolomite containing considerable silica. It is thinly bedded, commonly has a conchoidal fracture, and at certain horizons contains concretions of white chert.

The "Parting" quartzite is a thin but persistent white quartzite between the Silurian white limestone and the Carboniferous formations.

The Leadville limestone is heavy bedded and generally dark grayish blue, but ranges from drab to almost black. It is granular in texture, the upper part being in many places coarsely crystalline. Black chert concretions of irregular shape, many of them hollow in the center, are very characteristic of this upper portion. The Leadville limestone is a normal dolomite containing about 20 per cent magnesia and 30 per cent lime. 
The Weber formation consists of alternating calcareous and carbonaceous shales and quartzitic sandstones below, passing into coarse sandstones above. The shales form a transition zone several hundred feet thick between the massive Leadville limestone and the coarse sandstones of the Weber. These consist typically of coarse white sandstones passing into layers of conglomerate with quartz pebbles. Both contain fragments of feldspar, and in many places the sandstones contain considerable white mica, and also carbonaceous material. Next in importance to the sandstones and conglomerates are quartzose shales and mica schist, composed of quartz, feldspar, and muscovite. Thin layers of black carbonaceous shales occur at irregular intervals. Several beds of the gray dolomitic limestone are found near the middle of the series.

The "Upper Coal Measures" have at the base a nondolomitic compact limestone. Above this are calcareous and siliceous beds passing upward into red shales and sandstones.

The lake beds consist of fine-grained to còarse-grained stratified beds of slightly consolidated clay, sand, and rock fragments, with an abundance of marl, especially in the lower portion. They are of glacial origin and are supposed to have been deposited as broad deltas in a lake in the upper Arkansas Valley, formed by a glacial dam, the materials of which issued from Lake Creek valley in the Sawatch Range.

The wash is an unsorted glacial deposit of rock fragments and sand, of somewhat later origin. Both lake beds and wash in most places conceal the underlying rocks in the district around Leadville.

The white porphyry is a white compact rock composed of quartz, feldspar (mainly orthoclase), and muscovite. It is in the form of an intrusive sheet lying directly above the Leadville limestone.

The gray porphyry is a decomposed greenish-gray rock, in many places in the mines bleached and reduced to a pasty white mass. It occurs characteristically as a thin intrusive sheet near the middle of the Leadville limestone bed.

The other intrusives and Tertiary eruptives occur in several parts of the district, but they are not closely associated with the ore-bearing district proper.

OCCURRENCE OF THE ORES.

With regard to occurrence, the Leadville ores have been divided into three classes $a$-upper-contact ores, second-contact ores, and third-contact ores. (See fig. 25.) The upper-contact ores occur in the Leadville limestone between the white and gray porphyries, generally directly underneath the white porphyry. The second-contact ores occur in the Leadville limestone beneath the gray porphyry. 
The third-contact ores are in the Silurian white limestone underneath the "Parting" quartzite. Ores of the first class are by far the most abundant and are richest in silver. Ores of the second type contain a fair amount of silver, while those of the third type are low grade.

The ore bodies are irregular in shape and in many places pay ores grade imperceptibly into low-grade ores and finally into the inclosing country rock. This is especially true where the country rock is limestone, the contact with the porphyry being more regular.

\section{NATURE OF THE ORES.}

The ores of the Leadville district are of two classes-unoxidized and oxidized. ${ }^{a}$ The former consist of pyrite, galena, zinc blende, and

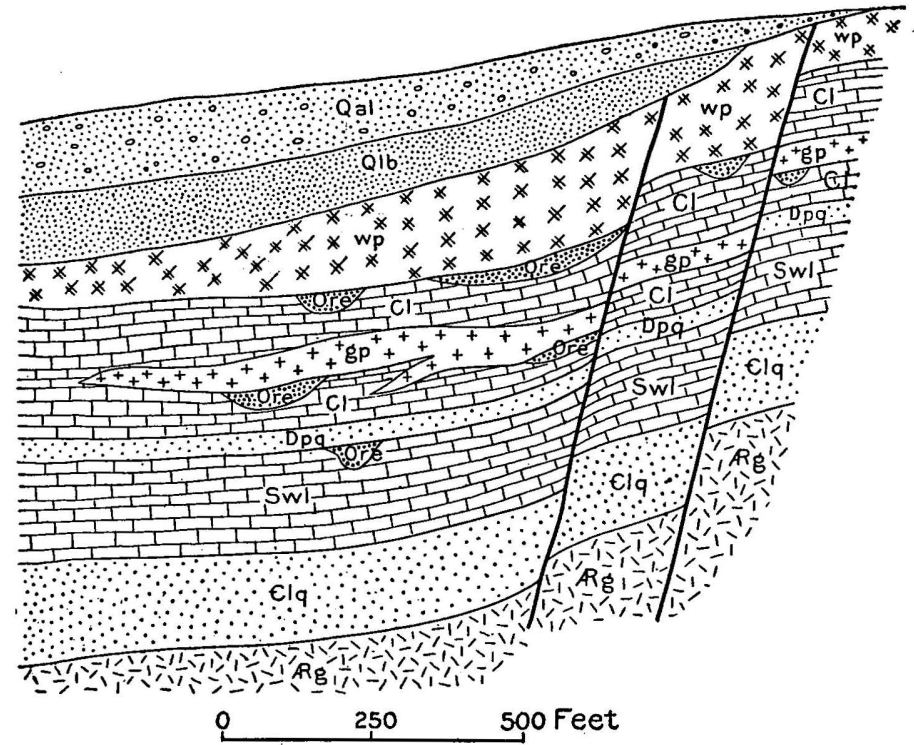

FIGURE 25.-Typical section showing the occurrence of the ore deposits at Leadville, Colo. (Modified from Emmons and Irving.) Qal, Wash; Qlb, lake beds; wp, white porphyry; Cl, Leadville limestone; gp, gray porphyry; Dpq, "Parting" quartzite; Swl, white limestone; Elq, lower quartzite; Ag, granite.

a small quantity of silver sulphide. Silver sulphide is contained mechanically or in actual combination in all the other minerals, though principally in galena and zinc blende.

The oxidized ores consist of lead carbonate and silver chloride in a gangue of iron and manganese oxides. The galena changes first to lead sulphate (anglesite) and finally to cerussite. In some of the richer deposits pyromorphite, the chlorophosphate of lead, is occasionally found. Sphalerite changes to hydrous zinc sulphate, which, being very soluble, is carried downward and probably deposited in the upper part of the unoxidized portion of the deposit. There is, there- 
fore, practically no zinc in the oxidized ores. Silver sulphide alters to the sulphate, which is readily soluble and becomes widely distributed through the ore bodies. Its stable form is the chloride, which is greenish and contains small amounts of the bromide and iodide. It generally occurs along cracks in the other minerals, though in some of the richer deposits it is found in small bodies. Native silver occurs rarely. The iron sulphides alter to the hydrous sulphate, melanterite, which changes partly to the basic ferric sulphate, but mainly to limonite, the hydrous sesquioxide, and which, together with manganese oxides and silica, forms the gangue of the other ores. Silica is the principal nonmetallic mineral found as gangue in the Leadville deposits, though calcite and barite are present.

The unoxidized ores contain an average of not over 1 per cent manganese, the mineral form of which is not known, for both rhodonite and rhodochrosite are conspicuously absent. The oxidized ores contain amounts of manganese varying in general from 15 to 25 per cent, although they may be as little as 10 per cent and as much as 40 per cent. The manganese is in the form of oxide, probably wad, and is intimately mixed with the limonite, giving it a brown-black color. It is most abundant in the upper parts of the deposits near the overlying porphyry and diminishes in quantity downward.

As a reason for this abnormal increase of manganese in the oxidized ores, it has been suggested that part of it was leached from the overlying porphyry. ${ }^{a}$ As a further suggestion it may be asked whether the other constituents may not have diminished relatively to manganese and silver by leaching, inasmuch as both these constituents are more abundant in the oxidized ores than in the sulphide ores.

\section{USES OF THE ORES.}

The Leadville ores are used for three purposes, according to their grade: (1) For their lead and silver content; (2) for their iron and manganese content in the manufacture of spiegeleisen and ferromanganese; and (3) for their iron and manganese oxides as flux in smelters.

(1) The high-grade ores are used for their lead and silver content. Those having a considerable quantity of iron and manganese oxides often draw a higher price because of the fluxing value of these constituents.

(2) Those ores which are too low in lead and silver to be utilized for these metals, but are high in manganese and iron, are commonly used in the manufacture of spiegeleisen and ferromanganese.

(3) A considerable portion of the ores are of too low grade for either of these purposes, but still contain considerable iron and 
manganese oxides and some lead and silver. Such ore is used for fluxing purposes in the smelters. The oxides of iron and manganese assist in smelting the higher-grade lead-silver ores, but finally become waste in the form of slag. The lead and silver content is recovered, as it mixes with the lead and silver obtained from the higher-grade ores.

Most of the Leadville ore used in the manufacture of iron alloys is sent to the Pueblo furnaces, but some of it has gone as far east as Joliet, Ill.

\section{PRODUCING MINES.}

The principal mines in the Leadville district which have produced manganiferous silver ore recently are the Evening Star, Morning Star, Grey Eagle, Little Chief, A. V. shaft, and Seneca. Those of minor importance are the Big Chief, Catalpa, Excelsior, Robert Emmet, Crescent, Hibschle, All Right, and Penrose.

\section{ANALYSES.}

The following tables show the composition of the Leadville manganiferous silver ores:

Analyses of Leadville oxidized ores. ${ }^{a}$

\begin{tabular}{|c|c|c|c|}
\hline & . & $\begin{array}{c}\text { Siliceous } \\
\text { hematite } \\
\text { from chryso- } \\
\text { lite mine. }\end{array}$ & $\begin{array}{l}\text { Iron ore } \\
\text { from Keno- } \\
\text { sha mine. }\end{array}$ \\
\hline \multirow{2}{*}{\multicolumn{2}{|c|}{ 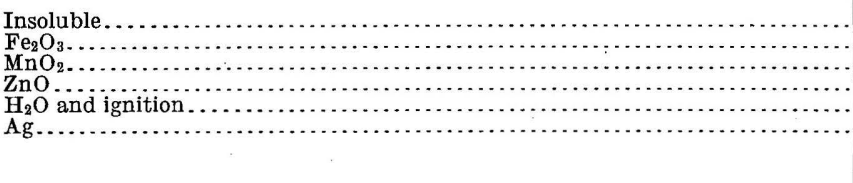 }} & $\begin{array}{r}8.20 \\
54.14 \\
22.36 \\
2.56 \\
12.709 \\
.031\end{array}$ & $\begin{array}{c}21.10 \\
7.70 \\
65.98 \\
1.00 \\
4.22 \\
.012\end{array}$ \\
\hline & & 100.00 & 100.00 \\
\hline
\end{tabular}

$a$ Emmons, S. F., Mon. U. S. Geol. Survey, vol. 12, 1886, Appendix B, Chemistry, by W. F. Hillebrand, p. 602, analysis 495 .

Analyses of manganiferous iron ores from Leadvill.e district.a

\begin{tabular}{|c|c|c|c|c|c|c|c|}
\hline & $\begin{array}{l}\text { Catalpa } \\
\text { mine. }\end{array}$ & $\begin{array}{c}\text { Crescent } \\
\text { mine. }\end{array}$ & $\begin{array}{c}\text { Crescent } \\
\text { mine. }\end{array}$ & $\begin{array}{c}\text { George } \\
\text { A. Hull. }\end{array}$ & $\begin{array}{c}\text { Emmett } \\
\text { mines. }\end{array}$ & $\begin{array}{c}\text { Emmett } \\
\text { mines. }\end{array}$ & ${ }^{(b)}$ \\
\hline 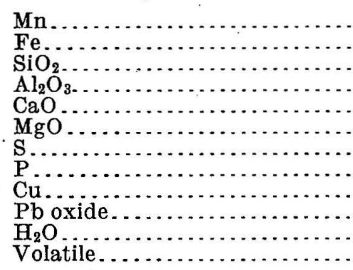 & $\begin{array}{r}21.30 \\
34.90 \\
6.90 \\
4.15 \\
.34 \\
.07 \\
.06 \\
.04 \\
\text { Trace. }\end{array}$ & 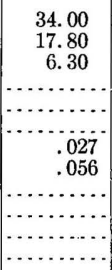 & 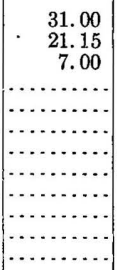 & \begin{tabular}{r}
19.30 \\
35.00 \\
3.83 \\
2.00 \\
.46 \\
.45 \\
\hdashline..$\%$ \\
.03 \\
1.85 \\
2.96 \\
9.36
\end{tabular} & $\begin{array}{r}35.36 \\
11.00 \\
8.06 \\
2.37 \\
1.23 \\
1.36 \\
.33 \\
.111 \\
\cdots . . . . . \\
18.06\end{array}$ & 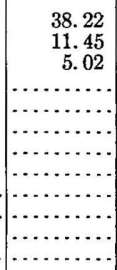 & $\begin{array}{c}30.98 \\
23.30 \\
5.71 \\
1.26 \\
1.56 \\
.57 \\
.068 \\
.038 \\
\ldots \ldots . . \\
\ldots \ldots . . \\
\ldots . . .\end{array}$ \\
\hline
\end{tabular}

$a$ Weeks, J. D., Sixteenth Annual Rept. U. S. Geol. Survey, pt. 3, 1895, p. 409.

$b$ Stated to be a fair average of the better grade of manganiferous iron ore as shipped in 1894 . 
Analyses of manganese ores and manganiferous iron ores from Leadville and vicinity, Colorado. $a$

\begin{tabular}{|c|c|c|c|c|c|}
\hline Name of mine or owner. & $\begin{array}{c}\text { Manga- } \\
\text { nese. }\end{array}$ & Iron. & Silica. & $\begin{array}{l}\text { Phos- } \\
\text { phorus. }\end{array}$ & Sulphur. \\
\hline 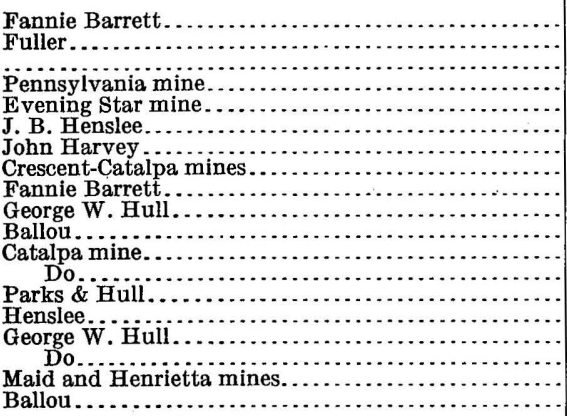 & $\begin{array}{l}51.20 \\
49.20 \\
40.56 \\
38.60 \\
37.14 \\
36.40 \\
34.64 \\
34.00 \\
33.00 \\
29.12 \\
24.69 \\
20.20 \\
20.14 \\
19.30 \\
18.66 \\
18.11 \\
16.20 \\
14.71 \\
9.30\end{array}$ & $\begin{array}{r}6.20 \\
6.00 \\
1.33 \\
2.05 \\
12.20 \\
19.50 \\
18.20 \\
17.80 \\
6.20 \\
25.10 \\
32.14 \\
34.12 \\
36.82 \\
35.00 \\
28.42 \\
30.86 \\
43.30 \\
41.48 \\
48.51\end{array}$ & $\begin{array}{r}2.90 \\
15.00 \\
4.70 \\
4.00 \\
7.60 \\
7.00 \\
8.00 \\
6.30 \\
6.10 \\
3.80 \\
4.40 \\
6.50 \\
6.83 \\
3.83 \\
8.49 \\
4.04 \\
3.10 \\
5.00 \\
4.20\end{array}$ & $\begin{array}{r}0.007 \\
.129 \\
\text { Trace. } \\
.022 \\
.025 \\
.033 \\
.045 \\
.008 \\
.084 \\
.022 \\
.008 \\
.007 \\
.045 \\
.040 \\
.039 \\
.012 \\
.039 \\
.017\end{array}$ & 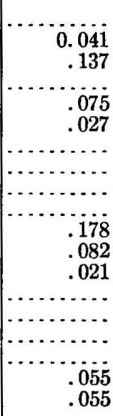 \\
\hline
\end{tabular}

$a$ Penrose, R. A. F., jr., op. cit., p. 464.

Analyses of manganiferous ores, with amount of silver per ton, from Leadville and vicinity, Colorado. $a$

\begin{tabular}{|c|c|c|c|c|}
\hline Name of mine or owner. & $\begin{array}{l}\text { Manga- } \\
\text { nese. }\end{array}$ & Iron. & Silica. & $\begin{array}{l}\text { Silver } \\
\text { per ton. }\end{array}$ \\
\hline & & & & Ounces \\
\hline Gray Eagle mine. & 29.65 & 18.10 & 11. 40 & 7.50 \\
\hline 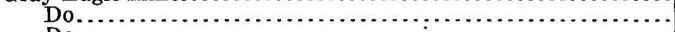 & 27.30 & 17.00 & 13. 30 & 6.00 \\
\hline 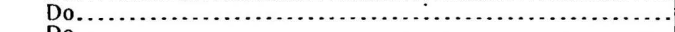 & 23.25 & 25. 10 & 7. 42 & 11.55 \\
\hline 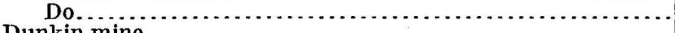 & 27.50 & 20.60 & 8. 60 & \\
\hline 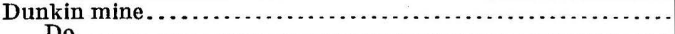 & 7.40 & 45. 50 & 8.40 & 7.70 \\
\hline Do & 8.90 & 43.10 & 12.50 & $\cdots$ \\
\hline Maid of Erin mine. & 11.20 & 39.40 & 6.20 & 4. 50 \\
\hline (1 & 16.80 & 33.20 & 9.80 & 4. 60 \\
\hline (n) & 22.50 & 28.60 & 9.40 & $\begin{array}{l}5.70 \\
3.20\end{array}$ \\
\hline 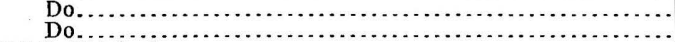 & $\begin{array}{l}14.60 \\
19.50\end{array}$ & $\begin{array}{l}38.20 \\
36.60\end{array}$ & $\begin{array}{l}7.60 \\
5.20\end{array}$ & $\begin{array}{l}3.20 \\
2.70\end{array}$ \\
\hline Little Chief mine.......... & 17.80 & 32.15 & 8.30 & 8.90 \\
\hline (n) & 15. 30 & 39.90 & 6.30 & \\
\hline Castle View mine... & 20.00 & 27.50 & 7.42 & 6.10 \\
\hline . & 24.90 & 26.50 & 4.00 & 1. 55 \\
\hline 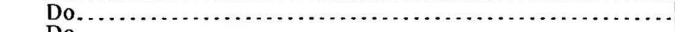 & 25.40 & 26.10 & 4. 70 & 1.20 \\
\hline n............... & 21.60 & 27.40 & 7.90 & \\
\hline Yankee Do & 13.10 & 28.50 & 14. 30 & 6.70 \\
\hline Coronado mine. & 25.20 & 28.30 & 7.20 & 11. 60 \\
\hline (., & 26.60 & 25.10 & 7.00 & \\
\hline Morning S & 17. 40 & 31.20 & 14. 00 & 10.30 \\
\hline Morning and Evening Star mi & 17. 60 & 31.50 & 8.30 & $\cdots$ \\
\hline Do... & 20.10 & 32.30 & 6.70 & \\
\hline Iron Silver Mining Co.. & 28.80 & 17.45 & 10.80 & 12.70 \\
\hline Do... & 24.15 & 21.80 & 9.80 & 4.60 \\
\hline the & 24. 70 & 25. 65 & 8.45 & 6.55 \\
\hline O. K. mine & 10.80 & 38.00 & 15. 20 & 5. 40 \\
\hline Tobin.... & 9.00 & 41. 30 & 11. 10 & 4. 60 \\
\hline$\ldots \ldots \ldots \ldots \ldots$, & 20.30 & 26.80 & 11.60 & 2.65 \\
\hline 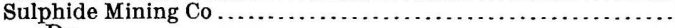 & 9.55 & 43. 40 & 9.00 & 2. 90 \\
\hline - & 9.30 & 41. 20 & 11.80 & 2.80 \\
\hline Bison min & 24.70 & 31.50 & 8.30 & $\cdots \cdot \cdot$ \\
\hline Do... & 25.80 & 22.20 & 10.30 & $\ldots \ldots . .$. \\
\hline Matchless mine & 6.20 & 44. 70 & 13.80 & \\
\hline Do.. & 6.80 & 44. 40 & 13.60 & ... \\
\hline Starr Lea & 26.20 & 22.50 & 6.50 & $\ldots \ldots \ldots$ \\
\hline Great Hopes Mining $\mathrm{Co}_{\text {. }}$ & 9.40 & 45.40 & 10.20 & .......... \\
\hline Leadville Consolidated Min & 33. 70 & 15. 20 & 9.00 & $\ldots \ldots$ \\
\hline Seneca Mir & 16. 60 & 35.00 & 9.20 & $\cdots \ldots$ \\
\hline
\end{tabular}

$a$ Weeks, J. D., Eighteenth Ann. Rept. U. S. Geol. Survey, pt. 5, 1897, p. 302. 
Average analyses of Colorado manganiferous silver ores used for the manufacture of spiegeleisen. $a$

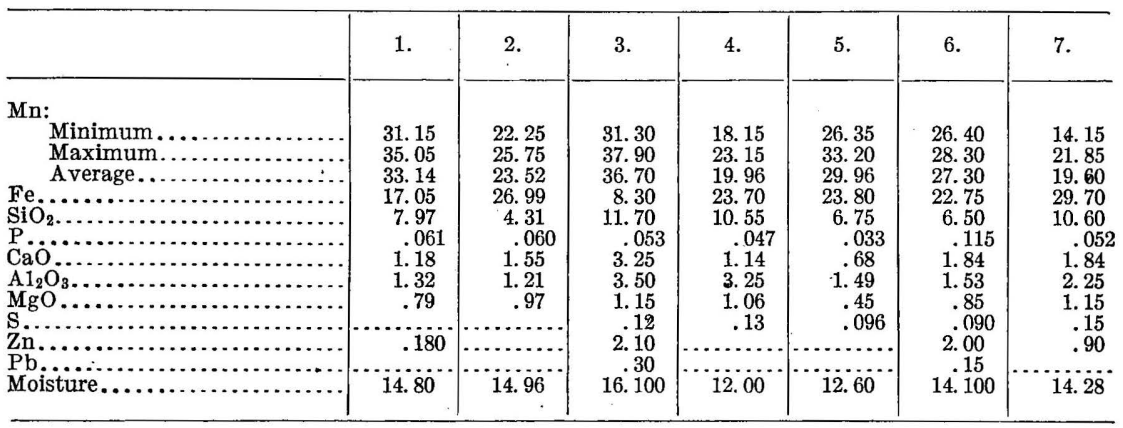

$a$ Weeks, J. D., Eighteenth Ann. Rept. U. S. Geol. Survey, pt. 5, 1897, p. 301.

Average analyses of Colorado manganiferous silver ores used for fuxing. ${ }^{a}$

\begin{tabular}{|c|c|c|c|c|}
\hline & 1. & 2. & 3. & 4. \\
\hline 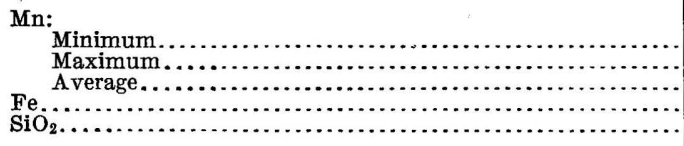 & $\begin{array}{r}8.50 \\
19.70 \\
10.00 \\
40.00 \\
10.00\end{array}$ & $\begin{array}{r}9.00 \\
25.25 \\
17.00 \\
38.00 \\
12.00\end{array}$ & $\begin{array}{r}19.33 \\
34.80 \\
28.30 \\
23.00 \\
7.60\end{array}$ & $\begin{array}{r}15.10 \\
35.00 \\
24.15 \\
26.45 \\
7.04\end{array}$ \\
\hline
\end{tabular}

$a$ Weeks, J. D., Eighteenth Ann. Rept. U. S. Geol. Survey, pt. 5, 1897, pp. 303-304.

LITTLE GRANDE DISTRICT.

GEOGRAPHY AND TOPOGRAPHY.

The Little Grande district is about 10 miles southwest of Little Grande, a station on the Rio Grande Western Railway in east-central Utah. It is a short distance east of Green River in a rough, barren region. The nearest town is Green River, 25 miles northwest, where the railroad crosses Green River.

The topography is typical of the Colorado Plateau-broad uplands and steep canyons. Everywhere are bare rock exposures and none but desert vegetation exists. Directly south of the principal part of the area there is an immense steep-walled chasm, many hundred feet deep and several miles wide, with sides and bottom of red sandstone carved into fantastic shapes. Here vegetation is almost totally absent.

The manganese ore is on a broad bench above the chasm; beyond to the north are undulating ridges and intervening canyons and valleys formed by alternating hard and soft layers of rock.

\section{GEOLOGY.}

The rocks of the manganese area and the adjacent country are sediments of Triassic, Jurassic (?), and Cretaceous age. The line of division between the first two has not been definitely established in $37336^{\circ}-$ Bull. $427-10-10$ 
this region, however. The manganese district itself is supposed to be in the Jurassic area, while Little Grande station and the town of Green River are in the Cretaceous area.

The following shows roughly the lithologic succession:

Succession of rocks in Little Grande manganese district, Utah.

Upper Cretaceous: $a$

Gray sandstone (Mesaverde formation). Great thickness. Exposed north of the Rio Grande Western Railway.

Gray shale (Mancos shale). Great thickness. Exposed south of the Rio Grande Western Railway.

Buff sandstone, in many places conglomeratic (Dakota sandstone).

Unconformity.

Jurassic (?):

Light-colored sandstones and variegated shales. Several hundred feet.

Massive brownish-white sandstone. $100+$ feet.

Light-green and purple shale. $50+$ feet.

Thin layer of manganese oxide. (Unconformity?)

Thin-bedded, red, calcareous sandstones and limestones. Several hundred feet.

Triassic: Heavy-bedded red sandstone, probably the Vermilion Cliff sandstone. Great thickness.

The beds have a gentle dip to the north, so that the formations are successively older southward. The chasm immediately south of the deposits has its bottom and lower walls formed by massive red sandstone (probably Vermilion Cliff), which is carved by wind erosion into rounded fantastic forms. The upper part of the walls and the bench on which the deposits occur are red calcareous sandstones and siliceous limestones. The ridges to the north are formed by overlying sandstones and shales of questionable age though probably largely Jurassic, and by the Cretaceous gray shale (Mancos shale). The area occupied by the Jurassic (?) beds contains steep-sided canyons; in the Mancos shale area are broad shallow valleys.

\section{OCCURRENCE OF THE ORES.}

The manganese ores occur in several adjacent areas, the largest about 5 miles in length. They are in the form of surface blankets, where the rocks have been eroded down to the thin-bedded red sandstone and limestone formation. These blankets consist partly of surface float and partly of replacements in the red limestones near or at the surface. The rocks are at or very near the surface throughout most of the area, disintegration having rarely reached more than a few feet below the surface. Small fragments of ore, generally less than 4 inches in diameter, are abundant in the disintegrated red sand

$a$ Richardson, G. B., Reconnaissance of the Book Cliffs coal field between Grand River, Colorado, and Sunnyside, Utah: Bull. U. S. Geol. Survey No. 371, 1909. 
and clay and on the surface. In the solid rock underneath this, and in the rock where it crops out at the surface, there are local irregular replacements, which in few places extend downward more than a foot or two from the surface. Some of these are in small specks or irregular masses; others follow distinct layers and bedding planes, and such replacements cover wider areas and are more thorough. Layers 3 to 4 inches thick are sometimes found entirely replaced by manganese oxide.

Manganese and iron stained chert occur abundantly in the red limestones and as float, but are not directly associated with the ore.

The manganese deposits do not appear to be in a definite bed, but rather in an undulating zone at the top of the thin-bedded red sandstone and limestone formation. This might suggest a possible erosion period after the deposition of that formation, during which small amounts of manganese oxide were deposited over a considerable area. The manganese may have been derived from eroded portions of the red sandstone and limestone formation, in which it may have been present in small quantities as manganese carbonate, or it may have been brought in from the outside. It was probably deposited as oxide. After the deposition of the overlying sediments and the reemergence and consolidation of the entire series, the.manganese oxide became solid and crystalline.

The ore is soft and is steel-gray or blue, consisting mainly of crystalline and granular pyrolusite. The crystalline ore is more common where openings have been filled, and with it is calcite in specks and seams. The granular pyrolusite is more abundant in the solid limestone, where there has been direct replacement of calcium carbonate by the manganese oxide.

\section{MINOR DEPOSITS.}

\section{SOUTH DAKOTA.}

Wad and bog limonite occur associated in fissures and horizontal layers $^{a}$ in Carboniferous limestone at Jewel Cave in Hell Gate Canyon 13 miles west-southwest of Custer, Custer County, S. Dak. The principal deposit is on the west slope of the canyon, where there is a vertical fissure 1 to 2 feet wide in the limestone. The fissure strikes northeast-southwest and is connected with a number of thin horizontal layers, which run out from it between the limestone layers. The deposit as exposed extends through a vertical distance of about 40 feet. In some of the layers- the ore is associated with calcite cave deposits. The ore for the most part is a mixture of hydrated oxides of iron and manganese, though locally wad occurs alone. It is soft and light and of low grade, a type specimen of the best grade yielding

$a$ Schrader, F. C., unpublished notes. 
only 27.9 per cent manganese. The following is a section by Schra$\operatorname{der}^{a}$ showing the succession of the horizontal layers through which the upper portion of this vein passes:

Section of upper portion of manganese deposit at Jewel Cave, S. Dak.

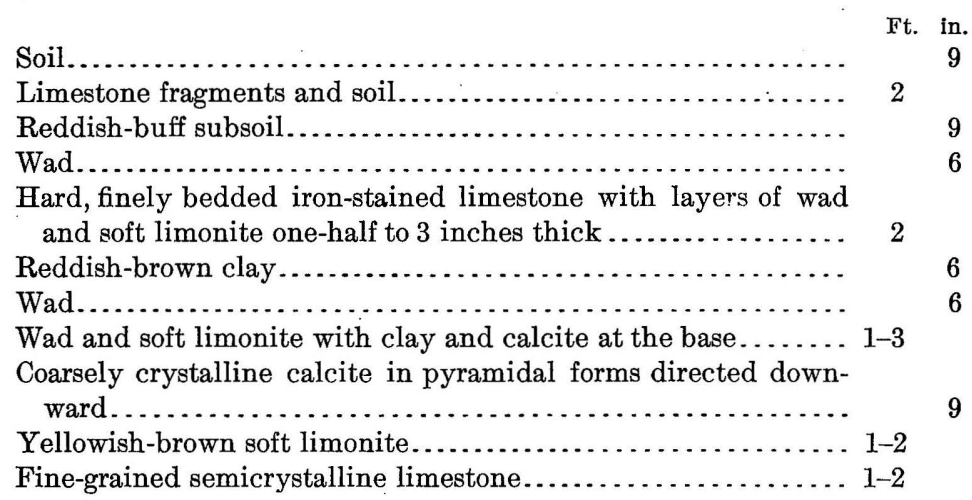

From the form of the deposit it appears that the manganese probably came into the fissure from the surface and spread from it along horizontal planes. Numerous fragments of wad occur locally on the floor of Jewel Cave.

Manganese ore of much higher grade than that described above has been reported from Custer County, but the locality is not known. It is said to contain from 30 to 92 per cent peroxide of manganese and from 0.05 to 0.4 per cent phosphorus. The following is an analysis of this ore:

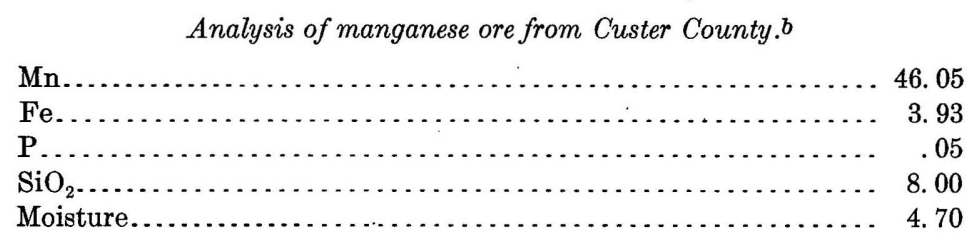

\section{MONTANA.}

Manganiferous silver ore similar to the Leadville ore occurs at Neihart, Cascade County, and at Castle, Meagher County, Mont.c At Neihart the ore is in the form of brown and black oxides in the upper portions of the veins, and grades below into sulphide ores of silver. They are associated with barite. A small amount of manganiferous silver ore has been mined at a few mines in the vicinity of Neihart, principally the Galt mine, and sent to the Great Falls smelters to be used for flux. As a rule, however, the ore is used for its silver and lead only, though when an appreciable amount of man-

$a$ Schrader, F. C., unpublished notes.

b Weeks, J. D., Sixteenth Ann. Rept. U. S. Geol. Survey, pt. 3, 1895, p. 423.

c Idem, p. 417. 
ganese and iron oxides are present the smelting charges are reduced, because of their fluxing value.

The manganiferous silver ores from the Galt mine have the following composition:

Analyses of manganiferous silver ore from the Galt mine, Montana.a

\begin{tabular}{|c|c|c|c|c|c|}
\hline & 1. & 2. & 3. & 4. & 5. \\
\hline $\begin{array}{l}\mathrm{Mn} \\
\mathrm{Fe} \\
\mathrm{Pb}(\ldots \ldots \ldots\end{array}$ & $\begin{array}{l}6.9 \\
5.5 \\
8.7 \\
6.9\end{array}$ & $\begin{array}{l}9.6 \\
6.5 \\
5.6\end{array}$ & $\begin{array}{l}6.7 \\
5.8 \\
6.0\end{array}$ & $\begin{array}{l}5.9 \\
5.3 \\
9.1\end{array}$ & $\begin{array}{l}7.7 \\
6.9 \\
4.6\end{array}$ \\
\hline 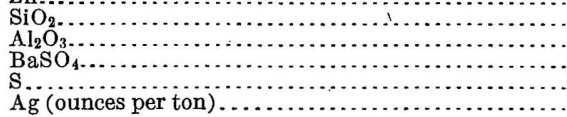 & $\begin{array}{r}18.8 \\
b 6.0 \\
28.3 \\
5 \\
128.7\end{array}$ & $\begin{array}{r}23.2 \\
b 6.0 \\
23.4 \\
4.2 \\
72.0\end{array}$ & $\begin{array}{l}21.4 \\
c 6.0 \\
25.2 \\
5 \\
77.4\end{array}$ & $\begin{array}{r}26.7 \\
c 6.0 \\
22.2 \\
3.5 \\
105.6\end{array}$ & $\begin{array}{r}27.0 \\
5.9 \\
20.5 \\
4.5 \\
54.3\end{array}$ \\
\hline
\end{tabular}

$a$ Weeks, J. D., Sixteenth Ann. Rept. U. S. Geol. Survey, pt. 3, 1895, p. 418.

b Approximate.

At Castle there are large veins of black oxide of a purer quality than those at Neihart, which carry small amounts of lead.

Recently manganiferous ores have been reported from Martinsdale, Meagher County.

\section{COLORADO.}

Manganiferous silver ores occur in several other metalliferous deposits in Colorado besides Leadville, as in Eagle County and in the San Juan district.

Manganese and manganiferous iron ores occur in small quantities in the iron-ore deposits in several localities. Among these are the deposits of Taylor Peak in the Elk Mountains on the border of Pitkin and Gunnison counties and those of Cebolla Valley, in the southern part of Gunnison County. Small deposits of manganese ore are found in Steuben Valley and near Sapinero, Gunnison County.

The iron-ore deposits of Taylor Peak ${ }^{a}$ contain manganiferous iron ore of the following composition:

Analysis of manganiferous iron ore from Taylor Peak, Colorado.

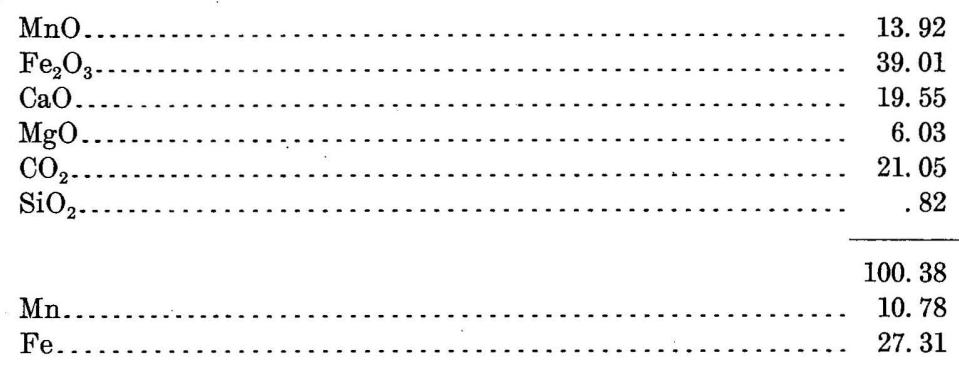

$a$ Penrose, R. A. F., jr., Manganese : Its uses, ores, and deposits: Ann. Rept. Arkansas Geol. Survey for 1890 , vol. 1,1893 , p. 458 . 
Analyses of manganiferous iron ore from Taylor Peak, Colorado. $a$

\begin{tabular}{|c|c|c|}
\hline & 1. & 2 \\
\hline 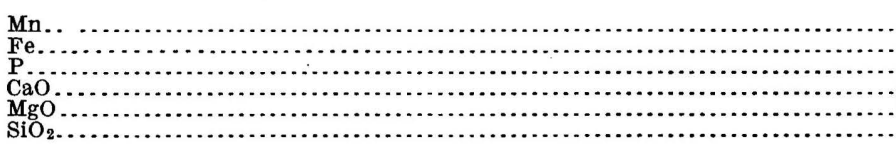 & $\begin{array}{l}19.815 \\
29.25 \\
.003 \\
4.46 \\
3.145 \\
3.405\end{array}$ & $\begin{array}{l}10.492 \\
24.70 \\
.035 \\
24.67 \\
.81 \\
.765\end{array}$ \\
\hline
\end{tabular}

$a$ Birkinbine, John, Eighteenth Ann. Rept. U. S. Geol. Survey, pt. 5, 1897, p. 304.

In the Cebolla Valley ${ }^{a}, 2$ miles above Powderhorn post-office, manganese oxide is associated with limonite and clay, which constitute surface alterations of iron-ore bodies. The rocks of this locality consist of granite, quartzite, and limestone overlain by trachyte flows. The iron-ore deposit is associated with the limestone as a bed apparently conformable with it. It consists of magnetite and hematite intimately interbedded with fine and coarse grained iron carbonate. At the surface the iron carbonate is altered to limonite and clay, with the development and introduction of chlorite, chalcedony, and manganese oxide, the last in some ores running as high as 45.92 per cent in metallic manganese. This surface alteration is principally confined to the area adjacent to the trachyte capping.

The following is an analysis of manganese ore from Cebolla Valley:

Analysis of manganese ore from Cebolla Valley. ${ }^{*}$ *

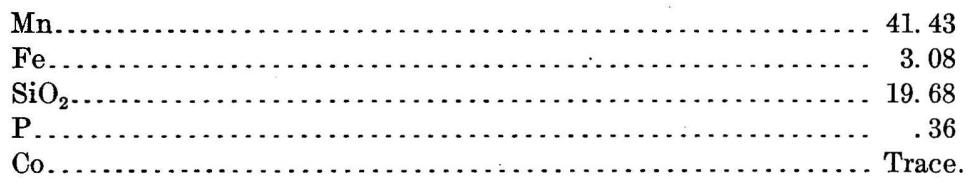

In Steuben Valley, ${ }^{c} 6$ miles southwest of Gunnison, black siliceous manganese oxide occurs in a series of lava flows and breccias. The breccia consists of fragments ranging up to several feet in diameter in a sandy matrix of the same material. The ore occurs in cavities in it and forms the matrix in which many of the lava fragments are embedded. In this manner it impregnates considerable masses of breccia. Seams and stains of ore are sometimes found in the massive lavas overlying the breccia.

Manganese also occurs in a certain bed in the massive lavas as a hard glossy black oxide in pockets and veins from one-half inch to 6 inches thick. The rock in which it occurs is a yellow brittle translucent rock with conchoidal fracture embedded as an oblong pocket 4 feet thick in a layer of black obsidian-like rock.

$a$ Leith, C. K., Iron ores of the West: Bull. U. S. Geol. Survey No. 285, p. 197; also Penrose, R. A. F. jr., op. cit., p. 456.

$b$ Penrose, R. A. F., jr., op. cit., p. 458.

cIdem, p. 459. 
The following analysis shows the composition of the Steuben Valley ore:

Analysis of Steuben Valley manganese ore.

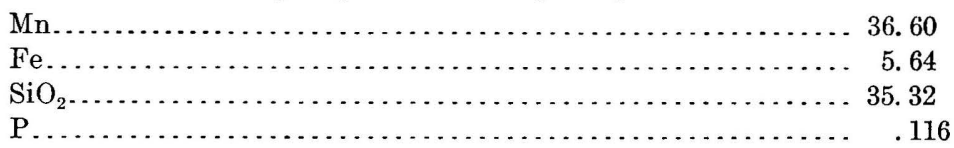

The Sapinero ${ }^{a}$ deposit consists of black siliceous manganese oxide occurring in a lava breccia similar to that at Steuben Valley. The ore is found in botryoidal forms in cavities ranging up to 4 feet in diameter, or in a network of thin veins from one-eighth inch to 1 inch thick. The breccia bed is overlain by a massive lava bed slightly stained by manganese, and is underlain by a white to brown sandstone of supposed Cretaceous age, which rests directly upon crystalline rocks.

The following is an analysis of Sapinero ore:

Analysis of Sapinero manganese ore.

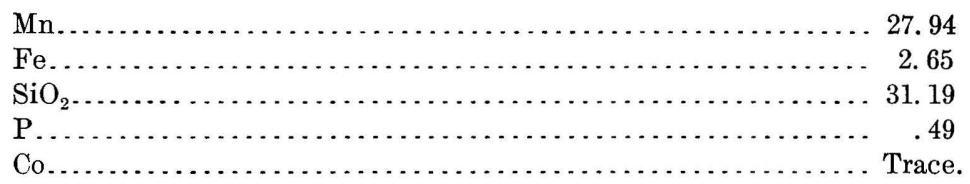

The Iron Mask group of mines at Gilman, Eagle County, has in recent years produced considerable manganiferous silver ore, which was used in the manufacture of iron-manganese alloys.

Ores of the same nature are said to occur at Telluride and Lake City in the region of the San Juan Mountains.

Psilomelane is reported from the vicinity of Canon City, Fremont County.

\section{NEW MEXICO.}

Manganiferous and ferruginous silver ores occur in southwestern New Mexico ${ }^{b}$ at Silver City, Grant County, and at Kingston and Lake Valley, Sierra County. The Silver City ores were mined on Legal Tender Hill and are said to have been used as a flux in smelters. They contained an average of 13 per cent metallic manganese. At Kingston the manganese occurs as black oxide and as manganocalcite in veins in blue limestone and black dolomite; at Lake Valley it is in the form of fibrous pyrolusite.

ARIZONA.

Manganese oxide is abundantly developed in the oxidized portions of the metalliferous deposits at Tombstone, Ariz. ${ }^{b}$ The ores are used for their silver content only, but the manganese is of assistance as a flux in smelting. 
The rocks of the district consist of a series of limestones, quartzites, and shales of probable lower Carboniferous age, associated with porphyritic and feldspathic dikes and granite. The ore occurs mainly in the limestones at the contact with porphyry dikes. The deposits are in the form of veins or chimneys. The ore is principally pyrolusite and earthy black wad, with some psilomelane, and occurs in a calcareous or siliceous gangue.

The following analyses show the composition of the Tombstone ore:

Analyses of manganiferous silver ore from the Big Comet mine, Tombstone, Ariz.

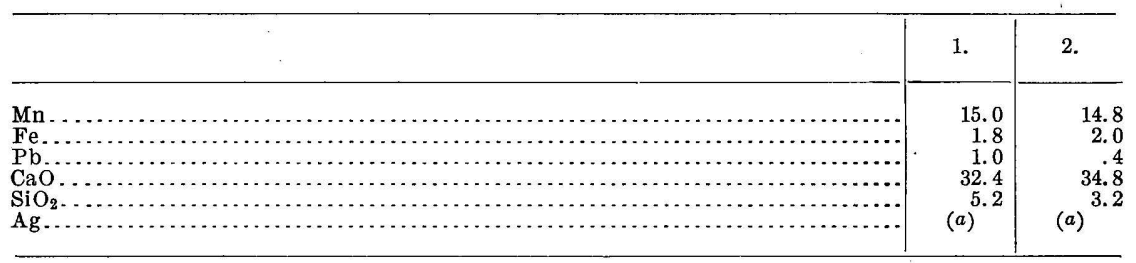

$a \$ 13.45$ to $\$ 15.75$ per ton.

COMMERCIAL IMPORTANCE OF THE ORES.

The manganese deposits of the Rocky Mountain region are small, widely scattered, and few in number, but the manganiferous silver ores are of considerable importance. Besides a few tons shipped from Montana the only manganese ore produced has come from the Little Grande district in Utah. The latter has recently been abandoned, so that at present no manganese ore is being produced in the Rocky Mountain region.

Manganiferous silver ores, however, have been produced in large quantities in many of the precious-metal districts. By far the larger part of this ore has been and is now being used for flux, but a small portion goes annually into the manufacture of spiegeleisen. So far the ore used for this purpose has come altogether from Leadville and vicinity. Of course, only those ores which are low in their percentage of precious metals can be considered as available for their iron and manganese content, and only a small proportion of these is used in steel manufacture, because the price of flux material is such that it does not pay producers to ship their ore to blast furnaces when it can be used in local smelters.

Manganiferous silver ores contain too much iron to be used for chemical purposes.

\section{GREAT BASIN REGION.}

GENERAI STATEMENT.

The Great Basin region includes the territory between the Wasatch Mountains on the east and the Sierra Nevada on the west. It is a dry desert region with numerous isolated mountain ranges. The 
desert areas are underlain by Pleistocene or Recent lake and stream deposits, while the mountain ranges consist of rocks ranging in age from pre-Cambrian to Tertiary.

The manganese ores of the Great Basin have been of no great importance. They consist largely of manganiferous silver ores associated with many of the metalliferous deposits and forming a considerable part of a number of them. Such deposits occur at Pioche and Eureka, Nev., and at Modena and in the Tintic district, Utah. There is a small bedded deposit of manganese ore near Golconda, Humboldt County, Nev., on Humboldt River, and a contact deposit is found near Joy, Juab County, Utah.

GOLCONDA AREA.

GEOGRAPHY AND TOPOGRAPHY.

The Golconda manganese area is in north-central Nevada about 3 miles east of the village of Golconda on the Southern Pacific Railroad. The deposits are in a small area one-fourth mile square, about one-half mile south of where Humboldt River issues from its canyon through the Edna Mountains, which rise about 1,000 to 1,200 feet above the deposits to the east. To the west is the undulating desert valley in which Golconda is situated. The entire region, the mountains as well as the valleys, except a narrow strip along Humboldt River, is destitute of trees, only sagebrush and other desert shrubs being found. Along the banks of the Humboldt grasses, green shrubs, and small trees grow.

\section{GEOLOGY.}

The rocks of the region are both igneous and sedimentary, but only the latter are associated with the ore deposits. The igneous rocks in the immediate vicinity are designated in the Fortieth Parallel Survey ${ }^{a}$ as granite, propylite, rhyolite, and basalt; the sedimentary rocks are given the following succession:

Succession of sedimentary rocks in Golconda district, Nevada.

Upper Quaternary: Tufa, etc.

Pliocene: Humboldt.

Triassic:

Star Peak.

Koipato.

The Edna Mountains are compósed largely of Star Peak formation (shales, limestones, and quartzites). The summit is formed by a heavy bed of quartzite, and the west slope is composed of slaty shale with some interbedded layers of limestone and quartzite. The beds dip at angles of $70^{\circ}$ to $80^{\circ} \mathrm{NE}$., that is, toward the mountains. (See fig. 26.) The shales are hard and slaty and vary in color from

$a$ King, Clarence, U. S. Geol. Expl. 40th Par., vol. 2, p. 680 (Arnold Hague), and Atlas. 
greenish or yellowish-gray to brown. The interbedded quartzites are hard and vitreous and contain numerous quartz veins; the limestone beds consist of blue crystalline limestone with abundant thin quartz seams.

Near the foot of the mountains there are two small knolls consisting of horizontally bedded tufa, which rests unconformably upon nearly vertical shales. The tufa is of Quaternary age, having been deposited near the shore line at the extreme eastern end of old Lake Lahontan. $^{a}$ It is of two varieties, soft calcareous tufa and hard flintlike siliceous tufa, the latter occurring in large masses, many of them several feet thick, through the former. Both contain locally abundant fragments of quartzite and shale identical with the rocks composing the neighboring slopes. The calcareous tufa is brownish

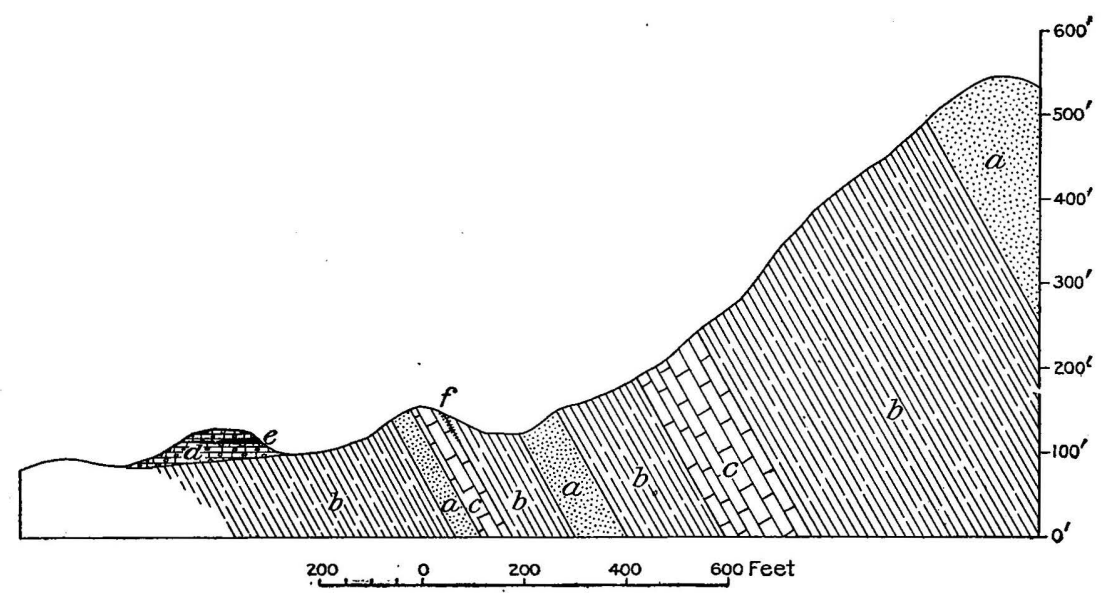

FIGURE 26.-Section showing the relation of the Golconda manganese deposit to the rocks of the Edna Mountains, Nevada. (Modified from Penrose.) a, Quartzite; $b$, shale; $c$, limestone; $d$, calcareous tufa; $e$, bedded manganese ore; $f$ limonite replacement deposit.

white with uneven fracture, and has the general appearance of impure limestone. The siliceous tufa is somewhat lighter in color, is very hard, breaks with conchoidal fracture, and contains small cavities lined with quartz. At the contact these tufas grade into each other. Both rocks are solid and compact.

\section{OCCURRENCE AND CHARACTER OF ORES.}

The ores of the Golconda area are of two types, (1) a horizontal layer of manganese oxide interbedded with tufa in the little knolls at the foot of the mountains, and (2) replacement deposits of manganiferous limonite along a crystalline limestone layer in the Star Peak formation, a few hundred yards up the slope from the horizontal bed. The first contains limonite locally, while the second is

$a$ Russell, I. C., Geological history of Lake Lahontan, a Quaternary lake of northwestern Nevada: Mon.; U. S. Geol. Survey, vol. 11, 1885. 
slightly manganiferous in some places. The bedded deposit (see fig. 27) is broadly lens shaped, being several feet thick where thickest and narrowing toward the edges till it consists only of small pockets, stains, and dendritic markings. A large part of the original bed has been removed by erosion, only small portions of it near the top of the two knolls remaining. These have semicircular outcrops on the east sides of the knolls and rapidly die out to the west.

The ore is black and friable, and consists of a mixture of hard glossy material and powder, the former composing a skeleton, while

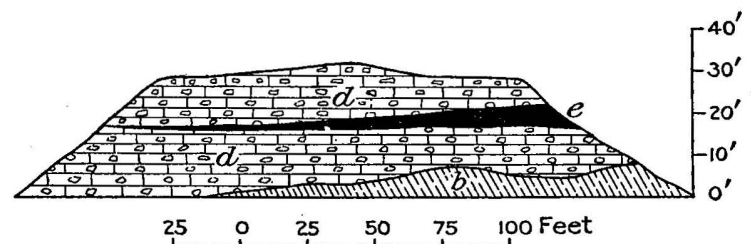

Figure 27.-Section through the Golconda manganese deposit, Nevada. (After Penrose.) $b$, Shale; $d$, calcareous tufa; $e$, manganese ore.

the powder fills the intervening spaces. In many parts of the bed there are small rock fragments similar to those in the tufa, some of them largely replaced by manganese oxide. The deposit on the northern knoll is composed of fairly pure manganese ore, while on the knoll to the south the bed is in places made up largely of limonite and ocher.

The following analysis shows the composition of the Golconda ore. The presence of 2.20 per cent of tungsten is especially noteworthy.

Analysis of manganese ore from Golconda, Nev.a

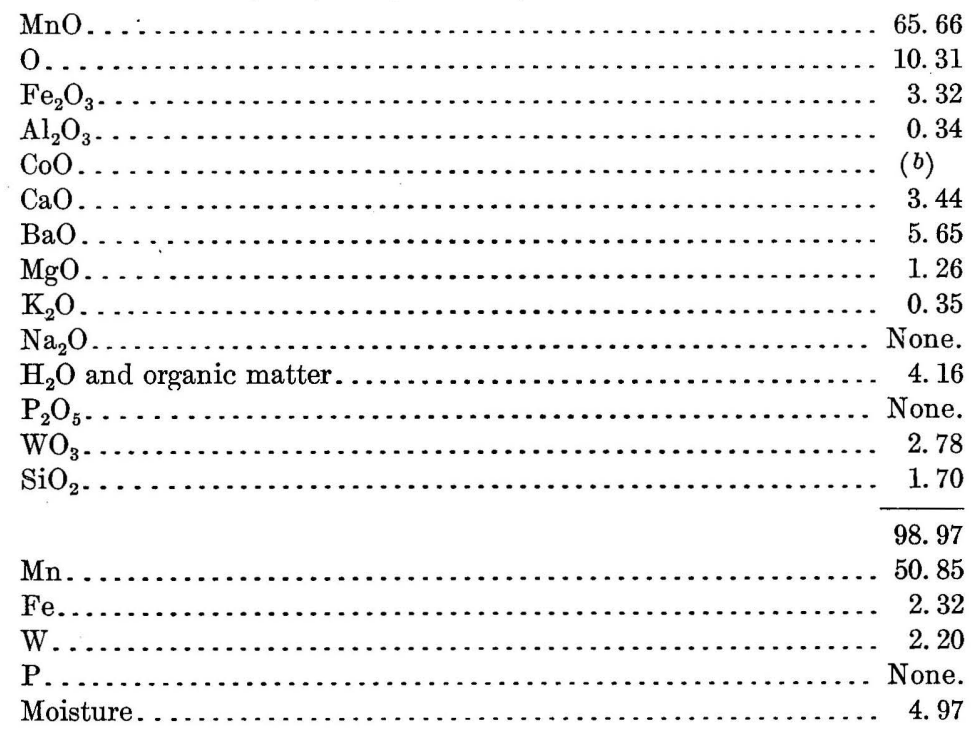

a Penrose, R. A. F., jr., op. cit., p. 470.

b Appreciable amount. 
The replacement deposits in the crystalline limestone bed (fig. 28) consist largely of siliceous materials, limonite, and ocher. They are found along the outcrop for several hundred feet. Their width, as a rule, does not exceed 15 or 20 feet and the depth is not known. The replaced rocks are crystalline limestone with associated thin shale and quartzite layers. The original sedimentary layers may be distinguished in some parts of the deposits.

The crystalline limestone is decomposed, consisting of a network of quartz seams inclosing ocherous powder. With it occur lenses, beds, and irregular masses of brown limonite in various stages of replacement, depending on the rock replaced. Quartzitic layers are stained and only partly replaced; shaly layers are largely replaced, though fragments of the original rock are commonly inclosed. The deposits are mainly limonite, but here and there pockets or seams of manganese oxide occur in them.

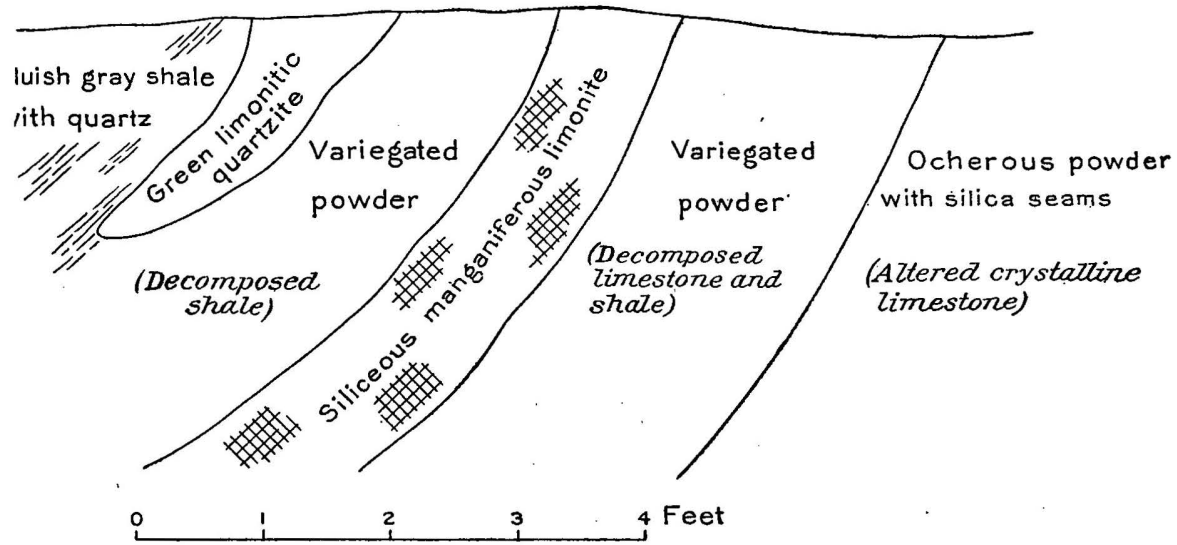

FIGURE 28.-Section through the replacement deposit of manganiferous iron ore near Golconda, Nev.

The bedded deposit of manganese oxide and limonite appears to have been precipitated from solution in an elliptical basin during a lull in the precipitation of calcareous tufa. It is conceivable that while the shore lines of Lake Lahontan were retreating small basins, partly or altogether isolated, should be formed. Waters from hot springs or other sources emptying into these basins would gradually produce in it a concentration of whatever foreign materials they carried, and at length precipitation would occur. It is probable that near the Golconda basin there were hot springs whose waters carried in solution considerable manganese and iron, as the present Golconda hot springs do. If these waters had emptied into Lake Lahontan directly, they would have been widely distributed and there would have been no concentration. In an isolated or partly connected basin, however, precipitation would occur after a considerable period of time. The replacement deposits on the slopes above the bedded 
deposit may indicate the vents of hot springs. The iron, being more readily precipitated than the manganese, was deposited in greater abundance around these vents, replacing limestones and associated rocks, while the manganese was for the most part carried down into the basin and there precipitated.

After a long period of precipitation there occurred an expansion of the old lake, bringing the shore line back to its original position and resulting later in the continued deposition of calcareous tufa.

\section{MINOR DEPOSITS.}

UTAH.

Manganese ores are reported ${ }^{a}$ from the vicinity of Joy, Juab County, Utah, 40 miles west of Oasis. The deposit is said to run 4,500 feet along the contact of a limestone and granite, the latter being on the foot wall, and to have been tested to a depth of 110 feet. The ores have the following composition:

Analyses of manganese ores from Joy, Utah.

[Booth, Garrett, and Blair, Philadelphia, analysts.]

\begin{tabular}{|c|c|c|}
\hline . & 1. & 2. \\
\hline $\begin{array}{l}\mathrm{Fe} \\
\mathrm{Mn} \\
\mathrm{MiO} \\
\mathrm{P} \\
\mathrm{Al}_{2} \mathrm{O}_{2}\end{array}$ & $\begin{array}{l}7.00 \\
41.00 \\
6.25 \\
.143 \\
3.68\end{array}$ & $\begin{array}{c}5.99 \\
42.54 \\
6.27 \\
.159 \\
\end{array}$ \\
\hline
\end{tabular}

A deposit of manganiferous silver ore is being developed near Modena, ${ }^{b}$ Iron County. It occurs in decomposed limestone on the foot wall of an igneous dike, consists of black oxide of manganese (probably wad), iron oxide, and calcite, and contains silver, lead, and gold. The iron oxide is next to the dike, and the calcite is generally farthest away, next to the limestone, the manganese oxide being inclosed between them.

Iron ores high in manganese occur with metalliferous ores in the Tintic district, and are being used for flux in the local smelters.

NEVADA.

Manganiferous and ferruginous silver ores are found at Pioche, Lincoln County, Nev., and at Eureka. ${ }^{c}$ Rhodochrosite occurs in association with quartz in the silver-bearing veins at Austin, Lander County, ${ }^{d}$ and the tungstate of manganese, hübnerite, is reported from the Mammoth district, ${ }^{c}$ Nye County. 
Beds of manganese ore occur at the foot of a range of basic eruptive masses in Boulder Canyon, ${ }^{a}$ near Rioville, in the St. Thomas mining district, Lincoln County. The ore is rhodochrosite, partly altered to pyrolusite, and contains from 18 to 48 per cent of metallic manganese.

\section{COMMERCIAI IMPORTANCE OF THE ORES.}

The Great Basin region contains few manganese or manganiferous ore deposits of any value. The only ore produced has been a small amount of manganese ore at Golconda, Nev., and considerable manganiferous iron ore in the Tintic district, the latter being used for flux in the local smelters. In view of the fact that large portions of the Great Basin have not yet been thoroughly prospected, it is not unlikely that important deposits may still be found. The largest deposits known at present are those of the Tintic district and the still undeveloped deposits near Joy, Utah. The latter are more than 40 miles from the railroad, and until better transportation facilities are obtained will doubtless remain untouched. The Golconda deposits, while of interest geologically, are too small to be considered of commercial importance. The manganiferous ores of some of the preciousmetal deposits, though present in considerable quantity, are used only for their content of silver, gold, or lead.

\section{PACIFIC COAST REGION.}

GENERAL STATEMENT.

The Pacific coast region includes the territory between the Sierra Nevada and Cascade Range on the east and the Pacific Ocean on the west. It is characterized by the absence of pre-Cambrian and early Paleozoic rocks, the oldest formations exposed being of Carboniferous age. The manganese ores of the region are confined to California and western Washington.

The characteristic occurrence of manganese in California is in the form of porous black oxide associated as layers and pockets with the jasper lenses of the Franciscan formation (Jurassic?) of the Coast Ranges. Smaller deposits are found in the Sierra Nevada in veins in the Calaveras (Carboniferous) formation, as fragments disseminated in auriferous gravels, or in deposits associated with igneous rocks.

Deposits of the first type are scattered through the Coast Ranges from Cape Mendocino on the north to the Channel Islands on the south. The principal occurrences so far known are in the Mount Diablo Range southeast of Livermore. This area has furnished nearly all of the ore mined in the State.

The deposits of the Sierra Nevada are small, and so far have been of no commercial importance. 
A ledge of manganese ore carrying 50 per cent manganese and 16 to 18 per cent silica is said to occur in the Olympic Mountains in western Washington. ${ }^{a}$ Some authorities report it as being of low grade, but traceable for several miles.

\section{LIVERMORE-TESLA DISTRICT.}

GEOGRAPHY AND TOPOGRAPHY.

The Livermore-Tesla district is in the mountainous region southeast of Livermore, in Alameda, Santa Clara, and San Joaquin counties, Cal., about 45 miles east-southeast of San Francisco. It is approximately 35 miles long in a northwest-southeast direction and 15 miles wide. The district is in the Diablo Range, one of the largest divisions of the Coast Ranges. It is drained on the west by Arroyo del Valle and its tributary, Arroyo Mocho, Arroyo del Valle flowing into San Francisco Bay. The eastern part is drained by Corral Hollow Creek, La Puerta Creek, and Orestimba Creek, the waters of which flow into San Joaquin River and so to San Francisco Bay.

Topographically, the district consists of several parallel northwestsoutheast ridges, including the Cedar Mountain Ridge, Crane Ridge, and others. They are separated by long, narrow, stream valleys. The range of elevations is from about 700 feet above sea level in the lower stream valleys to about 5,100 feet on the highest ridges. The slopes are steep, though rarely precipitous, and are generally covered with vegetation. The eastern part of the district is bare except for grasses and occasional live-oak trees, while in the western part there are large areas of brushwood, mainly chamiso and chaparral, interspersed with groves of oak, laurel, live oak, buckeye, cedar, and manzanita.

\section{GEOLOGY.}

The manganese deposits occur in jasper belonging to the Franciscan formation of probable Jurassic age. This formation consists of jasper lenses associated with a great thickness of sandstone, shale, and conglomerate. It is intruded by igneous rocks of different age and many varieties, among which are diorites, basalts, and peridotites. There are also associated with them metamorphic rocks, such as glaucophane and other schists and serpentine.

The Franciscan formation occupies by far the larger portion of the district. In the northeastern part around Tesla, however, there are coal-bearing rocks of probable Eocene age. The relations of this to the jasper is not known, nor whether Cretaceous rocks are present between them, as elsewhere in western California. 


\section{OCCURRENCE OF THE ORES.}

The manganese ores occur in the jasper lenses of the Franciscan formation in the form of oxides supposed to be largely manganite and an associated impure oxide. ${ }^{a}$ There are two principal types of deposits-(1) fault deposits and (2) interbedded lenses.

1. Fault deposits were found at only one locality, namely at the Old Ladd or Corral Hollow mine, about 5 miles southeast of Tesla in San Joaquin County.

2. Interbedded lenses of manganese ore occur in the jasper at many localities in the Livermore-Tesla district. They vary in extent up to 100 feet or more, and in thickness from a few inches to 5 feet or more, and consist mainly of black porous ore with abundant quartz seams. Deposits of this type have been prospected and exposed at the Black Jack, Bartlett, Fable, Isler (Eylar) Mountain, Homestead, Black Bear, Merchant, Pennsylvania, Black Wonder, and other mines, all of them southeast of Livermore, in Alameda, Santa Clara, and Stanislaus counties.

\section{DESCRIPTIONS OF MINES AND DEPOSITS.}

Old Ladd mine.-The workings at the old Ladd mine consist of a number of cuts and stopes. The deposit appears to be a filling of a fault fissure between walls of solid rock, and is exposed along the strike for several hundred yards, in which distance it.varies considerably in thickness, but averages about 4 or 5 feet. It has a strike of about N. $80^{\circ} \mathrm{W}$., and a dip varying from $45^{\circ} \mathrm{S}$. to nearly vertical. Smaller veins branch off from the main fissure at low angles and continue for short distances in the wall rock. Recent openings consisting of an incline and stopes have been made about one-half mile from the main exposures in a direction a little north of west, on what appears to be an extension of the same deposit.

The north wall of the deposit at the old Ladd mine is formed by thin-bedded, greenish-gray jasper and shale, and the south wall by massive green, gray, or red jasper with no apparent bedding. (See fig 29.) The thin-bedded material is very much contorted, forming intricate patterns of faulting and folding, while the massive rock on the south wall is considerably fractured and contains stains and seams of manganese oxide. In some places these are so abundant as to form a breccia. The north wall contains very little manganese, the small amount present being in the form of little beads along cracks. Between the deposit and the north wall there is generally a layer of grayish-white kaolin.

The ore occurs $(a)$ as an infiltration in and replacement of red and yellow clays along the fault fissure, $(b)$ as a filling in cavities in these 
clays, and $(c)$ in veins, as cement in breccias, and as replacements, in the wall rock. The ore is hard or soft according as it is associated with the jasper wall or with the clay.

(a) The ore in the clay is bluish black, amorphous, and impure, and has a tendency to nodular forms, occurring frequently in kidneys or wormlike aggregates. It is generally soft and is mixed with considerable clay.

(b) The main mass of ore occurring along the fissure is hard amorphous or granular material, black or steel-gray in color. Some portions are entirely amorphous and break with conchoidal fracture; other portions are composed of a mixture of granular and amorphous material.

(c) The ore in the breccias and small veins in the jasper wall is very hard, with either amorphous or finely crystalline structure. The former generally has a steel-gray luster, and the latter is bluish.

Black Jackmine.-The Black Jack mine, on the Overacker property, is about 12 miles southeast of Livermore, on the east side of Arroyo Mocho. The workings consist of a cut and several short tunnels. The country rock is jasper, thin layered and separated by seams of shale. The jasper layers differ in thickness from a fraction of an inch to several feet. The same layer varies in thickness, pinching out locally in

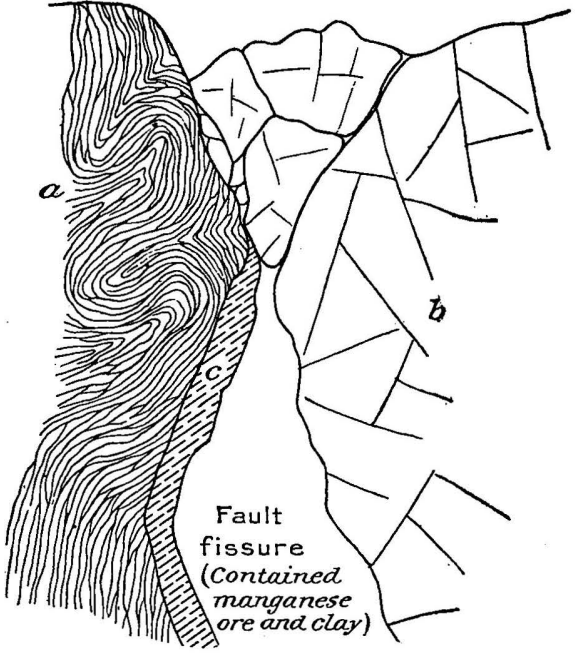

5

5 FEET

Figure 29.-Sketch showing the occurrence of manganese ore at the old Ladd mine, California. a, Thinbedded chert; $b$, hard massive chert, with manganese seams; $c$, gray kaolin.

many places. Most of the shale seams are thin. Both shale and jasper are greenish gray except where stained red or black by iron or manganese. The dip of the layers is about $35^{\circ} \mathrm{W}$., the strike being a little east of north.

The ore occurs in several interbedded lenses or pockets a few feet thick and of small extent. It is a soft, friable black oxide contained in cavities between numerous intersecting quartz seams, or as seams intersecting jasper fragments. Most of the quartz seams are later infiltrations, but the fragments are residual from jasper, which the ore has replaced. The seams are generally vitreous and the fragments earthy. In some places yellow decomposed jasper fragments have been largely replaced by manganese oxide; elsewhere only a 37336 - Bull. $427-10-11$ 
surface layèr is replaced. The deposits commonly have a foot wall that is thin bedded and more shaly than the hanging wall.

Fable mine.-The Fable mine is about 26 miles southeast of Livermore in a small gulch just west of Arroyo Mocho. The workings consist of several cuts. The country rock is greenish-gray jasper with shale seams, but is heavily stained with manganese oxide adjacent to the ore. The principal deposit is in an irregular layer interbedded with iasper. (See fig. 30.) It varies in thickness from 6 inches to 3 or 4 feet and is 50 feet long or more. In the wider portions it has no distinct boundary, being largely made up of replacements in chert, elsewhere it has distinct hanging and foot walls. The dip of the rocks and of the deposit is $45^{\circ} \mathrm{W}$., the strike being a little west of north. A smaller lens in a neighboring cut appears to be horizontal and to cut across the bedding.
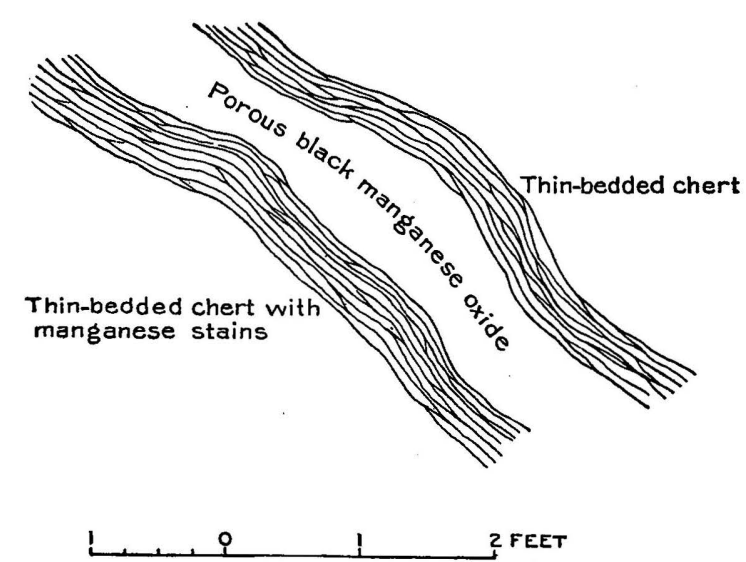

Figure 30.-Section through the manganese deposit at the Fable mine, California.
The ore at both localities is soft black oxide and is largely a replacement of jasper, partly decomposed porous masses of which are abundant. The replacement has taken place inward from the surface and along cracks. Quartz seams are found in a network through the ore masses, while here and there are admixtures of red clay.

Black Wonder group.-The Black Wonder group of manganese claims, owned by the California Manganese Mining Company of San Francisco, Howard A. Broughton, president, are on the border of Santa Clara and Stanislaus counties, about 40 miles southeast of Livermore. There are eight claims in the group, but the principal deposits occur on four of them.

The southern part of the area covered by the claims is greenish-gray sandstone of the Franciscan formation; the northern part is a mixture of jasper and fine shale interbedded. This jasper area is part of a larger area extending in a general east-west direction for 3 or 4 miles between the sandstone on the south and a large area of serpentine on the north. Where the principal manganese ore deposits occur the jasper-shale belt is about a mile wide. The manganese ores extend as discontinuous deposits along the jasper belt for more than a mile in a general northwest-southeast direction, the prin- 
cipal deposits being to the southeast and very near the sandstone contact.

The jasper-shale formation consists of beds and lenses of jasper interbedded with fine shale. The jasper may be thin bedded or very heavy bedded, in the latter case forming prominent outcrops. The beds generally strike in the direction of the main jasper belt, but the dips are exceedingly irregular.

The manganese ore occurs along heavy jasper beds as large masses replacing it, as veins, or merely as stains and partial replacements along cracks. The principal deposits - that is, those at the southeast end-are found along two or three prominent jasper beds 300 to 500 yards long, which are nearly parallel and 50 to 200 feet apart, separated by thin-bedded jasper and shale. Of these the deposits in the bed farthest south are most prominent. The ore in this bed is exposed in two tunnels, several surface workings, and numerous outcrops. In one of the tunnels a thickness of 7 or 8 feet of manganese ore, with irregular veins and bunches of jasper and quartz, is exposed, while in the other the thickness is 5 to 7 feet. At both of these places the hanging wall of the ore is thin-bedded jasper, and the foot wall gray shale. One outcrop between the two tunnels is 8 or 10 feet wide. Other smaller surface outcrops occur. No development work has been done in the other beds, and their extent is shown only by surface outcrops and float. Some of the ore is bluish-black, soft, and of very high grade, but the bulk is more or less mixed with jasper and quartz and will require concentration. The following analysis of the ore was kindly furnished the author by Mr. Broughton:

Analysis of manganese ore from Black Wonder mine, California.

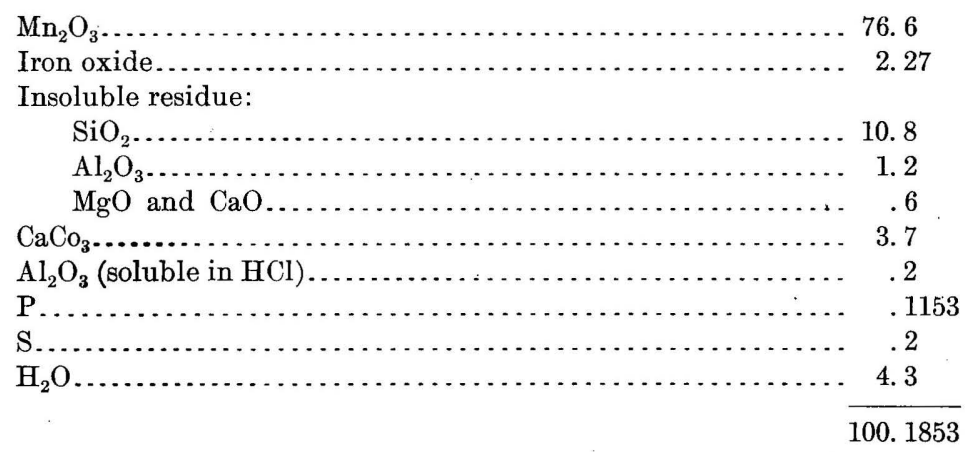

MINOR DEPOSITS IN CALIFORNIA.

Indications of manganese occur in the jasper lenses associated with sandstones and shales of the Franciscan formation in the Russian River valley in the western portion of the Coast Ranges, in Sonoma and Mendocino counties. Among these are the Cave mine, 10 miles northeast of Ukiah, and the Shaw mine, 8 miles northwest of Clover- 
dale. Workable deposits have not been found, the manganese oxides occurring merely as stains and small specks through the jasper.

Manganese has alșo been prospected on the east slope of the Coast Ranges in the northwestern part of Colusa County. The ore occurs as black oxide in jasper associated with shale on the eastern flanks of St. John Mountain ${ }^{a}$ near the town of Little Stony.

The island of Red Rock, ${ }^{b}$ in the northern part of San Francisco Bay, contains manganese ore in association with red jasper. The ore is hard and massive and has a steel-blue color and conchoidal fracture. It occurs along bedding planes and joint or fault planes in seams varying from mere films to a foot in thickness.

The mountains north of the Golden Gate in Marin County are composed largely of red shales and jasper. On the east slopes of these just west of Sausalito ${ }^{c}$ there are manganese deposits associated with the red jaspers. Black manganese oxide stains the jasper and forms seams and small pockets in it locally, the latter ranging up to 3 feet in diameter.

Several deposits of manganese ore are found near the boundary of San Benito and Merced counties about 20 miles east of Tres Pinos.

In San Luis Obispo County small deposits of manganese are found in association with jasper lenses of the Franciscan ("San Luis") formation. The ore is black oxide and occurs as a coating of seams and as nearly pure masses replacing the jasper. The principal deposits are 5 miles west of San Luis Obispo and 8 miles west of Cayucos. ${ }^{d}$ The ore west of San Luis Obispo is located on the summit of a small ridge about 1 mile south of Perfumo Canyon. Several trenches cut transversely across the ridge, and along them ore and manganese-stained jasper is exposed. The manganese ore occurs in pockets and as irregular replacements along jasper lenses. Masses of pure ore several feet in diameter are found, but in most places it is considerably mixed with partly replaced jasper. The jasper inclosing the ore is stained black by manganese oxide along cracks. Where fresh it is light brown, red, or yellow. Several tons of ore is on the dump.

Manganese occurs as pyrolusite and psilomelane in several veins, one of which is called the "Penrose lode," in the Calaveras formation 3 miles southwest of Meadow Valley, Plumas County.e

Two miles northeast of San Andreas, ${ }^{f}$ Calaveras County, it is found as oxide in mica schists of the same formation. The principal occurrences are on Fortner's ranch, where the ore is found in small quartz lenses a few feet in width, running parallel to the

a Penrose, R. A. F., jr., Manganese: Its uses, ores, and deposits: Ann. Rept. Arkansas' Geol. Survey for 1890 , vol. 1,1893, p. 490 .

$b$ Idem, p. 487.

c Idem, p. 489.

d Fairbanks, H. W., San Luis folio (No. 101), Geol. Atlas U. S., U. S. Geol. Survey, 1904.

e Turner, H. W., Bidwell Bar folio (No. 43), Geol. Atlas U. S., U. S. Geol. Survey, 1898.

$f$ Turner, H. W., Jackson folio (No. 11), Geol. Atlas U. S., U. S. Geol. Survey, 1894. 
schistosity of the inclosing mica schists. These quartz masses may be recrystallized jasper lenses or they may be later veins related to the gold-bearing quartz veins along the mother lode. Manganese ore is traceable in discontinuous pockets for 150 or 200 feet along the top of a ridge, and everywhere quartz accompanies it. At the best exposures ore is seen in irregular pockets a foot or two in diameter, which are subdivided into smaller pockets by a network of quartz veins, some of which are several inches in diameter. These smaller quartz veins are in turn stained with manganese along cracks, so there has evidently been a succession of depositions. Around the ore pockets the quartz is partly replaced by manganese oxide. The ore is bluish black in color and soft and friable.

Indications of manganese are reported from the foot of Cape Horn bluff, near Colfax, Placer County. ${ }^{a}$ The ore occurs here as black oxide in a network of thin veins from one-sixteenth to one-eighth inch in diameter in a series of slaty and schistose rocks.

Manganese ore has been found 2 miles north of Sonora, ${ }^{b}$ Tuolumne County, as oxide and silicate in a deposit varying up to 12 feet in thickness at the contact of a green porphyry with a green schist. The schist is a chloritic, micaceous rock with laminated structure, while the porphyry consists of white feldspar crystals in a green matrix. Both rocks dip nearly vertically in the vicinity of the deposit, and strike east and west. The silicate (rhodonite) and oxide are either intimately mixed or in distinct masses blending into each other. The oxide always has the most exposed positions, however, and kernels of rhodonite are generally included in oxide masses. The rhodonite is pink and translucent with granular structure. The oxide is black and varies from hard, compact material to soft masses.

Small quantities of manganese ore occur embedded in auriferous gravels near Columbia, ${ }^{c}$ Tuolumne County. The ore is in the form of kidneys of massive or granular black oxide. The underlying rocks are steeply dipping limestones and shales. Ore is found in them in a few places, principally as wad.

Several specimens of psilomelane obtained from the Maria Mountains in northeastern Riverside County were seen by the writer. The ore is said to occur as a network of small veins varying from 5 or 6 inches in diameter to mere stringers and covering many acres.

A deposit of high-grade manganese ore is said to occur in granite and schist 6 miles northeast of Elsinore, Riverside County. ${ }^{d}$

$a$ Aubury, L. E., Structural and industrial materials of California, p. 336; also Penrose, R.A. F.,jr., op. cit., p. 495.

$b$ Penrose, R. A. F., jr., op. cit., p. 492.

$c$ Idem, p. 494.

$d$ Aubury, L. E., loc. cit. 


\section{ANALYSES.}

In the following tables are given analyses of manganite from the Corral Hollow mine and impure manganese oxide from Red Rock Island:

Analyses of manganese ores from the Coast Ranges. ${ }^{a}$

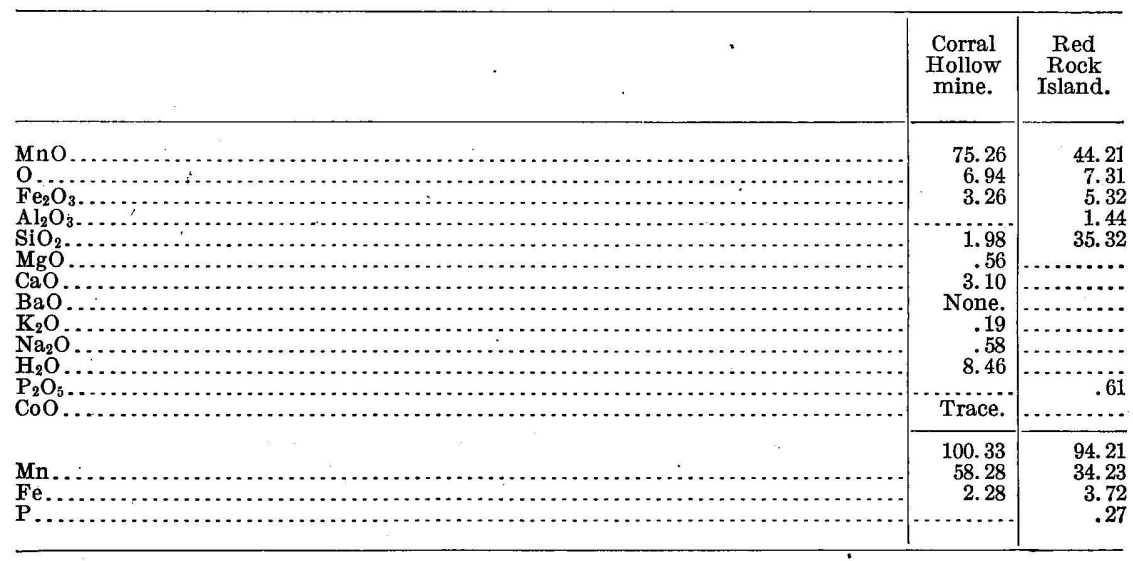

$a$ Penrose, R. A. F., jr., op. cit., pp. 481-483.

\section{ORIGIN OF MANGANESE ORES IN THE FRANCISCAN JASPERS.}

The manganese ores in the Franciscan jaspers in their present form are clearly secondary concentrations, as is shown by their replacement of jasper and by the intimate association of manganese oxide and quartz veins, suggesting their contemporaneous deposition. That the jasper itself is the source of the ore is shown by the facts that it is invariably associated with the ore deposits throughout the Coast Ranges and that ores do not occur in the sandstones and shales of the formation. In the limited time at the writer's disposal it was not possible to go into a detailed study of the original form of the manganese and its method of concentration. It might be suggested, however, that they are intimately connected in origin with associated jasper. Lawson ${ }^{a}$ discusses two ways in which the jasper might have been deposited-as deep-sea deposits or by siliceous springs. The theory that they are deep-sea deposits is discarded because of the associated sandstones and shales which were deposited in moderately shallow water. The presence of manganese oxide, which is very common in the deep sea, might well be accounted for by this theory if it were otherwise plausible.

Microscopic examination shows that but a small part of the mass of the jaspers consists of recognizable organic remains, and that the principal portion is probably a chemical precipitate. For this reason

a Lawson, A. C., Geology of San Francisco Peninsula: Fifteenth Ann. Rept. U. S. Geol. Survey, 1895, pp. 424-426. 
and on account of its local occurrence in lenses, Lawson suggests that the jasper had its principal source in local siliceous springs in the bottom of the ocean, and that small quantities of siliceous radiolarian remains became embedded in it as they dropped to the bottom.

This hypothesis would also account for the presence of manganese in many of the chert lenses, because manganese in the form of bog ore is a very common spring deposit. Whatever the origin, however, it is certain that the jasper and manganese have been closely associated from the beginning. Whether the manganese was originally disseminated through the lenses and later concentrated into pockets by replacement of the jasper, or was partly in small pockets originally and was spread by replacement of the surrounding jasper, is a question that can only be solved by further detailed work.

\section{COMMERCIAL IMPORTANCE OF THE ORES.}

The manganese deposits associated with the Franciscan jaspers are very abundant throughout western California, but they are small and pockety. They vary in size from mere stains and small veins in the chert to pockets containing 10,000 or 15,000 tons. Locally, where structural conditions are favorable, larger deposits occur, as at the old Ladd or Corral Hollow mine.

The ore varies from soft and powdery to hard and compact. Both varieties may be quite pure or they may contain much silica in the form of quartz veins and ưnaltered chert.

The manganese deposits of the Sierra Nevada are small and scattered and, with the present means of transport, are of no commercial value. The new line of the Western Pacific Railway Company penetrates a district in which several deposits of high-grade ore occur, namely, those in the neighborhood of Meadow Valley; it is possible that in a few years ore may be shipped from these. Up to the present time all the ore shipped has been derived from the jasper deposits. 


\section{CHAPTER III. \\ 'FOREIGN MANGANESE DEPOSITS. \\ NORTH AMERICA. \\ CANADA. $a$ \\ GENERAL STATEMENT.}

Considerable quantities of manganese ore have been mined in New Brunswick and Nova Scotia and small amounts in Quebec and Ontario.

The ores of New Brunswick and Nova Scotia occur mainly in the lower Carboniferous limestone, but small quantities are found in both older and younger rocks. The principal deposits are located on or near the shores of the Bay of Fundy, or its eastern extremities, Minas Basin and Chignecto Bay, and smaller ones on the Atlantic coast of Nova Scotia and Cape Breton.

The following section shows the stratigraphy of the rocks of New Brunswick and Nova Scotia: ${ }^{b}$

Succession of rocks in New Brunswick and Nova Scotia.

Triassic red sandstones and traps.

Carboniferous:

Upper coal formation; no productive coal beds.

Middle coal formation; productive coal beds.

"Millstone grit;" red and gray sandstone, shale and conglomerate.

Carboniferous limestone; manganese deposits and gypsum.

Devonian quartzite and sandstone ("Lower Coal Measures" of Penrose; no productive coal beds).

Silurian, Ordovician, Cambrian, and pre-Cambrian.

The ores are pyrolusite, manganite, psilomelane, and wad. The first three of these are found together in the same deposits, while wad commonly occurs in separate deposits.

$a$ References on Canadian manganese-ore deposits:

Penrose, R. A. F., jr., Manganese: Its uses, ores, and deposits: Ann. Rept. Arkansas Geol. Survey, vol. 1, 1893, p. 496.

Denis, Theo., Manganese: Ann. Rept. Geol. Survey of Canada, vol. 15, 1902-3, Section of mines, E. D. Ingall, pp. 148 s et seq.

Gilpin, E., Manganese ores of Nova Scotia: Trans. Roy. Soc. Canada, vol. 2.

Mineral Resources U. S. for 1885, pp. 350-356.

Idem for 1887, pp. 153-154.

Idem for 1888, pp. 133-136.

Idem for 1892, pp. 216-219.

Idem for 1893, p. 136.

Sixteenth Ann. Rept. U. S. Geol. Survey, pt. 3, 1895, pp. 435-438.

Seventeenth Ann. Rept. U. S. Geol. Survey, pt. 3, 1896, p. 206.

Eighteenth Ann. Rept. U. S. Geol. Survey, pt. 5, 1897, p. 311.

Twenty-first Ann. Rept. U. S. Geol. Survey, pt. 6, 1900, pp. 144-145.

b Penrose, R. A. F., jr., op. cit., pp. 496 et seq. (revised).

168 
Pyrolusite, manganite, and psilomelane occur in layers, lenses, and pockets along the bedding of the Carboniferous limestone, as veins in the brecciated portions, and as fragments in the surface clays derived from the limestone. The pyrolusite occurs in nests of fibrous orthorhombic prisms, many of them radiating from a center or encrusting masses of psilomelane. Some of the prisms are long and slender; others are short, even grading into granular aggregates. The manganite also occurs in prisms, but is markedly harder than pyrolusite. Psilomelane occurs in nodular masses of steel-gray or black color.

The following are analyses of Canadian pyrolusite and manganite:

Analyses of pyrolusite and manganite from Nova Scotia. ${ }^{a}$

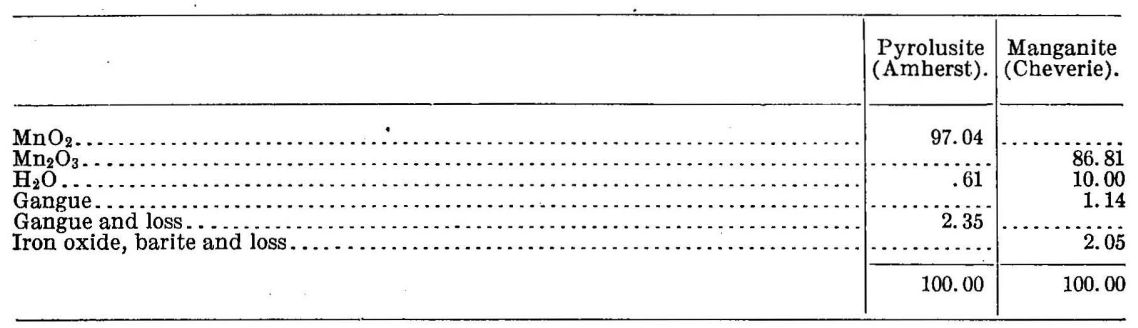

a Penrose, R. A. F., jr., op. cit., pp. 500-501.

Deposits of wad are much more abundant and widely distributed than those of the other minerals of manganese. They occur mainly in beds several feet thick near the surface, being derived from the decay of the underlying rocks. These are of various ages, but are more especially pre-Cambrian crystallines. The ore is of low grade and very siliceous, and the small quantities of it that have been mined have been used as pigment. It is porous and earthy, black or brown, and is commonly associated with limonite.

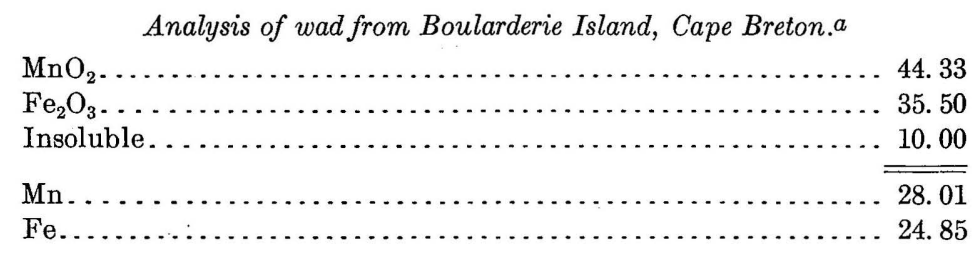

\section{NEW BRUNSWICK.}

The manganese deposits of New Brunswick occur throughout the southern part, in Kings, Albert, Westmoreland, and St. John counties, which comprise the area underlain by Carboniferous limestone.

Markhamville mine.-The most important deposit occurs at Markhamville, near Sussex, Kings County. The ore here is crystalline pyrolusite and manganite, with small amounts of psilomelane in some places. The deposits are in irregular pockets, or in flat lenticular 
layers in general following the bedding planes in the limestone. Veins of manganese oxides, many of them associated with calcite, cross the bedding of the limestone. At the surface the rock is decayed, forming a red residual clay in which are small bodies of ore derived from deposits originally in the limestone. The downward decomposition is more rapid along ore bodies than elsewhere. Decomposition has also gone on underground, forming subterranean caves and passages, and where these intersect ore bodies fragments of ore lie on the floors. While considerable ore has been procured from the last two sources, the bulk of the output has been derived from deposits in the limestone itself. The Markhamville mine has produced some ore of the highest grade known, much of the pyrolusite containing from $96 \frac{1}{2}$ to $98 \frac{3}{4}$ per cent peroxide of manganese with only one-half of 1 per cent of silica and three-fourths of 1 per cent of iron. The large amount of available oxygen and the freedom from impurities have caused it to be highly prized by glass makers. The manganite is also of high grade and has been used for steel manufacture.

The following table shows the composition of manganese ores from the Markhamville mine:

Analysis of manganese ore from Markhamville, New Brunswick.

\begin{tabular}{|c|c|c|c|c|}
\hline & \multicolumn{3}{|c|}{ High-grade pyrolusite. $a$} & \multirow{2}{*}{$\begin{array}{l}\text { Flux } \\
\text { ore.b }\end{array}$} \\
\hline & 1. & 2. & 3. & \\
\hline \multirow{8}{*}{ 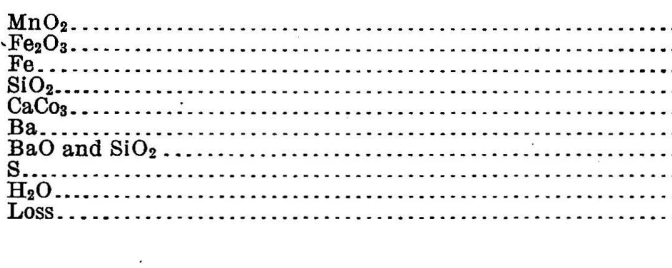 } & 98.70 & $\begin{array}{r}97.25 \\
.85\end{array}$ & $\begin{array}{r}96 . .62 \\
.78\end{array}$ & $\begin{array}{r}52.74 \\
3.75\end{array}$ \\
\hline & .75 & ........ & & \\
\hline & .55 & $\cdots$ & $\cdots \cdots$ & $\begin{array}{r}9.50 \\
13.40\end{array}$ \\
\hline & Trace. & & & \\
\hline & (n........ & .95 & .85 & \\
\hline & & Trace. & Trace. & \\
\hline & $\cdots$ & .95 & 1.75 & $\ldots \ldots \ldots \ldots$ \\
\hline & 100.00 & 100.00 & 100.00 & $\ldots$ \\
\hline
\end{tabular}

$a$ Sixteenth Ann. Rept. U. S. Geol. Survey, pt. 3, 1895, p. 436

$b$ Mineral Resources U. S. for 1885 , p. 351 .

Quaco Head mine.-The Quaco Head mine is situated on Quaco Head, a bold headland extending into the Bay of Fundy 1 mile south of St. Martins, St. John County. The ores occur in Carboniferous limestone and shale associated with a heavy conglomerate bed. The rocks dip steeply toward the bay, the conglomerate being the upper and the limestone the lower member, with the shale between. They are intruded by trap and unconformably overlain in places by Triassic red sandstone and conglomerate. These also contain some small nodules and seams of manganese ore. The ore in the limestone and shale is both crystalline and massive, the crystalline ore being chiefly pyrolusite and the massive ore psilomelane. There is also a porous honeycombed ore. The ore is in nodules and irregular veins in both the shale and the limestone, but in larger quantities in the shale. 
The nodules are an inch to several inches in diameter, and the veins also vary in thickness. The following are analyses of ore from the Quaco Head mine:

Analysis of manganese ore from Quaco Head, New Brunswick. ${ }^{a}$

\begin{tabular}{|c|c|c|}
\hline . & $\begin{array}{l}\text { Compact } \\
\text { variety. }\end{array}$ & $\begin{array}{l}\text { Porous } \\
\text { variety. }\end{array}$ \\
\hline 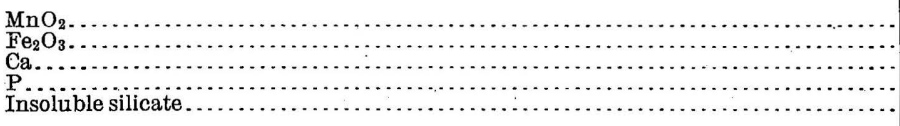 & $\begin{array}{r}71.54 \\
2.19 \\
\text { Trace. } \\
.02 \\
8.37\end{array}$ & $\begin{array}{r}65.00 \\
1.75 \\
\text { Trace. } \\
.04 \\
6.66 \\
\end{array}$ \\
\hline $\begin{array}{l}\text { Mn } \\
\text { Fe. }\end{array}$ & $\begin{array}{r}58.20 \\
1.53\end{array}$ & $\begin{array}{r}57.15 \\
1.23\end{array}$ \\
\hline
\end{tabular}

$a$ Penrose, R. A. F., jr., op. cit.. p. 513.

Other deposits.-Smaller deposits of manganese ore occur in the following localities in New Brunswick: At the Glebe mine, 3 miles from Markhamville, in lower Carboniferous limestone; at Jordan Mountain, near Sussex, at the contact of the lower Carboniferous sediments and the pre-Cambrian crystalline rocks; at Shepody Mountain, at the contact of the lower Carboniferous conglomerates and pre-Cambrian chloritic slates; on the east side of Salisbury Bay, near the contact of lower Carboniferous rocks and Triassic sandstone; at Hopewell Corner, near the contact of the "Millstone grit" and lower Carboniferous rocks; at Hillsdale, in the lower Carboniferous rocks; at Petitcodiac, near the contact of lower Carboniferous limestone and gypsum; at Henry's Lake, in the lower Carboniferous rocks; at Tete à Gauche Falls, 8 miles from Bathurst, as nodules and veins in "Cambro-Silurian red and black slates," and as detached masses in residual material; between Quaco and Markhamville, in pre-Cambrian rocks; and in Goodland Mountain, Albert County.

A large deposit of wad, or bog ore, occurs in a homogeneous bed from a few inches to 30 feet thick near Hillsborough. The bed has been shown to have an average thickness of $6 \frac{1}{2}$ feet over an area of 17 or 18 acres. Other deposits of similar nature are found near Fredericton and at Queensbury, York County, and at Lincoln, Sunbury County.

The following is an analysis of wad from Hillsborough:

Analysis of wad from Hillsborough, New Brunswick. ${ }^{a}$

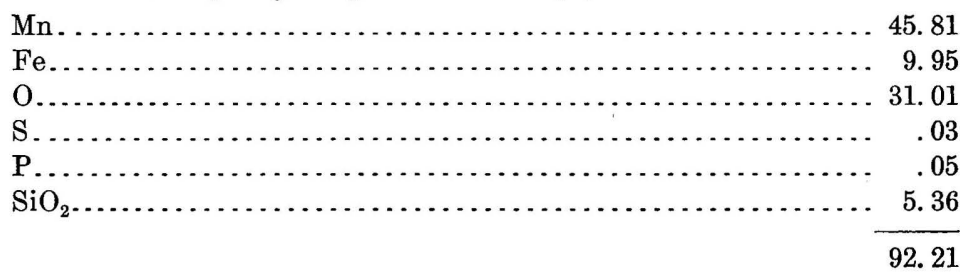

$a$ Eighteenth Ann. Rept. U. S. Geol. Survey, pt. 5, 1897, p. 311. 


\section{NOVA SCOTIA.}

Distribution of ores.-Manganese ores are found in Nova Scotia on the shores of Minas Basin, on the Atlantic coast, and in Cape Breton. They occur as pyrolusite and as wad in rocks of all ages ranging from Carboniferous to pre-Cambrian. Only the pyrolusite has been mined to any extent. Manganiferous iron ores, carrying up to 14 per cent manganese, are found in different parts of the province. Most commonly the manganese deposits occur in the lower Carboniferous limestone, which is very characteristic and widespread, being found in Kings, Hants, Cumberland, Colchester, Pictou, and Antigonish counties, and in the four counties of the island of Cape Breton.

The lower Carboniferous limestone series consists of sandstone shale, grit, and limestone, with beds of gypsum and marl. In places they rest directly on pre-Carboniferous rocks; in other places they are separated from those rocks by the "Lower Coal Measures," or by beds of conglomerate.

In the northern part of Hants County, in the Minas Basin district, the Carboniferous marine limestone and the underlying Devonian sandstone and quartzite are found in a series of east and west folds, shifted and broken by transverse subordinate flexures. The presence of manganese in the upper of these divisions is first observable on the east at the mouth of Shubenacadie River, where a dark-colored limestone underlies the gypsum and is associated, a short distance east of the river, with red shales carrying veins of red hematite, manganese oxides, and calcite. The westward continuation of this horizon is noticeable at Tenny Cape, where a series of these measures, extending to Walton and Cheverie, about 15 miles, contains several beds of limestone, which apparently underlie the gypsum and bear manganese. The rocks dip steeply southward, away from the shore, and within a short distance the manganese-bearing beds disappear under the gypsum and other overlying beds, but reappear south of Windsor and at Douglas, 15 miles south of Tenny Cape, near the line of their junction with the pre-Carboniferous rocks. In this range of measures the manganese appears to be principally connected with a compact red and gray dolomite. At the western end of the district it occurs as veins in conglomerates and sandstones, and also in limestones in places where they are decidedly magnesian.

Tenny Cape mines. - The most important deposits of manganese in Nova Scotia are those of the Tenny Cape mines in Hants County, on the south shore of Minas Basin, midway between Noel and Walton. They were discovered in 1862, and have been worked intermittently since that date. The ores occur along the outcrop of the dolomitic limestone and shale layer, which dips steeply southward and is generally less than 300 feet thick. This layer is very much brecciated, 
being composed of small fragments closely packed together, with here and there large solid masses. It is underlain by a massive sandstone of Devonian age, ${ }^{a}$ in some places separated from it by a layer of hard red clay, 2 to 4 inches thick, overlain by gypsum. The ore is found in the brecciated portions, between the fragments and surrounding them, and in the large solid masses along bedding planes and cross fractures. It occurs in the form of flat nodules, seams, and pockets, the last either isolated or connected by thin seams of ore. The seams vary in thickness from 1 to 6 inches, and the pockets from 1 inch to several feet. Some of the pockets are reported to have produced 300 . tons of ore.

The ore is chiefly high-grade fibrous pyrolusite, associated with psilomelane. Manganite occurs in small quantities and has a compact and partly fibrous structure. In some places, calcite, selenite, barite, and limonite are found in considerable quantities with the ore; at other places the ore is free from gangue.

Cheverie mine.-West of the Tenny Cape mine, near Cheverie on Minas Basin, is the Cheverie mine.

The ore at this locality is a black crystalline mixture of pyrolusite and manganite associated with calcite in a network of small veins from one-eighth inch to 4 inches thick, in a breccia composed of fragments of massive and shaly limestone. It commonly encircles fragments or penetrates along the bedding planes of unbroken fragments. Much of the calcite occurs in long crystals at right angles to the vein walls, the manganese filling the center.

The following are analyses of manganese ore from Tenny Cape: ${ }^{b}$

Analyses of manganese ore from Cheverie and Douglas mines, Tenny Cape, Nova Scotia.

\begin{tabular}{|c|c|c|}
\hline & Douglas. & Cheverie. \\
\hline \multirow{6}{*}{ 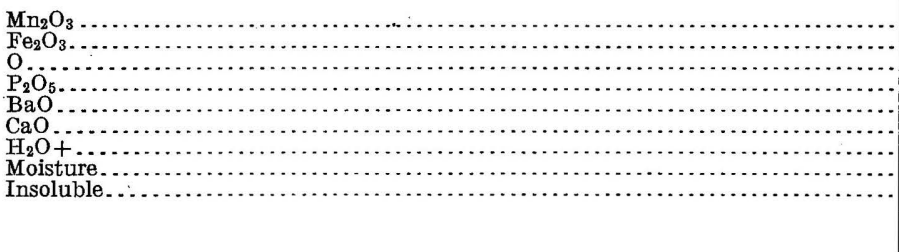 } & $\begin{array}{r}84.620 \\
.603\end{array}$ & $\begin{array}{r}90.15 \\
2.55\end{array}$ \\
\hline & 7.035 & 1.029 \\
\hline & .724 & 1.12 \\
\hline & & \\
\hline & $\begin{array}{l}\text { 1. } 66 \\
1.728\end{array}$ & $\begin{array}{l}2.05 \\
2.80\end{array}$ \\
\hline & 100.00 & 99.699 \\
\hline $\begin{array}{l}\mathrm{Mn} \\
\mathrm{F}\left(\mathrm{P}_{1}\right.\end{array}$ & $\begin{array}{r}53.47 \\
.42\end{array}$ & $\begin{array}{r}56.97 \\
1.78 \\
.45\end{array}$ \\
\hline
\end{tabular}

a Denis, Theo., op. cit., p. 1555.

$b$ Penrose, R. A. F., jr., op. cit., pp. 522, 524; also Mineral Resources U. S. for 1885, p. 353. 
Analyses of manganite from Tenny Cape, Nova Scotia.

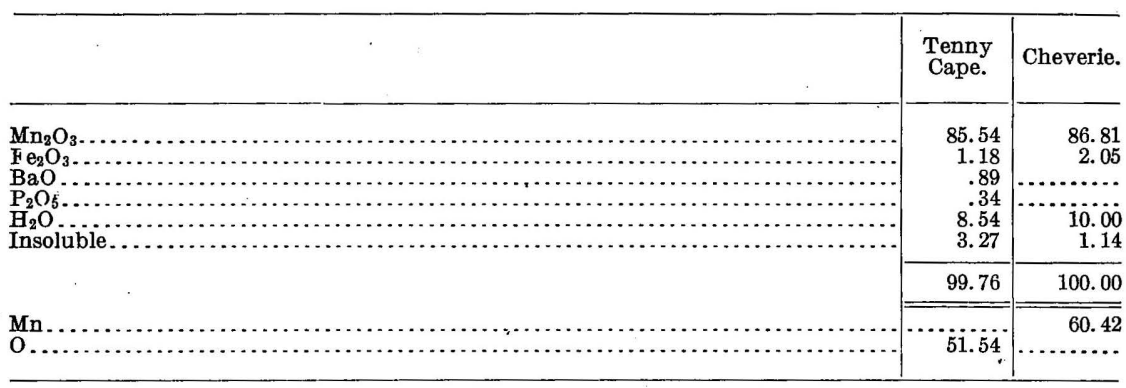

Other deposits in Minas Basin region.-Other deposits in the Carboniferous limestone in this vicinity are at the Parker mine, which is three-fourths of a mile northwest of Tenny Cape and shows the same type of ore as the latter; at the Moose Brook mine, 4 miles northeast of Tenny Cape; at the Walton mine and other localities near Walton, where the ore occurs as manganite and pyrolusite associated with barite in a breccia similar to that at Cheverie; near Windsor, in veins and pockets in limestone and sandstone; and at Noel, Douglas, and Rawdon.

Other deposits in northern counties.-Lower Carboniferous limestones at Minudie and Amherst, Cumberland County, have yielded small quantities of a soft fine-grained pyrolusite, that from Minudie showing on analysis 97.04 per cent of manganese peroxide. Ores similar to those of Tenny Cape are found at Onslow and on Salmon River near Truro, Colchester County, the latter yielding 92 to 95 per cent manganese peroxide. In these localities there are red shales and sandstones and beds of dark bluish limestone, covered by beds of gravel and clay, which contain nodules of granular pyrolusite. The ore also occurs in veins up to 4 inches in thickness in the sandstones, and in irregular nests and layers in the limestone. Calcite, barite, and selenite are found as gangue in the veins, the manganese occurring as fibrous oxide. Near Glengarry station, in Pictou County, nodules of fibrous pyrolusite, containing 84 per cent peroxide of manganese, are found with calcite in the dark-blue limestone near its junction with the pre-Carboniferous rocks. Bowlders of a mixture of psilomelane and manganite occur at Springville, Pictou County, lying on the dark limestone and on the associated red shales.

Cape Breton Island.-In Cape Breton Island ores are-found in the mountainous district between the Atlantic coast and Bras d'Or Lake The country rock consists of felsite overlain by a basal conglomerate and a series of shales and grits, which are in turn overlain by limestone. All are of lower Carboniferous age, and are overlain by "Millstone grit.". Locally the limestone and shales are absent and the "Millstone grit" lies directly on the basal conglomerate. The 
manganese ore occurs in beds associated with limestone and red shale, which dip at angles varying between $25^{\circ}$ and $32^{\circ}$. The rocks here are compact and not shattered as those of the Minas Basin district.

The only deposit of economic importance on the island is at the Moseley iron mine, near the head of Loch Lomond, in the western part of Cape Breton County. The ore is found in both crystalline and massive forms, part of it being pyrolusite, part manganite. Associated with it as gangue are barite, calcite, and selenite. It occurs as nodules, pockets, and interbedded layers in limestone and in overlying arenaceous soft red shale, being most abundant in the latter. In some places it impregnates a coarse conglomerate that overlies the red shale. The ore layers vary up to 18 inches in thickness, and at many places are connected by cross stringers.

A short distance southeast of the main mine manganese ore occurs as a bed underlying a dark limestone layer in a formation consisting of red and green shale, with coarse grits. The limestone and ore have an average thickness of 8 inches.

The ores from the Moseley mine contain about 88.9 per cent manganese peroxide with 2 per cent ferric oxide.

Deposits outside of Carboniferous areas.-Small manganese deposits are found in many places in Nova Scotia outside of the Carboniferous areas. Near Mount Uniacke, between Halifax and Windsor, manganese ore is found in small pockets and veins penetrating granite. It also occurs in the quartzites of the auriferous lower Cambrian of the Atlantic coast; in veinlets in the granites of Musquodoboit; as small irregular seams in the granite of Ship Harbor; and in quartzites and slates of Devonian age in the hills south of Wolfville, in Kings County. In the Triassic sandstone of Kings County manganese ore occurs in the bedded form near Cornwallis and Wolfville, and in the Triassic trap it is said to line cavities in association with zeolites.

Wad is found in superficial deposits in many localities in Nova Scotia: Among them are Jeddore, Ship Harbor, St. Margarets Bay, Shelburne, La Have, Chester, Parrsborough, Springhill, and Pictou and Antigonish counties.

Manganiferous iron ores occur in several localities in Nova Scotia, especially in Pictou, Colchester and Antigonish counties.

At several localities near Springville, Pictou County, limonite ores, found along the junction of the lower Carboniferous and pre-Carboniferous rocks, are heavily charged with manganese. The ore is dull brownish in color and softer than ordinary limonite. In Antigonish County similar ferriferous manganese ores have been found in the drift at several localities.

At the Londonderry iron mines, Colchester County, in a great vein of brown hematite, associated with ocher, ankerite, sideroplesite, and calcite, in strata of "Lower Silurian age," secondary changes have 
locally enriched the deposit with manganese peroxide up to 14 per cent. Some of the manganese is present as manganite in incrusting fibers and some is present as wad.

Analyses.-The following are analyses of manganiferous iron ore from Nova Scotia:

Analyses of ferriferous manganese ores from Springville, Nova Scotia.a

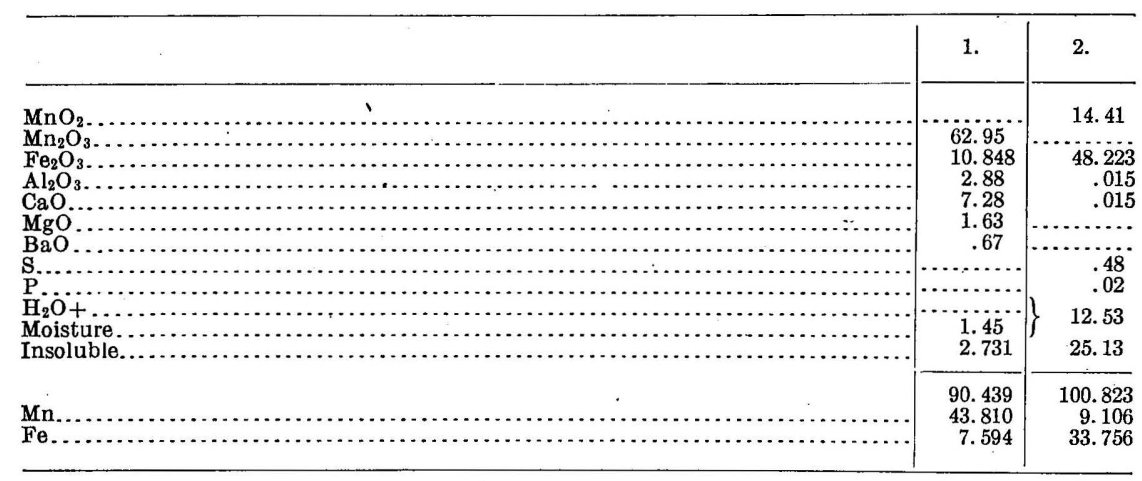

a Mineral Resources U. S. for 1885, p. 354 .

Analysis of ferriferous wad from Londonderry, Nova Scotia.

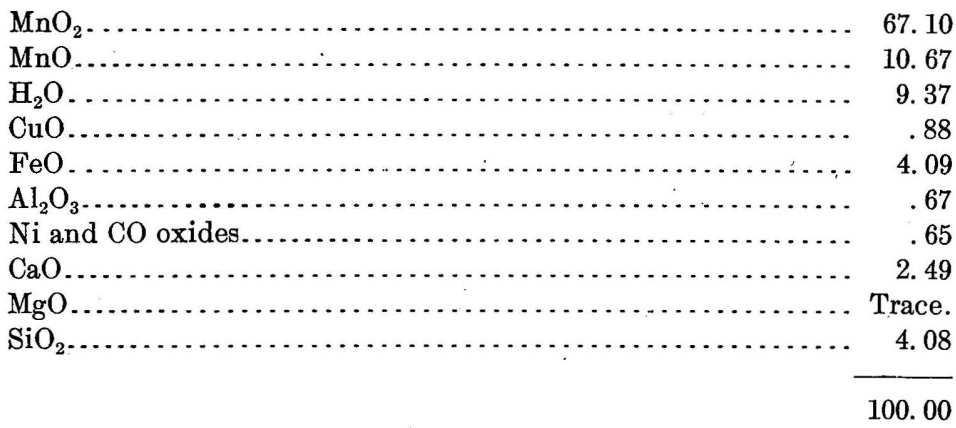

OTHER CANADIAN DEPOSITS.

A few deposits of manganese occur in Canada outside of Nova Scotia and New Brunswick. On Amherst Island of the Magdalen group, in the Gulf of St. Lawrence, manganese ores occur associated with sandstone, shale, gypsum, and doloritic rocks of lower Carboniferous age. The ore is principally crystalline manganite, containing 45.61 per cent peroxide, but pyrolusite occurs in it. It is found in loose blocks in débris at the foot of a cliff.

In the "eastern townships" in Quebec manganiferous dolomites are found in the metamorphic rocks. They contain manganese up to 8 per cent and in many places are stained brownish at the surface, owing to its oxidation. Small deposits of bog manganese occur locally. 
At Bachewanung Bay, on Lake Superior, manganese has been found in stringers in a reddish trappean rock, with quartz, calcite, and fluorspar. The ore, which is massive with small geodes of crystals, contains 60 per cent peroxide of manganese and is described as manganite.

Small quantities of manganese oxide are said to occur in some of the iron-ore deposits in the Gunflint Lake district in western Ontario.

In the Nastapoka chain of islands on the east coast of Hudson Bay carbonate of manganese is reported to occur in association with spathic iron ore. The ores yield about 25 per cent metallic iron and 24 per cent carbonate of manganese.

Little is known of the manganese deposits of western Canada, but no deposits of importance have been reported.

\section{NEWFOUNDLAND. $a$}

In Newfoundland manganese carbonate of brownish color occurs, interbedded with slates "of probable Silurian age," at Placentia Bay. It is partly oxidized in places and is reported to have the following composition:

Analysis of manganese carbonate from Newfoundland.

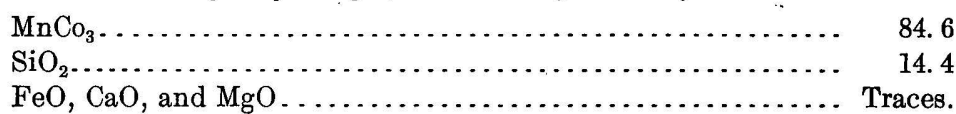

CUBA. $b$

SITUATION OF DEPOSITS.

Manganese deposits of considerable importance occur in the southeastern part of Cuba, in the province of Santiago de Cuba. The manganese-bearing area is located in the valleys of Cauto and Guantanamo rivers and on the north flanks of the Sierra Maestra the summits of which rise above it on the south to a height of 7,670 feet above sea level. It extends from Guantanamo on the east to Manzanillo on the west. The following description of the district is taken largely from an article by Spencer: ${ }^{c}$

$a$ Hunt, T. Sterry, Geological survey of Canada, 1879-80, p. 106.

$b$ References on Cuban manganese-ore deposits:

Spencer, A. C., Manganese deposits of Santiago, Cuba: Bull. U. S. Geol. Survey No. 213, 1903, p. 251.

Spencer, A. C., The manganese deposits of Santiago Province, Cuba (illustrated): Eng. and Min. Jour., August 23, 1902, p. 247.

Souder, Harrison, Mineral deposits of Santiago, Cuba: Trans. Am. Inst. Min. Eng., vol. 35, 1904, p. 308.

Brown, H. C., Mineral resources of Cuba in 1901, p. 24.

Hayes, C. W., Vaughan, T. W., and Spencer, A. C., A geological reconnaissance of Cuba, 1901, p. 62. Mineral Resources U. S. for 1888, p. 137.

Mineral Resources U. S. for 1891, p. 142.

Eighteenth Ann. Rept. U. S. Geol. Survey, pt. 5, 1897, p. 312.

Twentieth Ann. Rept. U. S. Geol. Survey, pt. 6, 1899, p. 146.

Twenty-first Ann. Rept. U. S. Geol. Survey, pt. 6, 1900, p. 146.

Mineral Resources U. S. for 1902, p. 147.

$c$ Spencer, A. C., Manganese deposits of Santiago, Cúba: Bull. U. S. Geol. Survey No. 213, 1903, p. 251. 37336 ${ }^{\circ}$-Bull. $427-10-12$ 
The rocks of this region form an east and west synclinal basin. Those exposed on the crests of the Sierra Maestra dip to the north and consist of coarse well-stratified volcanic breccias. They pass, on the north slope, beneath alternating strata of marine sediments and fine-grained volcanic tuff, which are in turn covered by basalt flows and still other fragmental volcanic rocks. This essentially volcanic series grades upward into and finally gives place to limestone and other marine sediments.

The ore is chiefly pyrolusite, but other oxides of manganese occur. The principal deposits comprise three groups of mines-the Ponupo group, the Boston mines, and the Ysabellita group-located east of Cristo, a town on the Sabanillo and Maroto Railroad, about 11 miles northeast of Santiago. Smaller deposits are found at several places south of Cristo and at Dos Bocas.

$$
\text { PONUPO, BOSTON, AND YSABELLITA MINES. }
$$

The Ponupo, Boston, and Ysabellita groups of mines are located on the crests of small anticlines of sedimentary rocks, well within the general synclinal basin above mentioned.

The Boston and Ysabellita mines are 3 and 4 miles, respectively, east of Cristo, and the Ponupo mines, which are the most important in the district, are 12 miles northeast. Ponupo is the terminal of the Ponupo branch of the Sabanillo and Maroto Railroad, which leaves the main line a short distance north of Cristo. It consists of seven mines, of which the Vencedora and Sultana are the most important.

The Boston and Ysabellita mines are supposed to be on the same anticlinal arch, and the Ponupo mines are on another anticline, the relation of which to the first is not known. The ores are associated with jasper masses in green sandstone. According to Spencer there is good reason to believe that all these mines are at the same stratigraphic horizon. A limestone band composed of Foraminifera of the type Orbitoides lies just above the ore-bearing bed at each of these localities, and the ore is found in a loose, disintegrated, dark-green sandstone of exactly the same nature in each place. Where the sandstone has been exposed at some distance from the ore bodies, as at the.Boston mines, it is found to be composed largely of shells of a large species of Foraminifera, filled with glauconite. Near the ore bodies the calcareous shells are not seen.

Large masses of jasper occur at the Boston and Ysabellita, as well as the Ponupo mines. At the Boston mine masses of jasper are entirely surrounded by ore. At the Ponupo mines there is highgrade ore at the contact of the jasper and decomposed rock and lowgrade ore mixed with rock farther away. Here the ore has also partly replaced the foraminiferal limestone above the ore-bearing bed. The jasper, generally red or yellow, is in irregular masses form- 
ing knolls, on which the mines are located, and the ore is in equally irregular pockets associated with them. Locally streaks and veins of jasper penetrate the ore in all directions, and in such places it is valueless. Generally, however, the ore is found in nodules easily separated from the matrix.

\section{DEPOSITS SOUTH OF CRISTO AND AT DOS BOCAS.}

The deposits south of Cristo and at Dos Bocas are in the mixed volcanic and sedimentary series on the south arm of the syncline, where the rocks dip at various angles to the north. Although these strata are at a different horizon geologically, the relations of ore, jasper, and country rock are the same in these mines as in the deposits east and northeast of Cristo.

The deposits are associated with lenses of jasper in a disintegrated green rock with red spots. The original nature of the green rock is not known, but it is possibly the alteration of a green sand or glauconite formation. The jasper masses vary from a few inches to 15 or 20 feet in thickness, and in some places have a lateral extent of several hundred feet along the bedding. They are very irregular and follow the bedding only in a general way.

The ore occurs (1) filling spaces between the jasper and the country rock, (2) in veins in the jasper, and (3) disseminated through the country rock adjacent to jasper masses. In the last position the ore commonly has the form of nodules arranged along the bedding planes of the decomposed rock which it has partly replaced. The relation of the ore and jasper is very intimate, minute veins of ore penetrating the jasper, and siliceous veins similarly penetrating the ore. This suggests a contemporaneous secondary origin of ore and jasper after the deposition of the country rock.

\section{OTHER DEPOSITS.}

Besides the San Luis district, which includes the Ponupo, Boston, and Ysabellita mines and the mines south of Cristo and near Dos Bocas, several other localities in southeastern Cuba have manganese deposits which may become important commercially. These include the Majuba Hill district, about 21 miles northwest of Santiago; the Los Negros district, about 75 miles west-northwest of Santiago; the Bueycito district, about 42 miles east of Manzanillo; the Portillo district, near Portillo, on the south coast; and the Macio district, between Guama and Santiago de Cuba.

Very little exploration work has been done in these localities, but the ore found up to the present has been chiefly in the form of surface fragments and small scattered deposits. 


\section{ANALYSES.}

The following are analyses of Cuban manganese ores:

Analyses of manganese ore from the Ponupo mines: Cuba.a

\begin{tabular}{|c|c|c|c|c|}
\hline Source of sample. & Mn. & P. & $\mathrm{Fe}$. & $\mathrm{SiO}_{2}$ \\
\hline 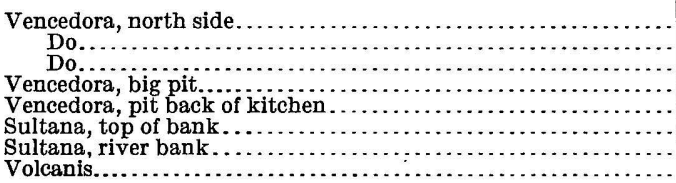 & $\begin{array}{l}49.19 \\
51.91 \\
50.51 \\
51.79 \\
51.12 \\
51.36 \\
44.63 \\
48.22\end{array}$ & $\begin{array}{r}0.062 \\
.049 \\
.057 \\
.063 \\
.033 \\
.070 \\
.038 \\
.063\end{array}$ & $\begin{array}{r}2.42 \\
.79 \\
.52 \\
.99 \\
.98 \\
.79 \\
1.77 \\
4.39\end{array}$ & $\begin{array}{l}2.72 \\
1.09 \\
1.33 \\
1.30 \\
1.17 \\
1.22 \\
6.11 \\
3.00\end{array}$ \\
\hline
\end{tabular}

$a$ Twentieth Ann. Rept. U. S. Geol. Survey, pt. 6, 1899, p. 140.

Cargo analyses of Cuban manganese ore ${ }^{a}$

\begin{tabular}{|c|c|c|}
\hline & 1. & 2. \\
\hline $\begin{array}{l}\mathrm{Mn} \\
\mathrm{SiO}_{2} \ldots \ldots \\
\mathrm{P}\end{array}$ & $\stackrel{47}{4} .03$ & $\stackrel{53}{9} .10$ \\
\hline
\end{tabular}

a Eighteenth Ann. Rept. U. S. Geol. Survey, pt. 5, 1897, p. 312.

Analyses of manganese ore from the Boston mines, Cuba.a

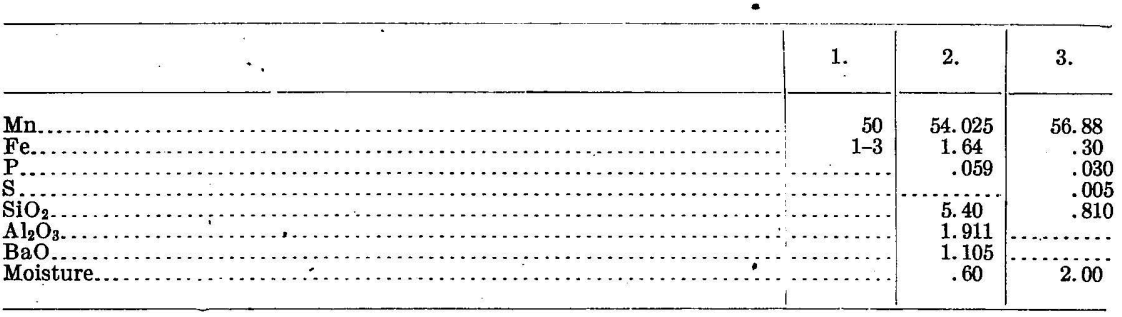

$a$ No. 1 is from Mineral Resources U. S. for 1902, p. 147; Nos. 2 and 3 from Souder, Harrison, op. cit., p. 312.

\section{OTHER WEST INDIES.}

A bed of manganese ore of superior quality is reported from the island of St. Martin in the West Indies, and another deposit has recently been discovered in Haiti.

\section{MEXICO. $a$}

Manganese ore has not been mined to any extent in Mexico. Few, if any, of the iron-ore deposits have associated manganese, though veins containing pure manganese ore are found at various localities. Veins of pyrolusite, psilomelane, and wad are found in the Cretaceous limestones in the districts of Acatlan and Tepexi, in the southern part

$a$ References on Mexican manganese-ore deposits:

Aguilera, José G., The geographical and geological distribution of the mineral deposits of Mexico: Trans. Am. Inst. Min. Eng., vol. 32, 1902, p. 505.

Biddle, C., Notes from Magdalena Bay, Mexico: Eng. and Min. Jour., vol. 82, p. 361. 
of Puebla. Irregular veins of psilomelane occur in the Cretaceous limestones in Sierrita de Metoche, near Coxcatlan, Guerrero. Manganese sulphide, alabandite, accompanies the silver-lead minerals of Sierrita de Tepeyahualco, Puebla. Manganese silicate and oxides accompany the minerals of some of the silver veins, the former being found in the unoxidized portion and the latter in the upper oxidized zone. The carbonate, rhodochrosite, is found in the intermediate zone. There are veins of this mineral at Pachua and Real del Monta, Hildalgo, and in the deposits of Tetela del Oro, Puebla.

Manganese ore is also reported from Margarita Island, Magdalena $\mathrm{Bay},{ }^{a}$ on the west coast of Lower California.

\section{PANAMA. $b$}

The Nombre de Dios manganese-bearing region of Panama covers an area of nearly 300 square miles along the Caribbean Sea, beginning near Porto Bello and extending eastward for 35 miles. All the ore is found on the east slopes of the Cordilleras at a maximum distance of 10 miles from the coast. It occurs on the lowlands near the sea, as well as on the slopes and tops of the ridges. One deposit, the Culebra, is on an island a short distance from the coast. The ore is shipped from the port of Nombre de Dios. The following six mines have shipped ore from the district: Viento Frio, Carano, Concepcion, Soledad, La Guaca, and Culebra. The ore occurs in pockets in clay, which is generally yellow at the surface and bright red where associated with ores, though all shades from red to white occur. The rocks immediately associated with the manganese deposits are of sedimentary origin, probably originally shales, but so greatly altered as to leave their original character doubtful. Near some of the deposits they have been metamorphosed into jasper and thus preserved. The underlying rock is reported to be serpentine.

The ores occur ás oxides, principally psilomelane, but also pyrolusite and braunite. Pyrolusite and psilomelane are intimately mixed, blending into each other. Pyrolusite fills many cavities in the psilomelane and commonly occurs in radiating crystals on a base of psilomelane.

Where the clay is worn away the pockets or masses of ore stick above the ground like bowlders. They vary from a few pounds to 500 tons in weight, and one mass has been found from which 1,000 tons of good ore were taken. Not all bowlders are pure ore, but many contain ore-bearing rock.

$a$ Biddle, C., loc. cit.

$b$ References on manganese-ore deposits of Panama:

Chibias, E. J., Manganese deposits of the department of Panama, Republic of Columbia: Trans. Am. Inst. Min. Eng., vol. 27, 1897, p. 63.

Eighteenth Ann. Rept. U. S. Geol. Survey, pt. 5, 1897, p. 313.

Mineral Resources U. S. for 1902, p. 147. 
The first shipments from the region were made in 1871, from the village of Viento Frio. The early mining was primitive, consisting of breaking up the surface bowlders near the sea and packing the ore to the coast upon men's backs.

The following are complete analyses of ore from Panama:

Analysis of pure ore from the Soledad mine, Panama. ${ }^{a}$

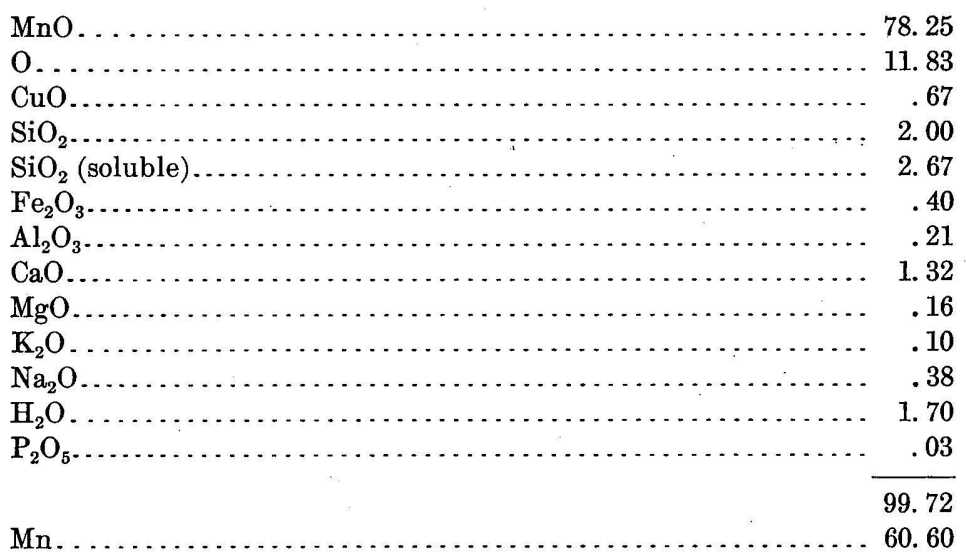

Analysis of average ore from La Guaca mine, Panama.b

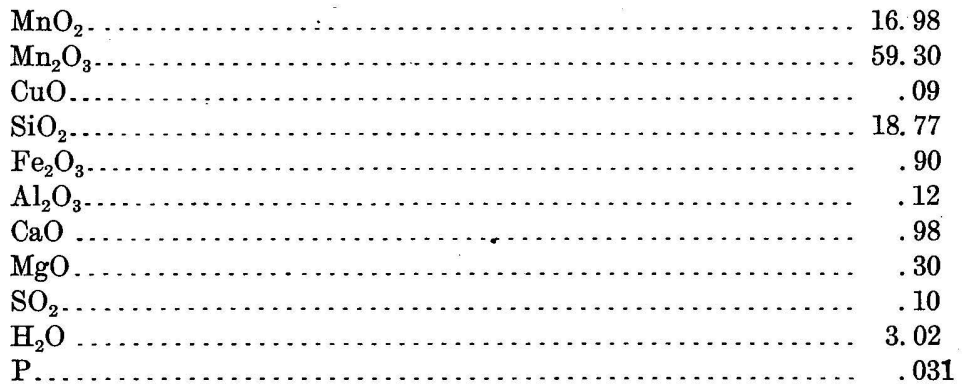

The following are other analyses of manganese ore from Panama:

Cargo analyses of Panama manganese ore. ${ }^{c}$

\begin{tabular}{|c|c|c|c|c|c|}
\hline & 1. & 2. & 3. & 4. & 5. \\
\hline $\begin{array}{l}\mathrm{Mn} \\
\mathrm{SiO} \\
\mathrm{H}_{2} \mathrm{O} \ldots \ldots \ldots \ldots \\
\mathrm{Phos}\end{array}$ & $\begin{array}{l}53 \\
13\end{array}$ & $\frac{47.5}{20}$ & $\begin{array}{l}57.502 \\
4.18 \\
2.734 \\
.054\end{array}$ & $\begin{array}{c}56.788 \\
5.82 \\
1.415\end{array}$ & $\begin{array}{c}54.561 \\
9.88 \\
5.372\end{array}$ \\
\hline
\end{tabular}

a Mineral Resources U. S. for 1902, p. 149.

$b$ Chibias, E. J., loc. cit.

c Eighteenth Ann. Rept. U. S. Geol. Survey, pt. 5, 1897, p. 314. 
Analyses of picked samples from Nispero, Panama. ${ }^{a}$

\begin{tabular}{|c|c|c|c|c|}
\hline & 1. & 2. & 3. & 4. \\
\hline 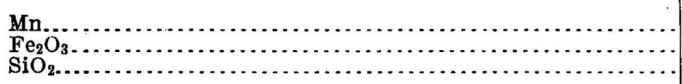 & $\begin{array}{r}63.74 \\
.28 \\
.25\end{array}$ & $\begin{array}{r}62.92 \\
1.13 \\
.39\end{array}$ & $\begin{array}{r}62.76 \\
.98 \\
5.42\end{array}$ & $\begin{array}{r}59.98 \\
1.19 \\
4.71\end{array}$ \\
\hline
\end{tabular}

a Eighteenth Ann. Rept. U. S. Geol. Survey, pt. 5, 1897, p. 314.

\section{SOUTP AMERICA.}

BRAZIL. $a$

Manganese ores are widely distributed in Brazil. Large deposits occur in the Miguel Burnier, Ouro Preto, and Lafayette or Queluz districts, in the State of Minas Geraes, and smaller deposits in the Nazareth district, in the State of Bahia. Ores are also reported from the States of Matto Grosso, Parana, and Santa Catharina, and from the region of Amazon River.

\section{NAZARETH DISTRICT.}

Situation.-The Nazareth district is about 16 miles west of Nazareth, a town which is on tide water about 30 miles west of Bahia and is reached by a steamer from that city by way of Jaguaripa River. Ore has been shipped from two mines situated close together, the principal one being the Pedras Pretas. The Nazareth-Amargosa Railway, running west from Nazareth, passes within half a mile of the mines.

G.eology.-The substance of the following description of the geology of the district is from the article by Branner. ${ }^{a}$

The city of Bahia stands upon crystalline schists cut by eruptive dikes. Immediately west of the city is a Cretaceous basin that extends westward almost within a mile of Nazareth, where the crystalline rocks again appear. At Nazareth the schists are so decomposed that solid rocks are to be seen in places only in the stream beds and here and there in the hills. It is in these decomposed rocks that

$a$ References on Brazilian manganese-ore deposits:

Branner, J. C., The manganese deposits of Bahia and Minas, Brazil: Trans. $\Lambda$ m. Inst. Min. Eng., vol. 29, 1899, p. 756.

Scott, H. K., The manganese ores of Brazil: Jour. Iron and Steel Inst., No. 1, 1900, p. 179.

Derby, O. A., On the manganese ore deposits of the Queluz (Lafayette) district, Minas Geraes: Am. Jour. Sci., July, 1901, p. 18.

Derby, O. A., On the original type of manganese-ore deposits of the Queluz district, Brazil: Am.Jour. Sci., March, 1908, p. 213.

Katzer, Ein eigentümliches Manganerz des Amazonasgebietes: Österr. Zeitschr. für Berg- und Hüttenwesen, vol. 46, 1898, pp. 41-46.

Stelzner, A. W., and Bergeat, A., Die Erzlagerstätten, pt. 1, pp. 254-255 and 263.

Twentieth Ann. Rept. U. S. Geol. Survey, pt. 6, 1899, p. 140.

Twenty-first Ann. Rept. U. S. Geol. Survey, pt. 6, 1900, p. 149.

Mineral Resources U. S. for 1900, p. 128.

Mineral Resources U. S. for 1901, p. 140.

Mineral Resources U. S. for 1902, p. 150.

Mineral Resources U. S. for 1905, p. 98. 
the manganese is found at the Pedras Pretas mine, 16 miles farther west.

In neighboring States granites and gneisses are associated with the schists. Nothing definite is known as to their age, but farther north rocks believed to be of Paleozoic age rest upon them unconformably.

The country in which the manganese mines are situated is the comparatively low, hilly, densely forested coastal region of eastern Brazil.

Ore deposits.-The Pedras Pretas mine is in soft earth, except where large masses of solid ore have been drifted into. Most of the ore thus far shipped has come from a great horizontal sheet that spreads out almost on the surface of the ground. (See fig. 31.) Underneath this, and connecting with it, is a sheet or vein standing at an angle of $60^{\circ}$ and varying in thickness from 1 to 33 feet. It seems evident that the horizontal surface sheet is the accumulation from the breaking up and weathering out of the ore in the underlying bed and the removal of the clays about it.

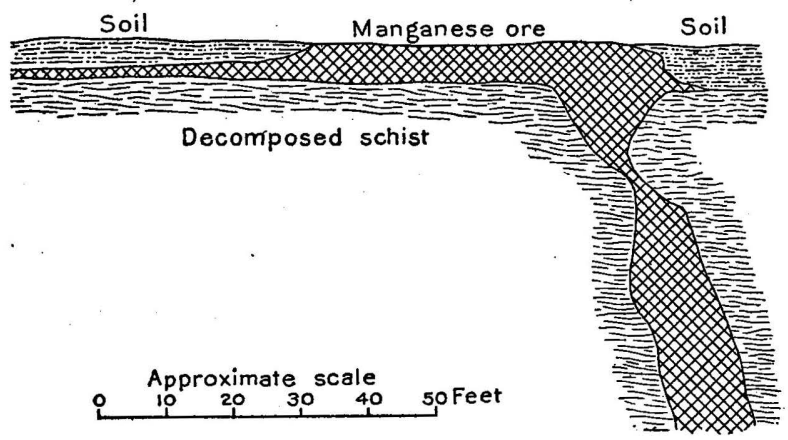

Frgure 31.-Section through the ore body of the Pedras Pretas mine, Brazil. (After Branner.)

The ore is psilomelane, occurring as lumps and large masses in the above-described beds. Some of the lumps are botryoidal in form, but most of them are angular. Many are more than 2 feet in diameter, the smallest ones shipped being about the size of a fist. Frequently masses are taken from the mines that weigh a ton and a half.

MINAS GERAES DISTRICTS.

GEOGRAPHY AND GEOLOGY.

The existence of manganese ores was discovered in the Miguel Burnier in 1888, and mining was begun at Usina Wigg in 1894. Active exploration of the surrounding territory, however, was not started until 1897. The following descriptions are condensed largely from the articles by Scott and Derby (cited on p. 183).

The deposits are situated along the main line of the Central Railway system northward from Lafayette to the point where the branch line to Ouro Preto turns off to the east, and along this branch line nearly to Ouro Preto. 
Lafayette is about 283 miles north of Rio Janeiro. The region along the branch line is very mountainous and is divided into the Miguel Burnier and Ouro Preto districts; the deposits north of Lafayette are in a gently undulating country known as the Lafayette district. Each of the districts is characterized by a different type of deposits.

According to Scott, ${ }^{a}$ the ancient crystalline rocks of Brazil are divided into two great series. The oldest is composed of various kinds of gneiss, which are frequently granitoid in texture, and which, with the massive granites and diorites injected into them, give the characteristic topographic features of needles and domes to the mountains formed by them. The second division is composed of a series of schistose quartzites, micaceous schists, and limestones and produces the characteristic jagged topographic features of monoclinal peaks and ridges. It has come to be kńown as the Itacolumite series trom a name given to its quartzitic members.

Intermediate in character and position between these two divisions, and perhaps constituting a third division, is a considerable body of

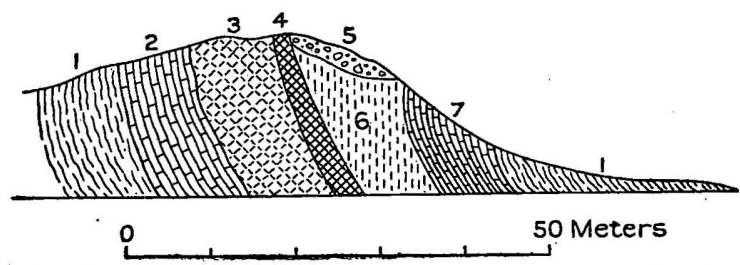

Frgure 32.-Typical section of the manganese-bearing series, Miguel Burnier, Brazil. (After Scott.) 1, Micaceous schists; 2, white limestone; 3, impure earthy ores of iron and manganese; 4 , manganese ore; 5, Iron-ore conglomerate or Canga; 6, Jacutinga or Itabirite formation; 7, gray. limestone.

true mica schists, of doubtful geologic relations because, in appearance at least, they shade off into the true gneisses on the one side and the micaceous schists or phyllites of the Itacolumite series on the other. All these rocks are cut by dikes and bosses of granite, syenite, diorite, diabase, and perhaps other types of eruptive rocks. The first three are more abundant in and characteristic of the gneissic division.

MIGUEL BURNIER DISTRICT.

Occurrence of the ores.-The Miguel Burnier deposits occur in a bed in the Itacolumite series. A typical section of the manganesebearing series is shown in figure 32 . The micaceous schists are the most important rocks of the district. They are of great thickness and much decomposed. The white limestone is about 33 feet thick. It is dolomitic and contains some iron and manganese and a very small amount of siliceous residue. The earthy iron and manganese ore bed is about 80 feet thick, including a manganiferous iron-ore stratum above and another below, varying in content of manganese 
oxides up to 20 per cent, and in ferric oxide up to 72 per cent. The upper iron-ore bed is micaceous. Between the iron-ore strata there are siliceous layers containing ferric oxide varying up to 15 per cent and a slight amount of manganese oxide, baryta, and alumina. The strata are dark colored or reddish and earthy, and above them is the manganese-ore bed.

This bed varies greatly in thickness, but probably has an average of about 7 feet. It is composed mainly of dark metallic ore showing bedding and interstratified with softer and hydrated ore. The hard ore makes up, on the average, 80 per cent of the bed and is generally in lenses or irregular blocks.

The Itabirite or Jacutinga formation consists of thin layers of fine quartz sand and micaceous iron ore in alternate bands. It varies from 65 to 130 feet in thickness and is generally much decomposed.

The gray limestone is dolomitic like the white limestone and contains iron and manganese, but has a much larger siliceous residue. It has about the same thickness as the white limestone.

The Canga or iron-ore conglomerate is a surface deposit on the Itabirite bed, consisting of broken fragments of iron ore recemented by limonite. Where free from quartz it is excellent iron ore.

The principal mines operating the manganese bed described above are the Miguel Burnier, Usina Wigg, and Bocania.

Analyses.-The following are analyses of ore from the Miguel Burnier district:

Analyses of two cargoes of manganese ore, Usina Wigg mine, Brazil.a

\begin{tabular}{|c|c|c|}
\hline & 1. & 2. \\
\hline 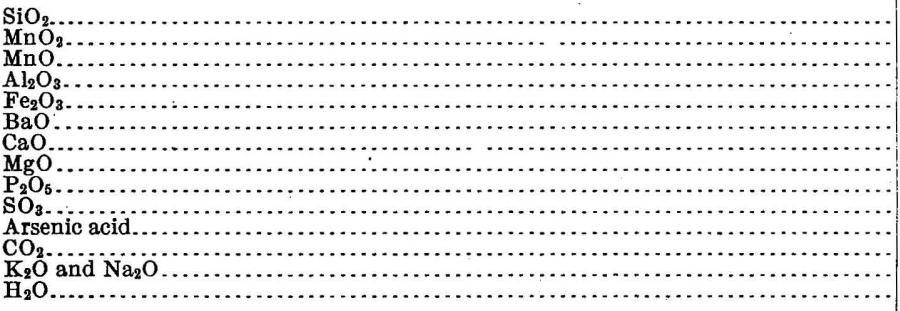 & $\begin{array}{r}0.53 \\
80.62 \\
5.47 \\
2.21 \\
2.50 \\
2.30 \\
.70 \\
1.05 \\
.07 \\
\text { Trace. } \\
\text { None. } \\
\text { None. } \\
\text { Trace. } \\
4.95\end{array}$ & $\begin{array}{r}1.25 \\
79.40 \\
6.23 \\
1.45 \\
4.03 \\
1.90 \\
\text { Trace. } \\
.05 \\
.048 \\
.065 \\
.034 \\
\text { None. } \\
.55 \\
4.74\end{array}$ \\
\hline $\begin{array}{l}M n \\
P\end{array}$ & $\begin{array}{r}100.30 \\
55.14 \\
.03\end{array}$ & $\begin{array}{l}99.757 \\
55.02 \\
.021\end{array}$ \\
\hline
\end{tabular}

$a$ Scott, H. K., op. cit.

Average analyses of manganese ore from Miguel Burnier district, Brazil.a

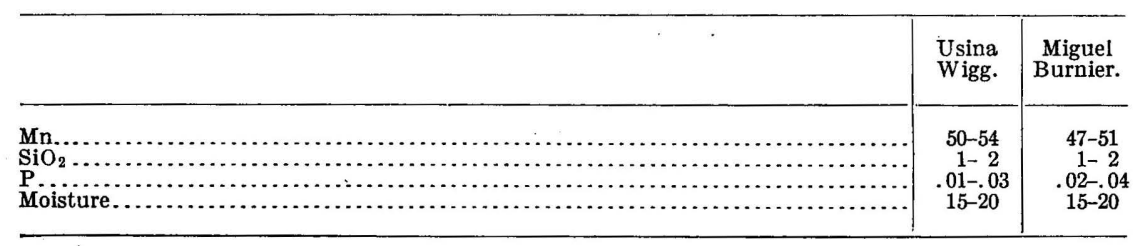

a Minera1 Resources U. S. for 1901, p. 142. 


\section{OURO PRETO DISTRICT.}

Occurrence of the ores.- The deposits west of Ouro Preto are in the same rock series as the ores of the Miguel Burnier region to the west, but their occurrence is different. The manganese ore is found in two distinct states:

(1) Crystallized ore occurs with the Jacutinga formation and is probably derived by denudation of the manganese bed beneath it and its subsequent recrystallization in superficial clays. It does not generally lie in well-defined beds, but is scattered over great areas.

(2) Hydrated ore is found as binding material in conglomerate masses of broken-down Jacutinga. The surface ore is of good grade, but the deeper ore is very siliceous. It contains an appreciable amount of nickel and cobalt, which give it a greenish appearance.

Properties containing these classes of ore are the Rodeio, Rodrigo Silva, Renera, and Gandarella, and some in the vicinity of Miguel Burnier and Bocania.

A later article on the Gandarella area $^{a}$ reports the occurrence of manganese in two forms of deposits, (1) as veins of pyrolusite, and (2) as pebbles and blocks of pyrolusite in stream beds, which are derived from deposits composed of pyrolusite fragments embedded in red marl, resulting from the decomposition of manganese-bearing rocks. Streams flowing through these deposits separate the fragments from the marl. Itabirite is commonly found where ores occur, so it is probable that the Gandarella deposits were derived from the manganese bed described as in the Miguel Burnier district.

Analyses.-The following are analyses of manganese ore from the Ouro Preto district:

Analyses of ore from Ouro Preto branch line manganese deposits, Brazil.b

$\mathrm{Mn}$

53.00

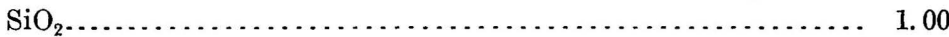

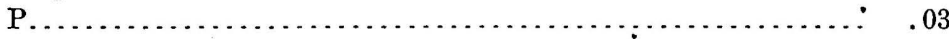

Analyses of manganese ore from the Gandarella estate, Ouro Preto district, Brazil.c

\begin{tabular}{|c|c|c|c|c|c|c|}
\hline & 1. & 2. & 3. & 4. & 5. & 6. \\
\hline 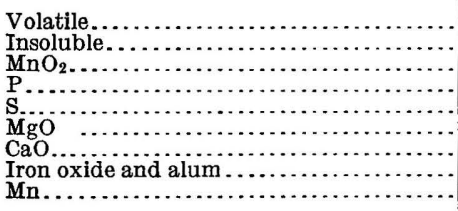 & $\begin{array}{r}1.00 \\
1.14 \\
92.31 \\
\text { Trace. } \\
\text { Trace. } \\
\text { Trace. } \\
.20 \\
6.50 \\
58.36\end{array}$ & $\begin{array}{r}1.00 \\
.50 \\
87.27 \\
\text { Trace. } \\
\text { Trace. } \\
\text { Trace. } \\
1.23 \\
10.50 \\
55.48\end{array}$ & $\begin{array}{r}1.50 \\
150 \\
78.94 \\
\text { Trace. } \\
\text { None. } \\
\text { None. } \\
\text { None. } \\
18.60 \\
49.90\end{array}$ & $\begin{array}{r}1.75 \\
78.45 \\
783 \\
\text { Trace. } \\
\text { Trace. } \\
\text { Trace. } \\
1.41 \\
18.12 \\
49.35\end{array}$ & $\begin{array}{r}1.95 \\
1.74 \\
89.76 \\
\text { Trace. } \\
\text { None. } \\
\text { None. } \\
1.50 \\
8.12 \\
56.74\end{array}$ & $\begin{array}{r}2.00 \\
1.65 \\
90.79 \\
\text { Trace. } \\
\text { None. } \\
\text { None. } \\
.90 \\
7.00 \\
57.30\end{array}$ \\
\hline
\end{tabular}

$a$ Mineral Resources U. S. for 1901, p. 140.

$b$ Mineral Resources U. S. for 1905 , p. 98.

c Mineral Resources U. S. for 1901, p. 142. 
LAFAYETTE OR QUELUZ DISTRICT.

General statement.-The deposits of the Lafayette or Queluz district are of a different nature from those of either the Miguel Burnier or the Ouro Preto district. The country rock is granite, gneiss, and mica schist, with a complete absence of limestones, Jacutinga, and others of the Itacolumite series. The ore is largely psilomelane and occurs in disseminated or brecciated surface deposits in clay or in large lenticular masses, varying in extent from a few meters to 100 meters or more. It is derived from the oxidation of lenses of manganiferous rock, consisting principally of rhodochrosite and tephroite. The clays containing the ore are derived from the disintegration of the granite and schist which inclose the manganiferous rock lenses. In this district are included the mines of Barrosa, Morro da Mina, Piquery, and São Gonçalo.

Piquery mine.-In a recent paper $^{a}$ Derby states that the oxidized ore of the Piquery mine has been largely removed, thus exposing the unaltered rock from which they were derived. This consists of a "black, fine-grained, highly-jointed, and somewhat flaggy rock with the aspect of a limestone, which contains broad bands and patches of a more massive yellowish-gray rock with the aspect of a quartzite." The first rock, on treatment with cold dilute acid, effervesces with the abundant separation of gelatinous silica, leaving an insoluble residue of graphite and spessartite. The solution contains much manganese and small amounts of lime and magnesia. The quartzite-like rock also effervesces somewhat, upon treatment with acid, with the separation of gelatinous silica. It contains a larger amount of spessartite than the other rock and some asbestiform amphibole; locally it contains considerable rhodonite concentrated in streaks and patches.

Microscopic examination shows the limestone-like rock to be composed of rhodochrosite, with probably dolomite, tephroite, and spessartite, the last being present in varying small quantities. Locally rhodonite occurs, and pyrite, ilmenite, and pyrophanite are accessory minerals. The quartzite-like rock differs from the other in containing a larger amount of spessartite and rhodonite, some amphibole, and a smaller amount of rhodochrosite and tephroite. The surface ores are largely psilomelane.

The following analyses give the composition of different phases of the limestone-like rock:

Analyses of unaltered manganiferous rock from Piquery mine, Brazil.b

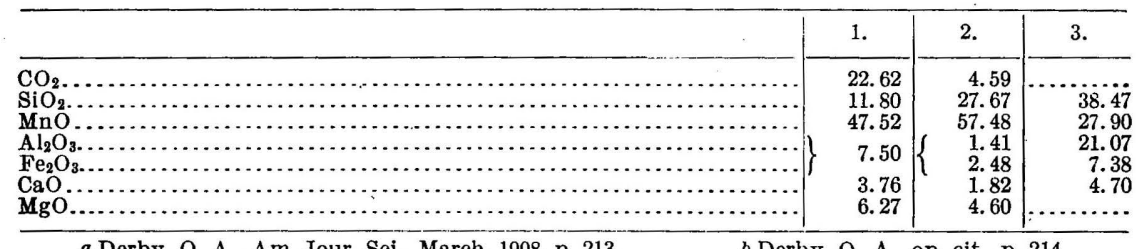

a Derby, O. A., Am. Jour. Sci., March, 1908, p. 213.

$b$ Derby, O. A., op. cit., p. 214. 
São Gonçato and Morro da Mina mines.-In the São Gonçalo and Morro da Mina mines the types of ores are very nearly the same. The unaltered material has a light-colored earthy aspect, platy structure, and spongy texture, due to numerous minute rounded cavities. The ore changes on weathering to the same type of oxidized ore (psilomelane) as that at Piquery.

Analyses.-The following are analyses of manganese ore from the Lafayette or Queluz district:

Average analyses of manganese ore from the Lafayette or Queluz deposits, Brazil.

\begin{tabular}{|c|c|c|c|}
\hline & 1. & 2. & 3. \\
\hline $\begin{array}{l}\text { Mn } \\
\text { SiO } \\
\text { P } \\
\text { Moisture }\end{array}$ & $\begin{array}{c}47-50 \\
3-6 \\
.08-12 \\
.\end{array}$ & $\begin{array}{c}49-51 \\
5-7 \\
.08-.10 \\
3-5\end{array}$ & $\begin{array}{c}50-52 \\
1-2 \\
.12-.15 \\
3-5\end{array}$ \\
\hline
\end{tabular}

1. Mineral Resources U. S. for 1905, p. 98.

2. Piquery mine. Mineral Resources U. S. for 1901, p. 142.

3. São Gonçalo mine. Same reference as 2 .

\section{AMAZON VALLEY.}

Peculiar manganese deposits, ${ }^{a}$ consisting largely of psilomelane, occur in the Amazon Valley in the district covered by the periodical floods. The ores occur embedded in sandstones in concretionary masses with botryoidal and stalactitic forms. In many parts the deposits contain an abundance of sand grains, so that they form a manganiferous sandstone. The ores are of the nature of bog deposits.

\section{CHILE. $b$}

\section{DISTRIBUTION OF DEPOSITS.}

Manganese ores are widely distributed in Chile, but the principal deposits are between $27^{\circ}$ and $34^{\circ}$ south latitude. They are all on the west slope of the Andes Mountains and are grouped into four districts, namely: Aculeo, in the Province of Santiago; Corral Quemada, in the Province of Coquimbo, and Huasco and Carrizal, in the Province of Atacama. Ores were discovered in the Aculeo district about 1880, and the first ore was exported in 1888. Mining operations soon ceased, however, because of lack of transportation facilities. About 1884 ore was discovered in the Corral Quemada district, and in 1886 the deposits of Carrizal were found.

\footnotetext{
$a$ Katzer, Ein eigentümliches Manganerz des A mazonasgebietes: Österr. Zeitschr. für Berg- und Hüttenwesen, vol. 46, 1898, pp. 41-46.

Stelzner, A. W., and Bergeat, A., Die Erzlagerstätten, pt. 1, p. 263.

$b$ References on Chilean manganese-ore deposits:

Mineral Resources U. S. for 1886, p. 206.

Mineral Resources U. S. for 1888, p. 139.

Mineral Resources U. S. for 1891, p. 138.

Mineral Resources U. S. for 1892, p. 208.

Sixteenth Ann. Rept. U. S. Geol. Survey, pt. 3, 1895, p. 439.

Twentieth Ann. Rept. U. S. Geol. Survey, pt. 6, 1899, p. 142.

Mineral Resources U. S. for 1901, p. 144.
} 


\section{ACULEO DISTRICT.}

The Aculeo district is situated about 32 miles south of Santiago and 6 miles from the Southern Railroad at Hospital station, to which the ore was carried in ox carts. The country is a rolling plain about 1,290 feet above sea level. The manganese ore was originally found outcropping on an elongated north and south hill about a quarter of a mile long and 350 feet above the plain. The lode has a dip of $30^{\circ} \mathrm{S}$. The ores are hard and brittle, have a reddish tinge, and yield about 50 per cent manganese. Several other deposits have been discovered recently in this region.

\section{CORRAL QUEMADA DISTRICT.}

The Corral Quemada or Coquimbo district is situated on a plain about 30 miles south of Serena and 20 miles from the railroad station of Angostura, and is 4,722 feet above sea level. The mines are located within a circumference of 5 miles. The ore was carried to Angostura on pack mules and thence to the port of Coquimbo by rail.

The deposits occur on the plain as horizontal layers between earthy matter. The ores are soft and crumble easily and have a dark bluish color. They are valuable on account of containing a considerable percentage of lime (12 to 20 per cent). Ores of a poorer grade than those on the plain occur on a black mound called Negra Loma, about 2,300 feet long and 50 feet above the plain.

The following are analyses of ores from the Corral Quemada district:

Analyses of manganese ores from the Corral Quemada district, Chile.

\begin{tabular}{|c|c|c|}
\hline . & $\begin{array}{c}\text { Santo Tomas } \\
\text { mine. }\end{array}$ & $\begin{array}{c}\text { Guillermo } \\
\text { mine. }\end{array}$ \\
\hline 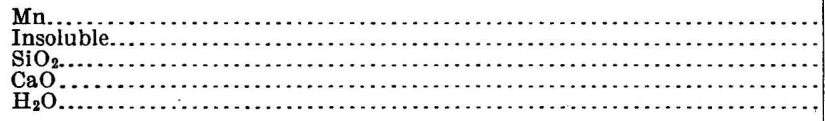 & $\begin{array}{r}51.65 \\
8.40 \\
5.95 \\
8.90 \\
.15\end{array}$ & $\begin{array}{r}50.08 \\
9.63 \\
4.73 \\
4.90 \\
.27\end{array}$ \\
\hline
\end{tabular}

a Twentieth Ann. Rept. U.S. Geol. Survey, pt. 6, 1899, p. 145.

HUASCO DISTRICT.

The Huasco district is on the north and south banks of Huasco River. It is sometimes included in the Carrizal district immediately to the north. On the south side of the river manganese ore of poor quality has been found in perpendicular lodes. It is of no commercial value. Northward from the river are other deposits, the principal ones being in a ridge about 18 or 20 miles distant, in association with large deposits of manganiferous iron ore. Beyond the ridge, in the plain about Salitre, there are scattered surface deposits of no value. 
CARRIZAL DISTRICT.

The Carrizal district is among barren mountain ridges southeast of the seaport of Carrizal. From that port a railroad ascends the mountains by a circuitous route to the copper camp of Cerro Blanco. About 30 miles east of the seashore a branch line 20 miles long turns southward and connects with the manganese district at the foot of the Tenmile Mountains. A spur from the mountains forms a line of pyramids and mounds, the highest of which are the Coquimbana, the Porvenir, and the Cerro Negra. Manganese ore is found on the tops of these mounds in parallel perpendicular lodes running down to an unknown depth. The lodes average from 13 to 17 feet wide, the spaces between them consisting of reddish clay and sandstone. They are faulted at many points, but by careful measurements the continuations are found. The ores are hard and brittle and of a dark-bluish color.

The following are analyses of manganese ore from the Carrizal district:

Analyses of manganese ore from the Carrizal district, Chile. ${ }^{a}$

\begin{tabular}{|c|c|c|c|}
\hline & Coquimbana. & Porvenir. & Monte Negra. \\
\hline $\begin{array}{l}\mathrm{Mn} \\
\mathrm{SiO}_{2} \ldots \ldots \ldots \\
\mathrm{P}\end{array}$ & $\begin{array}{l}51.18 \\
9.32 \\
.079\end{array}$ & $\begin{array}{l}40.26 \\
11.77 \\
.081\end{array}$ & $\begin{array}{r}48.85 \\
8.40 \\
.090\end{array}$ \\
\hline
\end{tabular}

$a$ Twentieth Ann. Rept. U. S. Geol. Survey, pt. 6, 1899, p. 146.

MINOR DEPOSITS.

Recently other manganese deposits have been discovered in Chile in the same general region. Among them are the deposits in the Los Chorros district south of Huasco, and in other places in Atacama, those near San Felipe in Aconcagua, and minor deposits in the Provinces of Santiago and Coquimbo.

\section{ANALYSES.}

The following are analyses of cargoes of Chilean manganese ores:

Cargo analyses of Chilean manyanese ores. ${ }^{a}$

\begin{tabular}{|c|c|c|c|}
\hline & 1. & 2. & 3. \\
\hline 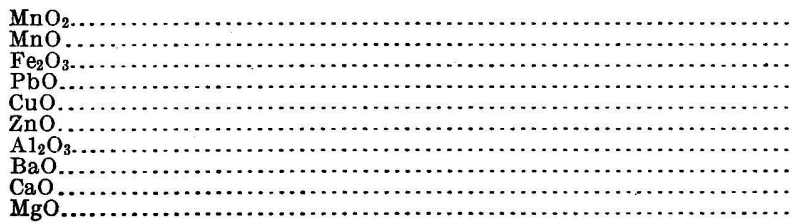 & $\begin{array}{r}69.23 \\
11.92 \\
1.62 \\
.09 \\
.15 \\
.10 \\
4.21 \\
\text { None. } \\
1.13 \\
.24\end{array}$ & $\begin{array}{r}55.06 \\
23.05 \\
4.71 \\
.06 \\
\text { None. } \\
\text { None. } \\
2.80 \\
\text { None. } \\
2.33 \\
.56\end{array}$ & $\begin{array}{r}66.03 \\
10.39 \\
1.50 \\
.05 \\
.14 \\
\text { None. } \\
1.60 \\
3.58 \\
5.36 \\
.13\end{array}$ \\
\hline
\end{tabular}


Cargo analyses of Chilean manganese ores-Continued.

\begin{tabular}{|c|c|c|c|}
\hline & 1. & 2. & 3. \\
\hline $\mathrm{K}_{2} \mathrm{O}$ & 2.86 & 0.46 & 0.15 \\
\hline $\begin{array}{l}\mathrm{Na}_{2} \mathrm{O} \\
\mathrm{SiO}_{2}\end{array}$ & $\begin{array}{r}.08 \\
4.17\end{array}$ & $\begin{array}{r}.26 \\
7.30\end{array}$ &. .11 \\
\hline $\mathrm{CO}_{2}$ & None. & $\begin{array}{l}.18 \\
.18\end{array}$ & $\begin{array}{l}2.153 \\
2.53\end{array}$ \\
\hline 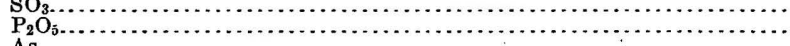 & & .13 & $\begin{array}{r}1.57 \\
.05\end{array}$ \\
\hline 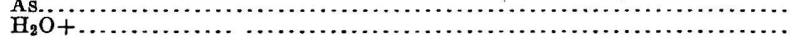 & 3.90 & $\begin{array}{r}.15 \\
3.00\end{array}$ & $\begin{array}{l}.04 \\
1.96\end{array}$ \\
\hline & $\begin{array}{l}99.92 \\
53 .\end{array}$ & $\begin{array}{r}100.19 \\
52.66\end{array}$ & $\begin{array}{l}99.94 \\
49.79\end{array}$ \\
\hline 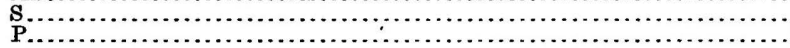 & .02 & $\begin{array}{l}.05 \\
.06\end{array}$ & .63 \\
\hline
\end{tabular}

EURASIA AND AFRICA.

SPAIN. $a$

Manganese occurs in Spain in the following associations and localities: (1) As carbonate and silicate in the Province of Huelva; (2) as oxide in the Provinces of Oviedo, Teruel, and Ciudad Real; and (3) in manganiferous iron ore in the Province of Murcia.

\section{HUELVA DISTRICT.}

Huelva is in southwestern Spain on the border of Portugal. Geologically the region consists of Paleozoic slates in which large tracts of eruptive rock are embedded. The ores are interbedded with Silurian (Culm) clay slate as lenses and beds associated with copper ore and quartzite or jasper. The lenses generally are found at the contact of jasper and clay slate and vary in length from 65 to 1,000 feet, and in thickness from a few feet to 150 feet or more. Several hundred of these lenses are known to exist. Pyrite is found in the same series in a similar manner.

The development of the mines was begun in 1860, the ores mined being oxides, largely psilomelane, which constituted the upper portions of the deposits. By 1880 most of the oxides had been removed and the mines were abandoned. About 1893 it was discovered that certain rocks in the abandoned workings had a black coating due to oxidation of the manganese compounds. Analysis showed these rocks to be manganese carbonate and silicate, and mining was recommenced.

The oxide ores, as a rule, do not extend much more than 65 feet below the surface, although occasionally they are found below 100

$a$ References on the manganese-ore deposits of Spain:

Mineral Resources U. S. for 1887, p. 159.

Sixteenth Ann. Rept. U. S: Geol. Survey, pt. 3, 1895, p. 453.

Eighteenth Ann. Rept. U. S. Geol. Survey, pt. 5, 1897, p. 318.

Wetzig, Bruno, Beitrüge zur Kenntniss der huelvaner Kieslagerstätten (Review): Trans. Inst. Min. Eng., vol. 33, pt: 6, 1908, p. 70 i.

Stelzner, A. W., and Bergeat, A., Die Erzlagerstätten, pt. 1, p. 251. 
feet, and in one mine at 330 feet. The oxides are mostly pyrolusite and psilomelane. They are now nearly exhausted, and the ore mined lately has been very largely carbonate and silicate, which occur in great quantities.

The following are analyses of carbonate ore from the Province of Huelva: ${ }^{a}$

$$
\text { Analysis of crude carbonate ore, Ysabel, Spain. }
$$

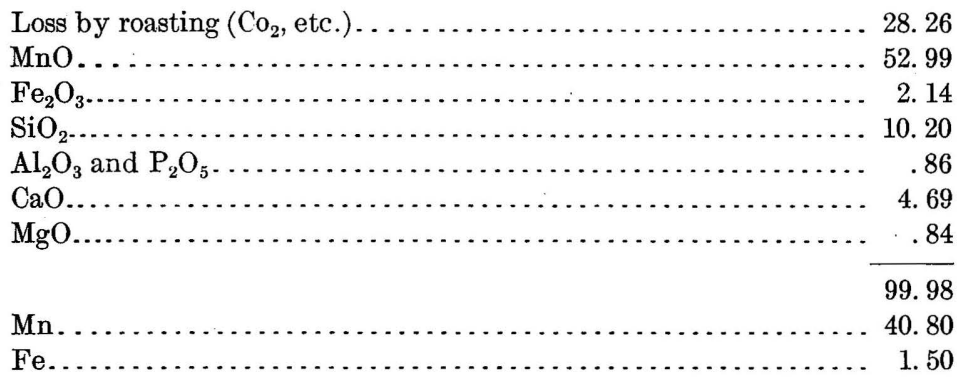

Cargo analyses of crude carbonate ore, Huelva, Spain.

\begin{tabular}{|c|c|c|c|}
\hline . & 1. & 2. & 3. \\
\hline $\begin{array}{l}\mathrm{Mn} \\
\mathrm{Si} \\
\mathrm{P} \mathrm{P}_{22}\end{array}$ & $\begin{array}{r}42.6 \\
10.46 \\
.07\end{array}$ & $\begin{array}{l}41.3 \\
10.5 \\
.10\end{array}$ & $\begin{array}{l}41.2 \\
9 \\
.08\end{array}$ \\
\hline
\end{tabular}

The following are analyses of Huelva oxide ores: ${ }^{b}$

Analyses of Resucitada (1) and Santa Aqueda (2) manganese ore, Huelva, Spain.

\begin{tabular}{|c|c|c|}
\hline & 1. & 2. \\
\hline 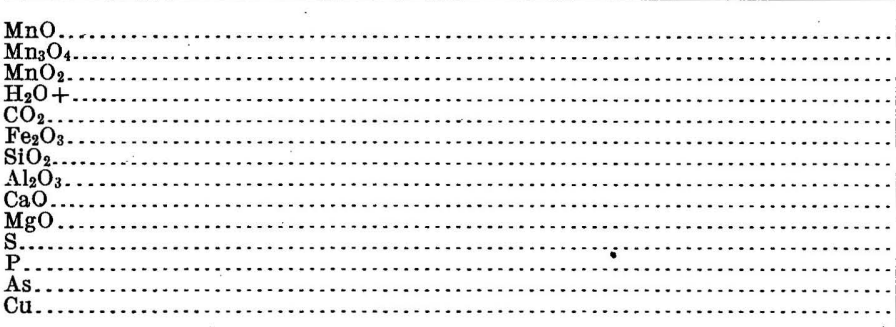 & $\begin{array}{l}4.16 \\
56.87 \\
6.80 \\
9.96 \\
6.57 \\
9.10 \\
1.52 \\
3.20 \\
.84 \\
.17 \\
.09 \\
.028 \\
\text { Trace. }\end{array}$ & $\begin{array}{r}70.92 \\
1.50 \\
3.52 \\
0.25 \\
2.30 \\
1.17 \\
\text { Trace. } \\
.036 \\
.028 \\
\text { Trace. }\end{array}$ \\
\hline $\begin{array}{l}\mathrm{Mn} \\
\mathrm{Fe}(\mathrm{n}, \ldots\end{array}$ & $\begin{array}{r}39.2 \\
4.6\end{array}$ & $\begin{array}{l}51.10 \\
-\ldots\end{array}$ \\
\hline
\end{tabular}

COVADONGA DISTRICT.

The Covadonga district is situated in the Province of Oviedo, in northern Spain. It is in a level valley in the Cantabrian mountain chain at the foot of Picos de Europa. Behind it limestone ranges rise 
abruptly in precipitous peaks, with interlying valleys, culminating in Peña Santa, 8,266 feet, and Picos de Cornion, 8,462 feet above sea level. A line between these peaks passes over the manganese deposits. Rivadesella, about 25 miles north, is the shipping port.

The manganese ore was discovered about thirty-five years ago in huge isolated blocks, entrapped between the serrated outcrops of the limestone ranges, where they had rested in their downward course from higher elevations. These blocks were broken up and carried down to Covadonga, from whence they were transported on donkeys to Rivadesella. Later, a government road was installed between these towns and the ore was hauled on carts. When the isolated bowlders were exhausted, open cuts were started at the foot of the limestone outcrops, and ore was discovered as fragments in glacial clays. Borings have shown the manganese to be scattered over the whole of the flat area between the limestone ranges, and not confined to narrow limits.

The ores are oxides found in manganiferous and ferruginous clay. The lower portion of the deposit consists of manganiferous clay, which grades upward into a clay strongly stained by hematite, which has given the name "Redcap" to the formation. Both types of clay contain lumps of manganese and iron ore, the former being more abundant in the lower part. Above the ore deposit is a few feet of blue clay with limestone nodules, and above this are bowlder clays containing angular and rounded fragments of limestone, sandstone, and shale, and in some places small lumps of cinnabar.

High up in the mountains above the deposits is a clean rock fissure, 6 feet wide, that has held manganese ore similar to that found in the deposits below, and also contained nodules of cinnabar. It was worked many years ago by a Belgian company and the ore has been removed. This fissure is taken to be the remains of what was once an extensive bed, the disintegration of which yielded the ores of the lower deposits.

The carrying of the ores down the mountains and their deposition throughout the level area where they now occur are supposed to have been performed by glaciers.

The following are analyses of manganese ore from Covadonga:

Analyses of manganese ore from Covadonga, Spain. ${ }^{a}$

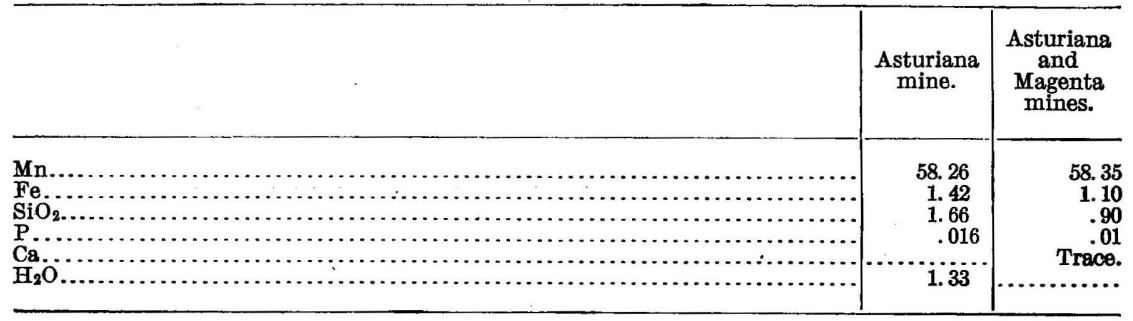

a Eighteenth Ann. Rept. U. S. Geol. Survey, pt. 5, 1897, p. 322. 
MINOR DEPOSITS.

In the northwestern part of the Province of Ciudad Real manganese ores occur as a bed 4 feet thick overlain by white Miocene clays, which also carry 15 to 20 per cent ore. The ore contains 40 to 60 per cent manganese and 0.25 per cent phosphorus. The manganese deposits of the Province of Teruel consist of oxides, but their associations are not known.

In the districts of Cartagena and Aguilas, in the Province of Murcia, large deposits of manganiferous iron ore are worked. In the district of Cartagena the manganiferous ores occur in an east and west range of mountains. In many of the mines lead and silver ores are found under the manganiferous iron ores. The manganese content varies from 10 to 20 per cent and the iron content from 20 to 35 per cent. The ore also contains considerable silica.

The following are analyses of manganiferous iron ore from the Province of Murcia:

Analyses of manganiferous iron ores from southern Spain. ${ }^{a}$

\begin{tabular}{|c|c|c|}
\hline & Cartagena. & Aguilas. \\
\hline 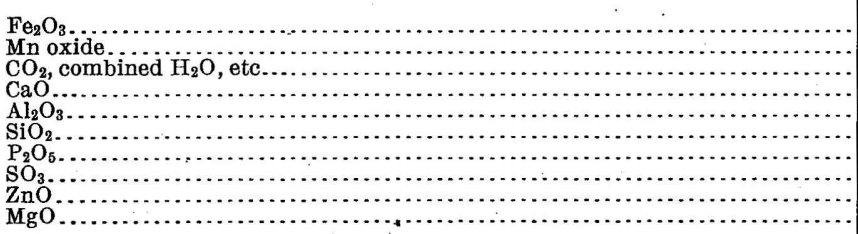 & \begin{tabular}{r}
35.84 \\
30.89 \\
16.33 \\
\hdashline .31 \\
5.14 \\
.04 \\
.31 \\
.84 \\
.45
\end{tabular} & $\begin{array}{r}69.92 \\
7.57 \\
12.90 \\
1.45 \\
.61 \\
8.00 \\
.02 \\
.14 \\
. . .23\end{array}$ \\
\hline $\begin{array}{l}\mathrm{Fe} \\
\mathrm{Mn}\end{array}$ & $\begin{array}{l}25.09 \\
22.26\end{array}$ & $\begin{array}{r}48.67 \\
5.74\end{array}$ \\
\hline
\end{tabular}

$a$ Eighteenth Ann. Rept. U. S. Geol. Survey, pt. 5, 1897, p. 323.

The iron ore from the Province of Almeria contains 2 to 6 per cent manganese, and that from the district of Parazuelos contains about 3 per cent manganese.

\section{PORTUGAL. $a$}

Manganese ore occurs in Portugal in the district of Beja, Province of Alemtejo. In this district there are eight or ten large mines, of which some produce manganese carbonate, yielding 34 to 50 per cent manganese, and others produce oxides.

The following are analyses of Portuguese manganese ores:

Analysis of manganese oxides from Alonzo Gomez mines, Portugal.a

\begin{tabular}{|c|c|c|c|c|c|c|}
\hline & 1. & 2. & 3. & 4. & 5. & 6. \\
\hline $\begin{array}{l}\mathrm{MnO}_{2} \\
\mathrm{SiO}_{2} \\
\mathrm{Fe}_{2} \\
\mathrm{Mn} \\
\mathrm{M}\end{array}$ & $\begin{array}{r}72.56 \\
4.71 \\
2.14 \\
55.20 \\
.03\end{array}$ & $\begin{array}{r}76.75 \\
6.58 \\
2.34 \\
54.88 \\
.04\end{array}$ & $\begin{array}{r}72.21 \\
4.75 \\
2.03 \\
54.65 \\
\end{array}$ & $\begin{array}{r}80.86 \\
2.78 \\
2.27 \\
59.73 \\
.04\end{array}$ & $\begin{array}{r}71.88 \\
1.62 \\
31.59 \\
51.03 \\
.1 . . .\end{array}$ & $\begin{array}{r}8.50 \\
2.25 \\
48.25 \\
.05\end{array}$ \\
\hline
\end{tabular}

a Mineral Resources U. S. for 1901, p. 149. 


\section{FRANCE. $a$}

The principal manganese mines of France are the Romaneche mines, in the western and central parts of the department of Saône-et-Loire, in east-central France, and the mines of Las Cabesses, Cazalas, and Brachy, in the department of Ariège, near the Spanish boundary. The Saône-et-Loire mines ship binoxide and the mines of Las Cabesses ship calcined and assorted carbonates.

Smaller deposits of ore occur at Chaillac, in the department of Indre, in central France; at Ferronnière and Villerambert, in the department of Aude, in southeastern France; and in the departments of Allier, Hautes Pyrénées, and Lozère.

The deposits at Romaneche ${ }^{b}$ occur along a fault contact where sediments of the Lias, Keuper, and Tertiary are brought in contact with granite. Two northeast-southwest-striking vertical veins occur in the granite and unite to form the "grand filon" (big vein) along the fault contact, which has a dip of $70^{\circ}$. The veins in the granite vary in thickness up to 20 feet and have no definite walls. The "grand filon" varies in thickness from 16 to 26 feet and has a definite foot wall of granite.

The principal ore is psilomelane, accompanied by quartz, barite, fluorspar, and a small amount of arsenosiderite. With depth a considerable quantity of hematite appears.

The deposits at Las Cabesses ${ }^{\circ}$ are in Ariège, 9 miles east of St. Girons. They consist of manganese carbonate occurring as lenses in a limestone formation of Devonian or Mississippian age called the Griotte. The formation is 1,000 feet thick, consists of white, red, green, and black limestones, and is overlain by phosphatic beds. Between 1881 and 1890 the deposits were mined along the outcrop, where they consisted of oxides. At a depth of about 65 feet a pure carbonate was reached and this is mined at present. The beds are very much folded and faulted.

The ore is gray, brown, and red and has a compact texture. The following is an average analysis:

Average analysis of manganese carbonate from Las Cabesses, France.

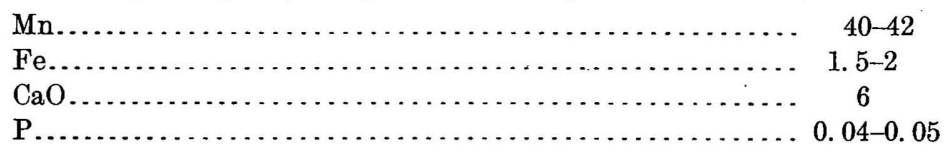

$a$ References on French manganese ores:

Stelzner, A. W. and Bergeat, A., Die Erzlagerstätten, pp. 249-251, 1047, and 576.

Mineral Resources U. S. for 1888, p. 141.

Sixteenth Ann. Rept. U. S. Geol. Survey, pt. 3, 1895, p. 445.

Seventeenth Ann. Rept. U. S. Geol. Survey, pt. 3, 1896, p. 210.

Nineteenth Ann. Rept. U. S. Geol. Survey, pt. 6, 1898, p. 111.

Mineral Resources U. S. for 1901, p. 145.

$b$ Stelzner and Bergeat, op. cit., p. 576.

$c$ Idem, p. 1047. 
A small deposit of gray manganese carbonate with a capping of oxides is reported from Rivernert, near St. Girons.

At Gouttes-Pommiers, ${ }^{a}$ in Allier, pyrolusite occurs in yellow and red ferruginous quartz in Cambrian schist and marble, and at Luzy, in Nièvre, it occurs in granite.

At several localities in the department of Hautes Pyrénées ${ }^{b}$ finely laminated beds of rhodonite and friedelite in quartz occur interlayered with Devonian clay slates containing trilobites. In a few places they are superficially altered to oxide and carbonate.

The following are analyses of French manganese ores:

Cargo analysis of French manganese ore.c

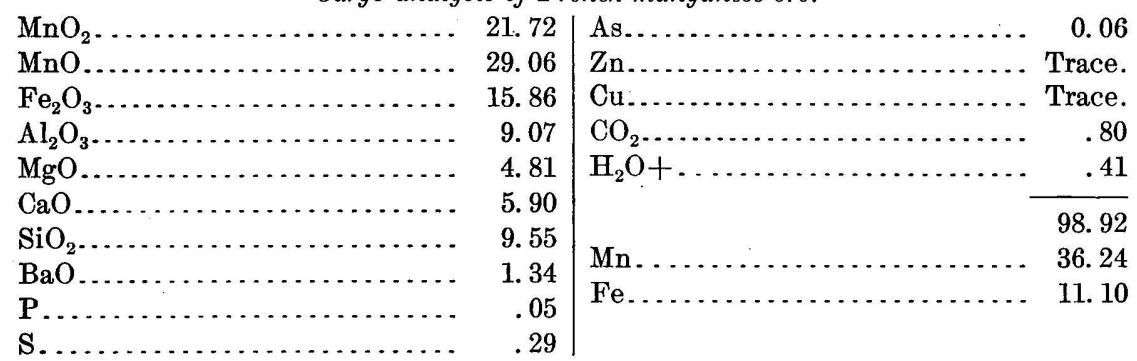

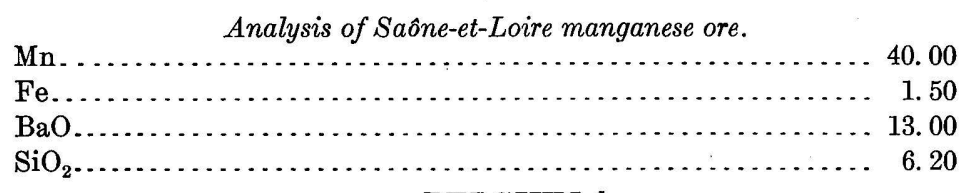

BELGIUM. $d$

Belgium does not produce manganese ores proper, but a considerable amount of manganiferous iron ores. The center of production for these is the Province of Liege. The manganese ore occurs at Chevron, in this province, as rhodochrosite associated with iron ores in upper Silurian rocks. They are also found elsewhere in Belgium associated with hematite.

The following are analyses of manganiferous iron ore from Chevron: Analyses of manganiferous iron ore from Chevron, Belgium.e

\begin{tabular}{|c|c|c|}
\hline . & 1. & 2. \\
\hline 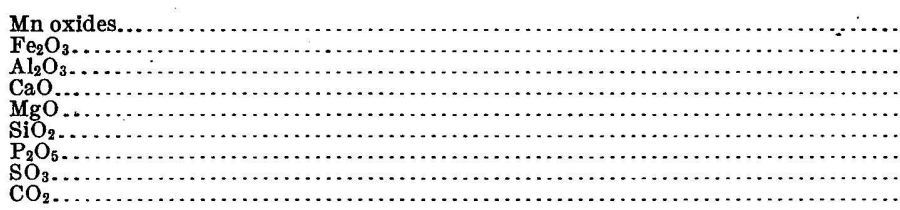 & $\begin{array}{r}28.42 \\
29.62 \\
3.87 \\
3.90 \\
1.15 \\
23.22 \\
.55 \\
\text { Trace. } \\
10.63\end{array}$ & $\begin{array}{r}31.75 \\
24.15 \\
4.06 \\
2.83 \\
.88 \\
22.01 \\
.46 \\
.01 \\
14.51\end{array}$ \\
\hline 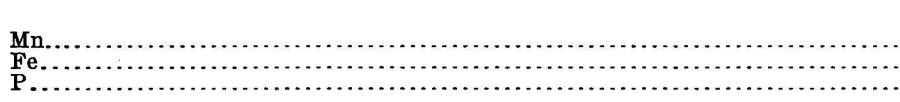 & $\begin{array}{r}101.36 \\
20.48 \\
20.73 \\
.24\end{array}$ & $\begin{array}{r}100.66 \\
22.87 \\
16.90 \\
.20\end{array}$ \\
\hline
\end{tabular}

$a$ Stelzner and Bergeat, op. cit., p. 576.

$b$ Idem, p. 249.

c Nineteenth Ann. Rept. U. S. Geol. Survey, pt. 6, 1898, p. 111.

d References to manganese ores of Belgium: Mineral Resources U. S. for 1893, p. 146.

e Mineral Resources U. S. for 1887, p. 158. 
The chief occurrence of manganese in Germany is along the Rhine in the districts of Wiesbaden and Koblentz, in Hesse-Nassau. Smaller deposits are found in the Harz Mountains, in Saxony, in the Bonn district, and in Coburg-Gotha, in Thuringia. Manganese ores occur with spathose iron ore at Siegerland and with the brown ores of Upper Silesia, Osnabrück, and other places. A large proportion of the manganiferous iron ores of Germany are produced in Prussia.

Manganese ores associated with iron ores occur disseminated and in large masses in clays overlying the Stringocephatus limestone (Middle Devonian) in Hesse-Nassau, ${ }^{b}$ the principal deposits being in the southern part of Hesse. The upper surface of the limestone is very uneven, consisting of numerous domes and ridges separated by intervening crevices and troughs filled with clay. The principal localities in this district are the area around Giessen; the area between Homburg, in Hesse-Nassau, and Friedberg, in Upper Hesse; the area around Limburg, in Hesse-Nassau; and the district between Stromberg and Bingerbrück, on the opposite side of the Rhine. Near Giessen extensive mining operations are being carried on at Lindener Mark. The ore occurs in troughs of clay on the uneven surface of the Stringocephalus limestone. This rock is dolomitized on the surface to depths ranging up to a meter and in many places is stained with iron and manganese oxides. Near the surface of the dolomite is an earthy manganiferous iron ore and above this a variegated clay containing beds and nodules of similar ore scattered irregularly. These clays grade upward into gray and blue plastic clays (Tertiary) which in turn are covered by sand and gravel. The ores consist of psilomelane, wad, hematite, and limonite. Many geodes consisting of concentric layers of these minerals occur in the clay.

In the vicinity of Homburg mining is carried on at several localities, but especially at Oberrosbach. Here a deposit of manganese ore several meters thick occurs in sand overlying the surface of the Stringocephalus limestone. The ores contain 25 to 26 per cent manganese and about the same quantity of iron.

At Niedertiefenbach, ${ }^{c}$ Heckholzhausen, and other localities near Limburg iron and manganese ores occur at depths from 30 to 160 feet under loess, gravel, and much-decomposed diabase. The foot wall here also is formed by the dolomitized Stringocephalus limestone. Above the limestone there are successive layers of clay which contain

$a$ References to German manganese ores:

Mineral Resources U. S. for 1887, p. 161.

Mineral Resources U. S. for 1893, p. 147.

Sixteenth Ann. Rept. U. S. Geoi. Survey, pt. 3, 1895, p. 448.

Stelzner, A. W., and Bergeat, A.,'Die Erzlagerstätten, pp. 250, 573-575, 1015-1020, and 1042.

$b$ Stelzner and Bergeat, pp. 1015-1020.

$c$ Stelzner and Bergeat, op. cit., pp. 1016-1017. 
iron and manganese ores, the former more abundant at the top and the latter at the base of each layer. The ores are thought to have been derived from the now decomposed diabase. The deposit at Heckholzhausen is covered with 45 feet of Tertiary clays and basaltic gravel and shows a thickness of 15 to 21 feet. The ore is amorphous manganic oxide, averaging 65 to 70 per cent manganese oxide, and contains large pockets of crystalline manganite and pyrolusite averaging 85 to 90 per cent manganese oxide.

Near Bingerbrück an earthy manganese deposit occurs partly between a clay shale layer and the Stringocephalus limestone and partly above the shale layer. At the Amalienhöhe mine near Waldalgesheim in the same region there is an extensive deposit of manganiferous iron ore carrying from 5 to 22 per cent manganese and up to 40 per cent iron. The ore occurs in masses several meters in diameter in decomposed, variegated, argillaceous schist overlain by a bed of Tertiary sandstone, gravel, and clay several meters thick. Mining has been carried to a depth of 377 feet. The clay carries an average of 2.4 to 2.7 tons of ore per cubic meter.

Earthy manganese ore deposits occur in Permian dolomite or on the underlying Rothliegendes at Waldmichelbach and other less important localities in Odenwald, ${ }^{a}$ which comprises parts of Hesse, Baden, and Bavaria. The dolomite overlies the Permian Rothliegendes sandstone and is overlain by 3 to 100 feet of red clay and schistose plastic clay belonging to the lower Bundsandstein of the Triassic. The surface of the dolomite is irregular and the manganese lies on it or has replaced parts of the dolomite itself. Locally the dolomite has been decomposed altogether and the ore lies on the Rothliegendes. The ores contain 10 to 22 per cent manganese and about the same quantity of iron. In addition many of them contain quartz, barite, copper, zinc, arsenic, cobalt, and nickel. Because of the presence of the metalliferous minerals it has been supposed that the ores originated from ascending thermal waters. It is to be noted that these deposits are very similar to those of Batesville, Ark.

At Elbingerode ${ }^{b}$ in the Harz Mountains, manganese silicates of various colors occur in a zone 26 feet wide in quartz schists of the Culm: They are associated with quartz and are superficially altered to manganese oxides and carbonate. The unaltered material consists of quartz and pale-red manganese pyroxenes, largely rhodonite. The oxidized material has all been mined and consisted largely of pyrolusite and psilomelane with impurities in the form of manganese silicates and fragments of schists.

In Biedendorf and Hadamar, in Hesse-Nassau, are found deposits of manganese similar to those at Elbingerode and in schists of the same age. 
Veins of mánganese ore containing chiefly manganite, subordinately pyrolusite, braunite, hausmannite, psilomelane, wad, and varvacite, occur at the Ilfeld, ${ }^{a}$ in the Harz Mountains. The associated gangue minerals are barite, calcite, dolomite, and manganiferous calcite. The veins are found in porphyry and range in thickness from a few inches to 2 feet and in depth from 15 to. 35 feet, though occasionally reaching a depth of 90 feet.

At Elgersburg, ${ }^{a}$ in the Thuringerwald, pyrolusite and psilomelane, associated with hausmannite, braunite, and wad, occur in veins which in some places reach a width of 9 to $13 \frac{1}{2}$ feet, and have been traced for more than three-fifths of a mile. The gangue minerals are largely calcite and barite; the inclosing rock is porphyry. Similar veins occur in melaphyre and porphyry at Ilmenau and Friedrichroda, in the same vicinity.

Near Schwarzenberg, ${ }^{b}$ in southeastern Saxony, manganese axides occur in association with iron ores. On Graul River near this locality there is a deposit of earthy manganese ore which contains up to 7 per cent bismuth and also some earthy cobalt.

SWEDEN. $c$

Manganese ores of three types occur in Sweden-(1) pyrolusite with manganite, (2) hausmannite with braunite, and (3) carbonate and silicate of manganese accompanying iron ores.

Pyrolusite with manganite.-Ores of the first type occur at Bolet and other places in Vestergotland, at Spexerejd, Höhult, Jacobsberg, and Ludwigsberg, in Smaland; at Skidberg and Nalberg, in the parish of Leksand, Dalarne, and at Spethult, Dalsland.

At Bolet the pyrolusite is found in fissures in a gneiss or gneissgranitic rock. These fissures, which vary in breadth from a fraction of an inch to 5 feet, are filled with breccia, containing chlorite, mica, barytes, calcite, and in certain places pyrolusite and manganite, with some braunite and wad as infiltrating cement. The fissures range up to 245 feet in length. The inclosing gneiss granite also contains small grains of pyrolusite.

In the Smaland district ore occurs similarly to that at Bolet. The ore appears in fissures in a schistic granite, which are filled with breccia, held together by limestone and manganese ore, the latter consisting of pyrolusite, manganite, and wad.

In Dalarne and Dalsland ore is found in fissures which are so small as to be of no commercial importance.

$a$ Stelzner and Bergeat, op. cit., p. 575.

$b$ Idem, pp. 573-574.

c References to Swedish manganese ores:

. Stelzner, A. W., and Bergeat, A., Die Erzlagerstätten, pp. 241-244.

Mineral Resources U. S. for 1893, p. 143.

Sixteenth Ann. Rept. U. S. Geol. Survey, pt. 3, 1895, p. 449.

Seventeenth Ann. Rept. U. S. Geol. Survey, pt. 3, 1896, p. 217. 
Hausmannite with braunite.-Ores of the second type occur at Pajsberg, Långban, Jacobsberg, and Nordmark (in Wermland) and at Sjogrufvan in Orebro. The ore consists of hausmannite and braunite, and contains jacobsite and several rare silicates of manganese. The deposits are found in lenses of dolomite or limestone inclosed in granulite, and are associated with iron-ore deposits consisting of hematite and magnetite. The rocks are classified as upper Archean.

At Pajsberg ${ }^{a}$ the manganese-ore deposits are associated with ironore deposits, and both are inclosed in dolomite. Hausmannite occurs disseminated through the dolomite and in granular concretions and is associated with a large number of silicates and carbonates, some of them very rare.

The deposits of Langban ${ }^{a}$ occur in the southern part of an area of dolomite striking north and south, about $2 \frac{1}{2}$ miles long and $1 \frac{1}{4}$ miles wide, inclosed in granulite. The ore deposits themselves have an east and west strike. They are associated with a large amount of gangue material known as "skarn." At least six deposits are known at this locality. Single deposits vary in thickness, and some of them divide or become disseminated through the dolomite or "skarn." The ore-bearing zone in places has an average width of 1,000 feet. The following section shows in general the layering of the orebearing bed:

Section of the ore bed at Langban, Sweden.b

Dolomite.

Grünskarn (gangue minerals) with disseminated magnetite and in many places hematite.

Magnetic iron ore with black garnet.

Hematite with ferruginous quartz.

Hausmannite with dolomite.

Braunite.

Manganese silicates (schefferite, tephroite, richterite, rhodonite, etc.).

Dolomite.

The manganese ores carry a small quantity of iron, generally less than 1 per cent. The associated iron ores carry about the same percentage of manganese and consist of 70 to 80 per cent hematite, the rest being magnetite. This is significant because of the fact that the Swedish iron ores of this type that are not associated with manganese ores consist almost entirely of magnetite.

At Jacobsberg and Nordmark ${ }^{c}$ hausmanite and braunite occur in limestone instead of dolomite. The ore-bearing bed has a maximum thickness of 13 feet. The manganese ores are not very important at these localities, the principal ores being magnetic iron ores, with which the former are associated. 
The manganese deposits at Sjogrufvan ${ }^{a}$ occur in an area of dolomite $2 \frac{1}{2}$ to 3 miles long and several hundred yards wide, surrounded by granulite. The deposit is about 25 or 30 feet wide and 330 feet long, and consists of very pure masses of braunite and hausmanite 12 or 16 feet in diameter overlain by an iron-ore deposit consisting of hematite and magnetite.

Carbonates and silicates with iron ores.-The ores of the third type are iron ores, mainly magnetite, but with some hematite, containing manganese. The manganese minerals consist principally of manganese carbonate and silicate, but oxides also are found in those ores which are more highly manganiferous. The ores occur in strata in limestone and "halleflinta." The average manganese content of the ores is not more than 6 per cent, but percentages as high as 25 occur in many of the fields.

The principal localities at which these ores occur are in Dannemora, Klackberg, and Kohnigsberg, Burangsberg, Langnik, Viker, Hillang, and Svartberg. Other localities are Gladkärn, Robergsfältet in Norberg; Skimarang, Knipgrufvan, and Penninggrufvan.

\section{GREAT BRITAIN. $b$}

No pure manganese ores are mined in Great Britain, but small amounts of manganiferous iron ore are produced. The localities where most of the ore has been mined are Barmouth and Harleck, in Merionethshire, North Wales; Carnarvonshire, North Wales; Tavistock in Devonshire and Launceston in Cornwall, southwest England; and in Derbyshire and adjacent territory in the Midlands of England. The ore of North Wales consists mainly of carbonate with some silicate and oxide in Cambrian rocks; that of England is psilomelane and pyrolusite in lower Silurian strata.

\section{NORTH WALES.}

The Cambrian rocks of Merionethshire are comprised in an irregular oval mountain tract, the longer axis of which is 17 miles and the shorter axis 10 miles. They consist principally of coarse quartzite and greenish-gray grit, in some parts of which the quartz grains are interspersed with grains of feldspar. The ore lies in beds from a few inches to 4 feet thick, the average being 18 inches to 2 feet. The undecomposed portion of the bed contains manganese carbonate witk a small proportion of silicate, but at the outcrop it is changed into a hydrated black oxide. The carbonate containing from 20 to 35 per

$a$ Stelzner and Bergeat, op. cit., p. 241.

$b$ References on the manganese ores of Great Britain:

Mineral Resources U. S. for 1886, p. 199.

Mineral Resources U. S. for 1887, p. 154.

Mineral Resources U. S. for 1891, p. 143.

Mineral Resources U. S. for 1892, p. 219. 
cent manganese is the principal ore mined. There are three manganese lodes, the principal one running in an unbroken line for about 2 miles almost north and south. Two and one-half miles north of this and a little to the west is the second lode, which is about a mile long; and one-half mile farther north is the third lode, of about the same length. These beds were first worked for the superficial black oxide, and when this had been removed, about 1840 , the mines were closed. In 1855 it was found that the oxide was simply the outcrop of impure beds of manganese carbonate and mining was resumed. The principal manganese lode is 8 to 18 inches thick, and in the Harleck mine consists of grit of medium grain, overlain by a thin band of quartzite. The roof consists of about 2 feet of hard schistose rock called "blue stone." The ore is in uniform layers, which are gray, white, yellow, green, and chocolate brown.

In some places the bed is considerably faulted and folded, so that mining is very difficult. Where the bed is thinnest the ore is richest. The ore is made up of about 30 per cent carbonate of manganese, 4 per cent silicate of manganese, 40 per cent oxides of manganese, iron oxides, carbonate and sulphide, magnesium carbonate, free silicate, etc., and 26 per cent clay.

Analyses of Merionethshire manganese ores follow:

Analyses of ore from Merionethshire, Wales. ${ }^{a}$

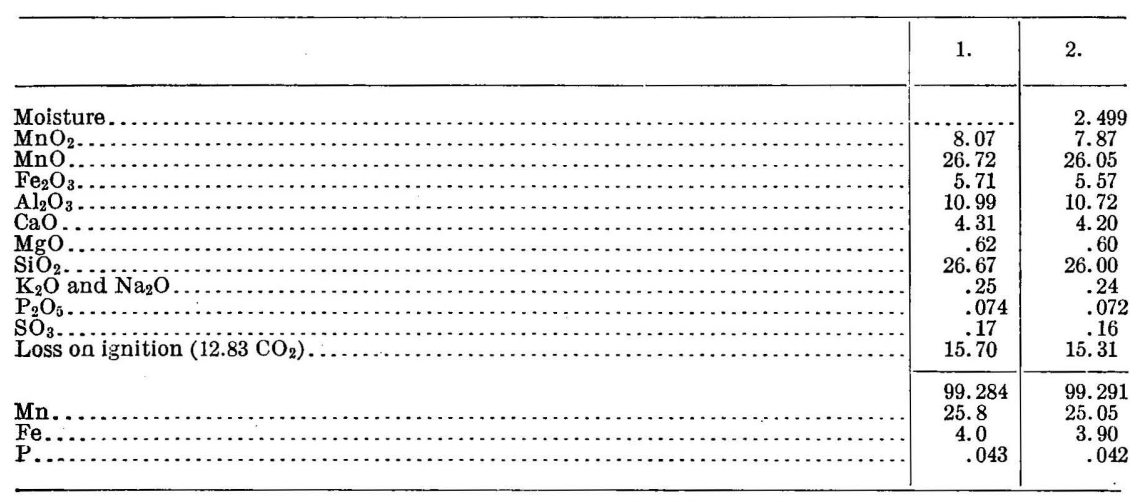

a Mineral Resources U. S. for 1887, p. 158.

In the hills northeast of Arenig, in Merionethshire, consisting of upper Trappean ash with a mass of feldspathic porphyry, there are found various veinlike fissures of manganese and iron. These veins vary in width up to 3 feet, and are commonly separated from one another by several feet of soft rock. They are filled with impure earthy and brown oxide of iron, pyrolusite, and psilomelane. 


\section{MINOR DEPOSITS.}

The manganese deposits of Devonshire and Cornwall were worked chiefly from surface openings, and the available ore has been removed. The deposits are known to extend downward, but the ore is of a poor grade and is mined but scantily.

The deposits of Derbyshire and adjacent parts of the Midlands are layers a few inches thick or, more generally, dark-brown or black masses of a crumbly, earthy appearance, not unlike that of hard balls of soot. The ore is soft and soils the fingers. The ore bodies occur in beds 6 inches to 2 feet thick, resting on blocks of limestone, and appear to be sedimentary deposits, presumably bog ore.

The following is an analysis of Derbyshire manganese ore:

Analysis of manganese ore (wad) from Derbyshire. ${ }^{a}$

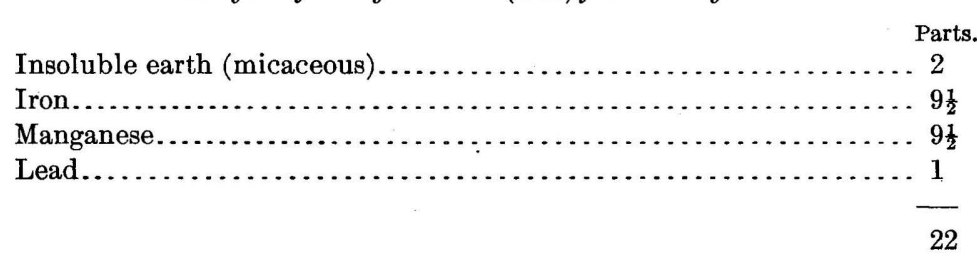

AUSTRIA-HUNGARY.b

Manganese ore is found in different parts of Austria-Hungary, namely, in Bukowina, Carniola, Moravia, Bosnia, Herzegovina, Transylvania, and Bohemia.

Bukowina.-In southern Bukowina, ${ }^{c}$ near the village of Jakobeni, is the manganese deposit of Arschitza. It is spread over an area 165 feet wide and 400 to 650 feet long and consists of a bed with a foot wall of quartzose hornblende-mica schist and a hanging wall of weathered brownish-yellow hornblende schist. The bed shows distinct layers and is composed of an upper workable portion consisting of manganese oxides, limonite, and quartz, and a lower barren grayish or bluish-black quartz schist 20 to 33 feet thick. The deposit originally consisted of manganese silicates with disseminated carbonate interbedded with mica-hornblende schist. Beds of this material are still exposed locally. The deposit reached its present condition through oxidation. The manganese ores are pyrolusite with cavities containing wad and botryoidal psilomelane.

a Mineral Resources U. S. for 1887 , p. 156.

$b$ References on the manganese ores of Austria-Hungary:

Stelzner, A. W., and Bergeat, A., Die Erzlagerstätten, pp. 248-256, 575, and 635.

Mineral Resources U. S. for 1888, p. 142.

Mineral' Resources U. S. for 1903, p. 151.

c Stelzner and Bergeat, op. cit., p. 248. 
The following analyses show the composition of the ore:

Analyses of manganiferous iron ore from Bukowina.

\begin{tabular}{|c|c|c|}
\hline & 1. & 2. \\
\hline 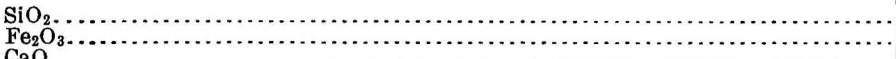 & $\begin{array}{r}27.5 \\
25.6\end{array}$ & $\begin{array}{l}35.5 \\
25.0\end{array}$ \\
\hline $\mathrm{MnO}_{2}$ & $\begin{array}{r}0.5 \\
32.4\end{array}$ & $\dddot{28.4}$ \\
\hline $\begin{array}{l}\mathrm{Mn}_{3} \mathrm{O}_{4} \ldots \ldots \\
\mathrm{H}_{2} \mathrm{O}\end{array}$ & $\begin{array}{l}6.9 \\
7.1\end{array}$ & $\begin{array}{l}4.7 \\
6.4\end{array}$ \\
\hline
\end{tabular}

Carniola.-In Carniola ${ }^{a}$ manganese ores are found in the upper valley of Save River at Vigunsica near Radmannsdorf. The ore consists of impure oxides occurring as a bed 3 to 13 feet thick and about 13. miles long, in Triassic slates. It has hanging and foot walls of slate overlain by a brecciated limestone bed. Some of the ores contain as much as 45 per cent manganese.

Moravia.-Manganese carbonate occurs as concretions in Oligocene clays near Austerlitz ${ }^{b}$ in central Moravia. Some of the masses are of the size of a man's head and are crusted with pyrolusite several centimeters thick. The interior mass contains manganese carbonate up to 40 per cent.

Bosnia.-The ore in Bosnia ${ }^{c}$ is on a plateau 3,000 feet above the sea at Cevljanovic 16 miles north of Sarajevo, in a series of variegated Triassic sandstones, which overlie a limestone of the lowest Triassic. The ore is associated with beds of variegated jasper in the sandstone and may be traced in a north and south belt about 2,300 feet long and 325 feet wide. The deposits are 5 to 10 feet thick and are separated from one another by sandstone layers from a few inches to several feet thick.

The ore is mainly hard steel-blue psilomelane with a conchoidal fracture, containing from 50 to 54 per cent of manganese. With it is associated limonite. There is also a black porous ore resembling wad, which occurs in large quantities, but is of too low grade to be workable. Silicate of manganese occurs locally. About 7,000 or 8,000 tons of ore are produced annually.

The following are average analyses of the ore:

Analyses of manganese ore from Cevljanovic, Bosnia.d

\begin{tabular}{|c|c|c|}
\hline . & 1. & 2. \\
\hline $\begin{array}{l}\mathrm{Mn} \\
\mathrm{SiO} \\
\mathrm{Fe} \\
\mathrm{Al}_{2} \mathrm{O}_{3} \\
\mathrm{P} \\
\mathrm{S}\end{array}$ & $\begin{array}{r}46.01 \\
12.38 \\
5.30 \\
2.76 \\
.07 \\
.94\end{array}$ & $\begin{array}{r}50.42 \\
11.48 \\
5.53 \\
.90 \\
.07\end{array}$ \\
\hline
\end{tabular}

$a$ Stelzner and Bergeat, op. cit., p. 252.

$b$ Idem, p. 256.

c Mineral Resources U. S. for 1888, p. 142; also Stelzner and Bergeat, op. cit., p. 252.

$d$ Stelzner and Bergeat, op. cit., p. 253. 
Ores similar to those in Bosnia occur in small quantities at Ivanjska and other localities in Servia, east of Bosnia.

Transylvania.-Alabandite, along with many other sulphides, occurs as a gangue in gold quartz veins at Nagyag, ${ }^{a}$ in the Erz Gebirge, in western Transylvania.

Bohemia.-Near Pribram, ${ }^{b}$ in Bohemia, decomposed and weathered veins of manganese ore are associated with diabase. The ores consist of pyrolusite and wad with small quantities of hematite, göthite, and limonite. The gangue material is largely quartz with subordinate amounts of calcite.

\section{SWITZERLAND.}

At Roffna, ${ }^{c}$ in Oberhalbstein, in the Swiss Canton of Graubünden, manganese ore occurs as beds in slates of Jurassic or Tertiary age. The ores are pyrolusite, polianite, and psilomelane penetrated by quartz veins and grading into quartz slate and red jasper.

\section{ITALY. $d$}

The chief manganese deposits in Italy are on Monte Argentario, at Carrara, at Rapolano, and on the island of Elba, in Tuscany; at Turin and Pralorgnan, in Piedmont; and at Gambatesa, in eastern Liguria. There are small mines at Iglesias, on San Pietro Island, off the west coast of Sardinia. Manganiferous iron ore occurs in Tuscany in the Apennines, near Florence. Manganese ore averaging 73 to 75 per cent oxide and manganiferous iron ore have been reported from Salerno, in Campania, on the coast south of Naples.

At the San Marcel (Aostatal) deposit, near Pralorgnan, ${ }^{e}$ in northwestern Piedmont, the ore consists largely of pyrolusite formed by the alteration of rhodonite. The deposits occupy a bed about 26 feet wide and over 325 feet long in gneiss, and in it the pyrolusite occurs in masses 4 or 5 yards in diameter. With the pyrolusite are associated braunite, hausmannite, quartz, piedmontite, spessartite, and other manganese silicates.

The deposits at Gambatesa ${ }^{f}$ consist of manganite and pyrolusite in red quartz slates. The mines are at present idle, but have been among the most important in Italy, some of the ore containing as much as 50 per cent manganese.

$a$ Stelzner and Bergeat, op. cit., p. 635 .

$b$ Idem, p. 575.

c Idem, p. 253.

$d$ References on the manganese-ore deposits of Italy:

Stelzner, A. W., and Bergeat, A., Die Erzlagerstätten, pp. 247, 254, 260, 1048.

Mineral Resources U. S. for 1886, p. 202.

Mineral Resources U. S. for 1887, p. 161.

Sixteenth Ann. Rept. U. S. Geol. Survey, pt. 3, 1895, p. 446.

Seventeenth Ann. Rept. U. S. Geol. Survey, pt. 3, 1896, p. 214.

Tonietti, G., Manganese ores in Elba: Min. Jour., vol. 84, p. 459; also Jour. Iron and Stegl Inst., 1908, p. 496 (review).

e Stelzner and Bergeat, op. cit., p. 247.

$f$ Idem, p. 254. 
The ores at Monte Argentario ${ }^{a}$ are near Santo Stefano, on the coast of Tuscany. They occur in irregular deposits in Rhætic limestone along the contact of Permian quartzite and argillaceous slate. The ores are a mixture of ocherous limonite and manganese, in some places one and in some the other being predominant. Together they compose about 50 per cent of the ore. Most of the ore is in the limestone, where at present a deposit 820 feet long and 100 feet thick is being worked.

The manganese ores on the island of Elba are said to occur in extensive deposits embedded in limestone or siliceous rock. ${ }^{b}$

On San Pietro Island ${ }^{c}$ the ore occurs in two seams, on an average 1 foot thick. The beds are separated by a thin layer of black clay and are overlain by a $4 \frac{1}{2}$-foot bed of red and yellow jasper. The ore is brown to black and together with the jasper is inclosed in a bed of soft white and red clay with trachyte fragments. The entire series is inclosed between beds of trachyte. The best ore contains 31 to 35 per cent manganese and 7 to 13 per cent iron.

\section{GREECE. $d$}

Manganiferous iron ore containing 18 to 19 per cent manganese and 34 to 35 per cent iron occurs at Laurium, in Greece. Manganese ore is found in small amounts in several localities, among which are Cape Vani, on the island of Melos, and Fourkovuni Point, also in the Cyclades. The ores at Cape Vani are in Pliocene clays in deposits $1 \frac{1}{2}$ to 5 feet thick. The ore-bearing bed has a hanging wall of trachyte. The ore beds at Fourkovuni Point occur in parallel layers in a hill rising abruptly from the shore to a height of 400 feet. The layers are said to be from 2 to 6 feet thick and to consist of intermixed ore and clay.

A manganiferous iron ore containing 7 to 15 per cent manganese and 33 to 50 per cent iron, said to be Grecian, has been shipped from Mazarron, in Spain; but the locality of the mines is not known. The following analyses give the composition of this ore:

Analyses of manganiferous iron ore from Greece.e

\begin{tabular}{|c|c|c|}
\hline & 1. & 2. \\
\hline $\begin{array}{l}\mathrm{SiO}_{\mathrm{O}} \\
\mathrm{Fe} \\
\mathrm{Mn} \\
\mathrm{P}\end{array}$ & $\begin{array}{c}3.60 \\
50.00 \\
7.64 \\
.022\end{array}$ & $\begin{array}{r}5.02 \\
33.59 \\
15.33 \\
.048\end{array}$ \\
\hline
\end{tabular}

$a$ Stelzner and Bergeat, op. cit., p. 1048.

$b$ Tonietti, G., loc. eit.

$c$ Stelzner and Bergeat, op. cit., p. 260.

$d$ References on the manganese ores of Greece:

Stelzner, A. W., and Bergeat, A., Die Erzlagerstätten, p. 260.

Mineral Resources U. S. for 1886, p. 203.

Sixteenth Ann. Rept. U. S. Geol. Survey, pt. 3, 1895, p. 447.

Nineteenth Ann. Rept. U. S. Geol. Survey, pt. 6, 1898, p. 121.

e Mineral Resources U. S. for 1886, p. 203. 
TURKEY. $a$

Manganese ores occur both in European and in Asiatic Turkey. In the former they are found in southern Macedonia, the shipping port being Stratoni, on the Egean Sea. In the latter, they are reported from Aptal in Trebizond, in northern Asia Minor, near the Black Sea, and also from Flatza, in the same region.

On the island of Cyprus, ${ }^{b}$ off the south coast of Asia Minor, manganese ores occur at Strullos, near Larnaka. The ore occurs in Miocene marl in the vicinity of areas of quartz andesite and tuff, and consists of nodules of pyrolusite and psilomelane grading into earthy iron and manganese ores.

The following analyses show the composition of the ore:

Analyses of manganiferous iron ore from Cyprus.

\begin{tabular}{|c|c|c|}
\hline & 1. & 2. \\
\hline 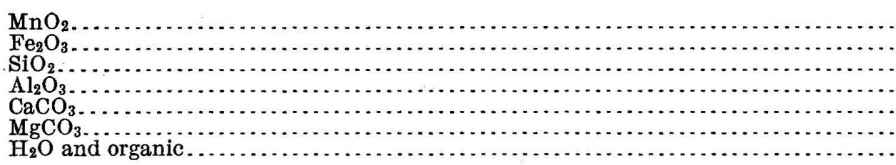 & \begin{tabular}{r|}
24.85 \\
40.03 \\
12.28 \\
5.20 \\
8.41 \\
1.70 \\
7.53
\end{tabular} & $\begin{array}{r}24.42 \\
41.27 \\
19.56 \\
6.61 \\
\text { Trace. } \\
1.02 \\
7.22\end{array}$ \\
\hline
\end{tabular}

RUSSIA. $c$

Russia has been for many years the leading producer of manganese in the world. By far the largest part of the ore has come from the Sharopan district in the Province of Kutais, Transcaucasia, on the Asiatic slope of the Caucasus Mountains. Smaller amounts of ore have been produced in the Nikopol district in the Province of Ekaterinoslav in south Russia, and in the provinces of Perm and Orenburg in the Ural Mountains.

$a$ References on the manganese ores of Turkey:

Stelzner, A. W., and Bergeat, A., Die Erzlagerstätten, p. 260.

Mineral Resources U. S. for 1888, p. 142.

Eighteenth Ain. Rept. U. S. Geol. Survey, pt. 5, 1897, p. 325.

$b$ Stelzner and Bergeat, op. cit., p. 260.

$c$ References on the manganese ores of Russia:

Drake, Frank, The manganese-ore industry of the Caucasus: Trans. Am. Inst. Min. Eng., vol. 28, 1898, p. 191.

Yakovlev, N., Gisements de manganese du district minier de Nizhine Taghilsk: Review in Trans. Inst. Min. Eng., vol. 33, pt. 6, p. 695.

Stelzner, A. W., and Bergeat, A., Die Erzlagerstätten, pp. 258-260.

Mineral Resources U. S. for 1886, p. 204.

Mineral Resources U. S. for 1893, p. 138.

Sixteenth Ann. Rept. U. S. Geol. Survey, pt. 3, 1895, p. 443.

Nineteenth Ann. Rept. U. S. Geol. Survey, pt. 6, 1898, p. 112.

Mineral Resources U.S. for 1905, p. 104. 


\section{SHAROPAN DISTRICT.}

The Sharopan district is near the town of Chiaturi, about 26 miles northeast of Kvrilli station, or Sharopan, on the Transcaucasian Railway, which runs between Baku, on the Caspian Sea, and Batum and Poti, on the Black Sea. A narrow-gage spur connects Chiaturi with Sharopan.

The manganese deposits were discovered in 1848 , but were not mined until 1879. The mines are in a very mountainous country on the west slope of the Lesser Caucasus, along high cliffs on either side of Kvrilli River. They are reached by a steep trail from Chiaturi, on the banks of the river, $1 \frac{1}{3}$ to $3 \frac{1}{3}$ miles distant, and 700 to 1,050 feet lower. The following description is condensed in part from the article by Drake already cited.

Seven mountains rise with almost perpendicular slope from Kvrilli River. Four of these, Organyi, Zedorganyi, Gwimavi, and Dark-

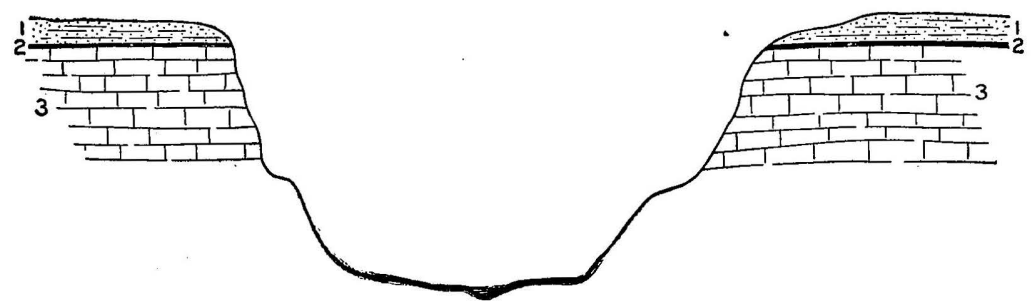

FIGURE 33.-Section showing the occurrence of manganese ores in the Sharopan district. (After Drake.) 1, Sandstone; 2 , manganese ore; 3 , limestone.

vetti, are on the north bank, and three, Perivissi, Ichocrotti, and Itvissi, on the south bank. They are separated from one another by small branches of the Kvrilli. On the upper slopes of these mountains are the mines, at about equal distances above the river, and extending along it for over 2 miles. The ore occurs in a horizontal bed (fig. 33) 6 to 7 feet thick, with a slight southeasterly dip, at the contact of Eocene ${ }^{a}$ brown sandstone with underlying Cretaceous limestone. The bed is without abrupt or extreme variations of thickness, and probably extends over an area of 22 square miles. It outcrops near the top of the cliffs along either side of the river about 1,000 feet above it.

The deposit has a distinctly stratified structure and is composed largely of pyrolusite, though other oxides of manganese occur. The ore is concretionary and oolitic and in many places shows botryoidal surfaces and concentric structure. In many places strata of sandstone or of loose, friable arenaceous or calcareous material are intercalated with the manganese ore, and vary in thickness from a fraction of an inch to as much as 10 inches or a foot. 
The Chiaturi ore is high in manganese, in some places containing 50 per cent without sorting or cleaning; the average percentage is from 40 to 45 . Some high-grade ores that have been thoroughly cleaned contain as much as 61 per cent manganese. The average sorted ore that is exported contains 51 or 52 per cent. Phosphorus averages about 0.16 per cent and silica not more than 8 per cent.

The physical characteristics of the ore are unfavorable, inasmuch as the proportion of large pieces obtained is small, and much of the ore is soft and grinds to a fine powder during the handling incidental to mining, cleaning, and transportation. The loss of ore is therefore considerable, and much of the fine ore that is shipped is considered objectionable by the consumers.

The following is an analysis of manganese ore from the Sharopan district:

Analysis of well-sorted and cleaned ore from Chiaturi, Russia. ${ }^{a}$

[Dried at $212^{\circ} \mathrm{F}$.]

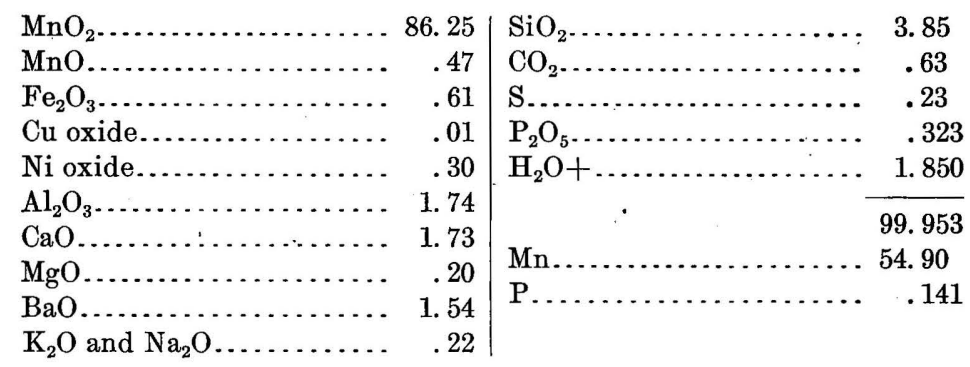

The mining is carried on by means of many galleries driven into the hillside along the manganese bed. They are only short distances apart along the outcrop, and cross tunnels branch from them in all directions. Few of the workings go back more than 300 feet from the face of the cliff; exceptionally they reach 400 or 500 feet. Hence only the outer edge of the ore bed has been worked. The ore is hauled from the tunnels in wheelbarrows and baskets. In a few places wooden rails have been laid and the ore is hauled out in primitive mine cars. It is taken from the mines to Chiaturi down a steep mountain trail by pack animals or on ox carts, and thence on the narrow-gage railway to Sharopan, whence it is carried on the Transcaucasian Railway to Batum and Poti, on the Black Sea.

\section{OTHER DEPOSITS IN TRANSCAUCASIA.}

Other deposits in Transcaucasia are near Choruk River in Kutais, southward from Batum and in the Governments of Tiflis, Erivan, and Elisabetpol. Ores are also reported from the stations of Samtredi and Novo-Senaki on the Transcaucasian Railway. 
NIKOPOL DISTRICT.

The deposits of South Russia are near Nikopol, ${ }^{a}$ on Dnieper River, 100 miles from its entrance into the Gulf of Odessa. They were first worked in 1886 . The ores are in beds about $3 \frac{1}{2}$ feet thick and are in Oligocene strata. The ore-bearing layer consists of 'sandy clay much stained by manganese, which contains nodules of psilomelane and pyrolusite with concentric or cellular structure. The hanging and foot walls of the ore bed consist of glauconitic clays, which on the foot wall are commonly sandy. The ores are but a short distance above crystalline bed rock and were probably derived from it through weathering processes. The better class of ore contains 57 per cent manganese.

The following is an analysis of manganese ore from the Nikopol district:

Analysis of manganese ore from the Nikopol district, Russia.b

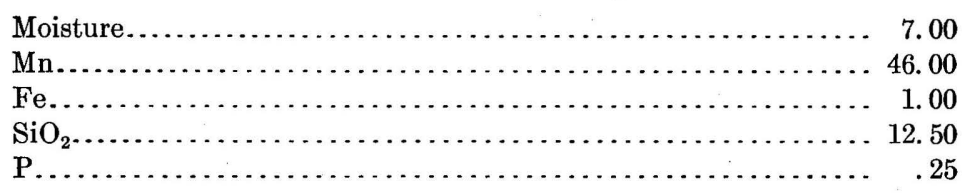

Near Horodizce, ${ }^{a} 11 \frac{1}{4}$ miles north of Nikopol, there is a bed of manganese ore 6 to 10 feet thick, overlain by Tertiary clays and underlain by granite but separated from it by a bed of kaolin and sand about a foot thick. The ore consists of a mixture of quartz grains and pyrolusite nodules.

\section{URAL MOUNTAINS.}

In the Urals there are manganese deposits in the Government of Perm, in the region of the Nizhne-Taghilsk works, and also in the Government of Orenburg.

Yakovlev reports six deposits of manganese ore in the NizhneTaghilsk works, including the Sapalsky mines, as being spread over about $12 \frac{1}{2}$ miles. The ore is accompanied by brown iron ores, and occurs at or near the contact of Devonian limestones and hornblendic igneous rocks (syenite, etc.). Some of it occurs directly at the contact, but elsewhere it is entirely within the limestone or within the igneous rocks.

In three of the six deposits the limestones have been contactmetamorphosed by eruptive rocks and have been so marmorized with the obliteration of bedding planes and joints as to be practically impermeable to water, and thus form less favorable places for the deposition of manganese than the unmetamorphosed limestones. The

a Stelzner and Bergeat, op. cit., p. 259.

$b$ Nineteenth Ann. Rept. U. S. Geol. Survey, pt. 6, 1898, p. 120. 
two richest deposits are connected with limestones that have undergone such folding and fissuring as to favor the circulation of underground waters and the precipitation of ore. The ore is supposed to be connected in origin with the manganese-bearing hornblende of the igneous rocks.

Large deposits of rhodonite occur in crystalline schists and later argillaceous schists near the village of Ssedelnikowaja, ${ }^{a} 15 \frac{1}{2}$ miles southeast of Jekaterinburg, in the Urals. The rhodonite is mixed with quartz and occurs as a bed about 9 feet thick in argillaceous schists. Locally veins and stains of manganite occur. The unaltered rhodonite is quarried and is used for ornamental purposes. It is polished in stone works at Jekaterinburg and St. Petersburg and is known as "orletz" in Russia.

\section{TUNIS. $b$}

Large deposits of manganese ore occur in Tunis near Ain-Mulares. The quantity available is said to reach a million tons.

\section{CAPE COLONY.c}

An important discovery of manganese ore has recently been made at Caledon, Cape Colony. The deposit is said to contain 30,000 tons of ore with a manganese content of 42 per cent.

\section{EGYPT.}

Manganese ores, manganiferous iron ores, and iron ores occur together in deposits in Carboniferous rocks on the Sinai Peninsula east of the Gulf of Suez.

According to Barron, ${ }^{d}$ the Carboniferous rocks consist of two sandstones, an upper and a lower, separated by a limestone bed. The lower sandstone bed consists of a series of dark-red sandstones and shales, resting on the eroded surface of a basement consisting of gray gneiss and schist. The limestone bed is crystalline in the upper and lower parts, but in the middle has fissile, ocherous layers. The lower part is strongly stained with manganese oxides in places. The upper sandstone consists of a thick series of reddish and brownish sandstones, which is overlain by a bed of olivine basalt of contemporaneous origin. Above this are lighter-colored Cretaceous sandstones.

The ores occur in pockets 2 to $4 \frac{1}{4}$ feet deep in the lower crystalline limestone layer at its contact with the underlying sandstone. They are found nearly everywhere that the lower portion of the limestone is exposed. The ore varies in composition in different places from

$a$ Stelzner and Bergeat, op. cit., p. 247.

$b$ Manganese ore in Tunis: Review in Jour. Iron and Steel Inst.. 1908, No. 3, p. 497.

c Manganese ore in Cape Colony: Review in Jour. Iron and Steel Inst., 1908, No. 1, p. 239.

$a$ Barron, T., The topography and geology of the peninsula of Sinai: Survey Dept. Egypt., 1907, pp. 160170, 205-207. 
pure hematite through a mixture of hematite and manganese oxides to pure manganese oxides, mainly psilomelane. Three localities were examined by Barron-Wadi Malha, Wadi Nasb, and Wadi Halliq, all at some distance from the seacoast. In the first, manganese and iron ores lie side by side, more or less distinct from each other but intermixed at their junction. The same is true of the second locality, but there is some earthy manganese ore (wad) in addition. In the third locality hematite is more abundant than manganese oxides.

The principal gangue material of the ores is silica. Calcite also occurs, and limonite is associated with the hematite.

The following are analyses of ore from Wadi Malha and Wadi Halliq, showing the gradation in composition between pure hematite and pure manganese oxide:

Analyses of manganese ores from Sinai Peninsula. ${ }^{a}$

\begin{tabular}{|c|c|c|c|c|c|}
\hline & $\mathrm{Fe}_{2} \mathrm{O}_{3}$ & Fe. & $\mathrm{MnO}$. & $\mathrm{MnO}_{2}$ & Mn. \\
\hline \multicolumn{6}{|l|}{ Wadi Malha: } \\
\hline Manganese oxides & $\begin{array}{r}40.90 \\
3.74\end{array}$ & $\begin{aligned} 02.01 \\
2.62\end{aligned}$ & 15.21 & 71.59 & 57.00 \\
\hline \multicolumn{6}{|l|}{ Wadi Halliq: } \\
\hline $\begin{array}{l}\text { Manganiferous iron ore ......... } \\
\text { Psilomelane................. }\end{array}$ & 25.34 & 17.74 & 41.03 & $\begin{array}{l}38.19 \\
45.50\end{array}$ & $\begin{array}{l}24.12 \\
60.48\end{array}$ \\
\hline 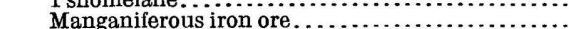 & 20.14 & 14.31 & 41.00 & $\begin{array}{l}40.00 \\
39.95\end{array}$ & 25.23 \\
\hline ese oxides... & & & & 71.41 & 45.10 \\
\hline Manganiferous iron ore. & 27.60 & 19.32 & 14.60 & 40.81 & 37.03 \\
\hline $\begin{array}{l}\text { Red ocher } \ldots \ldots \\
\text { Low-grade manganese ore } \ldots\end{array}$ & $\begin{array}{r}32.10 \\
2.32\end{array}$ & $\begin{array}{r}22.47 \\
1.62\end{array}$ & & 30.33 & 19.16 \\
\hline 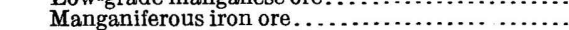 & 34.24 & 23.97 & & 29.52 & 18.66 \\
\hline Iron ore. & 69.34 & 48.54 & & 3.06 & 1.94 \\
\hline Manganiferous iron ore & 16.90 & 11.83 & 32.87 & 18.56 & 37.18 \\
\hline \multicolumn{6}{|l|}{ 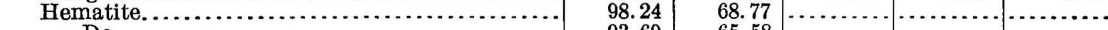 } \\
\hline Do & 93.69 & 65.58 & & & 为 \\
\hline …............ & 73.62 & 51.53 & & 9.58 & 6.05 \\
\hline Manganiferous iron ore & 38. 80 & 27.16 & 14.72 & 24.10 & 26.64 \\
\hline Low-grade iron ore. & 25.86 & 18. 10 & & & \\
\hline
\end{tabular}

$a$ Barron, T., op. cit., p. 206.

INDIA. $a$

\section{DISTRIBUTION AND CHARACTER OF ORES.}

Manganese ore is found in India in the Madras and Bombay Presidencies, in Central India, in the Central Provinces, in Bengal, and in Lower Burma.

In the Madras Presidency it is found in the Chipurupalle talug of the Vizagapatam district, in the Ganjam district of Kallikota State, and in the Sandur Hills of Bellary.

$a$ References on the manganese ores of India:

Fermor, L. L., Notes on the petrology and manganese-ore deposits of the Sausar tahsil, Chhindwara district, Central Provinces: Record Geol. Survey India, vol. 33, pt. 3, 1906, p. 159; Manganese-ore deposits of India: Mem. Geol. Survey India, vol. 37, 1909.

Holland, T. H., General report of the Geological Survey of India, 1905: Record Geol. Survey India, vol. 33 , pt. 3, 1906, p. 65.

Seventeenth Ann. Rept. U. S. Geol. Survey, pt. 3, 1896, p. 220.

Nineteenth Ann. Rept. U. S. Geol. Survey, pt. 6, 1898, p. 124.

Twentieth Ann. Rept. U. S. Geol. Survey, pt. 6, 1899, p. 154.

Mineral Resources U. S. for 1904, p. 136.

Mineral Resources U. S. for 1905, p. 106. 
On the Bombay side it is found at several places around Mahabaleshwar and Yeruli, in Satara, as irregular nodules distributed through the cover of the Dekkan trap; in the southern part of the Belgaum district; in Bijapur; in Narukot; near Jambughora, in Rewa Kantha, and in the Dharwar, Panch Mahals, and Ratnagiri districts.

In Central India manganese ore is found in Jhabua State, in Gwalior State, and in several localities in the Dhar forest.

In the Central Provinces deposits have long been known at Gosalpur and Sihora, in the Jabalpur district. Recently many deposits have been discovered in the Sausar tahsil, in the Chhindwara region, among which are those of Kachi Dhana, Lakhanwara, Gaimukh, Sitapar, Bichua, Alesur, Devi, Ghoti, Wagora, Gowari Warhona, and Dudhara. Deposits also occur in the Ramtek tahsil of the Nagpur district, in the northwestern part of the Nagpur district, in the northwestern part of the Bhandara district, in the Balaghat district near the town of Balaghat and in the western part, and at Ukua, in the Behir tahsil. Ore is also reported from the States of Khairagarh and Kalahandi. Manganese and manganiferous iron ores occur in the Singhbhum district in Bengal.

In Lower Burma ore is reported in the Tavoy and Mergin districts, on the banks of the Thugo stream and Thirabuen and Great Tenasserim rivers. The ore is stated to consist of black and gray oxides and wad.

Manganese ore also occurs in Hyderabad and in the form of manganiferous iron ore near Chaibassa, in the Chota Nagpur.

Following is a general summary of results obtained by Fermor in a recent survey of the manganese deposits of India, with reference to the geologic occurrence of the ores in the localities mentioned above: ${ }^{a}$

The ore occurs in three distinct forms of deposits:

(a) Braunite, psilomelane, and pyrolusite associated with and derived from manganese-bearing silicates (such as spessartite, rhodonite, and, less frequently, piedmontite), occurring as bands and lenticles in Archean schists and gneisses. Examples of these occur in-

(1) Narukot, in Bombay; manganese ores are associated with porphyritic biotite granite as an alteration of xenoliths of manganiferous rocks in these.

(2.) Jhabua, in Central India; manganese-ore deposits consist of much-folded alternating quartzite and manganese-ore layers associated with spessartite and rhodonitebearing rocks.

(3) Balaghat, Bhandara, Chhindwara, and Nagpur, in the Central Provinces; manganese ores are derived from the alteration of spessartite quartz rock often containing a small quantity of apatite, but usually quite free from feldspar.

(4) Ganyam, in Madras; manganese ores are associated with spessartite-feldspar and spessartite-rhodonite rocks.

(5) Vizagapatam, in Madras; manganese ores occur in a complex of Archean rocks in which have been intruded, as an igneous magma, manganiferous rocks containing manganese silicates, such as spessartite and manganese pyroxenes. The principal 
type of rock is an apatite-spessartite-feldspar rock which, under the influence of chemical waters, doubtless heated, has been decomposed and its manganese contents deposited elsewhere in the form of oxides.

(b) Psilomelane and pyrolusite superficially formed on outcrops of rocks of Dharwar age, consisting chiefly of quartzites, shales, slates, and hematite-schists banded with jaspery quartzite-

(1) Singhbhum, in Bengal; manganese and manganiferous iron ores, the former largely psilomelane, occur as a superficial replacement of sericitic phyllites, quartzites, and feldspathic grits.

(2) Dharwar, in Bombay; manganese ores occur on the outcrops of banded, limonitic, jaspery quartzites.

(3) Panch Mahals, in Bombay; manganese ores consist of psilomelane and pyrolusite occurring as superficial replacements of slates and quartzites.

(4) Jabalpur, in the Central Provinces; manganese ores of two classes, viz, (a) manganiferous iron ore and psilomelane and $(b)$ pyrolusite, occur in rocks of Dharwar age; the first consists of large masses of limonite veined with psilomelane occurring as superficial alterations of hematite schists; the second occurs in nests and stringers in quartzite.

(5) Sandur Hills, in Madras.

(c) Psilomelane and pyrolusite associated with or contained in laterite-

(1) Belgaum, in Bombay; manganese ore occurs in spherical concretions in a deposit of laterite 15 to 20 feet thick, passing downward into quartz schist underlain by slightly manganiferous limestone which, like the quartz schist, is of Dharwar age.

(2) Satara, in Bombay; concretions of psilomelane are embedded in lateritic soil resting on Deccan trap and are probably derived from the latter by the concentration of manganese which basic lavas often contain.

(3) Jabalpur, in the Central Provinces; manganese ore (pyrolusite) occurs as nodular segregations in lateritic débris derived from the decomposition of rocks of Dharwar age.

VIZAGAPATAM DISTRICT.

The Vizagapatam district, in the Madras Presidency, was the first of the Indian manganese areas to be exploited, attention being directed to it in 1890 .

The ore outcrops locally over an area of 100 square miles, situated within the extensive territories of the Maharajah of Vizianagram, stretching between the Eastern Ghats (mountains) and the Bay of Bengal. It is about 500 miles north of Madras and the same distance south of Calcutta.

The country rock is Archean granite and schist containing manganese silicates, from which the present oxide deposits are derived by weathering. The outcrops occur in a level country in the form of mounds, as low hills, and in isolated blocks; in some places the soil, impregnated with black oxide of manganese, gives indications of ore beneath. The first mound was discovered within a few hundred yards of the East Coast Railway, and the contractors broke up the manganese blocks for ballast, unaware of their nature. Investigation showed that this was but the end of a deposit of vein-like masses of ore and detached bowlders, in a detritus of country rock, about $2 \frac{1}{2}$ miles in length and comprising an area of 660 acres. Detached 
blocks of ore exhibited marks of being waterworn, and occurred in all sizes from pebbles up to bowlders of several hundredweight. These fragments were disseminated through the soil, in some places so sparsely as to make mining unprofitable, but elsewhere in beds several feet thick.

Some fragments are nodular, have a coating of iron oxide, and when broken present a steel-gray color. They contain 45 to 48 per cent manganese. Other fragments are angular, show a metallic luster, and contain 48 to 50 per cent metallic manganese. The vein-like masses have been worked to a depth of about 50 feet. They vary considerably in manganese, iron, and phosphorus content. Some of the ore is steel gray and contains 48 per cent manganese, and associated with it is a cindery ore of 35 per cent manganese.

The following is an analysis of manganese ore from the Vizagapatam district:

Analysis of ore shipped from the Vizagapatam district, India.a

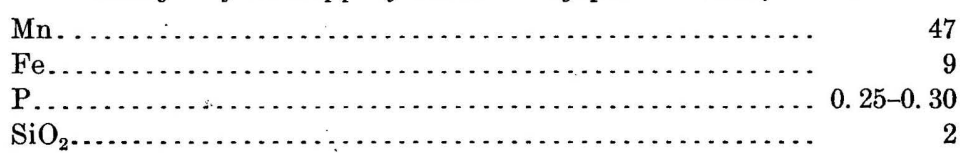

\section{JABALPUR DISTRICT,}

The deposits at Gosalpur, in the Jabalpur district, have been known for a long time, and the ore has been used to a small extent by native glass makers in the neighborhood. The ore occurs in the Dharwar schist series, outcropping in a belt 7 miles wide and stretching 20 miles northeast and southwest. It is dark steel-gray, finely crystalline pyrolusite mixed with a varying proportion of psilomelane, and has the following composition:

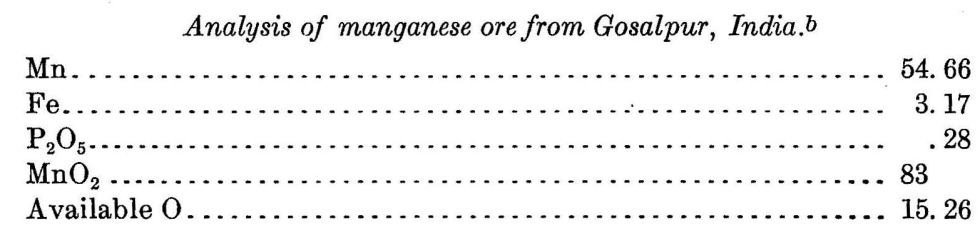

A considerable amount of psilomelane also occurs with the manganiferous micaceous iron ore in the same locality.

$a$ Nineteenth Ann. Rept. U. S. Geol. Survey, pt. 6, p. 125.

$b$ Seventeenth Ann. Rept. U. S. Geol. Survey, pt. 3, 1896, p. 221. 
The following are analyses of manganese ores from Gosalpur:

Analyses of manganese ores from Gosalpur, India.a

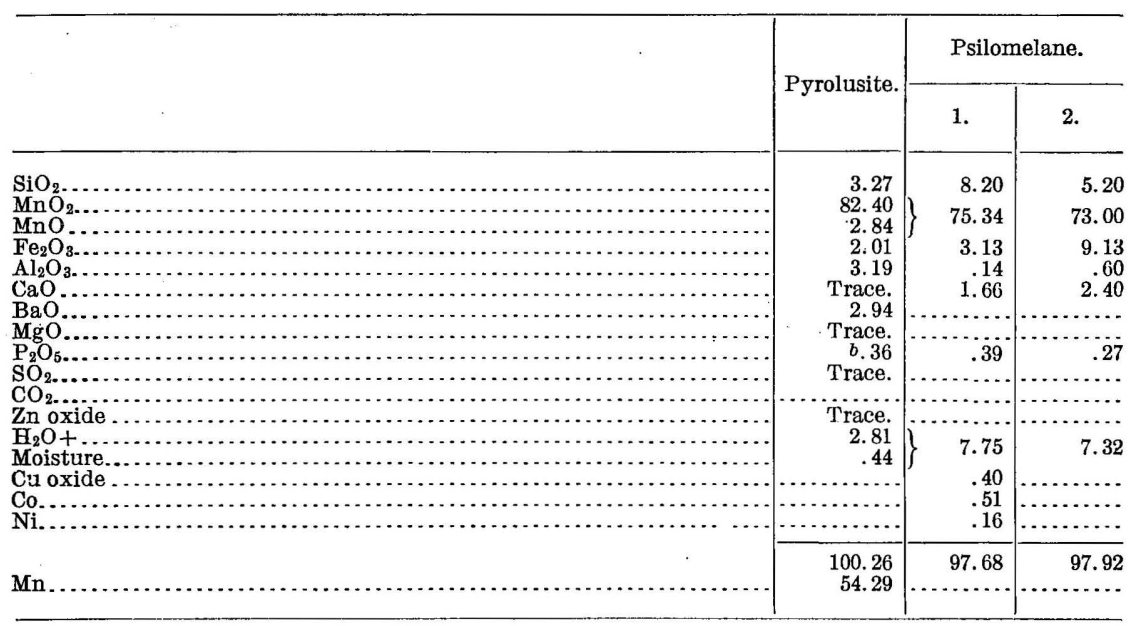

$a$ Seventeenth Ann. Rept. U. S. Geol. Survey, pt. 3, 1896, p. 221.

$b$ Phosphorus, 0.16 .

SAUSAR TAHSIL.

The ores of the Sausar tahsil in the Chhindwara district occur in lenticles and lenticular drawn-out bands of any thickness up to 50 or 100 feet (as at Kachi Dhana); as regards length the bands (at Wagora) have been traced at intervals for a mile. The deposits are inclosed in gneisses and schists or crystalline limestones and have the same strike and dip as those rocks. The ores commonly outcrop in hillocks. They consist mainly of braunite, psilomelane, and rhodochrosite, associated with spessartite and rhodonite, from which they are derived through processes of weathering.

The deposits of Bichua, Alesur, Devi, Ghoti, Wagora, and Dudhara consist mainly of spessartite-quartz rock with rhodonite, not sufficiently altered to form manganese-oxide deposits of commercial value. In the first three localities this rock is inclosed as bands in crystalline limestone; in the others, in biotite schist and gneiss. In some places the bands are partly altered to manganese oxides, and the inclosing limestones and schists are stained black. Rhodochrosite occurs in a few places. The bands vary in thickness and may be traced for considerable distances. In some places only single bands occur, but elsewhere a number of parallel bands are found together.

The Kachi Dhana deposit is the largest in the district, being probably 50 to 100 feet wide, and outcropping in five separate hillocks. It is composed of braunite and psilomelane associated with partly chalcedonized spessartite-quartz and magnetite-spessartite rocks. 
The Lakhanwara deposit consists mainly of gray crystalline braunite. The outcrop of the Gaimukh ore body is lenticular, 180 feet long east and west, and 75 feet broad. The ore is braunite with some rhodochrosite derived from spessartite and rhodonite, much of which is still unaltered. Only the central portion of the outcrop, 60 feet long and 20 feet wide, is sufficiently altered to be workable. The Sitapar deposit forms a hillock consisting of huge blocks containing a great variety of manganese minerals.

The Gowari Warhona deposit consists of a stratum $5 \frac{1}{2}$ to 6 feet thick and one-fourth mile long, dipping $50^{\circ} \mathrm{S} .30^{\circ} \mathrm{W}$. The ore is bedded in layers 1 to 4 inches thick. Outside of the limits mentioned, the ore grades into spessartite-quartz rock. In all of these localities the ore bodies occur in mica schist and gneiss.

Following are analyses of ores from the Sausar tahsil in the Chhindwara district:

Analyses of manganese ore from Sausar tahsil, Chhindwara, India.a

\begin{tabular}{|c|c|c|c|c|c|}
\hline Locality. & Mn. & Fe. & $\mathrm{SiO}_{2}$. & P. & $\begin{array}{l}\text { Mois- } \\
\text { ture at } \\
100^{\circ} \mathrm{C} .\end{array}$ \\
\hline Kachi Dhana. & $\begin{array}{l}54.73 \\
53.25\end{array}$ & 5.00 & 6.99 & \multirow{20}{*}{$\begin{array}{c}0.07 \\
.91 \\
.033 \\
.004 \\
.135 \\
.20 \\
.153 \\
.04 \\
.078 \\
1.036 \\
.06 \\
.12 \\
.072 \\
.055 \\
.28 \\
.28 \\
.276 \\
.306 \\
.15 \\
.07 \\
.03 \\
.09 \\
.122\end{array}$} & $\begin{array}{r}0.17 \\
.26\end{array}$ \\
\hline Do. & 51.87 & 4.92 & 16.27 & & \\
\hline Do.. & 53.05 & 2.82 & 1.10 & & \\
\hline Do. & 56.82 & 5.30 & 9.02 & & \\
\hline Lakhanwara.. & 50.41 & 11.77 & 4.86 & & .39 \\
\hline Do........ & 57.51 & 6.02 & 4.63 & & \\
\hline (....................... & 54.98 & 6.19 & 10.63 & & .32 \\
\hline (1, & $\begin{array}{l}56.68 \\
54.20\end{array}$ & $\begin{array}{l}6.21 \\
5.00\end{array}$ & $\begin{array}{l}7.68 \\
9.75\end{array}$ & & .... \\
\hline Sitapar......... & 54.97 & 6.89 & 6.95 & & .00 \\
\hline Do................. & 54.57 & 7.03 & 7.90 & & .04 \\
\hline (n.m. & 54.94 & 5.28 & 7.33 & & $\cdots \cdot$ \\
\hline Devi.1. & 48.95 & $\begin{array}{l}0.10 \\
7.03\end{array}$ & $\begin{array}{l}0.01 \\
4.98\end{array}$ & & 1.27 \\
\hline Ghoti... & 49.55 & 7.71 & 8.74 & & .52 \\
\hline Do. & 48.62 & 8.17 & 6.28 & & $\cdots$ \\
\hline (n.................... & 49.48 & 8.25 & 4.60 & & . \\
\hline (4) & 29.08 & 6.88 & 36.63 & & .86 \\
\hline 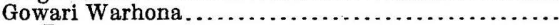 & 53.59 & 5.00 & 6.21 & & .31 \\
\hline ................... & 51.82 & 1.31 & 1.45 & & \\
\hline & 56.45 & 3.83 & 10.10 & & \\
\hline Do................. & 47.45 & 3.55 & 13.65 & & \\
\hline
\end{tabular}

$a$ Fermor, L. L., Notes on the petrology and manganese-ore deposits of the Sausar tahsil: Record Geol. Survey India, vol. 33, pt. 3, 1906, pp. 209, 214.

\section{OTHER DISTRICTS.}

In the Nagpur and Balaghat districts manganese ore occurs as lenticular masses and bands in quartzites, schists, and gneisses. Some of the ore bodies are very long and wide. At Balaghat one deposit is $1 \frac{3}{4}$ miles long; at Manegaon, in the Nagpur district, the ore body is $1 \frac{1}{2}$ miles long; and at Thiroi, in the Balaghat district, the deposit is nearly 6 miles long. At Kandri a deposit of pure ore is 100 feet wide, and at Ramdongri a body of mixed ore and spessartite rock is as much as 1,500 feet wide. 


\section{CEYLON. $a$}

Small deposits of manganese ore containing 1.61 per cent of cobalt occur at Ampituja, Ceylon.

\section{JAPAN. $b$}

Moderate quantities of manganese oxide are mined yearly in Japan, but the deposits are not extensive. The ores occur in the mountainous districts, are mined from shallow surface workings, and are carried down in small quantities by the natives. The chief exports are from the ports of Yokohama, Kobe, and Osaka.

Alabandite associated with rhodochrosite occurs in large quantities in the silver veins at Innai, in the Province of Akita. ${ }^{c}$

The following are analyses of manganese ores from Japan:

Analyses of Japanese manganese ores. ${ }^{a}$

\begin{tabular}{|c|c|c|c|c|}
\hline & 1. & 2. & 3. & 4. \\
\hline 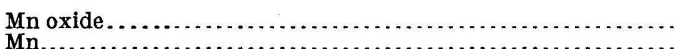 & 87.3 & 71.9 & 71.7 & \\
\hline $\mathrm{PLO}_{2}$ & $\begin{array}{l}1.4 \\
3.47\end{array}$ & 15.25 & 2.09 & $\begin{array}{r}49.00 \\
8.50\end{array}$ \\
\hline $\begin{array}{l}\mathrm{Al}_{2} \mathrm{O}_{3} \\
\mathrm{SO}_{3} \mathrm{P}_{2} \mathrm{O}_{5}\end{array}$ & $\begin{array}{l}.43 \\
.04 \\
.201\end{array}$ & $\begin{array}{r}4.44 \\
.03 \\
.07\end{array}$ & $\begin{array}{r}7.17 \\
.06 \\
.29\end{array}$ & $\cdots$ \\
\hline "1 & 1.25 & 2.05 & 2.30 & .09 \\
\hline Moisture. & & & & 9.00 \\
\hline
\end{tabular}

a Nineteenth Ann. Rept. U. S. Geol. Survey, pt. 6, 1898, p. 123.

\section{OCEANIA.}

\section{PHILIPPINE ISLANDS. $d$}

Manganese deposits are found in the Philippine Islands in the Provinces of Ilocos Norte and Tarlac, on Luzon Island; and on Masbate Island. In Ilocos Norte the ores occur as nodules on the surface, derived from the weathering of veins. On Masbate Island and in Tarlac they occur as bowlders in bedded deposits apparently residual. $e$

$a$ Dunstan, W. R., Manganese: Rept. Results Mineral Survey Ceylon, 1903-4, p. 8.

$b$ References on the manganese ores of Japan:

Mineral Resources U. S. for 1893, p. 152.

Sixteenth Ann. Rept. U. S. Geol. Survey, pt. 3, 1895, p. 451.

Nineteenth Ann. Rept. U. S. Geol. Survey, pt. 6, 1898, p. 122.

Mineral Resources U. S. for 1903, p. 154.

c Stelzner, A. M., and Bergeat, A., Die Erzlagerstätten, pp. 716-717.

$d$ References on the manganese deposits of the Philippine Islands:

Smith, W. D., The asbestos and manganese deposits of Ilocos Norte, with notes on the geology of the region: Philippine Jour. Sci., vol. 2, June, 1907, p. 145.

Smith, W. D., Nonmetallic minerals: Far Eastern Review, June, 1907, p. 10.

McCaskey, H. D., unpublished notes.

e McCaskey, H. D., unpublished notes. 
The Masbate Island deposit is in the Arparoy mining district in the northern part of the island. The ores are argentiferous and occur as nodules in reddish shales. They have the following composition:

Analysis of manganese ore from Masbate Island, Philippines. ${ }^{a}$

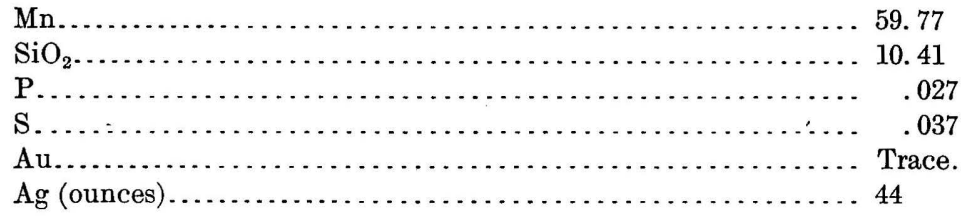

The deposit in Tarlac Province is on the road between Capiz and Iba. Both of these bedded deposits are undeveloped and their extent is unknown.

The deposits of Ilocos Norte are near Nagpartian, in the northern part of the province. The following succession of rocks is given for this region by Smith: ${ }^{b}$

Succession of rocks in Ilocos Norte, Philippines.

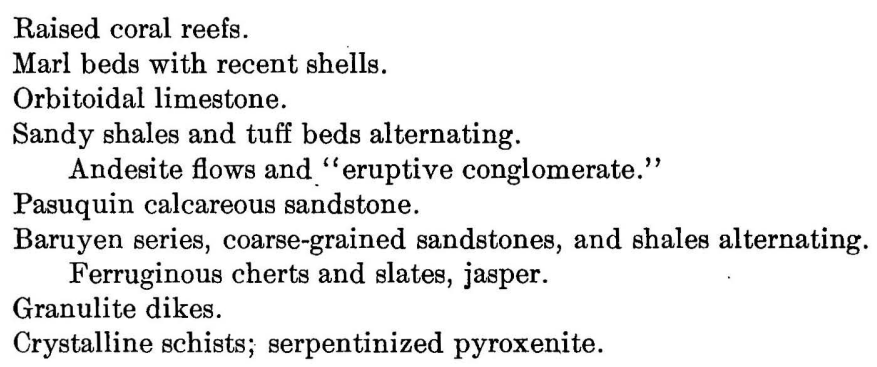

The pyroxenite and crystalline schists were formed by the regional metamorphism of a diorite batholith and associated sediments, and by the intrusion of granulite dikes. They constitute the basement upon which other comparatively unaltered sediments and volcanic rocks were deposited. The only volcanic rocks present in the overlying sediments are a series of tuffs, andesite flows, and eruptive conglomerates near the middle of the section.

The manganese ores occur in a region underlain by the "eruptive conglomerate." This rock consists of masses of lava fragments with a soft tuff-like matrix, also volcanic. The fragments are porphyritic, the phenocrysts being mainly plagioclase and augite, with some magnetite. In origin the rock is probably closely related to the andesite flows and the tuff beds in the same series.

Flattened nodules of pyrolusite and limonite, one-half to 2 or 3 inches in diameter, scattered over the surface, form the principal deposits. These are derived from the disintegration of small man-

a McCaskey, H. D., unpublished notes.

$b$ Smith, W. D., Philippine Jour. Sci., vol. 2, 1907, p. 170. 
ganese and iron-oxide veins in the matrix between the hard fragments in the underlying eruptive conglomerate. The veins are 5 to 50 millimeters wide and occur locally in the matrix, penetrating it in different directions.

The most important of the deposits is between Punta Negra and Punta Blanca, close to the sea. Here 2 feet of pyrolusite surface concentrates occur on the surface of the eruptive conglomerate in a depression between outcrops of the overlying Orbitoidal limestone. Underneath the deposits is a thin layer of limonite.

The following is an analysis of ore from this region:

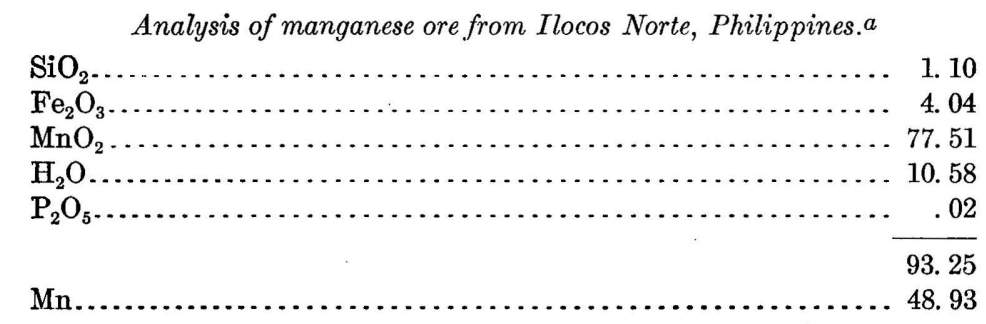

JAVA. $b$

Manganese deposits have been exploited in the regencies of Pegasin and Mongolaen, in Java, and a small amount of ore has been shipped from the island.

\section{BORNEO. $c$}

Considerable deposits of manganese ore were recently discovered at Taritipan, in Maruda Bay, British North Borneo.

NEW ZEALAND. $d$

The manganese ores of New Zealand consist mainly of braunite and wad, with pyrolusite here and there in small quantities. Small amounts of rhodonite also are found. The principal work has been done near Russell and at Waiheki, a considerable distance north of Russell. The ore here contains 75 per cent oxide of manganese. At the Bay of Islands, Napier, an ore with 45 per cent manganese is found.

$a$ Smith, W. D., Philippine Jour. Sci., vol. 2, 1907, p. 170.

$b$ Mineral Resources U. S. for 1903, p. 155.

$c$ Manganese ore in Borneo (Review): Jour. Iron and Steel Inst., 1907, No. 3, p. 329.

$d$ References on the manganese ores of New Zealand:

Mineral Resources U. S. for 1886, p. 207.

Mineral Resources U. S. for 1893, p. 154.

Sixteenth Ann. Rept. U. S. Geol. Survey, pt. 3, 1895, p. 452. 
AUSTRALIA. $a$

In Australia there are manganese deposits in New South Wales, South Australia, and Queensland.

\section{NEW SOUTH WALES.}

The ores of New South Wales are brown and black oxides, which contain on an average 40 to 50 per cent of metallic manganese but may run as high as 53 per cent. They are found in the Bathurst and Bendemeer districts.

\section{SOUTH AUSTRALIA.}

Ores of the following composition occur near Gordon, South Australia:

Analysis of manganese ore from South Australia. ${ }^{b}$

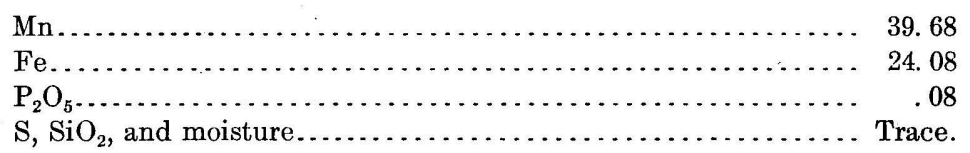

\section{QUEENSLAND.}

The principal manganese deposits in Queensland are in the Gladstone district, extending from Targinie on the northwest to Calliope on the south, and Quoin Island, on the east. It has, roughly, as its greatest dimensions a length of 15 miles and a width of 12 miles.

The area consists of massive slates, quartzites, jasperoids, and sandy clay schists, variously intersected by dikes of trachyte, syenite, and diorite, and locally overlain by river and estuarine alluvials.

The typical country rock for manganese is hard, flinty, red or brown, in places quartz-veined, jasperoid clay slate, indurated and colored, owing to partial or complete replacement by silica and oxides of iron. These indurated rocks pass at 20 to 50 feet in depth into soft brown or yellow clay, slate (or schist), or bluish quartzite.

The deposits are lenticular, lying, with very few exceptions, with their longer axes parallel to the bedding of the slates. As a rule, the outcrop is small, and the work thus far indicates that the depth of the lenses is no greater than their greatest length. There are probably a number of overlapping lenses, extending to a considerable depth. The deposits may be considered to form belts running about north and south, with a tendency to north-northwest, parallel to the strike of the rocks. One deposit (in the Mount Miller mine) is 3 to 21 feet thick. 
The typical ore is chiefly psilomelane, but contains pyrolusite and probably also braunite. It is massive and mostly steel-gray, passing into dull bluish in bands and patches. In some places it is honeycombed, and there the cavities are lined with a dead-black deposit of binoxide.

The following analyses of ore from the Gladstone district show the limits between which the composition varies:

Analyses of manganese ore from the Gladstone district, Queensland.a

\begin{tabular}{|c|c|c|}
\hline & 1. & 2. \\
\hline $\begin{array}{l}\mathrm{Mn} \\
\mathrm{Fe} \\
\mathrm{SiO} \\
\mathrm{S} \\
\mathrm{P} \\
\mathrm{S}\end{array}$ & $\begin{array}{r}30.3 \\
1.2 \\
5.8 \\
\text { Trace. } \\
\text { Trace. }\end{array}$ & $\begin{array}{r}48.7 \\
7.2 \\
15.3 \\
.11 \\
\cdots\end{array}$ \\
\hline
\end{tabular}

a Mineral Resources U. S. for 1904, p. 138.

Manganese occurs at Auckland Hill, Queensland, in bunches of 20 or 30 tons connected by stringers. In this locality it has replaced slate. The ore is a mixture of psilomelane, pyrolusite, and braunite, massive and steel-gray, having the following composition:

Analyses of manyanese ore from Auckland Hill, Queensland. ${ }^{a}$

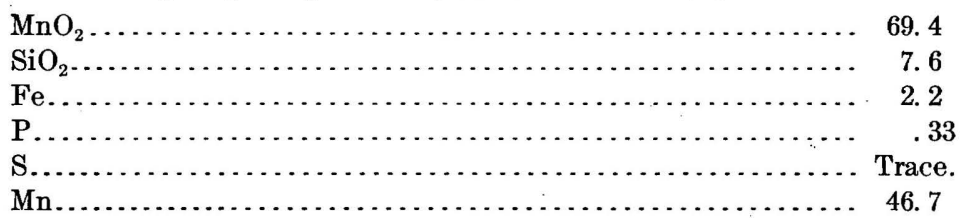

Manganese ore occurs in Queensland, also in the district between Rockhampton and Emu Park, in the Ipswich district, in the Hodgkinson district, in the parish of Rosenthal, and at Mount Gammie in the Darling Downs district. 


\section{CHAPTER IV. \\ CHEMISTRY OF MANGANESE. ${ }^{a}$ \\ METALLIC MANGANESE AND ITS ALLOYS.}

Manganese is a white or grayish-white metal having the appearance of cast iron, but possessing a reddish luster like bismuth. It is very hard and brittle, has a specific gravity between 7.13 and 8 , and an atomic weight of $54.6(\mathrm{H}=1)$ or $54.93(\mathrm{O}=16)$. Manganese oxidizes readily and is never found free in nature. It crumbles when exposed to the air, is soluble in dilute acids, and decomposes warm water with the evolution of hydrogen. It melts at about $1,900^{\circ} \mathrm{C}$.

The various processes for the preparation of manganese may be arranged in three groups, ${ }^{b}$ namely:

1. Reduction of the oxides or salts with sodium, magnesium, aluminum, hydrogen, or iron sulphide.

2. Electrolysis of manganese salts.

3. Carbon reduction (a) in gas or coke-fired furnaces, or $(b)$ in electric furnaces.

By the first two methods the pure metal is produced, while by the third impure alloys are obtained which contain admixtures of carbon, silicon, or iron.

The original process for the preparation of manganese, proposed by John in $1807,^{c}$ consists in reducing the oxide produced by the calcination of the carbonate, by mixing it with carbon and oil, covering the mixture with charcoal in a charcoal-lined crucible, and heating it to high temperature. The metal produced contained considerable carbon and silicon from the charcoal, but by further ignition with borax a very pure metal was obtained.

Sainte-Claire Deville ${ }^{d}$ reduced $\mathrm{Mn}_{3} \mathrm{O}_{4}$ with sugar charcoal and obtained a regulus coated with a violet crystalline mass, which appeared to be calcium manganese spinel, $\mathrm{CaO} \cdot \mathrm{Mn}_{2} \mathrm{O}_{3}$.

\footnotetext{
$a$ References on the chemistry of manganese used in the preparation of this chapter:

Roscoe, H. E., and Schorlemmer, C., A treatise on chemistry, vol. 2, 1907, p. 1096.

Newth, G. S., Text-book of inorganic chemistry, 1908, pp. 666-670.

Moissan, H., Traite de chimie minérale, IV, Métaux: Manganese, p. 487.

$b$ Roberts, Edwin G. Ll., and Wraight, Ernest A., The preparation of carbon-free ferromanganese: Jour. Iron and Steel Inst., London, 1906, No. 2, p. 239.

c John, J. F., Contributions toward a chemical knowledge of manganese: Thomson's Annals of Philosophy, vol. 2, 1813.

$d$ Sainte-Claire Deville, M. H., Mémoire sur la production des températurs très élevées: Annales chim. phys., vol. 46, 1856, p. 199.
} 
Tamm ${ }^{a}$ suggested the following method for its preparation: A flux is prepared of twenty parts of powdered soda-lime glass and seven parts of fluorspar, and is added to one part of lampblack and eleven parts of manganese oxides. The material is heated to a white heat in a plumbago crucible lined with a mixture of graphite and fire clay. A green slag and metallic manganese are produced. The slag is used as flux for further smelting operations. The metal contains a variety of impurities which may be largely removed by fusion with half its weight of manganese carbonate.

The following are analyses of the impure regulus and the pure form of the metal:

Analyses of metallic manganese. ${ }^{a}$

\begin{tabular}{|c|c|c|}
\hline & 1. & 2. \\
\hline 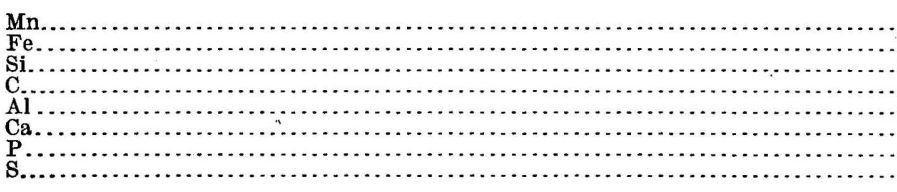 & $\begin{array}{r}96.90 \\
1.05 \\
.85 \\
.95 \\
.10 \\
.05 \\
.05 \\
.05\end{array}$ & $\begin{array}{r}99.910 \\
.050 \\
.015 \\
.025 \\
\cdots \\
\cdots \\
\cdots\end{array}$ \\
\hline & 100.00 & 100.000 \\
\hline
\end{tabular}

$a$ Roscoe and Schorlemmer, op. cit., p. 1099.

By reduction in a blast furnace, manganese of the following composition has been obtained: Manganese, 85 per cent; iron, 8 per cent; carbon, 6 per cent; silicon, phosphorus, and sulphur, traces.

Manganese has also been prepared by igniting a mixture of fluorspar and manganese chloride with metallic sodium, or by gradually adding metallic magnesium to a mixture of manganese chloride and potassium chloride.

The preparation of the metal by reduction with aluminum has received considerable attention, and high-grade products have been produced. By this method powdered aluminum and manganese oxide are mixed together in equivalent proportions, forming what is known as manganese thermite. This is ignited with a barium oxide cartridge; after the reduction molten metallic manganese occupies the lower part of the crucible with a slag of alumina $\left(\mathrm{Al}_{2} \mathrm{O}_{3}\right)$ above it.

When the oxides of manganese are heated in a stream of hydrogen at a white heat they are reduced to the metal, but at a red heat only the lower oxide is formed. Moissan, by using excess of the oxide, has prepared metallic manganese free from carbon and silicon in the electric furnace.

Alloyed with iron, as in ferromanganese, manganese steel, spiegeleisen, silicospiegel, and silicomanganese, manganese may be obtained by the reduction of the oxides with carbon in the ordinary 
blast furnace or in the electric furnace. These products contain considerable carbon and some silicon. Cupromanganese, an alloy of copper and manganese, is obtained by the reduction of the oxides of these metals in a graphite crucible or reverberatory furnace. Other alloys, such as manganese bronze, manganese brass, and manganese German silver are commonly obtained by mixing cupromanganese with metals such as zinc, tin, aluminum, and others. Manganese amalgam, an alloy of manganese and mercury, is prepared by electrolysis. More complete descriptions of the alloys are. given in the chapter on the uses of manganese (p. 243).

\section{MANGANESE COMPOUNDS. $a$}

\section{MANGANESE OXIDES, HYDRATES, AND ACIDS.}

List of manganese oxides, hydrates, and acids.

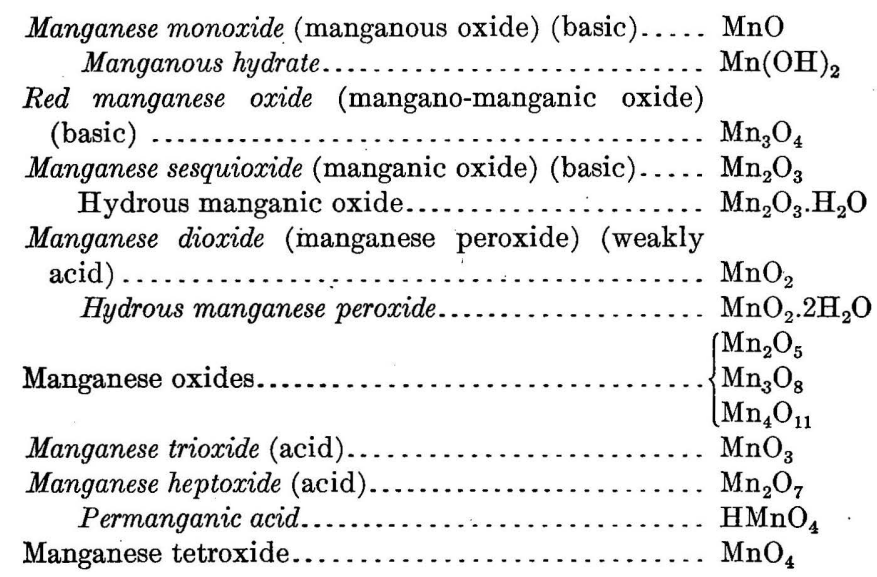

DOUBLE OXIDES.

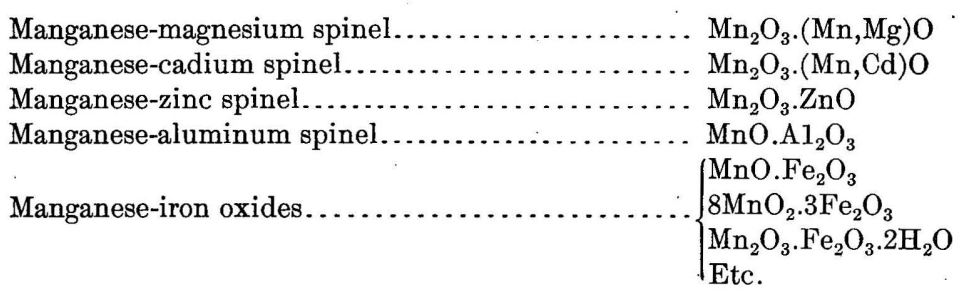

Manganous oxide and manganic oxide give rise to manganous and manganic salts, respectively. Mangano-manganic oxide yields with acid both manganous and manganic salts or a mixture of the two. Manganese dioxide gives manganous salts with the elimination of available oxygen, and also, by combining with certain basic oxides

$a$ In the tables showing the composition of compounds of manganese the names of the most important compounds are printed in italic. 
of other metals, forms unstable compounds called manganites. Manganese trioxide and manganese heptoxide give rise to manganates and permanganates, respectively.

In the formation of manganous and manganic salts, manganese acting as a metal unites with the halogens to form chlorides, fluorides, bromides, iodides, chlorates, bromates, and iodates; with sulphur to form sulphides, sulphites, and sulphates; with selenium to form selenides, selenites, and selenates; with nitrogen to form nitrides and nitrates; with phosphorus to form phosphides, phosphites, and phosphates; with arsenic to form arsenides, arsenites, and arsenates; with antimony to form antimonide and antimonates; with vanadium to form vanadates; with boron to form borides, borates, and boracites; with carbon to form carbides and carbonate; with cyanogen to form cyanides and a thiocyanate; and with silicon to form silicides and silicates; with titanium to form titanates; with tin to form stannates, and with zirconium to form zirconates. Manganese forms double salts with all the principal metals, such as potassium, sodium, calcium, magnesium, barium, zinc, etc. Compounds of manganese with organic acids such as acetates are also well known.

In the formation of manganites, manganates, and permanganates, manganese acts as a nonmetal, or rather as an electro-negative element uniting with oxygen to form the acid radicle in salts in which the bases are potassium, sodium, calcium, barium, or other metals. Manganites may be regarded as salts of hypothetical manganous acid; manganates, as salts of hypothetical manganic acid $\left(\mathrm{H}_{2} \mathrm{MnO}_{4}\right)$; and permanganates, as salts of permanganic acid $\left(\mathrm{HMnO}_{4}\right)$, an unstable, deep-red liquid.

Manganese monoxide ( $\mathrm{MnO})$ is a light-green powder obtained by igniting a mixture consisting of equal parts of manganous chloride and sodium carbonate, with some ammonium chloride, or by heating higher manganese oxides or the carbonate in a stream of hydrogen. It has been found in Sweden as the mineral manganosite.

When solutions of potassium hydroxide and a manganous salt are mixed, air being excluded, manganous hydroxide, $\mathrm{Mn}(\mathrm{OH})_{2}$, is obtained as a white precipitate, which readily oxidizes and turns brown on exposure to air. It occurs in Sweden as the mineral pyrochroite.

Manganous salts $\left(\mathrm{MnR}_{2}^{\prime}\right)$ are abundant. They are generally faintly pink, but this color may be due to a slight admixture of manganic salts.

Mangano-manganic oxide $\left(\mathrm{Mn}_{3} \mathrm{O}_{4}\right)$ is the most stable of the manganese oxides, being formed both when higher and when lower oxides are strongly heated. Thus when the dioxide is heated oxygen is given off, and the red oxide remains; and when the monoxide is 
heated in air and oxygen is absorbed the same compound is formed. When prepared thus it appears as a brownish-red powder, which may be crystallized by heating gently in a slow current of gaseous hydrochloric acid. It is also obtained by heating mixtures of manganese sulphate and potassium sulphate, or of manganous oxide and calcium chloride, to bright redness. When the red oxide is treated with cold acids a mixture of manganous and manganic salts is produced; but when it is heated with dilute acids manganous salts and manganese peroxide are formed. Thus $\mathrm{Mn}_{3} \mathrm{O}_{4}$ might be considered either as a mixture of $\mathrm{MnO}$ and $\mathrm{Mn}_{2} \mathrm{O}_{3}$ or of $2 \mathrm{MnO}$ and $\mathrm{MnO}_{2}$. Mangano-manganic oxide is found in nature as the mineral hausmannite.

Manganic oxide $\left(\mathrm{Mn}_{2} \mathrm{O}_{3}\right)$ is obtained as a black powder when manganic hydrate, formed from the oxidation of manganous hydrate, is heated, or when any of the oxides of manganese are heated in oxygen. In nature it is found as the basic silicate, braunite, $3 \mathrm{Mn}_{2} \mathrm{O}_{3} \cdot \mathrm{MnSiO}_{3}$.

Manganic hydrate, $\mathrm{Mn}_{2} \mathrm{O}_{3} \cdot \mathrm{H}_{2} \mathrm{O}$ or $\mathrm{MnO}(\mathrm{OH})$, occurs in nature as a black mineral, manganite. When this is heated at $270^{\circ}$ to $310^{\circ} \mathrm{C}$. it is converted into the dioxide without change of form. Artificially, manganic hydrate is obtained as a dark-brown powder from the oxidation of manganous hydrate in moist air, or by passing chlorine into water in which an excess of manganese carbonate is suspended.

The manganic salts, $\mathrm{MnR}_{3}^{\prime}$ and $\mathrm{Mn}_{2} \mathrm{R}^{\prime \prime}{ }_{3}$, are very unstable and are strongly colored. They are not as abundant as manganous salts.

Manganese peroxide $\left(\mathrm{MnO}_{2}\right)$ is found in nature as polianite and pyrolusite and with other oxides, water, and impurities as psilomelane. Artificially manganese peroxide may be prepared as black powder or fragments by melting manganous nitrate and heating it until red fumes appear and the lower oxides are deposited. The clear liquid, after being decanted, is heated for forty to sixty hours at $150^{\circ}$ to $160^{\circ} \mathrm{C}$ : and manganese dioxide is deposited. Manganous carbonate, when it is heated to $260^{\circ} \mathrm{C}$. in the presence of air and the residue is treated with hydrochloric acid, leaves pure manganese dioxide. When manganese dioxide is heated it loses its oxygen, changing first to $\mathrm{Mn}_{2} \mathrm{O}_{3}$, and finally to $\mathrm{Mn}_{3} \mathrm{O}_{4}$.

A compound approximating in composition to hydrated manganese peroxide may be obtained by the action of oxidizers like potassium permanganate or sodium hypochlorite on manganous salts. As it readily loses part of its oxygen, or combines to form manganites, the pure hydrated peroxide is almost impossible to prepare. It commonly consists of mixtures like $\mathrm{xMnO}+\mathrm{yMnO}_{2}+\mathrm{zH}_{2} \mathrm{O}$. Hydrated manganese dioxide in which part of the water is replaced by barium oxide occurs in nature as the mineral psilomelane. 
Manganese trioxide $\left(\mathrm{MnO}_{3}\right)$ is obtained as a reddish amorphous mass by dropping a solution of potassium permanganate in sulphuric acid on dry sodium carbonate:

$$
2\left(\mathrm{MnO}_{3}\right) \mathrm{SO}_{4}+2 \mathrm{Na}_{2} \mathrm{CO}_{3}=2 \mathrm{Na}_{2} \mathrm{SO}_{4}+2 \mathrm{MnO}_{3}+2 \mathrm{CO}_{2}+\mathrm{O}_{2} \text {. }
$$

It is carried forward by the carbon dioxide as pink fumes and may be deposited on fragments of glass in a freezing mixture. It decomposes in water with the formation of permanganic acid and manganese dioxide.

Manganese heptoxide $\left(\mathrm{Mn}_{2} \mathrm{O}_{7}\right)$ is obtained on the addition of water to a solution of potassium permanganate in concentrated sulphuric acid:

$$
\begin{aligned}
& 2 \mathrm{KMnO}_{4}+2 \mathrm{H}_{2} \mathrm{SO}_{4}=\left(\mathrm{MnO}_{3}\right)_{2} \mathrm{SO}_{4}+\mathrm{K}_{2} \mathrm{SO}_{4}+2 \mathrm{H}_{2} \mathrm{O} . \\
& \left(\mathrm{MnO}_{3}\right)_{2} \mathrm{SO}_{4}+\mathrm{H}_{2} \mathrm{O}=\mathrm{Mn}_{2} \mathrm{O}_{7}+\mathrm{H}_{2} \mathrm{SO}_{4} .
\end{aligned}
$$

The salt decomposes with the formation of green oily drops, which dissolve in the acid and produce an olive-green solution, from which the heptoxide separates out as a dark reddish-brown liquid on the addition of water.

Permanganic acid $\left(\mathrm{HMnO}_{4}\right)$ is obtained in solution when a requisite amount of dilute sulphuric acid is added to barium permanganate, or when any manganous salt, except the haloid compounds, is warmed with nitric acid and lead dioxide, or with dilute sulphuric acid and potassium bromate. The solution is deep-red and exhibits a blue color by reflected light. On exposure to light, or when gently heated, it gives off oxygen and the hydrated dioxide separates out. It is a strong oxidizing agent.

MANGANESE AND THE HALOGENS.

List of manganese halogen salts.

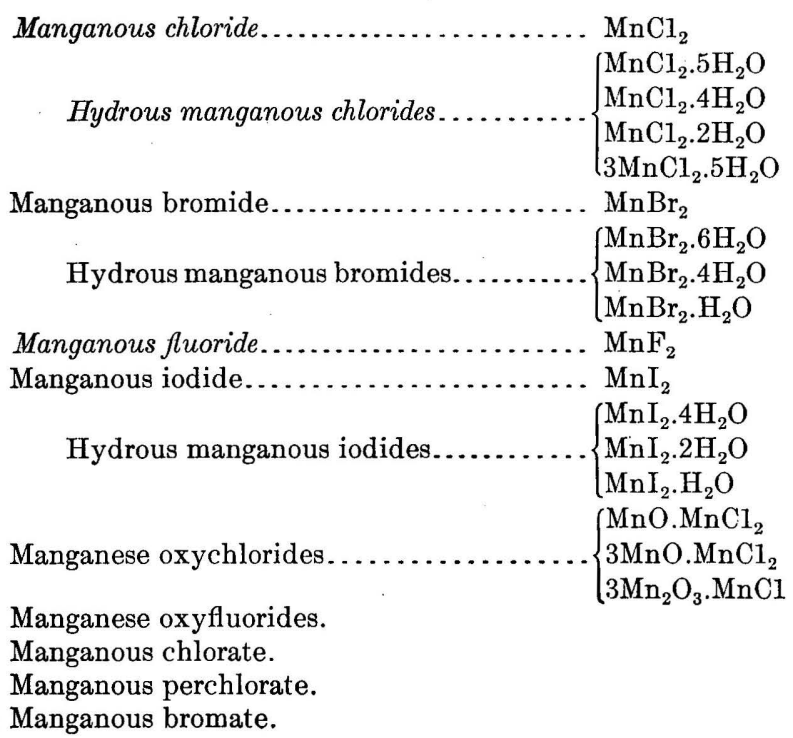




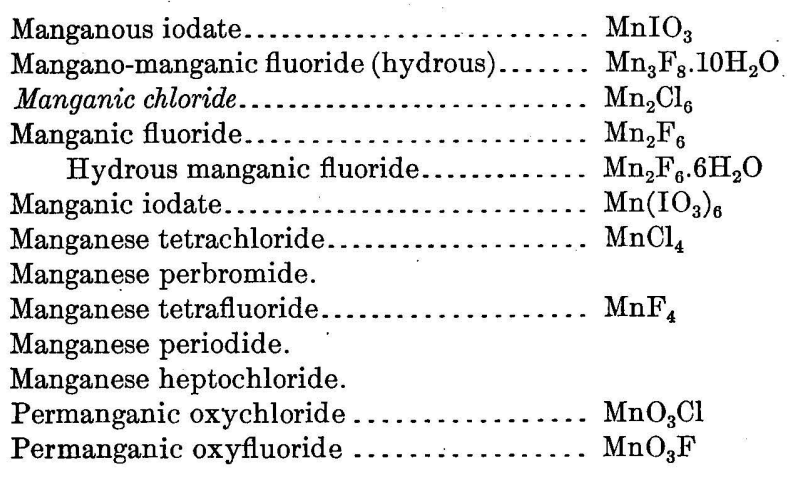

DOUBLE SALTS.

Manganese-potassium chloride............. $\mathrm{MnCl}_{4} .2 \mathrm{KCl}$

Manganese-potassium chlorides (hydrous). . $\left\{\mathrm{MnCl}_{2} \cdot \mathrm{KCl} \cdot 2 \mathrm{H}_{2} \mathrm{O}\right.$

Manganese-ammonium chloride (hydrous) ... $\mathrm{MnCl}_{2} \cdot \mathrm{NH}_{3} \mathrm{Cl} \cdot 2 \mathrm{H}_{2} \mathrm{O}$

Manganese-lithium chloride (hydrous) ........ $\mathrm{MnCl}_{2} \cdot \mathrm{LiCl}_{2} \cdot 6 \mathrm{H}_{2} \mathrm{O}$

Manganese-magnesium chloride and bromide (hydrous).

Manganese-cadmium chloride (hydrous) ..... $\mathrm{MnCl}_{2} \cdot 2 \mathrm{CdCl}_{2} \cdot 12 \mathrm{H}_{2} \mathrm{O}$

Manganese-cæsium chloride ............... $\mathrm{MnCl}_{2}, 2 \mathrm{CsCl}$

Manganese-cæsium chloride (hydrous) ....... $\mathrm{MnCl}_{2} \cdot 2 \mathrm{CsCl} \cdot \mathrm{nH}_{2} \mathrm{O}$

Manganese-rubidium chloride (hydrous) ...... $\mathrm{MnCl}_{2} \cdot 2 \mathrm{RbCl} .2 \mathrm{H}_{2} \mathrm{O}$

Manganese-potassium fluorides (anhydrous $\left\{\mathrm{Mn}_{2} \mathrm{~F}_{6} \cdot 4 \mathrm{KF} \cdot 2 \mathrm{H}_{2} \mathrm{O}\right.$

and hydrous) $\ldots \ldots \ldots \ldots \ldots \ldots \ldots \ldots \ldots, \mathrm{MnF}_{4} \cdot 2 \mathrm{KF}$

Manganese-ammonium fluorides............ $\left\{\begin{array}{l}\mathrm{Mn}_{2} \mathrm{~F}_{6} \cdot 4 \mathrm{NH}_{3} \mathrm{~F}_{4} \\ \mathrm{MnF}_{4} \cdot 2 \mathrm{NH}_{3} \mathrm{~F}\end{array}\right.$

Manganese-sodium fluoride............... $\mathrm{Mn}_{2} \mathrm{~F}_{6} .4 \mathrm{NaF}$

Manganese-nickel fluoride.

Manganese-zinc fluoride (hydrous) .......... $\mathrm{Mn}_{2} \mathrm{~F}_{6} \cdot 2 \mathrm{ZnF}_{2} \cdot 8 \mathrm{H}_{2} \mathrm{O}$

Manganese-potassium iodate................ $\mathrm{Mn}\left(\mathrm{IO}_{3}\right)_{4} .2 \mathrm{KIO}_{3}$

Manganese-ammonium iodate........... $\mathrm{Mn}\left(\mathrm{IO}_{3}\right)_{4} \cdot 2 \mathrm{NH}_{3} \mathrm{IO}_{3}$

Manganese-barium iodate............... $\mathrm{Mn}\left(\mathrm{IO}_{3}\right)_{4} \cdot \mathrm{Ba}\left(\mathrm{IO}_{3}\right)_{2}$

Manganous chloride is obtained by dissolving any of the oxides or the carbonate in hydrochloric acid and evaporating, $\mathrm{MnCl}_{2} \cdot 4 \mathrm{H}_{2} \mathrm{O}$ being deposited in pink crystals, which may be made anhydrous by heating in a stream of hydrochloric acid. It is also prepared by burning the metal in chlorine gas, or by passing hydrochloric acid over the heated carbonate. Various hydrated manganous chlorides exist. Manganous chloride forms double salts with the chlorides of other metals.

Manganous bromide $\left(\mathrm{MnBr}_{2}\right)$ is a pale-red solid obtained by heating the powdered metal in bromine vapor; the hydrated form $\left(\mathrm{MnBr}_{2}\right.$. $4 \mathrm{H}_{2} \mathrm{O}$ ) is obtained by dissolving the carbonate in hydrobromic acid and evaporating the solution.

Manganous fluoride $\left(\mathrm{MnF}_{2}\right)$ is obtained by dissolving metallic manganese or the carbonate in hydrofluoric acid. On evaporation the fluoride is deposited as a white crystalline powder. It is obtained 
as a rose-colored mass by the action of hydrogen fluoride on manganese. Manganese fluoride is insoluble in water, but dissolves in strong acids.

Manganous iodide $\left(\mathrm{MnI}_{2}\right)$ is obtained by the dehydration of the hydrated salts in a vacuum. The hydrated salts are obtained as rose-red crystals by dissolving the carbonate in hydroiodic acid.

Manganic chloride is obtained in a dark solution by dissolving any of the oxides, $\mathrm{Mn}_{3} \mathrm{O}_{4}, \mathrm{Mn}_{2} \mathrm{O}_{3}$, or $\mathrm{MnO}_{2}$, in cold concentrated hydrochloric acid. From this solution it has never been isolated, but it is supposed to have the composition $\mathrm{Mn}_{2} \mathrm{Cl}_{6}$. The solution yields double salts of the type $\mathrm{Mn}_{2} \mathrm{Cl}_{6} \cdot 2 \mathrm{R}^{\prime} \mathrm{Cl}$ with potassium and ammonium. When the solution is heated chlorine is evolved and manganous chloride remains.

Manganic fluoride $\left(\mathrm{Mn}_{2} \mathrm{~F}_{6}\right)$ is obtained in purple pseudomorphs after manganous iodide by the action of fluorine on the iodide. It is decomposed by heat into manganous fluoride and fluorine, dissolves in acids, and is decomposed by water. The hydrated fluoride $\left(\mathrm{Mn}_{2} \mathrm{~F}_{6} \cdot 3 \mathrm{H}_{2} \mathrm{O}\right)$ is obtained in ruby-red crystals by dissolving the oxides, $\mathrm{Mn}_{2} \mathrm{O}_{3}$ or $\mathrm{MnO}_{2}$ in hydrofluoric acid.

Manganese tetrafluoride $\left(\mathrm{MnF}_{4}\right)$ has been obtained by dissolving the dioxide in concentrated hydrofluoric acid. It has energetic oxidizing properties and is a decolorizer.

Manganese tetrachloride $\left(\mathrm{MnCl}_{4}\right)$ has been obtained as a green solution by the action of hydrochloric acid gas on manganese dioxide in the presence of alcohol or ether. A blue solution has been obtained by other methods of formation.

Permanganic oxychloride $\left(\mathrm{MnO}_{3} \mathrm{Cl}\right)$ is obtained by gradually adding fused sodium chloride to a solution of potassium permanganate in concentrated sulphuric acid. It is evolved as yellow gas and is condensed by a freezing mixture to a greenish-brown liquid, which, when exposed to the air, emits a purple-red vapor. When heated it explodes violently, and water decomposes it into permanganic and hydrochloric acids. The corresponding oxyfluoride $\left(\mathrm{MnO}_{3} \mathrm{~F}\right)$ is also known.

Manganese chlorides form double salts with alkaline chlorides. A dark crystalline precipitate of potassium manganichloride $\left(\mathrm{MnCl}_{4} \cdot 2 \mathrm{KCl}\right)$ is prepared by boiling potassium permanganate with glacial acetic acid and saturating the resulting reddish-brown solution with hydrochloric acid.

Manganese fluorides form double salts with the alkali fluorides. Potassium manganifluoride $\left(\mathrm{MnF}_{4} .2 \mathrm{KCl}\right)$ is obtained in golden-yellow hexagonal tablets by dissolving potassium manganite in a mixture of hydrofluoric acid and potassium fluoride. It is decomposed by water, and is dissolved by hydrochloric acid into a dark-brown solution. A rubidium salt of similar nature has been prepared. 


\section{MANGANESE AND SULPHUR.}

List of sulphur compounds of manganese.

Manganese monosulphide.................. MnS

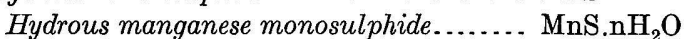

Manganese oxysulphide.................. MnS.MnO

Manganese sulphites (hydrous).............. $\left\{\begin{array}{l}\mathrm{MnSO}_{3} \cdot 3 \mathrm{H}_{2} \mathrm{O} \\ \mathrm{MnSO}_{3} \cdot 2 \mathrm{H}_{2} \mathrm{O} \\ \mathrm{MnSO}_{3} \cdot \mathrm{H}_{2} \mathrm{O}\end{array}\right.$

Basic manganese sulphite............ $5 \mathrm{MnSO}_{3} \cdot 2 \mathrm{Mn}(\mathrm{OH})_{2} \cdot \mathrm{nH}_{2} \mathrm{O}$

Manganese hyposulphite................... $\mathrm{MnS}_{2} \mathrm{O}_{3}$

Manganous sulphate.................... $\mathrm{MnSO}_{4}$

Hydrous manganous sulphates............. $\left\{\begin{array}{l}\mathrm{MnSO}_{4} \mathrm{H}_{2} \mathrm{O} \\ \mathrm{MnSO}_{4} \cdot 2 \mathrm{H}_{2} \mathrm{O} \\ \mathrm{MnSO}_{4} \cdot 3 \mathrm{H}_{2} \mathrm{O} \\ \mathrm{MnSO}_{4} \cdot 4 \mathrm{H}_{2} \mathrm{O} \\ \mathrm{MnSO}_{4} \cdot 5 \mathrm{H}_{2} \mathrm{O} \\ \mathrm{MnSO}_{4} \cdot 6 \mathrm{H}_{2} \mathrm{O} \\ \mathrm{MnSO}_{4} \cdot 7 \mathrm{H} 2 \mathrm{O}\end{array}\right.$

Acid manganese sulphates............. $\left\{\begin{array}{l}\mathrm{MnH}_{2}\left(\mathrm{SO}_{4}\right)_{2} \\ \mathrm{MnH}_{6} .\left(\mathrm{SO}_{4}\right)_{4}\end{array}\right.$

Basic manganese sulphate............ $3 \mathrm{MnO} .2 \mathrm{SO}_{3} \cdot 3 \mathrm{H}_{2} \mathrm{O}$

Manganese dithionate (hydrous) ............ $\mathrm{MnS}_{2} \mathrm{O}_{6} \cdot \mathrm{nH}_{2} \mathrm{O}$

Mangano-manganic sulphide.............. $\mathrm{Mn}_{3} \mathrm{~S}_{4}$

Manganese bisulphide.................... $\mathrm{MnS}_{2}$

Sulphate of manganese dioxide.

Manganic sulphite..................... $\mathrm{Mn}_{2}\left(\mathrm{SO}_{3}\right)_{3}$

Manganic sulphate.................. $\mathrm{Mn}_{2}\left(\mathrm{SO}_{4}\right)_{3}$

Acid manganic sulphate................ $\mathrm{Mn}_{2}\left(\mathrm{SO}_{4}\right)_{3} \cdot \mathrm{H}_{2} \mathrm{SO}_{4} \cdot 4 \mathrm{H}_{2} \mathrm{O}$

DOUBLE SALTS.

Manganese-potassium sulphide

$2 \mathrm{Mns} . \mathrm{K}_{2} \mathrm{~S}$

Manganese-sodium sulphide.

$\mathrm{nMnS} . \mathrm{Na}_{2} \mathrm{~S}$

Manganese-potassium sulphite

$\mathrm{MnSO}_{3} \cdot \mathrm{K}_{2} \mathrm{SO}_{3}$

Manganese-ammonium sulphite.

$\mathrm{MnSO}_{3} .\left(\mathrm{NH}_{3}\right)_{2} \mathrm{SO}_{3}$

Manganese-sodium sulphite.

$4 \mathrm{MnSO}_{3} \cdot \mathrm{Na}_{2} \mathrm{SO}_{3}$

Manganese-sodium sulphite (hydrous) . ....... $\mathrm{MnSO}_{3} \cdot \mathrm{Na}_{2} \mathrm{SO}_{3} \cdot \mathrm{H}_{2} \mathrm{O}$

Manganese-sodium hyposulphite (hydrous).. $\mathrm{MnS}_{2} \mathrm{O}_{3} \cdot 2 \mathrm{Na}_{2} \mathrm{~S}_{2} \mathrm{O}_{3} \cdot 16 \mathrm{H}_{2} \mathrm{O}$

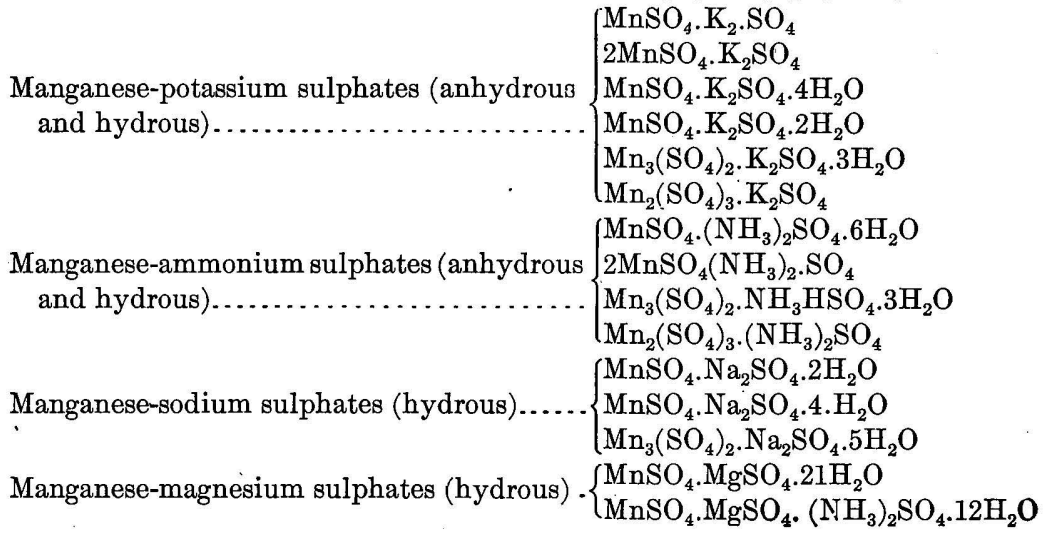




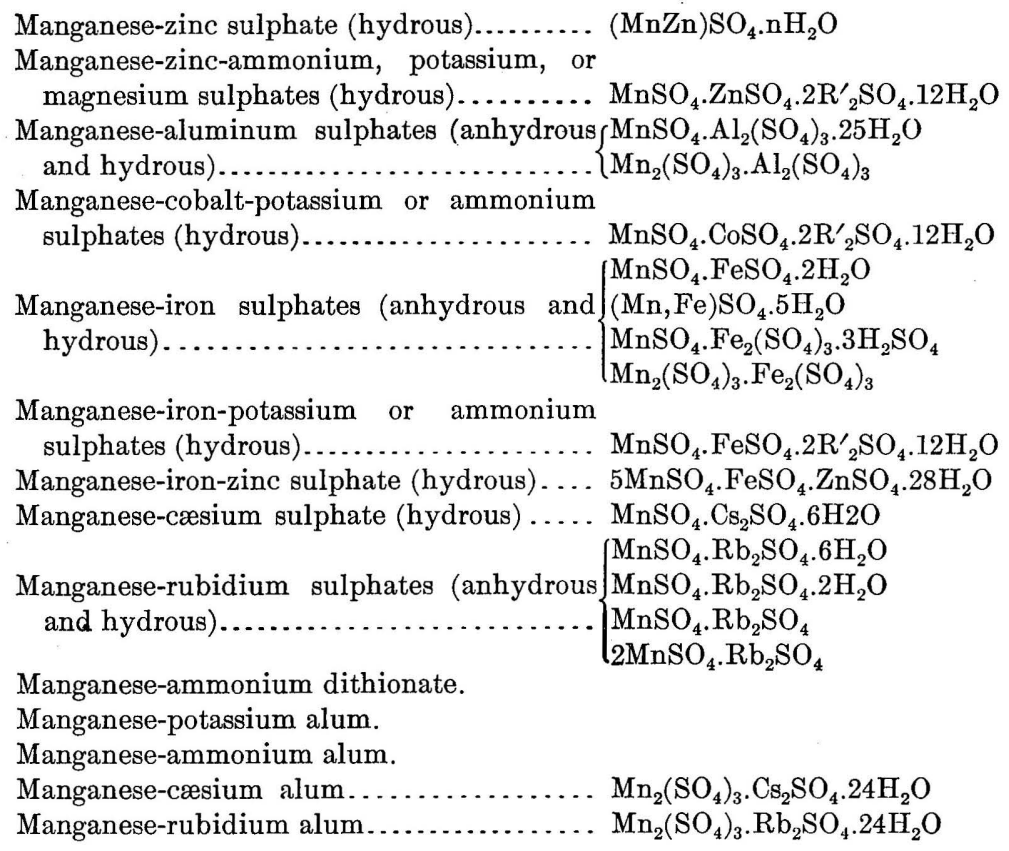

Manganese monosulphide (MnS) occurs in nature in steel-gray crystals having a green streak, as the mineral alabandite. Artificially it is prepared as a dark-gray powder by heating the monooxide, carbonate, or sulphate in a current of hydrogen sulphide. At a high temperature this powder melts and forms a steel-gray crystalline mass, or, when heated with a little sulphur in the electric furnace, forms green octahedra. Ammonium sulphide and other alkaline sulphides precipitate hydrous manganese sulphide from a solution of a manganous salt, as a flesh-colored precipitate, which passes into green crystals when heated in the solution to $300^{\circ} \mathrm{C}$. Manganese monosulphide forms double salts with the monosulphides of the alkalies, thus, $\mathrm{K}_{2} \mathrm{~S} .3 \mathrm{MnS}$.

Manganous sulphate $\left(\mathrm{MnSO}_{4}\right)$ is prepared by strongly neating a mixture of manganese peroxide and sulphuric acid. From the calcined mass manganous sulphate is dissolved by water and precipitated on evaporation below $27^{\circ} \mathrm{C}$. as $\mathrm{MnSO}_{4} .5 \mathrm{H}_{2} \mathrm{O}$, or as $\mathrm{MnSO}_{4} .7 \mathrm{H}_{2} \mathrm{O}$ below $8^{\circ} \mathrm{C}$. Above $27^{\circ} \mathrm{C}$. the monohydrate, $\mathrm{MnSO}_{4} \cdot \mathrm{H}_{2} \mathrm{O}$, is formed, but the last traces of water are removed from this only at $450^{\circ} \mathrm{C}$. It decomposes and leaves a residue of $\mathrm{Mn}_{3} \mathrm{O}_{4}$ when heated to a bright-red heat. Manganous sulphate forms double salts with the sulphates of the alkalies as $\mathrm{K}_{2} \mathrm{SO}_{4} \cdot \mathrm{MnSO}_{4} \cdot 6 \mathrm{H}_{2} \mathrm{O}$, and with aluminum sulphate as $\mathrm{MnSO}_{4} \cdot \mathrm{Al}_{2}\left(\mathrm{SO}_{4}\right)_{3} \cdot 24 \mathrm{H}_{2} \mathrm{O}$ (manganese-aluminum pseudo-alum).

Manganous dithionate $\left(\mathrm{MnS}_{2} \mathrm{O}_{6} \cdot 3 \mathrm{H}_{2} \mathrm{O}\right.$ is obtained by passing sulphur dioxide through water in which finely divided manganese peroxide is suspended. 
Manganese bisulphide $\left(\mathrm{MnS}_{2}\right)$ is found in nature as the reddishbrown mineral hauerite.

Manganic sulphate, $\mathrm{Mn}_{2}\left(\mathrm{SO}_{4}\right)_{3}$, is obtained, with the evolution of oxygen, as a green deliquescent powder by the action of sulphuric acid upon finely divided, precipitated peroxide at a temperature of $138^{\circ} \mathrm{C}$. Manganic sulphate replaces aluminum sulphate in the alums, forming a series of manganese alums with the general formula $\mathrm{R}_{2}^{\prime} \mathrm{SO}_{4} \cdot \mathrm{Mn}_{2}\left(\mathrm{SO}_{4}\right)_{3} \cdot 24 \mathrm{H}_{2} \mathrm{O}$, which crystallize in pink or red octahedra. The potassium and ammonium manganese alums are very unstable and have not been obtained pure, but the caesium and rubidium manganese alums have been prepared.

\section{MANGANESE AND SELENIUM.}

List of selenium compounds of manganese.

Manganese selenide........................MnSe.

Manganese oxyselenide.

Manganous selenite (hydrous) $\ldots \ldots \ldots \ldots \ldots . . . \mathrm{MnSeO}_{3} \cdot \mathrm{H}_{2} \mathrm{O}$

Manganese selenate.

Hydrous manganese selenate............. $\left\{\begin{array}{l}\mathrm{MnSeO}_{4} \cdot 2 \mathrm{H}_{2} \mathrm{O} \\ \mathrm{MnSeO}_{4} \cdot 5 \mathrm{H}_{2} \mathrm{O}\end{array}\right.$

Manganic selenite....................... $\mathrm{Mn}_{2} \mathrm{O}_{3 \cdot 4} \mathrm{SeO}_{2}$

Hydrous manganic selenite.............. $\mathrm{Mn}_{2} \mathrm{O}_{3} \cdot 3 \mathrm{SeO}_{2} \cdot 5 \mathrm{H}_{2} \mathrm{O}$

DOUBLE SALT.

Manganese-potassium selenate (hydrous).... $\mathrm{MnK}_{2}\left(\mathrm{SeO}_{4}\right)_{2} \cdot 2 \mathrm{H}_{2} \mathrm{O}$

MANGANESE AND NITROGEN.

List of nitrogen compounds of manganese.

Manganese nitrides....................... $\left\{\begin{array}{l}\mathrm{Mn}_{5} \mathrm{~N}_{2} \\ \mathrm{Mn}_{3} \mathrm{~N}_{2}\end{array}\right.$

Basic manganese nitride............. $\mathrm{Mn}(\mathrm{OH}) \mathrm{N}_{3}$

Manganese nitrite.

Manganous nitrate..................... $\mathrm{Mn}\left(\mathrm{NO}_{3}\right)_{2}$

Hydrous manganous nitrates............. $\left\{\begin{array}{l}\mathrm{Mn}\left(\mathrm{NO}_{3}\right)_{2} \cdot 6 \mathrm{H}_{2} \mathrm{O} \\ \mathrm{Mn}\left(\mathrm{NO}_{3}\right)_{2} \cdot 3 \mathrm{H}_{2} \mathrm{O}\end{array}\right.$

Basic manganous nitrate............. $2 \mathrm{MnO} \cdot \mathrm{N}_{2} \mathrm{O}_{5} \cdot 3 \mathrm{H}_{2} \mathrm{O}$

Manganic nitrate.

DOUBLE SALTS.

Manganese-cerium nitrate (hydrous)....... $3 \mathrm{Mn}\left(\mathrm{NO}_{3}\right)_{2} \cdot \mathrm{Ce}_{2}\left(\mathrm{NO}_{3}\right)_{6} \cdot 16 \mathrm{H}_{2} \mathrm{O}$

Manganese-thorium nitrate (hydrous)...... $2 \mathrm{Mn}\left(\mathrm{NO}_{3}\right)_{2} \cdot \mathrm{Th}_{2}\left(\mathrm{NO}_{3}\right)_{8} \cdot 16 \mathrm{H}_{2} \mathrm{O}$

Manganese nitrides $\left(\mathrm{Mn}_{5} \mathrm{~N}_{2}\right.$ and $\left.\mathrm{Mn}_{3} \mathrm{~N}_{2}\right)$ are dark powders, the first being obtained when nitrogen, and the second when ammonia, is passed over finely divided manganese at a red heat. Both yield ammonia when heated with hydrogen, or when fused with potash.

Manganous nitrate, $\mathrm{Mn}\left(\mathrm{NO}_{3}\right)_{2}$, exists with $6 \mathrm{H}_{2} \mathrm{O}$ and $3 \mathrm{H}_{2} \mathrm{O}$. At $129.5^{\circ} \mathrm{C}$. it decomposes with the formation of manganese oxides. Manganous nitrate is easily obtained by dissolving manganous carbonate in nitric acid. 
MANGANESE AND PHOSPHORUS.

List of phosphorous compounds of manganese.

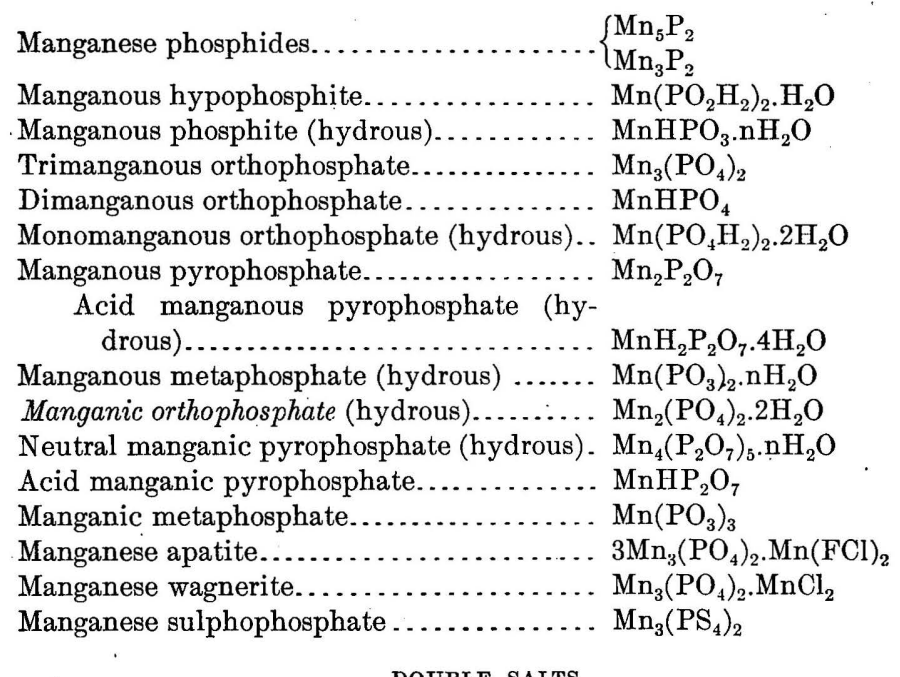

DOUBLE SALTS.

Manganese-potassium hypophosphate (hy-

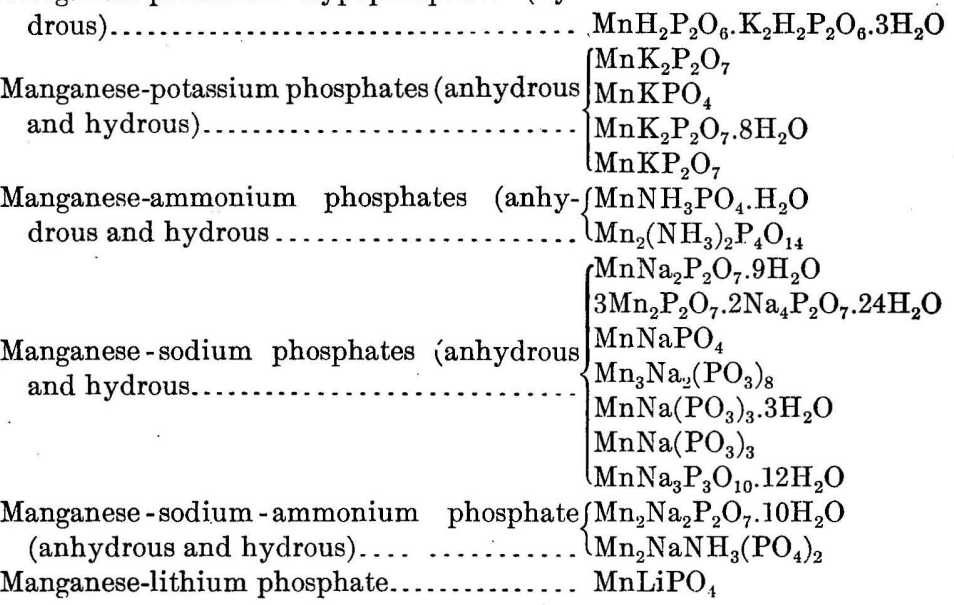

Two manganese phosphides, $\mathrm{Mn}_{5} \mathrm{P}_{2}$ and $\mathrm{Mn}_{3} \mathrm{P}_{2}$, are known. The phosphide $\mathrm{Mn}_{5} \mathrm{P}_{2}$ has been obtained by passing phosphorous vapor and hydrogen over manganous chloride. The phosphide $\mathrm{Mn}_{3} \mathrm{P}_{2}$ is prepared by heating manganese and red phosphorus in an atmosphere of hydrogen. Both are magnetic.

Manganous phosphates of several kinds have been prepared. The orthophosphate, $\mathrm{Mn}_{3}\left(\mathrm{PO}_{4}\right)_{2} .7 \mathrm{H}_{2} \mathrm{O}$, is a white crystalline salt; the monohydrogen salt, $\mathrm{HMnPO}_{4} \cdot 3 \mathrm{H}_{2} \mathrm{O}$, forms rose-colored crystals soluble in water; and the dihydrogen salt, $\mathrm{H}_{4} \mathrm{Mn}\left(\mathrm{PO}_{4}\right)_{2} \cdot 2 \mathrm{H}_{2} \mathrm{O}$, forms deliquescent crystals which decompose on exposure to air into 
phosphoric acid and the monohydrogen salt. Ammonium phosphate precipitates from manganous salts manganous ammonium phosphate, $\mathrm{Mn}\left(\mathrm{NH}_{4}\right) \mathrm{PO}_{4} \cdot \mathrm{H}_{2} \mathrm{O}$.

Manganic metaphosphate, $\mathrm{Mn}\left(\mathrm{PO}_{3}\right)_{3} \cdot \mathrm{H}_{2} \mathrm{O}$, orthophosphate, $\mathrm{MnPO}_{4} \cdot \mathrm{H}_{2} \mathrm{O}$, acid pyrophosphate, $\mathrm{MnHP}_{2} \mathrm{O}_{7}$, and other salts with phosphorus have been obtained. Manganic oxide and the dioxide, when dissolved in phosphoric acid, form a deep violet liquid from which a violet crystalline mass separates out. This decomposes with water, and manganic hydrate is precipitated from it by the alkalies. On evaporation of the red solution manganic metaphosphate is precipitated as a pink powder. Manganic orthophosphate is formed by the action of concentrated orthophosphoric acid on manganic acetate or simply by the addition of a concentrated solution of manganous nitrate little by little to dilute orthophosphoric acid heated to $100^{\circ} \mathrm{C}$. It is a grayish-green crystalline powder, insoluble in water, but easily soluble in hydrochloric acid.

MANGANESE AND ARSENIC.

List of arsenic compounds of manganese.

\begin{tabular}{|c|c|}
\hline \\
\hline Manganese arsenides... & $\left\{\begin{array}{l}\mathrm{Mn}_{5} \mathrm{As}_{4} \\
\mathrm{MnAs}\end{array}\right.$ \\
\hline 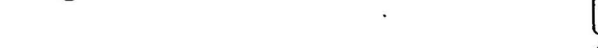 & $\mathrm{Mn}_{2} \mathrm{As}$ \\
\hline . & $3 \mathrm{MnO} \cdot \mathrm{As}_{2} \mathrm{O}_{3} \cdot 5 \mathrm{H}_{2} \mathrm{O}$ \\
\hline Manganic arsenites (anhydrous and hydrous). & $\left\{\begin{array}{l}3 \mathrm{MnO} \cdot \mathrm{As}_{2} \mathrm{O}_{3} \cdot 3 \mathrm{H}_{2} \mathrm{O} \\
3 \mathrm{MnO} \cdot 2 \mathrm{As}_{2} \mathrm{O}_{3}\end{array}\right.$ \\
\hline Trimanganous arsenate (hydrous). & $\mathrm{Mn}_{3}\left(\mathrm{AsO}_{4}\right)_{2} \mathrm{H}_{2} \mathrm{O}$ \\
\hline Dimanganous arsenate (hydrous). & $\mathrm{MnHAsO}_{4} \cdot \mathrm{H}_{2} \mathrm{O}$ \\
\hline Monomanganous arsenate....... & $\mathrm{MnH}_{4}\left(\mathrm{AsO}_{4}\right)_{2}$ \\
\hline Manganous pyroarsenate.... & $\mathrm{Mn}_{2} \mathrm{As}_{2} \mathrm{O}_{7}$ \\
\hline Basic manganese arsenate.... & $5 \mathrm{MnO} .2 \mathrm{As}_{2} \mathrm{O}_{5} .5 \mathrm{H}_{2} \mathrm{O}$ \\
\hline Manganic arsenate (hy & $\mathrm{Mn}_{2}\left(\mathrm{AsO}_{4}\right)_{2} \cdot 2 \mathrm{H}_{2} \mathrm{C}$ \\
\hline
\end{tabular}

DOUBLE SALTS.

Manganese-potassium arsenate............. $\mathrm{MnKAsO}_{4}$ Manganese-ammonium arsenate.

Manganese-sodium arsenates $\left\{\begin{array}{l}2 \mathrm{MnO} .4 \mathrm{Na}_{2} \mathrm{O} .3 \mathrm{As}_{2} \mathrm{O}_{5} \\ \mathrm{MnNa}_{4}\left(\mathrm{AsO}_{4}\right)_{2}\end{array}\right.$

Manganese arsenide, $\mathrm{Mn}_{5} \mathrm{As}_{4}$, occurs in nature as the mineral kaneite. The arsenide $\mathrm{Mn}_{2} \mathrm{As}$ is magnetic and is obtained by heating the nonmagnetic arsenide MnAs.

Manganese arsenites are prepared by the action of alkaline arsenites on salts of manganese.

Manganous arsenates are formed by the action of arsenic acid on manganese carbonate. 
MANGANESE AND ANTIMONY.

List of antimony compounds of manganese.

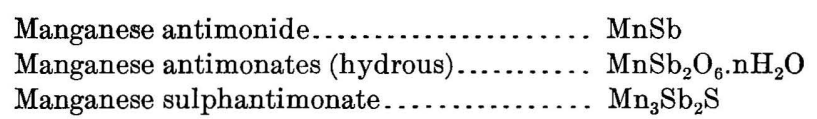

DOUBLE SALT.

Manganese-potassium sulphantimonite...... $\mathrm{MnKSbS}_{3}$

Manganese antimonide is a black crystalline and strongly magnetic powder obtained by igniting a mixture of antimony and manganese thermite.

\section{MANGANESE AND VANADIUM.}

List of vanadium compounds of manganese.

Manganese vanadate....................... $\mathrm{MnV}_{2} \mathrm{O}_{6}$

DOUBLE SALT.

Manganese-potassium vanadate (hydrous) ... $\mathrm{MnKV}_{5} \mathrm{O}_{14} \cdot 8 \mathrm{H}_{2} \mathrm{O}$

MANGANESE AND BORON.

List of boron compounds of manganese.

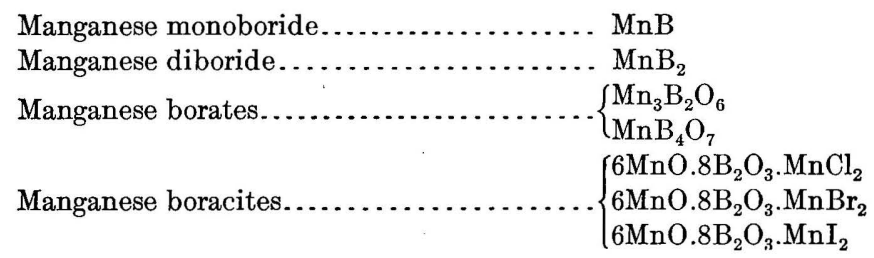

Manganese monoboride ( $\mathrm{MnB})$ is a black crystalline magnetic powder prepared by the reduction of red oxide of manganese with boron, in a magnesia crucible, at a white heat.

Manganese diboride $\left(\mathrm{MnB}_{2}\right)$, in gray-black crystals which decompose in warm water, is obtained by igniting a mixture of manganese thermite and boron, or by heating a mixture of boric acid and manganese carbide.

Manganese borate $\left(\mathrm{MnB}_{4} \mathrm{O}_{7}\right)$ is formed as a white powder when manganese sulphate is added to a solution of borax and the precipitate dried at $100^{\circ} \mathrm{C}$.

MANGANESE AND CARBON.

List of carbon compounds of manganese.

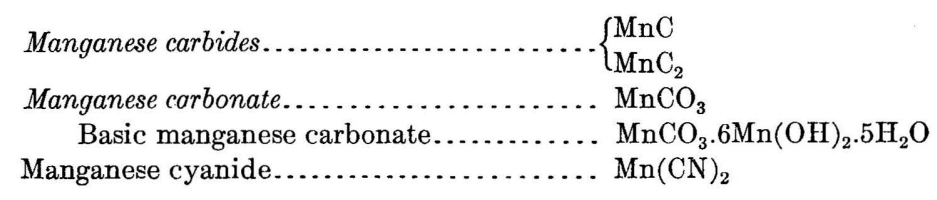




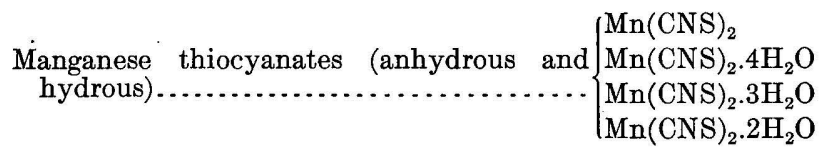

DOUBLE SALTS.

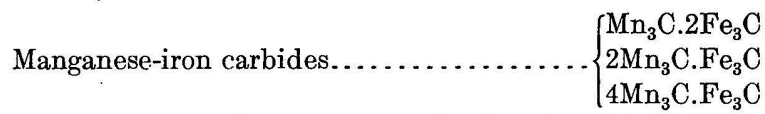

Manganese-potassium carbonate (hydrous)... $\mathrm{MnK}_{2}\left(\mathrm{CO}_{3}\right)_{2} \cdot 4 \mathrm{H}_{2} \mathrm{O}$

Manganese-cadmium carbonate.

Carbonate of manganese and hydroxylamine

(hydrous)........................... $4 \mathrm{MnCO}_{3} .3 \mathrm{NH}_{2}(\mathrm{OH}) .2 \mathrm{H}_{2} \mathrm{O}$

Manganocyanide of potassium (hydrous) .... Mn $(\mathrm{CN})_{6} \mathrm{~K}_{4} \cdot 3 \mathrm{H}_{2} \mathrm{O}$

Manganocyanide of potassium and manga-

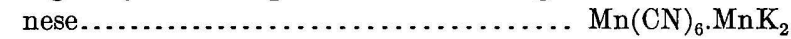

Manganocyanide of ammonium............. $\mathrm{Mn}(\mathrm{CN})_{6} \cdot\left(\mathrm{NH}_{3}\right)_{4}$

Manganocyanide of ammonium and manga-

nese................................ $\mathrm{Mn}(\mathrm{CN})_{6} \cdot \mathrm{Mn}\left(\mathrm{NH}_{3}\right)_{2}$

Manganocyanide of sodium (hydrous) ...... Mn(CN) ${ }_{6} \mathrm{Na}_{4} .8 \mathrm{H}_{2} \mathrm{O}$

Manganocyanide of sodium and manganese.. $\mathrm{Mn}(\mathrm{CN})_{6} \cdot \mathrm{MnNa}_{2}$

Manganocyanide of calcium............. $\mathrm{Mn}(\mathrm{CN})_{6} \mathrm{Ca}_{2}$

Manganocyanide of strontium.............. $\mathrm{Mn}(\mathrm{CN})_{6} \mathrm{Sr}_{2}$

Manganocyanide of strontium and manga-

nese.....................................

Manganocyanide of barium............... $\mathrm{Mn}(\mathrm{CN})_{6} \mathrm{Ba}_{2}$

Manganocyanide of barium and manganese.. $\mathrm{Mn}(\mathrm{CN})_{6} \cdot \mathrm{MnBa}$

Ferrocyanide of manganese (hydrous) . ...... Fe(CN) $)_{6} \mathrm{Mn}_{2} \cdot 7 \mathrm{H}_{2} \mathrm{O}$

Ferrocyanide of manganese and potassium

or ammonium.................... $\mathrm{Fe}(\mathrm{CN})_{6} \mathrm{MnR}_{2}$

Manganicyanide of potassium........... $\mathrm{Mn}(\mathrm{CN})_{6} \mathrm{~K}_{3}$

Manganicyanides of sodium (hydrous) $\ldots . .\left\{\begin{array}{l}\mathrm{Mn}(\mathrm{CN})_{6} \mathrm{Na}_{3} .4 \mathrm{H}_{2} \mathrm{O} \\ \mathrm{Mn}(\mathrm{CN})_{6} \mathrm{Na}_{3} .2 \mathrm{H}_{2} \mathrm{O}\end{array}\right.$

Manganicyanide of calcium ............... $\mathrm{Mn}_{2}(\mathrm{CN})_{12} \mathrm{Ca}_{3}$

Manganicyanide of barium ............... $\mathrm{Mn}_{2}(\mathrm{CN})_{12} \mathrm{Ba}_{3}$

Manganicyanide of iron .................. $\mathrm{Mn}_{2}(\mathrm{CN})_{12} \mathrm{Fe}_{3}$

Nitroprussiate of manganese.

Manganese carbide $\left(\mathrm{Mn}_{3} \mathrm{C}\right)$ is prepared by heating red oxide of manganese with charcoal or calcium carbide in the electric furnace. This is supposed to be the common form in which manganese occurs in the iron-manganese alloys. When strongly heated it dissociates, the manganese volatilizing, and the carbon remaining as graphite. When treated with water it yields hydrogen and marsh gas:

$$
\mathrm{Mn}_{3} \mathrm{C}+6 \mathrm{H}_{2} \mathrm{O}=\mathrm{CH}_{4}+\mathrm{H}_{2}+3 \mathrm{Mn}(\mathrm{OH})_{2}
$$

It burns in oxygen and is readily attacked by fluorine and chlorine.

Manganese carbonate $\left(\mathrm{MnCO}_{3}\right)$ occurs in nature as rhodochrosite and as a constituent of manganocalcite, manganosiderite, and other carbonates. The hydrated carbonate is obtained as a white precipitate by mixing solutions of chloride or sulphate of manganese and sodium carbonate. 
Manganese thiocyanate, $\mathrm{Mn}(\mathrm{CNS})_{2}$, a yellow salt, is prepared from manganous sulphate and barium thiocyanate. With $3 \mathrm{H}_{2} \mathrm{O}$ a hydrated green salt is formed.

Manganocyanide of potassium, $\mathrm{K}_{4} \mathrm{Mn}(\mathrm{CN})_{6} \cdot 3 \mathrm{H}_{2} \mathrm{O}$, in dark-blue crystals, is obtained by the alteration of a green precipitate, $\mathrm{KCN} . \mathrm{Mn}(\mathrm{CN})_{2}$, formed when a concentrated solution of manganese acetate is warmed with solid potassium cyanide. It is also obtained in violet-blue crystals when manganous carbonate is heated to $40^{\circ}$ or $50^{\circ} \mathrm{C}$. in a solution of potassium cyanide.

Manganicyanide of potassium, $\mathrm{K}_{3} \mathrm{Mn}(\mathrm{CN})_{6}$, is obtained in dark-red crystals from the oxidation in air of a solution of potassium manganocyanide.

MANGANESE AND SILICON.

List of silicon compounds of manganese.

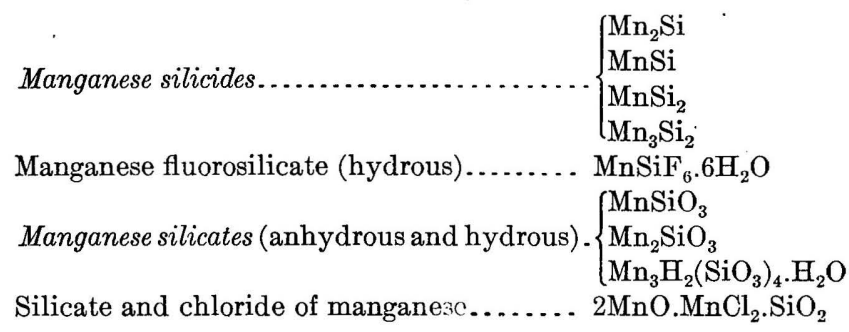

DOUBLE SALTS.

Manganese-iron silicides.

Silicates of manganese with magnesium, calcium, aluminum, and iron.

Four silicides of manganese have been described, $\mathrm{Mn}_{2} \mathrm{Si}, \mathrm{Mn} \mathrm{Si}$, $\mathrm{MnSi}_{2}$, and $\mathrm{Mn}_{3} \mathrm{Si}_{2} . \mathrm{Mn}_{2} \mathrm{Si}$ forms in a steel-gray hard brittle mass when the two elements are heated together in the electric furnace, or when a mixture of silica, manganese oxide, and aluminum is fired. It is also prepared by heating a mixture of potassium silicofluoride, red oxide of manganese, copper, and sodium. It is decomposed by fluorine at ordinary temperatures, is attacked by steam, oxygen, and chlorine at a red heat, and dissolves in hydrochloric acid. Manganese monosilicide $(\mathrm{MnSi})$ forms hard lustrous tetragonal crystals, and the disilicide $\left(\mathrm{MnSi}_{2}\right)$ forms dark-gray octahedra. $\mathrm{Mn}_{3} \mathrm{Si}_{2}$ is a new silicide which has recently been described by Gin. ${ }^{a}$ It is obtained in prismatic crystals by the reduction of rhodonite in the electric furnace. It is attacked by hydrochloric and nitric acids.

Manganous silicate occur as isomorphous mixtures with silicates of iron, calcium, magnesium, aluminum, and many other metals, widely distributed through the earth's crust. Some have been prepared in the laboratory. Pure manganese silicates occur as rhodonite $\left(\mathrm{MnSiO}_{3}\right)$ and tephroite $\left(\mathrm{Mn}_{2} \mathrm{SiO}_{4}\right)$. 
MANGANITES.

List of manganites.

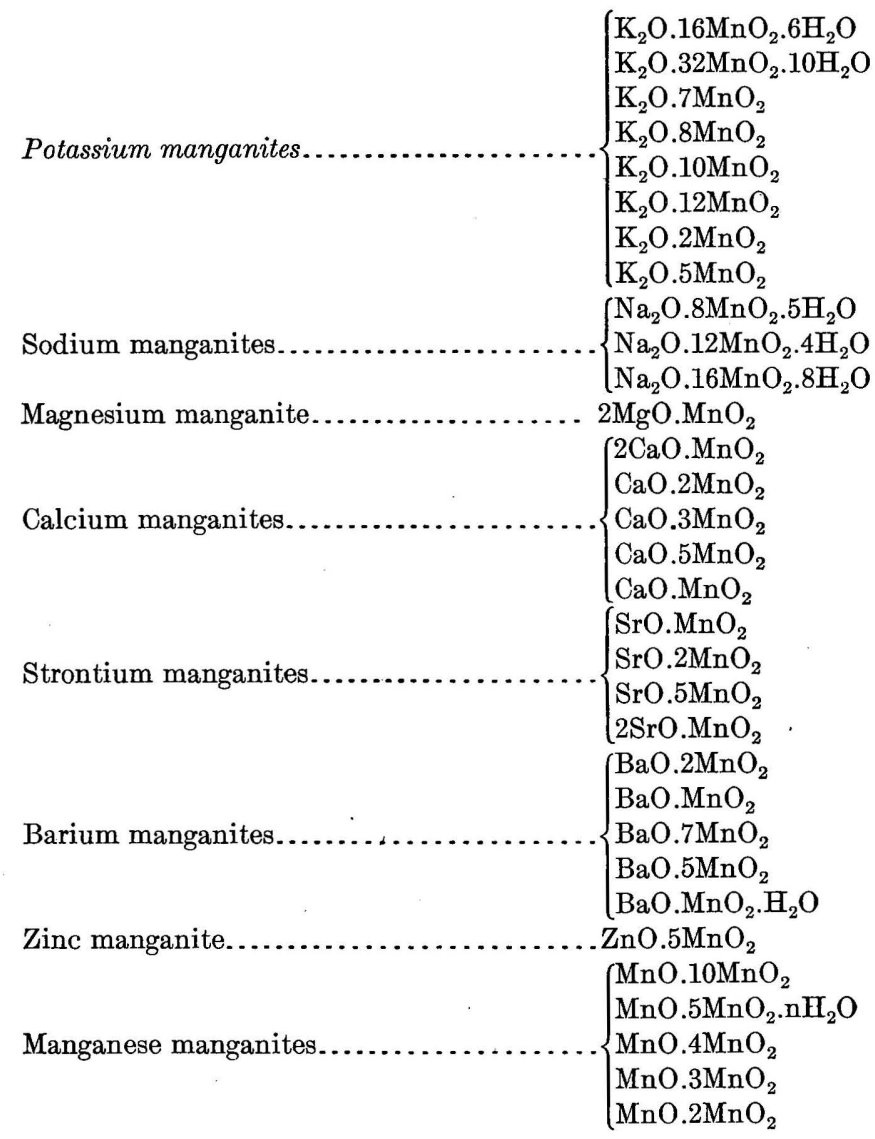

Manganites are unstable compounds formed by the union of manganese dioxide with basic oxides of other metals. These are of various types, as $\mathrm{R}_{2}^{\prime} \mathrm{O} . \mathrm{MnO}_{2}, \mathrm{R}_{2}^{\prime} \mathrm{O} .2 \mathrm{MnO}_{2}$, and $\mathrm{R}_{2}^{\prime} \mathrm{O} .5 \mathrm{MnO}_{2}$, their composition depending on the amount of alkali present. Potassium manganite $\left(\mathrm{K}_{2} \mathrm{O} .5 \mathrm{MnO}_{2}\right.$ or $\left.\mathrm{K}_{2} \mathrm{Mn}_{5} . \mathrm{O}_{11}\right)$ is obtained as a yellow precipitate when carbon dioxide is passed into a potassium-manganate solution. Calcium manganite $\left(\mathrm{CaO} .5 \mathrm{MnO}_{2}\right.$ or $\left.\mathrm{CaMn}_{5} \mathrm{O}_{11}\right)$ is a black-brown precipitate prepared by pouring manganous nitrate into an excess of bleaching powder solution.

\section{MANGANATES.}

List of manganates.

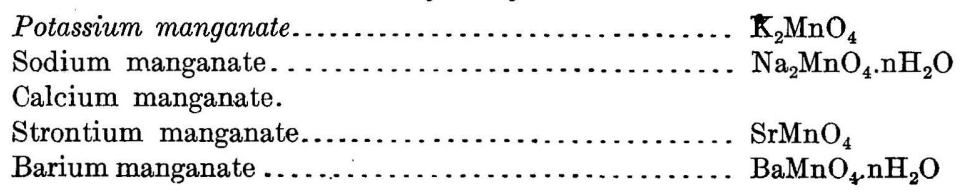


The manganates $\left(\mathrm{R}_{2}^{\prime} \mathrm{O} \cdot \mathrm{MnO}_{3}\right.$ or $\left.\mathrm{R}_{2}^{\prime} \mathrm{MnO}_{4}\right)$ are derived from the hypothetical acid $\mathrm{H}_{2} \mathrm{MnO}_{4}$ corresponding to the trioxide. They form green solutions which are stable only in the presence of free alkali. When diluted and warmed, or made slightly acid, they change to a pink, blue, or violet color, being converted to permanganates, and manganese dioxide is deposited:

$$
3 \mathrm{~K}_{2} \mathrm{MnO}_{4}+2 \mathrm{H}_{2} \mathrm{O}=2 \mathrm{KMnO}_{4}+\mathrm{MnO}_{2}+4 \mathrm{KOH} \text {. }
$$

Manganates may be obtained by the partial reduction of permanganates by such reducers as alcohol or sodium thiosulphate, or by the action of organic matter in the atmosphere.

Potassium manganate $\left(\mathrm{K}_{2} \mathrm{MnO}_{4}\right)$ is formed by the fusion of potassium hydrate and manganese dioxide. In the absence of air the following reaction takes place:

$$
3 \mathrm{MnO}_{2}+2 \mathrm{KOH}=\mathrm{K}_{2} \mathrm{MnO}_{4}+\mathrm{Mn}_{2} \mathrm{O}_{3}+\mathrm{H}_{2} \mathrm{O} \text {. }
$$

In the presence of air or oxidizers more manganate is produced:

$$
2 \mathrm{KOH}+\mathrm{MnO}_{2}+\mathrm{O}=\mathrm{K}_{2} \mathrm{MnO}_{4}+\mathrm{H}_{2} \mathrm{O} \text {. }
$$

The fused mass is deep green and dissolves in water, forming a darkgreen solution. The crystalline salt is deposited upon evaporation in a vacuum. Potassium manganate is also prepared by boiling a saturated potassium permanganate solution with a caustic potash solution.

Sodium manganate $\left(\mathrm{Na}_{2} \mathrm{MnO}_{4}\right)$ is obtained by heating a mixture of sodium hydrate and manganese dioxide for sixteen hours. The mass formed is dissolved in a small quantity of water, from which the salt, $\mathrm{Na}_{2} \mathrm{MnO}_{4} \cdot 10 \mathrm{H}_{2} \mathrm{O}$, crystallizes out. It is soluble in water, forming a green solution.

Barium manganate $\left(\mathrm{BaMnO}_{4}\right)$ is an emerald-green powder insoluble in water, but decomposed by acids. It is obtained when manganese dioxide is heated with baryta, or barium carbonate or nitrate, or when baryta water and barium permanganate are heated together.

PERMANGANATES.

List of permanganates.

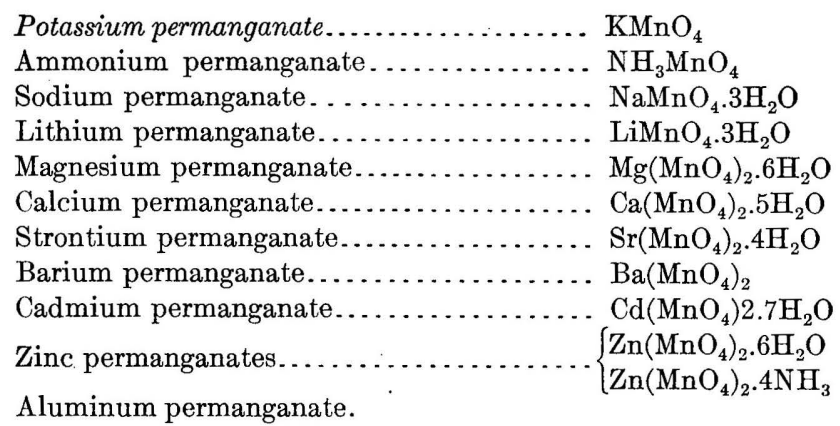

37336 - Bull. $427-10-16$ 


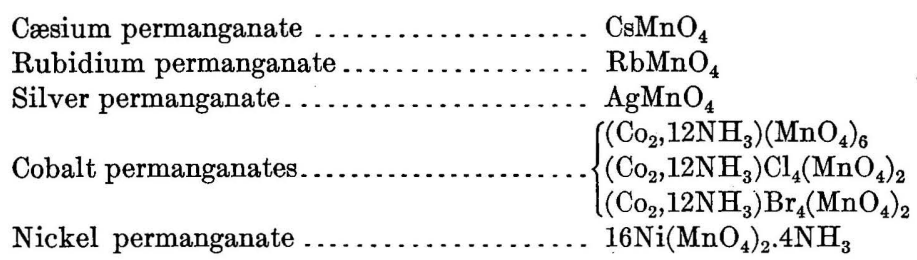

Permanganates $\left(\mathrm{R}_{2}^{\prime} \mathrm{O} \cdot \mathrm{Mn}_{2} \mathrm{O}_{7}\right.$ or $\left.\mathrm{R}^{\prime} \mathrm{MnO}_{4}\right)$ are salts of permanganic acid $\left(\mathrm{HMnO}_{4}\right)$.

Potassium permanganate $\left(\mathrm{KMnO}_{4}\right)$ is prepared by dissolving 10 parts of caustic potash in water and adding to this a mixture of 8 parts of manganese dioxide and 7 parts of potassium chlorate. On evaporating to dryness and heating the residue until the potassium chlorate is completely decomposed, a green mass is obtained. This is dissolved in boiling water, and the clear solution, on cooling, deposits black crystals of potassium permanganate, with greenish luster, which changes to steel-blue on exposure.

Potassium permanganate is also prepared from a solution of potassium manganate, by passing carbon dioxide through it:

$$
3 \mathrm{~K}_{2} \mathrm{MnO}_{4}+2 \mathrm{CO}_{2}=2 \mathrm{KMnO}_{4}+\mathrm{MnO}_{2}+2 \mathrm{~K}_{2} \mathrm{CO}_{3} \text {. }
$$

When this solution is evaporated, after filtering out the manganese dioxide, potassium permanganate is deposited. When boiled with strong caustic alkalies, the solution is reconverted to potassium manganate:

$$
2 \mathrm{KMnO}_{4}+2 \mathrm{KOH}=2 \mathrm{~K}_{2} \mathrm{MnO}_{4}+\mathrm{H}_{2} \mathrm{O}+\mathrm{O} \text {. }
$$

Crystals of potassium permanganate yield a red powder and are soluble in water, forming a deep-purple solution. When they are heated to $240^{\circ} \mathrm{C}$., they evolve oxygen and form potassium manganate and manganese dioxide. A mixture of potassium permanganate and sulphur or phosphorus explodes violently on percussion.

Sodium permanganate $\left(\mathrm{NaMnO}_{4}\right)$ is prepared like the potassium salt, but crystallizes with greater difficulty. Ammonium permanganate $\left(\mathrm{NH}_{3} \mathrm{MnO}_{4}\right)$ is prepared by the decomposition of the potassium salt with ammonium chloride. Barium permanganate, $\mathrm{Ba}\left(\mathrm{MnO}_{4}\right)_{2}$, is obtained by the decomposition of the silver salt by barium chloride, or by passing carbon dioxide into water containing barium manganate in suspension. Silver permanganate $\left(\mathrm{AgMnO}_{4}\right)$ separates out on cooling from a warm solution of silver nitrate and potassium permanganate. 


\section{CHAPTER V.}

\section{USES OF MANGANESE.}

\section{HISTORY.}

The use of manganese in the arts is of great antiquity, having been known at least as long ago as the time of the ancient Egyptians. ${ }^{a}$ One of its first uses was in glass making. Egyptian and Roman glasswares have been shown by analyses to contain over 2 per cent of manganous oxide. Pliny mentions the use of manganese oxide under the name of "magnes" among the Romans for decolorizing glass. He considered it a variety of lodestone or magnetic iron ore.

The first experiments with oxide of manganese were made about 1656 by Glauber, but manganese oxide continued to be considered a variety of iron until late in the eighteenth century. In 1740 Pott showed that it formed a series of salts distinct from those of iron, but the existence of a metal in it was not known until the experiments of Scheele and Bergman in 1774. Even as late as 1758 Cronstedt speaks of it as a kind of earth with no metal except sometimes a small percentage of iron or a little tin. Scheele and Bergman were unable to isolate the metal (as Gahn did later), but their experiments showed that manganese oxide was a compound and not an element. Rinman, at about the same time, first called attention to the fact that manganese by degrees deprives iron of its magnetic qualities.

Up to the latter part of the eighteenth century the principal commercial use of manganese was in decolorizing glass and coloring both glass and pottery.

Chlorine was discovered by Scheele in 1774 in connection with his investigations on manganese compounds. About $1785^{\circ}$ its use in the arts as a bleaching agent was introduced by Berthollet, and thenceforth manganese ores were consumed to a considerable extent in the manufacture of chlorine. This consumption, however, decreased materially after 1855 , when successful processes came into use for the regeneration of the manganiferous waste product and its reconversion into manganese peroxide.

The use of manganese in steel manufacture started in $1839^{\circ}$ from experiments by Heath for improving the malleable iron and cast

$a$ Penrose, R. A. F., jr., Manganese: Its uses, ores, and deposits: Ann. Rept. Geol. Survey Arkansas for 1890 , vol. 1 , p. 3 .

$b$ Idem, p. 43.

$c$ Idem, pp. 12 et seq. 
steel derived from certain low-grade iron ores. He found that the addition of manganese produced a great improvement by making the product malleable and easily weldable. At first he added manganese in the form of manganese pig produced by smelting together the oxide and coal tar. Later he dispensed with the smelting and simply used dried bricks made of a mixture of manganese oxide and tar.

The Bessemer process for making steel was announced in 1856 by Sir Henry Bessemer, but was not perfected until 1858. Soon after its invention it was found that owing to the extensive oxidation in the converter all the carbon was burned off and the metal reduced to wrought iron instead of steel. Robert Mushet invented a triple compound of iron, manganese, and carbon, essentially spiegeleisen, the addition of which, in a molten state, to the final product in the Bessemer converter introduced the requisite amount of carbon. The mixture was also found to counteract the effect of phosphorus and sulphur and to reduce small quantities of iron oxide formed. The part played by the manganese in these results was not understood until later. The extensive use of spiegeleisen and experiments for its perfection into high-grade ferromanganese began at that time.

Ferromanganese, containing 25 to 30 per cent manganese, was first produced for commercial use in 1865 by Henderson, followed closely by Prieger, who produced an alloy with 75 per cent manganese. The Terre Noir Company improved upon these earlier processes, and to them we owe the first production of rich and cheap ferromanganese.

The first successful experiments and tests of manganese steel were made by R. A. Hadfield, of Sheffield, England, about 1883.

\section{METALLURGICAL USES.}

\section{FERROMANGANESE, SPIEGELEISEN, SILICOMANGANESE, AND SILICOSPIEGEL.}

GENERAL DESCRIPTION.

Ferromanganese and spiegeleisen are alloys of manganese and iron, containing some carbon and usually some silicon. Alloys containing considerable quantities of silicon are silicospiegel and silicomanganese.

Spiegeleisen includes all iron-manganese alloys containing less than 20 per cent manganese; ferromanganese contains 20 to 80 or even 90 per cent manganese; an alloy containing more than 90 per cent is unstable under weathering conditions. Commercially, ironmanganese alloys containing up to 35 per cent manganese are frequently termed spiegeleisen, but texturally they are ferromanganese when they contain more than 20 per cent manganese. Carbon is present in varying amounts, depending somewhat on the amount of manganese, and ranging as high as 7 per cent in high-grade ferromanganese. In spiegeleisen or ferromanganese the percentage of 
silicon is rarely great, but in silicospiegel it may be as much as 15 per cent or more. If the iron is decreased and the silicon and manganese are increased, the alloy becomes silicomanganese. Spiegeleisen containing 20 per cent manganese should not have more than 1 per cent silicon, and ferromanganese with 80 per cent manganese not more than 1.6 per cent. ${ }^{a}$ The greater the percentage of silicon present the less is the quantity of carbon. Small amounts of phosphorus and sulphur may be present. Of the former, however, there should not be more than 0.1 per cent in spiegeleisen containing 20 per cent manganese, nor more than 0.22 per cent in ferromanganese containing 80 per cent manganese.

The following table gives analyses of iron-manganese alloys, showing the variations in amounts of the different elements:

Analyses of iron-manganese alloys. ${ }^{a}$

\begin{tabular}{|c|c|c|c|c|c|}
\hline & Mn. & Si. & Fe.b & Graphite. & Combined C. \\
\hline 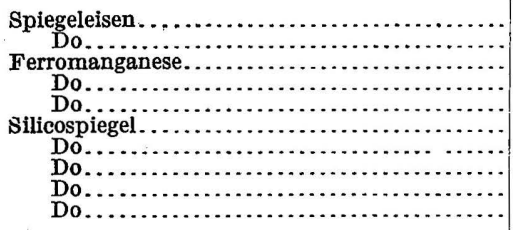 & $\begin{array}{r}8.11 \\
19.74 \\
41.82 \\
80.04 \\
80.04 \\
23.90 \\
50.00 \\
19.64 \\
19.74 \\
24.36\end{array}$ & $\begin{array}{r}1.10 \\
.52 \\
.42 \\
.97 \\
.14 \\
4.90 \\
4.20 \\
10.74 \\
12.60 \\
15.94\end{array}$ & $\begin{array}{l}86.52 \\
74.96 \\
52.13 \\
12.46 \\
12.62 \\
67.66 \\
43.24 \\
67.44 \\
66.01 \\
58.50\end{array}$ & 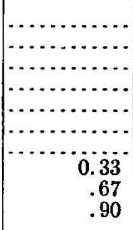 & $\begin{array}{r}4.27 \\
4.78 \\
5.63 \\
6.53 \\
7.20 \\
3.56 \\
2.56 \\
1.85 \\
.98 \\
.30\end{array}$ \\
\hline
\end{tabular}

$a$ Hadfield, R. A., On alloys of iron and silicon: Jour. Iron and Steel Inst., 1889, No. 2, p. 226. $b$ Iron by difference. Phosphorus and sulphur are practically absent.

Spiegeleisen is used in steel manufacture when only small quantities of manganese are required. When larger quantities are necessary the addition of spiegeleisen would introduce an injuriously high amount of carbon; hence an alloy containing a higher percentage of manganese and proportionately lower percentage of carbon is required. Ferromanganese supplies this demand to some extent, but even it contains too much carbon for many purposes. Numerous experiments have been conducted recently and are being conducted for the preparation of carbon-free ferromanganese.

Phosphomanganese $^{b}$ is an iron-manganese alloy which has been used like ferrophosphorus in the manufacture of phosphorus steel. It has been produced with the following composition from manganese ore and apatite in the blast furnace:

Composition of phosphomanganese.

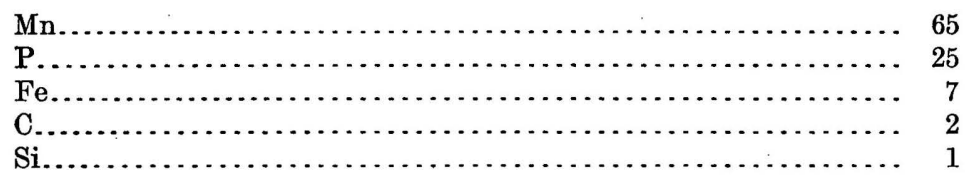

$a$ Simmersbach, O., Berg- und Hüttenmännisches Rundschau, 1905, p. 305. Review, Jour. Iron and Steel Inst., 1905, No. 2, p. 680.

$b$ Use of ferrophosphorus and phosphomanganese: Iron Trade Rev., Apr. 16, 1903, pp. 45-46; also Jour. Iron and Steel Inst., 1903, No. 2, p. 669 (Review). 


\section{MANUFACTURE.}

Spiegeleisen is generally produced in ordinary blast furnaces from a manganiferous iron ore, or a mixture of manganese and iron ores in proportion to the percentages of manganese and iron desired in the alloy. With an increase in the percentage of manganese more heat is required for smelting, so that in early days ferromanganese could be produced in the blast furnaces only under great difficulties. With modern improvements, however, the reduction of the metal is facilitated, and at the present time ferromanganese may be produced in any properly arranged blast furnace with strong hot blasts. More recently ferromanganese is being produced on a small scale in electric furnaces.

The blast furnace is fed with coke, limestone, manganese ore, and iron ore, the last two being in the proportion that is desired for the metals in the pig. Manganese spar and roasted manganite ore are said ${ }^{a}$ to be most suitable for the manufacture of iron-manganese alloys, but pyrolusite, psilomelane, and wad are most used. Hot air is blown through this mixture, entering through tuyères near the bottom of the furnace. The heat causes the decomposition of the coke and ores, producing the gases $\mathrm{CO}_{2}$ and $\mathrm{CO}$, which, on rising, heat the material in the upper part of the furnace. The melting occurs directly where the hot blasts enter the furnace. In the upper portion of the blast furnace the higher oxides are reduced by the heated gases to lower oxides, while in the lower portion the latter are reduced by $\mathrm{CO}$ to $\mathrm{MnO}$, which in turn is reduced to metallic manganese by carbon.

Conditions for the production of iron-manganese alloys in the blast furnace are most favorable with good coke fuel, basic slag, slow reduction, and strong hot blasts. Coke is used for fuel because it admits of a sharper blast and gives greater heat. Charcoal, however, may be used. A basic slag is secured by uising large charges of lime. This is important, because manganese unites too readily with an acid slag, and so is wasted. The fuel consumption is high, varying between 4,800 and 5,000 pounds $^{b}$ of coke per ton of the alloy, the higher-grade alloys requiring the most fuel. Hadfield in 1888 gave as a fuel consumption 38 to 44 hundredweight of coke per ton of metal, with ore containing between 40 and 50 per cent of manganese. A modern blast furnace produces about 34 to 36 tons of ferromanganese of 78 to 82 per cent manganese, in twenty-four hours. A very high temperature is required, and a blast of about $1,200^{\circ} \mathrm{F}$. is used. ${ }^{b}$. If a blast of higher temperature is used, say, about 1,400 or $1,500^{\circ} \mathrm{F}$., silica is reduced and the furnace lining worn out. Even with moderate heat furnace linings have to be replaced frequently.

a Simmersbach, O., Berg- und Hüttenmännisches Rundschau, 1905, p. 305.

$b$ Weeks, J. D., Mineral industries of the U. S.: Eleventh Census, 1890, pp. 285-329. 
Considerable manganese is lost in the slag and fumes, though the loss has been greatly reduced in the last few years. According to Simmersbach ${ }^{a}$ an alloy containing 40 per cent manganese should be produced with a slag containing about 7 per cent manganese, and an 80 per cent alloy with about 10 per cent in the slag. The following table shows the composition of the average ferromanganese slag of the present day: ${ }^{b}$

\section{Average composition of ferromanganese slag.}

Silica........................................... 28. 21

Alumina......................................... 9.87

Lime........................................... 42.60

Calcium sulphide.................................. 3.42

Sulphur........................................... 1.60

Magnesia........................................ 1.72

Barium sulphate.................................. 2.07

Manganous oxide. . . . . . . . . . . . . . . . . 97

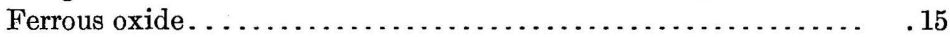

Alkali. . . . . . . . . . . . . .

The alloy obtained from the same furnace as this slag had the following composition:

Composition of alloy produced with slag of composition given above.

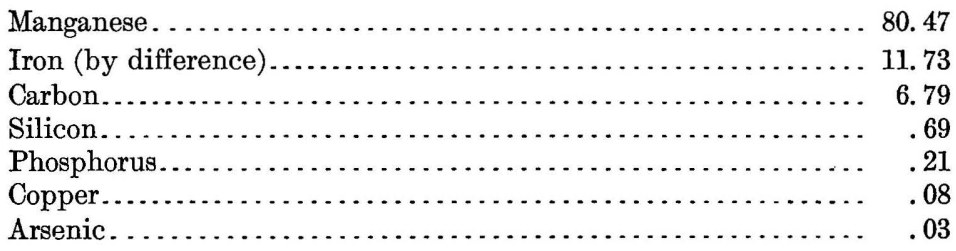

When manganese spar is used in the furnace instead of the oxide, the resulting slag is higher in manganese.

The preparation of ferromanganese in the electric furnace is accomplished by mixing manganese and iron oxides with powdered carbon and suitable slagging materials and heating the mixture in a furnace of the resistance type until the reduction is complete. ${ }^{c}$ The metallurgical side of the process is similar to others in which carbon is the reducing material, but electric heating gives a higher temperature.

The furnaces are generally designed for resistance heating, but combined arc and resistance heating is employed in the earlier stages of the operation. The simplest form of the furnace is merely a column with square cross section lined with suitable refractory material and provided with two massive carbon electrodes, a fixed one at the base and a movable one in the shaft of the furnace. As

$a$ Simmersbach, O., loc. cit.

$b$ Roberts, Edwin G. Ll., and Wraight, Ernest A., The preparation of carbon-free ferromanganese: Jour. Iron and Steel Inst., 1906, No. 2, p. 237.

c Kershaw, J. B. C., The manufacture and use of ferro alloys: Iron Trade Rev., July 16, 1908. 
a lining the oxide of the metal to be reduced is generally employed, as this contains only elements already present in the charge. The charge, consisting of a mixture of ore, coke, and slagging materials, all in a finely divided state, is fed to the furnace from above, and the molten metal or alloy is tapped periodically at the foot of the shaft.

The aluminum reduction process is also employed in the manufacture of ferro alloys, more especially the alloys of iron with silicon, tungsten, vanadium, chromium, and molybdenum.

\section{CONSTITUTION.}

The exact nature of the iron alloys of manganese is not known, but the metals are supposed to be partly in the form of carbide and partly in solid solution. The common carbides of iron and manganese are $\mathrm{Fe}_{3} \mathrm{C}$ and $\mathrm{Mn}_{3} \mathrm{C}$, but many analyses of ferromanganese show carbon present in amounts greater or less than that required by mixtures of these carbides. The excess amounts are not present as free carbon (graphite); hence either there are other carbides present that are not known or the excess carbon is in solid solution in the carbides present. The quantity of carbon absorbed by a manganeseiron alloy is dependent (1) on the percentage of manganese present, as there is a great affinity between carbon and manganese; (2) on the temperature of fusion and other furnace conditions, and (3) on the presence of carbides besides $\mathrm{Mn}_{3} \mathrm{C}$ and $\mathrm{Fe}_{3} \mathrm{C}$. With an increase in the proportion of manganese in alloys, a marked change in the capacity to dissolve carbon occurs at about 20 per cent of manganese, and this percentage also governs the change from the platelike crystalline structure of spiegeleisen to the granular crystalline structure of ferromanganese. A similar change occurs at about 70 per cent of manganese. The amount of silicon present depends on the quantity of silica in the ore and flux fed to the furnace.

Ferromanganese and spiegeleisen are white or light-gray with bright metallic luster. Spiegeleisen has a brilliant platelike crystalline structure, whence it takes its name "mirror iron." When it contains less than 4 per cent of manganese it assumes a fibrous or columnar structure. Ferromanganese ${ }^{a}$ has a granular compact matrix, in which two main types of crystalline forms occur. The less common of the crystal types is platelike and similar to the crystalline structure of spiegeleisen; the other type is prismatic. There is no regularity in the formation of these crystals; both may form in the same mass, or different masses may have different crystalline forms. The two types of crystals taken from the same alloy mass have been analyzed and show practically no difference in composition; neither do they show a marked difference in composition from the matrix.

$a$ Roberts, Edwin G. Ll., and Wraight, Ernest A., op. cit., p. 243. 
The same crystalline forms are present in low and high grade ferromanganese; hence their structure does not change with the composition of the alloy.

The following analyses show the composition of the matrices of two specimens of ferromanganese, one containing prismatic and the other platelike crystals, and of prismatic crystals from one of these:

Composition of ferromanganese groundmass and prismatic crystals.

\begin{tabular}{|c|c|c|c|}
\hline & $\begin{array}{l}\text { Groundmass } \\
\text { of specimen } \\
\text { with pris- } \\
\text { matic crys- } \\
\text { tals. }\end{array}$ & $\begin{array}{l}\text { Groundmass } \\
\text { of specimen } \\
\text { with plate- } \\
\text { like crystals. }\end{array}$ & $\begin{array}{l}\text { Prismatic } \\
\text { crystals. }\end{array}$ \\
\hline 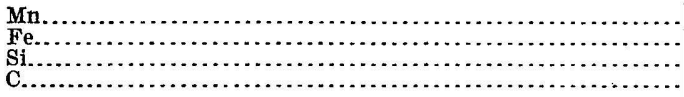 & $\begin{array}{r}80.00 \\
12.60 \\
.61 \\
6.65\end{array}$ & $\begin{array}{r}79.20 \\
13.60 \\
.75 \\
6.06\end{array}$ & $\begin{array}{r}83.60 \\
8.80 \\
.56 \\
6.81\end{array}$ \\
\hline
\end{tabular}

The first specimen was produced by slowly cooling a large mass of the molten alloy, and the second by rapidly cooling a smaller quantity from a temperature far above the melting point by pouring it into a cold steel mold. The prismatic crystals correspond closely in composition with the double carbide $\mathrm{Fe}_{3} \mathrm{C} .10 \mathrm{Mn}_{3} \mathrm{C}$.

The following analyses show the composition of the two types of crystals from the same mass, prepared by slowly cooling it for twenty hours:

\begin{tabular}{|c|c|c|}
\hline & $\begin{array}{l}\text { Prismatic } \\
\text { erystals. }\end{array}$ & $\begin{array}{l}\text { Platelike } \\
\text { crystals. }\end{array}$ \\
\hline $\begin{array}{l}\mathrm{Mn} . \\
\mathrm{Fe} .\end{array}$ & $\begin{array}{l}80.88 \\
10.52\end{array}$ & 79. 76 \\
\hline Fi $\mathrm{Fe..............}$ & $\begin{array}{l}10.22 \\
1.12\end{array}$ & $\begin{array}{r}11.38 \\
1.70\end{array}$ \\
\hline 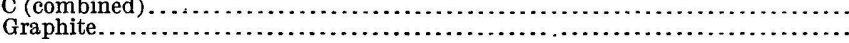 & None. & \\
\hline
\end{tabular}

Carnot and Goutal ${ }^{a}$ have separated carbides from various grades of iron-manganese alloys, and have deduced the following:

Double carbide $\mathrm{Fe}_{3} \mathrm{C} .4 \mathrm{Mn}_{3} \mathrm{C}$ exists in ferromanganese having $85-74$ per cent manganese.

Double carbide $\mathrm{Fe}_{3} \mathrm{C} .2 \mathrm{Mn}_{3} \mathrm{C}$ exists in ferromanganese having $74-60$ per cent manganese.

Double carbide $2 \mathrm{Fe}_{3} \mathrm{C} . \mathrm{Mn}_{3} \mathrm{C}$ exists in ferromanganese having $60-30$ per cent manganese.

Double carbide $4 \mathrm{Fe}_{3} \mathrm{C} . \mathrm{Mn}_{3} \mathrm{C}$ exists in ferromanganese having below 18 per cent man- . ganese.

The last double carbide is supposed to be that present in spiegeleisen. 
According to Moissan, however, no definite double carbide of iron and manganese exists, and the two carbides $\mathrm{Fe}_{3} \mathrm{C}$ and $\mathrm{Mn}_{3} \mathrm{C}$ are able to replace each other in the mixed carbide $(\mathrm{Fe}, \mathrm{Mn})_{3} \mathrm{C}$.

The following general statements ${ }^{a}$ may be made with regard to the constitution of iron-manganese alloys: Ferromanganese consists of manganese and iron in which-

1. Carbon may be present in such an amount as to form some carbide of iron and manganese, leaving either free manganese or iron in which these carbides are dissolved.

2. Carbon may be present in such a degree that the alloy consists entirely of a mixture of double carbides of iron and manganese, mechanically or chemically combined.

3. The carbon may be present in excess to satisfy such carbides, the remainder of the carbon being dissolved in them.

It has been found that a single mass of ferromanganese is not homogeneous with regard to composition. Samples have been taken from different parts of the same mass for analysis and found to vary over 2 per cent in metallic manganese content. It has been found also that the crystals contain a slightly higher percentage of manganese than the matrix.

\section{USES IN STEEL MANUFACTURE.}

Spiegeleisen and ferromanganese are used in the manufacture of steel in the following ways: (a) As reducers of iron oxide formed in the final melting, the manganese oxide formed going into the slag; (b) As recarbonizers of steel, the alloys being used for their carbon as well as their manganese content; $(c)$ for counteracting phosphorus and sulphur by the formation of manganese phosphide and sulphide; and $(d)$ in the manufacture of manganese steel, used for railroad and street-car rails on curves, for burglar-proof safes, dredger pins, car wheels, shoes and crusher plates in gold mills, and for other purposes. The addition of small amounts of manganese gives to steel hardness, ductility, and strength.

(a) During the final melting the molten iron in the converter absorbs small quantities of oxygen from the blast, forming iron oxide, the presence of which makes the steel difficult to forge. When a small amount of manganese is added it absorbs the oxygen from the oxide of iron, forming manganese oxide, which combines with the slag to form a protosilicate. Small particles of slag that are disseminated through the molten metal also contain small quantities of oxygen. Though the presence of oxygen in this form is less objectionable, the removal of the slag particles is very desirable, and is largely accomplished by manganese. The manganese unites with the silicate of iron composing the slag particles and forms a double silicate of iron

$a$ Roberts, E. G. Ll., and Wraight, E. A., op. cit., p. 248. 
and manganese, the presence of which causes the coalescence of the slag particles from their disseminated condition. They rise and join the main body of the slag at the surface. It is not all removed, however, and even the best steels contain small particles of manganese silicate. Some of the manganese combines directly with the slag, some is volatilized, and some combines with other impurities, so it is difficult to determine what quantities of the ferromanganese or spiegeleisen should be added in each case to produce the desired result.

(b) On account of the extensive oxidation in the Bessemer converter, all or nearly all of the carbon is oxidized, leaving the metal in the form of wrought iron instead of steel. To remedy this, ferromanganese or spiegeleisen; either solid or molten, is added during the final melting to restore the requisite amount of carbon and prevent further oxidation.

(c) Manganese neutralizes the effect of sulphur by forming a manganese sulphide, which probably goes partly into the slag and partly remains in the steel. All good steels contain sulphur in this form. It counteracts the effect of phosphorus by forming the phosphide, $\mathrm{Mn}_{3} \mathrm{P}_{2}$. Manganese tends to keep carbon from separating out as graphite, and to increase the power of carbon to combine with iron.

(d) Ferromanganese is used in the manufacture of manganese steel, the nature and uses of which are described in the next section.

\section{HADFIELD'S MANGANESE STEEL. $a$}

FIRST EXPERIMENTS.

Experiments with manganese steel were first carried on by the Terre Noir Company about 1878, while they were perfecting the manufacture of commercial ferromanganese. The use of manganese was limited to $2 \frac{1}{2}$ per cent, however, on account of the brittleness of the product when more than this percentage was used.

About 1883 experiments on mánganese steel were begun by R. A. Hadfield, at the Hecla Works, Sheffield, England. He discovered that though the product containing between $2 \frac{1}{2}$ and 6 per cent manganese was extremely brittle a return in strength occurred after 7 per cent was passed, and that as the percentage of manganese increased to 14 or 15 a very strong and hard alloy was obtained. He found that above this percentage there was a decrease in toughness, though not in transverse strength, which continued up to 20 per cent, after which a rapid decrease took place. These facts apply to both the cast and the forged alloys, but more especially to the latter. The decrease in

$a$ Hadfield, R. A., Tron alloys, with special reference to manganese steel: Trans. Am. Inst. Min. Eng., vol. 23, 1893, p. 148; On manganese steel: Jour. Iron and Steel Inst., 1888, No. 2, p. 41; Manganese and its application to metallurgy: Minutes Proc. Inst. Civ. Eng., vol. 93, 1887-1888, pt. 3, p. 1; Some newly discovered properties of iron and manganese: Idem, p. 61. 
strength that accompanies an increase of manganese to more than 14 or 15 per cent is partly due to the resulting increase in the carbon to $1 \frac{1}{2}$ to 2 per cent.

\section{PHYSICAL PROPERTIES.}

Manganese steel, in its most serviceable form, contains about 13 or 14 per cent manganese. This alloy possesses a combination of hardness, tenacity, and ductility which makes it valuable for many purposes. Its use, however, has been limited somewhat by its extreme hardness, on account of which it is almost impossible to work it with machine tools. The material, therefore, has to be cast in very nearly the form in which it is intended to be used.

Manganese steel is not so liable to honeycombs as ordinary steel, and the addition of silicon is unnecessary. It is very fluid and can be run into thin sections but cools more rapidly than ordinary steel and has a greater contraction. It is manufactured by any of the ordinary steel-making processes; the basis (the material before the ferromanganese is added) is preferably decarbonized iron or mild steel. The ferromanganese is added in a molten state, or very highly heated. It is important that carbon should be kept as low as possible, especially in the 14 per cent material, in which it should not exceed about 1 per cent, as the product would be inferior. For this reason the ferromanganese used should contain a high percentage of manganese - that is, 80 to 84 per cent. To obtain 14 per cent manganese steel, $14 \frac{1}{2}$ per cent of manganese must be added, as one-half per cent is oxidized in reducing the iron oxide.

Ordinary steel, whether cast or forged, may contain as much as $1 \frac{1}{4}$ per cent manganese without showing any marked difference in quality, provided the carbon percentage is low. But with higher percentages there is a decrease in strength and ductility, which is accentuated to a remarkable degree between $3 \frac{1}{2}$ and 5 per cent.

Cast manganese steel containing from $2 \frac{1}{2}$ to 6 per cent manganese is extremely brittle and can be chipped with a small hammer and ground to a powder. When hot, however, it is extremely ductile and may be drawn down to any desired sizes. It is worthy of note that the amount of carbon in this brittle material is very small, little more than that in mild steel. The remarkable weakness of the cast product is no doubt intensified by a peculiar crystallization which resembles that of "scalded" crucible steel. The brittleness is not so marked if the metal is poured at lower temperature, but steel with $3 \frac{1}{2}$ to $6 \frac{1}{2}$ per cent manganese in whatever shape or under whatever conditions it is cast is always deficient in strength compared with ordinary steel. With the increase of manganese beyond about $6 \frac{1}{2}$ per cent a remarkable change occurs, the exact point being somewhat influenced by the casting temperature and other considerations. By this change the brit- 
tleness gradually disappears and toughness and ductility return. The alloy also loses its magnetism, and at 13 per cent is practically nonmagnetic. At about 14 per cent the maximum of strength is obtained; the cause of the succeeding decrease is complicated by the higher carbon content. It is possible that if the carbon content could be kept low steel containing 25 or 30 per cent of manganese might have considerable strength.

The toughness and resistance to fracture of manganese steel containing between 8 and 20 per cent of manganese is not altogether produced immediately upon casting; further treatment, such as "water toughening," gives the best results. The material as cast is often remarkably tenacious and ductile, notwithstanding its great hardness, but this property is to some extent uncertain without further treatment. The uncertainty is probably due to variation in the casting temperature and other similar causes.

"Water toughening" consists in heating the article to $1,800^{\circ}$ or $2,000^{\circ} \mathrm{F}$. and then plunging it in cold water. The nearer this temperature is approached and the colder the water the harder will be the metal. Such treatment would cause water cracking, brittleness, and other defects in ordinary steel.

Forged manganese steel containing between $2 \frac{1}{2}$ and 6 per cent manganese is very much stronger than the same material when cast, but is still very brittle as compared with ordinary steel. It is most brittle with about 5 per cent. Heating or water quenching does not seem to modify this character to any extent.

The peculiar crystallization of the cast material disappears after hammering and the grain is then coarse and open. If it is reheated and cooled quickly in the open air a fine close grain is obtained.

With 10 per cent manganese the water-toughened forged manganese steel possesses about as much ductility as mild steel, but much higher tenacity.. With increase past 13 per cent there is a considerable increase both of ductility and tenacity; the maximum is reached at 14 per cent, as it is in the cast product. With increase above 14 per cent, there is a decrease in strength, also complicated by the presence of carbon, and at 22 per cent the malleability is lost. With the forged product, as with the cast product, there is no object in manufacturing a material containing more than 14 per cent manganese, the best results being obtained with the 10 to 14 per cent material.

Water quenching is also of great importance in producing strength and tenacity in the forged manganese steel.

Experiments have been attempted to note the effect of plunging manganese steel in sulphuric acid and in oil. The acid was found to be more satisfactory than the oil, but neither was found to be preferable to water. A beneficial effect is also produced by reheating and cooling in air. This increases both the tenacity and the ductility. 
The physical properties of manganese steel depend largely upon the microstructure, as is true of all other alloy steels. The microstructure is largely dependent on the sum of the quantities of carbon and manganese $(\mathrm{C}+\mathrm{Mn})$ present. The following table shows the microstructures which develop in manganese steel with varying percentage of carbon and manganese:

Constitution of manganese steel. ${ }^{a}$

\begin{tabular}{|c|c|c|}
\hline \multirow{2}{*}{ Microstructure. } & \multicolumn{2}{|c|}{$\begin{array}{l}\text { Percentage of manga- } \\
\text { nese with- }\end{array}$} \\
\hline & $\begin{array}{l}\text { Carbon } 0.2 \\
\text { per cent. }\end{array}$ & $\begin{array}{l}\text { Carbon } 0.8 \\
\text { per cent. }\end{array}$ \\
\hline 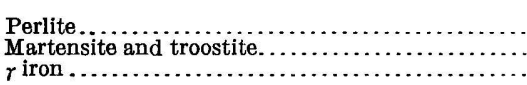 & $\begin{array}{l}0-5 \\
5-12 \\
12+\end{array}$ & $\begin{array}{l}\stackrel{0-3}{3-7} \\
3+7\end{array}$ \\
\hline
\end{tabular}

a Guillet, L., Quaternary steeis: Jour. Iron and Steel Inst., 1906, No. 2, p. 6.

The manganese steels containing $\gamma$ iron are the most desirable for commercial use because of their härdness and tenacity. Martensitic steels though hard are generally very brittle.

On account of their great hardness, it is scarcely possible to machine manganese steels on a practical scale. The cast material, with about 5 or 6 per cent of manganese, is hardest; and no tool will face or touch it. With increase of manganese there is a decrease in hardness up to 10 per cent, at which percentage it is in its softest condition. After this point is passed the hardness again increases, until at 22 per cent of manganese another hard stage is reached, but not as hard as the 5 per cent stage. The cause of the great hardness of manganese steel is not known. Manganese when added to copper has no similar effect. It is thought possible that iron has the property of changing its form, when combined with manganese, in a way not yet understood.

Manganese steel, although it has a large iron content, has the property of being almost entirely nonmagnetic, not being attracted by the strongest magnets. An alloy with 87 per cent iron, 12 per cent manganese, and 1 per cent carbon has a permeability between 1.3 and 1.5. ${ }^{a}$ It retains no residual magnetism even after strong magnetizing forces have been applied. It is believed that the alloy is not a mechanical mixture, but that the manganese and iron combine to form a molecule with properties different from either. ${ }^{b}$ It has been found that when manganese steel drillings of 20,30 , and 36 per cent manganese were heated to redness and then cooled, they became magnetic. That this was not due to the oxidation of the manganese was shown 
by the fact that the material had the same weight before and after heating, and that it acquired the same magnetic property when cooled in hydrogen.

USES.

Manganese steel is used for many purposes, although its application is considerably restricted because of the difficulty of machining it. In a large number of articles for which it is used this difficulty is surmounted by so arranging the castings or forgings that they can be used without any tooling. The greater first cost is compensated by the saving of the cost of machining. Manganese steel has a considerable advantage in being almost free from blow holes or honeycombs, and in possessing greater fluidity than cast steel.

Manganese steel is used for dredger pins and other parts of dredging machines; for dipper teeth of steam shovels; for parts of crushing and grinding machinery, such as shoes and crusher plates in ore mills; for ore chutes and screens; for elevator links, especially where the wear and tear is heavy; for agricultural implements, as plow shares and plow points, cultivator fingers, and even shovels, spades, rakes, hoes, and forks; for wheels, tires, and axles on railway cars, street cars, and mining wagons; for cogwheels; for couplers between railway cars; for railroad and street-car rails on curves; for burglar-proof safes; and for many other purposes. One of its most important uses at the present time, on account of its nonmagnetic property and hardness, is for cover plates and coil shields in large electromagnets, ${ }^{a}$ such as are used for clutches in lifting pig and scrap iron at foundries.

\section{QUATERNARY MANGANESE STEELS. $b$}

A quaternary steel is distinguished from a ternary steel by the fact that it contains two elements besides carbon and iron, while a ternary steel contains but one. Thus manganese steel, chromium steel, nickel steel, and tungsten steel are ternary steels, while manganese-nickel and chromium-tungsten steel are quaternary steels. The principal manganese quaternary steels are manganese-nickel steel, manganesechromium steel, and manganese-silicon steel.

The microstructures of these steels consist in general of a superposition of the microstructures of the constituent ternary steels, modified by the total quantity of hardening elements present, that is, the sum of the elements besides iron. For instance, if chromium is added to manganese steel it has the same effect as the addition of more manganese would have, and superimposed upon this effect would be a tendency toward developing a new and distinct microstructure characteristic of chromium steel-that is, carbide microstructure. 
Nickel-manganese steels are either perlitic, martensitic, or contain $r$ iron, according to the quantity of "carbon + manganese + nickel" present. As the structures of nickel steel and manganese steel are very similar the addition of one to the other produces no new structures. Nickel-manganese steels are capable of being substituted for nickel steels for many purposes and possess the advantage of a smaller cost.

Manganese-silicon steels are either perlitic or contain $r$ iron. The addition of silicon to manganese steel weakens its mechanical properties in the normal state, but confers the advantage of greater tenacity upon quenched steels, provided both manganese and silicon are present in small quantities. The high-class spring steels consist of manganese-silicon steel in which neither manganese nor silicon is present in excess of 1 per cent.

Manganese-chromium steels consist of the following microstructures: Perlite, martensite with or without carbide, and $\gamma$ iron with or without carbide. Apparently the addition of chromium to manganese steel has no other effect on the structure than the addition of manganese would have, except that if the percentage is sufficiently high a double carbide of chromium and manganese is formed, especially if the carbide also is increased. Manganese-chromium steels possess great hardness and resistance to shock, and might be substituted for nickel-chromium steels. In fact, manganese might be substituted for nickel in many of the quaternary nickel steels, thus lowering the cost.

\section{ALILYS WITH OTHER METALS THAN IRON. $a$}

Manganese forms alloys with copper, zinc, tin, aluminum, lead, magnesium, and other metals.

\section{CUPROMANGANESE.}

The most important of the manganese alloys, with the exception of the iron alloys, is cupromanganese, an alloy with copper. This is used in the manufacture of manganese bronze, manganese brass, and manganese German silver.

Cupromanganese may be prepared by heating to a white heat for several hours, in a graphite crucible, a mixture of powdered manganese ore, coal dust, and granulated copper, with a cover of fluorspar, common salt, and charcoal dust. At the proper time the liquid alloy may be poured out and when cooled is a hard, tough, whitishgray material.

\footnotetext{
$a$ References on alloys other than iron:

Brannt, Wm. T., The metallic alloys, 1896, p. 312.

Thurston, R. H., Materials of engineering, pt. 3.

Mc'Taggart, H. A., On the constitution and properties of Heusler's alloys: Univ. Toronto Studies; Papers from physical laboratories, No. 23, 1908.

Elect. Eng., London, vol. 3, p. 704.
} 
Another method of preparing it is to melt in a reverberating furnace with regenerative firing a mixture of cupric oxide, coal, and manganic oxide, the last obtained as a by-product in the manufacture of chlorine. The result is a malleable, ductile alloy, with from 5 to 30 per cent of manganese.

Cupromanganese has also been prepared by mixing metallic manganese and copper, or ferromanganese and copper, the latter mixture producing a ferriferous alloy. When the alloy contains but a small percentage of manganese, about 4 per cent or less, it has a copper-red color. With 10 to 15 per cent manganese it is yellowish-gray, and with a larger percentage it becomes gray, $18 \frac{1}{2}$ per cent having as much bleaching effect as 25 per cent of nickel. An alloy with 8 per cent manganese is ductile and malleable, but one with 12 to 15 per cent is brittle.

Cupromanganese is added in small quantities to copper or its alloys to withdraw the oxygen and thus give them greater density and strength. By the addition of larger amounts greater hardness is imparted.

\section{MANGANESE BRONZE.}

Manganese bronze is prepared by adding small pieces of cupromanganese to ordinary bronze, melted in a crucible under cover of charcoal with possibly some potash and soda. The whole is melted and the mixture is stirred together with a retort graphite rod. Or, copper and cupromanganese may be melted together in a crucible under a cover of coal dust and then the requisite quantity of tin added, with thorough stirring. Frequently the alloy is produced by adding ferromanganese or spiegeleisen to bronze; such an alloy contains a small quantity of iron.

Tough, malleable manganese bronze of a brass-yellow color contains essentially 75 to 76 per cent copper, 16 to 17 per cent manganese, and 5 to 6 per cent tin. An addition of aluminum up to 5 per cent increases the strength and elasticity and gives it a silver-white appearance. Zinc is often added up to 5 per cent, and lead is sometimes added in small quantities.

Another common proportion ${ }^{a}$ in manganese bronze is copper 88 per cent, tin 10 per cent, and manganese 2 per cent. This is a ductile, hard, and tenacious alloy of a reddish-white color. With 10 per cent manganese the color is white with a reddish tinge, with 20 per cent manganese it is a silver white, and with 40 per cent manganese it is an iron gray. When rich in copper the alloy has a decided rose hue.

Early experiments with this alloy were unsatisfactory, and led to the conclusion that it was useless on account of its ready oxidation at high temperature. More recent experiments have shown a small

$a$ Thurston, R. H., Materials of engineering, pt. 3. 
quantity of manganese, advisably about two-thirds of 1 per cent, to be very serviceable. It frees the alloy from oxides and makes it homogeneous, thus producing greater strength and resistance to wear, being especially adapted for bearings.

When forged, manganese bronze acquires remarkable strength and toughness. During this process the alloy should not be heated to a higher temperature than cherry-red and should not be worked at a black heat. Thus strengthened, manganese bronze is used for screws, nails, wire, pins, bolts and nuts, pump rods, rudders, and steamboat propellers. Articles manufactured from manganese bronze are used especially in the construction of ships.

\section{MANGANESE BRASS.}

Manganese brass is a silver-like alloy with about 10 parts copper, 30 parts manganese, and 20 to 30 parts zinc, which can be forged and rolled at a red heat. Where not required to stand high temperatures, it contains 49 parts copper, 21 parts manganese, and 5 to 10 parts zinc. It is used for soldering with the following composition: Copper, 7; manganese, 3 ; silver, 1 to 2 . For coins, an alloy with 65 per cent copper, 25 per cent manganese, and 10 per cent zinc may be used. From 5 to 10 per cent nickel may be substituted for part of the manganese.

\section{MANGANESE GERMAN SILVER.}

An alloy containing copper 60, zinc 15, and ferromanganese (with 70 to 80 per cent manganese) 40 is used as a substitute for German silver. It is also known as silver bronze. For bearings, cocks, and valves this alloy is used with the following composition: Copper 60 , zinc 10, and ferromanganese (containing 60 per cent manganese) 40 . Nickel is frequently added and also small quantities of aluminum and silicon. The addition of $1 \frac{1}{4}$. per cent of aluminum gives to the alloy good casting qualities and noncorrodibility.

\section{MANGANESE AMALGAM.}

Manganese amalgam is a manganese-mercury alloy with the composition $\mathrm{Hg}_{5} \mathrm{Mn}_{2}$. It is prepared by electrolyzing a saturated solution of manganese chloride, mercury being used as the negative pole. A pasty mass is obtained, which, when compressed, yields a slatecolored mass with a specific gravity of 12.8 .

\section{MANGANESE-ALUMINUM ALLOYS.}

Manganese-aluminum alloys with crystalline forms and definite chemical composition have been produced ${ }^{a}$ by direct fusion of the metals, by the fusion of manganese salts with aluminum, or by the 
reduction of manganese oxides with aluminum. Alloys of the following compositions have been prepared: $\mathrm{MnAl}_{3}, \mathrm{Mn}_{2} \mathrm{Al}_{7}, \mathrm{MnAl}_{4}$, $\mathrm{MnAl}_{6}, \mathrm{MnAl}_{2}$, and $\mathrm{Mn}_{2} \mathrm{Al}_{3}$. These may be comparable to manganese carbides and silicides (pp.237,238,239). Some manganese-aluminum alloys are hard enough to scratch glass.

Both manganese and aluminum when alloyed with iron destroy. its magnetic properties. Triple alloys of manganese, aluminum, and iron, however, of the following composition, are reported by Hogg ${ }^{a}$ as strongly magnetic.

Anulyses of magnetic alloys of manganese, aluminum, and iron.

\begin{tabular}{|c|c|c|}
\hline & 1. & 2. \\
\hline 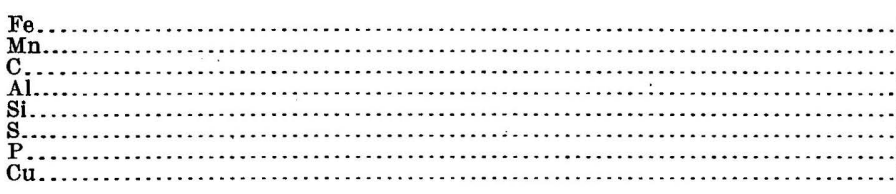 & $\begin{array}{r}10.80 \\
54.86 \\
2.32 \\
25.34 \\
.79 \\
\text { Trace. } \\
.11 \\
.07\end{array}$ & $\begin{array}{r}14.80 \\
75.40 \\
5.55 \\
3.05 \\
.89 \\
\text { Trace. } \\
.18 \\
.08\end{array}$ \\
\hline
\end{tabular}

The alloy shown by analysis 1 was found to disintegrate on exposure; the other was stable.

\section{HEUSLER'S ALLOYS. ${ }^{b}$}

Much attention is being directed at the present time to certain magnetic alloys of copper, manganese, and aluminum, known as Heusler's alloys. They were discovered some years ago and numerous experiments have been conducted to ascertain the cause of their peculiar magnetic properties. It has been found that the permeability increases with the addition of manganese until aluminum and manganese are present in the ratio of their atomic weights (Al 27.11

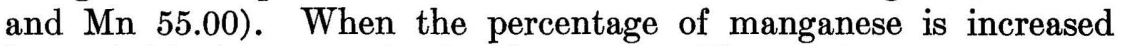
beyond this the magnetization decreases. The maximum magnetization attained up to the present is about one-third of that of the best iron. Copper apparently serves no other purpose than to make the alloy-otherwise hard and brittle-soft enough to be cast and handled.

It was found by Asteroth that heating the alloy to a high temperature and quenching it eliminated hysteresis, but that when it was reheated above the temperature of transformation, cooled for three hours, and aged at a temperature of $140^{\circ} \mathrm{C}$. the hysteresis returned. It seems probable that the magnetism depends on the molecular arrangement and that quenching prevents the magnetic molecules from settling into positions in which they can obey magnetizing forces. Crystallization facilitates such a molecular arrangement.

$a$ Hogg, T. W., Notes on some alloys of iron, aluminum, and manganese: Chem. News, vol. 46, p. 140.

b McTaggart, H. A., op. cit.; also Elect. Eng., loc. cit. 
Recent experiments on the microstructure of the alloys, conducted in the physical laboratory of the University of Toronto, by $\mathrm{H}$. A. McTaggart, served to emphasize their crystalline texture. Alloys of different composition were etched and examined under the microscope, and it was found that those having the highest magnetization had a pronounced and peculiar crystalline structure. The following table shows the composition of some of the alloys used:

Analyses of Heusler's alloys.

\begin{tabular}{|c|c|c|c|c|}
\hline & 1. & 2. & 3. & 4. \\
\hline $\begin{array}{ll}\mathrm{Al} \\
\mathrm{Mn} \\
\mathrm{Cn}\end{array}$ & $\begin{array}{r}8.00 \\
32.10 \\
59.80\end{array}$ & $\begin{array}{r}9.70 \\
25.60 \\
64.60\end{array}$ & $\begin{array}{l}14.30 \\
28.60 \\
57.10\end{array}$ & $\begin{array}{l}15.90 \\
23.90 \\
60.30\end{array}$ \\
\hline
\end{tabular}

Though all exhibited considerable magnetism, it was found that the alloy of the composition shown by analysis 3 was the most magnetic. Under the microscope this alloy was found to consist of large, distinct, regular crystals through which were scattered smaller fern-shaped crystals of what appeared to be manganese. The alloy shown by analysis 2 also exhibited a crystalline structure, but the crystals were irregular and were interlocked with each other; the alloy. shown under analysis 1 exhibited no definite crystalline structure. Neither alloy had the fernlike crystals of manganese. The alloy shown under analysis 4 had distinct regular crystals, but the fernlike forms had changed to rosettes or star-shaped masses. The experimenter therefore concludes that the magnetic properties of these alloys accompany the fern-shaped crystals. Experiments have not been conducted to show the effect of heat and quenching on the crystalline forms, nor have the different crystal forms been analyzed to show their composition.

\section{OTHER ALLOYS.}

Various combinations in various proportions of copper, zinc, tin, magnesium, and to some extent iron with manganese have been experimented on and alloys with different properties produced. Alloys of manganese with aluminum, tin, antimony, arsenic, bismuth, and boron are receiving attention on account of their peculiar magnetic properties.

\section{COPPER, LEAD, AND SILVER REDUCTION.}

Manganese oxides are used as substitutes for iron oxide for flux in the reduction of copper and silver ores. Many such ores themselves contain considerable iron and manganese oxides, so that a less amount of flux has to be added in the smelters. Any metals, such as silver and lead, that may be contained in the flux are recovered during the smelting. The iron and manganese go into the slag and become waste products. 


\section{CHEMICAL USES. $a$}

\section{USES AS AN OXIDIZER.}

\section{GENERAL STATEMENT.}

The peroxide of manganese $\left(\mathrm{MnO}_{2}\right)$, occurring in nature as the minerals polianite, pyrolusite, and psilomelane, is the only oxide of this metal that can be used for oxidizing purposes. It can be so used because one of its oxygen atoms is loosely combined and may be liberated by heat or with acids. This part is known as its "available oxygen." $\mathrm{MnO}_{2}$ theoretically contains 63.2 per cent metallic manganese and 36.8 per cent oxygen, and as half of the latter may be liberated the available oxygen amounts to 18.4 per cent. Practically, however, 13 to 17 per cent of oxygen only is available, on account of impurities in the peroxide. Both the manufactured peroxide of manganese and the native minerals, especially pyrolusite, are used for oxidizing purposes, but the latter must be very pure. Manganates. and permanganates are also used as oxidizers. Braunite and manganite are not used, because they are lower oxides $\left(\mathrm{Mn}_{2} \mathrm{O}_{3}\right)$ and have no available oxygen, though their manganese content is higher than that of the peroxide. For oxidizing purposes, therefore, the manganese itself is not used, but acts only as a carrier of oxygen, and is valuable because of the facility with which it unites with a large amount of oxygen and the equal facility with which it yields part of this oxygen upon treatment with acid or heat.

\section{MANUFACTURE OF CHLORINE.}

In the manufacture of chlorine manganese peroxide is used as an oxidizer in producing a more powerful oxidizer. The process is accomplished through the action of the available oxygen in the peroxide upon a compound of chlorine, breaking it up and setting free the chlorine. This is accomplished either with $\mathrm{HCl}$ or with $\mathrm{NaCl}$ in the presence of $\mathrm{H}_{2} \mathrm{SO}_{4}$, as shown in the reactions below:

$$
\begin{aligned}
& \mathrm{MnO}_{2}+4 \mathrm{HCl}=2 \mathrm{H}_{2} \mathrm{O}+\mathrm{MnCl}_{2}+\mathrm{Cl}_{2} . \\
& 2 \mathrm{NaCl}+\mathrm{MnO}_{2}+2 \mathrm{H}_{2} \mathrm{SO}_{4}=\mathrm{Na}_{2} \mathrm{SO}_{4}+\mathrm{MnSO}_{4}+2 \mathrm{H}_{2} \mathrm{O}+\mathrm{Cl}_{2} .
\end{aligned}
$$

It will be noticed that in the second of these equations all the chlorine is set free, but in the first part of it remains in combination with the manganese. In early times, when hydrochloric acid was very expensive, the second method was generally used; but at present the very first is employed almost exclusively.

In the commercial manufacture of chlorine manganese peroxide, generally pyrolusite, is treated with hydrochloric acid in a closed oblong stone box. The chlorine escapes through a pipe into a main. 
The hydrochloric acid is run in through a funnel tube, which empties into a bowl filled with acid, so that no chlorine escapes through it. The action goes on without heating for some time, and when it slackens steam is blown in from time to time.

Very pure pyrolusite must be used, as some impurities, carbonates, for example, tend to waste the acid and add objectionable gases, and others, such as silica and other insoluble materials, obstruct the action of the acid. Ferrous iron, if present, not only uses up acid, but absorbs oxygen. Soft ore is more easily treated than hard ore.

The reaction taking place in the still is the same as that given above, except that as pyrolusite is not pure $\mathrm{MnO}_{2}$ the remaining product, or "still liquor," contains small quantities of other compounds.

The following analysis by Black $^{a}$ gives the general composition of "still liquor:"

Composition of "still liquor" in process for production of chlorine.

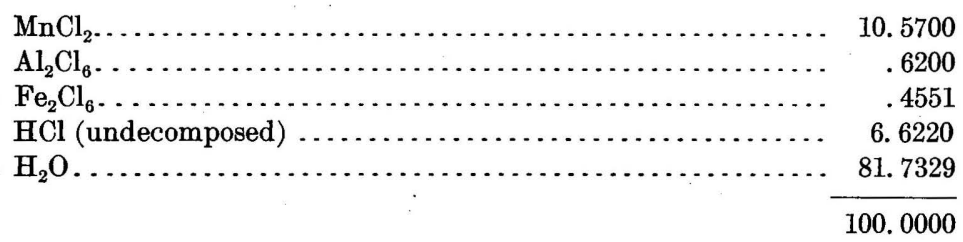

In former years this liquid was allowed to go to waste, thus necessitating a fresh supply of pyrolusite every time the still was charged. As this was expensive, methods were devised by which the manganese chloride in the still liquor was converted into peroxide and used again. The first of these to be successful was discovered by Charles Dunlop in 1855. In the Dunlop process the still liquor is mixed with ground chalk or limestone dust and the free acid is neutralized with the formation of calcium chloride and carbonic acid, while the iron is precipitated as hydrated oxide. The neutral liquid, consisting of manganous and calcium chlorides, after settling, is pumped into large boilers supplied with agitating shafts, and more chalk is mixed with it. Steam is then blown in until a pressure of 2 to $2 \frac{1}{2}$ atmospheres is reached. In about twenty-four hours a chemical reaction takes place between the calcium carbonate and manganous chloride, resulting in the production of manganous carbonate and calcium chloride, thus:

$$
\mathrm{CaCO}_{3}+\mathrm{MnCl}_{2}=\mathrm{MnCO}_{3}+\mathrm{CaCl}_{2} \text {. }
$$

The manganese carbonate is then washed, pressed, and partly dried, and placed in a furnace. The temperature is gradually raised to $315^{\circ}$ C. A draft runs through the furnace and the manganese carbonate is occasionally splashed with water. After about twenty-four hours 
of heating the carbonate is changed to a mixture of oxides consisting of about 72 per cent peroxide of manganese, 26 per cent lower oxides of manganese, and 2 per cent calcium oxide. This material is used again in the still.

In 1867 another process was discovered by Walter Weldon, which, being much less expensive than the Dunlop process, has now completely replaced it. In the Weldon process, the neutralization of the liquid is accomplished in the same way as described above, and the resulting manganous and calcium chlorides are pumped into a settling tank. The clear liquid is drawn off through a pipe into a large iron cylinder without disturbing the sediment. In this cylinder, called the "oxidizer," it is mixed with milk of lime (calcium hydroxide) and manganous hydroxide, $\mathrm{Mn}(\mathrm{OH})_{2}$, is precipitated. The mixture now consists of manganous and calcium hydroxides and some calcium chloride. A stream of compressed air is then forced into the cylinder, oxidizing the manganese and converting it largely into calcium manganite, $\mathrm{CaO} \cdot \mathrm{MnO}_{2}$. By further addition of the neutral liquid from the settling tank, and by raising the temperature within the oxidizer by injecting steam, some of the material is converted into a compound which has the composition $\mathrm{CaO}_{2} \cdot \mathrm{MnO}_{2}$. The contents are then run into settling tanks and the product settles as a thin black mud known as "Weldon's mud." This is used again in the chlorine stills.

The most valuable property of chlorine, from a commercial standpoint, is its bleaching power. For this purpose it is combined with slaked lime to form bleaching powder (chloride of lime), and reliberated, when ready to be used, by treatment with dilute hydrochloric acid.

Chlorine bleaches all materials dyed with organic colors. This is performed in the presence of water, the chlorine combining with hydrogen and liberating oxygen, which oxidizes the coloring materials. Its use consists in bleaching vegetable fiber, as cotton, hemp, etc., as well as manufactured cloths, and old rags for paper manufacture. It is also used as a disinfectant and deodorizer for sanitary purposes, and as an oxidizer in many other ways.

\section{MANUFACTURE OF BROMINE.}

The action of manganese peroxide in the manufacture of bromine is the same as in the case of chlorine. Many saline springs, besides containing various chlorides, contain bromides, mainly of magnesium, but also of calcium, potassium, and sodium. In preparing bromine this brine is partly evaporated, and most of the chlorides are precipitated and removed, leaving a mother liquor containing some chlorides and the bromides. The mother liquor is mixed with manganese peroxide and sulphuric acid, which act upon the chlorides remaining 
with the evolution of chlorine, which in turn decomposes the bromides, displacing the bromine:

$$
\begin{aligned}
& \mathrm{MgCl}_{2}+\mathrm{MnO}_{2}+2 \mathrm{H}_{2} \mathrm{SO}_{4}=\mathrm{MnSO}_{4}+\mathrm{MgSO}_{4}+2 \mathrm{H}_{2} \mathrm{O}+\mathrm{Cl}_{2} . \\
& \mathrm{MgBr}_{2}+\mathrm{Cl}_{2}=\mathrm{MgCl}_{2}+\mathrm{Br}_{2} .
\end{aligned}
$$

The bromine is condensed in passing through a worm condenser.

\section{MANUFACTURE OF OXYGEN.}

Various compounds of manganese are used in generating oxygen. Manganese peroxide, when heated to redness, gives up one-third of its oxygen:

$$
3 \mathrm{MnO}_{2}=\mathrm{Mn}_{3} \mathrm{O}_{4}+\mathrm{O}_{2} \text {. }
$$

Potassium chlorate, when heated considerably above the melting point, gives up its oxygen with effervescence:

$$
\mathrm{KClO}_{3}=\mathrm{KCl}+\mathrm{O}_{3} \text {. }
$$

When previously mixed with about one-fourth of its weight of $\mathrm{MnO}_{2}$, however, it gives up all its oxygen considerably below the melting point, and at the end of the reaction the $\mathrm{MnO}_{2}$ is found to be unchanged. In this case manganese peroxide acts as a catalytic agent, and it is believed that it goes through a series of reactions before the final product is evolved. The power possessed by manganese to enter into higher states of oxidation is believed first to result in the formation of potassium permanganate:

$$
2 \mathrm{MnO}_{2}+2 \mathrm{KClO}_{3}=2 \mathrm{KMnO}_{4}+\mathrm{Cl}_{2}+\mathrm{O}_{2} \text {. }
$$

The potassium permanganate passes into potassium manganate with evolution of oxygen and partial reformation of manganese peroxide-

$$
-2 \mathrm{KMn}_{4} \mathrm{O}=\mathrm{K}_{2} \mathrm{MnO}_{4}+\mathrm{MnO}_{2}+\mathrm{O}_{2} ;
$$

and finally potassium manganate is decomposed by the chlorine evolved in the first reaction into potassium chloride, manganese dioxide, and oxygen:

$$
\mathrm{K}_{2} \mathrm{Mn}_{4} \mathrm{O}+\mathrm{Cl}_{2}=2 \mathrm{KCl}+\mathrm{MnO}_{2}+\mathrm{O}_{2} .
$$

Manganese peroxide parts with half of its oxygen when heated with sulphuric acid:

$$
\mathrm{MnO}_{2}+\mathrm{H}_{2} \mathrm{SO}_{4}=\mathrm{MnSO}_{4}+\mathrm{H}_{2} \mathrm{O}+\mathrm{O} \text {. }
$$

Potassium permanganate, as well as other highly oxidized salts, yields oxygen when acted upon by sulphuric acid:

$$
2 \mathrm{KMnO}_{4}+3 \mathrm{H}_{2} \mathrm{SO}_{4}=\mathrm{K}_{2} \mathrm{SO}_{4}+2 \mathrm{MnSO}_{4}+3 \mathrm{H}_{2} \mathrm{O}+5 \mathrm{O} \text {. }
$$

If hydrogen peroxide be added to dilute sulphuric acid and the mixture be added to potassium permanganate, a rapid evolution of oxygen takes place:

$$
2 \mathrm{KMnO}_{4}+3 \mathrm{H}_{2} \mathrm{SO}_{4}+5 \mathrm{H}_{2} \mathrm{O}_{2}=\mathrm{K}_{2} \mathrm{SO}_{4}+2 \mathrm{MnSO}_{4}+8 \mathrm{H}_{2} \mathrm{O}+5 \mathrm{O}_{2} \text {. }
$$




\section{DISINFECTANTS.}

Manganates and permanganates are extensively used as disinfectants and oxidizers on account of the readiness with which they give up their oxygen to organic and other oxidizable compounds. The oxygen combines with and carries off injurious elements in decaying material. Sodium permanganate $\left(\mathrm{NaMnO}_{4}\right)$, under the name of "Condy's disinfecting fluid," is largely used for this purpose.

\section{DECOLORIZER OF GLASS.}

In the manufacture of glass, the sand and other materials used almost invariably have a small quantity of iron impurities, as a result of whose presence the glass has a green color. This color is due to the iron existing in the ferrous state, and is removed by mixing the glass with peroxide of manganese during its manufacture. Two explanations are given for this action. It is thought by some that part of the oxygen in the peroxide of manganese is released and unites with the ferrous iron, making it ferric and changing the color from green to a scarcely perceptible yellow. Others believe that the purple color caused by manganese neutralizes the green caused by the iron, and that no chemical reaction takes place. If too much manganese peroxide is used, or not sufficient heat, the glass is likely to receive a pink or violet color. The same coloration appears in glass long exposed to sunlight.

\section{DRYER IN PAINTS AND VARNISHES.}

When manganese peroxide is immersed for some time in oils used for paints and varnishes, and then removed, it is found that the drying qualities of the oil are greatly increased. After being dried and exposed to the air, the manganese peroxide is ready to be used again. It is maintained that the manganese peroxide gives up some of its oxygen to the oil and on exposure to the atmosphere takes up a fresh supply. It is possible, however, that the oxygen is carried from the air into the oil by being mechanically held in the interstices of the peroxide. Manganese metaborate, $\mathrm{Mn}\left(\mathrm{BO}_{2}\right)_{2}$, also is used in the preparation of drying oils and oil varnishes.

\section{LECLANCHÉ CELL.}

An electric cell is essentially composed of two metals immersed in a liquid, in which one is soluble and one relatively insoluble. In the Leclanché cell the liquid is ammonium chloride, the soluble metal zinc, and the insoluble element carbon. Ammonium chloride attacks the zinc and forms a salt of that metal, at the same time liberating hydrogen, which settles on the carbon and soon retards 
the action of the cell. Peroxide of manganese is used as a coating of the carbon, or is mixed with it, so that, when the hydrogen comes in contact with it, the peroxide of manganese gives up part of its oxygen, converting the hydrogen into water, and being itself converted into a lower oxide. The peroxide of manganese has to be renewed occasionally.

In continuous work the Leclanché cell soon becomes polarized and loses strength, but rapidly regains it when left at rest. For this reason, it is not adapted for closed-circuit work like telegraphy, but is well fitted for open-circuit work, as in telephones and electric bells, and is extensively used for these purposes.

\section{DRY CELL.}

Manganese peroxide is used extensively in the manufacture of Bamboni's dry cell. ${ }^{a}$ To prepare such a cell a piece of paper is tinned or silvered on one side and coated on the other with finely powdered manganese peroxide, which is moistened and rubbed on with a cork. The manganese powder used must contain 82 to 92 per cent available $\mathrm{MnO}_{2}$, must be free from iron oxides, and must be ground to a fineness varying from 30 or 40 mesh down to a fine powder. $^{b}$ A number of sheets thus coated are placed one on top of another, the tinned or silvered side of one in contact with the manganese peroxide coated side of the next. They are then cut by a punch into disks an inch in diameter, and these disks are arranged in the same way. When 1,200 or 1,800 couples have been piled up, they are placed in a glass tube with a brass cap at each end, which contains a rod and knob for pressing the leaves together to insure a good contact. The knob in contact with the manganese peroxide corresponds to the positive pole of the cell, while the other is the negative pole. Dry cells are remarkable for their duration of action, which may go on for several years.

\section{MISCELLANEOUS.}

Potassium permanganate powder, when mixed with organic substances, is subject to spontaneous combustion and is used as an explosive. It is also used in a slightly acid solution for bleaching cotton that has been boiled in caustic soda to remove gums and oily matters. The cloth is deep brown when removed from the bath, but on passing through sodium disulphate or sulphuric acid it becomes pure white. 


\section{USES AS A COLORING MATERIAL.}

Various compounds of manganese, on account of the quality and fast nature of their color, are used for dyeing, for painting, and other coloring purposes.

\section{CALICO PRINTING AND DYEING.}

Manganese brown, a color used in dyeing cotton, consists of the hydroxide or oxide of manganese. It is obtained by steeping the goods in a solution of manganous chloride or acetate, free from acid, and developing the oxide in a mixed solution of caustic soda and bleaching powder.

Manganese brown is fast against light, soap, and dilute acids and alkalies, and is used plain or serves as a ground on which to print figures of other colors, these being so composed as to remove the brown immediately under them. It is used also as a base on which to dye aniline blacks, the oxide in the fiber assisting in oxidizing the aniline.

A deep brown is obtained by passing the goods through a bath containing potassium permanganate and sodium carbonate solutions.

COLORING OF GLASS, POTTERY, AND BRICKS.

A small amount of manganese peroxide free from iron will give a pink or violet color to glass. An excess of pyrolusite, especially if iron is present, causes a deep yellow or brown, while a large excess of pyrolusite, with iron and copper oxides, produces a black color. A red color may be obtained by adding certain mixtures of pyrolusite and sesquioxide of iron.

Pottery and bricks also are colored by manganese peroxide. Black and various shades of brown are produced in the glaze of pottery by mixtures of manganese peroxide and oxides of iron. Black door knobs contain an excess of pyrolusite. Wad and other low-grade oxides of manganese are used for giving bricks a chocolate color; pyrolusite and psilomelane are used in giving the spots to fancy speckled bricks and in coloring red bricks brown and buffcolored bricks gray.

The use of manganese in the brick industry has become of considerable importance in recent years on account of the increased use of fancy colored brick in architecture. The ore used in this connection, after being thoroughly washed and concentrated, is crushed into granules or ground into a fine powder, according as it is to be used in the manufacture of speckled brick or of brown and gray brick. In these forms it is shipped to the brickmakers.

In order to insure uniform results in the coloring of brick the manganese is generally prepared into a "stock stain," formed by 
mixing one part of manganese ore with nine parts of clay. This mixture may have a thin consistency when powdered manganese ore is used, but should be fairly thick when the granulated material is used, so as to prevent the heavy manganese from settling to the bottom. The "stock stain" is mixed with the brick clay in proportion to the depth of color desired in the finished product. Only a very small quantity of manganese is required, a 2 per cent mixture being commonly used. The degree of heat also affects the depth of color; the greater the heat the darker will be the color of the brick. Extreme care must be exercised both in the mixing of the materials and in regulating the temperature of the kilns.

\section{PAINTS.}

Wad is used in the crude state as a pigment in some chocolate and brown paints. "Manganese green" is a barium manganate prepared by mixing three or four parts of caustic baryta moistened with water, two parts of manganese oxide, and two parts of barium nitrate, and fusing it in a crucible already heated to redness. It is then digested in hot water, washed in cold water, and dried in an atmosphere free from carbonic acid. "Nuremberg violet" also is prepared from compounds of manganese.

\section{MISCELLANEOUS.}

Mottled soap is colored by oxide of manganese. Potassium permanganate is used for giving a deep-brown stain to wood.

\section{MINOR USES.}

Manganese protoxide is used to a slight degree as a mordant in fixing a color on cloth fiber by its affinity for it. The goods are treated with potassium permanganate and then subjected to a strong reducing agent, causing the precipitation of the hydrated protoxide, after which they are ready to hold the required dye.

Rhodonite commonly has a beautiful pink color and such rhodonite is used for jewelry or ornamental stone. Sulphate of mąnganese and potassium permanganate are used in medicine, and small quantities of all the manganese compounds are used in chemical laboratories. Potassium permanganate is used for purifying carbon dioxide and ammonia gases. 


\section{CHAPTER VI.}

\section{THE MANGANESE INDUSTRY IN THE UNITED STATES.}

\section{PRODŲCTION OF ORES.}

The manganese mining industry in the United States is reported to have begun about 1837 , but the production previous to 1865 was insignificant. From 1865 to 1883 there was a small annual production, but immediately after that the industry received a great impetus. The maximum yearly production of 34,524 tons was reached in 1887 and was followed by a slow decline to 6,308 in 1894 . Subsequently there was a slight increase followed by a still greater decline, the minimum (2,825 tons) being reaches in 1903. At present the prospects are favorable for an increased annual production.

\section{HISTORY OF PRODUCTION BY STATES.}

The history of the industry is taken up by States, given in the order in which they appeared as producers.

Tennessee.-The first manganese mining in the United States of which there is any record was done near Whitfield, ${ }^{a}$ Hickman County, Tenn., in 1837. Small quantities, measurable in pounds, have been mined occasionally at this locality in succeeding years and used for coloring earthenware, but the total production has been insignificant. In 1886 a small intermittent production of manganese and manganiferous iron ores began in eastern Tennessee and has continued to the present time. The mining operations have been mainly ${ }^{b}$ in Unicoi, Cocke, and Monroe counties and in Shady Valley. Operations are at present conducted near Del Rio, Cocke County, by Col. John N. Adams.

Arkansas.-About 1850 to 1852 mining operations were begun on a small scale in the Batesville district of Arkansas, ore being shipped by Col. Matthew Martin ${ }^{c}$ from lands near Cushman. Up to 1880 small quantities continued to be mined at intervals, but large shipments were not begun until 1881. ${ }^{d}$. The first ore from this district for use in steel manufacture consisted of about 10 tons shipped by William Einstein, of St. Louis, in 1868, to the Juniata Iron Works at Pittsburg. In 1881 the Batesville district became a regular producer

a Penrose, R. A. F., jr., Manganese: Its uses, ores, and deposits: Ann. Rept. Geol. Survey Arkansas for 1890 , vol. 1 , p. 58 .

$b$ Weeks, J. D., Sixteenth Ann. Rept. U. S. Geol. Survey, pt. 3, 1895, p. 424.

c Penrose, R. A. F., jr., op. cit., p. 57; also Weeks, J. D., Mineral Resources U. S. for 1885 and 1888.

d Penrose, R. A. F., jr., op. cit., pp. 62-63. 
of manganese and continued so until 1903, although several years before that the production had dwindled considerably. There was a small production in 1906, but at present the mines are idle. The stimulus in 1881 was caused by the appearance of Mr. E. M. Woodward of the Ferromanganese Company, who had already gained considerable experience in the Appalachian region; and who worked in Arkansas the Southern, Turner, Trent, Montgomery, and other mines. In 1885 the Keystone Iron and Manganese Company commenced operations at the Southern mine, and in 1888 the predecessors of John B. Skinner \& Co. began to open up properties in the southern part of the district. The period of greatest production in Arkansas was between 1884 and 1898. In recent years a considerable amount of manganiferous iron ores has been mined at the Cason mine in this district by the Frisco Ore Mining Company of St. Louis.

Vermont.-In the later fifties shipments of manganese ore to England began from the Brandon and Chittenden areas of Vermont. ${ }^{a}$ Although for many years iron ores had been mined at these localities, the associated manganese ores had been avoided, as it was supposed that they were harmful to the iron. The amount mined in succeeding years, however, was very small and was not recorded. In 1887, 1888, 1889 , and 1891 manganiferous iron ore was mined at South Wallingford, and in 18971,200 tons of similar ore were produced. Since then no manganese-ore production has been reported from the State.

Virginia.-The production of manganese ore in Virginia began in $1859,{ }^{b}$ when Mr. Sibert prospected and opened up several localities in the valley of Virginia, among which were the Lyndhurst and Kennedy mines. The amount of ore mined, however, was very small. About the same time manganiferous iron ore was being mined in the State in small quantities.

In 1867 Mr. James E. Mills began a systematic search for manganese in the eastern United States in the interests of a firm in Newcastle, England. He opened up the Cabell mine in the James River valley in Virginia and in the following years shipped 4,500 tons of manganese ore from this mine to England to be used in chlorine works.

The year 1867 also marked the opening of the Crimora mine in the valley of Virginia. It was worked by a stock company for several years; then operations were suspended and until 1882 only occasional small quantities were mined. In 1882 it was leased by James B. White \& Co. of Pittsburg, and operations were begun on a large scale. Later it was acquired by the American Manganese Company. During these years the Crimora mine was the greatest producer of manganese in this country and perhaps in the world. About 1892 underground operations were discontinued and a system installed for surface hy- 
draulic mining. This has never been fully tested, and since its installation mining at Crimora has been intermittent and conducted on a small scale.

Since 1880 a large number of mines have been opened and operated in Virginia, both in the Piedmont region and in the valley of Virginia. Among them are the Mount Athos, Bugley, Midvale, Houston, and Vesuvius mines. Considerable high-grade manganese ore was produced at the Houston mine in the late eighties, at which time it was being operated by James B. White \& Co. The Lyndhurst and Kennedy mines have continued to be fairly regular producers. In recent years Kendall \& Flick, of Washington, D. C., have done much toward developing properties in the valley of Virginia, having operated ore banks near Elkton, Grottoes, and Lithia.

At present the Piedmont Manganese Company, D. W. Myers, of Lynchburg, president, is conducting operations on a small scale southeast of Lynchburg, the ore being used for coloring brick. The Metallic Alloys Company, of Elkton, successor to Kendall \& Flick, is operating the Lyndhurst mine and others in the valley of Virginia, and the Manganese Corporation of Virginia is operating the Vesuvius mine. Small quantities of ore are being mined at the Dry Run mine near Compton, at the Theresa mine near Otter River, at the Crimora mine, and in the New River region.

The Virginia production was greatest between 1884 and 1892, when the Crimora mine was being worked on a large scale. Since 1892 small quantities ranging between 1,000 and 8,000 tons have been produced annually. Manganiferous iron ores have been mined intermittently at many of the iron-ore deposits.

Georgia.-Manganese mining began in the Cartersville district of Georgia in 1866 with the production of 550 tons of ore. In 1867 the Dobbins mine in this district was opened, and in following years other properties were exploited. Since 1867 a lärge number of mines have been opened and operated in the Cartersville district, in the Cave Springs district, and at Tunnel Hill, Ga. The Dobbins mine was leased by $\mathrm{E}$. H. Woodward in 1885 and together with other mines of the district was actively worked for a number of years. Both the Cartersville and the Cave Springs districts were regular producers of manganese ore until about 1903 , but since then no ore has been mined except 150 tons in 1905.

A small production of manganiferous iron ore was reported from Georgia in 1887, but there has doubtless been more of this ore produced which has not been recorded as such.

California. ${ }^{a-T h e}$ production of manganese ore began in California in 1867, with the opening of the old Ladd mine in San Joaquin County and deposits on Red Rock Island in San Francisco Bay. 
Mining was started at the old Ladd mine oy Mr. A. S. Ladd and was continued by him until 1874, up to which time about 5,000 tons of ore was shipped to England, together with a small quantity of ore from Red Rock Island. In 1875 the old Ladd mine was purchased by Mr. Justinian Caire, of San Francisco, and shortly afterward work was stopped because of the inability to compete in England with Spanish manganese ore.

In 1882 a small deposit near Sausalito was opened and operated on a small scale, the ore being used as flux in a local smelter. Since then a number of small deposits have been discovered and opened in Alameda, Santa Clara, and San Joaquin counties, but very little ore has been produced.

New Jersey.-Neither manganese ores nor manganiferous ores used for their manganese content have been produced in New Jersey. Since 1870, however, the residuum of the manganiferous zinc ores which remains after the zinc oxide is roasted off has been utilized in the manufacture of ferromanganese and spiegeleisen. The production of this material was not recorded until 1889 , but since that time there has been a steady increase.

Alabama.-Small quantities of manganese ores were mined in Alabama in 1886, 1898, and 1901. The product of 1886 was obtained from Cleburne County, in the vicinity of Stocks Mills. ${ }^{a}$

As early as 1875 manganiferous iron ores were mined at Woodstock, ${ }^{a}$ Bibb County, and used in the manufacture of spiegeleisen at the Woodstock furnaces, at Anniston, Calhoun County. It is said to have been the first domestic ore used for this purpose.

Missouri.-Considerable amounts of manganese and manganiferous iron ores are said to have been mined in the Pilot Knob district in Missouri for use in the St. Louis furnaces. ${ }^{b}$

In 1881, at Arcadia, Iron County, 2,000 tons of manganiferous iron ore were mined and manufactured into an iron with 0.75 per cent manganese. This production has not been recorded as a manganiferous iron ore, but as an iron ore. Small quantities of manganese ore were produced in 1899 and 1901.

Lake Superior region.-A large quantity of manganiferous iron ore is mined annually in the Lake Superior iron district. The ore is so low in manganese, however, that it is not used in the manufacture of spiegeleisen or ferromanganese, but it yields a manganiferous pig iron of a somewhat different nature from ordinary pig iron. Small quantities of high-grade manganese ore were shipped from Michigan in 1888 and in 1897.

North Carolina.-Small quantities of manganese and manganiferous iron ores have occasionally been mined in North Carolina for 
development purposes ${ }^{a}$ and in connection with iron ores, but the total amount produced has been very small.

Maine.-Maine produced 50 tons of manganiferous iron ore in 1887. This is the only production reported from that State.

South Carolina.-South Carolina produced manganese ore in 1889, 1902,1903 , and 1907, the product of the last year being greater than the entire amount mined previously in this State.

Pennsylvania.-Manganese and manganiferous iron ores in small quantities he been produced intermittently in Pennsylvania where they occur largely in connection with the iron-ore deposits.

Colorado.-Colorado has produced no manganese ore proper, but considerable manganiferous silver ore from the Leadville district, and from Gilman, Eagle County, has been shipped to Pueblo and even to Chicago, and manufactured into spiegeleisen and ferromanganese. This practice began late in the eighties ${ }^{b}$ and has continued to the present. Large quantities of the same ore have been sent to smelters to be used for flux in lead and silver smelting.

Montana.-During the eighties manganiferous silver ores were being mined in Montana and used for flux by the Butte smelters. A considerable tonnage was reported in 1885 , a part of which probably came from the Butte district. Similar ores were mined at Neihart ${ }^{c}$ in 1893 and 1894, and sold as flux to the smelters at Great Falls. In 1900 there were 37 tons of manganese ore mined.

Nevada.b-Nevada produced small amounts of ore from 1885 to 1890. Part of it came from the Golconda deposit; the source of the rest is not known. Considerable manganiferous silver ore occurs in this State, but none has been reported as being used for its manganese content.

Oklahoma.-In 1891 a small quantity of ore was mined at Lehigh, ${ }^{d}$ Ind. T., this being the only manganese ore produced by Oklahoma. The ore was shipped to the Illinois Steel Company.

South Dakota.e - South Dakota was a producer of manganese only for one year, 1891. The ore was from Custer County.

West Virginia.-Manganese ores were produced in West Virginia between 1894 and 1899, being obtained partly ${ }^{f}$ if not entirely from Glenmore, Greenbrier County.

Maryland.-Maryland is reported ${ }^{g}$ to have produced manganese ores, but none have been recorded.

Utah.-Manganese mining began in Utah in 1901, when the deposit near Little Grande was opened up by the Colorado Fuel and

$a$ Weeks, J. D., Sixteenth Ann. Rept. U. S. Geol. Survey, pt. 3, 1895, p. 420.

$b$ Penrose, R. A. F., jr., op. cit., p. 64.

$c$ Weeks, J. D., op. cit., p. 418.

$d$ Idem, p. 413 .

$e$ Idem, p. 423.

$f$ Idem, p. 434.

$g$ Penrose, R. A. F., jr., op. cit., p. 61.

$37336^{\circ}$-Bull. $427-10-18$ 
Iron Company. Since then small amounts have been shipped from this locality, but at present the mines are not being operated. Other manganese deposits are being exploited in Utah, but there has been no production from them. Manganiferous silver ores occur in a few localities, but have not been mined for their manganese content.

New Mexico.-Considerable manganiferous iron ore has been produced at Silver City, N. Mex. This ore is too low in manganese to be used for that metal, but contains a high percentage of iron and so is classed with iron ores. In 1907 there was produced of this ore 7,000 tons, which had an iron content of 46 per cent and a manganese content of 6 per cent.

\section{PRODUCTION TABLES.}

The following tables show the production of manganese ores, manganiferous ores, and manganiferous zinc residuum in the United States as far as known: 
Production of manganese ore in the United States, 1838-1908, in long tons.

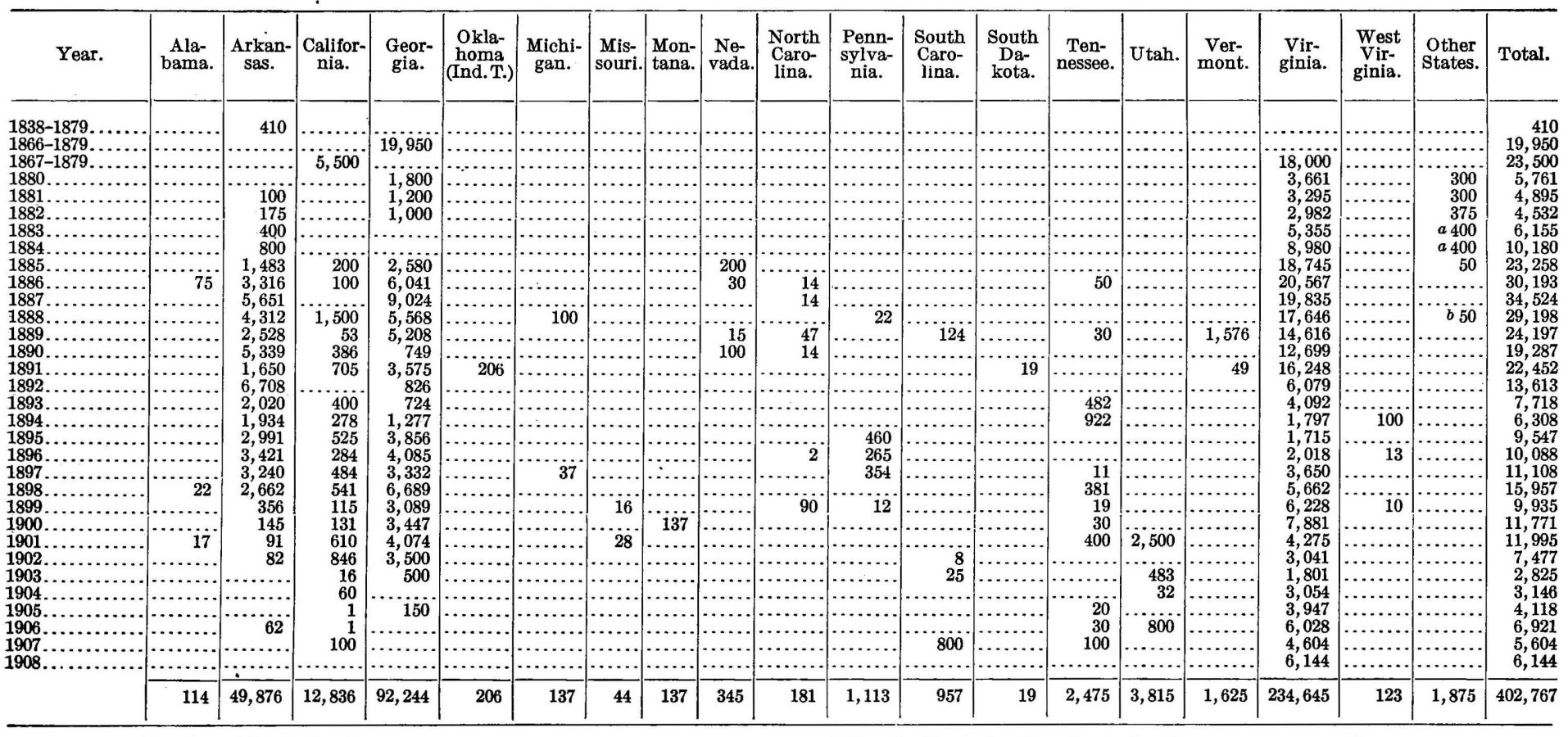


Production of manganiferous ores in the United States, 1885-1908, in long tons.

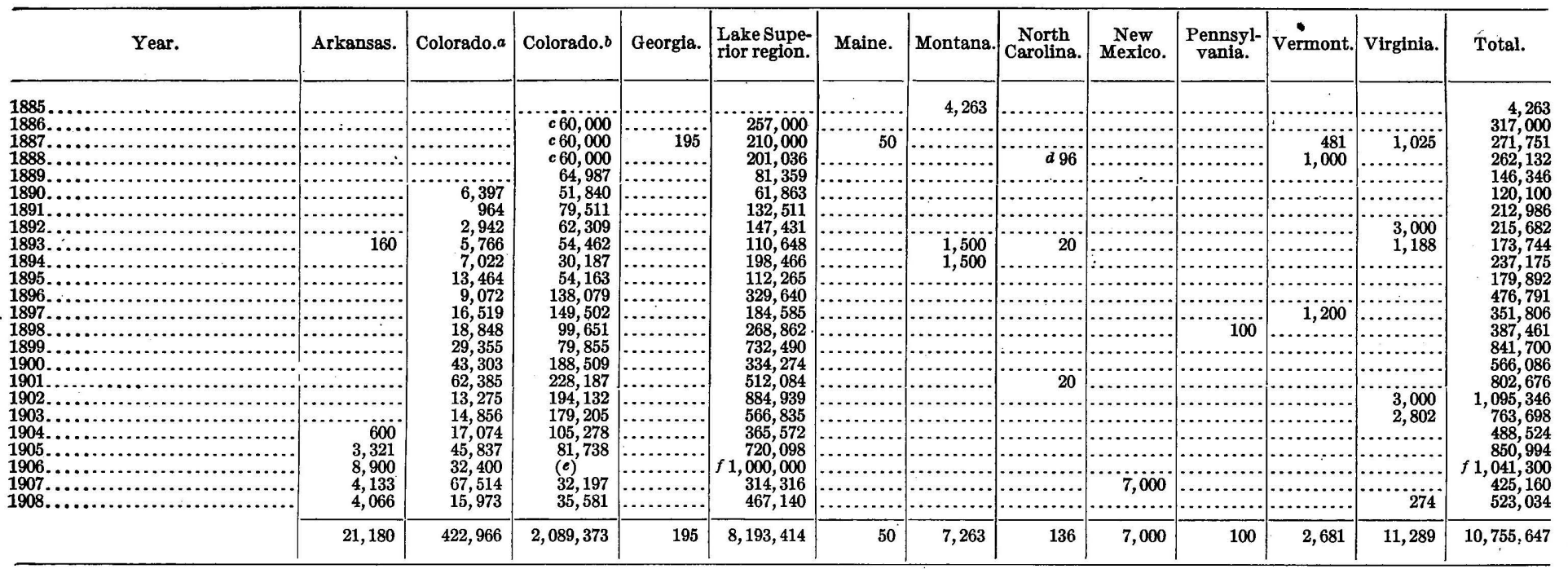

a Manganiferous silver ore used in the manufacture of spiegeleisen and ferromanganese.

$b$ Manganiferous silver ore used for flux; mainly from Colorado, but in a few cases including ore from other Western States.

$\boldsymbol{d}$ Contains some South Carolina and Tennessee ore.

e Not recorded. 
Production of manganiferous residuum from zinc roasting in the United States, 1889-1908, in long tons. $a$

\begin{tabular}{|c|c|c|c|}
\hline $1889 \ldots$ & 43,648 & 1900. & 87,110 \\
\hline $1890 \ldots$ & 48,560 & 1901.. & 52,311 \\
\hline 1891. & 38,228 & 1902. & 65,246 \\
\hline 1892. & 31,859 & $1903 \ldots$ & 73,264 \\
\hline $1893 \ldots$ & 37,512 & $1904 .$. & 68,189 \\
\hline $1894 \ldots$ & 26,981 & $1905 \ldots$ & 90,289 \\
\hline $1895 \ldots$ & 43,249 & $1906 .$. & 93,461 \\
\hline 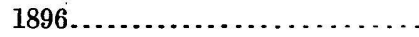 & 44,935 & $1907 .$. & 93,413 \\
\hline 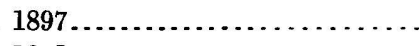 & 33,924 & 1908. & 110,225 \\
\hline $\begin{array}{l}1898 \ldots \\
1899 .\end{array}$ & $\begin{array}{l}48,502 \\
65,010\end{array}$ & & $1,195,916$ \\
\hline
\end{tabular}

The following tables show the quantity and value of manganese ores, manganiferous ores, and manganiferous zinc residuum produced in the United States during 1905, 1906, 1907, and 1908:

Production and value of manganese ores in the United States, 1905-1908, by States.

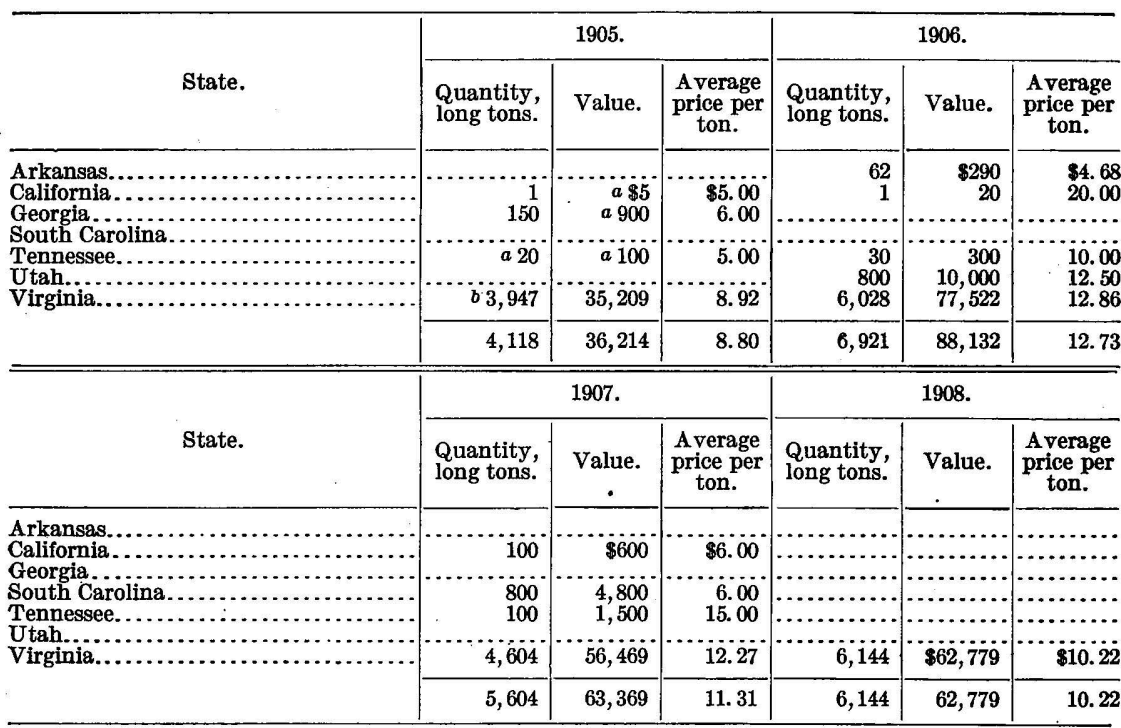

$a$ Estimated. $\quad b$ In addition, 453 tons of tailings, valued at $\$ 406$, were shipped.

Production and value of Colorado manganiferous silver ores used in the manufacture of ferromanganese and spiegeleisen, 1905-1908, in long tons.

\begin{tabular}{|c|c|c|c|c|}
\hline Year. & $\begin{array}{l}\text { Percentage } \\
\text { of man-- } \\
\text { ganese. }\end{array}$ & Quantity. & Value. & $\begin{array}{c}\text { Average } \\
\text { price per } \\
\text { ton. }\end{array}$ \\
\hline \multirow[t]{2}{*}{$\begin{array}{l}1905 \ldots \ldots \\
1906 \ldots \\
1908 \ldots\end{array}$} & $\begin{array}{l}14-41 \\
26-36 \\
10-25 \\
22-26\end{array}$ & $\begin{array}{l}45,837 \\
32,400 \\
67,514 \\
15,973\end{array}$ & $\begin{array}{r}\$ 110,497 \\
97,600 \\
153,328 \\
39,468\end{array}$ & $\begin{array}{r}\$ 2.41 \\
3.01 \\
2.27 \\
2.47\end{array}$ \\
\hline & $10-41$ & 161,724 & 400,893 & 2.48 \\
\hline
\end{tabular}

$a$ The manufacture of spiegeleisen from manganiferous residuum was begun in 1870 , but there is no record of the amount of raw material used prior to 1889 . 
Production and value of manganiferous ores used for fluxing or other purposes in Colorado and Arkansas, 1905-1908, in long tons.

\begin{tabular}{|c|c|c|c|c|c|}
\hline Year. & State. & $\begin{array}{c}\text { Percentage } \\
\text { of man- } \\
\text { ganese. }\end{array}$ & Quantity. & Value. & $\begin{array}{l}\text { Average } \\
\text { price per } \\
\text { ton. }\end{array}$ \\
\hline \multirow{2}{*}{$\begin{array}{l}1905 \ldots \ldots \ldots \ldots \ldots \ldots \\
1906 \ldots \ldots \ldots \ldots \ldots \\
1907 \ldots \ldots \ldots \ldots \ldots \ldots \\
1908 \ldots \ldots \ldots \ldots \ldots \ldots\end{array}$} & \multirow[t]{2}{*}{ 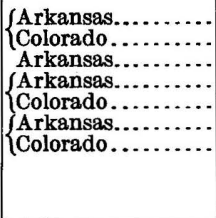 } & $\begin{array}{r}28 \\
20-25 \\
14 \\
8-26 \\
14 \\
6-22\end{array}$ & $\begin{array}{r}3,321 \\
81,738 \\
8,900 \\
4,133 \\
32,197 \\
4,066 \\
35,581\end{array}$ & $\begin{array}{r}\$ 6,642 \\
270,299 \\
24,800 \\
8,266 \\
a 97,879 \\
9,149 \\
83,939\end{array}$ & $\begin{array}{r}\$ 2.00 \\
3.31 \\
2.79 \\
2.00 \\
3.04 \\
2.25 \\
2.36\end{array}$ \\
\hline & & $6-28$ & 169,936 & 500,974 & 2.95 \\
\hline
\end{tabular}

a Partly estimated.

Production and value of manganiferous zinc residuum in the United States, 1905-1908, in long tons.

\begin{tabular}{|c|c|c|c|}
\hline 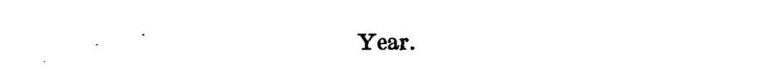 & Quantity. & Value. & $\begin{array}{c}\text { Average } \\
\text { price per } \\
\text { ton. }\end{array}$ \\
\hline \multirow{2}{*}{$\begin{array}{l}1905 \\
1906, \ldots \ldots \ldots\end{array}$} & $\begin{array}{r}90,289 \\
93,461 \\
93,413 \\
110,225\end{array}$ & $\begin{array}{r}\$ 90,289 \\
93,461 \\
280,239 \\
330,675\end{array}$ & $\begin{array}{r}\$ 1.00 \\
1.00 \\
3.00 \\
3.00\end{array}$ \\
\hline & 387,388 & 794,664 & 2.05 \\
\hline
\end{tabular}

\section{PRICES OF ORES.}

The prices of manganese ores used in the steel industry vary from $\$ 5$ to $\$ 15$ per long ton, according to the grade of the ore. They are governed by the following schedule of prices established by the Carnegie Steel Company: ${ }^{a}$

Schedule of prices paid per ton of 2,240 pounds for domestic manganese ore delivered at Pittsburg or Bessemer, Pa., and South Chicago, Ill.

Prices are based on ores containing not more than 8 per cent silica or 0.20 per cent phosphorus, and are subject to deductions as follows: For each 1 per cent in excess of 8 per cent silica there shall be deduction of 15 cents per ton; fractions in proportion.

For each 0.02 per cent, or fraction thereof, in excess of 0.20 per cent phosphorus there shall be a deduction of 2 cents per unit of manganese per ton.

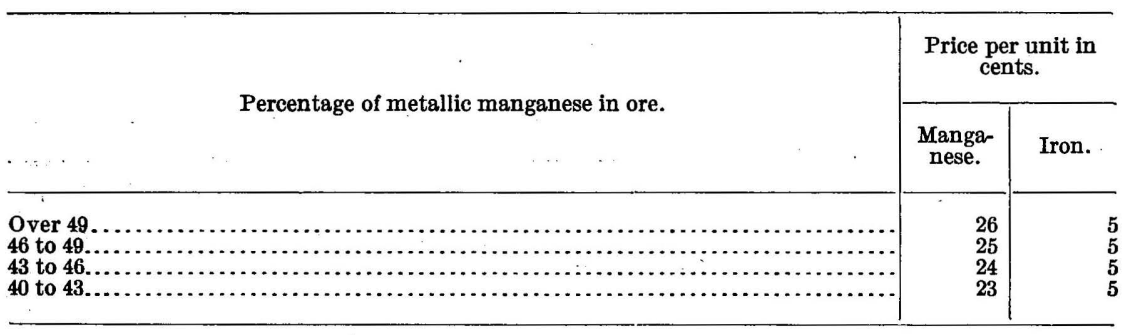

Ores containing less than 40 per cent manganese or more than 12 per cent silica or 0.225 per cent phosphorus are subject to acceptance or refusal at the buyer's option.

Settlements are based on analysis of sample dried at $212^{\circ} \mathrm{F}$., the percentage of moisture in the sample as taken being deducted from the weight. 
The manganese ores for oxidizing and coloring purposes are valued according to the quantity of manganese peroxide present, their consistency, etc., and prices range up to $\$ 35$ per ton for the better grades of ore. Manganiferous ores used in steel manufacture and for fluxing range in price from $\$ 2$ a ton upward.

\section{IMPORTATION OF ORES.}

Large quantities of manganese ores, compared with which the domestic production is insignificant, are annually imported into the United States from foreign countries. They are being obtained at present largely from India, Brazil, and Cuba, with smaller amounts from Germany, Great Britain, Russia, East Indies, France, the Netherlands, Belgium, Spain, Japan, Canada, and other countries.

Before about $1886^{a}$ manganese ores were imported into this country mainly from Canada and Spain, but at that time shipments commenced from Cuba, Chile, and Russia, as well as Greece and Turkey. For many years Russian ores constituted by far the largest portion of the impoirted product, but in late years imports from both India and Brazil have exceeded them in quantity, until at present the manganese-ore imports from Russia are almost insignificant. Small amounts of manganese ore have been imported annually from Germany, Great Britain, Japan, and Belgium.

The following table shows the total quantity of manganese ore imported into the United States as far as has been recorded. The figures from 1868 to 1888 represent imports from Canada only. Those from 1889 to the present time represent total imports.

Imports of manganese ore into the United States, 1868-1908, in long tons.

\begin{tabular}{|c|c|c|c|}
\hline Year ending June $30-$ & & Year ending December 31- & \\
\hline $1868 \ldots \ldots \ldots \ldots \ldots \ldots$ & 1,017 & $1883 \ldots \ldots \ldots \ldots \ldots \ldots$ & 1,326 \\
\hline . $\ldots \ldots \ldots \ldots$ & 488 & 1884. & 603 \\
\hline $1870 \ldots$. & 1,402 & 1885. & 1,684 \\
\hline $1871 \ldots \ldots \ldots \ldots \ldots \ldots$ & 1,056 & $1886 \ldots$ & 1,818 \\
\hline $1872 \ldots \ldots \ldots \ldots \ldots \ldots$ & 1,206 & $1887 \ldots$ & 1,630 \\
\hline $1873 \ldots \ldots \ldots \ldots \ldots \ldots$ & 838 & $1888 \ldots$ & 1,182 \\
\hline Year ending December 31- & & 1889 b. . & 4,286 \\
\hline $1873 \ldots \ldots \ldots \ldots \ldots \ldots$ & 1,031 & $1890 \ldots$ & 34,154 \\
\hline $1874 \ldots \ldots \ldots \ldots \ldots \ldots$ & 782 & $\ldots \ldots \ldots \ldots \ldots \ldots$ & 28,825 \\
\hline$\ldots \ldots \ldots \ldots$ & 203 & ............. & 58,572 \\
\hline n........... & 412 & 1893. & 68,113 \\
\hline n.......... & 891 & 1894. & 44,655 \\
\hline n....... & 626 & 1895 & 86,111 \\
\hline 1879. & 1,886 & 1896. & 31,489 \\
\hline 1880. & 2,179 & 1897. & 119,961 \\
\hline 1881. & 1,704 & 1898. & 114,885 \\
\hline 1882. & $89 \dot{4}$ & 1899. & 188,349 \\
\hline
\end{tabular}

a Penrose, R. A. F., jr., op. cit., p. 69.

$b$ Figures prior to 1889 represent imports from Canada only, total importations from other countries for these years not being obtainable. 
Imports of manganese ore into the United States, 1868-1908, in long tons-Continued.

Year ending December 31-

$1900 . . . \ldots \ldots \ldots . . . . . .$.

$1901 \ldots \ldots \ldots \ldots \ldots \ldots$

$1902 \ldots \ldots \ldots \ldots \ldots \ldots$

$1903 \ldots \ldots \ldots \ldots \ldots \ldots$

$1904 \ldots \ldots \ldots \ldots \ldots \ldots$

1905

The following tables, compiled from statistics furnished by the Bureau of Statistics, Department of Commerce and Labor, show the imports of manganese ore into the United States from different countries and by ports of entry for 1905, 1906, 1907, and 1908:

Imports of manganese ores into the United States, 1905-1908, by countries, in long tons.

\begin{tabular}{|c|c|c|c|c|c|c|c|c|}
\hline \multirow{2}{*}{ Country. } & \multicolumn{2}{|c|}{1905.} & \multicolumn{2}{|c|}{1906.} & \multicolumn{2}{|c|}{1907.} & \multicolumn{2}{|c|}{1908.} \\
\hline & Quantity: & Value. & Quantity. & Value. & Quantity. & Value. & Quantity. & Value. \\
\hline 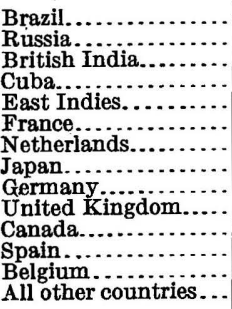 & $\begin{array}{r}1,329 \\
2,336 \\
1,298 \\
7 \\
50 \\
80 \\
5,094\end{array}$ & $\begin{array}{r}13,950 \\
54,150 \\
30,555 \\
575 \\
708 \\
1,762 \\
52,983\end{array}$ & \begin{tabular}{r}
2,000 \\
4,386 \\
1,330 \\
112 \\
\hdashline 1,710 \\
1,776
\end{tabular} & \begin{tabular}{r}
21,664 \\
112,511 \\
37,711 \\
1,125 \\
\hdashline 30,377 \\
25,341
\end{tabular} & $\begin{array}{r}52,922 \\
1,000 \\
95,300 \\
30,006 \\
12,552 \\
1,588 \\
1,795 \\
1,787 \\
6,702 \\
3,999 \\
16 \\
1,354 \\
\end{array}$ & $\begin{array}{r}\$ 522,510 \\
19,570 \\
552,228 \\
262,847 \\
82,832 \\
31,536 \\
35,473 \\
15,020 \\
150,388 \\
96,833 \\
500 \\
23,406 \\
2 . . .\end{array}$ & \begin{tabular}{r}
17,150 \\
250 \\
143,813 \\
1,469 \\
7 \\
5,546 \\
761 \\
3,336 \\
2,620 \\
2,973 \\
73 \\
\hdashline 202 \\
3
\end{tabular} & $\begin{array}{r}\$ 163,561 \\
4,599 \\
912,646 \\
13,489 \\
170 \\
75,857 \\
11,265 \\
41,930 \\
62,045 \\
59,092 \\
1,245 \\
24 \\
4,214 \\
86\end{array}$ \\
\hline & 257,033 & $1,952,407$ & 221,260 & $1,696,043$ & 209,021 & $1,793,143$ & 178,203 & $1,350,223$ \\
\hline
\end{tabular}

Manganese ores imported into the United States, 1905-1907, by customs districts, in long tons.

\begin{tabular}{|c|c|c|c|c|c|c|c|c|}
\hline \multirow{2}{*}{ Customs districts. } & \multicolumn{2}{|c|}{1905.} & \multicolumn{2}{|c|}{1906.} & \multicolumn{2}{|c|}{1907.} & \multicolumn{2}{|c|}{1908.} \\
\hline & Quantity. & Value. & Quantity. & Value. & Quantity. & Value. & Quantity. & Value. \\
\hline 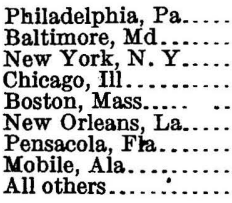 & $\begin{array}{r}117,591 \\
126,018 \\
5,954 \\
20 \\
4 \\
199 \\
650 \\
6,489 \\
108\end{array}$ & $\begin{array}{r}\$ 822,525 \\
993,163 \\
90,942 \\
496 \\
127 \\
1,822 \\
4,284 \\
35,049 \\
3,999\end{array}$ & $\begin{array}{r}93,590 \\
120,051 \\
6,802 \\
239 \\
5 \\
411\end{array}$ & $\begin{array}{r}\$ 682,485 \\
860,112 \\
136,037 \\
10,096 \\
209 \\
3,675\end{array}$ & $\begin{array}{r}106,494 \\
92,331 \\
7,867 \\
266 \\
\ldots .7 \% \\
1,949\end{array}$ & $\begin{array}{r}\$ 888,239 \\
694,732 \\
177,323 \\
11,839 \\
\ldots 16,539\end{array}$ & $\begin{array}{r}68,491 \\
103,043 \\
5,963 \\
\ldots \ldots \\
232\end{array}$ & $\begin{array}{r}\$ 504,094 \\
724,913 \\
105,665 \\
\ldots . \\
2880 \\
2,752\end{array}$ \\
\hline & 257,033 & $1,952,407$ & 221,260 & $1,696,043$ & 209,021 & $1,793,143$ & 178,203 & $1,350,223$ \\
\hline
\end{tabular}

\section{WORLD'S PRODUCTION OF ORE.}

The following table gives the latest available statistics with regard to the world's production of manganese ore. The unit is either the long or the metric ton; except for Canada, where the short ton is used. 
World's production of manganese ores.

\begin{tabular}{|c|c|c|c|c|c|}
\hline Country. & Year. & Quantity. & Country. & Year. & Quantity. \\
\hline 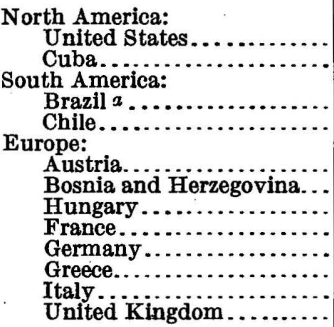 & $\begin{array}{l}1908 \\
1907 \\
1905 \\
1905 \\
1907 \\
1906 \\
1906 \\
1907 \\
1907 \\
1906 \\
1907 \\
1907\end{array}$ & $\begin{array}{r}\text { Tons. } \\
6,144 \\
34,171 \\
233,950 \\
1,324 \\
16,800 \\
7,651 \\
11,000 \\
18,200 \\
75,000 \\
10,000 \\
3,700 \\
16,400\end{array}$ & 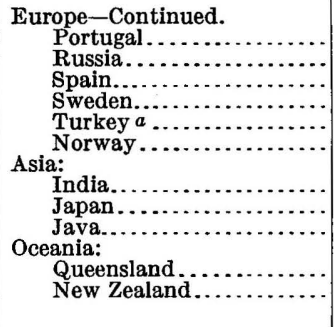 & $\begin{array}{l}1906 \\
1906 \\
1906 \\
1907 \\
1905 \\
1904 \\
1906 \\
1906 \\
1905 \\
1906 \\
1906\end{array}$ & $\begin{array}{r}\text { Tons. } \\
22 \\
1,016,000 \\
63,000 \\
4,300 \\
28,600 \\
22 \\
\\
504,000 \\
13,000 \\
1,600 \\
1,130 \\
16\end{array}$ \\
\hline
\end{tabular}

a Exports.

FERROMANGANESE AND SPIEGELEISEN.

\section{PRODUCTION.}

The manufacture of spiegeleisen in the United States began in $1870^{a}$ from the manganiferous zinc residuum of zinc-oxide works, using New Jersey manganiferous zinc ores. This production has continued and has increased yearly up to the present. About 1875 manganiferous iron ores were first used in this country in the manufacture of iron-manganese alloys at the Woodstock furnaces ${ }^{b}$ at Anniston, Calhoun County, Ala. Soon after this a considerable portion of the domestic production of manganese and manganiferous iron ores began. yearly to go into the manufacture of the iron alloys. During late years, however, the proportion of domestic ore used for this purpose has decreased materially and at present most of it is being consumed in the coloring of brick and pottery. The imported manganese ore, however, is used largely in the manufacture of spiegeleisen and ferromanganese, though considerable quantities are being consumed in the manufacture of dry cells.

Manganiferous silver ores were not used in the manufacture of iron-manganese alloys until about 1886 or 1887 , but since then there has been a steady though small production from this quarter.

By far the larger part of the iron-manganese alloys are at present produced in Pennsylvania, but small quantities are produced in New Jersey, Maryland, Illinois, and Colorado. The New Jersey product is manufactured from manganiferous zinc residuum and the Colorado product largely from manganiferous silver ores.

The production of ferromanganese and spiegeleisen in the United States has been recorded since 1872, there being no record of the product for the two years previous. In general there has been a

a Penrose, R. A. F., jr., op. cit., p. 27.

$b$ Weeks, J. D., Sixteenth Ann. Rept. U. S. Geol. Survey, pt. 3, 1895, p. 400. 
steady increase in production from 4,072 tons in 1872 to 339,348 tons in 1907, although in a number of years the production has fallen behind the previous years. The production during 1908 amounted to only 152,018 long tons.

The following table gives the total quantity of spiegeleisen and ferromanganese produced in the United States as far as it has been recorded:

Production of spiegeleisen and ferromanganese in the United States, 1872-1908, in long tons.

\begin{tabular}{|c|c|c|c|}
\hline 872 & 4,072 & 1892. & 179,131 \\
\hline 1873. & 3,930 & 1893. & 81,118 \\
\hline 1874 . & 4,070 & 1894 & 120,180 \\
\hline 375 . & 6,993 & 1895 . & 171,724 \\
\hline 76. & 5,907 & 1896 & 131,940 \\
\hline .... & 7,897 & 1897. & 173 \\
\hline 78 & 9,530 & 1898：. & 213 \\
\hline 1879 & 12,438 & $1899 \ldots \ldots \ldots \ldots \ldots$ & 219 \\
\hline .... & 17,503 & $1900 \ldots$ & 977 \\
\hline ...... & 18,827 & ....... & 461 \\
\hline .... & 610 & & 212 \\
\hline$\cdots$ &, 941 & $\ldots \ldots \ldots \ldots \ldots \ldots \ldots$ & 192,661 \\
\hline$\ldots \ldots \ldots \ldots \ldots \ldots \ldots$ & 0,262 & …............... & 219,446 \\
\hline$\ldots \ldots \ldots \ldots \ldots \ldots \ldots$ & 0,956 & $\ldots \ldots \ldots \ldots$ & 983 \\
\hline$\ldots \ldots \ldots$ & 41 & n............... & 500 \\
\hline$\ldots \ldots \ldots$ & 42,498 & 19 & 348 \\
\hline ... & 48,901 & $1908 \ldots \ldots$ & 152,018 \\
\hline & 76,628 & & \\
\hline & & & \\
\hline & 9 & & \\
\hline
\end{tabular}

PRICES.

The prices of iron-manganese alloys vary with the content of these metals. However, as the alloys are generally made with a fairly definite composition, the prices vary only within small limits.

The following table shows the average range of prices for various iron-manganese alloys during 1908.

Prices per long ton of iron-manganese during 1908.

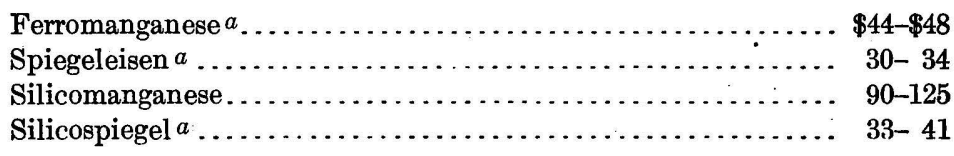

IMPORTATION.

Before 1870 all the ferromanganese and spiegeleisen used in the steel industry in this country was imported from Europe, amounting to a maximum yearly importation of about 25,000 tons. $^{b}$ During 
the early seventies the imports amounted to 20,000 or 30,000 tons yearly, but they rapidly increased until during the fiscal year 1884, the first year of which we have a definite record, the imported product was 94,210 tons. Since then the amounts imported yearly have been variable, ranging from 8,127 tons in the fiscal year 1895 as a minimum to 176,966 in 1907 as a maximum. On the whole, however, there has been a great increase in the quantity of imports.

The following table gives the quantity of ferromanganese and spiegeleisen imported into the United States, by fiscal years, as far as has been recorded:

Imports of ferromanganese and spiegeleisen into the United States during fiscal years ending June 30, 1884-1908, in long tons. ${ }^{a}$

\begin{tabular}{|c|c|c|c|}
\hline Year ending June 30 & $\begin{array}{c}\text { Ferro- } \\
\text { manganese. }\end{array}$ & $\begin{array}{l}\text { Spiegel- } \\
\text { eisen. }\end{array}$ & Total. \\
\hline 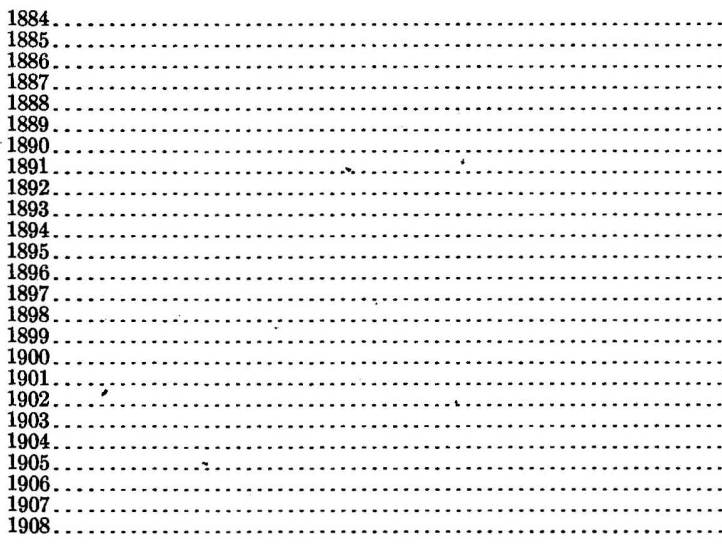 & \multicolumn{2}{|c|}{$\begin{array}{r}94,210 \\
65,406 \\
99,426 \\
150,205 \\
108,973 \\
93,032 \\
108,771 \\
54,239 \\
55,080 \\
49,157 \\
11,579 \\
8,127 \\
66,608 \\
11,301\end{array}$} & $\begin{array}{r}94,210 \\
65,406 \\
99,426 \\
150,205 \\
108,973 \\
93,032 \\
108,771 \\
54,239 \\
55,080 \\
49,157 \\
11,579 \\
8,127 \\
66,608 \\
11,301 \\
16,454 \\
14,007 \\
24,359 \\
25,303 \\
69,034 \\
175,687 \\
74,523 \\
63,609 \\
150,288 \\
176,966 \\
76,605\end{array}$ \\
\hline Total .............. & & & $1,842,949$ \\
\hline
\end{tabular}

$a$ Imports prior to 1884 not recorded. Estimated tonnage imported yearly during the seventies is about 20,000 to 30,000 tons.

The following table gives the importation of spiegeleisen and ferromanganese into the United States from 1903 to 1907, by calendar years:

Ferromanganese and spiegeleisen imported and entered for consumption, 1903-1908, in long tons.

\begin{tabular}{|c|c|c|c|c|c|c|}
\hline \multirow{2}{*}{ Year. } & \multicolumn{2}{|c|}{ Ferromanganese. } & \multicolumn{2}{|c|}{ Spiegeleisen. } & \multicolumn{2}{|c|}{ Total. } \\
\hline & Quantity. & Value. & Quantity. & Value. & Quantity. & Value. \\
\hline 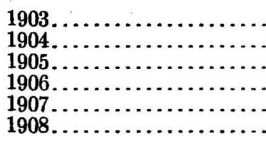 & $\begin{array}{l}41,519 \\
21,813 \\
52,841 \\
84,359 \\
87,400 \\
44,624\end{array}$ & $\begin{array}{r}\$ 1,699,666 \\
707,037 \\
1,884,651 \\
4,953,644 \\
5,354,656 \\
1,860,664\end{array}$ & $\begin{array}{r}122,015 \\
4,623 \\
55,457 \\
103,268 \\
48,994 \\
4,579\end{array}$ & $\begin{array}{r}\$ 2,709,317 \\
132,461 \\
1,336,104 \\
2,942,940 \\
1,399,381 \\
125,054\end{array}$ & $\begin{array}{r}163,534 \\
26,436 \\
108,298 \\
187,627 \\
136,394 \\
49,203\end{array}$ & $\begin{array}{r}\$ 4,408,983 \\
839,498 \\
3,220,755 \\
7,896,584 \\
6,754,037 \\
1,985,718\end{array}$ \\
\hline
\end{tabular}




\section{CHAPTER VII.}

\section{BIBLIOGRAPHY.}

(Articles relating to the geology of the districts described in this report but not concerned with manganese are marked with a star.)

*Adams, G. I., AND others. Zinc and lead deposits of northern Arkansas: Prof. Paper U. S. Geol. Survey No. 24. 1904 . 118 pp.

Aguilera, José G. The geographical and geological distribution of the mineral deposits of Mexico: Trans. Am. Inst. Min. Eng., vol. 32, 1902, p. 505.

Ahlers, R. O. A manganese deposit in southern India: Min. World, Jan. 23, 1909.

American Chemist. August, 1871, p. 51.

American Journal of Science. Black oxide of manganese (near Sheffield, Mass.). 1st ser., vol. 4, 1822, p..189.

Atkinson, E. Ganot's Physics. 1901. p. 829.

AUbURy, L. E., AND others. Structural and industrial materials of California; Manganese, p. 335. California State Mining Bureạu, 1906.

Ball, S. Mays. Manganese deposits of Virginia: Eng. and Min. Jour., May 22, 1909.

Barron, T. The topography and geology of the Peninsula of Sinai: Survey Department of Egypt, 1907.

* Bassler, R. S. Cement materials of western Virginia: Econ. Geology, vol. 3, 1908, p. 510 .

BeCK, L. S. Mineralogy. N. Y. Nat. Hist., Div. 3, 1842.

Bergeat, A., and Stelzner, A. W. Die Erzlagerstätten.

Brodle, C. Notes from Magdalena Bay, Mexico: Eng. and Min. Jour., vol. 82, p. 361.

Birkinbine, JoHn. Manganese ores: Mineral Resources U. S. for 1896-1905 (18961899 included in Eighteenth to Twenty-first Ann. Repts. U. S. Geol. Survey).

-Manganese ores. Mines and quarries, p. 433. Census U. S., Special Rept., 1902.

Branner, J. C. The manganese deposits of Bahia and Minas, Brazil: Trans. Am. Inst. Min. Eng., vol. 29, 1899, p. 756.

Brannt, William T. The metallic alloys. 1896.

Brewer, Wrlliam M. The manganese ores of Georgia: Proc. Alabama Indus. and Sci. Soc., vol. 4, pt. 2, p. 72, 1894.

Brown, H. C. Mineral resources of Cuba in 1901, p. 24.

* Campbeld, H. D. The Cambro-Ordovician limestones of the middle portion of the valley of Virginia: Am. Jour. Sci., 4th ser., vol. 20, p. 445.

Campbeli, H. H. The manufacture and properties of iron and steel. 1907.

Carnot, M., and Goutal, M. Recherches sur la constitution chimique des fontes et des aciers: Annales des mines, vol. 18, 1900, p. 263.

Carpenter, G. W. On the mineralogy of Chester County (Pa.), with an account of some of the minerals of Delaware, Maryland, and other localities: Am. Jour. Sci., lst. ser., vol. 14, 1828, pp. 4 and 12.

Clarke, F. W. Data of geochemistry: Bull. U.S. Geol.Survey No.330. (See index.)

Chibias, E. G. Manganese deposits of the Department of Panama, Republic of Colombia: Trans. Am. Inst. Min. Eng., vol. 27, 1897, p. 63.

Dana, E. S. Textbook of mineralogy. 1903.

- System of mineralogy. 
DARTon, N. H. Franklin folio (No. 32), Geol. Atlas U. S.

* Staunton folio (No. 14), Geol. Atlas U. S.

* Monterey folio (No. 61), Geol. Atlas U. S.

DAY, D. T. Manganese: Mineral Resources U. S. for 1882, 1883, and 1884.

Denis, Theo. Manganese: Ann. Rept. Geol. Survey Canada, vol. 15, 1902, p. 150.

Derby, O. A. On the manganese ore deposits of the Queluz (Lafayette) district, Minas Geraes: Am. Jour. Sci., July, 1901, p. 18.

On the original type of manganese ore deposits of the Queluz district, Brazil: Am. Jour. Sci., March, 1908, p. 213.

Drake, Frank. The manganese ore industry of the Caucasus: Trans. Am. Inst. Min. Eng., vol. 28, 1898, p. 191.

Ducatel, J. T., and Alexander, J. H.: Am. Jour. Sci., lst ser., vol. 27, 1835, pp. 20, 25 , and 33 .

Dunstan, W. R. Manganese: Rept. Results Min. Survey Ceylon, 1903, p. 8.

EckEL, E. C. Manganese ores: Mineral Resources U. S. for 1906.

Electrical Engineering, London, vol. 3, 1908, p. 704.

Emerson, B. K. Mount Holyoke folio (No. 50), Geol. Atlas U. S.

Emmons; S. F., Weed, W. H., and Tower, G. W., jr. Butte special folio (No. 38), Geol. Atlas U. S.

Emmons, S. F., and Irving, J. D. The Downtown district of Leadville, Colorado: Bull. U. S. Geol. Survey No. 320, 1907.

* Emmons, S. F. The geology and mining industry of Leadville: Mon. U. S. Geol. Survey, vol. 12, 1886.

EwING, J. A. Magnetic induction in iron and other metals.

Fairbanks, H. W. San Luis folio (No. 101), Geol. Atlas U. S.

Fermor, L. LeIgh. On manganite from the Sandur Hills: Rec. Geol. Survey India, vol. 33, 1906, p. 229.

- Manganese-ore deposits of India: Mem. Geol. Survey India, vol. 37, 1909.

- Notes on the petrology and manganese-ore deposits of the Sausar tahsil, Chhindwara, Central Provinces: Rec. Geol. Survey India, vol. 33, pt. 3, 1906, p. 159.

Fontaine, W. M. Notes on mineral resources at certain localities in the western part of the Blue Ridge: The Virginias, vol. 4, pp. 44, 55, 57, 73-75, 92-93.

GaRRISON, F. L. The Greene-Wahl process for manufacturing manganese and alloys of manganese free from carbon: Trans. Am. Inst. Min. Eng., vol. 21, 1892-1893, p. 887 .

GiLPIN, E. Manganese ores of Nova Scotia: Trans. Roy. Soc. Canada, vol. 2.

GIN, C. Sur un nouveau silicure de manganèse: Compt. Rend., vol. 143, pp. 1229-1230.

GrAEF, E. H. Effect of manganese on steel and iron: Iron Trade Review, July 9, 1908, p. 88.

GUILLET, L. Quaternary steels: Jour. Iron and Steel Inst., 1906, No. 2, pp. 1-141.

HADFIELD, R. A. Manganese in its application to metallurgy: Proc. Inst. Civ. Eng., vol. 93, 1887-1888, pt. 3, p. 1.

- Some newly discovered properties of iron and manganese: Proc. Inst. Civ. Eng., vol. 93, 1887-1888, p. 61.

__ On manganese steel: Jour. Iron and Steel Inst., 1888, No. 2, p. 41.

- On alloys of iron and silicon: Jour. Iron and Steel Inst., 1889, No. 2, p. 226.

- Iron alloys with special reference to manganese steel: Trans. Am. Inst. Min. Eng., vol. 23, 1893.

* Hague, Arnold, and Emmons, S. F. Descriptive geology, U. S. Geol. Expl. 40th Par., vol. 2, p. 680.

Hall, Chas. E. Geological notes on the manganese ore deposits of Crimora, Virginia: Trans, Am. Inst. Min. Eng., vol. 20, 1892, p. 46. 
HARDer, E. C. Manganese ores: Mineral Resources U. S. for 1907 and for 1908.

- Manganese deposits of the United States: Bull. U. S. Geol. Survey No. 380, 1909, p. 255.

* Hayes, C. W. Geological relations of the iron ores of the Cartersville district: Trans.

Am. Inst. Min. Eng., vol. 30, 1901, p. 403.

Manganese ores of the Cartersville district, Georgia: Bull. U. S. Geol. Survey

No. 213, 1903, p. 232.

* Chattanooga folio (No. 6), Geol. Atlas U. S.

* Cleveland folio (No. 20), Geol. Atlas U. S.

Ringgold folio (No. 2), Geol. Atlas U. S.

Rome folio (No. 78), Geol. Atlas U. S.

HAyes, C. W., and Ecked, E. C. Iron ores of the Cartersville district, Georgia: Bull. U. S. Geol. Survey No. 213, 1903, p. 233.

Hayes, C. W., Vaughan, T. W., and Spencer, A. C. A geological reconnaissance of Cuba. 1901. p. 62.

HitchCock, EDWARD. Report on the geology of Massachusetts: Am. Jour. Sci., lst ser., vol. 22,1832, p. 61.

HoGG, T. W. Notes on some alloys of iron, aluminum, and manganese: Chem. News, vol. 66,1892, p. 140.

* Holden, R. J. The brown ores of the New River-Cripple Creek district, Virginia: Bull. U. S. Geol. Survey No. 285, 1906, p. 190.

* Iron: Mineral Resources Virginia, by Thos. L. Watson, 1907, p. 94.

Holland, T. H. Manganese: Gen. Rept. Geol. Survey India for 1905; Rec. Geol. Survey India, vol. 33, p. 94.

Hopkinson, Doctor. Magnetism of iron: Philos. Trans. Roy. Soc. London, 1786-1885, p. 445.

IndUstrial World. Ferromanganese in the blast furnace. November 29, 1909.

INGALLS, W. R. The metallurgy of zinc and cadmium, p. 668 .

Iron AgE. Manganese steel rails on curves. October 29, 1908, p. 1224.

Iron Trade Review. Use of ferrophosphorus and phosphomanganese. April 16, 1903, pp. 45-46; also in Iron Age, May 7, 1903, pp. 29-30.

JACkson, C. T. Report on the geological and agricultural survey of the State of Rhode Island in 1839. Am. Jour. Sci., lst ser., vol. 40, p. 185.

JонN, J. F. Contri butions towards a chemical knowledge of manganese: Thompson's Ann. Philos., vol. 2, 1813, pp. 172 and 263.

Journal of the Iron and Steel Institute. Manganese ore in Borneo (Review). 1907. No. 3, p. 329 .

- Manganese ore in Cape Colony (Review). 1907. No. 1, p. 329.

Manganese ore in Tunis (Review). 1908. No. 3, p. 497.

JuDd, E. K. The Crimora manganese mine: Eng. and Min. Jour., March 9, 1907.

Katzer. Ein eigentümliches Manganerz des Amazonasgebietes: Österr. Zeitschr. für Berg- und Hüttenwesen, vol. 46, 1898, pp. 41-46.

*Keith, Arthur. Asheville folio (No. 116), Geol. Atlas U. S.

${ }^{*}$ Cranberry folio (No. 90), Geol. Atlas U. S.

*Greenville folio (No. 118), Geol. Atlas U. S.

*Knoxville folio (No. 16), Geol. Atlas U. S.

*Loudon folio (No. 25), Geol. Atlas U. S.

*Morristown folio (No. 27), Geol. Atlas U. S.

*Mount Mitchell folio (No. 124), Geol. Atlas U. S.

*Nantahala folio (No. 143), Geol. Atlas U. S.

*Roan Mountain folio (No. 151), Geol. Atlas U. S.

Kershaw, J. B. C. The manufacture and use of ferro alloys: Iron Trade Review, July $16,1908$.

Progress in the electric steel and ferro alloys industries: Iron Trade Review, November 5, 1908. 
*King, Clarence. Systematic geology: U. S. Geol. Expl. 40th Par., vol. 1. *Atlas: U. S. Geol. Expl. 40th Par.

Lawson, A. C. A sketch of the geology of the San Francisco Peninsula: Fifteenth Ann. Rept. U. S. Geol. Survey, 1895, p. 399.

LeITH, C. K. Iron ores of the West: Bull. U. S. Geol. Survey No. 285, 1906, p. 194.

Lustosa, Joquin, and Branner, J. C. Manganese deposits of Morro de Mina, Brazil: Eng. and Min. Jour., December 19, 1908.

McCreath, A. S. Second Geological Survey of Pennsylvania, 1879. Vol. MM, pp. 159-184 and 213.

McTaGgart, H. A. On the constitution and properties of Heusler's alloys: Univ. Toronto Studies; Papers from physical laboratories No. 23, 1908.

MeAd, William. Localities of minerals: Am. Jour. Sci., 1st ser., vol. 7, 1824, p. 54.

Mineral Industry. Vols. 1 (1892) to 15 (1906): Manganese, by R. A. F. Penrose, jr., 1892-93; R. B. Rothwell, 1894-1900; J. Struthers and Frank Drake, 1901; D. H. Newland, 1902-1903; E. K. Judd, 1904; W. R. Ingalls, 1905; E. K. Judd, 1906.

Mining Journal. Manganese in North Wales. June 22, 1907, p. 828.

Mining World. A new use for manganese steel. June 6, 1908.

Morssan, H. 'Traité de chimie minérale; IV, Métaux; Manganèse, p. 487.

Nason, Frank. Iron ores of Missouri: Missouri Geol. Survey, vol. 2, 1892.

NewTH, G. S. Text-book of inorganic chemistry. 1903. Manganese, p. 666.

Penrose, R. A. F., jr. Manganese: Its uses, ores, and deposits: Ann. Rept. for 1890. Arkansas Geol. Survey, vol. 1, 1893.

A Pleistocene manganese deposit near Golconda, Nevada: Jour. Geology, vol. 1,1893, p. 275.

Purdue, A. H. Developed phosphate deposits of northern Arkansas: Bull. U. S. Geol. Survey No. 315, 1907, p. 463.

Ransome, F. L. Mother Lode district folio (No. 63), Geol. Atlas U. S.

*Richardson, G. B. Reconnaissance of the Book Cliffs coal field: Bull. U. S. Geol. Survey No. 371, 1909.

RoberTs, E. G. LL., and Wraight, E. A. The preparation of carbon-free ferromanganese: Jour. Iron and Steel Inst., 1906, No. 2, p. 229.

Rogovin, I. I. Manganese in Russia during 1907: Eng. and Min. Jour. October $17,1908$.

Roscoe, H. E., and Schorlemmer, C. A treatise on chemistry. Vol. 2, 1907, p. 1096.

*Russeld, I. C. Geological history of Lake Lahontan, a Quaternary lake of northwestern Nevada: Mon. U. S. Géol. Survey, vol. 11, 1885.

Sainte-Claire Deville, M. H. Mémoire sur la production des températures très élevées: Ann. Chim. Phys., vol. 46, 1856, p. 199.

Scoтt, H. K. The manganese ores of Brazil: Jour. Iron and Steel Inst., 1900, No. $1, \mathrm{p} .179$.

Simmersbach, O. Manufacture of ferromanganese: Berg- und Hüttenmännisches Rundschau, 1905, p. 305. (Review, Jour. Iron and Steel Inst., No. 2, 1905, p. 680.)

Sloan, Earle. Catalogue of mineral localities of South Carolina: Bull. South Carolina Geol. Survey, No. 2, ser. 4, pp. 95-98.

Sмiтн, W. D. Nonmetallic minerals: Far Eastern Review, June, 1907, p. 10.

- The asbestos and manganese deposits of Ilocos Norte, with notes on the geology of the region: Philippine Jour. Sci., vol. 2, No. 3, June, 1907, p. 145.

Snodgrass, J. H. Manganese mining in Japan: Min. World, April 24, 1909.

Souder, Harrison. Mineral deposits of Santiago, Cuba: Trans. Am. Inst. Min. Eng., vol. 35, 1904, p. 308. 
Spencer, A. C. Manganese deposits of Santiago province, Cuba: Eng. and Min. Jour., August 23, 1902, p. 247.

Manganese deposits of Santiago, Cuba: Bull. U. S. Geol. Survey No. 213, 1903, p. 251.

The geology of Massanutten Mountain in Virginia, p. 12.

Spencer, A. C., Kümmel, H. B., Salisbury, R. D., Wolff, J. E., and Palache, Chas. Franklin Furnace folio (No. 161), Geol. Atlas U. S.

Spencer, J. W. Paleozoic group. The geology of ten counties of northwestern Georgia and resources: Geol. Survey Georgia, 1893.

Stose, G. W. Mercersburg-Chambersburg folio (No. 170), Geol. Atlas U. S.

Stoughton, Bradley. Metallurgy of iron and steel, 1908.

TAMM, HUGo. On the metallurgy of manganese and the docimastic assaying of manganese ores: Chem. News, vol. 26, 1872, p. 111.

Tновр, F. H. Outlines of industrial chemistry, 1901.

Thurston, R. H. Materials of engineering, pt. 3.

Text-book of materials of construction.

Tonietri, G. Foreign notes. Min. Jour., vol. 84, p. 459, 1908.

Turner, H. W. Bidwell Bar folio (No. 43), Geol. Atlas U. S. Jackson folio (No. 11), Geol. Atlas U. S.

Van Ingen, Gilbert. The Siluric fauna near Batesville, Arkansas: School of Mines Quart., vol. 22, 1901, p. 318.

Watson, Thos. L. Geological relations of the manganese-ore deposits of Georgia: Trans. Am. Inst. Min. Eng., vol. 34, 1904, p. 207.

- Manganese-ore deposits of northern Georgia: Min. World, April 3, 1909.

Manganese oxides: Mineral Resources Virginia, 1907, p. 235.

Preliminary report on the manganese deposits of Georgia: Bull. Geol. Survey Georgia No. 14, 1908.

The manganese-ore deposits of Georgia: Econ. Geology, vol. 4, p. 46.

WeED, W. H. Ore deposits of Butte, Montana: Bull. U. S. Geol. Survey No. 213, 1903, p. 170.

WeEKs, J. D. Manganese: Mineral Resources U. S. for 1885-1895. (1894 and 1895 included in Sixteenth and Seventeenth Ann. Repts. U. S. Geol. Survey.)

- Manganese: Eleventh Census, Mineral industries U. S., 1890, p. 285.

Wetzig, Bruno. Beiträge zür Kenntniss der huelvaner Kieslagerstätten. (Review, Trans. Inst. Min. Eng., vol. 33, pt. 6, 1908, p. 707.)

Wisurs, BaIley. Notes on eamples of iron ore collected in East Tennessee. Tenth Census, 1880; vol. 15, Mining industries, p. 331.

Notes on samples of manganese ore collected in Georgia: Tenth Census, 1880; vol. 15, Mining industries, p. 379.

WolfF, J. E. Tinc and manganese deposits of Franklin Furnace, N. J.: Bull. U. S. Geol. Survey No. 213, 1903, p. 214.

Yakovlev, N. Gisement de manganèse du district minier de Nizhne Taghilsk. (Review, Trans. Inst. Min. Eng., vol. 33, pt. 6, p. 695.) 


\section{INDEX.}

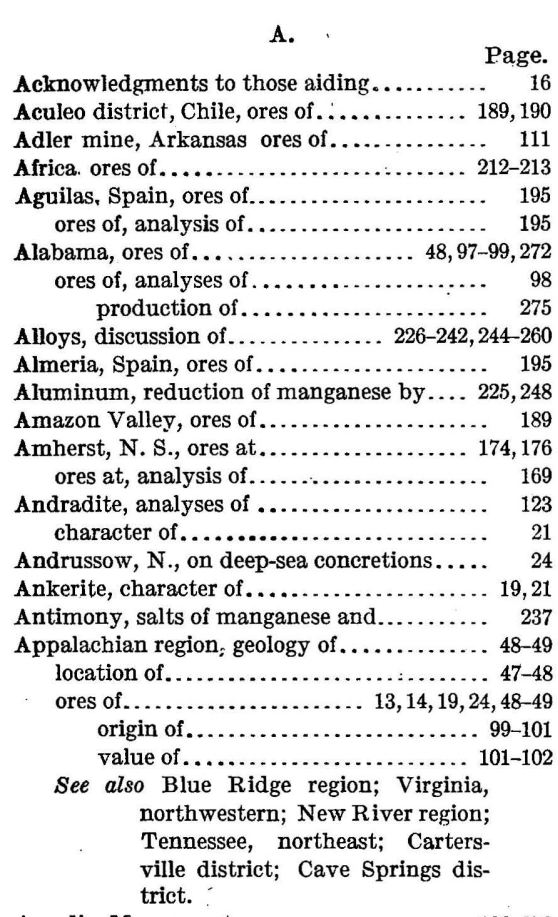

Arcadia, Mo., ores at................ 126,272

Arizona, ores of . . . . . . . . . . . . . 132, 151-152 ores of, analyses of. ................ 152

Arkansas, ores of ......... 13,14,17,18, 24, 102-122 ores of, production of . . 269-270, 275-276, 277-278 See also Batesville district; Arkansas, west central.

Arkansas, west central, description of. . .... 119 geology of ........................ 119

ores of......................... 120-121 analyses of ................... 121-122

Arsenic, salts of manganese and......... 236

Asia, ores of . ........................ 208-219 ores of, production of ............... 281

Atkins property, Va., ores at, analysis of .... 72

Attoway, Va., ores at .................. 71

Auckland Hill, Queensland, ores of......... 223 ores of, analyses of................. 223

Austerlitz, N. Y., ores at................. $\quad 31$ ores at, analysis of................. $\quad 31$

Austin, Nev., ores at................... $\quad 157$

Australia, ores of . . . . . . . . . . . . . . . 222-223

Austria-Hungary, ores of . . . . . . . . . . . . . . 204-206 ores of, production. 281
B.

Bachewanung Bay, Que., ores on. Balaghat district, India, ores of ............

Bales mine, Ark., ores of ............... 112

Barnsley tract, Ga., ores of ............... 96

Barron, T., on Egyptian ores............. 212

Barrow mine, Ga., ore of, analysis of........ 85

Batesville district, Ark., description of... . . 102-103

geology of . . . . . . . . . . . . . . . . . . 103-108

ores of. $\ldots \ldots \ldots \ldots \ldots \ldots \ldots \ldots \ldots \ldots$ 108-109,121

analyses of.................... 115

forms of . . . . . . . 109

occurrence of, figure showing....... 108

origin of . . . . . . . . .

production of . . . . . . . . . . . . . . 269-270

map of ....................... 111

mines of , description of . . . . . . . . . . 110-115

Baxter mine, Ark., ores of. . . . . . . . . . . . 112-113

ores of, analyses of .................. 116

Beaver limestone, description of .......... 78,87

ores of $\ldots \ldots \ldots \ldots \ldots \ldots \ldots \ldots \ldots \ldots \ldots .78,100$

Belgium, ores of . . . . . . $197 \ldots \ldots \ldots \ldots \ldots . . . . \ldots$

Bengal, ores of ....................... 214

Bibliography .......................... 284-288

Big Run mine, Va., ores of..............49,57

Big Texas Valley, Ga., ores in ........... 97

Bingerbruck, Germany, ores near ....... 198,199

Black Jack mine, Cal., ores of . . . . . . . . . . . 161-162

Blacksburg, S. C., ores at. . ............ 43-44 ores at, analyses of ................. 44

Black Wonder group, Cal., ores of . . . . . . . 162-163 ores of, analysis of ................. 163

Bleaching, use of manganese in ......... 263, 266

Blue bank, $\mathrm{Va}$, ores of . ............ 50,64,102

Bluebird aplite, occurrence and character of. . 133

Blue Hill, Me., ores at. ............... 27, 31 ores at, analyses of............... $\quad 27$

Blue Ridge, Ga., ores near................ 97

Blue Ridge region. description of . ......... 50 geology of . ....................... 50-53

mines in, description of. . . . . . . . . . . 55-66

ores of. ....................... 53-55,101

distribution of . .............. 49-50 occurrence of, figure showing...... 52

section in ..................... 51

figure showing................ 52

Bog manganese, character of . ....... 14, 18, 20, 136 occurrence of ................... 27, $30-31,43,121,127-128,147,171,176,189$

Bohemia, Austria-Hungary, ores of........ 206

Bolet, Sweden, ores at. . . . . . . . . . . . ...... 200

Bombay Presidency, India, ores of........ 214

Boone chert, description of .............. 107 ores in . . . . . . . . . . . . 108, 113-114, 115, 118

Borden Springs, Ala., ores near.......... 98 
Page

Boron, salts of manganese and.

Bosnia, Austria-Hungary, ores of. ores of, analyses of. production of.

Boston mines, Cuba, ores of ores of, analyses of .

Boulder Canyon, Nev., ores in

Bowersville, Ga., ores near.

Brandon, Vt., ores at. ores at, analysis of $\ldots \ldots \ldots \ldots \ldots \ldots \ldots \ldots$

Branner, J. C., on Brazilian ores ............ 183

Braunite, analyses of . . . . . . . . . . . . . . 115-116 character and distribution of. ......... 18, 20 occurrence of . ............42,109,127,181, 201

Brazil, ores of . . . . . . . . . . . . . . . . 183 189 ores of, production of ................ 281

Breccia ores, figures showing . . . . . . . . . 88, 90 occurrence and character of ........... 45, $53,54-55,70,78,87-88,90-91,92,109$

Breezewood, S. C., ores near............. 45 ores near, analysis of ............... 45

Breton, Cape, geology of. . . . . . . . . . . . . 172 ores on . . . . . . . . . . . . . . . . analysis of...................... 169

Bricks, coloring of . . . .................. 267

Bromine, manufacture of . . . . . . . . . . . 263-264

Buckhorn mine, ores at. .............. 43 ores at, analysis of . ................. 44

Buena Vista shale, ores in . . ............ 52,100

Buford bank, Mo., ores at.............. 126

Bukowina, Austria-Hungary, ores of....... 204 ores of, analyses of.................. 205

Burmah, ores of..................... 218

Butte district, Mont., description of....... 132 geology of . . . . . . . . . . . . . . . . . . . . 132-133 ores of .................. 14, 132, 133-135, 273 analyses of.

Butte granite, occurrence and character of. 132-133

C.

Cabell mine, Va., description 0. analyses of................. 41

Calaveras formation, ores in . . . . . . . . . 158

Calico, coloring of . . . ................... 267

California, ores of........... 13,14, 17, 18, 158-166 ores of, analyses of.................. 166 origin of .................... 166-167 production of............ 271-272, 275, 277

Canaan Center, N. Y., ores at. ......... 30 ores at. analysis of .................. 31

Canada, ores of .................... 168-177

Cape Breton Island, N. S., geology of. . . . . 174-175 ores of........................ 175

Cape Colony, ores of ................... 212

Carbon, salts of manganese and . ........ 237-239

Carnot, - , and Goutal, -, on alloys........ 249

Carniola, Austria-Hungary, ores of . . . . . . 205

Carrizal district, Chile, ores of . ......... 189, 191 ores of, analyses of. . . . . . . . . . . . . . . . . 191

Cartagena, Spain, ores of ................. 195 ores of, analysis of ................. 195

Cartersville, Ga., ores near............... 96 See also Cartersville district.
Page.

Cartersville district, Ga., description of..... 77 geology of ...................... 77-78

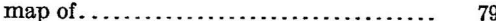

mines of, descriptions of . . . . . . . . . . . 81-84 ores of.................. 78-80, 101, 271 analyses of ................... 85

Cason mine, Ark., ores of ............... 110,270 ores of, analyses of................ 116 section of, figure showing ............. 106

Cason shale, description of............... 105 ores in.................. 105, 108, 110, 118 sections of, figures showing........... 106 Castile mine, Ala., ores from, analyses of . . . 116 Castle, Mont., ores at............... 132, 148-149 Cave Springs district, Ga., description of.... 86 geology of . . . . . . . . . .

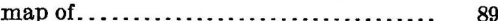
mines of, descriptions of . . . . . . . . . . 89 89-92 ores of..................... 87-89,271 analyses of . .................. 93 figures showing............. 88, 90,91,92

Cebolla Valley, Colo., ores of......... 132,149-150 ores of, analysis of ................. 150

Cedar Creek, Va, ores at................. 66

Cedartown, Ga., ores near. .............. $\quad 89$

Ceylon, ores of........................ 219

Chaibassa, India, ores near.............. 214

Chattanooga shale, description of . ......... 107

Chemistry, use of manganese in .......... 261-268

Chemistry of manganese, discussion of. . . . 224-242

Cheverie mine, U. S., ores at............. 173 ores at, analyses of.............. 169,173-174

Chevron, Belgium, ores of . .............. 197

Chhindwara district, ores of . . . . . . . 214, 217-218

Chiaturi, Russia, ores of ................. 210 ores of, analysis of ................. 210

Chickamauga limestone, description of...... 86 Chile, ores of . . . . . . . . . . . . . . . . . . 189-191 ores of, analyses of.................. 191-192 production of .................... 281

Chlorine, discovery and use of......... 243, 263 manufacture of . ................... 261-263

Chumbler Hill mine, Ga., description of.... 81-82 ores of, analyses of................. 85 figures showing................ 81

Chun, Carl, on deep-sea concretions........ 24 Church Mountain mine, Va., ores of, analysis of.................. 57

City Point, Va., ores of ................. 32 Ciudad Real; Spain, ores of. ............. 195 Clay ores, occurrence and character of ...... 53 $54,70,73,75-76,87,88,90-91,108-109$

Clinton, N. J., ore of, composition of ....... 42

Clinton formation, ores in.............. 66

Coastal Plain, geology of................ $\quad 32$ location of............................. ores of......................... 32 Cohutta Springs, Ga., ores near........... 97 Coles property, Tenn., ores of, analysis of. ... 74 Colfax, Cal. ores near................... 165 Colorado, ores of. - 14, 19, 25, 132, 137-145, 149-151, 281 ores of, analyses of. . . . . . . . . . 143-145, 149-151 production of. . . . . . . 273, 275-276, 277-278 Coloring, use of manganese for . . . . . . . 243, 267-268 Columbia, Cal., ores near............... 165 
Page.

Compton, Va., ores near................., 49,55

Conasauga formation, description of........ 87 ores of .......................... 87, 100

Concentration ores, character and distribution

$$
\text { of.......................... }
$$

Connecticut, ores of.

Copper reduction, use of manganese in...... 260

Cornwall, England, ores of ............... 204

Cornwallis, N. S., ores near .............. $\quad 175$

Corral Hollow mine. See Ladd mine.

Corral Quemada district, Chile, ores of. . . . 189, 190 ores of, analyses of.................. 190

Covadonga district, Spain, ores of........ 193-194 ores of, analyses of................... 194

Crimora, Va., mining at............. 15, 58-61 ores at............. 49,53-55,58,101,270-271

analyses of ...................... 61 distribution of, figure showing....... 60

plan of, figure showing............ 58 sections of, figure showing........... 59

Cripple Creek, Va., ore at, analysis of....... 72 Cristo, Cuba, ores near................. 178, 179

Cuba, ores of........................ 177-179 ores of, analyses of .................. $\quad 180$ production of................... 281

Culbertson, Ga., ores near............... 97

Culebra, Panama, ores at .............. 181

Cummington, Mass., ores at.............. 27

Cupromanganese, nature and preparation of. $\quad 256$

Currin Valley mine, Va., ores of........... 70,71 ores of, analysis of ................... 72

Cushman, Ark., ores near........... 113-115, 269

Custer, S. Dak., ores near................ 147

Cuthbertson tract, Mo., ores on ........... 125-126

Cuyuna iron range, Minn., ores from ...... 130-131 ores from, analyses of................. 131 section showing................ 130

Cyprus, ores of ....................... 208 ores of, analyses of.................. 208

D.

Dagger Springs, Va., ore at............... 95

Dana, J. D., on origin of manganese ores..... 99

Davis mine, ore of, analysis of ........... 41-42

Deal bank, Va., ores of ................. 50,65

Deans Branch, Va, ores at, analysis of ....

Del Rio, Tenn., ores of . ................. 72, 269

Derby, O. A., on Brazilian ores........... 183, 184

Derbyshire, England, ores of . . . . . . . . ..... 204

Devonshire, England, ores of............. 204

Disinfectants, use of manganese in........... 265

Dobbins mine, Ga., description of......... 83 ores of, analyses of................. 85,271

figure showing.................... 84

Doom, Va., ores near.................... 49, 62

Dos Bocas, Cuba, ores at................ $\quad 179$

Draketown, Ga., ores near................. $\quad 46$

Dry cell, use of manganese in ............... . .266

Dry Run mine, Va., ores at................ 49,55

Dyeing, use of manganese in............. 267

E.

Edna Mountains, Nev., description of....... 153

Egypt, ores of . ...................... 212-213 ores of, analyses of.
, Island of, ores of ............... 206, 207

Electric furnace, use of ................... 247

Elgersburg, Germany, ores of............. 200

Elkton, Va., ores near................... 49,57 ores near, analyses of ................. 57

Elsinore, Cal., ores near.................. 165

Emerson, Ga., ores near................. 81

Erwin quartzite, ores in .................. 70,100

Eureka, Nev., ores at................... 153,157

Eureka mine, Va., ores of ............... 49,55-56

Europe, ores of . ..................... 192-212 ores of, production of ................. 281

Explosives, use of manganese in ............ 266

\section{F.}

Fable mine, Cal., ores of ................. 162 ores of, section showing............... 162

Fermor, L. L., on India ores. . .......... 214-215

Ferromanganese, analyses of.............. 249 imports of ....................... 15, 282-283 invention of ......................... 244 manufacture of ....................... 246-248 nature of .................... 244,248-250 prices of ............................ 282 production of...................... 281-282 use of . . . . . . . . . . . . . . . .

Field work, extent of ................... 15

Flat Top Mountain, Va., ores at............ $\quad 95$

Fort Payne chert, ores in.................. 98

France, ores of . . . . . . . . . . . ores of, analyses of. ................ 196-197 production of..................... 281

Franciscan formation, ores in..... 158, 159-160,164 ores in, origin of .................. 166-167

Franklin Furnace, N. J., ores at . . . . ....... 32-37 ores at, treatment of................. 35-37 See also Mine Hill.

Franklinite, character of.................. 19,20 composition of....................... 34 occurrence of .......................... 33-34

Freeman mine, Ga., ores of, analyses of...... $\quad 85$

Fronk property, Va., ores at............. $\quad 55$

Front Royal, Va., ores near............. 49,55

Fundy, Bay of, ores of . . .............. 168,170

G.

Galt mine, Mont., ores of ............... 148-149 ores of, analyses of..................... 149

Gambatesa, Italy, ores of ................. 206

Gandarella area, Brazil, ores of ............... $\quad 187$ ores of, analyses of................... $\quad 187$

Garrison bank, Va., ores of............... 49,56 ores of, analyses of.................... 56

Geissen, Germany, ores near................ 198

Georgia, ores of .................... $32,45-46,48,77-93,96-97,99-100$ ores of, analysis of .................. 96 production of. ............ 271, 275-276, 277 See also Cartersville district; Cave Spring district.

Germany, ores of .................... 198-200 ores of, production of .................. 281

Gilman, Colo., ores at. . ............. 151,273

Glade Mountain, Va., ores at, analysis of .... 72 
Gladstone district, Queensland, ores of.... $222-223$ ores of, analyses of. ................. 223

Glass, coloring of, use of manganese in. $243,265,267$

Glebe mine, N. B., ores of ............. 171

Glengarry, N. S., ores at................. 174

Glenmore, W. Va., ores of. ........... 95, 273 ores of, analysis of .................. 95

Glenn Springs, S. C., ores at............ 43 ores at, analyses of................. 44

Golconda district, Utah, description of . .... 153 geology of....................... 153 ores of................. 14, 154-157, 158, 273 analyses of . . . . . . 156 sections showing . . . . . . . . . . . . 155,156 tungsten in..................... 155

Goodland Mountain, N. B., ores on........ 171

Gosalpur, India, ores at........... 214,216-217 ores at, analysis of.................. $\quad 216$

Gouttes-Pommiers, France, ores at........ 197

Gowens bank, Va., ores of............. 50,65

Gray mine, Ark., ores of, analyses of........ 116

Great Basin, description of . . . . . . . . . . . 152-153 ores of. ............................ 153 See also Golconda area.

Great Britain, ores of................... 202-204 ores of, production of . ................ . 281

Great North Mountain, Va., ores on ....... 66

Greece, ores of....................... 207 ores of, analyses of.................. 207 production of.................... 281

Green Mountains, geology of.............. 28

Greenwood, S. C., ores near............ 43,45

Grindstone Mountain, ores on ............ 56

Ground Hog Valley, Pa., ores in.......... 93

Grubb cut, Ark., ores of............... 115

Guerrero, Mex., ores of. . . . . ........... 181

Gulf region, ores of . . . . . . . . . . . . . . . 102-127 ores of, value of................... 127 See also Arkansas; Texas; Tennessee; Missouri; Oklähoma.

Gümbell, K. W., on deep-sea concretions... .

Gunflint Lake, Ont., ores near.... . . . . . . . .

Gunnison, Colo., ores near................

Guy Run, Va., ores on. ores on, analysis of.

\section{$\mathrm{H}$.}

Hadfield, R. A., manganese steel invented by .................... 244, 251-252

Haiti, W. I., ores of . .................. 180 Halogens, salts of manganese and........ . 229-230

Hampton property, Ga., ores at. . . . . . . . . 89,91

Happy Creek mine, Va., ores at. . ........ 49,55

Hard ore, occurrence and character of....... 75,92

Harz Mountains, Germany, ores in . . . 198, 199-200

Hausmannite, character of............. 19, 20 occurrence of . .......................... 201

Hautes Pyrénées, France, ores of . . . . . . . . 197

Hayesville, Tenn., ore at ............... 76

Heath mine, Ga., ore of, analysis of........ 85

Heberlin mine, Tenn., ores of............. 74 ores of, analyses of................... 74

Hell Gate Canyon, S. Dak., ores near....... 147

Henrys Lake, N. B., ores at.............. 171

Hesse-Nassau, Germany, ores of .......... 198-200
Heusler's alloys, analyses of . . Page. nature of . . . . . . . . . . . . . . . . 258-259

Hidalgo, Mex., ores of .................. 181

Hillsborough, N. B., ores at............. 171 ores at, analysis of.................. 171

Hillsdale, N. B., ores at................ 171

Hodge mine, ores of, analysis of........... 75

Holden, R. J., on Powells Fort ores......... 67

Holobolite, character of............... 20,23

Homburg, Germany, ores near.............. 198

Hopewell Corner, N. B., ores of........... 171

Horse Mountain, Tex., ores at............. 124

Hot Springs, N. C., ores of............. 76-77 ores of, analyses of. ................... 77

Houston mines, Va., ores of......... 50,65-66, 271 ores of, analyses of.................. 66

Huasco district, Chile, ores of. ........... 189, 190

Hubnerite, character of. ............... 23 occurrence of ....................... 157

Hudson Bay, ores on ................... 177

Hudson River shale, ores in ............. 66

Huelva district, Spain, ores of . . . . . . . . 192-193 ores of, analyses of................... 193

Hungary. See Austria-Hungary.

Hyderabad, India, ores of . .............. 214

\section{I.}

Illinois, ores of...................... 281 Ilocos Norte, P. I., ores of ... . . . . . . . 219, 220-221 ores of, analysis of ................. 221 section in........................ 220

Imports, sources of . . . . . . . . . . . . . . . . statistics of . . . . . . . . . . . . . . . . . 279-280

India, ores of . . . . . . . . . . . . . . . . . . 213-218 ores of, production of ................ 281

Iron, alloys of manganese and . . .... . . . . . . 244-256 alloys of manganese and, analyses of.... 245 constitution of.................. 248-250 manufacture of.................. 246-248 See also Spiegeleisen; Ferromanganese.

Iron Mask mines, Colo., ores of . ........... 151

Iron ores. See Manganiferous iron ores.

Ironton, Pa., ores at.................... 93 ores at, analyses of . . . . . . . . . . . .

Islandford, Va., ores near. . . ........... 49, 57-58

Italy, ores of . . . . . . . . . . . . . . . . . . . . 206-207 ores of, production of ................ 281

Izard limestone, description of............ 104 ores of . . . . . .

J.

Jabalpur district, India, ores of...... 214, 216-217. ores of, analysis of ................... $\quad 216$

Jacobsberg, Sweden, ores at................ 201

James River-Staunton River region, geology of....................... 37 location of................ 37 mines in, descriptions of. . . . . . . . . . . 38-42 ores of. . . . . . . . . . . . . .

Japan, ores of . . . . . . . . . . . . 219 ores of, analyses of.................. 219 production of.................... 281

Java, ores of . . . . . . . . . . . . . . . . ores of, production of $\ldots \ldots \ldots \ldots \ldots \ldots \ldots . .281$ Jewell Cave, S. Dak., ores in .......... 147, 148 
Jewelry, rhodonite as. $\quad . . . .268$

John, J. F., on manganese. . . . . . . . . . . . . 224

Jones bank, Tenn., ore of .................. 76

Jordan Mountain, N. B., ores of . ......... 171

Joy, Utah, ores near................ 153, 157, 158 ores near, analyses of. ............. 157

\section{$\mathrm{K}$.}

Keeseville, N. Y., ores at.............. 30 ores at, analysis of................. 31

Kelly bank, ores of . . . . . . . . . . . . . . 50,64

Kendall and Flick mine, Va., ores at. . . . . 49, 57 ores at, analyses of . . . . . . . . . . . . . . . 57

Kennedy tract, Va., ores on ....... 50,63, 270,271 ores on, analyses of

Kidney ores, occurrence and character of . 28, 29-30, $37,39,40,53-54,75,78-79,88-89,92,109$

Kimball, Va., ores near............... 49, 55

Kimball mine, Va., ores of . . . ........... $\quad 56$ ores of, analyses of................. 56

King bank, ores of, analysis of............ 74

Kings Mountain, N. C., ores at . . ........ 43, 47 ores at, analyses of ................ 44

Kingston, N. Mex., ores at. . . . . . . . 132, 151

Knox dolomite, description of . . . . . . . . . . 86-87, 96 ores of . . . . . . .

Kothman tract, Tex., ores near.

$$
\text { L. }
$$

Ladd mine, Cal., ores of . . . . . 160-161, 167, 271-272 ores of, analysis of section showing ................ 161

Lafayette region, Brazil, ores of.... 184-185, 188-189 ores of analyses of. ................ 188-189

La Guaca mine, Panama, ores of ......... 181 ores of analysis of .................. 182

Lake City, Colo., ores at................. 151

Lake Superior region, ores of . . . . . . 13, 14, 24, 127-131 ores of, analyses of. . ............ 128-129,131 production of. .................. 272,276

Lake Valley, N. Mex., ores at........... 132,151

Långban, Sweden, ores at............... 201 ores at, section of ................... 201

Laramore mine, Ga., ores of, analyses of.... 85

Las Cabesses, France, ores of............ 196 ores of, analysis of .................. 196

Lead reduction, use of manganese in....... 260

Leadville district, Colo., description of....... 137 geology of . . . . . . . . . . . . . . . . mines of.............................. 143 ores of . . . . . . . . . analyses of..................... 143-145 section showing................. 141 uses of ........................... 142-143

Leadville limestone, description of......... 139

Leclanché cell, use of manganese in......... 266

Leets mine, description of ............... 40 ore of, analyses of...................... 40

Legal Tender Hill, N. Mex., ores of....... · 151

Lehigh, Okla., ores of................. 126, 273 ores of, analyses of................ 127

Lick Mountain, Va., ores at, analysis of..... 72

Ligon, Ga., ores near................... 97

Limburg, Germany, ores near . . . . . . . . . . 198-199

Lindale, Ga., ores near ................... $\quad 97$

Literature, lists of

284-288
Page.

Lithia, Va., ores near. ............... 50,65

Little Grande district, Utah, description of. . 145 geology of . . . . . . . . . . . . . . . . . . . 145-146 ores of.................. 146-147,152,274 section in........................ 146

Little Stony, Cal., ores near . . . . . . . . . . . . 164

Livermore-Tesla district, Cal., description of. 159 geology......................... 159 ores of. ............................ 160

Londonderry mine, N. S., ores of . . . . . . 175-176 ores of, analysis of ................. 176

Lowe mine, Ga., ores at. ............. 89,91 ores at, figure showing............. 91

Lower California, ores of................ 181

Lynchburg, Va., ores near............... 271

Lyndhurst, Va., ores near...... 50,62-63, 270, 271

Lyndhurst mine, Va., ores at. . .......... 50,62 ores at, analyses of $\ldots \ldots \ldots \ldots \ldots \ldots \ldots .62$

\section{M.}

McComber mine, Mich., ores of, analysis of. . . 128

McCormick, S. C., ores near . . . . . . . . . 44-45,47 ores near, analyses of ............... 45

McHenry Creek, Ark., bog ore on.......... 121 bog ore on, analyses of.............. 122

Macks Mountain, Va., ores at, analysis of... 72

McMahon bank, Tenn., ore of ........... $\quad 76$

Madras Presidency, India, ores of.......... 213

Magdalena Bay, Mexico, ores at.......... 181

Maine, ores of ...................... 19,27 ores of, production of . . . . . . . . . 273,276

Mammoth district, Nev., ores of .......... 157

Manganates, list of . . . . . . . . . . . . . . . . . 240-241

Manganese, alloys of. .................. 226-260 analyses of . . . . . . . . . . . . . . . . . . 225 character of . . . . . . . . . . . . . preparation of . . . . . . . . . . . . . . . . 224-226 sources of. . . . . . . . . . . . uses of. . . . . . . .

history of................... 243-244 See also Metallurgy; Chemistry.

Manganese-aluminum alloys, analyses of..... 259 description of..................... 258-259

Manganese amalgam, use of............. 258

Manganese brass, nature and uses of....... 258

Manganese bronze, preparation of . . . . . . 257-258

Manganese-chromium steel, nature of ....... 256

Manganese german silver, uses of . . . . . . . . . 258

Manganese green, use of ............... 268

Manganese industry, account of . . . . . . . . 269

Manganese minerals, list and description of . . 20-23

Manganese ores, character of. ............ 17-23 sources of.................. 13, 17-23

Manganese oxides, hydrates, and acids, data on. .................... 226-229

Manganese-silicon steel, nature of.......... 256

Manganese steel, constitution of . ......... 254 invention of . . . . . . . . . . . . . 244, 251-252 properties of. . . . . . uses of $\ldots \ldots \ldots \ldots \ldots \ldots \ldots \ldots \ldots \ldots \ldots$

Manganiferous iron ores, analyses of...... 31, $128-129,143-144,195$ character of . . . . . . . . . . . . . . 24, 102 distribution of . .................... 13-14, $24,28-30,32,38,43,49,56,57,69,72,74,76,91$, $102,109,127-128,149-150,157,172,175,195,202$ 
Page

Manganiferous silver ores, analyses of.. 136, 143-145 character of..................... 25,140-142 distribution of....................... 132-152 production of....................... 277 sources of......................... 13-14,25 uses of

Manganiferous zinc ores, occurrence of ....... 32

Manganiferous zinc residuum, analyses of.... 36 character of........................... 26

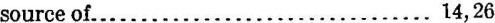
use of................................ 281

Manganite, analyses of................ 169, 174 character and distribution of........... 18, $20,168-169,173,176,200$ forms of.

Manganocalcite, character of .............. 19

Manganosiderite, character of .............. 19

Maria Mountain, Cal., ores near............. 165

-Marion, Va., ores near....................... 69 ores near, analysis of................. 72

Markhamville mine, N. B., ores at........ 169-170 ores at, analysis of ................. 170

Martinsburg shale, ores in ................ 66

Maryland, ores of................ 42, 94, 273, 281

Masbate Island, P. I., ores of . ............ 219, 220 ores of, analysis of.................... 220

Mason, Tex., ores near.................... 123

Massachusetts, ores of ............... 19, 27, 28, 30

Massanutten Mountain, Va., ores of.......... 66

Mayburn mine, Ga., description of.......... 82-83 ores of, analyses of ..................... 85 figure showing................... 82

Meadow Valley, Cal., ores near............. 164

Medicine, use of manganese for ............. 268

Meeker mine, Ark., ores of............... 113-114 ores of, figure showing............... 114 section of, figure showing.............. 106

Merionethshire, Wales, ores of .......... 202-203 ores of, analyses of................... 203

Metallurgy, use of manganese in ......... 244-260

Mexico, ores of........................ 180-181

Michigan, ores from................... 128, 275

Middlebrook, Va., ores at................... 95

Midvale, Va., ores at................. 50,65

Miguel Burnier district, Brazil, ores of.. 184, 185-186 ores of, analyses of.................. 186 section in, figure showing.............. $\quad 185$

Milner Harris mine, Ga., description of..... 83 ore of, analysis of ................... $\quad 85$

Minas Basin, N. S., ores on.............. 172-174

Minas Geraes, Brazil, geology of............ 184 ores of............................... 184-189

Mine bank, Va., ores at............... 50,64,102 ores at, analyses of.

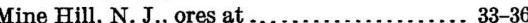
ores at, analyses of .................... 35 composition of ....................... 34

Mining, methods of...................... 15

Minnesota, ores of .................... 130-131

Minudie, N. S., ores at.................... 174

Mississippi Valley (lower) region, ores of... 102-127 ores of, value of.

See also Arkansas; Texas; Tennessee; Missouri; Oklahoma.

Missouri, ores of $\ldots . . .125-126$ ores of, analyses of..................... 126 production of................... 272,275
Page.

Moccasin mine, Ga., description of........... 82 Modena, Utah, ores at................. 153,157 Moissan, H., on alloys ................... 250 Montana, ores of...... 14,19,25,132-136,148-149,152 ores of, analyses of................... 149 production of ................. 273,275-276 See also Butte district; Wickes area.

Montgomery mine, Ark., ores of ........... 113 ores of, figure showing................ 113

Moose Brook mine, N. S., ores of........... 174

Moravia, Austria-Hungary, ores of.......... 205

Mordant, use of manganese for.............. 268

Morra da Mina mine, Brazil, ores of......... $\quad 189$

Mosquito Range, Colo., geology of......... 138

Mount Airy, Ga., ores of................. 45-46 ores of, analysis of .................... 46

Mount Torry property, Va., ores at........ 50,63

Murphrees Valley, Ala., ores in............ $\quad 98$

Mushet, Robert, invention of spiegeleisen by . 244

Musquodoboit, N. S., ores at.............. 175

N.

Nagpur district, India, ores of.............. 218

Nazareth district, Brazil, description of...... 183 geology of. . . . . . . . . . . . . . . . . . 183-184 ores of.............................. 184

Negaunee, Mich., ores at, analysis of ......... 128

Neihart, Mont., ores at. . ........ 132, 148-149, 273

Nevada, ores of................ 14,19,153-158, 273 ores of, production of ................. 275

New Brunswick, geology of................ 168 ores of........................ 168,169-171

New England, ores of............... 14,24, 27-30 value of ........................... 31 See also particular States.

Newfoundland, ores of................. 177 ores of, analysis of ................... 177

New Hampshire, ores in ............... 27

New Jersey, ores of ... 14, 19, 26, 32, 33-37, 42, 272, 281

New Mexico, ores of ................ 132, 151,274 ores of, production of................. 276

Newport, Tenn., description of............ 75 mines of, description of............... 75-76 ores of ........................ 72,75-77

New River region, description of........... 69 geology of........................... $69-70$ mines of, description of .............. $71-72$ ores of............................. $70-71$ analyses of....................... 72

New South Wales, ores of................ 222

New York, ores of .................. 14, 30-31 ores of, value of...................... 31

New Zealand, ores of ..................... 221 ores of, production of ................. 281

Nickel-manganese steel, nature of........... 256

Nikopol district, Russia, ores of............ $\quad 211$ ores of, analysis of ................... 211

Nispero, Panama, ores of, analyses of....... 183

Nitrogen, salts of manganese and ........... 234

Noble Furnace, Va., ores at, analysis of...... 72

Nombre de Dios region, Panama, ores of..... 181

Nordmark, Sweden, ores at.............. 201

North America, foreign, ores of . ......... 168-183

North Carolina, ores of.......... $32,43-45,48,76,96$ ores of, analyses of.................. 44,45 production of............. 272-273, 275-276

Norway, ores of, production of............ $\quad 281$ 
Novaculite, occurrence and character of..... 119

Nova Scotia, geology of................ 168 ores of.................... 168, 172-176 analyses of.................... 176

Nuremberg violet, nature of . ............ 268

\section{0 .}

Oasis, Utah, ores near............... 157

Oceania, ores of.................... 219-223 ores of, production of ................ 281

Odenwald, Germany, ores of............... 199

O'Flinn mine, Ark., ores of. ............. 110

Ogdensburg, N. J. See Sterling Hill.

Oklahoma, ores of . ................. 126,273

ores of, analyses of................ 127

Old Dominion mine, Va., ores of . . . . . . . 49,61

Olympic Mountains, Wash., ores of....... 159

Onslow, N. S., ores at................. 174

Ontario, ores of...................... 168

Oriskany limestones, ores in...........66, 94

Ouachita region. See Arkansas, west central.

Oưro Preto district, Brazil, ores of........ 187 ores of, analyses of. ................. 187

Oxides, character and distribution $*$ of . . . . . . . 17-19

Oxidizing, use of manganese in . . . . . . 261-266

Oxygen, manufacture of................. 264

Ozark region, Mo., ores of............... 126

P.

Pacific coast, description of............. 158 ores of ........................ 158-159 See also Livermore-Tesla region; California; Sierra Nevada.

Paddy Mills mine, Va., ores of............ ores of, analysis of.

Paints, drying of, use of manganese in...... use of manganese for . ....................

Pajsberg, Sweden, ores of................. 201 ores of, analyses of. . . . . . . . . . . . . . . . . . 182-183

Parazuelos, Spain, ores of ................ 195

Parker mine, N. S., ores of.............. 174

Patillo mine, Ga., ore of, analysis of . ...... 85

Pedras Pretas mine, Brazil, ores of........ 184 ores of, section showing................ 184

Pelagite, character of.............. 19, 20,23

Pennsylvania, ores of. ......... 42, 48,193-194,281. ores of, analyses of. production of

Penrose, R. A. F., jr., on manganese ores. . 99, 117 Permanganates, list of................ 241-242 Petitcodiac, N. B., ores at.............. 171 Philippines, ores of ................. 219-221

Phosphomanganese, analysis of............ 245 use of .......................... 245

Phosphorus, salts of manganese and . . .... 235-236

Piedmont, Ala., ores near................ 98

Piedmont, Italy, ores of . . . . ............ 206

Piedmont Manganese Company's mine, description of.............. 38-40,47 ores of, analysis of .................. 40

figure showing. ................. 39

Pieämont mine, description of.......... 41 ore of ............................. 41
Page.

Piedmont region, geology of . ........... 31-33 location of. ...................... $31-32$ ores of . . . . . . . . . . . origin of................... $46-47$ value of . ..................... 47 See also Franklin Furnace; James RiverStaunton River region.

Pilot Knob, Mo., ores near................ 125 ores near, analyses of .............. 126 Pioche, Nev., ores at. . . . . . . . . . . . 153, 157

Piquery mine, Brazil, ores of . . . . . . . . . . . 188 ores of, analyses of. . ............... 188, 189

Pittsville, Va., ore at, analyses of......... 42

Placentia Bay, Newfoundland, ores at. ..... 177

Polianite, character of............... 19

Polk Bayou limestone, description of ..... 104-105 ores of . ........... 111, 112,113-114, 115, 117

Polk-Southerd mine, Ark., ores of.......... 115

Pond Mountain, Va., ores near, analysis of. - 72

Ponupo mines, Cuba, ores of............ 178-179 ores of, analyses of. ................. 180

Portugal, ores of...................... 195 ores of, analyses of. ................ 195 production of..................... 281

Pottery, coloring of. .................. 267

Powderhorn, Colo., ores near............. 150

Powells Fort, Va., ores at............... 67-68 ores at, analyses of................. 67

Prices, statistics of.................... 278-279

Primary concentration ores, distribution of. . 14

Production, United States, statistics of... 269-278

Production, world, statistics of......... 280-281

Prussia, ores of ...................... 198

Psilomelane, character of . . . . . . . . . . . occurrence of . . . . . . . . . . . . . . . . Passim. mode of, figures showing........... 60

Puebla, Mex., ores of. . . . . . . . . . . . . . . . 180-181

Purdue, A. H., on Cason shale... . . . . . . . 105-106

Pyrolusite, analysis of ................. 168 character of...................... 18, 20 occurrence of . . . . . . . . . . . mode of, figure showing........... 60

\section{Q.}

Quaco Head mine, N. B., ores of....... 170-171 ores of, analysis of ................. 171 Quaternary manganese steel, nature of . .. 255-256 Quebec, ores of ..................... 168, 176 Queluz region. Sec Lafayette region.

Queensland, ores of................. 222-223 ores of, production of ................ $\quad 281$

\section{R.}

Radford Furnace, Va., ores at, analysis of.... 72 Raines property, ores of............... $\quad 76$ Razor bank, Va., ores at, analysis of........ $\quad 72$ Red Mountain, ores at................50,64 Red Rock Island, Cal., ores on........ 164, 271-272 ores on, analysis of ................. 166 Reeves mine, Ark., ores of.............. . 110-111 Replacement ores, oscurrence and character of........................ 55 Reynolds Mountain, Ga., ores at.......... 89-91 ores at, figure showing.............. 90 
Rhode Island, ores in ...................

Rhodochrosite, character and distribution of. 19 157-158

Rhodochrosite veins, occurrence of......... 14, 19

Rhodonite, character of................. 19,21 occurrence of ............ 19,21,27,31,33-34 use of, as jewelry ................... 268

Rhodonite veins, occurrence of. .......... 14, 19

Rioville, Nev., ores of................... 158

Rivernert, France, ores at . ............. 197

Roach mine, Ark., ores of............... 112

Rocky Mountain region, ores of......... . 132-152 ores of, value of.................... 152 See also Butte district; Wickes area; Little Grande district.

Romaneche, France, ores of............. 196

Rome, Ga., ores near................ $\quad 97$

Rome formation, description of.......... 87 ores of ............................. 100

Russia, ores of..................... 208-212 ores of, production of ................ 281

Rye Valley, Va., ores from, analysis of..... $\quad 72$

$$
\mathrm{S} \text {. }
$$

St. Clair limestone, description of. ........ 106-107 ores in.................... 109,110,117,118 Sainte-Claire Deville, M. H., on manganese.. 224 St. John Mountain, Cal., ores on........... 164 St. Martin Island, W. I., ores of . . . . . . . . . . 180 St. Peter sandstone, description of. . . . . . . . 103-104 Salerno, Italy, ores near................ 206 Salisbury Bay, N. B., ores of . . . . . . . . . . . 171 San Andreas, Cal., ores near ............. 164-165 Sanders property, Ga., ores of......... 89, 91-92 San Luis Obispo, Cal., ores near........... 164

Saǹ Pietro Island, Italy, ores of......... 206, 207

Santiago de Cuba, ores of................ 177-178

São Gonçalo mine, Brazil, ores of. ......... 189 ores of, analysis of ................... 189

Saône et Loire, France, ores of. ............ 196 ores of, analysis of................... 197

Sapinero, Colo., ores at............. 132, 149,151 ores at, analysis of................. 151

Sardinia, Italy, ores of. ................. 206

Satterfield mine, Ga., ores of, analysis of.... 85

Saunders property, description of......... 41 ore of............ 41

Sausar, India, ores of .............. 214, 217-218 ores of, analyses of................... 218

Sausalito, Cal., ores near................ 164,272

Saxxony, ores of ..................... 198, 200

Scarborough mine, Ga., ores of .......... 89,92 ores of, figure showing.............. 92

Scott, H. K., on Brazilian ores....... 1S3, 184, 185

Sea, manganese concretions in ........... 23-24 manganese concretions in, analyses of.... 23

Secondary concentration ores, distribution of. 14

Selenium, salts of manganese and......... 234

Seller mine, Va., ores of . . . . . . . . . . 49,57

Servia, ores of ........................ 206

Shady limestone, ores in............ 70,73, 100

Shady Valley, Tenn., description of........ 73 ores of..................... 72,73-74 analyses of.
Sharopan district, Russia, ores of ......... $\begin{array}{r}\text { Page. } \\ 208-210\end{array}$ ores of, analysis of................ 210 section in, figure showing............. 209

Shaver bank, Va., ores of . ............. 49,58

Sheafer bank, Tenn., ores of, analysis of . . . . 74

Shenandoah, Va., ores near............. 49,56

Shenandoah limestone, ores in............ 95

Shepody Mountain, ores of . . . . . . . . . . . 171

Sherando, Va., ores near............. 50,62-63

Sherwood limestone, ores in . . . . . . . . . . 52,100

Ship Harbor, N. S., ores at . . . . . . . . . . . 175

Siegerland, Germany, ores of. . . . . . . . . . 198

Sierra Maestro, Cuba, ores of . . . . . . . . . . 177-178

Sierra Nevada, ores of . . . . . . . . . . . . . 158, 167

Silicomanganese, nature of............. 245 prices of........................ $\quad 282$

Silicon, salts of manganese and........... $\quad 239$

Silicospiegel, nature of . . . . . . . . . . . . . 245 prices of............................... 282

Silver City, N. Mex., ores at......... 132, 151, 274

Silver ores. See Manganiferous silver ores.

Silver reduction, use of manganese in....... 260

Simmersbach, O., on manganese.......... 247

Sinai Peninsula, ores of............... 212-213 ores of, analy"ses of................... 213

Sing Sing, N. Y., ores at................ 31 ores at, analysis of.................. 31

Sjogrufvan, Sweden, ores at.............. 202

Skinner-Abbot mine, Ark., ores of......... 112 ores of, analyses of . ................ 116

Smaland, Sweden, ores of. ............... 200

Smith mine, Ga., ore of, analysis of........ 85

Smith Mountain, S. C., analyses of. ......... 44

Sneech Pond, R. I., ores at, analysis of. . . . $\quad 28$

Soap, mottling of....................... 268

Soft ores, occurrence and character of....... 75,

$78,80,89,91-92$

Soledad mine, Panama, ores of............ 181 ores of, analysis of.................. 182

Sonora, Cal., ores near.................. 165

South America, ores of . ............... 183-192 ores of, production of.................. 281

South Australia, ores of. . . . . . . . . . . . . . . 222 ores of, analysis of ................... 222

South Carolina, ores of . . . . . . . . . . . . 32, 43-45, 47 ores of, analysis of . ............... 44,45 production of.............. 273, 275, 277

South Dakota, ores of. . . . . . . . . . . . . 147-148,273 ores of, analysis of ................. 148 production of.................. 275

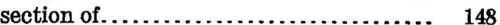

Southern mine, Ark., ores of. ........... 114-115 ores of, analyses of.................. 116 section of, figure showing . . ........... 106

South Wallingford, Vt., ores at.......... 28-30 ores at, analyses of................ $\quad 30$ section at, figure showing............ $\quad 29$ Spain, ores of........................ 192-195 ores of, production of . ............... 281 Spencer, A. C., on Cuban ores............ 177

Spessartite, analysis of................ 123 character of ........................ 19,21

Spiegeleisen, analyses of............... 37 imports of . . . . . . . 
Page.

Spiegeleisen, invention of

manufacture of

nature of.

prices of.

production of..

use of.

Spiller mine, Tex., ores of

ores of, analyses of. ores at, analyses of ................. 176

Stanleyton, Va., ores near............ 49,55-56 ores near, analyses of ................ 56

Stapleton Mills, Va., ore at, analysis of...... 42

Star Peak formation, ores in............... 154

Staunton River region. See James RiverStaunton River region.

Steel, manufacture of, use of maganese in. . 243-244, 250-251

Stephens mines, Tenn., ores of............ 76

Stephenson mine, Ga., ores of, analyses of... $\quad 85$

Sterling Hill, N. J., ores at............... 33-34 ores at, analyses of ................... 35

Steuben Valley, Colo., ores of......... 132,149,150 ores of, analysis of ................... 150

Stocks Mills, ores at.................... 272 ores at, analysis of................... 99

Stoner mine, Va., ores of .............. 50,65

Stony Creek valley, ores from, analysis of.... 74

Stuarts Draft, Va., ores near............. 50,63

Sugar Grove, Va., ores near.............. 71,72

Sulphur, salts of manganese and ......... 232-234

Sussex, N. B., ores near............... 169,171

Sweden, ores of..................... 200-202 ores of, production of .................. 281

Sweetwater, Tenn., ores of ............... 96 ores of, analysis of ................... 96

Switzerland, ores of.................... 206

\section{T.}

Tamm, Hugo, on manganese

Tarlac, P. I., ores of.. 225 ores of, analysis of

Taylor Peak, Colo., ores of.

ores of, analyses of $: \ldots \ldots \ldots \ldots \ldots \ldots \ldots .149-150$

Telluride, Colo., ores at................. 151

Tennessee, ores of.. 17, 18, 48, 72-77, 95-96, 99-100, 125 ores of, analysis of. . production of .............. 269, 275, 277 See also Shady Valley; Newport.

Tenny Cape mines, N. S., ores at......... 172-173 ores at, analyses of .................. 173-174

Tephroite, analysis of................... 123 character of........................... 19,21 occurrence of .......................... 33

Tesla. See Livermore-Tesla.

Tete à Gauche Falls, N. B., ores at......... 171

Texas, mines of, descriptions of. .......... 123-124 ores of ........................ 14,122-123 analyses of........................ 125

Thuringia, Germany, ores of............. 198, 200

Tintic district, Utah, ores in............ 153,158

Toccoa, Ga., ores near.................... 46

Tombstone, Ariz., ores at............ 132,151-152 ores at, analyses of................... 152
Page.

Transcaucasia, Russia, ores of ............ 208-210

Transylvania, A ustria-Hungary, ores of...... 206

Trent mine, Ark., ores of . ............... 110

Tres Pinos, Cal., ores near................ 164

Troutville, Va., ores near................ 50,65

Truro, N. S., ores at.................... 174

Tug Hill, N. Y., ores at.................. 30 ores at, analysis of.................. 31

Tunis, ores of......................... 212

Turkey, ores of ........................ 208 ores of, production of ................. 281

Turner mine, Ark., ores of................. $\quad 115$

Tuscany, Italy, ores of............... 206, 207

U.

Umber, occurrence and character of.......... 38

Umbarger mine, Va., ores of .............. 71 ores of, analysis of .................... 72

Uniacke, Mount, N. S., ores at........... 175

Unicoi City, Tenn., ores at................ 76,269

Unionvale, $\mathrm{N}$. Y., ores at. ................. $\quad 30$

United States, ores of .................... 27-167 ores of , production of ................. 281

Ural Mountains, ores of .................. 211-212

Usina Wigg mine, Brazil, ores of, analyses of. $\quad 186$

$\mathrm{Utah}$, ores of ........ 145-147,152,153,157,273-274 ores of, production of .............. 275,277

V.

Vanadium, salts of manganese and......... $\quad 237$

Van Buren furnace, Va., ores at........... 67

Vermont, ores of ............. 17, 28-30,31,99-100 ores of, analyses of ................... 30 production of............... 270,275-276

Vesuvius mine, Va., ores at...... 50,63-64, 102, 271

Virginia, ores of . . ...... 13,17,18,32,48,49-72,94-95 ores of , analyses of.............. 95,99-100 production of....... 270-271, 275-276, 277

See also Blue Ridge region; Virginia, northwestern; New River region.

Virginia, northwestern, mines of, descriptions of .....................66-68

ores of............................. 66

Vizagapatam district, India, ores of.... 213, 215-216 ores of, analysis of .................... 216

W.

Wad, analysis of ...................... 176 character of $\ldots \ldots \ldots \ldots \ldots \ldots \ldots \ldots \ldots \ldots, 18,20$ occurrence of...................... 27, $30-31,43,57,147,168-169,171,175,180$ use of as paint...................... 268

Wales, ores of......................... 202-203 ores of, analyses of.................. 203

Walkers Ford, Va., ore at................. 42

Walton, N. S., ores at and near............ 174

Warwick, N. Y., ores at............ ores at, analysis of.................... 31

Washington, ores of ................... 159

Watson bank, Va., ores of ............... 49,56

Watt property, Va., ores of............... 49,62

Weisner quartzite, description of ........... 78,87 ores of......................... 78,98,100

West Red Mountain, ores from............ 98 
Page.

West Virginia, ores of ................ 95,273 ores of, analysis of .................. $\quad 95$ production of.................... 275

White, Ga., ores near.................. 81

White bank, Va., ores of . . . . . . . . . . . . 50,65

Whitfield, Tenn., ores near ............. 125, 269

Wickes area, Mont., description of...... 135-136 ores of...................... 14,136-137 section showing ............... 136

Willemite, character of................ 21 composition of .................. 34 occurrence of ...................... 33-34

Wilson, Wis., bog ore at................ 128

Windsor, N. S., ores near................ 174

Wisconsin, ores of ................... 14

Wolfville, N. S., ores near.

Wood, staining of.................... 268
Page.

ores from, analyses of ............... 99

Wright bank, Tenn., ores of, analysis of.... 74

Wytheville, Va., analyses of.............. 72

Y.

Yellow Springs mine, Tenn., ores of...... 75-76

Ysabellita mines, ores of . ............... 178

Z.

Zincite, character of . .................. 21

composition of ....................

occurrence of . .................. 33-34

Zinc ores. See Manganiferous zinc ores.

Zinc oxide furnaces, clinker from, analyses of. $\quad 36$

Zinc residuum. See Manganiferous zinc residuum. 





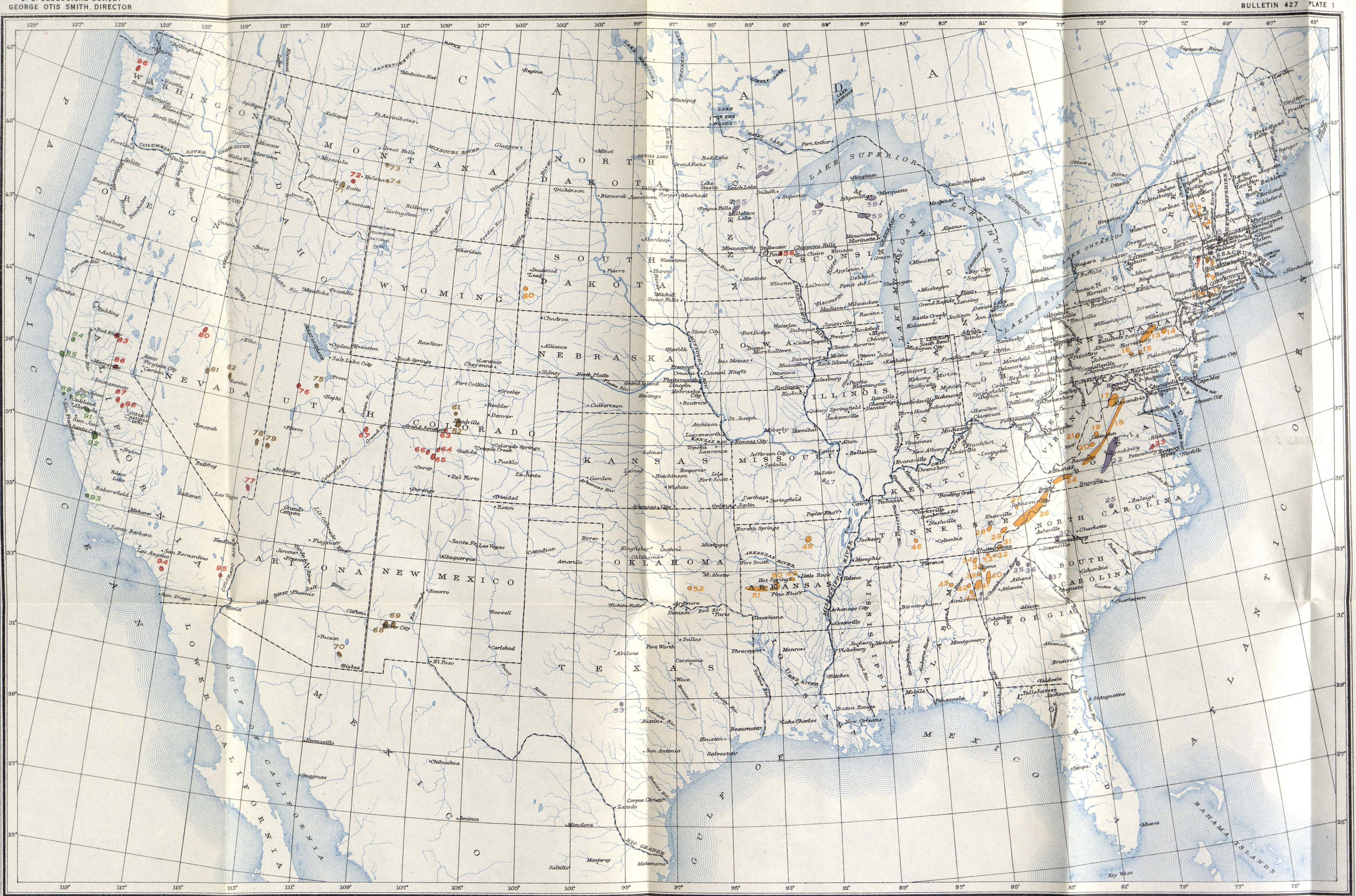


